


\section{INNOWACYJNE TECHNOLOGIE W STRAŻY POŻARNEJ}

Opracowano w ramach projektu nr: DOB-BIO6/06/113/2014 finansowanego przez Narodowe Centrum Badań i Rozwoju pod tytułem „Mobilny turbinowy system ratowniczo-gaśniczy”

\section{Projekt realizowany przez konsorcjum w składzie:}

Szkoła Główna Służby Pożarniczej;

Centrum Naukowo-Badawcze Ochrony Przeciwpożarowej im. Józefa Tuliszkowskiego

- Państwowy Instytut Badawczy; Wojskowy Instytut Chemii i Radiometrii;

JAS technologie Sp. z o.o.
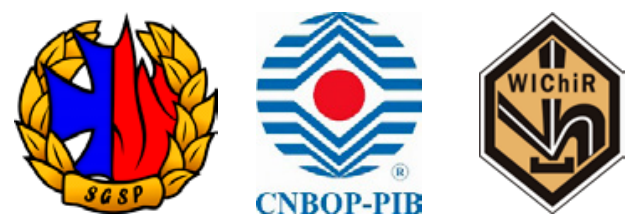

technologie 


\title{
Redakcja naukowa:
}

dr inż. Jacek Roguski

\author{
Recenzja: \\ prof. dr hab. inż. Janusz Kręcikij \\ prof. dr hab. inż. Jan Posobiec
}

\author{
Redakcja i korekta: \\ Agata Ludwińska \\ Anna Pacek
}

Projekt okładki:

Julia Pinkiewicz

Grafika na okładce:

made by Freepik.com

\section{ISBN 978-83-948534-1-9 \\ DOI 10.17381/2018.3}

(C) Copyright by Wydawnictwo CNBOP-PIB, Józefów 2018

\author{
Skład i druk: \\ BEL Studio Sp. z o.o. \\ 01-355 Warszawa \\ ul. Powstańców Śl. 67 B \\ tel./fax (+48 22) 6659222 \\ e-mail: studio@bel.com.pl \\ księgarnia: http://www.iknt.edu.pl
}

\section{Wydawca:}

Centrum Naukowo-Badawcze Ochrony Przeciwpożarowej im. Józefa Tuliszkowskiego - Państwowy Instytut Badawczy

05-420 Józefów k/Otwocka ul. Nadwiślańska 213

www.cnbop.pl 


\section{SPIS TREŚCI}

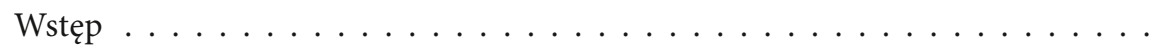

\section{Część I}

Innowacyjne rozwiązania konstrukcyjne zrealizowane w projektach naukowo-badawczych na potrzeby straży pożarnej

Jacek Roguski

Przykłady rozwiązań konstrukcyjnych opracowanych w czasie realizacji projektów naukowo-badawczych

\section{Część II}

Innowacyjne rozwiązania konstrukcyjne w pojazdach pożarniczych

Jacek Roguski

Pojazdy pożarnicze: rozwiązania i technologie $\ldots \ldots \ldots \ldots \ldots \ldots \ldots$

Włodzimierz Kupicz, Jarosław Kończak, Marcin Mieteń, Marcin Grubek, Grzegorz Wiśniewski

Badania ergonomii i bezpieczeństwa pojazdu pożarniczego $\ldots \ldots \ldots \ldots$

\section{Część III}

Logistyka działań w jednostkach ochrony przeciwpożarowej

Michał Chmiel, Karolina Równicka, Emil Sulak

Zarządzanie procesami logistycznymi jednostek PSP w działaniach

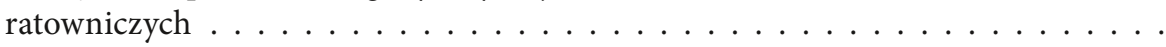

Robert Piec

System kompleksowego zabezpieczenia logistycznego wielopodmiotowych akcji ratowniczych

\section{Część IV}

Innowacyjne systemy gaśnicze w działaniach ratowniczo-gaśniczych

Tomasz Wesierski, Małgorzata Majder-Łopatka, Wiktor Wąsik, Bernard Król Mobilny turbinowy system ratowniczo-gaśniczy. Podstawowe założenia systemu gaśniczego bazującego na wykorzystaniu turbiny samolotowej $\mathrm{SO} 3 \ldots$. . . . . . . .

Aleksander Adamski, Wiktor Wąsik, Tomasz Węsierski, Małgorzata Majder-Łopatka Organizacja zaopatrzenia wodnego mobilnego turbinowego systemu

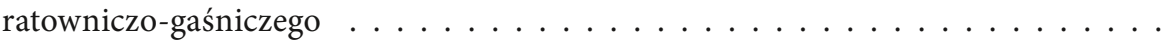


Jacek Pirszel

Wykorzystanie środków dekontaminacyjnych w mobilnym turbinowym systemie ratowniczo-gaśniczym . . . . . . . . . . . . . . . . . . 191

\section{Czesść V}

Innowacyjne technologie $\mathrm{w}$ działaniach ratowniczo gaśniczych

Beata Wojtasiak, Konrad Zaciera

Projekt OZAB - innowacyjne podejście do ochrony przeciwpożarowej . . . . . . 205

Norbert Tuśnio, Paweł Wolny, Paweł Ogrodnik

Bezzałogowe systemy rozpoznania uszkodzonych konstrukcji budowlanych . . . . 229

\section{Część VI}

Monitoring stanu technicznego sprzętu w straży pożarnej

Łukasz Apiecionek

System Internetu Rzeczy do monitorowania wyposażenia straży pożarnej . . . . . 243

Łukasz Apiecionek, Robert Palka, Piotr Brążkiewicz, Mateusz Biedziak

Możliwości zastosowania sieci 4G do monitorowania urządzeń eksploatowanych

w Straży Pożarnej . . . . . . . . . . . . . . . . . . . . . . . . . . . . . . . 259

Włodzimierz Kupicz, Paweł Ogrodnik, Dariusz Baranowski

Opracowanie funkcjonalnej koncepcji systemu monitorowania sprzętu

$\mathrm{z}$ uwzględnieniem rodzaju danych i poziomu raportowania

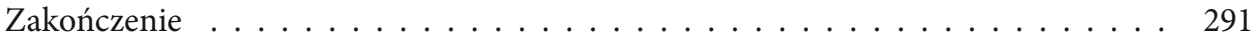

Notki biograficzne . . . . . . . . . . . . . . . . . . . . . . 293 


\section{Wstęp}

Jacek Roguski

Publikacja Innowacyjne technologie w straży pożarnej jest wynikiem realizowanych w Centrum Naukowo-Badawczym Ochrony Przeciwpożarowej - Państwowym Instytucie Badawczym (CNBOP-PIB) projektów z obszaru bezpieczeństwa i obronności finansowanych przez Narodowe Centrum Badań i Rozwoju. Zaprezentowane opracowania dotyczą projektów badawczych, w realizacji których uczestniczyło CNBOP-PIB, zarówno w roli lidera, jak i członka konsorcjów takich jak:

- DOB-BIO6/06/113/2014 „Mobilny turbinowy system ratowniczo-gaśniczy”;

- DOBR BIO4/051/13087/2013 „Opracowanie metodologii stałego nadzoru eksploatacji wybranych obszarów wyposażenia straży pożarnej w zakresie niezawodności i skuteczności działania”;

- DOBR BIO4/047/13419/2013 „System kompleksowego zabezpieczenia logistycznego wielopodmiotowych akcji ratowniczych"3.

W ujęciu definicyjnym pojęcie innowacji (z łac. innovare - odnawiać) zostało wprowadzone w latach trzydziestych ubiegłego wieku. J. Schumpeter za innowację uznał wprowadzenie na rynek nowego produktu, wykorzystanie nowych metod wytwarzania, a także wprowadzenie zmian organizacyjnych. Jest również inna definicja, która mówi, że innowacja to wdrożenie nowego lub istotnie ulepszonego produktu (wyrobu, usługi) lub procesu, nowej metody organizacyjnej lub nowej metody marketingowej w praktyce gospodarczej, organizacji miejsca pracy lub w stosunkach $z$ otoczeniem. Nowy lub istotnie ulepszony produkt zostaje wdrożony, gdy jest wprowadzony na rynek. Nowe procesy, metody organizacyjne lub metody marketingowe zostaja wdrożone, kiedy rozpoczyna się ich faktyczne wykorzystywanie w działalności przedsiębiorstwa ${ }^{4}$. Istotnym jest, że w ujęciu definicyjnym, za innowację może być uznane to, co niekoniecznie uznaje się za innowację w innym państwie.

Na podstawie przedstawionych ujęć można wyróżnić5:

Innowacje produktowe - polegające na wdrażaniu nowych lub udoskonalonych zastosowań i technologii w wytwarzaniu nowego lub udoskonalonego produktu.

1 DOB-BIO6/06/113/2014 „Mobilny turbinowy system ratowniczo-gaśniczy”, dokumentacja projektu.

2 DOBR BIO4/051/13087/2013 „Opracowanie metodologii stałego nadzoru eksploatacji wybranych obszarów wyposażenia straży pożarnej w zakresie niezawodności i skuteczności działania”, dokumentacja projektu.

3 DOBR BIO4/047/13419/2013 „System kompleksowego zabezpieczenia logistycznego wielopodmiotowych akcji ratowniczych", dokumentacja projektu.

4 Por. Działalność innowacyjna przedsiębiorstw w latach 2009-2011, 2012, Warszawa, Główny Urząd Statystyczny.

5 Innowacja, http://pi.gov.pl/PARP/data/Prezentacja_17_12_08/modul_1.pdf(dostęp: 15.02.2018). 
Proces modernizacji wyrobu powinien zapewnić uzyskanie lepszych charakterystyk technicznych (taktyczno-technicznych) lub funkcjonalności użytkowej.

Innowacje procesowe - polegające na wprowadzaniu zmian w technologii wytwarzania zarządzania dystrybucją usług przy optymalizacji kosztów, organizacji pracy lub minimalizacji wpływu na środowisko. Innowacje procesowe obejmują również działalność wspomagająca (pomocnicza) w obszarach logistycznych oraz księgowości czy obszaru IT.

Innowacje organizacyjne - polegające na modernizacji struktur organizacyjnych, procedur postępowania w zakresie organizacji i zarządzania. Innowacje w zakresie organizacji pracy oraz podziału zadań i uprawnień decyzyjnych są sposobem na optymalizację zarządzania oraz maksymalizację wykorzystania zasobów ludzkich. Wprowadzone zmiany mogą decydować o efektywności funkcjonowania organizacji/ przedsiębiorstwa poprzez wywieranie korzystnego wpływu na organizację oraz bezpieczeństwo i higienę pracy.

Wszystkie z rozpatrywanych opracowań spełniają przedstawione powyżej wymagania definicyjne i mogą być traktowane jako rozwiązania innowacyjne znajdujące zastosowanie w jednostkach ochrony przeciwpożarowej.

W części I Przykłady rozwiązań konstrukcyjnych opracowanych $w$ czasie realizacji projektów naukowo-badawczych przedstawione zostały projekty badawcze, które dotyczą sprzętu i wyposażenia dla straży pożarnej. Prezentowany materiał ma przedstawić stosowane aparaty badawcze, metody pozyskiwania danych oraz sposobem wykorzystania rezultatów, co w efekcie przybliży tematykę realizowanych projektów badawczych. Zadaniem autora jest przekonanie czytelnika, że nadrzędną jest zasada realizacji projektów badawczych ściśle związanych z oczekiwaniami gestora reprezentującego środowisko zawodowe. Dodatkowo, celem szerszego podejścia do zagadnień wykorzystania nowych technologii zaprezentowano wybrane problemy związane z wdrażaniem do użytkowania innych grup wyposażenia i sprzętu wykorzystywanego w straży pożarnej oraz zarządzania procesem eksploatacji. Omówione zostały rozwiązania bezzałogowych platform lądowych przeznaczonych do prowadzenia działań ratowniczo-gaśniczych. Bezzałogowa platforma lądowa (BPL) „Strażak” używana jest do prowadzenia, rozpoznania i likwidacji skutków awarii chemicznych w zakładach produkcyjnych i spedycji materiałów niebezpiecznych, może prowadzić działania gaśnicze oraz prace dekontaminacyjne. Wyposażona zastała w osprzęt przeznaczony do podawania wody i środków neutralizujących i odkażających. Podobną funkcję spełnia robot ratowniczy „Florian” - przeznaczony do prowadzenia akcji ratowniczych oraz rozpoznawczych. Wyposażony jest w wymienne akcesoria w postaci chwytaka/manipulatora o udźwigu $200 \mathrm{~kg}$ i wysięgu $4 \mathrm{~m}$ oraz ładowarkę o udźwigu $1000 \mathrm{~kg}$ i wysokości podnoszenia $1,5 \mathrm{~m}$. Żeby poprawić funkcjonalność użytkową „Florian” został wyposażony w przyłącza pozwalające na dołączenie osprzętu stosowanego w minikoparkach. Przedstawione zostały efekty projektów pozwalających na prowadzenie działań ratowniczych 
w sposób systemowy. Zaprojektowany system wspomagania działań antyterrorystycznych i antykryzysowych „PROTEUS” powstał z współzależnych elementów pozwalających na optymalne wykorzystanie w różnych sytuacjach kryzysowych. W skład całego systemu wchodzą następujące elementy:

- mobilne centrum zarządzania działaniami (MCD) wraz z systemem koordynacji działań robotów (MCOR);

- zestaw robotów mobilnych (RM);

- samolot bezzałogowy (BSL);

- zestawy czujników do rozpoznawania skażeń.

W grupie projektów, których celem systemowym było wytworzenie aparatu wspomagającego prowadzenie działań ratowniczych są:

- Projekt 0013/R/ID2/2011/01 „Optymalizacja procedur, dyslokacji baz i doskonalenie rozwiązań technicznych sprzętu stosowanego przez polskie służby ratownicze $\mathrm{w}$ zakresie przeciwdziałania zagrożeniom naturalnym ze szczególnym uwzględnieniem powodzi (rękawy przeciwpowodziowe) ${ }^{6}$. Dzięki przekrojowemu prowadzeniu prac zrealizowano zadania obejmujące opracowanie Lokalnego Systemu Ostrzegania przed powodzią, przygotowanie dokumentacji ochrony przeciwpowodziowej na wybranym terenie zalewowym, która obejmowała weryfikację procedur reagowania, alarmowania ludności na tym terenie. Zaproponowano również możliwość poprawy dyslokacji baz sprzętowych zawierających wyposażenie przeciwpowodziowe. W projekcie wytworzono poniższe produkty:

- Rękaw przeciwpowodziowy, którego innowacyjny charakter opiera się na niezwykle prostym założeniu wypełnieniu wnętrza wewnętrznego rękawa wodą.

- Wyspecjalizowany Zestaw Przeciwpowodziowy (WZP) składający się z pływającego pojazdu ratowniczego "Wydra” oraz przyczepy z wyposażeniem przeznaczonym do prowadzenia akcji przeciwpowodziowej.

- Projekt DOBR BIO4/051/13087/2013 „Opracowanie metodologii stałego nadzoru eksploatacji wybranych obszarów wyposażenia straży pożarnej w zakresie niezawodności i skuteczności działania”.

Najciekawszym elementem projektu jest demonstrator technologii - system teleinformatyczny zbierający dane $\mathrm{z}$ eksploatacji wybranego sprzętu znajdującego się w użytkowaniu w jednostkach straży pożarnej oraz analizujący uzyskane $\mathrm{z}$ sensorów pomiarowych dane w sposób pozwalający na ich wykorzystanie w ramach wspomagania działań logistycznych. Przyjęta struktura pozyskiwania danych $\mathrm{z}$ budowanego systemu pozwala na niezależne i zautomatyzowane pozyskiwanie

6 Projekt 0013/R/ID2/2011/01 „Optymalizacja procedur, dyslokacji baz i doskonalenie rozwiązań technicznych sprzętu stosowanego przez polskie służby ratownicze w zakresie przeciwdziałania zagrożeniom naturalnym ze szczególnym uwzględnieniem powodzi (rękawy przeciwpowodziowe)", dokumentacja projektu. 
informacji na różnych szczeblach zarządzania - począwszy od poziomu JRG, na KGPSP kończąc. Zdaniem wykonawców projektu, wytworzony system monitorowania stanu technicznego, generując w sposób automatyczny raporty bez konieczności angażowania pracowników do ręcznej analizy danych, pozwoli na sprawniejsze zarządzanie operacyjne i logistyczne.

- Projekt DOBR BIO4/047/13419/2013 "System kompleksowego zabezpieczenia logistycznego wielopodmiotowych akcji ratowniczych".

Nowatorskim podejściem jest wytworzenie jednorodnego systemu zbierania wybranych informacji i przesyłania wybranych komunikatów, który będzie możliwy do wykorzystania przez wszystkie podmioty biorące udział w akcji ratowniczej. Opracowany system informatyczny wykorzystuje stworzone oprogramowanie komputerowe, które z bazą wiedzy, zasadami postepowania w zakresie zabezpieczenia logistycznego oraz przyjętym sposobem dokumentowania realizowanych działań wspomaga zarządzanie $\mathrm{w}$ zakresie zabezpieczenia logistycznego wielopodmiotowymi działaniami ratowniczymi.

W projektach 0014/R/ID1/2011/01 „Nowoczesne ochrony osobiste służb ratowniczych KSRG w oparciu o potrzeby użytkowników końcowych"7 oraz DOBR/0011/R/ID1/2013/03 „Opracowanie innowacyjnego systemu stanowisk do badań ochron osobistych" 8 podjęto tematykę bezpieczeństwa ratowników w trakcie działań. Produktem wspierającym działania decyzyjne w zakresie bezpieczeństwa ratowników w prowadzonych czynnościach ratowniczo-gaśniczych jest system monitorowania funkcji życiowych oraz lokalizacji położenia ratownika. Wynikiem projektu jest narzędzie pozwalające na weryfikację cech użytkowych odzieży strażackiej oraz sprawdzenia cech psychomotorycznych ratowników oparte na elektronicznym systemie umożliwiający zdalne pomiary parametrów środowiskowych oraz fizjologicznych. Pozwala to kierującemu działaniami na kontrolę stanu zdrowia i sprawności ratowników oraz możliwość ich wycofania w przypadku stanu zagrożenia zdrowia lub życia. Podobną funkcję profilaktyczną spełnia system stanowisk badawczych zbudowanych przy realizacji projektu „Opracowanie innowacyjnego systemu stanowisk do badań ochron osobistych”. Efektem tych działań jest możliwość oceny aktualnie użytkowanych struktur materiałowych do produkcji ochron osobistych w znacznie szerszym ujęciu niż dotychczas przy wykorzystaniu opracowanych metod badawczych pozwalających na lepszą ocenę skuteczności ochron osobistych. W warunkach rzeczywistych może wystąpić spiętrzenie czynników niekorzystnych, co może zostać odwzorowane w powstałych stanowiskach badawczych. Pozwalają one na badanie wyrobu, który był poddany procesowi starzenia w warunkach jednoczesnego obciążenia mechanicznego i termicznego, co pozwala uzyskać pełniejszą informację o właściwościach ochron. Wykonane

7 0014/R/ID1/2011/01 „Nowoczesne ochrony osobiste służb ratowniczych KSRG w oparciu o potrzeby użytkowników końcowych”, dokumentacja projektu.

8 DOBR/0011/R/ID1/2013/03 „Opracowanie innowacyjnego systemu stanowisk do badań ochron osobistych”, dokumentacja projektu. 
stanowiska pozwalają na określenie istotnych własności krytycznych w warunkach złożonych obciążeń zewnętrznych. Wyniki badań właściwości termofizycznych oraz badań na zaprojektowanych stanowiskach pojedynczych materiałów oraz ich zestawów w różnych konfiguracjach warunków użytkowania dostarczają informacji dotyczących możliwych i celowych modyfikacji materiałów i ich zestawów oraz pozwalają na realizację procesu badawczego skuteczności systemów ochronnych stosowanych w jednostkach ochrony przeciwpożarowej.

Część II - Innowacyjne rozwiązania konstrukcyjne w pojazdach pożarniczych poświęcona została tematyce innowacyjności rozwiązań konstrukcyjnych pojazdów pożarniczych oraz procesu badań laboratoryjnych, których celem jest uzyskanie najlepszych z punktu widzenia ergonomii rozwiązań konstrukcyjnych optymalizujących proces obsługi sprzętu pożarniczego przy minimalnym wysiłku.

W rozdziale Pojazdy pożarnicze: rozwiązania i technologie omówiono coraz szerszą ofertę rozwiązań konstrukcyjnych pojazdów pożarniczych w różnych grupach użytkowych. Mimo sformalizowania wielkości pojazdów i ich wyposażenia, producenci, uwzględniając oczekiwania różnych grup użytkowników, proponują różne modyfikacje sprzętu biorąc pod uwagę postęp w technice i technologii gaszenia. Przedstawione zostały pojazdy ratowniczo-gaśnicze specjalnie dostosowane do prowadzenia działań w trudnych warunkach terenowych, przeznaczone do prac w ekstremalnie niskich temperaturach oraz w szczególnych warunkach środowiskowych. Omówiono rozwiązania konstrukcyjne pojazdów stosowanych w tunelach komunikacyjnych, pojazdy kontenerowe oraz pojazdy turbinowe. Jako generator gazów wyrzutowych w tych pojazdach wykorzystywane są turbinowe silniki lotnicze gdzie w strumień gazów wylotowych podawane są za pomocą odpowiednich dysz środki gaśnicze. Wysokie własności gaśnicze uzasadnione są kombinowanym sposobem gaszenia uwzględniającym proces schładzania oraz oddziaływania gazodynamicznego na źródło pożaru. W zależności od potrzeb wykorzystywane są podwozia gąsienicowe lub kołowe obsługiwane przez załogę lub systemy zdalnego kierowania pojazdem. Pojazdy turbinowe przeznaczone są do prowadzenia działań ratowniczo-gaśniczych w górnictwie, w zakładach przetwórczych ropy i gazu, zakładach chemicznych w warunkach silnego promieniowania cieplnego. Zdalne sterowanie pojazdem realizowane jest w zależności od potrzeb z wykorzystaniem łączy wizyjnych i radiowych ze stanowiska kierowania. Zdalne sterowanie pozwala na gaszenie, schładzanie konstrukcji obiektów oraz instalacji technologicznych w obiektach szczególnego przeznaczenia, np. elektrowni jądrowych, magazynów uzbrojenia zakładów produkcyjnych wykorzystujących lub produkujących toksyczne lub trujące substancje. Omówiono również, coraz częściej wykorzystywane w trakcie prowadzenia działań, pojazdy do wentylacji pożarowej. Samochody pożarnicze tego typu przeznaczone są do prowadzenia prac polegających na przewietrzaniu/oddymianiu i schładzaniu dużych obiektów, takich jak pawilony, podziemne garaże, wysokie budynki, hangary lotnicze, tunele kolejowe oraz drogowe itp. Omówiono również stale rosnącą grupę pojazdów pożarniczych 
karosowanych na motocyklach jako pojazdy interwencyjne przeznaczone w dużych aglomeracjach miejskich do działań ratowniczo-gaśniczych. Dzięki swoim zdolnościom manewrowym i dynamice, motocykle gaśnicze mogą przybyć na miejsce zdarzenia, przeprowadzić rozpoznanie i gaszenie pożaru w początkowej fazie rozwoju, przeprowadzić wstępne działania ratownicze $\mathrm{z}$ wykorzystaniem dostępnego na wyposażeniu sprzętu. W obszarach trudnodostępnych, leśnych oraz miejscach pozbawionych utwardzonych dróg komunikacyjnych wykorzystywane są również quady, szczególnie do gaszenia pożarów w początkowej fazie rozwoju. W ciągu ostatnich lat liczba producentów pożarniczych takich pojazdów stale rośnie. Na rynku pojawiły się firmy proponujące odbiorcom nowe typy quadów różnego przeznaczenia wykonanych w różnych wersjach. W większości z nich zastosowano systemy gaśnicze: plecakowe, mgłowe, pianowe oraz sprzęt pomocniczy w różnych konfiguracjach (narzędzia hydrauliczne i elektromechaniczne narzędzie ratownicze, agregaty prądotwórcze, kamery termowizyjne). Przedstawiono również możliwości stosowania w jednostkach ochrony przeciwpożarowej poduszkowców, które są wielofunkcyjnym uniwersalnym środkiem transportowym przeznaczonym do:

- gaszenia pożarów na jednostkach pływających;

- prowadzenia prac podwodnych i prac nurkowych;

- ratowania tonących i uwięzionych na krach;

- dostarczania sprzętu ratunkowego (łodzie, pontony pneumatyczne) na miejsce prowadzonych działań.

Jednocześnie w rozdziale Badania ergonomii i bezpieczeństwa pojazdu pożarniczego przedstawiono inne ujęcie tematu bezpieczeństwa pojazdu pożarniczego. W pracy autorzy skupili się na zagadnieniach związanych z badaniem i oceną ergonomii pojazdów specjalnych. Komfort pracy załogi jest bardzo ważnym czynnikiem, ponieważ wpływa na efektywność działania podczas wykonywania konkretnego zadania. W szerokim pojęciu ergonomii jest szereg cech, które wymagają oceny. Głównym problemem badawczym jest ocena cech niemierzalnych. Autorzy w ramach pracy przybliżyli jak w Wojskowym Instytucie Techniki Pancernej i Samochodowej dokonuje się badania ergonomii pojazdów specjalnych. W opracowaniu skoncentrowano się przede wszystkim na wykorzystaniu inżynierii odwrotnej. Nowe technologie pozwalają na zastosowanie inżynierii odwrotnej (skaner 3D), która eliminuje subiektywne odczucia osoby przeprowadzającej badanie. Skanując obiekt odtwarzamy pojazd oraz przestrzeń wewnątrz kabiny jako model przestrzenny 3D. W środowisku wirtualnym możemy zaimplementować wirtualnego manekina 3D, dzięki któremu można sprawdzić następujące cechy: widoczność z miejsca pracy użytkownika pojazdu, zasięg pracy użytkownika pojazdu (np. nóg i rąk), widoczność z miejsca kierowcy, widoczność w lusterkach wstecznych, siły w układzie szkieletowo-mięśniowym użytkownika pojazdu w zależności od wykonywanej czynności (np. zmiana przełożeń skrzyni biegów, otwieranie schowka, podnoszenie osprzętu). Odpowiednio zaprojektowana i wykonana przestrzeń wewnętrzna kabiny pojazdu 
specjalnego jest konieczna do prawidłowego współdziałania systemu w układzie człowiek - pojazd. Pozwala to zaznajomić czytelnika z nowoczesnym podejściem do zasad projektowania pojazdu pożarniczego $\mathrm{z}$ uwzględnieniem komfortu użytkowania oraz ergonomiki.

Część III Logistyka działań w jednostkach ochrony przeciwpożarowej poświęcona została analizie sposobu zabezpieczenia logistycznego długotrwałych akcji ratowniczych. Autorzy skupili się na sposobie zarządzania zasobami logistycznymi, podmiotach odpowiedzialnych za organizację zabezpieczenia logistycznego. Porównano organizację zabezpieczenia logistycznego i główne problemy dotyczące zabezpieczenia logistycznego jakie wystąpiły podczas trzech dużych zdarzeń jakimi były: pożar w Kuźni Raciborskiej w 1992 roku, powódź w 1997 roku oraz katastrofa budowlana na terenie Międzynarodowych Targów w Chorzowie. W publikacji przedstawiono postulatywne propozycje zmian w organizacji zabezpieczenia logistycznego w Państwowej Straży Pożarnej, opierające się na nieustającym rozwoju technologii usprawniających działanie oraz zarządzanie zasobami logistycznymi w czasie rzeczywistym. System logistyczny w Państwowej Straży Pożarnej (PSP) ma szczególne znaczenie nie tylko podczas prowadzonych działań ratowniczo-gaśniczych o mniejszym zasięgu zagrożenia, lecz przede wszystkim w trakcie długotrwałych akcji ratowniczych, wówczas mamy do czynienia z pełnym rozwinięciem zabezpieczenia i wsparcia logistycznego. Znaczny wpływ na jakość zabezpieczenia logistycznego, przekładającego się często na powodzenie prowadzonej akcji i zwalczania skutków powstałego zagrożenia, ma zarządzanie logistyczne w ujęciu procesowym, formujące bezpieczeństwo na danym terenie. Zabezpieczenie logistyczne organizowane jest w ramach Krajowego Systemu Reagowania Kryzysowego. Wprowadzenie postulowanych przez autorów zmian na podstawie przeprowadzonych analiz i badań pozwoli na sprawniejsze prowadzenie długotrwałych akcji ratowniczych i procesu zabezpieczenia logistycznego działań oraz polepszenie warunków współpracy jednostek PSP z pozostałymi formacjami mundurowymi i władzami samorządu terytorialnego. W rozdziale System kompleksowego zabezpieczenia logistycznego wielopodmiotowych akcji ratowniczych opisano wyniki projektu o tym samym tytule, finansowanego przez Narodowe Centrum Badań i Rozwoju (NCBR). Przedstawiono opracowany system informatyczny wykorzystujący stworzone oprogramowanie komputerowe, które z bazą wiedzy, zasadami postępowania w zakresie zabezpieczenia logistycznego oraz przyjętym sposobem dokumentowania realizowanych działań wspomaga zarządzanie w zakresie zabezpieczenia logistycznego wielopodmiotowymi działaniami ratowniczymi. W celu walidacji opracowanego rozwiązania przeprowadzono demonstrację w warunkach zbliżonych do rzeczywistych, na którą zaproszono potencjalnych użytkowników. W czasie przeprowadzonych ćwiczeń sprawdzono (w warunkach zbliżonych do rzeczywistych) wytworzone narzędzie informatyczne oraz funkcjonalność kontenera logistycznego, który w czasie wielopodmiotowych akcji ratowniczych miałby stanowić mobilne centrum koordynacji działań logistycznych. Kontener składa się 
z dwóch niezależnych pomieszczeń. Jedno przeznaczone zostało na miejsce pracy sztabu, drugie - do prac zespołu ds. logistyki. W pierwszym pomieszczeniu został zamontowany serwer, telewizor, krzesła i stoły. Drugie pomieszczenie zaaranżowano dla 4 osób pracujących w zespole ds. logistyki, wyposażono je w komputery przenośne oraz terminale mobilne.

Przedstawione w czasie demonstracji założenia teoretyczne oraz narzędzie informatyczne zostały ocenione bardzo pozytywnie. Wnioski z wyników ankiety są niezaprzeczalne - przydatność tego typu narzędzia do przyszłych działań ratowniczych jest bardzo duża.

W części IV Innowacyjne systemy gaśnicze w działaniach ratowniczo-gaśniczych przedstawiono zagadnienia związane z realizacją projektu DOB-BIO6/06/113/2014 „Mobilny turbinowy system ratowniczo-gaśniczy”. W ramach tego projektu realizowanego przez konsorcjum w składzie: Szkoła Główna Służby Pożarniczej, Centrum Naukowo-Badawcze Ochrony Przeciwpożarowej im. Józefa Tuliszkowskiego - Państwowy Instytut Badawczy, Wojskowy Instytut Chemii i Radiometrii oraz JAS technologie Sp. z o.o. został wykonany prototyp mobilnego turbinowego systemu ratowniczo-gaśniczego, który pozwala na gaszenie pożarów dużych instalacji technologicznych, obiektów wielkokubaturowych oraz pożarów lasów na dużej przestrzeni a także może być wykorzystany w dekontaminacji masowej oraz ograniczaniu rozprzestrzenia i likwidacji skażeń.

W rozdziale Mobilny turbinowy system ratowniczo-gaśniczy. Podstawowe założenia systemu gaśniczego bazującego na wykorzystaniu turbiny samolotowej SO3 wykonano szereg wielkoskalowych badań poligonowych, $\mathrm{w}$ tym pożary testowe grupy A i B oraz badania: zasięgu rzutu, kroplistości, liczby spieniania, efektywność zasilania systemu przez agregaty pompowe i inne samochody pożarnicze. Badanie pożarów grupy B środkiem typu AFFF wypadło pozytywnie, przy czym wykazano bardzo duży wpływ warunków atmosferycznych oraz ustawienia pojazdu na obszar skutecznego działania.

Wykazano ograniczenia wykorzystania samej technologii turbinowej do gaszenia pożarów grupy A oraz grupy B z uwagi na bardzo duży wpływ warunków atmosferycznych oraz ustawienia pojazdu na obszar skutecznego działania technologii. Wykazano skuteczność zasilania technologii na odległość z wykorzystaniem agregatów pompowych.

W rozdziale Organizacja zaopatrzenia wodnego mobilnego turbinowego systemu ratowniczo-gaśniczego przedstawiono optymalne wyposażenie oraz taktykę niezbędną do realizacji zaopatrzenia wodnego turbinowego systemu ratowniczo-gaśniczego (MTSRG) w trakcie działań ratowniczych. W Europie do budowy wysokowydajnych systemów zaopatrzenia w wodę do celów gaśniczych stosowane są obecnie zestawy pompowe o wydajności nie mniejszej niż $10000 \mathrm{dm} 3 / \mathrm{min}$ i ciśnieniu tłoczenia wody nie mniejszym niż 1,2 MPa. Do współpracy z powyższymi pompami przygotowane są moduły wężowe wyposażone $\mathrm{w}$ węże tłoczne o średnicy 150 lub $300 \mathrm{~mm}$. W jednym module wężowym może być od $5000 \mathrm{~m}$ 
do 10000 m węży ułożonych w systemie szybkiego sprawiania. Rozpatrując moduł wężowy o długości $5000 \mathrm{~m}$ i założeniu, że pojazd z modułem będzie poruszał się z prędkością $250 \mathrm{~m} / \mathrm{min}$ czas sprawienia linii zasilającej na dystansie $5000 \mathrm{~m}$ wynosić będzie około $20 \mathrm{~min}$. Dla porównania - w Polsce samochód wężowy, ze względów konstrukcyjnych, nie będzie poruszał się szybciej niż $80 \mathrm{~m} / \mathrm{min}$ czyli czas sprawienia SW 5000 będzie trwał około $62 \mathrm{~min}$. Przy zastosowaniu węży tłocznych o średnicy $150 \mathrm{~mm}$ straty ciśnienia w zasilających liniach wężowych będą mniejsze niż dla węży stosowanych w Polsce.

W rozdziale Wykorzystanie środków dekontaminacyjnych w mobilnym turbinowym systemie ratowniczo-gaśniczym omówiono sprawdzanie stabilności wybranych składników odkażalników w warunkach symulujących strumień gazów wylotowych z silnika turboodrzutowego w mobilnym turbinowym systemie ratowniczo-gaśniczym. Użycie turbinowego sytemu ratowniczo-gaśniczego do likwidacji skażeń substancjami wysokotoksycznymi, takimi jak bojowe środki trujące, wymaga użycia odkażalników zawierających reaktywne substancje, między innymi związki nadtlenowe i podchloryny. $Z$ przeprowadzonych badań wynika, że większość sprawdzanych odkażalników może być stosowana w turbinowym systemie ratowniczo-gaśniczym bez znaczącej zmiany aktywności.

W części V Innowacyjne technologie $w$ działaniach ratowniczo-gaśniczych są dwa rozdziały: Projekt OZAB - innowacyjne podejście do ochrony przeciwpożarowej oraz Bezzałogowe systemy rozpoznania uszkodzonych konstrukcji budowlanych. Obydwa poświęcone innowacyjnemu podejściu zgodnie z definicjami innowacji produktowej oraz procesowej. Projekt OZAB to innowacyjny, teleinformatyczny system wspomagania zarządzania bezpieczeństwem w kontekście podniesienia poziomu bezpieczeństwa kompleksów obiektów zabytkowych. Demonstrator będzie uwzględniał scenariusze zagrożeń dla takich obiektów wraz z możliwością reagowania ratowniczego, kompleksowej technologii ratowniczej i systemu szkoleniowego. Wypracowane w trakcie projektu OZAB rekomendacje (np. certyfikacja obiektów pod względem bezpieczeństwa ppoż.) dotyczące zarządzania bezpieczeństwem obiektów zabytkowych zlokalizowanych w centrach miast doprowadzą do zwiększenia bezpieczeństwa samych obiektów, jak i eksponatów o szczególnej wartości.

Wdrożenie wyników projektu wpłynie w istotny sposób na bezpieczeństwo obywateli poprzez wprowadzenie systemu zarządzania obiektami zabytkowymi. Dzięki w prowadzeniu innowacyjnego systemu nastąpi poprawa procesu ewakuacji dóbr i eksponatów znajdujących się w chronionych obiektach. Znacząco spadnie ryzyko ich uszkodzenia lub zniszczenia podczas sytuacji nadzwyczajnych. Zgodnie z założeniami projektu przewiduje się, że głównym zastosowaniem systemu będzie ochrona dóbr muzealnych/zabytków, która będzie realizowana poprzez usprawnienie procesu ewakuacyjnego w przypadku wystąpienia zdarzenia niekorzystnego, np. pożaru. Elementy systemu mają również za zadanie usprawnić procesy logistyczne związane z magazynowaniem dóbr po opuszczeniu ewakuowanego 
obiektu. Ważnym podkreślenia jest fakt, że pewne elementy systemu, tj. tablet oraz smartfon, będą wykorzystywane przez kierującego działaniami ratowniczymi oraz przez samych ratowników, w tym przypadku elementy będą wspomagały ochronę zdrowia ratowników, jak również ułatwiały nawigację w pomieszczeniach.

Przykładem praktycznego wykorzystania środków technicznych w działaniach straży pożarnej jest koncepcja jednoczesnego zastosowania dwóch systemów: bezzałogowych statków powietrznych (BSP) oraz mobilnych robotów lądowych, w działaniach ratowniczych prowadzonych podczas katastrof budowlanych. Technologia ta zostanie opracowana $w$ ramach osiągnięcia IX poziomu gotowości technologicznej w projekcie nr DOB-BIO6/03/48/2014 „Innowacyjne rozwiązania metod stabilizowania konstrukcji budowlanych i technologicznych w warunkach działań ratowniczych podczas likwidacji skutków katastrofy budowlanej" 9 . Zgodnie z sugestiami gestora, system złożony z mobilnego robota lądowego oraz tachimetru elektronicznego, który spełnił dotychczasowe oczekiwania, należy rozbudować o „komponent pozwalający na dokonywanie rozpoznania uszkodzonych konstrukcji budowlanych z wykorzystaniem bezzałogowych platform latających, które stałyby się naturalnym uzupełnieniem możliwości oferowanych przez przygotowaną platformę kołową". W opracowaniu zaprezentowano możliwości oraz warianty użycia BSP w działaniach ratowniczych, w tym stosowane w ramach KSRG oraz przez służby innych państw.

Celem opracowania jest zaprezentowanie koncepcji połączonego zastosowania różnych systemów w działaniach ratownictwa technicznego oraz korzyści płynących z takiego rozwiązania. W ocenie autorów rozszerzenie możliwości pozyskiwania danych z poziomu lądu o dane zbierane przez sensory umieszczone na platformie latającej zdecydowanie wpłynie na czas i jakość podejmowanych decyzji, zarówno na poziomie interwencyjnym, jak i taktycznym. W przypadku zdarzeń o dużych rozmiarach, takich jak wielkie awarie przemysłowe oraz katastrofy naturalne (trzęsienia ziemi), pozwoli to na dobór odpowiedniej strategii działań ratowniczych prowadzonych na szeroką skalę.

W części VI Monitoring stanu technicznego sprzętu w straży pożarnej przedstawiono możliwości ewaluacji efektów projektu DOBR BIO4/051/13087/2013 "Opracowanie metodologii stałego nadzoru eksploatacji wybranych obszarów wyposażenia straży pożarnej w zakresie niezawodności i skuteczności działania”. W projekcie został opracowany system teleinfomatyczny, który, bazując na informacjach pobieranych z sensorów zainstalowanych na wytypowanych do badań jednostkach sprzętu stosowanego w jednostkach ochrony przeciwpożarowej, pozwala na samodzielne gromadzenie informacji eksploatacyjnych oraz prognozowanie stanu technicznego i napraw. W warunkach poligonowych zbliżonych do rzeczywistych zostały sprawdzone parametry funkcjonalne wytworzonego demonstratora

9 Projekt DOB-BIO6/03/48/2014 „Innowacyjne rozwiązania metod stabilizowania konstrukcji budowlanych i technologicznych w warunkach działań ratowniczych podczas likwidacji skutków katastrofy budowlanej”, dokumentacja projektu. 
systemu zarządzania eksploatacją wytypowanego sprzętu. Końcowym produktem projektu jest demonstrator, na który składają się:

- system sensorów monitorujący stan wybranych urządzeń;

- system łączności umożliwiający przekaz pozyskanych danych operacyjnych oraz zdalny dostęp do stworzonego systemu;

- system informatyczny gromadzący i transformujący pozyskane oraz uzupełniający dane logistyczne dotyczące obsługi i zakupów sprzętu.

W rozdziale System Internetu Rzeczy do monitorowania wyposażenia straży po$\dot{z}$ arnej zaprezentowano wykorzystanie narzędzia jakim jest Internet Rzeczy, które można określić jako rozwiązanie w budowie. Jedną z obecnie dostępnych i bardzo często wykorzystywanych usług jest monitorowanie różnego rodzaju wielkości fizycznych, linii produkcyjnych, procesów im towarzyszących. Dostarczane rozwiązania pozwalają podejmować lepsze decyzje. Maciej Kranz w swojej książce podaje, że połączenie technologii i podejmowania decyzji pozwala na osiągnięcie lepszego wyniku finansowego przedsiębiorstw i właśnie dlatego rozwiązania te powinny być rozważane do wdrożenia. Jednak wdrażanie rozwiązań generuje problemy: jak dokonać analizy, jakie rozwiązanie wybrać, komu zaufać przy jego modelowaniu, wykonaniu i wdrażaniu. Ze względu na proces wdrażania, idealnym rozwiązaniem byłaby uniwersalna architektura rozwiązania, która uwzględniała by wszystkie aspekty pracy: szybkość działania, bezpieczeństwo transmisji i przetwarzania danych. W publikacji wykorzystano metodę analizy, aby rozważyć możliwość zastosowania idei Internetu Rzeczy do wytworzenia systemu monitorowania wyposażenia sprzętu straży pożarnej. Wykonana analiza wykazała, że zastosowanie idei Internetu Rzeczy sprawdza się również w przypadku budowy systemów rozproszonych dla straży pożarnej.

W rozdziale Możliwości zastosowania sieci $4 G$ do monitorowania urządzeń eksploatowanych $w$ straży pożarnej autorzy podjęli próbę znalezienia odpowiedzi na to zagadnienie oraz określenia jakie to daje możliwości zasięgu oraz prędkości transmisji. W przypadku gdy obszar monitorowania jest bardzo rozległy można wykorzystać sieci kratowe - mesh, budując w ten sposób własną sieć. Istnieje jednak inne rozwiązanie - można spróbować wykorzystać istniejącą architekturę sieci komórkowej 3G/4G/LTE a w przyszłości nawet 5G. Na wykorzystanie tego typu łączności pozwala obecny stopień pokrycia sieci na terytorium Rzeczpospolitej Polskiej. Taką łączność zastosowano w rozwiązaniu projektu "Opracowanie metodologii stałego nadzoru eksploatacji wybranych obszarów wyposażenia straży pożarnej w zakresie niezawodności i skuteczności działania”. Wykorzystana sieć $3 \mathrm{G} / 4 \mathrm{G} / \mathrm{LTE}$, pozwala na połączenie węzłów sieci do serwera i umożliwia użytkownikom mobilnym dostęp do zasobów niezależnie od miejsca ich pracy, ponieważ budowany w ramach projektu system obejmował tylko sześć węzłów, konieczna była analiza wykorzystania sieci w przyszłości na szeroką skalę, uwzględniając, poza zasięgami i prędkościami transmisji, również koszty utrzymania systemu. 
W rozdziale Opracowanie funkcjonalnej koncepcji systemu monitorowania sprzetu $z$ uwzględnieniem rodzaju danych i poziomu raportowania przedstawiono wyniki prac nad realizacją projektu rozwojowego nr DOBR-BIO4/051/13087/2013 „Opracowanie metodologii stałego nadzoru eksploatacji wybranych obszarów wyposażenia straży pożarnej w zakresie niezawodności i skuteczności działania”. Zadania Szkoły Głównej Służby Pożarniczej obejmowały opracowanie funkcjonalnych założeń koncepcyjnych oraz przeprowadzenie badań w rzeczywistych warunkach eksploatacji. Wyniki badań wskazują na dużą przydatność opracowanego systemu do nadzorowania eksploatacji wybranego sprzętu straży pożarnej. Przeprowadzone końcowe badania opracowanego systemu monitorowania stanu technicznego wybranych urządzeń potwierdziły, że:

- możliwe jest prowadzenie monitorowania stanu technicznego urządzeń podczas rzeczywistej służby w jednostce ratowniczo-gaśniczej;

- wszystkie kluczowe parametry diagnostyczne zapisywane są w systemie w sposób poprawny, umożliwiający ich odczyt po upływie czasu;

- na podstawie danych zapisanych w systemie możliwe jest określenie położenia sprzętu w dowolnie wybranym przedziale czasowym;

- korzystając z menu Wykresy możliwe jest monitorowanie szczegółowych parametrów nadzorowanego sprzętu w dowolnie wybranym czasie.

\section{Bibliografia}

[1] DOB-BIO6/06/113/2014 „Mobilny turbinowy system ratowniczo-gaśniczy”, dokumentacja projektu.

[2] DOBR BIO4/051/13087/2013 „Opracowanie metodologii stałego nadzoru eksploatacji wybranych obszarów wyposażenia straży pożarnej w zakresie niezawodności i skuteczności działania”, dokumentacja projektu.

[3] DOBR BIO4/047/13419/2013 „System kompleksowego zabezpieczenia logistycznego wielopodmiotowych akcji ratowniczych", dokumentacja projektu.

[4] Działalność innowacyjna przedsiębiorstw w latach 2009-2011, Główny Urząd Statystyczny, Warszawa 2012.

[5] 0013/R/ID2/2011/01 „Optymalizacja procedur, dyslokacji baz i doskonalenie rozwiązań technicznych sprzętu stosowanego przez polskie służby ratownicze w zakresie przeciwdziałania zagrożeniom naturalnym ze szczególnym uwzględnieniem powodzi (rękawy przeciwpowodziowe)”, dokumentacja projektu.

[6] 0014/R/ID1/2011/01 „Nowoczesne ochrony osobiste służb ratowniczych KSRG w oparciu o potrzeby użytkowników końcowych”, dokumentacja projektu.

[7] DOBR/0011/R/ID1/2013/03 „Opracowanie innowacyjnego systemu stanowisk do badań ochron osobistych", dokumentacja projektu.

[8] Projekt DOB-BIO6/03/48/2014 „Innowacyjne rozwiązania metod stabilizowania konstrukcji budowlanych i technologicznych w warunkach działań ratowniczych podczas likwidacji skutków katastrofy budowlanej”, dokumentacja projektu.

[9] Innowacja, http://pi.gov.pl/PARP/data/Prezentacja_17_12_08/modul_1.pdf (dostęp: 15.02.2018). 


\section{CzĘŚć I}

INNOWACYJNE ROZWIĄZANIA KONSTRUKCYJNE ZREALIZOWANE W PROJEKTACH NAUKOWO-BADAWCZYCH NA POTRZEBY STRAŻY POŻARNEJ 



\title{
Przykłady rozwiązań konstrukcyjnych opracowanych w czasie realizacji projektów naukowo-badawczych
}

\author{
Examples of design solutions developed \\ during scientific research projects
}

\author{
Jacek Roguski \\ Centrum Naukowo-Badawcze Ochrony Przeciwpożarowej \\ im. Józefa Tuliszkowskiego - Państwowy Instytut Badawczy (CNBOP-PIB)
}

\section{Streszczenie}

Prezentowany materiat ma za zadanie zapoznać czytelników ze stosowanym aparatem badawczym, metodami pozyskiwania danych oraz sposobem wykorzystania rezultatów, co $w$ efekcie przyblizy tematykę realizowanych projektów badawczych. Zadaniem autora jest przekonanie czytelnika, że nadrzędna jest zasada realizacji projektów badawczych ściśle związanych $z$ oczekiwaniami gestora reprezentującego środowisko zawodowe. Dodatkowo, celem szerszego podejścia do zagadnień wykorzystania nowych technologii zaprezentowano wybrane problemy związane $z$ wdrażaniem do użytkowania innych grup wyposażenia $i$ sprzetu wykorzystywanego w straży pożarnej oraz zarzadzania procesem eksploatacji.

Wybrane do omówienia tematy dotycza tylko tych projektów, których treść zdaniem autora ma bezpośredni związek z omawiana tematyką.

\begin{abstract}
The material presented aims to present research apparatus, data acquisition methods and means of utilisation of results, and in effect to outline the range of subjects of realised research projects. The author is tasked with convincing the reader, that the rule of carrying on research projects strictly related to expectations of the administrator representing professional community is precedent. In addition, for broader approach to issues of utilising new technologies, the selected problems, concerning deployment of different equipment groups used in the Fire Department and operation management, were presented.

The topics selected for presentation apply only for those projects, of which substance is, in author's opinion, directly related with topics discussed.
\end{abstract}




\section{Projekt POIG.01.02.01-00-014/08 Zintegrowany mobilny system wspomagający działania antyterrorystyczne i antykryzysowe - Proteus"1, 2}

Projekt Proteus realizowany był w latach 2007-2013 w ramach programu Innowacyjna Gospodarka i współfinansowany ze środków Europejskiego Funduszu Rozwoju Regionalnego w ramach Programu Operacyjnego Innowacyjna Gospodarka na lata 2007-2013. Wymagania dotyczące tworzonego systemu zostały wypracowane przez przyszłych użytkowników w oparciu o posiadane doświadczenie i wiedzę techniczną. Schemat powiązań poszczególnych elementów systemu Proteus przedstawiono poniżej:

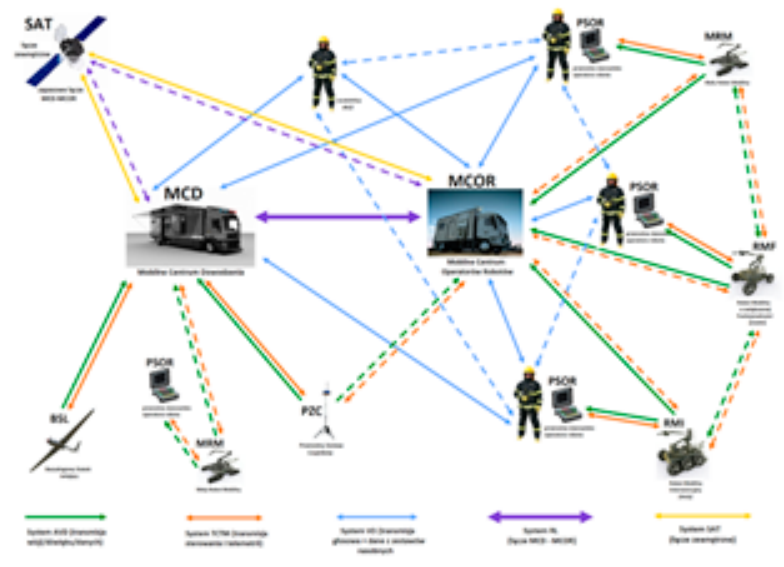

Rysunek 1. Schemat funkcjonalny systemu Proteus wg Łukasza Skrzypkowskiego Figure 1. Functional diagram of the Proteus system, by Łukasz Skrzypkowski

System operacyjny Proteus powstał z współzależnych elementów pozwalających na optymalne wykorzystanie w różnych sytuacjach kryzysowych. Wytworzenie produktów/efektów projektu przez zespół konsorcjantów posiadających unikalną specjalistyczną wiedzę pozwoliło na powstanie produktów innowacyjnych na skalę międzynarodową. Elementy systemu zostały wprowadzone do pracy w jednostkach zawodowo przeznaczonych do działań np. ratowniczych.

W skład całego systemu wchodzą następujące elementy:

- mobilne centrum zarządzania działaniami (MCD) wraz z systemem koordynacji działań robotów (MCOR);

- zestaw robotów mobilnych (RM);

- samolot bezzałogowy (BSL);

- zestawy czujników do rozpoznawania skażeń.

1 http://www.ire.pw.edu.pl/zrk2/pl/component/content/article/101.html, Copyright @ 2009-2010 Zakład Radiokomunikacji, created by Łukasz Skrzypkowski.

2 http://www.projektproteus.pl

3 html Copyright ( ) 2009-2010 Zakład Radiokomunikacji, created by Łukasz Skrzypkowski. 
Wszystkie elementy systemu zostały wyposażone w spójny układ łączności, co umożliwia współdziałanie na miejscu akcji nawet w przypadkach, gdy zostaną oddelegowane z różnych jednostek. Centralnym elementem systemu jest Mobilne Centrum Dowodzenia $(\mathrm{MCD})^{4}$, gdzie zbierane są wszystkie dane pozyskiwane z systemu oraz informacje ze źródeł zewnętrznych. Na tej podstawie podejmowane są decyzje związane z prowadzonymi działaniami oraz określone sposoby wykorzystania elementów systemu w operacjach eliminujących zagrożenia życia i zdrowia poszkodowanych oraz ratowników. Mobilne Centrum Operatorów Robotów (MCOR) ${ }^{5}$ zostało przygotowane do prowadzenia prac w rejonie zagrożenia. Stworzono zespół robotów wyposażonych w różnego rodzaju urządzenia rozpoznawcze, kamery wideo dla promieniowania widzialnego i podczerwieni oraz manipulatory.

W skład zespołu wchodzą:

- mały robot mobilny do celów inspekcyjno-ratowniczych;

- robot o zwiększonej funkcjonalności;

- robot interwencyjny.
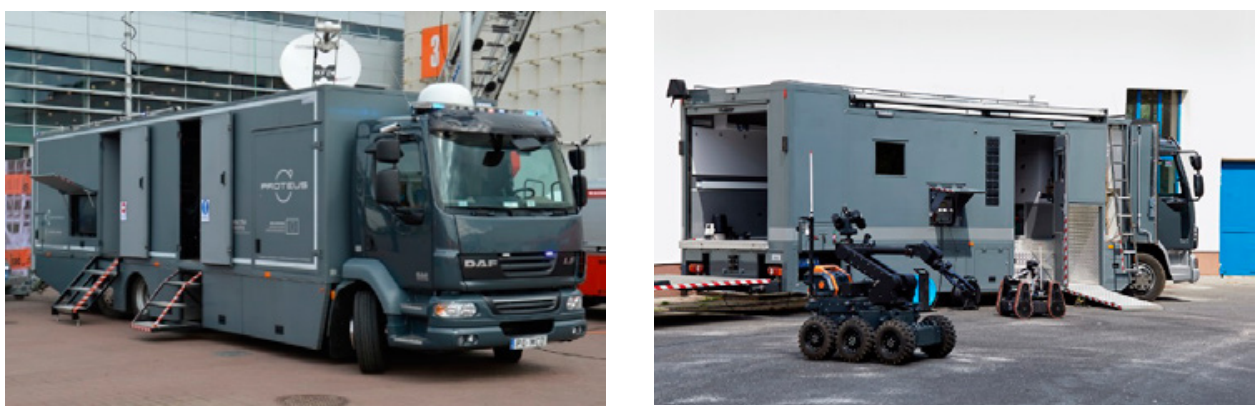

Rysunek 2. Mobilne Centrum Dowodzenia (MCD) i Mobilne Centrum Operatorów Robotów (MCOR)

Źródło: https://www/google.pl, (dostęp: 12.07.2017)

Figure 2. Mobile Command Centre (MCC) and Mobile Robot Operator Centre (MROC) source: https://www/google.pl, access date 12.07.2017

\section{Mały robot mobilny (MRM)}

Zadaniem MRM jest zdalne sprawdzanie miejsc zanieczyszczonych substancjami niebezpiecznymi za pomocą zainstalowanego wyposażenia pozwalającego na pobranie próbek gruntu i innych substancji w zależności od potrzeb.

\section{Robot o zwiększonej funkcjonalności (RMF)}

RMF, dzięki gąsienicowemu układowi napędowemu pozwalającemu na jazdę zarówno na zewnątrz a także, jak i wewnątrz badanych budynków, może wypełniać zadania rozpoznawcze przy pomocy zainstalowanych czujników, interwencyjne dzięki zainstalowanemu manipulatorowi. Wielofunkcyjny manipulator o zasięgu

\footnotetext{
$4 \mathrm{http}: / /$ www.projektproteus.pl

5 Tamże.
} 
Jacek Roguski

2 metrów ma udźwig $28 \mathrm{~kg}$. Manipulator może też być uzbrojony w dodatkowe akcesoria, np. saperskie.

\section{Robot Mobilny Interwencyjny (RMI)}

RMI dzięki zastosowanym rozwiązaniom konstrukcyjnym podwozia ma dobre własności eksploatacyjne również na podłożu nieutwardzonym. Jego konstrukcja pozwala na transport i operowanie ładunkami o masie ok. $40 \mathrm{~kg}$. Zainstalowany manipulator ma zasięg ok. 2,5 m oraz możliwość zainstalowania różnego wyposażenia, takiego jak: prądownica wodna do gaszenia pożarów czy wytwarzania kurtyny wodnej (celem zabezpieczenia RMI przed efektem promieniowania cieplnego), czy sprzęt do cięcia metali.

\section{Zestawy Czujników Nasobnych (NAS)}

Zestawy Czujników Nasobnych są innowacyjną konstrukcją na bazie radiotelefonów nasobnych Motorola. Dzięki stałej komunikacji z Mobilnym Centrum Dowodzenia oraz zainstalowanym urządzeniom (pulsometr, czujnik bezruchu, czujnik temperatury i wilgotności otoczenia) lokalizacja oraz stan zdrowia ratowników są w sposób ciągły monitorowane w formie graficznej na mapie sytuacyjnej stanowiska dowodzenia. Taki ciągły nadzór pozwala na racjonalne i jednocześnie bezpieczne wykorzystanie zasobów ludzkich.

\section{Samolot Bezzałogowy (BSL)}

Jego zadaniem jest obserwacja i pozyskiwanie informacji z zagrożonych obszarów przy wykorzystaniu zainstalowanych urządzeń oraz przekazywanie danych do MCD. Z uwagi na zastosowane rozwiązania konstrukcyjne (start z wykorzystaniem katapulty) oraz częściową autonomię lotu nie wymaga od operatora pełnego przeszkolenia w zakresie pilotażu.

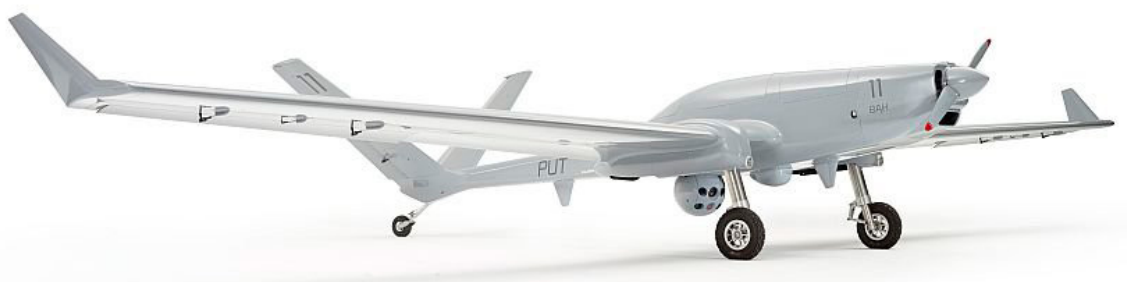

Rysunek 3. Samolot bezzałogowy

Źródło: PIAP

Figure 3. Unmanned Aerial Vehicle

source: PIAP 

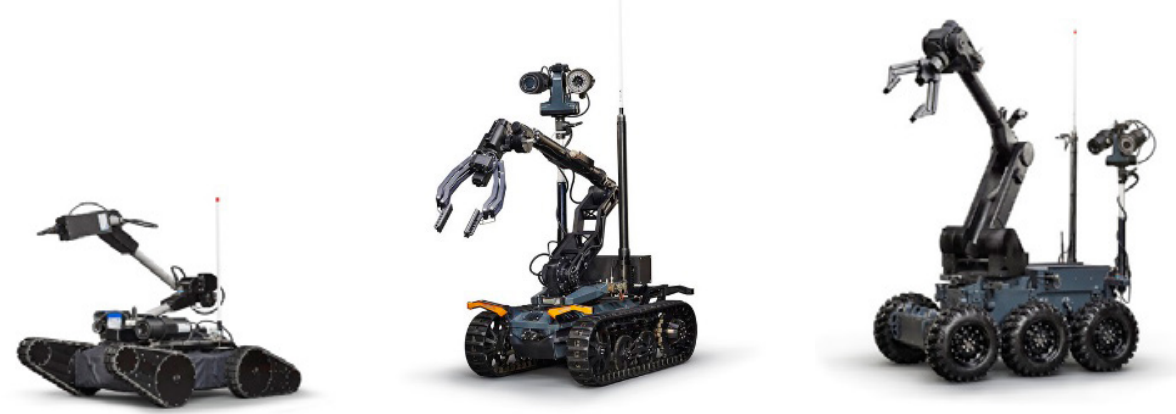

Rysunek 4. Zespół robotów (mały, średni, duży) przewożonych w Mobilnym Centrum Operatorów Robotów (MCOR)

Źrodło: PIAP

Figure 4. A collection ofrobots(small, medium, large) transportedin MobileRobot OperatorCentre(MROC) source: PIAP

W trakcie realizacji projektu oprócz nowatorskich rozwiązań konstrukcyjnych zostały wypracowane innowacyjne systemy przetwarzania i przekazywania informacji oparte o:

- system transmisji danych pozwalających na odbiór informacji z sieci robotów naziemnych i latających przez operatorów i MCD; w sieci istnieje możliwość wykorzystywania jednego z robotów środka wzmacniającego sygnał do transmisji danych;

- system łączności tzw. „małej przepływności” do przekazywania sygnałów sterujących robotami z możliwością wykorzystywania tej sieci do transmisji danych pomiędzy obiektami systemu;

- system łączności przeznaczony do komunikacji i obrazowania sytuacji taktycznej pomiędzy elementami zarządczymi, tzn. MCD i MCOR;

- system łączności głosowej uczestników działań oraz transmisji informacji przekazywanych z czujników nasobnych;

- system łączności umożliwiający dostęp do źródeł zewnętrznych (serwisy meteorologiczne, bazy danych, ekspertyzy zewnętrzne)oraz do zewnętrznych sieci resortowych i telekomunikacyjnych.

Więcej informacji na temat projektu można znaleźć pod adresem: http://www. projektproteus.pl. 


\section{Projekt badawczy „Technologia zmniejszenia zagrożenia wywołanego niekontrolowanym uwalnianiem substancji niebezpiecznych", którego efektem jest bezzałogowa platforma lądowa (BPL) Strażak}

Bezzałogowa platforma lądowa (BPL) Strażak przeznaczona jest do prowadzenia, rozpoznania i likwidacji skutków awarii chemicznych w zakładach produkcyjnych i spedycji materiałów niebezpiecznych. Wyposażona została w osprzęt przeznaczony do podawania wody i środków dekontaminacyjnych. Pompa pożarnicza wraz z układem wodno-pianowym jest umieszczona z przodu pojazdu w przedziale zamykanym drzwiami uchylnymi. Otwarcie i zamknięcie drzwi jest możliwe z poziomu gruntu. Konstrukcja przedziału umożliwia odprowadzanie wody z jego wnętrza. W zbiornik wody o pojemności $1000 \mathrm{dm}^{3}$ wbudowany jest wskaźnik poziomu wody (płynowskaz). Na pulpicie operatora znajduje się kontrolka włączenia pompy.

Układ wodno-pianowy umożliwia:

- podawanie z działka TORNADO RC model: Y2-E12A wody i wodnego roztworu środka pianotwórczego;

- pracę pompy o nominalnym ciśnieniu 10 bar i wydatku wody 2000 l/min przy zasilaniu ze zbiornika wody pojazdu;

- napełnianie zbiornika wody z hydrantu lub za pomocą samochodu gaśniczego.

Konstrukcja układu wodno-pianowego została wykonana z zachowaniem wymagań stosowanych w samochodach pożarniczych. Istnieje możliwość zdalnego odłączania linii tłocznej w celu zapewnienia możliwości ewakuacji pojazdu ze strefy zagrożenia. Ponieważ BPL Strażak przeznaczony jest do pracy w środowisku, gdzie obecność człowieka powinna być ograniczona do minimum, podstawowym zadaniem systemu wizyjnego jest zapewnienie bezpieczeństwa maszynie, operator musi mieć możliwość oceny czy zadanie, które ma wykonać nie naraża sterowanego pojazdu na niebezpieczeństwo bądź nie stwarza zagrożenia dla środowiska. Ze względu na wyposażenie BPL w dodatkowy osprzęt do zwalczania zagrożeń chemicznych, system wizyjny dostarcza informacje odnośnie sposobu jego funkcjonowania. W ten sposób możliwa jest natychmiastowa reakcja w przypadku błędnego zadziałania, minimalizując tym samym negatywne oddziaływanie osprzętu na pojazd i bezpośrednie otoczenie.

Zastosowany system wizyjny to grupa układów współpracujących ze sobą w celu przekazania operatorowi informacji wizualnej dotyczącej pojazdu i jego otoczenia.

Przyjęta koncepcja zakłada wykorzystanie kamer wideo rozmieszczonych w specjalnie wytypowanych miejscach pojazdu. Łącze wideo przesyła obraz z pojazdu do pulpitu operatorskiego jednocześnie z trzech wybranych źródeł. W zależności od realizowanego zadania następuje automatyczne przełączenie się pomiędzy wyselekcjonowanymi grupami kamer wraz z możliwością manualnej kontroli przez operatora pojazdu. 


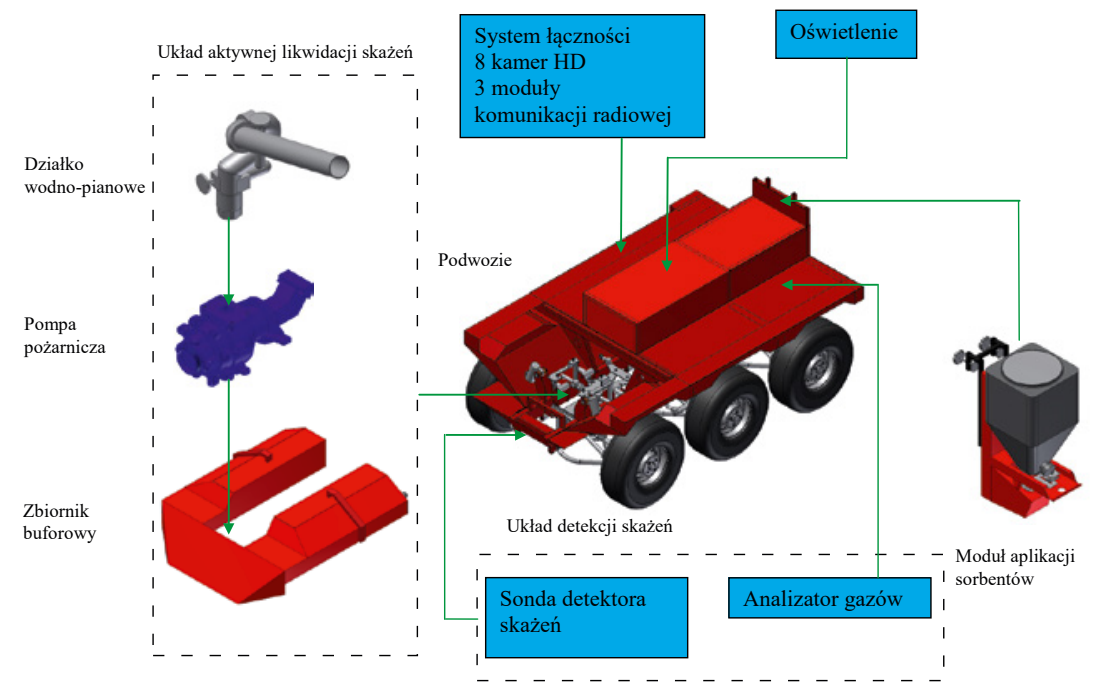

Rysunek 5. Zestawienie systemów BPL Strażak

Źródło: BiTP vol. 30, Issue 2, 2013, pp. 81-90

Figure 5. BPL Strażak system - a configuration

source: BiTP Vol. 30 Issue 2, 2013, pp. 81-90

W grupie kamer przeznaczonych do jazdy z dużymi prędkościami są kamery wideo ustawione w taki sposób, aby ich obraz tworzył jak najdokładniejszą panoramę otoczenia pojazdu - o kącie obserwacji 180 stopni przed pojazdem. Podobnie tworzony jest obraz z kamer do jazdy do tyłu (kąt obserwacji do 180 stopni), zapewnia również wgląd w sposób funkcjonowania urządzeń dodatkowych znajdujących się bądź pracujących z tyłu pojazdu. Natomiast do jazdy w trudnym terenie wykorzystywane są kamery umożliwiające obserwację otoczenia możliwie najbliżej wymiarów obrysowych pojazdu.
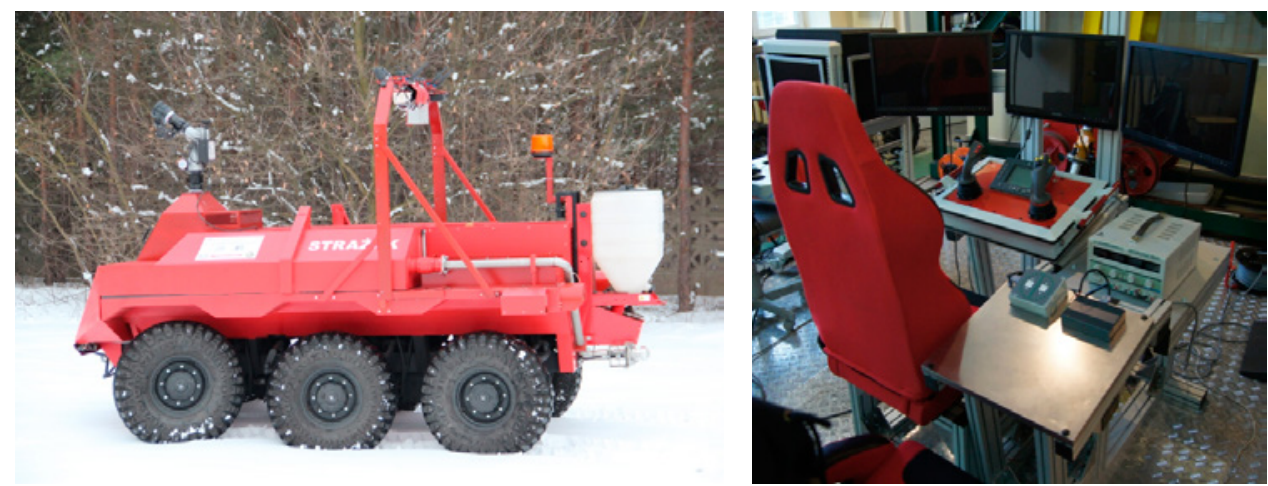

Rysunek 6. BPL Strażak, widok z boku oraz stanowisko sterowania Źrodło: archiwum CNBOP-PIB

Figure 6. BPL Strażak - side view and control station source: $C N B O P-P I B$ archive 


\section{Projekt badawczo-rozwojowy INNOTECH-K1/IN1/70/154619/NCBR/12 „Opracowanie i wdrożenie systemu bezzałogowego pojazdu ratowniczego" finansowany przez NCBR}

Innym rodzajem bezzałogowej platformy lądowej, opracowanej przez Instytut Budowy Maszyn Wydziału Mechanicznego WAT w konsorcjum z WB Electronics S.A. (lider) i Hydromega Sp. z o.o., jest robot ratowniczy „Florian”6, 7 (rys. 7). Powstał on w wyniku realizacji projektu badawczo-rozwojowego „Opracowanie i wdrożenie systemu bezzałogowego pojazdu ratowniczego” dofinansowanego przez Narodowe Centrum Badań i Rozwoju (NCBR).
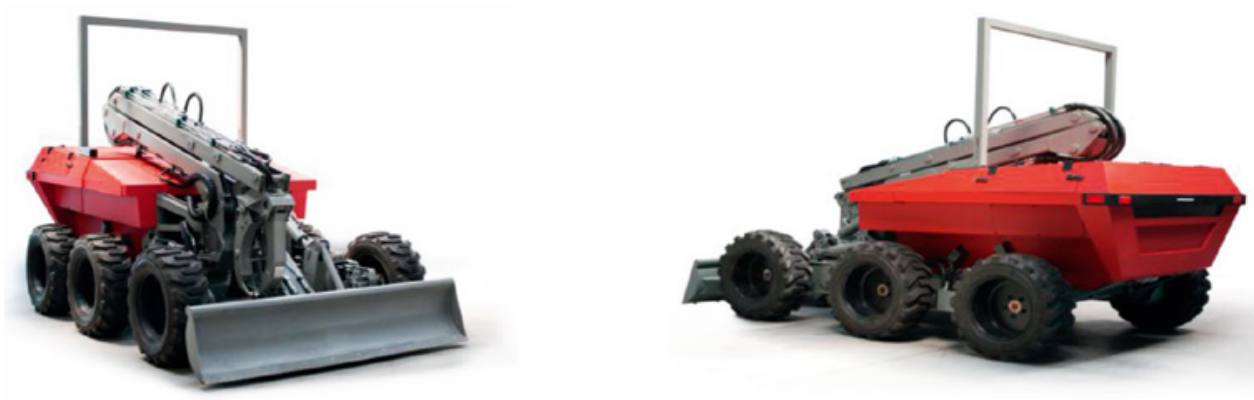

Rysunek 7. Robot ratowniczy „Florian”

Źrodło: http://wb.com.pl/florian

Figure 7. Rescue robot "Florian”

source: http://wb.com.pl/florian

W trakcie projektu opracowano:

- bezzałogowy pojazd ratowniczy z systemem osprzętu roboczego;

- system transportowy do przemieszczania BPL Florian;

- mobilne stanowisko kierowania wraz z systemem łączności pozwalające na zdalne kierowanie oraz zbiór informacji z zainstalowanych czujników/sensorów.

Masa platformy wynosząca $2800 \mathrm{~kg}$ zapewnia dobre własności trakcyjne i ruchowe $\mathrm{w}$ różnych warunkach terenowych oraz pozwala na transport pojazdu do miejsca prowadzenia działań z wykorzystaniem nośnika transportowego o DMC = $=3500 \mathrm{~kg}$ holowanego przez lekki samochód ciężarowy o DMC $=4655 \mathrm{~kg}$.

Do prac ratowniczych przygotowane są dwa urządzenia:

- manipulator o udźwigu $200 \mathrm{~kg}$ i wysięgu ok. 4 m;

- ładowarka o udźwigu do $1000 \mathrm{~kg}$ i wysokości podnoszenia 1,5 m.

Pojazd został wyposażony w lemiesz pozwalający na usuwanie przeszkód o masie do $2000 \mathrm{~kg} \mathrm{z}$ drogi, po której porusza się platforma. W celu poprawienia funkcjonalności użytkowej Florian został wyposażony w przyłącza pozwalające na dołączenie osprzętu stosowanego w minikoparkach.

6 http://klastermorski.com.pl/wp-content/uploads/2014/04/Pojazd-Ratowniczy-Florian-HYDROMEGA

7 http://wb.com.pl/florian/ 
W pojeździe zastosowano, wg informacji podanej przez WB Electronics, innowacyjny układ napędowy jazdy i sterowania osprzętami, pracujący w technologii CANbus. Uzyskano bardzo dobre własności terenowe, wysoką stateczność podłużną i poprzeczną, umożliwiającą wjazd na zbocza o pochyleniu do $60 \%$ oraz możliwość jazdy wzdłuż zbocza o pochyleniu do $30 \%$.

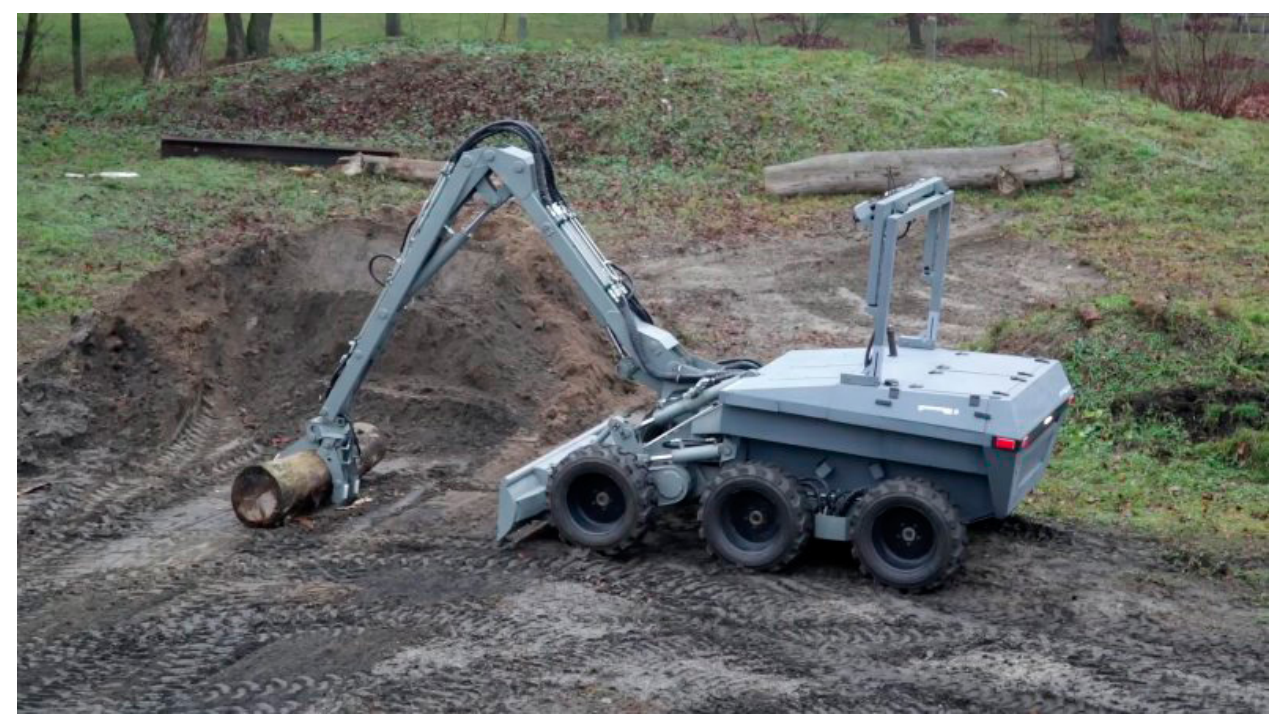

Rysunek 8. Robot Florian

Źródło: http://www.altair.com.pl/magazines/htmlissue?issue_id=704\&ref=issue\#page/14

Figure 8. Florian robot

source: http://www.altair.com.pl/magazines/htmlissue?issue_id=704むref=issue\#page/14

\section{Projekt 0013/R/ID2/2011/01 „Optymalizacja procedur, dyslokacji baz i doskonalenie rozwiązań technicznych sprzętu stosowanego przez polskie służby ratownicze w zakresie przeciwdziałania zagrożeniom naturalnym ze szczególnym uwzględnieniem powodzi (rękawy przeciwpowodziowe)"}

Cel projektu obejmuje wielopłaszczyznowe działania, które mają za zadanie kompleksowe ujęcie problemu ochrony przeciwpowodziowej w naszym kraju. Dzięki przekrojowemu prowadzeniu prac zrealizowano zadania obejmujące opracowanie Lokalnego Systemu Ostrzegania przed powodzią, przygotowanie dokumentacji ochrony przeciwpowodziowej na wybranym terenie zalewowym, która zawierała weryfikację procedur reagowania i alarmowania ludności na tym obszarze. $\mathrm{W}$ projekcie zaproponowano również możliwość poprawy dyslokacji baz sprzętowych zawierających wyposażenie przeciwpowodziowe. W efekcie projektu opracowane zostały: 
Rękaw przeciwpowodziowy, który ma za zadanie ochronę terenów zagrożonych przed zalaniem. Ich innowacyjny charakter opiera się na niezwykle prostym założeniu wypełnieniu wnętrza wewnętrznego rękawa wodą.

Wyspecjalizowany Zestaw Przeciwpowodziowy (WZP) składa się z pływającego pojazdu ratowniczego Wydra oraz przyczepy $\mathrm{z}$ wyposażeniem przeznaczonym do prowadzenia akcji przeciwpowodziowej. Amfibia Wydra zaprojektowana została do realizacji zadań ratowniczych i ewakuacyjnych prowadzonych na miejscach rozlewisk występujących w czasie powodzi. Podstawową funkcją zaprojektowanej przyczepy jest dostarczenie odpowiedniego zestawu sprzętu i wyposażenia, $\mathrm{w}$ tym również rękawów przeciwpowodziowych, na miejsce akcji.
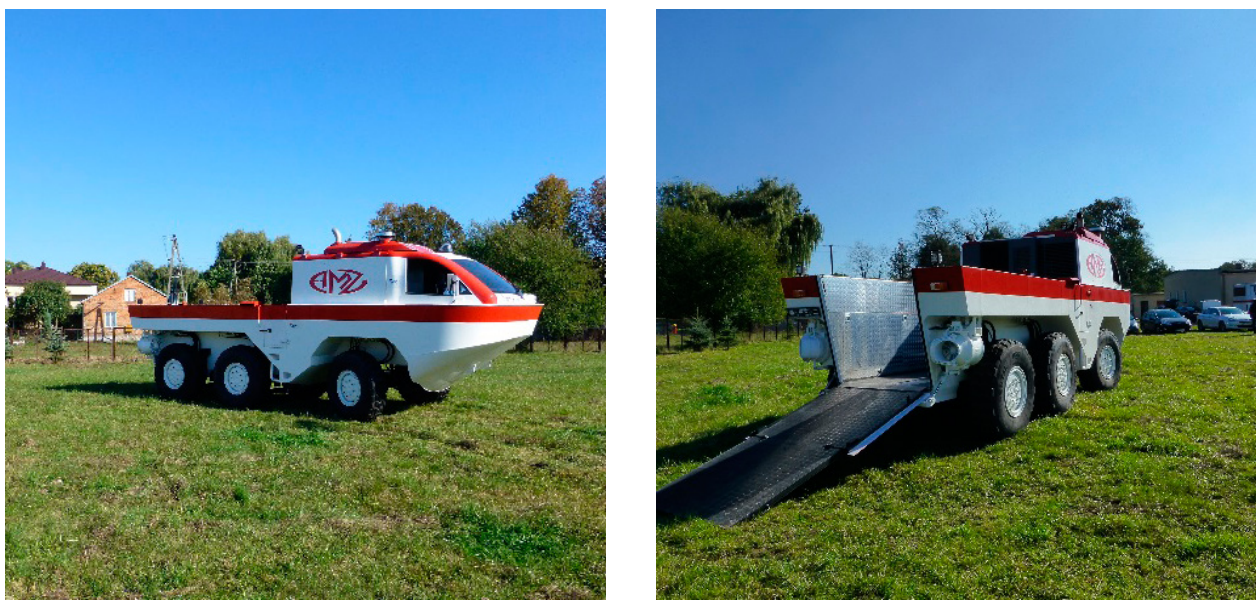

Rysunek 9. Amfibia Wydra

Źródło: autorzy zdjęć: P. Suchorab, D. Riegert

Figure 9. Wydra (Otter) amphibious vehicle source: P. Suchorab, D. Riegert

\section{Projekt DOBR BIO4/051/13087/2013 „Opracowanie metodologii stałego nadzoru eksploatacji wybranych obszarów wyposażenia straży pożarnej w zakresie niezawodności i skuteczności działania"}

W ramach prac realizowanych w projekcie został opracowany system teleinfomatyczny, który, bazując na informacjach pobieranych z sensorów zainstalowanych na wytypowanych do badań jednostkach sprzętu stosowanego w jednostkach ochrony przeciwpożarowej, pozwala na samodzielne gromadzenie informacji eksploatacyjnych oraz prognozowanie stanu technicznego i napraw. W warunkach poligonowych zbliżonych do rzeczywistych zostały sprawdzone parametry funkcjonalne wytworzonego demonstratora systemu zarządzania eksploatacją wytypowanego sprzętu. 


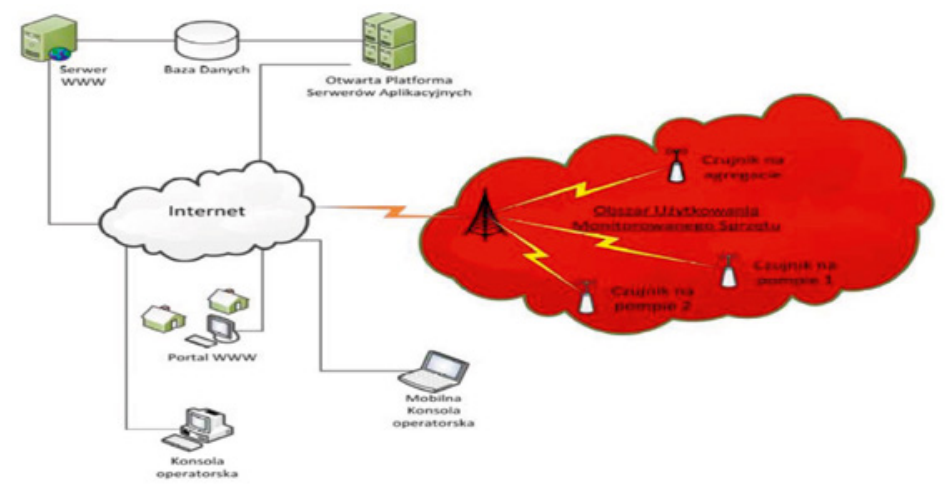

Rysunek 10. Schemat funkcjonalny systemu monitorowania stanu technicznego Źródło: Opracowania własne z projektu „Opracowanie metodologii stałego nadzoru eksploatacji wybranych obszarów wyposażenia straży pożarnej w zakresie niezawodności i skuteczności działania"

Figure 10. Functional diagram of the system for monitoring of technical condition of assets source: own work from project „Opracowanie metodologii stałego nadzoru eksploatacji wybranych obszarów wyposażenia straży pożarnej w zakresie niezawodności i skuteczności działania" (Development of methodology for constant supervision operation of selected areas of firefighters accessory in terms of reliability and efficiency)

Powstałe narzędzie informatyczne wraz z systemem diagnostyki technicznej środków może wykonywać prognozy eksploatacyjne, a na ich podstawie raporty pomocne do podejmowania decyzji logistycznych.

Końcowym produktem projektu jest demonstrator, na który składają się:

- system sensorów monitorujący stan wybranych urządzeń;

- system łączności umożliwiający przekaz pozyskanych danych operacyjnych oraz zdalny dostęp do stworzonego systemu;

- system informatyczny gromadzący i transformujący pozyskane oraz uzupełniający dane logistyczne dotyczące obsługi i zakupów sprzętu.

Do podstawowych funkcji operacyjnych systemu stworzonego w ramach projektu należą:

- monitoring eksploatacji wybranego wyposażenia straży pożarnej za pomocą sensorów wytworzonych w ramach projektu;

- archiwizowanie oraz zarządzanie pozyskanymi informacjami;

- bezpieczne udostępnianie informacji dzięki wieloetapowemu systemowi uprawnień;

- przedstawianie informacji zgromadzonych $\mathrm{z}$ różnych źródeł w postaci specjalnie utworzonych raportów oraz wykresów ${ }^{8}$.

Przykładowy odczyt $\mathrm{z}$ sensorów przedstawiono poniżej:

8 Wspomaganie procesów zarządzania działaniami w straży pożarnej, wyd. CNBOP-PIB, 2015, s. $5-68$. 

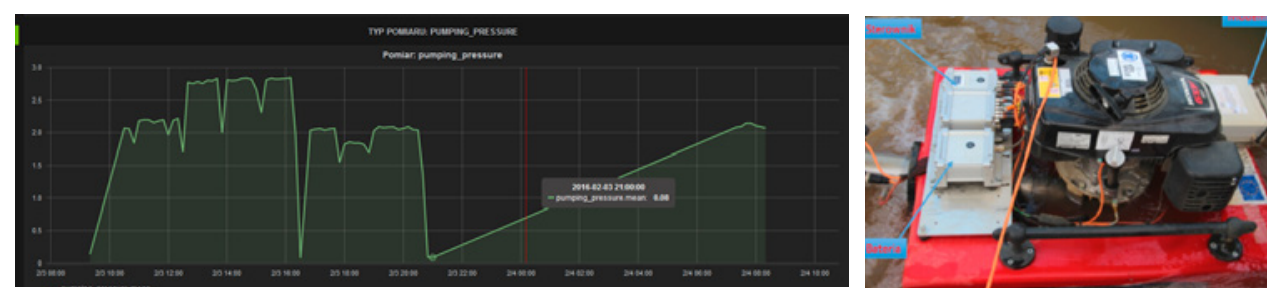

Rysunek 11. Przykładowy zapis ciśnienia tłoczenia dla monopompy Niagara I

Źródło: Sprawozdanie częściowe z projektu „Opracowanie metodologii stałego nadzoru eksploatacji wybranych obszarów wyposażenia straży pożarnej w zakresie niezawodności i skuteczności działania"

Figure 11. An example recording of the displacement pressure for the Niagara I motor pump source: partial report from the project Opracowanie metodologii stałego nadzoru eksploatacji wybranych obszarów wyposażenia straży pożarnej w zakresie niezawodności i skuteczności działania (Development of methodology for constant supervision operation of selected areas of firefighters accessory in terms of reliability and efficiency)

\section{Projekt DOBR BIO4/047/13419/2013 „System kompleksowego zabezpieczenia logistycznego wielopodmiotowych akcji ratowniczych"9, 10}

Nowatorskim podejściem jest wytworzenie jednorodnego systemu zbierania wybranych informacji i przesyłania wybranych komunikatów, który będzie możliwy do wykorzystania przez wszystkie podmioty biorące udział $w$ akcji ratowniczej. Osiągnięcie tego celu będzie możliwe dzięki wyposażeniu wybranych pojazdów w terminale - końcówki systemu wspomagającego kompleksowe zabezpieczenie logistyczne wielopodmiotowej akcji ratowniczej. Terminale te mają postać tabletów montowanych do przedniej szyby pojazdu (lub w innym miejscu w przypadku jej braku). Zbędne jest stosowanie dużo większego urządzenia wyposażonego w klawiaturę, gdyż załoga pojazdu nie powinna być zmuszona do wpisywania długich wiadomości tekstowych (odpowiedzi ze strony załogi powinny być ograniczone do prostych działań, takich jak wysłanie potwierdzenia przyjęcia komunikatu wysłanego przez centralny serwer, a to wymaga naciśnięcia tylko jednego przycisku). Każde takie urządzenie będzie wyposażone w odbiornik sygnału GPS i/lub GLONAS oraz moduł komunikacji radiowej, np. modem LTE. Dzięki transmisji bezprzewodowej terminal spełnia trzy zasadnicze funkcje:

- przesyła informacje o położeniu pojazdu do serwera systemu;

- pobiera $z$ serwera systemu informacje o dostępnych zasobach i innych pojazdach z uwzględnieniem ich położenia w przestrzeni;

- wyświetla polecania/rozkazy przekazane za pośrednictwem centralnego serwera systemu.

9 Logistyka wielopodmiotowych akcji ratowniczych, wyd. CNBOP-PIB, 2016, s. 77-84.

10 Wspomaganie procesów zarządzania działaniami w straży pożarnej, wyd. CNBOP-PIB, 2016, s. $97-107$. 
Strukturę systemu w powiązaniu z używanym sprzętem przedstawia poniższy schemat.

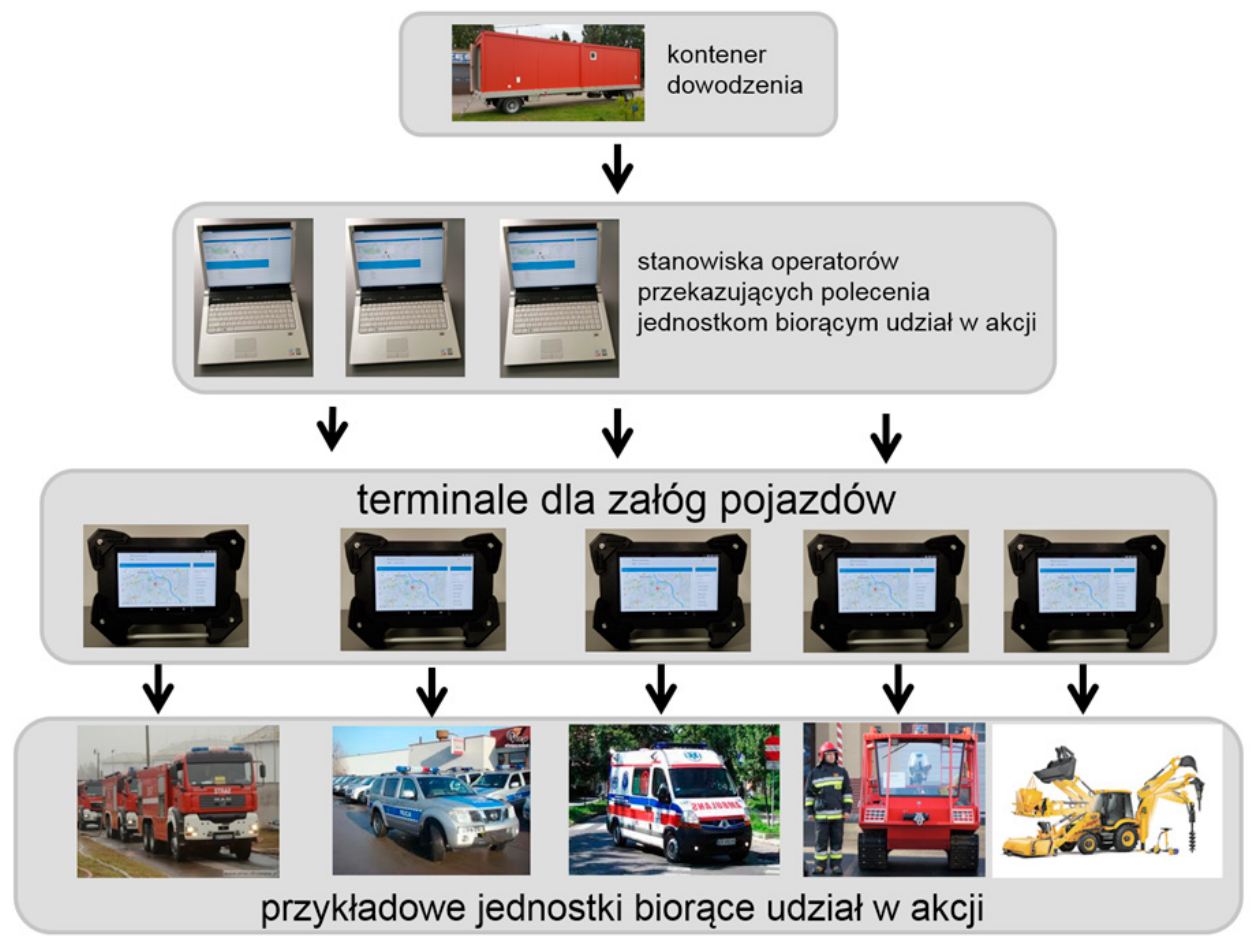

Rysunek 12. Struktura systemu w powiązaniu z używanym sprzętem Źródło: A. Grabowski

Figure 12. System structure in connection with assets used source: A. Grabowski

Centrum zarządzania systemu jest kontener $\mathrm{z}$ wyposażeniem do wspomagania działań Kierującego Działaniami Ratowniczymi (KDR) oraz jego Zastępcy ds. Logistyki. Stanowisko kierowania zostało zaopatrzone we własne źródło zasilania (z możliwością wykorzystania zewnętrznych źródeł), oświetlenie, klimatyzację i niewielkie zaplecze socjalne. Funkcjonalnie zostało podzielone na dwie części, pierwszą przeznaczoną dla KDR i jego zastępców, wyposażoną w sprzęt wideo do prezentacji danych na mapie taktycznej, drukarkę, skaner oraz narzędzia informatyczne wspomagające kierowanie działaniami ratowniczymi. W drugiej części przewidziane są stanowiska dla operatorów koordynujących realizację zaplanowanych zadań. Operatorzy mają połączenie z centralnym serwerem za pośrednictwem bezprzewodowych stanowisk komputerowych. Pozwala to na ich funkcjonowanie w sposób najbardziej korzystny z punktu widzenia logiki zarządzania. Mogą być w danym momencie tam, gdzie znajduje się osoba odpowiedzialna za zarządzanie w oparciu o dowolną infrastrukturę przy zapewnieniu niezbędnej infrastruktury telekomunikacyjnej. 
Operatorzy komunikują się z osobami realizującymi działania ratownicze za pomocą terminali umieszczonych w pojazdach. Terminale mocowane są za pomocą przyssawek do przedniej szyby pojazdu, pozwalają na przesyłanie rozkazów oraz lokalizacji miejsca docelowego, w którym będzie działać dany pojazd wyświetlają na mapie taktycznej wszelkie niezbędne informacje o lokalizacji wszystkich pojazdów, drogi przejazdu oraz o etapie wykonywanych prac. Zastosowanie terminali uzupełnia stosowane rozwiązania i systemy łączności (np. poprzez wizualizację mapy) oraz pozwala na połączenie różnych elementów w jedną całość. W szczególności umożliwia objęcie tym samym systemem łączności pojazdów nietypowych, np. amfibie, a przede wszystkim pojazdów, które nie mają własnych środków łączności (np. pojazdy cywilne), a których wykorzystanie z pewnych powodów w działaniach ratowniczych jest niezbędne. W przypadku aplikacji „System kompleksowego zabezpieczenia logistycznego wielopodmiotowych akcji ratowniczych" oprogramowanie jednostki centralnej zachowuje wszystkie pozyskane dane, pozwalając na ich wykorzystanie w zależności od posiadanych uprawnień. Użytkownik, korzystając $\mathrm{z}$ aplikacji poprzez terminal, wysyła zapytania serwerowi w sprawach istotnych dla posiadanego poziomu uprawnień (posiadane zapasy, podgląd raportów, generowanie tras dojazdu itp.). Serwer wyszukuje informacje z bazy danych lub wykonuje funkcje i wysyła odpowiedź do terminala użytkownika. Po wykonaniu powyższych czynności terminal odpowiednio reaguje na otrzymane dane i automatycznie je prezentuje, a następnie umożliwia połączenie mające na celu pozyskanie kolejnych informacji.

Stworzone oprogramowanie pozwala na realizowanie przykładowych funkcji:

- zarządzanie dostępem do systemu w celu określenia roli użytkownika, jego praw i możliwości dostępu do danych, jak również funkcjonalności oprogramowania;

- ewidencja zasobów oraz możliwości logistycznych w trakcie prowadzonych działań takich jak: system zarządzania bazą danych zasobów użytkowanych w trakcie działań, ewidencji podmiotów logistycznych, posiadanych zasobów i źródeł zaopatrzenia, niezbędnych norm zaopatrzeniowych, dostępności do zasobów itp.;

- wspomaganie realizacji potrzeb logistycznych takich jak: rezerwacja określonego produktu, zabezpieczenie przed możliwością jednoczesnego wielokrotnego rezerwowania zasobu;

- wspomaganie opracowania logistycznych dokumentacji planistycznych takich jak: plan świadczenia usług w zakresie logistycznym, medycznym, organizacyjnym w zakresie wzorów dokumentacji;

- wspomaganie w zakresie dokumentacji pomocniczej w zakresie meldunków, raportów, wykresów graficznych, w tym importu do plików PDF;

- wspomaganie osób zarządzających działaniami poprzez wyświetlanie aktualnych map uwzględniających obecne położenie sił i środków, możliwość rejestracji przebiegu działań, prowadzonej komunikacji radiowej, kontroli 
czasu pracy każdej jednostki w ramach działań ratowniczych, prezentowania stref zagrożenia, alertów czasowych dla ludzi i sprzętu;

- wspomaganie pracy osób wyposażonych w terminale w zakresie wyświetlania map z uwzględnieniem aktualnego położenia pojazdu, stref zagrożenia, komunikatów tekstowych od KDR oraz zgłaszania potrzeb logistycznych.

Projekty dotyczące bezpieczeństwa strażaków-ratowników w trakcie działań.

\section{Projekt 0014/R/ID1/2011/01 „Nowoczesne ochrony osobiste służb ratowniczych KSRG w oparciu o potrzeby użytkowników końcowych"}

Produktem wspierającym działania decyzyjne w zakresie bezpieczeństwa ratowników w prowadzonych czynnościach ratowniczo-gaśniczych jest system monitorowania funkcji życiowych oraz lokalizacji o akronimie FIREGUARD 2015 powstały w ramach projektu finansowanego przez NCBR. W projekcie stworzono narzędzie pozwalające na sprawdzenie w rzeczywistych warunkach eksploatacji cech użytkowych odzieży strażackiej oraz cech psychomotorycznych ratowników oparte na elektronicznym systemie złożonym z jednostki centralnej, przekaźników radiowych oraz tzw. ubrania „inteligentnego” (typu „smart”), wyposażonego w urządzenia elektroniczne umożliwiające zdalne pomiary parametrów środowiskowych oraz fizjologicznych. System ćwiczebny zintegrowany opracowany został do zautomatyzowanego weryfikowania poziomu zmęczenia strażaka (oraz ewentualnego zagrożenia życia), analizy wydolności organizmu na podstawie wyników testu wysiłkowego pozycjonowania strażaka ratownika w warunkach symulowanego środowiska pracy (poligon i komora testowa), weryfikacji parametrów użytkowych odzieży oraz jej komfortu.

System ćwiczebny niezależny ma analogiczne funkcje monitorowania parametrów ratowników jak system zintegrowany. Różnica polega na umieszczeniu układów pomiarowych w specjalnie zaprojektowanym podkoszulku zamiast w kurtce. Takie rozwiązanie umożliwia sprawdzenie parametrów fizjologicznych ratownika w trakcie prac wykonywanych w różnych wersjach odzieży ochronnej. Przyjęta metodyka pozwala na ocenę komfortu użytkowania/eksploatacji odzieży ochronnej różnej konstrukcji. Pomiary dowolnego ubrania wierzchniego mogą być wykonywane za pomocą systemu niezależnego pod warunkiem podłączenia od zewnątrz modułu osobistego. 


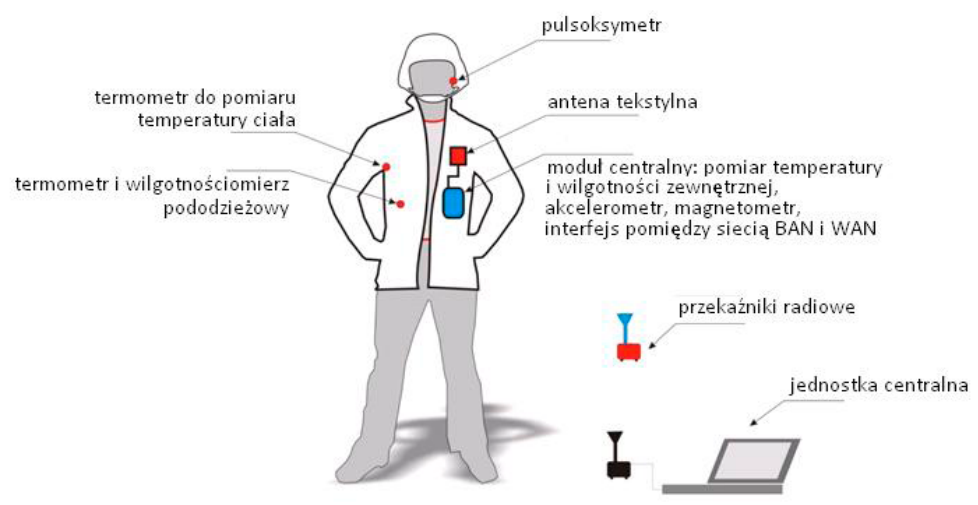

Rysunek 13. Ćwiczebny system zintegrowany

Źródło: Politechnika Łódzka, Uniwersytet Medyczny, Texa S.C, Ł. Januszkiewicz

Figure 13. Integrated training system

source: Lodz Technical University, Medical University, Texa S.C, Ł. Januszkiewicz

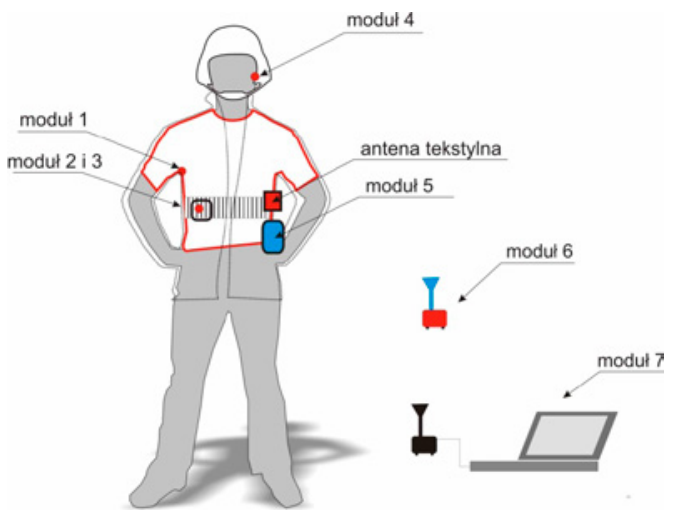

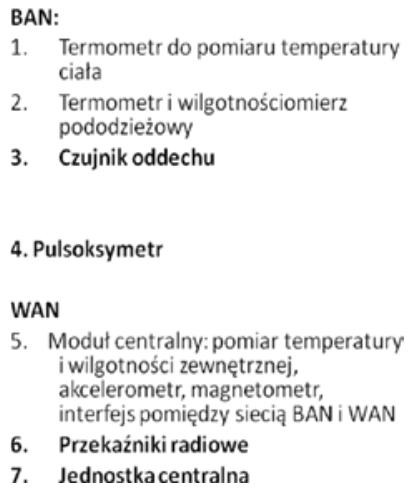

1. Termometr do pomiaru temperatury ciala

2. Termometr i wilgotnościomierz pododzieżowy

3. Czujnik oddechu

4. Pulsoksymetr

WAN

5. Moduł centralny: pomiar temperatury

i wilgotności zewnętrznej,

akcelerometr, magnetometr.

interfejs pomiędzy siecią BAN i WAN

6. Przekaźniki radiowe

7. Jednostkacentralna

Rysunek 14. Ćwiczebny system niezależny

Źródło: Politechnika Łódzka, Uniwersytet Medyczny, Texa S.C, Ł. Januszkiewicz

Figure 14. Independent training system

source: Lodz Technical University, Medical University, Texa S.C, Ł. Januszkiewicz

Oprócz działań charakterystycznych dla innowacyjnych rozwiązań systemowych dla projektów rozwojowych zmierzających do transformacji w sferze bezpieczeństwa ratowników Krajowego Systemu Ratowniczo-Gaśniczego, w projekcie zrealizowano tzw. systemy monitorowania funkcji życiowych ratownika podczas czynności ratowniczych.

Ten właśnie produkt zasługuje na szczególną uwagę. Jego realizacja zmierzała do stworzenia metodyki pozwalającej na sprawdzenie i weryfikację w warunkach zbliżonych do rzeczywistych własności ergonomicznych odzieży strażackiej oraz sprawdzenia cech psychomotorycznych ratowników (biorących udział w szkoleniach KSRG). Metoda oparta jest na elektronicznym systemie złożonym 
z jednostki centralnej, przekaźników radiowych oraz tzw. ubrania „inteligentnego” (typu „smart”), wyposażonego w odpowiednio zaprojektowane urządzenia elektroniczne umożliwiające zdalne pomiary parametrów środowiskowych oraz fizjologicznych.

Zaprojektowano konstrukcje, materiały i sposoby wytwarzania anten tekstylnych wbudowanych w ubrania specjalne, a także wypracowano projekt geometrii anteny, przeprowadzono optymalizację doboru materiałów do jej wykonania oraz zweryfikowano różne metody nanoszenia materiałów na podłoża elastyczne oraz sposoby izolowania wytworzonych promienników tekstylnych.

Anteny systemowe zostały zintegrowane z inteligentnym ubraniem. Użycie tekstylnych materiałów elektroprzewodzących i elektroizolujących pozwalało uzyskać dużą elastyczność, mały ciężar oraz skuteczne połączenie anteny z ubraniem bez ograniczeń swobody ruchów użytkownika. Rozwiązanie to było efektem zastosowania miniaturowych jednoukładowych programowalnych nadajników, elastycznych anten tekstylnych oraz elastycznych obwodów drukowanych, miniaturowych źródeł zasilania. Masa zastosowanych układów pomiarowych nie przekracza $400 \mathrm{~g}$.

Inne produkty projektu, tj. prototypy innowacyjnych środków ochrony indywidualnej, stanowią najnowsze osiągnięcia technologii ochron osobistych. Zastosowano w nich optymalizowane układy materiałowe w kompozycjach inżynierskich uwzględniających wymagania funkcjonalne ratowników Krajowego Systemu Ratowniczo-Gaśniczego i zapisów Dyrektywy 89/686 EWG „Środki ochrony indywidualnej”.

Ostatecznemu wykreowaniu demonstratora towarzyszy szereg badań nawiązujących do rzeczywistych warunków realizacji czynności ratowniczych przez strażaków ratowników Krajowego Systemu Ratowniczo-Gaśniczego.

Wynikami końcowymi realizacji projektu są w szczególności:

- system monitorowania uczestnika akcji ćwiczebnej, prototyp systemu ubrania ćwiczebnego (z systemem monitorowania pracy ratownika) tzn. bezprzewodowego systemu monitorowania składającego się z następujących modułów: kurtka inteligentna, inteligentny podkoszulek, moduł osobisty współpracujący z podkoszulkiem, przekaźniki lokalizujące, moduł centralny;

- partia prototypowa innowacyjnego ubrania specjalnego nowej generacji (o maksymalnie ograniczonej masie);

- partia prototypowa innowacyjnego „ubrania do działań ratowniczo-gaśniczych na przestrzeniach otwartych";

- partia prototypowa innowacyjnych hełmów strażackich kompatybilnych z projektowanymi ochronami tułowia (ubrania specjalne).

Dotychczasowa pragmatyka procesu oceny konstrukcji oraz oceny funkcjonalno-ergonomicznej oparta była na sprawdzeniach i doświadczeniach wykonanych przez producentów/dostawców. W zaproponowanych rozwiązaniach bardzo istotną rolę spełniły badania opinii użytkowników, zarówno w etapie założeń wstępnych, jak i oceny wyrobu końcowego, znacząco rozszerzając spektrum opiniowania. 
W obu modelach ubrań specjalnych zastosowano szereg rozwiązań niewystępujących w obecnie użytkowanych ochronach. Duży nacisk położony na ergonomiczne walory wpłynął na znaczące rozszerzenie konstrukcji ogólnej ubrań. Pojawiło się w niej szereg nowych, uznanych przez respondentów i środowisko ekspertów rozwiązań. Dotyczą one sfery materiałowej i strukturalnej konstrukcji. W sferze materiałowej duży nacisk położono na trwałość, odporność na jak najszerszą gamę czynników oddziaływania destrukcyjnego środowiska operacyjnego działań ratowniczo-gaśniczych przy minimalnej masie powierzchniowej. Masę powierzchniową uznano w trakcie projektu za bardziej reprezentatywny parametr od masy całkowitej ze względu na specyfikę i różnorodność dodatkowego wyposażenia (charakterystycznego dla poszczególnych jednostek KSRG) sprzężonego z ubraniem specjalnym, które wpływa na wielkość masy całkowitej ubrania.

Hełm strażacki, stanowiący kolejny produkt główny projektu, charakteryzuje się następującymi innowacyjnymi rozwiązaniami:

- konstrukcją wyrobu zapewniającą wysoką ergonomię noszenia i użytkowania, optymalizacja kształtu czaszy zapewnia uzyskanie złożonego kształtu ze zintegrowanymi funkcjami, co umożliwia właściwą eksploatację i obsługę najnowszej techniki w warunkach operacyjnych;

- wyposażeniem w podwójną sferyczną osłonę oczu i twarzy zawierającą powłoki ochronne o działaniu refleksyjnym umożliwiające zastosowanie w warunkach oddziaływania wysokich temperatur;

- wyposażeniem wewnętrznym mającym bezpośredni kontakt ze skórą użytkownika, będzie wykonane na bazie zaawansowanych technologicznie materiałów o właściwościach bakteriostatycznych, które utrzymują naturalną równowagę w ilości bakterii na skórze, co eliminuje ryzyko wystąpienia alergii oraz powstawania nieprzyjemnych zapachów.

Rozwiązania te mają na celu zapewnienie hełmowi właściwości użytkowych na poziomie wyższym niż w przypadku wyrobów dotychczas stosowanych przez jednostki straży pożarnej spełniających wymogi obowiązującej normy PN-EN 443:2008 „Hełmy stosowane podczas walki z ogniem w budynkach i innych obiektach”.

\section{Projekt DOBR/0011/R/ID1/2013/03 „Opracowanie innowacyjnego systemu stanowisk do badań ochron osobistych" (2013-2016)}

W ramach projektu DOBR/0011/R/ID1/2013/03 „Opracowanie innowacyjnego systemu stanowisk do badań ochron osobistych” finansowanego przez NCBR zrealizowano następujące stanowiska badawcze do ponadnormatywnych badań próbek oraz materiałów wykorzystywanych w produkcji ochron osobistych:

- stanowiska do oceny właściwości mechanicznych i cieplnych materiałów ochron osobistych;

- metodologia prowadzenia badań materiałów elementów ochron osobistych;

- modele fizyczne i matematyczne transportu ciepła i wilgoci w elementach ochron osobistych; 
- symulacje numeryczne obciążenia różnymi czynnikami termicznymi ochron osobistych ratownika;

- dokumentacja techniczno-ruchowa stanowisk badawczych.

Wytworzone stanowiska pozwoliły na przeprowadzenie badań statycznych i dynamicznych materiałów z uwzględnieniem oddziaływań termicznych oraz płomienia. Wyposażone zostały w wielokanałowe układy akwizycji danych pozwalające na przeprowadzenie badań materiałów i pakietów materiałowych ochron osobistych strażaka.
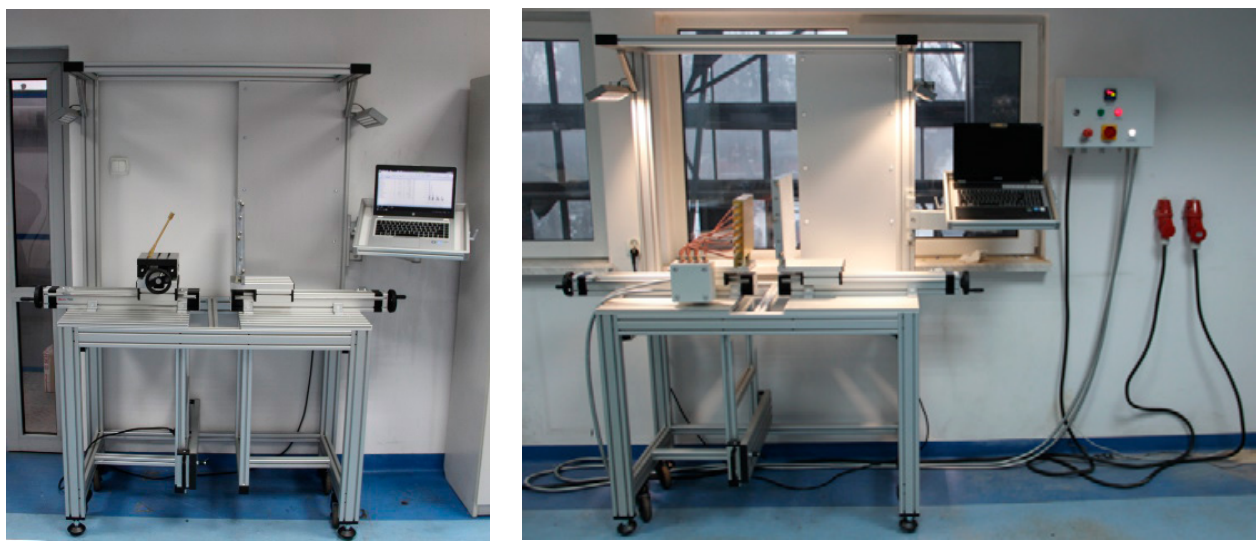

Rysunek 15. Widok stanowisk badawczych - oddziaływanie płomienia oraz ciepła kontaktowego Źródło: opracowania projektu

Figure 15. Research stations - impact of flames and contact with high temperature source: project description

W ramach projektu zespół pracowników Instytutu Techniki Cieplnej Politechniki Warszawskiej stworzył modele transportu ciepła i wilgoci w elementach ochron osobistych z uwzględnieniem różnych materiałów i ich konfiguracji. Wzrost wilgoci w złożonych strukturach materiałowych powoduje obniżenie własności ochron osobistych, co przekłada się bezpośrednio na bezpieczeństwo strażaków-ratowników.

Efektem tych działań jest możliwość oceny aktualnie użytkowanych struktur materiałowych do produkcji ochron osobistych w znacznie szerszym ujęciu niż dotychczas przy wykorzystaniu opracowanych metod badawczych pozwalających na lepszą ocenę skuteczności ochron osobistych. W warunkach rzeczywistych może wystąpić spiętrzenie czynników niekorzystnych, co może zostać odwzorowane w powstałych stanowiskach badawczych. Pozwalają one na badanie wyrobu, który był poddany procesowi starzenia $\mathrm{w}$ warunkach jednoczesnego obciążenia mechanicznego i termicznego, co pozwala uzyskać pełniejszą informację o właściwościach ochron. Wykonane stanowiska pozwalają na określenie istotnych własności krytycznych w warunkach złożonych obciążeń zewnętrznych. Wyniki badań właściwości termofizycznych oraz badań na zaprojektowanych stanowiskach pojedynczych materiałów oraz ich zestawów w różnych konfiguracjach warunków użytkowania dostarczają informacji dotyczących możliwych i celowych 
modyfikacji materiałów i ich zestawów oraz pozwalają na realizację procesu badawczego skuteczności systemów ochronnych stosowanych w jednostkach ochrony przeciwpożarowej.

\section{Bibliografia}

[1] Opracowania projektu POIG.01.02.01-00-014/08 „Zintegrowany mobilny system wspomagający działania antyterrorystyczne i antykryzysowe - „Proteus «".

[2] Opracowania projektu „Technologia zmniejszenia zagrożenia wywołanego niekontrolowanym uwalnianiem substancji niebezpiecznych".

[3] Opracowania projektu 0013/R/ID2/2011/01 „Optymalizacja procedur, dyslokacji baz i doskonalenie rozwiązań technicznych sprzętu stosowanego przez polskie służby ratownicze $\mathrm{w}$ zakresie przeciwdziałania zagrożeniom naturalnym ze szczególnym uwzględnieniem powodzi (rękawy przeciwpowodziowe)”.

[4] Opracowania projektu DOBR BIO4/ 051/13087/2013 „Opracowanie metodologii stałego nadzoru eksploatacji wybranych obszarów wyposażenia straży pożarnej w zakresie niezawodności i skuteczności działania”.

[5] Roguski J. (red.), Wspomaganie procesów zarządzania działaniami w straży pożarnej, wyd. CNBOP-PIB, 2015.

[6] Roguski J. (red.), Logistyka wielopodmiotowych akcji ratowniczych, wyd. CNBOP-PIB, 2016.

[7] Roguski J. (red.), Wspomaganie procesów zarzadzania działaniami w straży pożarnej, wyd. CNBOP-PIB, 2016.

[8] Dokumentacja projektu 0014/R/ID1/2011/01 „Nowoczesne ochrony osobiste służb ratowniczych KSRG w oparciu o potrzeby użytkowników końcowych".

[9] Dokumentacja projektu DOBR/0011/R/ID1/2013/03 „Opracowanie innowacyjnego systemu stanowisk do badań ochron osobistych".

[10] http://www.projektproteus.pl (dostęp: 28.01.2018).

[11] html Copyright @ 2009-2010 Zakład Radiokomunikacji, created by Łukasz Skrzypkowski (dostęp: 28.01.2018).

[12] http://www.projektproteus.pl (dostęp: 28.01.2018).

[13] http://klastermorski.com.pl/wp-content/uploads/2014/04/Pojazd-Ratowniczy-Florian-HYDROMEGA (dostęp: 28.01.2018).

[14] http://wb.com.pl/florian/ (dostęp: 28.01.2018). 
Część II

INNOWACYJNE ROZWIĄZANIA KONSTRUKCYJNE W POJAZDACH POŻARNICZYCH 



\title{
Pojazdy pożarnicze: rozwiązania i technologie
}

\author{
Firefighting vehicles, solutions and technologies
}

\author{
Jacek Roguski \\ Centrum Naukowo Badawcze Ochrony Przeciwpożarowej - Państwowy Instytut Badawczy
}

\section{Streszczenie}

Współczesny rynek pojazdów pożarniczych obejmuje coraz szerszą ofertę rozwiązań konstrukcyjnych $w$ różnych grupach użytkowych. Mimo sformalizowania wielkości pojazdów i ich wyposażenia, producenci, uwzględniając oczekiwania różnych grup użytkowników, proponuja różne modyfikacje sprzętu, uwzględniając postęp $w$ technice i technologii gaszenia.

W publikacji podjęto próbę prezentacji nowych rozwiązań konstrukcyjnych dla niektórych grup pojazdów pożarniczych uwzględniajacych nowe tendencje w rozwoju techniki pożarniczej i związanego z tym postępowania producentów.

\begin{abstract}
The contemporary market of firefighting vehicles encompasses a wide-growing offer of solutions in construction of different use groups. Despite of formalisation of size and equipment of the vehicles, the manufacturers, complying with expectations of different user groups, suggest various modifications of equipment following the progress of technique and technology of firefighting.

The publication tries to present new solutions in construction of selected groups of firefighting vehicles to meet new tendencies in fire protection technology and related proceedings of the producers.
\end{abstract}

Współczesny rynek pojazdów pożarniczych niezmiennie wzbudza zainteresowanie specjalistów, ponieważ to na nim właśnie oczekujemy innowacyjnych rozwiązań konstrukcyjnych sprzętu do działań ratowniczo-gaśniczych, a nawet wprowadzenia rewolucyjnych zmian w technologii gaszenia. W ostatnim dziesięcioleciu nie zanotowano istotnych nowości, chociaż niektórzy producenci prezentują swoje rozwiązania konstrukcyjne co najmniej jako innowacyjne. Podsumowując działania producentów można sformułować nowe tendencje w rozwoju techniki pożarniczej. Podwozie należy traktować jako jeden z najważniejszych elementów konstrukcyjnych samochodu/pojazdu pożarniczego determinujące jego własności trakcyjne, możliwości terenowe, bezpieczeństwo konstrukcji oraz możliwości funkcjonalne wykorzystywane przy prowadzeniu działań. Dlatego prawidłowy dobór podwozia jest najważniejszy w tworzeniu pojazdu pożarniczego. Uwzględniając doświadczenie producentów można określić dwa podstawowe sposoby tworzenia pojazdów pożarniczych: 
- stosowanie seryjnych (handlowych) podwozi z wprowadzonymi modyfikacjami niezbędnymi do wykonania specjalistycznej zabudowy pożarniczej;

- wykonanie specjalnego podwozia przeznaczonego dla pojazdu pożarniczego z wykorzystaniem agregatów, węzłów i mechanizmów zamontowanych w podwoziach seryjnych lub specjalnie wykonanych podwozi, które zmontowane w całość pozwolą uzyskać pojazd pożarniczy o nowych własnościach i parametrach, których nie posiadają konstrukcje wykonane na bazowych podwoziach lub ich modyfikacjach.

Na podwoziach specjalnych instalowane są zabudowy pożarnicze o wyższych wskaźnikach taktyczno-technicznych niż zabudowy na podwoziach standardowych. Najczęściej stosowane są w konstrukcjach pojazdów amerykańskich, co wiąże się z preferowaniem innej koncepcji funkcjonalnej samochodów pożarniczych.
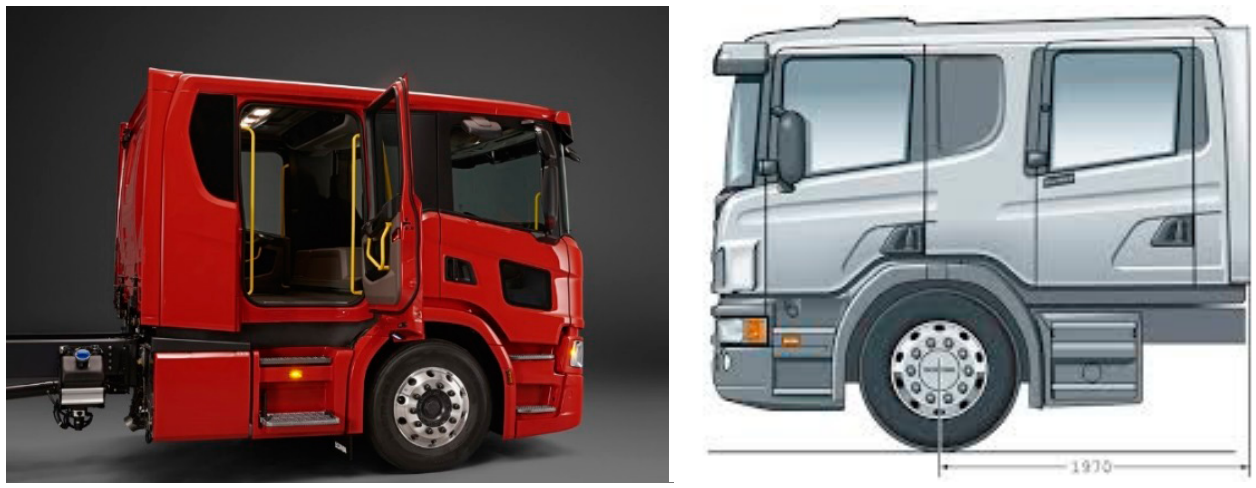

Rysunek 1. Przykład kabiny do samochodu pożarniczego

Źródło: https://www.google.pl/search?q=kabiny+dla+straży+pozarnej\&client=

Figure 1. An example of a fire vehicle cab

source: https://www.google.pl/search?q=kabiny+dla+straży+pozarnej eclient $=$

W USA szereg firm produkujących pojazdy pożarnicze wykonuje swoje samochody korzystając z gotowych elementów kooperacyjnych. Pozwala to na stworzenie pojazdu pod konkretne zamówienie wykonując tylko własną ramę nośną oraz kabinę.

W Europie producenci zdecydowanie zachowali klasyczne podejście, większość firm karosujących pojazdy pożarnicze na podwoziach Mercedes-Benz, Renault, Volvo, Scania, przedkłada wykorzystanie większości elementów własnej produkcji. Chociaż i tu znajduje się miejsce na wykorzystanie produktów wyspecjalizowanych firm, jednakże głównie przestrzegana jest zasada „wszystko od jednego dostawcy”.

Przy tworzeniu samochodów pożarniczych istotne znaczenie ma kompozycja podwozia. Praktycznie większość podwozi samochodów typu średniego oraz ciężkiego budowana jest z kabiną umieszczoną nad silnikiem, co jest uzasadnione warunkami eksploatacji w coraz bardziej rosnącej gęstości strumienia pojazdów, szczególnie w ruchu miejskim. 
Podstawową zależnością, na której opiera się europejska koncepcja konstruowania samochodów pożarniczych polega na następującej zasadzie: bez względu na warunki najpierw ratujemy ludzi, następnie organizujemy działania gaśnicze. Mniejsze wymiarowo i wagowo pojazdy, posiadające wysoką manewrowość i dynamikę ruchu w warunkach dużego natężenia ruchu ulicznego i gęstej zabudowy obszarów zurbanizowanych, pozwalają na bardziej efektywne dostarczenie sił i środków w celu realizacji nałożonych na ochronę przeciwpożarową zadań. Właśnie dla tego w państwach europejskich dominują samochody pożarnicze klasy lekkiej i średniej, a samochody pożarnicze typu ciężkiego wykorzystywane są do zabezpieczenia obiektów pożarowo niebezpiecznych lub specjalnych, dla których efektywność/dynamika nie jest czynnikiem dominującym. Zgodnie z PN EN 1846 Samochody pożarnicze, struktura typoszeregów samochodów pożarniczych jest uregulowana prawnie, dlatego dalszy rozwój koncepcyjny skierowany jest głównie na doskonalenie poziomu technicznego sprzętu transportowego i gaśniczego.

Jednak można zauważyć dwa kierunki postępujących zmian:

- stały postęp w wyglądzie zewnętrznym/stylistyce samochodów pożarniczych;

- zwiększenia stopnia automatyzacji systemów kierowania układami stosowanymi w samochodach pożarniczych.

Najnowsze modele proponowane przez europejskich producentów wyposażone są $\mathrm{w}$ skomplikowane mechanizmy z wbudowanymi elementami diagnostyki stanu technicznego, co pozwala na w pełni automatyczną pracę zainstalowanych urządzeń i mechanizmów oraz kontrolę ich stanu. Przyjęte rozwiązania techniczne powodują konieczność organizowania szkoleń specjalistycznych przez producentów dla przyszłych użytkowników z zakresu zasad użytkowania i obsługi.

Wyspecjalizowane pojazdy pożarnicze użytkowane w jednostkach ochrony przeciwpożarowej dostosowywane są konstrukcyjnie do realizacji założonych funkcji użytkowych związanych zarówno $\mathrm{z}$ warunkami środowiskowymi, jak i technicznymi.

Przykładem takiego rozwiązania są samochody pożarnicze przeznaczone do użytkowania w warunkach niskich temperatur otoczenia.

\section{Pojazdy do prac w ekstremalnie niskich temperaturach}

W celu efektywnego prowadzenia działań ratowniczo-gaśniczych w ekstremalnie niskich temperaturach otoczenia zostały opracowane i wyprodukowane samochody typu PSA-S-6,0-40 (6339) oraz AC-S-8,0-70 (6339) dostosowane do użytkowania w temperaturach otoczenia do minus $60^{\circ} \mathrm{C}^{1}$. Wyróżniającymi cechami konstrukcyjnymi są:

1 http://www.mchs.gov.ru/document/2578010 
- zapewnienie komfortu cieplnego kabiny załogi i zabudowy pożarniczej z uwagi na zdalne sterowanie urządzeniami;

- zapewnienie komfortu pracy kierowcy w zakresie użytkowania zespołu pompowego poprzez zastosowanie zdalnego sterowania armaturą wodno-pianową;

- stałego podgrzewania środków gaśniczych w rurociągach;

- zapewnienia możliwości rozwinięć linii wężowych w warunkach niskich temperatur;

- wykorzystanie systemów wytwarzających ciepło w sytuacjach awaryjnych.

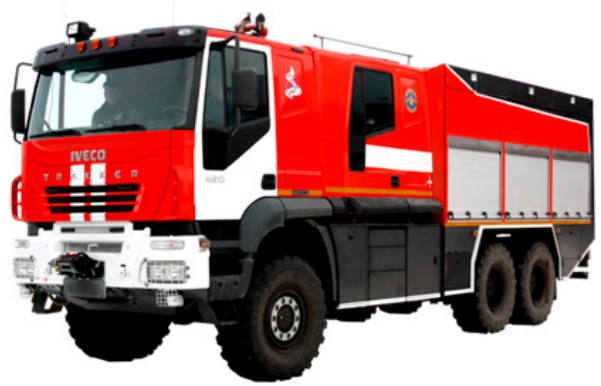

Rysunek 2. Samochód ratowniczo-gaśniczy PSA-S6,0-40 w wykonaniu klimatycznym Chł. Figure 2. Fire/rescue vehicle PSA-S6, 0-40 (6339) in cold in cold climate configuration

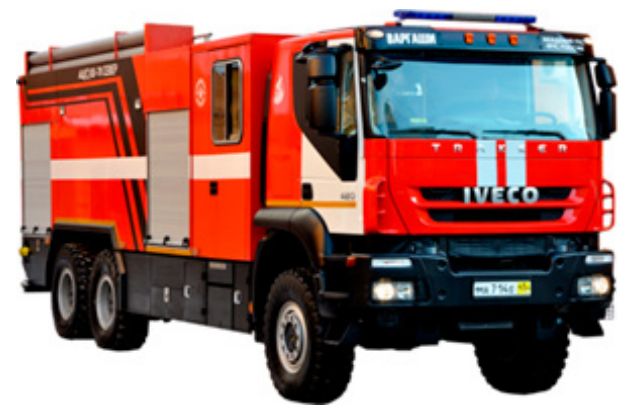

Rysunek 3. Samochód gaśniczy AC-S 8, 0-70 w wykonaniu klimatycznym Chł.

Figure 3. Firefighting vehicle AC-S 8,0-70 in cold climate configuration

Dodatkowo sprzęt i wyposażenie przewożone tymi samochodami zostały wykonane w wersji specjalnej, przystosowanej do użytkowania w niskich temperaturach otoczenia, poczynając od elementów gumowych oraz pokrycia powierzchni wyposażenia i sprzętu specjalnymi powłokami ochronnymi ograniczającymi przewodność cieplną.

\section{Pojazdy ratowniczo-gaśnicze przeznaczone do prac w tunelach}

Statystyki dotyczące wypadków i awarii w tunelach komunikacyjnych wskazują, że są to obiekty podwyższonego ryzyka. Wg danych statystycznych zdarzenia komunikacyjne w tunelach doprowadzają do pożaru ponad 1,4 razy częściej niż na drogach szybkiego ruchu. Takim sytuacjom towarzyszy wydzielanie szkodliwych produktów spalania oraz mieszanin gazowych, a co za tym idzie utraty widoczności na drogach ewakuacyjnych w efekcie ich zadymienia. Wszystkie te zjawiska utrudniają ewakuację ludzi i środków transportu oraz efektywne działania specjalnych jednostek ratowniczych, co prowadzi do śmierci ludzi i długotrwałego wyłączenia z normalnej eksploatacji tuneli. Do prowadzenia efektywnych działań $\mathrm{w}$ takich miejscach stworzono pojazdy pozwalające na poruszanie się $\mathrm{w}$ tunelach 
bez konieczności zawracania w celu prowadzenia działań ratowniczo-gaśniczych. Jednym $\mathrm{z}$ najnowszych rozwiązań konstrukcyjnych jest zespół samochodów PSA-T-3,0-40/4 oraz PSA Cz-20 (rys. 4) ${ }^{2}$.
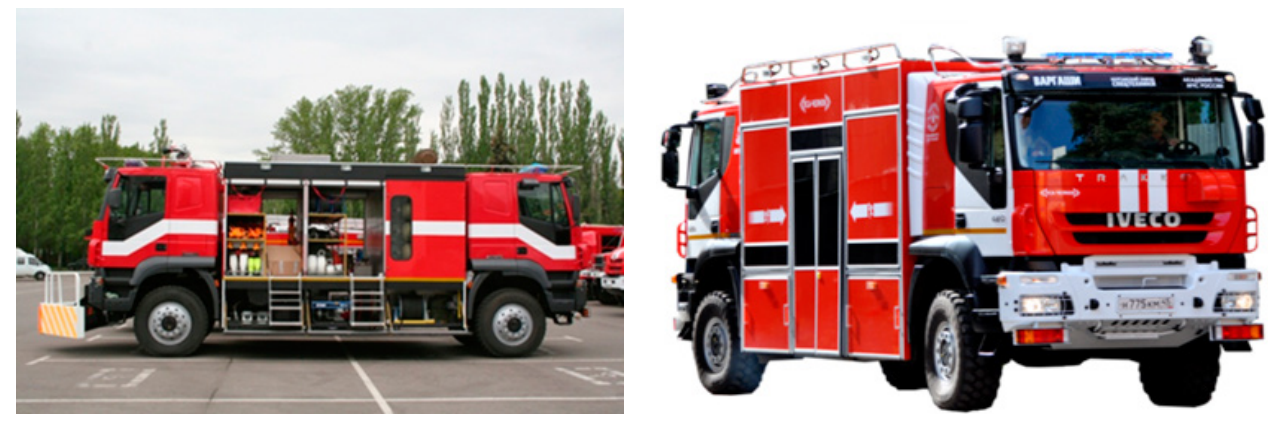

Rysunek 4. Samochody ratowniczo-gaśnicze: PSA-T-3,0-40/4 i PSA-Cz-20 do prac w tunelach komunikacyjnych

Źródło: www.mchs.gov.ru/document/2578010

Figure 4. Fire/rescue vehicles PSA-T 3,0-40/4 and PSA-Cz-20 for works in tunnels and passageways source: www.mchs.gov.ru/document/2578010

Konstrukcja samochodów PSA-T przeznaczonych do działania w tunelach jest unikalna i składa się z poniższych elementów:

- specjalnego podwozia $\mathrm{z}$ kabiną kierowcy oraz dodatkową kabiną dla ruchu wstecznego;

- nadwozia do rozmieszczenia sprzętu i wyposażenia przeznaczonego do działań ratowniczo-gaśniczych;

- systemów zabezpieczenia życia załogi (urządzenie filtrujące układu tłoczącego powietrze);

- systemu zraszającego kabiny w celu ochrony przed promieniowaniem cieplnym / oddziaływaniem ciepła (podawanie rozpylonej wody);

- systemu monitoringu przestrzeni wokół pojazdu w warunkach ograniczonej widoczności z rozpoznawaniem i lokalizacją otwartego ognia i jego gaszeniem pozwalającego kierowcy na bezpieczne poruszanie się $\mathrm{w}$ strefie zagrożenia;

- systemu zabezpieczenia pracy silnika w warunkach zadymienia (pozwalającą na pracę $\mathrm{w}$ warunkach silnego zadymienia do $40 \mathrm{~min}$ ).

PSA-T wyposażony został w sprzęt ratowniczo-gaśniczy oraz środki gaśnicze, może sprawnie poruszać się w obu kierunkach, w tunelach komunikacyjnych bez konieczności zawracania. Załoga może pracować w warunkach ograniczonej widoczności (zadymienia) również w przypadku braku powietrza. W samochodzie znajdują się środki i sprzęt do udzielania pierwszej pomocy medycznej oraz ratowania i ewakuacji poszkodowanych. Przed podstawową kabiną załogi został

2 http://www.mchs.gov.ru/document/2578010 
zamontowany lemiesz o zmiennej geometrii przeznaczony do torowania drogi. Pod drugą kabiną została zamontowana autopompa.

PSA-Cz przeznaczony jest do prowadzenia działań ratowniczych w tunelach komunikacyjnych w warunkach zadymienia oraz braku powietrza. Podobnie jak PSA-T został wyposażony w dwie kabiny kierowcy. Wewnątrz modułu ratowniczego znajduje się przedział ewakuacyjny wyposażony w maski oddechowe oraz aparaty ucieczkowe przeznaczone do indywidualnej ochrony układu oddechowego oraz wzroku. Przedział ratunkowy ma szerokie drzwi typu przesuwnego ułatwiające załadunek ewakuowanych lub poszkodowanych. Pojazd wyposażono w instalację zraszacza o pojemności 500 l, która chroni przed nadmiernym nagrzaniem. W celu zabezpieczenia pracy silnika w warunkach silnego zadymienia układ zasilania silnika wyposażono butlę ze sprężonym powietrzem o pojemności 12001.

Samochody ratowniczo-gaśnicze PSA-Cz-20 wyposażony jest w podwozie z napędem na wszystkie koła z systemem kierowania kół osi przedniej i tylnej. Zastosowane autonomiczne instalacje zapewniają załodze oraz ratowanym, w przypadku zadymienia lub zanieczyszczenia atmosfery w tunelu substancjami toksycznymi dostęp do powietrza magazynowanego w butlach zamontowanych w pojeździe pozwalających na dystrybucję powietrza w kabinie pasażerskiej, jak i kabinie kierowcy, jak również zasilanie indywidualnych masek dla pasażerów i załogi. System ochrony życia zaprojektowano tak, aby w trakcie przebywania w pojeździe nie trzeba bylo korzystać z aparatów oddechowych. W samochodzie w przedziale ratunkowym wyposażonym w maski oddechowe można przewieźć 20 osób. Pojazd PSA składa się z następujących części składowych:

- specjalnego podwozia z możliwością ruchu wstecznego;

- kabiny załogi;

- nadwozia z przedziałem ratunkowym dla transportu ewakuowanych z wewnętrznym nadciśnieniowym układem czystego powietrza, wyposażonym w maski typu otwartego do ciągłego podawania powietrza;

- zespołu butli ze sprężonym powietrzem;

- układu dystrybucji powietrza do cyrkulacji powietrza w kabinie pasażerskiej oraz w kabinach kierowcy oraz układu dostarczającego powietrze do oddychania przez maski dla pasażerów i załogi;

- układu dystrybucji czystego powietrza do zasilania silnika;

- automatycznego układu indykacji składu powietrza;

- systemu przeznaczonego do monitoringu zewnętrznego środowiska, w którym porusza się pojazd, składającego się z ultradźwiękowego skanera przestrzeni oraz termowizji wspomagającej kierowcę w strefie zadymienia;

- systemu zabezpieczającego ogumienie przed przebiciami;

- dodatkowego wyposażenia elektrycznego.

Podobne rozwiązanie konstrukcyjne zastosowała w roku 1993 Firma AEG Daimler Benz projektując na potrzeby EUROTUNELU pod kanałem La Manche pojazdów ratowniczych przeznaczonych dla straży pożarnej, pogotowia ratunkowego, 
policji i służb technicznych. Stworzenie pojazdu z dwoma stanowiskami kierowania umieszczonymi na końcach pojazdu pozwoliło zastosować oddzielne moduły na potrzeby straży pożarnej, pogotowia, służb technicznych czy policji. Samochód STTS może rozpędzić się do prędkości $80 \mathrm{~km} /$ godz. z zablokowanym układem kierowniczym przy stosowaniu automatycznego sterowania wykorzystującego sygnały z dwóch kabli wmurowanych w nawierzchnię drogi. Taki wariant przemieszczania wydaje się optymalnym przy ograniczonej widoczności lub jeździe do tyłu. W przypadku jazdy z odblokowanym układem kierowniczym prędkość zostaje ograniczona do $50 \mathrm{~km} /$ godz. W każdym końcu tunelu znajdują się cztery takie pojazdy, z których dwa wyposażone są w sprzęt umożliwiający działania ratowniczo-gaśnicze.

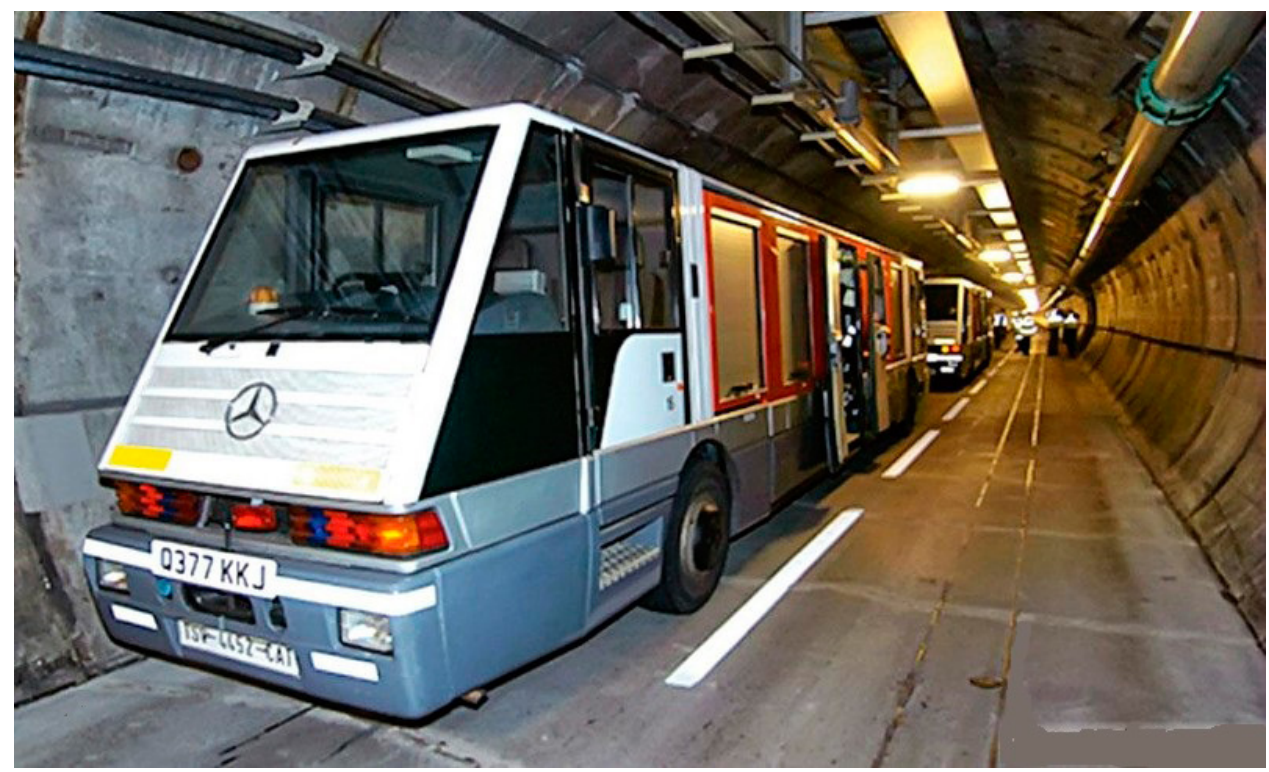

Rysunek 5. Pojazd ratowniczy AEG Daimler Benz Źródło: http://www.gruzovikpress.ru/article/4184

Figure 5. AEG Daimler Benz rescue vehicle

source: http://www.gruzovikpress.ru/article/4184

W roku 2000 został zbudowany BAI MAN Janus 40000 Bi-front. Włoska firma Brescia Antincendi International S.r.l. wykorzystała podwozie ciężarówki MAN średniej ładowności z dwoma kabinami oraz układem wszystkich osi kierowanych i napędzanych. Silnik wysokoprężny wyposażono w automatyczną skrzynię biegów ZF z rewersem, dzięki czemu uzyskujemy taką samą prędkość niezależnie od kierunku jazdy. Układ kierowniczy działa w trzech wariantach. Standardowo - kierowana oś przednia, oś tylna zablokowana w położeniu do jazdy na wprost. $\mathrm{W}$ drugim wariancie tylna oś kierowana jest za pomocą serwomotorów pozwalając na poruszanie się po torze kół przednich. Trzeci wariant - kiedy koła osi tylnej skręcone są tak jak koła osi przedniej umożliwiając poruszanie się po skosie (ruch kraba). 


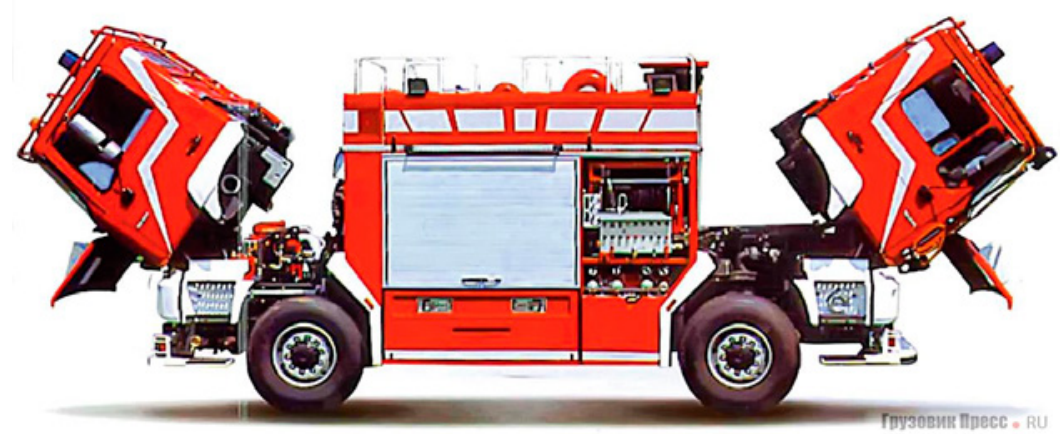

Rysunek 6. Samochód BAI MAN Janus 4000 Bi-front Źródło: http://www.gruzovikpress.ru/article/4184

Figure 6. BAI MAN Janus 4000 Bi-front vehicle source: http://www.gruzovikpress.ru/article/4184

W skład wyposażenia wchodzi zbiornik wody $4000 \mathrm{l}$ oraz środka pianotwórczego 500 l. Autopompa Godiva WTA 4010 o wydajności 4000 l/min z liniami szybkiego natarcia o długości $60 \mathrm{~m}$. Oprócz standardowego wyposażenia do prowadzenia działań ratowniczo-gaśniczych zamontowano maszt oświetleniowy i wyciągarkę, w kabinach zastosowano kamery termowizyjne Argus pozwalające na obserwację w warunkach ograniczonej widoczności/zadymienia. Trzy takie pojazdy służą do zabezpieczenia tunelu drogowego pod Mont Blanc.

Podobne rozwiązanie, jeżeli chodzi o koncepcję pojazdu, zaproponowała w 2007 roku amerykańska firma Spartan przedstawiając prototyp modelu Spartan Evolution z dwoma kabinami. Pomimo przedstawiania konstrukcji na wielu imprezach wystawienniczych, nie podjęto produkcji seryjnej.

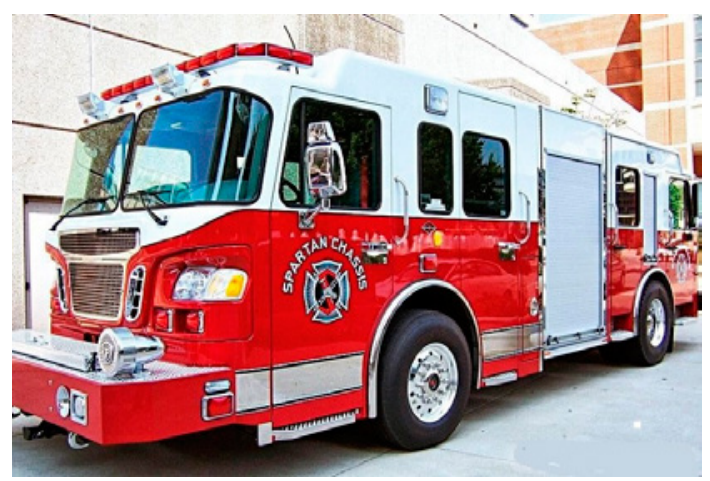

Rysunek 7. Prototyp modelu Spartan Evolution Źródło: http://www.gruzovikpress.ru/article/4184

Figure 7. Spartan Evolution series prototype source: http://www.gruzovikpress.ru/article/4184

W 2010 roku austriacka firma EMPL Fahrzeugwerk GmbH zaprezentowała samochód pożarniczy TLF 2000/400 z wykorzystaniem elementów samochodu MAN 
TGM 18.330. Kabina główna/podstawowa jest powiększona, druga kabina standardowa, do ruchu wstecznego służy skrzynia biegów ZF przełączana specjalnym przyciskiem. Maksymalna prędkość to $110 \mathrm{~km} /$ godz., w ruchu wstecznym - $90 \mathrm{~km} / \mathrm{godz}$. Zapas przewożonych środków gaśniczych wynosi 20001 wody oraz 4001 środka pianotwórczego. Z wyprodukowanych w 2010 roku pojazdów dwa użytkowane są w Chinach, jeden w Austrii, natomiast w 2013 roku 1 egzemplarz otrzymała straż pożarna w mieście Nankin.

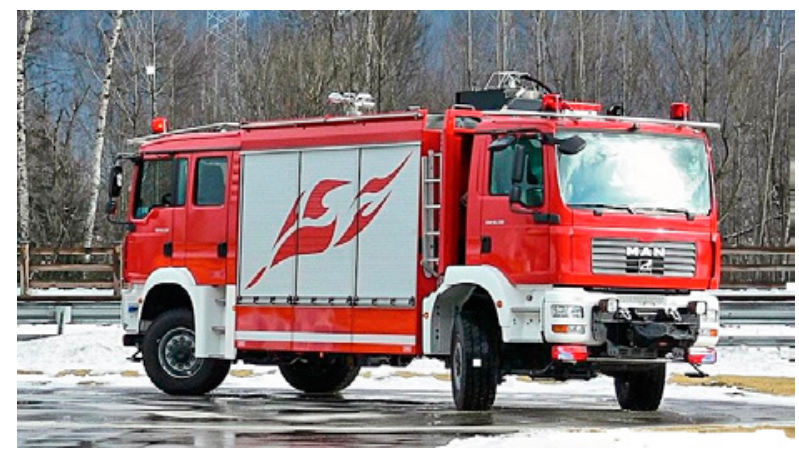

Rysunek 8. Samochód pożarniczy TLF 2000/400

Źródło: http://www.gruzovikpress.ru/article/4184

Figure 8. TLF 2000/400 firefighting vehicle

source: http://www.gruzovikpress.ru/article/4184

W 2012 roku firma Chongqing Hongyan Automobile przedstawiła samochód pożarniczy Dakang Twin Cab na podwoziu $4 \times 4$ produkowanym na licencji firmy Steyr. Samochód przeznaczony jest do patrolowania i rozpoznania na miejscu zdarzenia, zapas środka gaśniczego to 25001 wody. Zdublowane kabiny wyposażono w kamery wideo przeznaczone do przekazu bieżących informacji do stanowiska dowodzenia celem oceny sytuacji w czasie rzeczywistym.

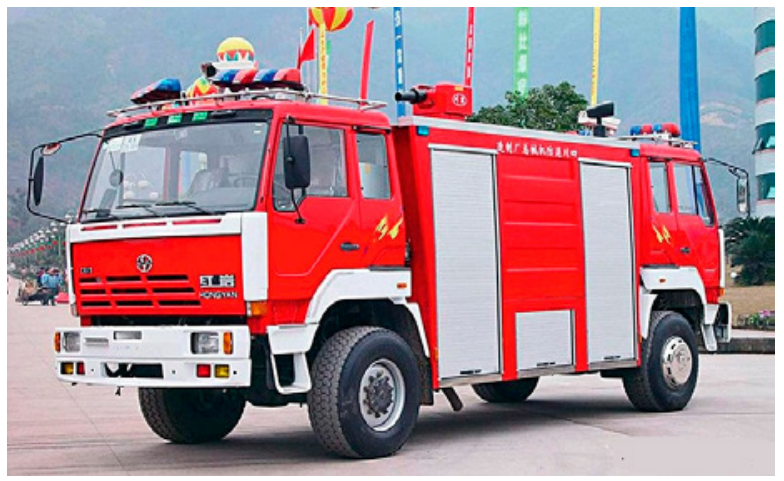

Rysunek 9. Samochód pożarniczy Dakang Twin Cab Źródło: http://www.gruzovikpress.ru/article/4184

Figure 9. Dakang Twin Cab firefighting vehicle source: $h t t p: / / w w w . g r u z o v i k p r e s s . r u / a r t i c l e / 4184$ 
Latem 2011 roku niemiecki koncern Albert Ziegler GmbH \& Co. KG zaprezentował pierwszy ratowniczy samochód elektryczny z dwoma kabinami - TRV ZE 1 Merkur. Pojazd wykorzystywany jest do działań na autostradzie Bina Istra w Chorwacji, do zabezpieczenia 5-kilometrowego tunelu Tu Učka - Pula. Wyposażony w dwa silniki o łącznej mocy $190 \mathrm{~kW}$ osiąga prędkość $60 \mathrm{~km} /$ godz. Zasięg do $240 \mathrm{~km}$ lub 4 godzin pracy ciągłej. Zmiana kierunku jazdy możliwa jest bez opuszczania pojazdu ponieważ kabiny załogi połączone są ze śluzami i przedziałem ratunkowym. Załoga w warunkach zadymienia używa indywidualnych aparatów oddechowych. Przedział ratunkowy przewidziany jest do ewakuacji 12 osób (8 miejsc siedzących, 4 stojące). Wszystkie miejsca zaopatrzono w maski tlenowe podłączone do centralnego systemu zasilania. Autonomia obliczona jest na 5 godzin. Instalacja zraszaczowa pozwala na zabezpieczenie pojazdu przed promieniowaniem cieplnym na odległość do $1 \mathrm{~m}$ od pojazdu.

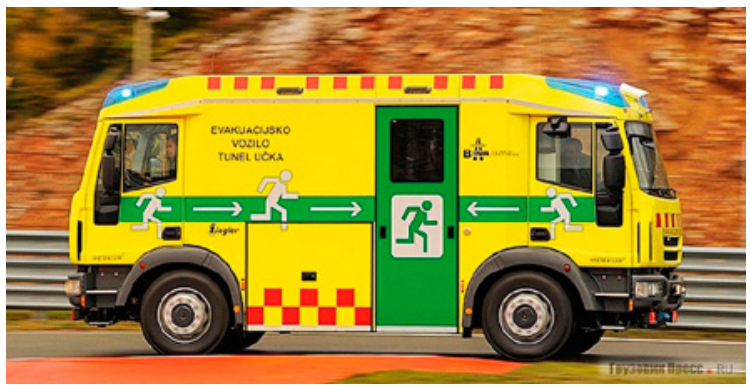

Rysunek 10. Ziegler TRV ZE 1 Merkur

Źródło: http://www.gruzovikpress.ru/article/4184

Figure 10. Ziegler TRV ZE 1 Merkur

source: http://www.gruzovikpress.ru/article/4184

Podobną rolę w zabezpieczeniu tunelu Mont Blanc spełnia skonstruowany w 2013 roku samochód specjalny GEF/SDIS 73 Orthros 1 na podwoziu Renault Kerax, dysponujący większą ilością miejsc w przedziale ratunkowym.

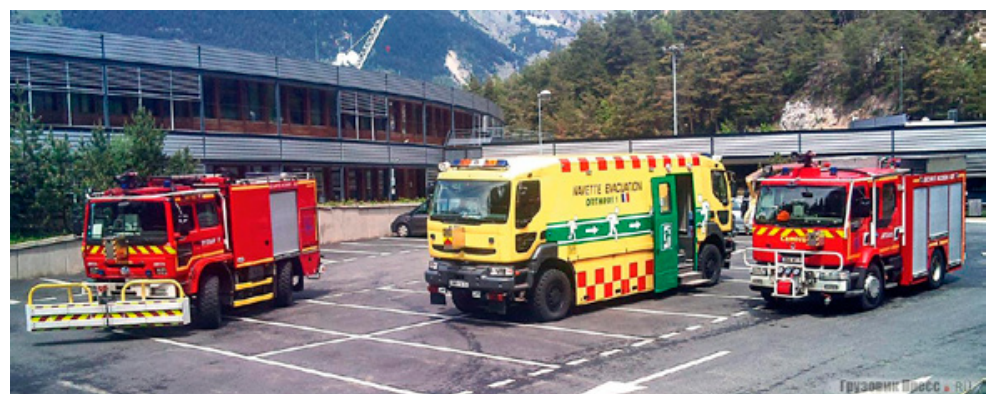

Rysunek 11. Samochód specjalny GEF/SDIS 73 Orthros 1

Źródło: http://www.gruzovikpress.ru/article/4184

Figure 11. GEF/SDIS 73 Orthros 1 special vehicle source: http://www.gruzovikpress.ru/article/4184 
Z przedstawionych przykładów wynika, że stosowane rozwiązania znajdują zastosowanie w pojedynczych przyypadkach związanych z zabezpieczeniem tuneli komunikacyjnych oraz w ograniczonym zakresie w obszarach miejskich o gęstej zabudowie i ograniczonej przepustowości sieci drogowej.

\section{Samochody kontenerowe}

Dążąc do bardziej specjalizowanego wyposażenia jednostek ochrony przeciwpożarowej w sprzęt, ograniczając jednocześnie koszty zakupu i użytkowania wprowadzono na wyposażenie pojazdy kontenerowe składające się z samochodu przeznaczonego do wykonywania pracy transportowej, tzw. nośnika kontenerowego, oraz wymiennych kontenerów wyposażonych w sprzęt specjalistyczny montowany na nośniku lub specjalnej przyczepie dostosowanej do przewozu kontenerów. Specjalistyczne kontenery pożarnicze znajdują się na wyposażeniu polskiej straży pożarnej od lat osiemdziesiątych ubiegłego wieku. W większości wypadków mają za zadanie wspomagać kierowanie działaniami ratowniczo-gaśniczymi, jako zaplecze logistyczne dużych akcji. Z uwagi na swoje zalety, często wykorzystywane są w działaniach ponadregionalnych przy likwidacji skutków awarii o charakterze technogennym. W Państwowej Straży Pożarnej jest 16 baz kontenerowych, po jednej w każdym województwie. Specjalistyczne kontenery sanitarno-socjalne oraz dekontaminacyjne bardzo często znajdują się również na wyposażeniu lotniskowych i zakładowych straży pożarnych. Kontenery dzielą się w zależności od przeznaczenia na następujące kategorie:

1. Kontenery dowodzenia:

- dowodzenia i łączności.

2. Kontenery bojowe:

- ze sprzętem ochrony dróg oddechowych;

- inżynieryjno-techniczny;

- przeciwpowodziowy z pompą do wody zanieczyszczonej;

- agregat pompowy;

- ratownictwa chemiczno-ekologicznego.

3. Kontenery logistyczne:

- kwatermistrzowski;

- organizacji wyżywienia;

- sanitarny;

- ze zbiornikiem na wodę;

- do transportu środków pianotwórczych.

Obowiązujące standardy wyposażenia poszczególnych rodzajów kontenerów dla Państwowej Straży Pożarnej zostały zawarte w dokumencie „Wytyczne standaryzacji pojazdów pożarniczych i innych środków transportu Państwowej Straży Pożarnej”, zatwierdzonym w dniu 14 kwietnia 2011 r. przez Komendanta Głównego 
PSP. Standaryzacja wyposażenia została skonstruowana jako system otwarty, tzn. możliwe jest dodawanie nowych standardów wyposażenia, w postaci kolejnych załączników do wytycznych.

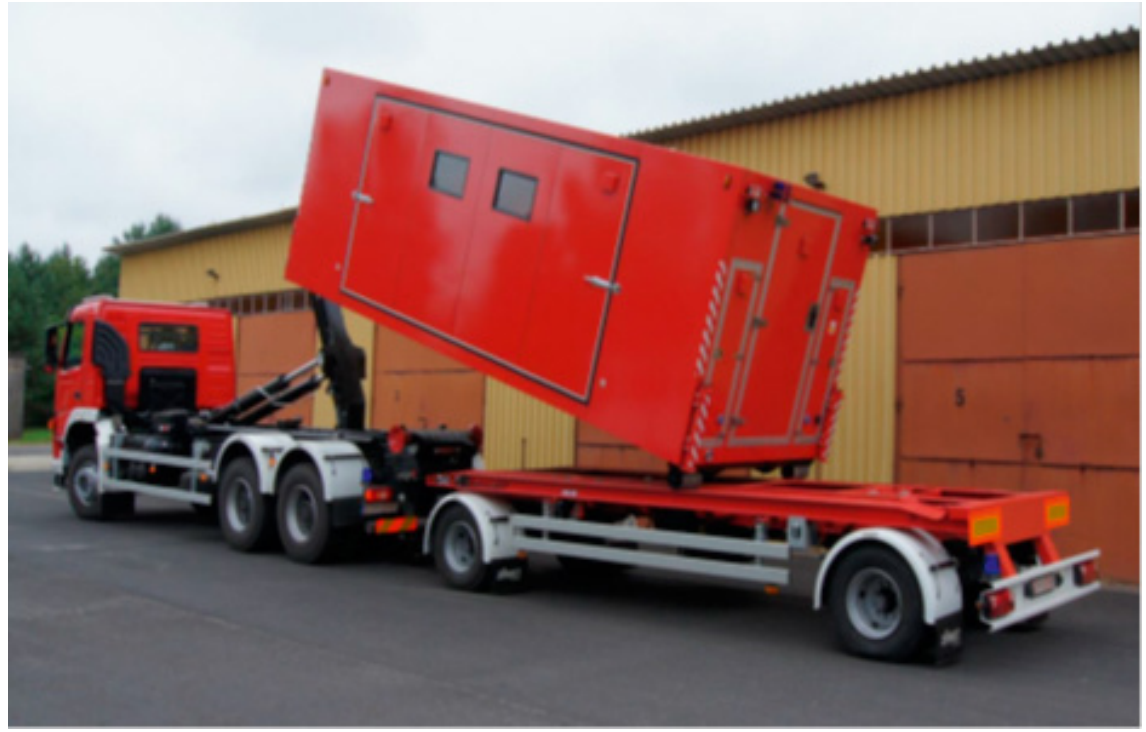

Rysunek 12. Przykład nośnika kontenerów - samochodu i przyczepy

Źródło: http://www.wsei.lublin.pl/upload/file/konferencje-materialy/2015-12-15/System\%20kontenerowy\%20w\%20Pa\%C5\%84stwowej\%20Stra\%C5\%BCy\%20Po\%C5\%BCarnej.pdf

Figure 12. An example of container carrier - tractor and trailer source: http://www.wsei.lublin.pl/upload/file/konferencje-

Analizując największe działania ratowniczo-gaśnicze, które miały miejsce w ostatnich latach, można stwierdzić konieczność wykorzystania zestawów pompowo-wężowych i sprzętu o podwyższonej wydajności przeznaczonego do efektywnego zapobiegania i prowadzenia działań w sytuacjach dużych akcji ratowniczych. Przykładem takiego rozwiązania jest zestaw KNRM 350-1,5/300 Szkwał (Rosja) przeznaczony do dostarczania na miejsce pożaru załogi, sprzętu i wyposażenia do tłoczenia i odpompowywania dużych objętości wody, zmechanizowanego układania i zwijania linii wężowych, również w trudnym terenie. W skład zestawu oprócz nośników kontenerowych wchodzą kontenery pompowy oraz wężowy. Wyróżniającymi cechami użytkowymi zestawu jest zastosowanie dodatkowej pompy wspomagającej, przeznaczonej do zasysania wody ze zbiornika zewnętrznego oraz jej podawania do pompy głównej (głębokość ssania do $15 \mathrm{~m}$ ), pompy głównej o wydajności 3-krotnie przekraczającej osiągi pomp standardowych (wydajność 21000 l/min przy ciśnieniu 14 ba), mechanizmu do układania i zwijania linii wężowych (długość do $1,5 \mathrm{~km}$, czas sprawiania poniżej $5 \mathrm{~min}$ ). Zastosowana konstrukcja modułowa zestawu pozwala na bardzo szybkie sprawianie na miejscu działań. Moduły pompowy i wężowy wyposażone są w urządzenia do ich załadunku i rozładunku 
oraz transportu za pomocą nośnika przy wykorzystaniu systemu załadunku typu multilift lub śmigłowca.

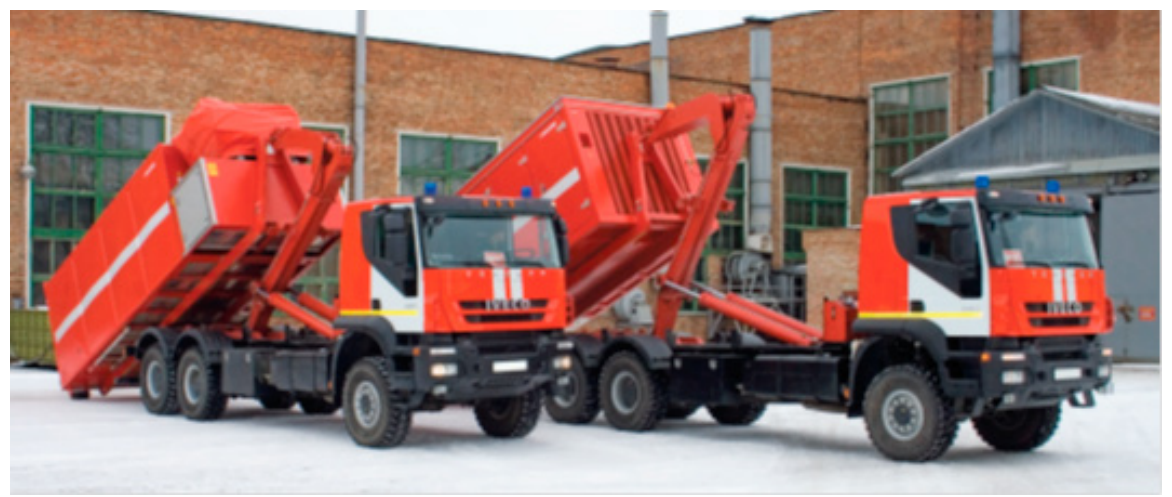

Rysunek 13. Zestaw KNRM 350-1,5/300 Szkwał

Źródło: www.mchs.gov.ru/document/2578010

Figure 13. KNRM 350-1,5/300 Squall modular system

source: www.mchs.gov.ru/document/2578010

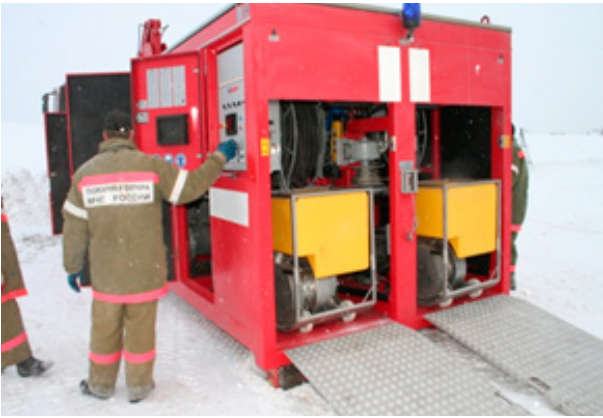

Kontener pompowy

Pump module container

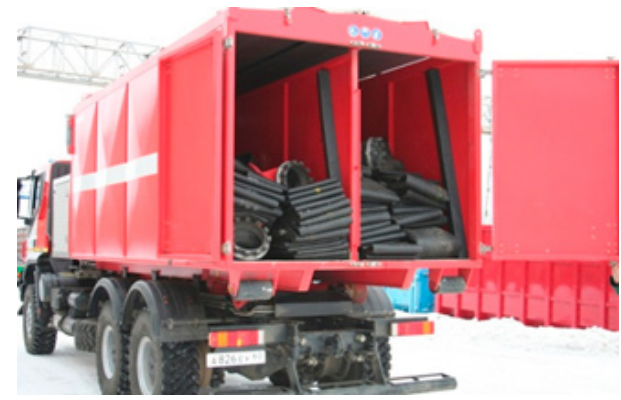

Kontener wężowy

Hose storage container

Rysunek 14. Zestaw Szkwał

Źródło: www.mchs.gov.ru/document/2578010

Figure 14. Squall modular system

source: www.mchs.gov.ru/document/2578010

Ciekawym przykładem, który nie ma krajowego odpowiednika, jest kombinowany samochód gaśniczy pompowo-wężowy PANRK 4,0/1,2-1303 (6370). Jego cechami szczególnymi jest to, że jednocześnie jest samochodem gaśniczym (zbiornik wody 4000 l), ruchomą stacją pompową (wydajność do ok. 8000 l/min) oraz samochodem wężowym (długość linii tłocznych - $1200 \mathrm{~m}$ ). Wysoka efektywność użycia osiągana jest dzięki ergonomii zastosowanych rozwiązań węzłów i agregatów, a także zastosowaniu dwustopniowego systemu podawania wody.

3 http://www.mchs.gov.ru/document/2578010 

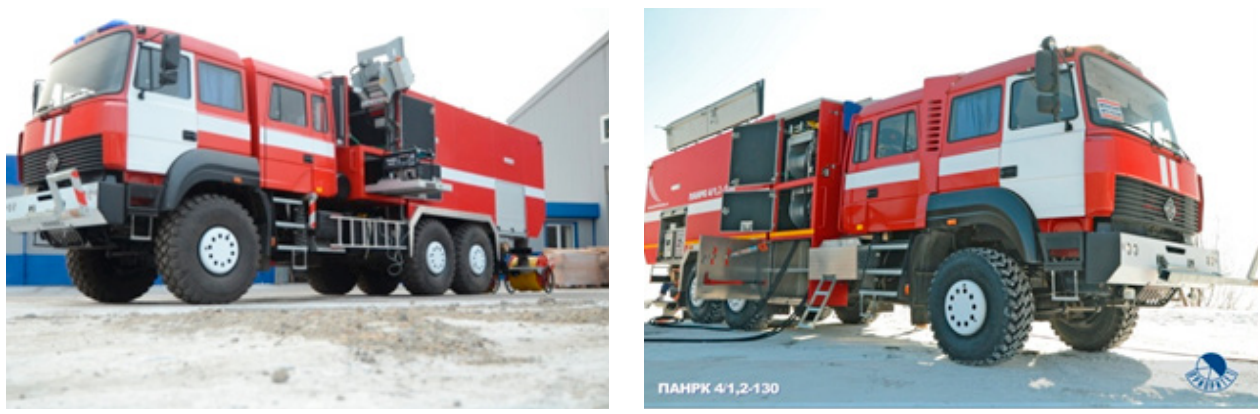

Rysunek 15. Samochód gaśniczy pompowo-wężowy PANRK 4,0/1,2-130

Źródło: www.mchs.gov.ru/document/2578010

Figure 15. PANRK 4,0/1,2-130 fire tanker with pump and hose storage

source: $w$ ww.mchs.gov.ru/document/2578010

\section{Pojazdy na podwoziu gąsienicowym}

Prowadzeniedziałań ratowniczo-gaśniczych wutrudnionych warunkach terenowych wymaga stosowania pojazdów o wysokich zdolnościach terenowych, które mogą poruszać się w grząskim terenie, obszarach rozlewisk oraz na terenach ograniczających wykorzystanie podwozi kołowych. W większości przypadków takie pojazdy tworzone są na bazie istniejących już konstrukcji produkowanych na potrzeby wojska lub innych służb.

Na bazie przegubowego pojazdu gąsienicowego Bandvagn 206 (BV-206) - opracowanego w 1974 r. przez szwedzką firmę Haegglunds (aktualnie jako część firmy BAE Systems) stworzono pojazd ratowniczo-gaśniczy UMK-A z kabiną dla załogi w przedniej sekcji i specjalizowanym modułem sprzętowym umieszczonym w sekcji tylnej. Pojazd przeznaczony jest do prowadzenia rozpoznania oraz gaszenia pożarów w miejscach trudno dostępnych.
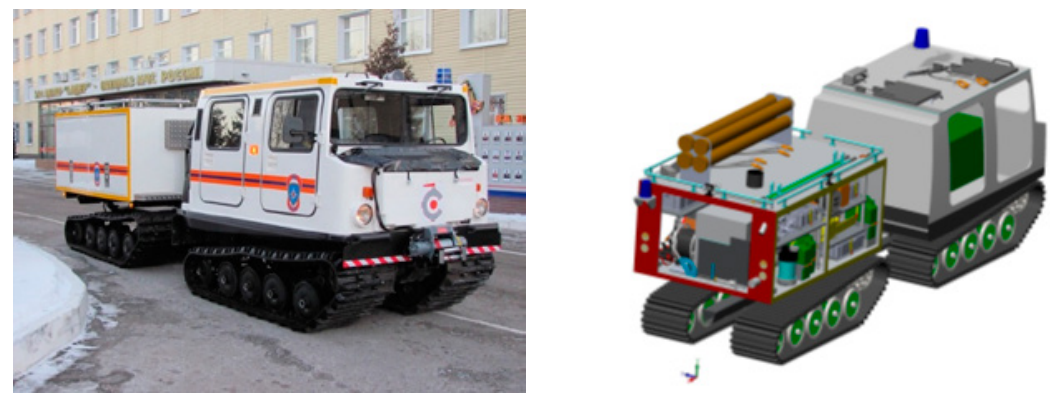

Rysunek 16. Gąsienicowy pojazd ratowniczo-gaśniczy UMK-A

Źródło: www.armsexpo.ru/armament/expo.ru/armament/samples/1831/70932/, www.vitalykuzmin. net/Military/ISSE-2011/i-r8w54Qv/A

Figure 16. UMK-A tracked vehicle

source: www.armsexpo.ru/armament/expo.ru/armament/samples/1831/70932/, www.vitalykuzmin.net/ Military/ISSE-2011/i-r8w54Qv/A 
Konstrukcja tylnej sekcji zapewnia możliwość zastosowania, oprócz modułu sprzętowego do prac ratowniczo-gaśniczych, sprzętu i wyposażenia do prowadzenia prac poszukiwawczo-ratunkowych. Wymiana modułu następuje przy wykorzystaniu podnośnika. W module ratowniczo-gaśniczym zamontowano półki na sprzęt i wyposażenie. Dostęp do wnętrza nadwozia zapewniają drzwi uchylne. W pojeździe zastosowano zbiornik na wodę $800 \mathrm{l}$ oraz środek pianotwórczy o pojemności $50 \mathrm{l}$. Nadwozie oraz zbiorniki na środki gaśnicze wykonano z materiału odpornego na korozję, o niskiej przewodności cieplnej. UMK-A na miejsce akcji może być przewożony transportem kołowym lub lotniczym. Konstrukcja zapewnia możliwość pływania na spokojnej wodzie. Jest wyposażony w urządzenia nawigacyjne GPS, do podawania sygnałów awaryjnych oraz sprzęt łączności radiowej.

- UMK-A składa się z dwóch wózków wyposażonych w gąsienice z zamontowaną nadbudową; przy poruszaniu się obie części pojazdu mogą przemieszczać się w kierunku pionowym i poziomym w zakresie ograniczonym konstrukcją sprzęgu;

- konstrukcja UMK-A przewiduje stosowanie szybkozłącznych modułów różnorodnego funkcjonalnego przeznaczenia (gaśniczych, ratowniczych, medycznych, pasażerskich, transportowych i itp.);

- UMK-A przystosowane jest do pokonywania pochyłości o nachyleniu do 45 stopni przy nacisku jednostkowym na grunt $0,12 \mathrm{~kg} / \mathrm{cm}^{2}$ (co odpowiada naciskowi stojącego człowieka);

- UMK-A może być wykorzystane na bezdrożach, zaspach śnieżnych, rozlewiskach oraz przy niesprzyjających warunkach pogodowych;

- po dodatkowym uszczelnieniu UMK-A przystosowany jest do pływania;

- ruch UMK-A realizowany jest przez gąsienice napędzane niezależnie;

- w module ratowniczo-gaśniczym zainstalowano pompę wysokociśnieniową o wydajności 38 l/min zasilaną ze zbiornika o pojemności 800 l;

- załoga UMK-A składa się z 5 osób;

- zainstalowane środki łączności i nawigacji pozwalają na pozycjonowanie UMK-A oraz przekaz niezbędnych informacji operacyjnych;

- masa całkowita UMK-A wynosi $7000 \mathrm{~kg}$.

Innym przykładem wykorzystania seryjnie produkowanego pojazdu gąsienicowego jest pojazd ratowniczo-gaśniczy ASM-GD 4 (АCM-ГД) (Rosja). Jest to dwuczłonowy przegubowy gąsienicowy wszędołaz na bazie transportera TTM 4902 ASM (TTM 4902ACM) z kabiną dla załogi w przednim module i specjalizowanym modułem do przewozu sprzętu i wyposażenia. ASM-GD przeznaczony jest do transportu grup poszukiwawczo-ratowniczych po bezdrożach, pokonywania wpław przeszkód wodnych, przewozu zapasu środków gaśniczych, wyposażenia i sprzętu ratowniczego, gaśniczego, środków łączności i oświetlenia na miejsce działań oraz udzielania pierwszej pomocy medycznej ludziom, gaszenia pożarów oraz zabezpieczenia komfortowych

$4 \mathrm{https} / /$ fireman.club/statyi-polzovateley/snegobolotohodyi-mchs-na-gusenitsah-i-kolesah-sverhnizkogo-davleniya/ 
warunków życiowych załóg jednostek poszukiwawczo-ratowniczych w ekstremalnych warunkach pogodowych, w tym również na dalekiej północy i w Arktyce. Na wyposażeniu znajduje się nawigacja pracująca w systemie GLONASS/GPS oraz KOSPASS/SARCAT, służąca do podawania sygnałów awaryjnych, oraz instalacja łączności radiowej. W pojeździe zamontowano zbiornik na wodę $800 \mathrm{l}$ oraz środek pianotwórczy pojemności $50 \mathrm{l}$. Nadwozie oraz zbiorniki na środki gaśnicze wykonano z materiału odpornego na korozję, o niskiej przewodności cieplnej.

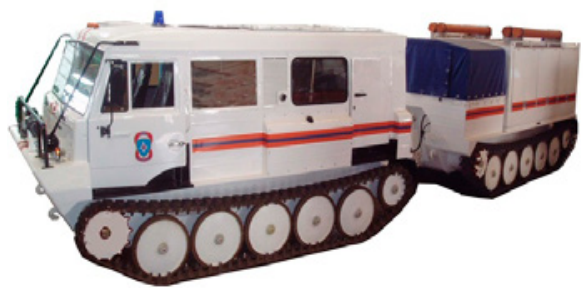

Rysunek 17. Pojazd ratowniczy na bazie przegubowego pojazdu gąsiennicowego ASM-GD (АСМ-ГД)

Źródło: www.mchs.gov.ru/document/2578010

Figure 17. Rescue vehicle based on ASM-GD (АСM-ГД) tracked vehicle source: www.mchs.gov.ru/document/2578010

Do prowadzenia ewakuacji dużej ilości ludzi, zarówno z obiektów budowlanych, jak i pasażerów samolotów, wykorzystano samochody wyposażone w ruchome trapy. Przykładem takiego rozwiązania jest mobilny trap typu TM-12 (43118), który umożliwia ewakuację grup o ograniczonej mobilności z obiektów użyteczności publicznej, takich jak szpitale, szkoły z internatem, domy opieki itp. Dodatkowo w konstrukcji trapu/pomostu ewakuacyjnego przewidziano instalację dwóch elastycznych rękawów ratowniczych, co z kolei daje jeszcze więcej możliwości organizacji działań ratowniczych. Trap wytrzymuje obciążenie rozproszone $1500 \mathrm{~kg}$. Zmodyfikowaną wersję producent proponuje jako samochód dla lotniskowych straży pożarnych.
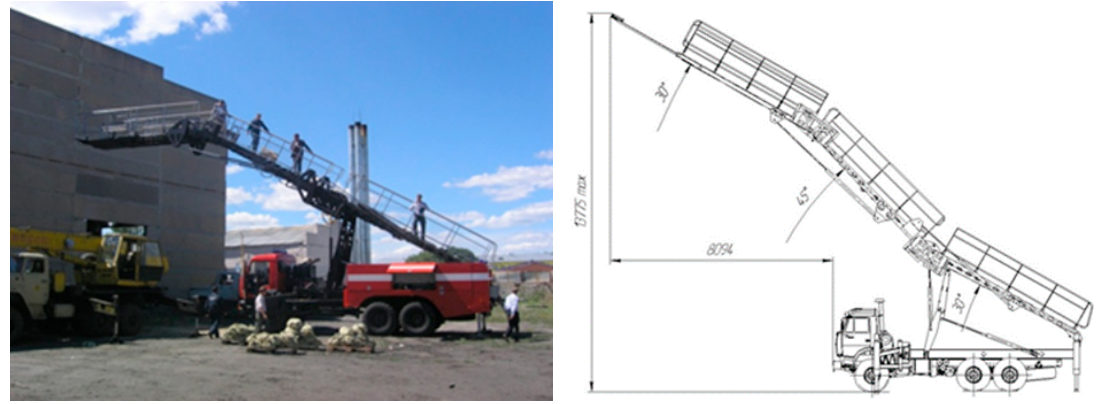

Rysunek 18. Mobilny trap typu TM-12 (43118) ${ }^{5}$ Figure 18. TM-12 (43118) mobile ladder 6

5 http://www.mchs.gov.ru/document/2578010

6 Tamże. 


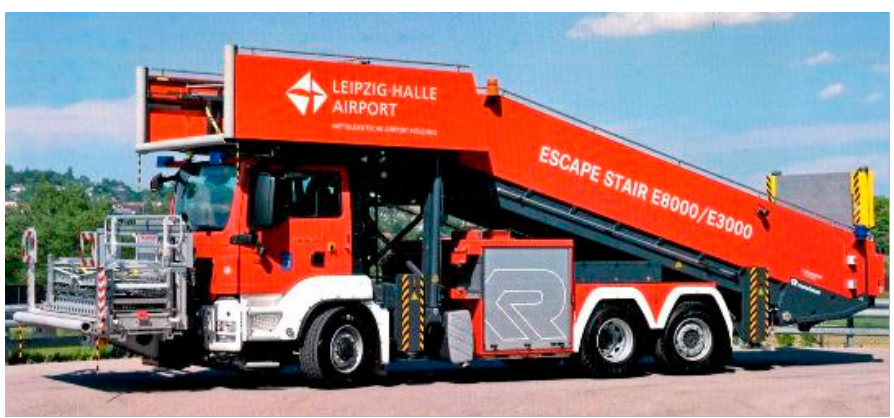

Rysunek 19. Mobilny trap firmy Metz ${ }^{7}$

Figure 19. Metz mobile ladder ${ }^{8}$

W wersji lotniskowej samochód wyposażony jest w trap pozwalający na ewakuację pasażerów samolotu z wysokości do $10 \mathrm{~m}$. Segmenty trapu automatycznie zachowują poziom przy jego podnoszeniu i opuszczaniu. Własności funkcjonalne pojazdu, posiadającego załogę składającą się z 5 osób, zostały powiększone przez zastosowanie autopompy działka gaśniczego zamontowanego pod zderzakiem przednim, zbiorników na wodę (5000 l) oraz środek pianotwórczy (300 l), dwutlenek węgla $(50 \mathrm{~kg})$ oraz proszków gaśniczych ABCD w ilości $200 \mathrm{~kg}$. Zastosowane wyposażenie pozwala na zabezpieczenie strefy bezpieczeństwa przy ewakuacji pasażerów, a także wykorzystanie samochodu jako dodatkowego sprzętu gaśniczego przy prowadzeniu działań ratowniczo-gaśniczych.

Podobne funkcjonalnie rozwiązanie proponuje firma Metz należące do koncernu Rosenbauer (rys. 19). Pojazd zbudowano na podwoziu typu ciężkiego MAN, gwarantującym wysokie własności dynamiczne (prędkość max. $105 \mathrm{~km} /$ godz., czas rozpędzania do $\mathrm{v}=80 \mathrm{~km} /$ godz. poniżej $30 \mathrm{~s}$.). Pojazd został wyposażony w trap o wysokości podnoszenia $8,3 \mathrm{~m}$, oraz teleskopową platformę zamontowaną przed kabiną załogi o wysokości podnoszenia $3 \mathrm{~m}$, samochód nie został wyposażony w sprzęt gaśniczy.

$\mathrm{W}$ celu efektywnego zastosowania nowych technik i technologii w gaszeniu pożarów i prowadzeniu działań ratowniczych, opracowano szereg nowych środków transportowych do działań ratowniczo-gaśniczych. W ofercie producentów znajdują się samochody gaśnicze z rozszerzonymi własnościami funkcjonalnymi. Pozwala to na wysnucie wniosku o formującej się tendencji tworzenia pojazdów wielofunkcyjnych. Powoduje to zauważalne działania producentów, którzy montują dodatkowe wyposażenie, co wymaga stosowania alternatywnych rozwiązań podlegających ograniczeniu stosowanego wyposażenia (np. ograniczenia pojemności stosowanych środków gaśniczych $\mathrm{z}$ uwagi na ograniczenia wynikające $\mathrm{z}$ dopuszczalnej masy całkowitej pojazdu), ewentualnie konieczność stosowania podwozia większej ładowności. W obu przypadkach poprawa jednych parametrów związana jest $\mathrm{z}$ pogorszeniem innych.

7 http://rykovodstvo.ru/exspl/17384/index.html?

8 Tamże. 
Jednym z takich rozwiązań jest pojazd ratowniczo-gaśniczy szybkiego reagowania ПCA-MM wyposażony w moduł medyczny. Samochód wyposażono w motopompę oraz zbiornik na środki gaśnicze o pojemności $200 \mathrm{l}$ oraz niezbędny sprzęt i wyposażenie pożarnicze. Zamontowany moduł medyczny daje możliwość udzielania pierwszej pomocy poszkodowanym, a także ich transportu do szpitalnych placówek medycznych. Podobne rozwiązanie proponuje firma Magirus w swoim specjalnym samochodzie ratowniczo-gaśniczym FRAP. Jest to pojazd klasy lekkiej ${ }^{9}(5,2 \mathrm{t})$ na podwoziu Iveco Daily. Może przewozić 5 osób załogi, środki gaśnicze, sprzęt medyczny i ratowniczy niezbędny do pełnienia roli samochodu pierwszej pomocy - również medycznej. W tym konkretnym rozwiązaniu istotna jest przyjęta koncepcja pojazdu, ponieważ ukompletowanie zależy od konkretnych potrzeb zamawiającego.

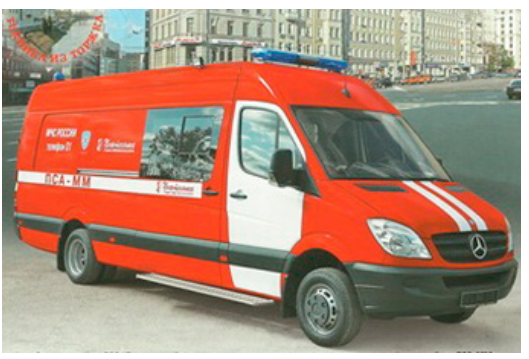

a) ПCA-MM (Rosja) ${ }^{10}$

a) $\Pi C A-M M(\text { Russia })^{12}$

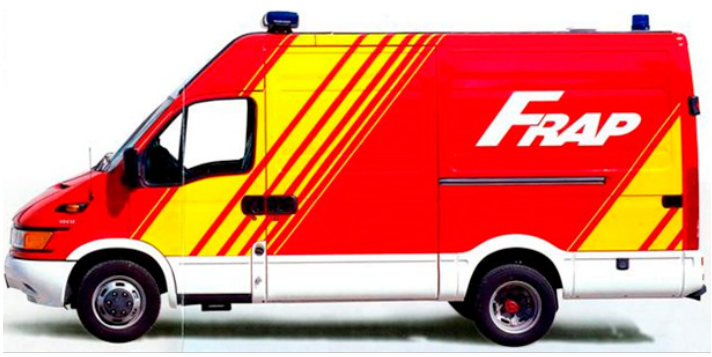

b) FRAP -Magirus (Niemcy) ${ }^{11}$

b) FRAP-Magirus (Germany) ${ }^{13}$

Rysunek 20. Samochód ratowniczo-gaśniczy z modułem medycznym Figure 20. Fire-rescue vehicle with medical module

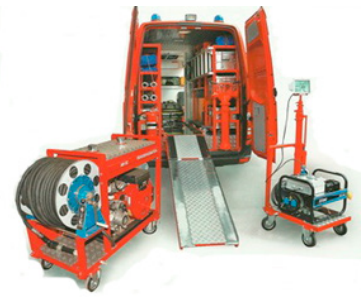

$A$

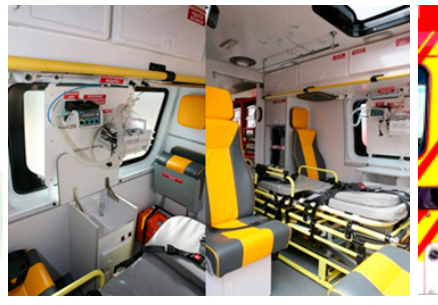

$B$

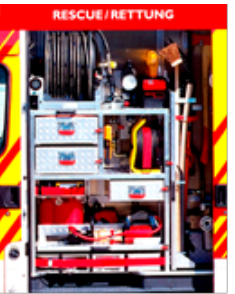

C

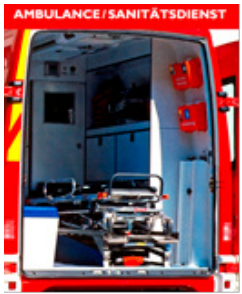

$D$

Rysunek 21. Widok przedziałów sprzętowych A, B - ПCA-MM (Rosja) C, D - FRAP (Niemcy) ${ }^{14}$

Figure 21. Equipment compartments: A, B - ПCA-MM (Russia); C,D - FRAP (Germany) ${ }^{15}$

\footnotetext{
${ }^{9}$ CNBOP-PIB-0026:2015 wydanie 1, Klasyfikacja, oznaczenie i podział pojazdów pożarniczych.

$10 \mathrm{http}: / /$ www.mchs.gov.ru/document/2578010

${ }^{11} \mathrm{http}: / /$ rykovodstvo.ru/exspl/17384/index.html?page $=2$

$12 \mathrm{http} / / /$ www.mchs.gov.ru/document/2578010

$13 \mathrm{http}: / /$ rykovodstvo.ru/exspl/17384/index.html?page $=2$

14 www.mchs.gov.ru/upload/site1/document_file/J1jSob6yJN.do

15 Tamże.
} 
Stosunkowo nowym kierunkiem jest prowadzenia działań ratowniczo-gaśniczych przy użyciu środków transportu o wysokich własnościach ruchowych wykorzystywanych w miastach o dużej intensywności ruch drogowego i ciasnej zabudowie. Stale rosnące natężenie ruchu drogowego, korki w ruchu ulicznym powodują konieczność stosowania rozwiązań zastępczych polegających na stosowaniu do działań ratowniczo-gaśniczych pojazdów o wysokiej mobilności. Zastosowane w tej roli motocykle zostały wyposażone w efektywne instalacje gaśnicze. Przykłady rozwiązań przedstawiono poniżej (rys. 22) ${ }^{16}, 17,18$.
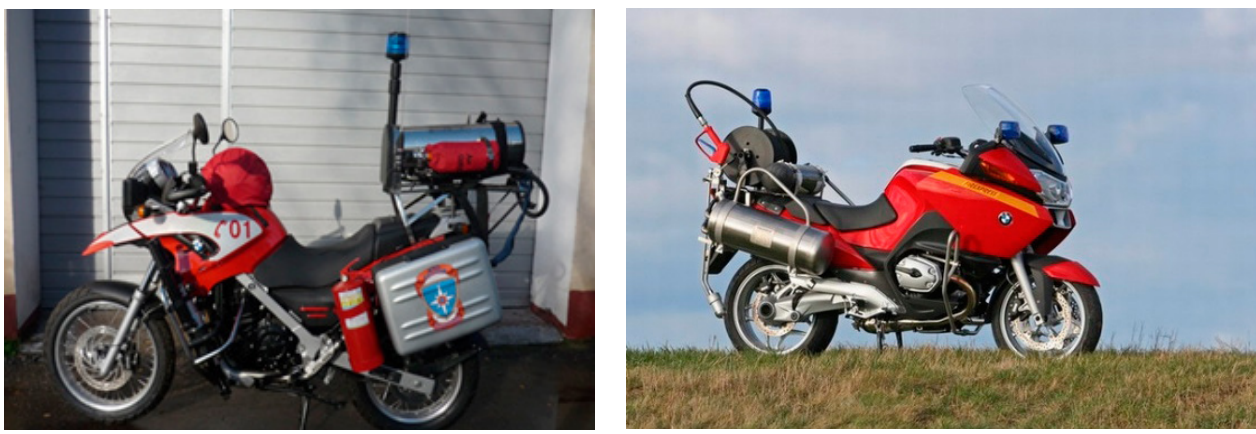

a) rozwiązanie rosyjskie (Russian approach); b) rozwiązanie duńskie (Danish approach)

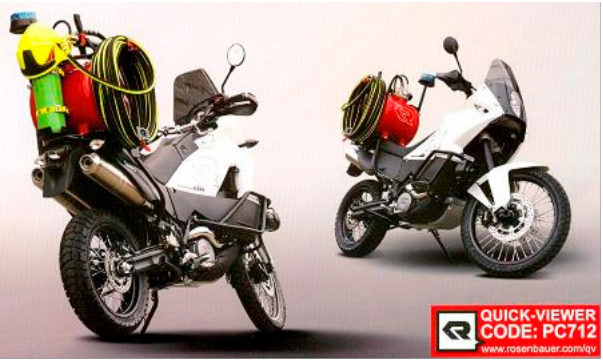

c) rozwiązanie niemieckie (German approach)

Rysunek 22. Przykłady motocykli gaśniczych

Figure 22. Examples of fire motorcycles

Konstrukcja opracowana przez VNIIPO (Rosja), wykonana na bazie motocykla BMW 650 oraz BMW 1200, została wyposażona w generatory aerozolu gaśniczego oraz instalację gaśniczą. Motocykl KTM prezentowany przez firmę Rosenbauer (Niemcy) wyposażono w agregat piany sprężonej CAFS SL50, natomiast firma Fireexpress (Dania) na motocyklu BMW R120RT zamontowała instalację do gaszenia rozpyloną wodą (mgłą wodną) z dodatkiem środka pianotwórczego. Instalacja gaśnicza wyposażona została w dwa 25 -litrowe zbiorniki na wodę i pianę chemiczną. Dzięki swoim zdolnościom manewrowym i dynamice, motocykle gaśnicze mogą

\footnotetext{
16 www.mchs.gov.ru/document/2578010

$17 \mathrm{http}: / /$ motoryzacja.interia.pl/news-motocykl-z-mala-sikawka,nId,1385267

18 http://www.mchs.gov.ru/document/2578010
} 
przybyć na miejsce zdarzenia, wykonać rozpoznanie i gaszenie pożaru w początkowej fazie rozwoju, przeprowadzić wstępne działania ratownicze z wykorzystaniem dostępnego na wyposażeniu sprzętu.

W obszarach trudnodostępnych, obszarach leśnych, miejscach pozbawionych utwardzonych dróg komunikacyjnych wykorzystywane są również quady, szczególnie do gaszenia pożarów w początkowej fazie rozwoju. Począwszy od roku 2005, kiedy takie pojazdy zaprezentowały firmy Magirus i Rosenbauer, w ciągu ostatnich lat liczba producentów pożarniczych quadów stale rośnie. Na rynku pojawiły się nowe firmy proponujące odbiorcom nowe typoszeregi quadów różnego przeznaczenia, wykonanych w różnych wersjach. W większości z nich zastosowano systemy gaśnicze: plecakowe, mgłowe, pianowe oraz sprzęt pomocniczy w różnych konfiguracjach (narzędzia hydrauliczne i elektromechaniczne, narzędzia ratownicze, agregaty prądotwórcze, kamery termowizyjne) ${ }^{19}, 20$.
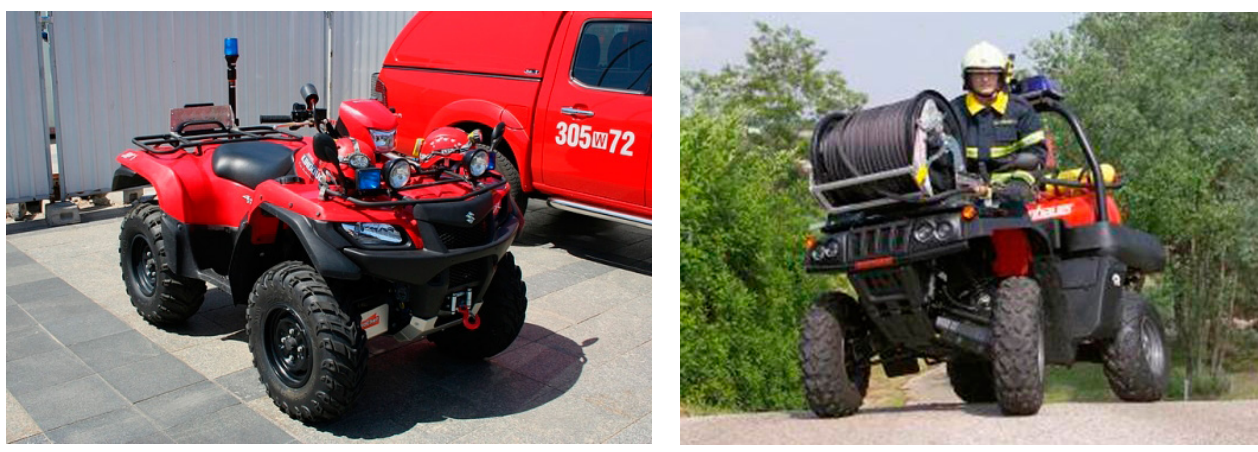

Rysunek 23. Przykładowe rozwiązania quadów wykorzystywanych w straży pożarnej Źródło: www.rc.fm/polityczne/quad-dla-strazakow.html, www.steo.com.pl/view/page/id/52/quad_ gasniczy_poly-cafs.html

Figure 23. All-terrain vehicles (quad-bikes) used in fire departments source: www.rc.fm/polityczne/quad-dla-strazakow.html, www.steo.com.pl/view/page/id/52/quad_ gasniczy_poly-cafs.html

Jednym z przykładowych bardziej zaawansowanych rozwiązań jest Arctic Cat wyposażony przez firmę Rosenbauer w agregat piany sprężonej POLY CAFS SL100, (rys. 23 po prawej). W warunkach polskich panuje duża dowolność w formułowaniu wymagań taktyczno-technicznych dla jednostek ochrony przeciwpożarowej. Związane to jest ze specyfiką prowadzonych działań, a także możliwościami finansowania zakupów. W innych państwach zostały stworzone klasyfikacje sprzętu oraz związane z tym wymagania taktyczno-techniczne. Wprowadzenie zasad standaryzacji w zakresie sprzętu i kompletacji wyposażenia ułatwia prowadzenie zagadnień eksploatacyjno-logistycznych oraz planowania operacyjnego.

19 http://www.rc.fm/polityczne/quad-dla-strazakow.html

$20 \mathrm{http}: / /$ www.steo.com.pl/view/page/id/52/quad_gasniczy_poly-cafs.html 
Jednocześnie, uwzględniając pozytywne doświadczenia innych, wynikające z eksploatacji pojazdów posiadających wszechstronne własności dynamiczno-ruchowe, można stwierdzić, że ich zastosowanie w prowadzeniu działań gaśniczych oraz ratowniczych będzie wzrastać.

\section{Zwiększanie funkcjonalności pojazdów turbinowych do gaszenia aerozolami gaśniczymi}

Turbinowe pojazdy gaśnicze znalazły swoje zastosowanie w działaniach ratowniczo-gaśniczych w latach $70 \mathrm{XX}$ wieku. Od tego czasu poddawane są kolejnym modyfikacjom, głównie poprzez ulepszanie podwozi. Jako generator gazów wyrzutowych w tych pojazdach wykorzystywane są turbinowe silniki lotnicze, gdzie w strumień gazów wylotowych za pomocą odpowiednich dysz podawane są środki gaśnicze. Wysokie własności gaśnicze są wynikiem kombinowanego sposobu gaszenia uwzględniającego proces schładzania oraz oddziaływania gazodynamicznego na źródło pożaru. W zależności od potrzeb wykorzystywane są podwozia gąsienicowe lub kołowe. VNIIPO (rosyjski odpowiednik CNBOP-PIB) opracowało konstrukcję mobilnego robota gaśniczego na podwoziu gąsienicowym МРУ ГВТ-15021, który przeznaczony jest do prowadzenia działań ratowniczo-gaśniczych w górnictwie, zakładach przetwórczych ropy i gazu, zakładach chemicznych w warunkach silnego promieniowania ciepłego. Zdalne sterowanie pojazdem realizowane jest $\mathrm{w}$ zależności od potrzeb $\mathrm{z}$ wykorzystaniem łączy wizyjnych i radiowych ze stanowiska kierowania na odległość do $1000 \mathrm{~m}$ od źródła pożaru. Pozwala to na gaszenie, schładzanie konstrukcji obiektów oraz instalacji technologicznych w obiektach szczególnego przeznaczenia, np. elektrowni jądrowych, magazynów uzbrojenia zakładów produkcyjnych wykorzystujących lub produkujących toksyczne lub trujące substancje.

Swoją wersję produkuje firma Zikun 22 (Niemcy) pod nazwą Turbo-Löscher (TL). Firma przedstawiła następujące kierunki zastosowań samochodu TL:

- gaszenie dużych pożarów obiektów i zakładów przemysłowych;

- walka z wyrzutami trujących i niebezpiecznych wybuchowo gazów;

- schładzanie konstrukcji i instalacji technologicznych na obiektach;

- ciśnieniowa wentylacja tuneli i analogicznych obiektów również przez podawanie strumienia gazów bez dodatku wody.

22 http:// zikun.de/project/aerosolloeschtechnik-turboloescher/ 

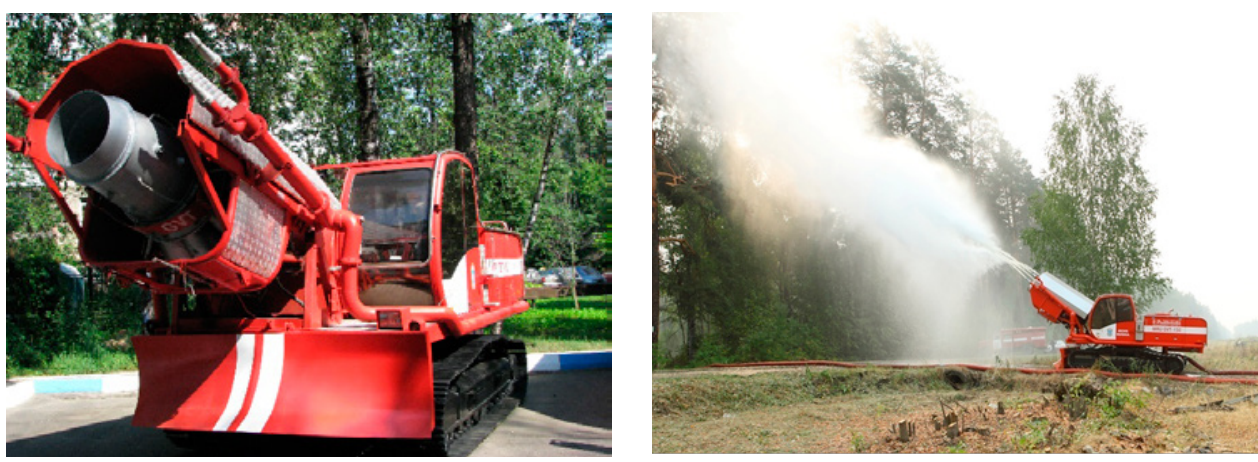

a) MPУ ГВТ-150 (Rosja) 23

a) MRU GVT-150 (Russia)
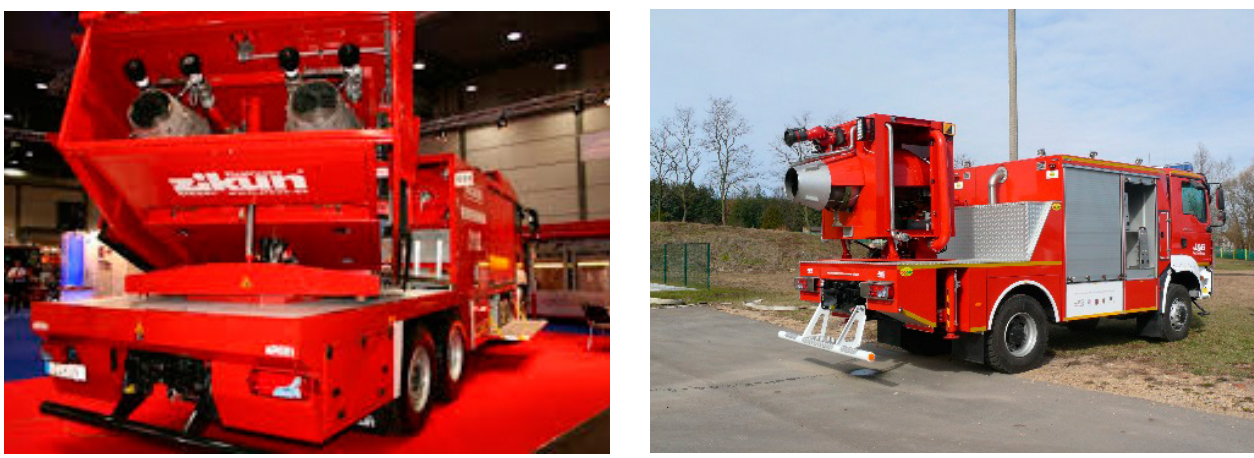

b) Turbo-Löscher firmy Zikun (Niemcy)

c) MTSRG (Polska) zdjęcie CNBOP-PIB

b) Zikun Turbo-Löscher (Germany)

c) MTSRG (Poland), picture CNBOP-PIB

Rysunek 24. Turbinowe pojazdy gaśnicze Figure 24. Turbine-based firefighting vehicles

Samochód firmy Zikun wyposażono w autopompę Rosenbauer o wydajności 6000 l/min służącą do podawania wody w strumień gazów spalinowych wytwarzanych przez 2 turbiny lotnicze. Silniki zostały zamontowane na obrotowym stanowisku z możliwością zmiany kąta ustawienia.

W ramach projektu Mobilny Turbinowy System Ratowniczo-Gaśniczy (MTSRG) finansowanego przez NCBR wykonany został demonstrator technologii karosowany na podwoziu MAN TGM 18.290 (4×4), w którym źródłem gazów jest turbina lotnicza typu SO 3 stosowana w samolotach Iskra. W odróżnieniu od poprzednich rozwiązań, została powiększona funkcjonalność samochodu z uwagi na możliwość podawania zarówno wody, jak i proszków gaśniczych, a także środków dekontaminacyjnych ze źródeł zewnętrznych. 


\section{Samochody wentylatorowe dużej wydajności}

Samochody pożarnicze tego typu przeznaczone są do prowadzenia prac polegających na przewietrzaniu/oddymianiu i schładzaniu dużych obiektów takich jak pawilony, podziemne garaże, wysokie budynki, hangary lotnicze, tunele kolejowe oraz drogowe itp. Tego typu pojazdy znajdują coraz szersze zastosowanie od kiedy firma BIG Brandschutz-Innovationen ${ }^{24}$ (Niemcy) wprowadziła do produkcji serię zespołów wentylatorowych dużej wydajności BIG MGV S 60 montowanych na różnych podwoziach. Przykłady zastosowanych rozwiązań funkcjonalnych przedstawiono na rys. 25. W zaprezentowanych samochodach zastosowano zestawy wentylatorowe zamontowane na stałe lub $\mathrm{z}$ możliwością demontażu $\mathrm{z}$ pojazdu. Przy stosowaniu zespołów wykonanych ze stali wydajność agregatu wynosi (dla powietrza) $230000 \mathrm{~m}^{3} /$ godz., źródłem napędu wentylatora jest hydrauliczny agregat z silnikiem wysokoprężnym lub silnik pojazdu. Funkcjonalność pojazdu została rozszerzona dzięki zastosowaniu trapezowego układu unoszącego wentylator oraz możliwości obrotu wokół osi poziomej o 360 stopni. Po raz pierwszy wprowadzono możliwość pionowego ustawienia wentylatora.

Przewidziano wykonanie wentylatorów o lżejszej, bardziej zwartej budowie - 125 wykonanych z włókna węglowego, wydajność $220000 \mathrm{~m}^{3}$ /godz., co pozwala na montowanie zespołu na mniejszych podwoziach.

Poniżej przedstawiono przykładowe rozwiązania dla zamontowanych agregatów BIG MGV S 60.
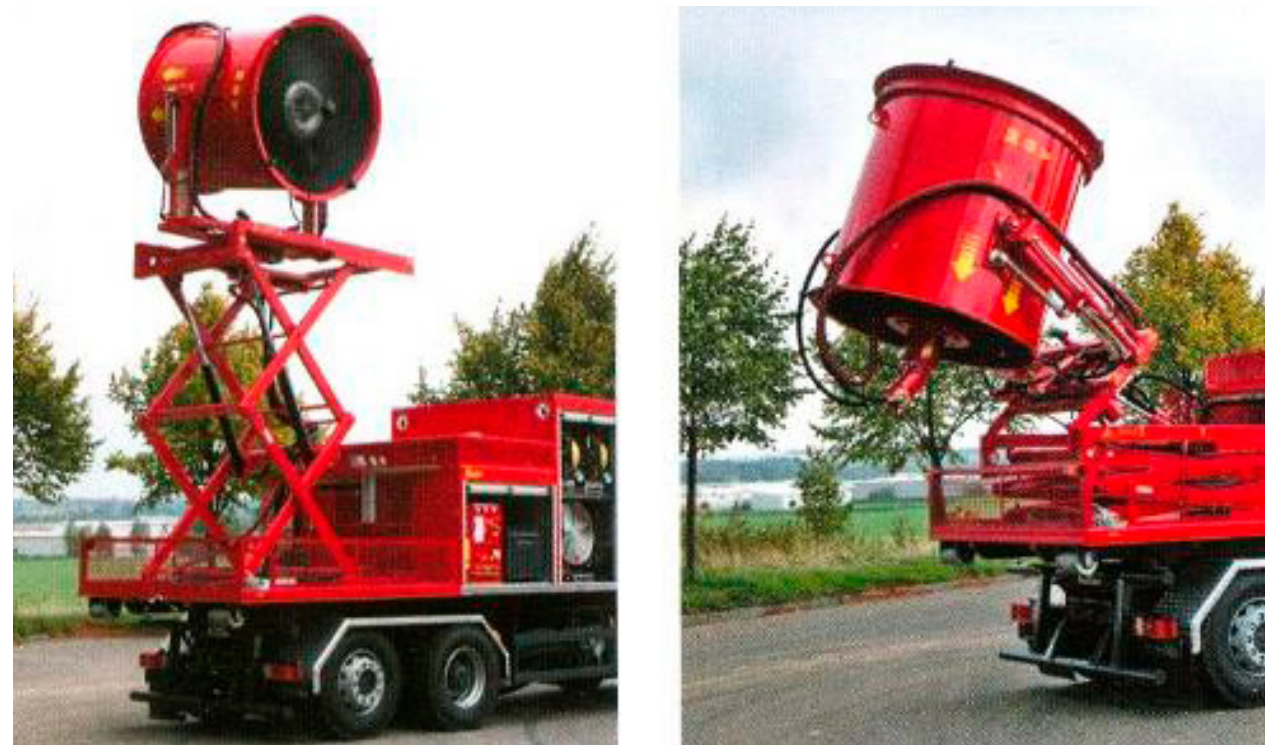

${ }^{24} \mathrm{http}: / /$ www.big-fire.eu/catalog/ 

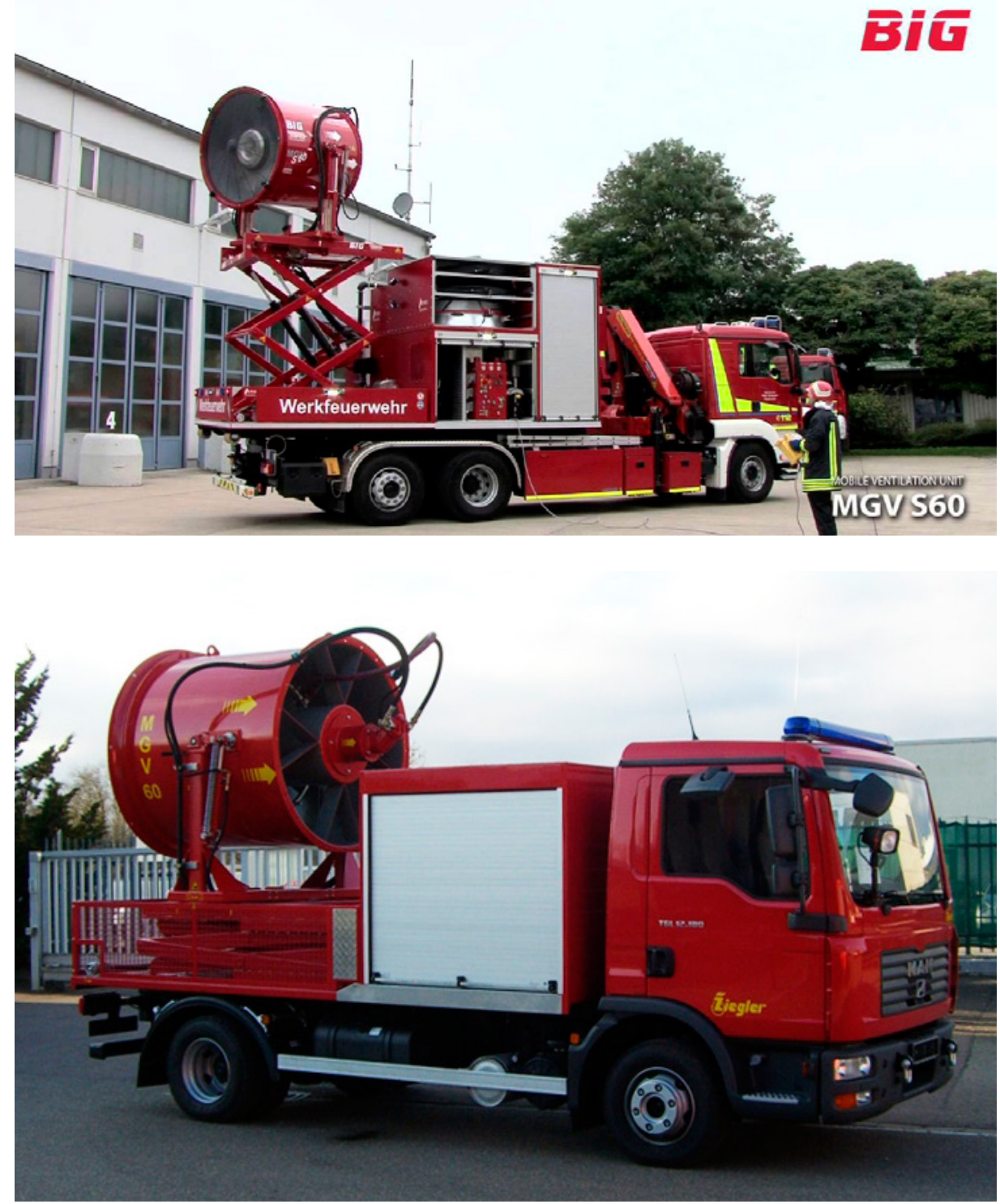

Rysunek 25. Samochód wentylatorowy

Źródło: https://www.google.pl/search?q=BIG+MGV+S+60\&client=firefox-b\&dcr=0\&tbm=isch\&source=iu\&ictx

Figure 25. Fan unit vehicle

source: $h t$ tps://www.google.pl/search?q=BIG+MGV+S+60

Przykładem wentylatorowego samochodu pożarniczego znajdującego się w produkcji seryjnej jest pojazd kontenerowy Pnumonik (rys. 26) ${ }^{25}$ (Rosja), składający się z nośnika kontenerów z systemem załadowczym oraz kontenera, w którym zamontowano:

25 www.mchs.gov.ru/document/2578010 


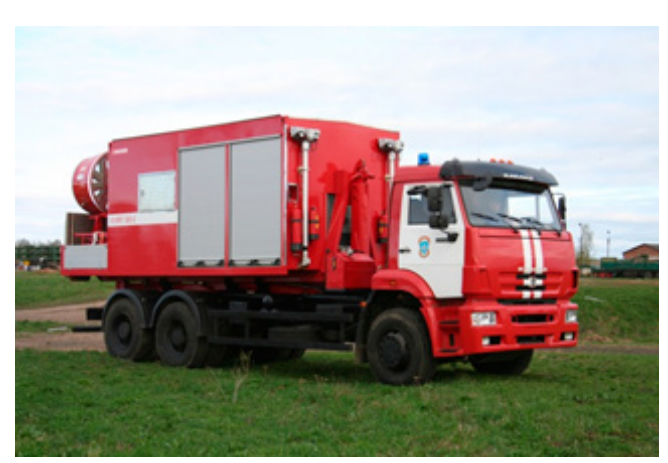

a) nośnik kontenerowy (Container carrier)

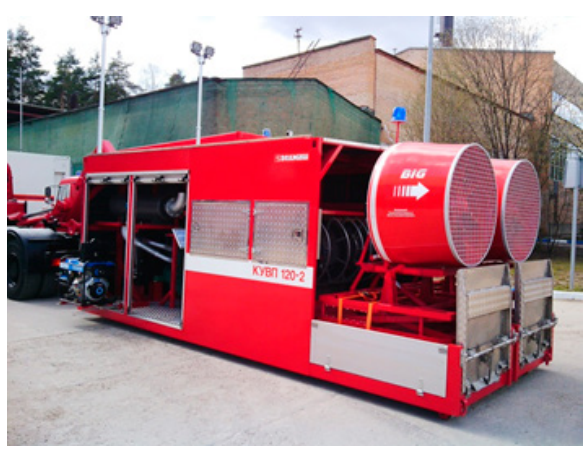

b) kontener wentylatorowy (Fan unit container)

Rysunek 26. Zestaw kontenerowy Pneumonik (Rosja)

Figure 26. Container unit Pneumonik (Russia)

- dwa wentylatory na podnoszonych statywach, o wydajności $120000 \mathrm{~m}^{3} /$ godz., każdy z możliwością zdjęcia z platformy transportowej i ustawienia w odległości do $30 \mathrm{~m}$;

- urządzenia do wytwarzania mgły wodnej zasilane ze źródeł zewnętrznych;

- systemu zdalnego sterowania pracą wentylatorów;

- zbiorniki na odczynniki, wykonane z materiałów antykorozyjnych, z zaworami odcinającymi (dla odczynników kwasowych i alkalicznych), pozwalającymi na ich podawanie przez dozownik do linii głównych i gaśniczych;

- sprzęt elektryczny.

Zastosowane wyposażenie pozwala na:

- usuwanie produktów spalania z zamkniętych pomieszczeń dużej objętości;

- obniżenia obciążeń cieplnych;

- obniżenia nasycenia powietrza ciężkimi cząsteczkami produktów spalania metodą ich osadzania;

- obniżenia poziomu nasycenia powietrza gorącymi gazami lub parami (propanu, butanu, metanu, benzyny itp.);

- obniżenia nasycenia powietrza parami amoniaku, chloru itp.;

- dostarczenia na miejsce działań ratowniczo-gaśniczych załogi oraz sprzętu i wyposażenia.

\section{Poduszkowce do działań ratowniczych oraz rozpoznania26, 27, 28}

Jednym z bardziej uniwersalnych pojazdów, który ma możliwość poruszania się praktycznie w dowolnym terenie takim jak woda, lód, śnieg, bezdroża czy tereny podmokłe i zalewowe, jest poduszkowiec. Ograniczenia, które wpływają na swobodę

\footnotetext{
$26 \mathrm{http}: / /$ www.airslide.eu

$27 \mathrm{http}: / /$ www.straz.krakow.pl/

${ }^{28} \mathrm{http} / / /$ www.portalmorski.pl/inne/31954
} 
użytkowania to nierówności terenu oraz wysokość przeszkód terenowych, ponieważ większość poduszkowców stosowanych w polskiej straży pożarnej oraz innych służbach ratowniczych może poruszać się na wysokości $20-30 \mathrm{~cm}$ nad poziomem gruntu. Różnica pomiędzy poduszkowcem a gruntem niwelowana jest przez kołnierz wykonany z elastycznej tkaniny mającej za zadanie utrzymanie nadciśnienia w poduszce powietrznej. Jednocześnie trwałość kołnierza decyduje o możliwościach eksploatacyjnych.

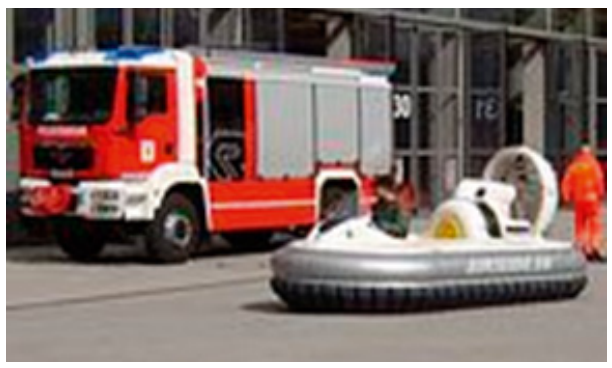

Rysunek 27. Poduszkowiec Airslide H 37 Figure 27. Airslide $H 37$ hovercraft

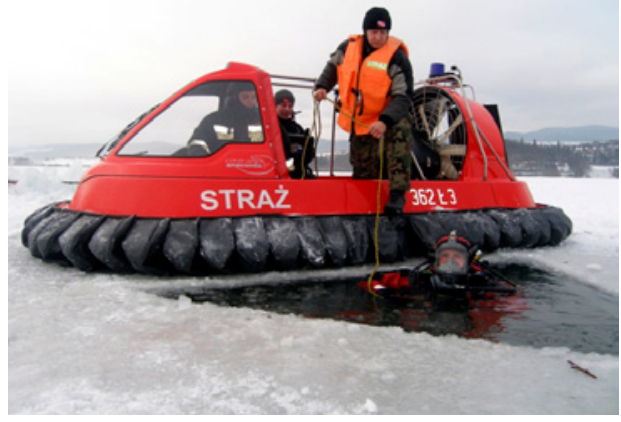

Rysunek 28. Poduszkowiec Anaconda HT-P400 Figure 27. Airslide H 37 hovercraft

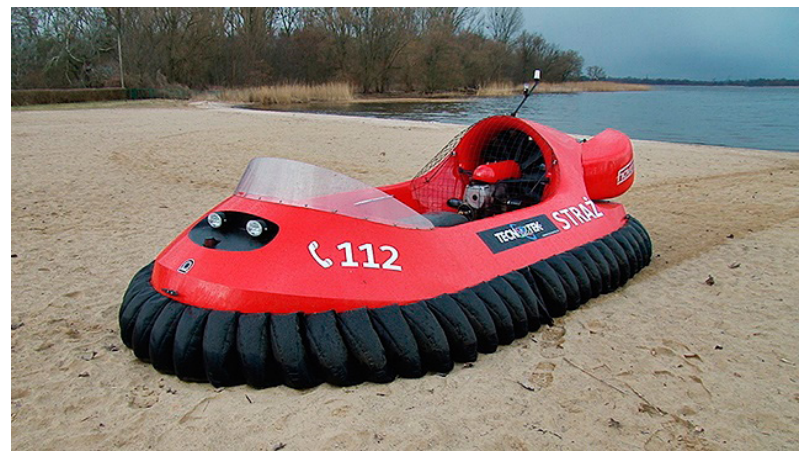

Rysunek 29. Poduszkowiec ratowniczy typ Hovertek 4p

Źródło: www.mchs.gov.ru/document/2578010

Figure 29. Hovertek 4p. rescue hovercraft

source: www.mchs.gov.ru/document/2578010

Poduszkowiec Airslide H3729 jest konstrukcją polską opracowaną w 2009 r. W celu zapewnienia optymalnej konstrukcji kadłub został wykonany z kompozytów. Dla zabezpieczenia 3-osobowej załogi oddzielono przestrzeń silnikową od pasażerskiej oraz zapewniono niezatapialność kadłuba posiadającego wyporność $700 \mathrm{~kg}$. Rozwiązania zastosowane w konstrukcji kadłuba pozwalają na eksploatację poduszkowca na wodzie o dowolnej głębokości. Z uwagi na niewielką masę

${ }^{29} \mathrm{http}: / / w w w . a i r s l i d e . e u /$ 
poduszkowiec może być przewożony po drogach publicznych na jednoosiowej przyczepie holowanej przez samochód osobowy.

Dane taktyczno-techniczne:

- silnik $57 \mathrm{~kW}$;

- prędkość na wodzie ok. 70 km/godz.;

- wysokość unoszenia 0,2;

- ladowność $240 \mathrm{~kg}$.

Poduszkowiec HT-P400 ANACONDA ${ }^{30}$ produkowany jest przez firmę Hovertech S.A. Od 2003 r. użytkowany jest przez jednostki straży pożarnej oraz inne służby ratownicze. Wykorzystywany w działaniach ratowniczych na wodzie, lodzie i lądzie w sytuacjach klęsk żywiołowych. Ma możliwość transportu 4 osób, w tym 2 poszkodowanych w pozycji siedzącej lub leżącej. Może być przewożony po drogach publicznych na jednoosiowej przyczepie holowanej przez samochód osobowy.

Dane taktyczno-techniczne:

- silnik $49 \mathrm{~kW}$

- prędkość na wodzie ok. $50 \mathrm{~km} / \mathrm{godz}$;

- wysokość unoszenia $0,25 \mathrm{~m}$;

- ładowność 300/400 kg.

Poduszkowiec Hovertek 4p ${ }^{31}$ firmy Hovercrafts jest jedną z najnowocześniejszych maszyn do prowadzenia działań ratowniczych dostępnych w kraju. Został zaopatrzony w innowacyjny system sterowania pozwalający na bardzo precyzyjne manewry jednostką.

Dane taktyczno-techniczne:

- silnik $47 \mathrm{~kW}$

- prędkość na wodzie ok. $40 \mathrm{~km} / \mathrm{godz}$;

- wysokość unoszenia $0,3 \mathrm{~m}$;

- ładowność $340 \mathrm{~kg}$.

Jak widać, zaprezentowane jednostki pozwalają na prowadzenie działań w ograniczonym zakresie, wymagają jednocześnie dość dużych nakładów na sprzęt - wynoszących około 120-150 tys. zł.

W innych państwach poduszkowce stosowane w jednostkach ochrony przeciwpożarowej są odmianami produkowanymi przez wyspecjalizowane zakłady i są bardziej profesjonalnie dostosowane do zakresu wykonywanych zadań. Przykładem takiego rozwiązania jest poduszkowiec Posejdon 32 (Rosja), który jest wielofunkcyjnym uniwersalnym środkiem transportowym przeznaczonym do realizacji zadań związanych z:

\footnotetext{
$30 \mathrm{http}: / /$ www.hovertech.com.pl/app/webroot/files/Files/ht-p400_anaconda_pl.pdf

$31 \mathrm{http} / / /$ tecnotek.pl/poduszkowce_ratownicze.php

32 http://www.mchs.gov.ru/document/2578010
} 
- gaszeniem pożarów na jednostkach pływających;

- prowadzeniem prac podwodnych i nurkowych;

- ratowaniem tonących i uwięzionych na krach;

- dostarczaniem sprzętu ratunkowego (łodzie, pontony pneumatyczne) na miejsce prowadzonych działań.
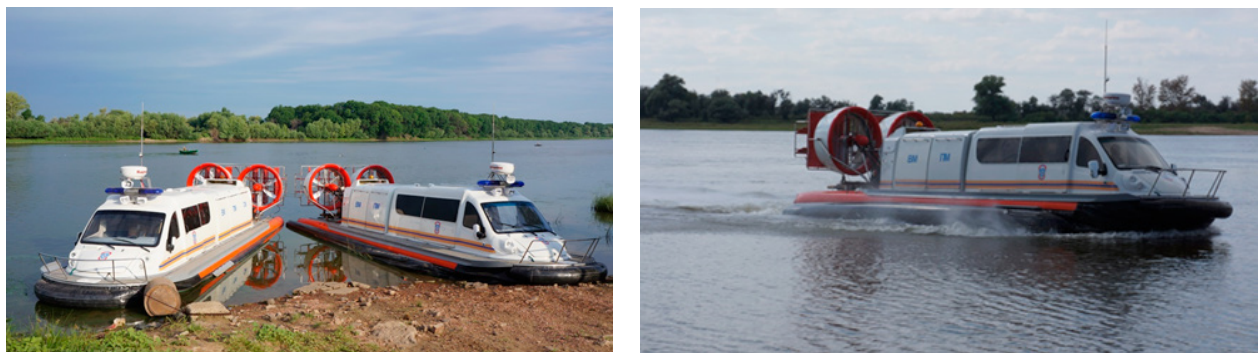

Rysunek 30. Poduszkowiec Posejdon (Rosja)

Źródło: www.mchs.gov.ru/document/2578010

Figure 30. Poseydon hovercraft (Russia)

source: www.mchs.gov.ru/document/2578010

Jednostka może być eksploatowana przez cały rok w zakresie temperatur od $-50^{\circ} \mathrm{C}$ do $+50^{\circ} \mathrm{C}$, niezależnie od wilgotności, po względnie równych powierzchniach. Może pokonywać nierówności ze startu stojącego $7^{\circ}$, natomiast przy prędkości $50 \mathrm{~km} /$ godz. do $30^{\circ}$. Załoga 1-osobowa (pilot). Liczba pasażerów - od 6 do 10 osób (w zależności od wersji). Cechą charakterystyczną Posejdona są wymienne moduły sprzętowe, pozwalające na szybkie dostosowanie do planowanego zadania (pożarniczy, nurkowy, ratowniczy, medyczny).

Podsumowując przedstawione przykłady innowacyjnych konstrukcji i technologii można pokusić się o określenie tendencji rozwojowych techniki pożarniczej:

- producenci w budowie pojazdów pożarniczych wykorzystują modyfikacje standardowych podwozi z powiększoną kabiną dostarczaną przez producenta pojazdu; wykorzystywane podwozia przeznaczone do montażu nadbudowy pożarniczej wyposażane są w silniki o mocy jednostkowej co najmniej $20 \mathrm{KM} / \mathrm{t}$; coraz częściej w układach napędowych wykorzystywane są automatyczne skrzynie biegów z przystawkami odbioru mocy; wymagania ekologiczne powodują, że silniki muszą spełniać normy Euro 6;

- w produkcji pojazdów pożarniczych regułą staje się używanie elementów aluminiowych oraz nowoczesnych technologii łączenia oraz wykorzystanie do tworzenia zabudowy włókiem węglowych oraz tworzyw sztucznych;

- tradycyjne samochody gaśnicze zastępowane są przez wielofunkcyjne samochody ratowniczo-gaśnicze o poszerzonej kompletacji, wyposażone w powiększone kabiny załogi; standardowe kabiny (1+2) wykorzystywane są w klasycznych samochodach typu ciężkiego; 
- rośnie udział pojazdów specjalnych do prowadzenia działań ratowniczo-gaśniczych wykorzystujących agregaty turbinowe oraz agregaty oddymiające dużej wydajności;

- uwzględniając pozytywne doświadczenia innych wynikające z eksploatacji motocykli oraz quadów pożarniczych o wszechstronnych własnościach taktyczno-ruchowych, można stwierdzić, że ich zastosowanie w prowadzeniu działań gaśniczych oraz ratowniczych będzie rosło.

\section{Bibliografia}

[1] Jakowienko J., Sowriemiennyje pożarnyje awtomobili: modielnyje riady, effiektiwnyje rieszenija i tiechnołogi, Katałog „Pożarnaja biezopasnost” 2017 (dostęp: 08.01.2018).

[2] Jakowienko J., Pożarnyje awtomobili nowogo pokolenija: effiektiwnyje rieszenija Opublikowano, Katałog „Pożarnaja biezopasnost” 2017 (dostęp: 08.01.2018).

[3] Jakowienko J., Riealizacyja koncepcyi mnogofunkcyonalnosti awtomobilej tuszenija, Katałog „Pożarnaja biezopasnost” 2017 (dostęp: 08.01.2018).

[4] 12. POŻARNAJA TIECHNIKA, http://rykovodstvo.ru/exspl/17384/index.html? (dostęp: 15.01.2018).

[5] Innowacyonnyje razrabotki MCZS Rossii w obłasti pożarno-spasatielnoj tiechniki i tiechnołogij prieduprieżdienija i likwidacyi czriezwyczajnych situacyj http://www. mchs.gov.ru/document/2578010 (dostęp: 28.01.2018).

[6] System kontenerowy w Państwowej Straży Pożarnej, http://www.wsei.lublin.pl/upload/ file/konferencje-materialy/2015-12-15/System\%20kontenerowy\%20w\%20Pa\%C5\%84stwowej\%20Stra\%C5\%BCy\%20Po\%C5\%BCarnej.pdf (dostęp: 28.01.2018).

[7] Standaryzacja wyposażenia pojazdów pożarniczych i innych środków transportu PSP, http://www.straz.gov.pl/panstwowa_straz_pozarna/standaryzacja_wyposazenia_pojazdow_psp (dostęp: 28.01.2018).

[8] Katalog BIG Brandschutz-Innovationen, http://www.big-fire.eu/catalog/ (dostęp: 18.01.2018).

[9] www.airslide.eu

[10] www.straz.krakow.pl/

[11] http://tecnotek.pl/poduszkowce_ratownicze.php 



\title{
Badania ergonomii i bezpieczeństwa pojazdu pożarniczego
}

\section{Researches of ergonomics and safety of fire truck}

\author{
Włodzimierz Kupicz \\ Jarosław Kończak \\ Marcin Mieteń \\ Marcin Grubek \\ Grzegorz Wiśniewski
}

Wojskowy Instytut Techniki Pancernej i Samochodowej

\section{Streszczenie}

Na podstawie analizy narażeń ratowników podczas typowych akcji ratowniczo-gaśniczych oraz dojazdu do nich, przeprowadzono badania weryfikujące główne cechy, które decyduja o ergonomii pojazdu pożarniczego z uwzględnieniem warunków środowiskowych. W ramach badań przeprowadzono analize ergonomii użytkowania pojazdu $w$ środowisku wirtualnym przy pomocy skanera $3 \mathrm{D}$ oraz pakietu specjalistycznego oprogramowania. Przeprowadzono sprawdzenia ochrony członków załogi przed oddziaływaniem czynników środowiskowych, t.j. wysoka i niska temperaturą, zwiększona wilgotnością oraz zwiększonym zapyleniem, których zakres obejmował sprawdzenia skuteczności układów ogrzewania, klimatyzacji $i$ wentylacji wnętrza kabiny oraz jej pyłoszczelności i kroploszczelności. Ponadto w warunkach narażeń środowiskowych przeprowadzono sprawdzenia funkcjonalne zabudowy pożarniczej pojazdu. Przeprowadzone zostały pomiary drgań oraz hałasu na stanowiskach pracy członków załogi pojazdu.

\begin{abstract}
Based on the analysis of exposures of rescuers during the typical rescue and firefighting operations and the arrival to them, made tests to verify the main features that determine the ergonomy of the fire vehicle, taking into account environmental conditions. During the research, made analysis of the ergonomy of vehicle using virtual environment ( $3 D$ scanner and a specialized software package). The checks concerned the methods of the protect crew members against the impact of environmental factors as high temperature, low temperature, increased humidity and increased dustiness, which range included checking the effectiveness of heating, air-conditioning and ventilation systems inside the cabin, as well as dust-tightness and drop-tightness. In addition, made the functional checks of the fire-fighting structure of the vehicle in difficult environmental conditions. Were also made measurements of the vibrations and noise on workplaces of vehicle crew.
\end{abstract}




\section{Wstęp}

W dobie modernizacji i wdrażania nowych pojazdów do służb mundurowych jedną z ważniejszych cech jest ergonomia wnętrza pojazdu oraz jego zewnętrznych przestrzeni użytkowych. W pracy autorzy skupili się na zagadnieniach związanych z badaniem i oceną ergonomii pojazdów specjalnych. Komfort pracy załogi jest bardzo ważnym czynnikiem, ponieważ wpływa na efektywność działania podczas wykonywania konkretnego zadania. W szerokim pojęciu ergonomii jest szereg cech, które wymagają oceny. Głównym problemem badawczym jest ocena cech niemierzalnych. Autorzy w ramach pracy przybliżyli jak w Wojskowym Instytucie Techniki Pancernej i Samochodowej dokonuje się badania ergonomii pojazdów specjalnych. W opracowaniu skoncentrowano się przede wszystkim na wykorzystaniu inżynierii odwrotnej do prowadzenia badań ergonomii. Przestrzeń robocza powinna być dostosowana do określonej populacji oraz uwzględniać wyposażenie indywidualne załogi. Tego typu badania przeprowadza się zazwyczaj poprzez oględziny oraz pomiary liniowe. Nowe technologie pozwalają na zastosowanie inżynierii odwrotnej (skaner 3D), która eliminuje subiektywne odczucia osoby przeprowadzającej badanie. Skanując obiekt odtwarzamy pojazd oraz przestrzeń wewnątrz kabiny jako model przestrzenny - 3D. W środowisku wirtualnym możemy zaimplementować wirtualnego manekina 3D, dzięki któremu można sprawdzić następujące cechy: widoczność z miejsca pracy użytkownika pojazdu, zasięg pracy użytkownika pojazdu (np. nóg i rąk), widoczność z miejsca kierowcy, widoczność w lusterkach wstecznych, siły w układzie szkieletowo-mięśniowym użytkownika pojazdu w zależności od wykonywanej czynności (np. zmiana przełożeń skrzyni biegów, otwieranie schowka, podnoszenie osprzętu). Odpowiednio zaprojektowana i wykonana przestrzeń wewnętrzna kabiny pojazdu specjalnego jest konieczna do prawidłowego współdziałania systemu w układzie człowiek - pojazd. To samo dotyczy obsługiwania urządzeń, schowków, szaf w zabudowie specjalistycznej, włączając także dach pojazdu, np. strażackiego.

\section{Wymagania dotyczące ergonomii i bezpieczeństwa}

W trakcie analizy literatury w zakresie ergonomii i bezpieczeństwa użytkowania wytypowano następujące wskaźniki oraz cechy funkcjonalne podlegające ocenie [1, 3-16]:

- w zakresie ergonomii:

- kabinę kierowcy i przedział załogi, a w tym:

> siedziska kierowcy i załogi pod kątem możliwości swobodnego zajmowania miejsc i opuszczenia pojazdu w trybie alarmowym, z pełnym wyposażeniem w odzieży ochronnej oraz w aparatach ochrony dróg oddechowych; 
> przestrzeń wokół miejsca każdego z członków załogi, w szczególności odpowiednią ilością miejsca na nogi, na wysokości ramion oraz nad głową ratownika $z$ hełmem ochronnym; parametry te decydują o bezpieczeństwie podczas dynamicznych manewrów oraz podczas jazdy terenowej;

> poziom hałasu w kabinie podczas dynamicznej jazdy (hałas od zespołu napędowego pojazdu) przy włączonej sygnalizacji ostrzegawczej (syrena alarmowa w różnych trybach pracy);

> skuteczność działania układów ogrzewania wnętrza, w tym postojowego używanego podczas długotrwałych akcji ratowniczych;

> skuteczności układu klimatyzacji i wentylacji podczas wysokich temperatur otoczenia oraz jako skuteczny sposób na zapobieganie intensywnemu parowaniu szyb kabiny od wilgotnych (nasiąkniętych podczas intensywnych opadów atmosferycznych) ubrań ochronnych ratowników;

- zabudowy pożarniczej, a w tym:

> zabudowy podestów roboczych po kątem ich umieszczenia na odpowiedniej wysokości;

> odpowiedniego sposobu rozmieszczenia sprzętu, aby jego wyjmowanie nie narażało ratowników na nadmierne obciążenia układu kostno-mięśniowego oraz połączeń ruchomych - stawów;

> funkcjonowania zamków, szuflad, tac, rolet oraz całego sprzętu zamocowanego na stałe w zabudowie w ekstremalnych warunkach środowiskowych takich jak niskie i wysokie temperatury (np. oblodzenie powierzchni roboczych, rozgrzanie uchwytów), wysoka wilgotność, zapylenie;

> funkcjonowania układu wodno-pianowego w warunkach ujemnych temperatur (do $-15^{\circ} \mathrm{C}$ dla strefy klimatycznej Polski oraz do $-25^{\circ} \mathrm{C}$ dla strefy klimatycznej np. w krajach skandynawskich) i związanych z tym zagrożeń: obmarzanie nasad tłocznych, utrudnione stawianie linii gaśniczych, operowanie sprzętem ratowniczym w grubych ocieplanych rękawicach;

- w zakresie bezpieczeństwa użytkowania:

- kabinę kierowcy i przedział załogi, a w tym:

> stopnie, poręcze, uchwyty, klamki, wykładziny antypoślizgowe, gabaryty drzwi i kinematykę ich otwierania pod kątem możliwości bezpiecznego wchodzenia i opuszczania pojazdu w trybie alarmowym, z pełnym wyposażeniem w odzieży ochronnej oraz w aparatach ochrony dróg oddechowych;

> siedziska załogi pod kątem możliwości szybkiego zapięcia pasów oraz założenia aparatów ochrony dróg oddechowych zabudowanych w oparciu siedziska; 
> wytrzymałość mocowań butli ciśnieniowych aparatów ochrony dróg oddechowych zabudowanych w oparciu siedziska na obciążenia do wartości $10 \mathrm{~g}$, mogące powstać podczas dynamicznej jazdy w warunkach terenowych lub kolizji;

> siedziska kierowcy i załogi pod kątem narażeń na drgania występujące podczas dynamicznej jazdy po nierównych drogach, a w szczególności w pojazdach terenowych poza drogami utwardzonymi;

> mocowania podręcznego sprzętu, np. środków łączności, latarek itp., umieszczonego w kabinie załogi;

> narażenia załogi wynikające z niewłaściwego umieszczenia osprzętu, ostrych krawędzi oraz małej trwałości mocowań.

- zabudowy pożarniczej, a w tym:

> zabudowy podestów roboczych po kątem ich wyposażenia w poręcze, barierki, powierzchnie antypoślizgowe;

> odpowiedniego sposobu rozmieszczenia sprzętu, aby jego wyjmowanie nie narażało ratowników na kontuzje;

> sposobu zamocowania i zabezpieczenia oraz trwałości szuflad, tac i półek na przenośny sprzęt ratowniczo-gaśniczy;

> hałasu, w szczególności na stanowisku operatora autopompy; podczas długotrwałych akcji operator narażony jest na wielogodzinne oddziaływanie wysokiego poziomu dźwięku od napędu autopompy; oprócz zmian fizjologicznych narządu słuchu i w konsekwencji układu nerwowego, wysoki poziom hałasu może powodować zakłócenia w komunikacji pomiędzy dowódcą i ratownikami, co stwarza istotne zagrożenia w niebezpiecznym środowisku pożaru bądź innego niebezpiecznego zdarzenia;

> oświetlenia pola pracy, wszystkich skrytek, podestów i stopni, granicy światła i cienia wokół pojazdu, co powoduje chwilowe olśnienie podczas zbliżania do pojazdu oraz po wejściu na nieoświetlony teren, co wywołuje chwilowy brak widoczności (w warunkach prowadzenia działań ratowniczych sytuacja taka jest uciążliwa oraz stwarza zagrożenie kontuzji na skutek potknięcia lub zranienia podczas wyjmowania sprzętu);

> zagrożenia porażeniem prądem związane z pracą agregatu prądotwórczego w bezpośrednim sąsiedztwie układu wodno-pianowego pracującego pod ciśnieniem do 40 bar, przy rozłączanej linii gaśniczej i ewentualnych nieszczelnościach węży tłocznych.

Powyższe wymagania zostały opracowane na podstawie następujących dokumentów odniesienia:

- norma PN-91 N-08018 Strefy pracy kończyn górnych;

- norma PN-80 N-08001 Granice zasięgu rąk;

- norma PN-81 N-08002 Granice ruchu stopy; 
- norma PN-83 N-08015 Ergonomia;

- norma PN-EN 1846-1: 2011 Samochody pożarnicze - Podział i oznaczenie;

- norma PN-EN 1846-2+A1: 2013-07 Samochody pożarnicze - Część 2: Wymagania ogólne - Bezpieczeństwo i parametry;

- ustawa z dnia 24 sierpnia 1991 r. o Państwowej Straży Pożarnej (Dz.U. z 2006 r. Nr 96, poz. 667 z późn. zm.);

- norma MIL-STD-1472G (rys. 1-3);

- norma Obronna NO-06-A104, pkt. 2.14.

Każdy z powyższych dokumentów zawiera wymagania do różnych cech/wskaźników odnoszących się do ergonomii. Brakuje jednego dokumentu odniesienia, który by jednoznacznie precyzował badane wskaźniki i cechy oraz określał metody ich badań.

\section{Analiza ergonomii w środowisku wirtualnym}

Analiza ergonomii w środowisku wirtualnym jest możliwa z wykorzystaniem skanera 3D i pakietu oprogramowania do badań ergonomii [2]. Przy wykorzystaniu skanera 3D wykonuje się model 3D pojazdu pożarniczego (rys. 1) oraz jego wnętrza. Do badań można również użyć modelu 3D pojazdu zaprojektowanego w środowisku CAD.

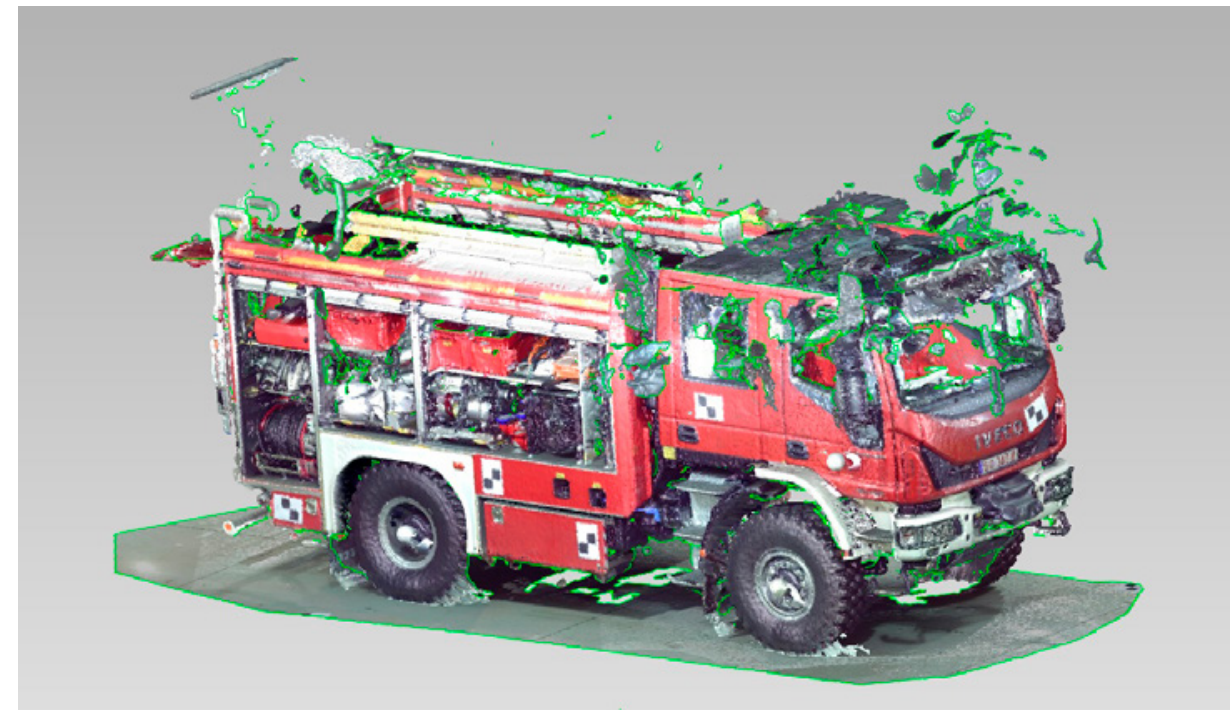

Rysunek 1. Widok modelu 3D zeskanowanego pojazdu pożarniczego Źródło: opracowanie własne

Figure 1. View of the 3D model of the scanned fire truck

W oprogramowaniu do badań ergonomii można wykorzystać manekiny w dowolnym wymiarze wzrostu oraz masy, można również określić płeć manekina. $\mathrm{Na}$ 
rys. 2 i w tabeli 1 przestawiono widok i parametry manekinów reprezentujących 5, 50, 95 centyl populacji.

TABELA 1. WZROST I MASA MANEKINÓW REPREZENTUJĄCYCH 5, 50, 95 CENTYL

POPULACJI MĘSKIEJ

TABela 1. Height And mass of MANnequins Representing 5, 50, 95 PerCentile

OF THE MALE POPULATION

\begin{tabular}{|c|c|c|}
\hline Centyl & Wzrost $[\mathrm{cm}]$ & Masa $[\mathrm{kg}]$ \\
\hline 5 & 165 & 63 \\
\hline 50 & 175 & 79 \\
\hline 95 & 187 & 101 \\
\hline
\end{tabular}

Źródło: opracowanie własne

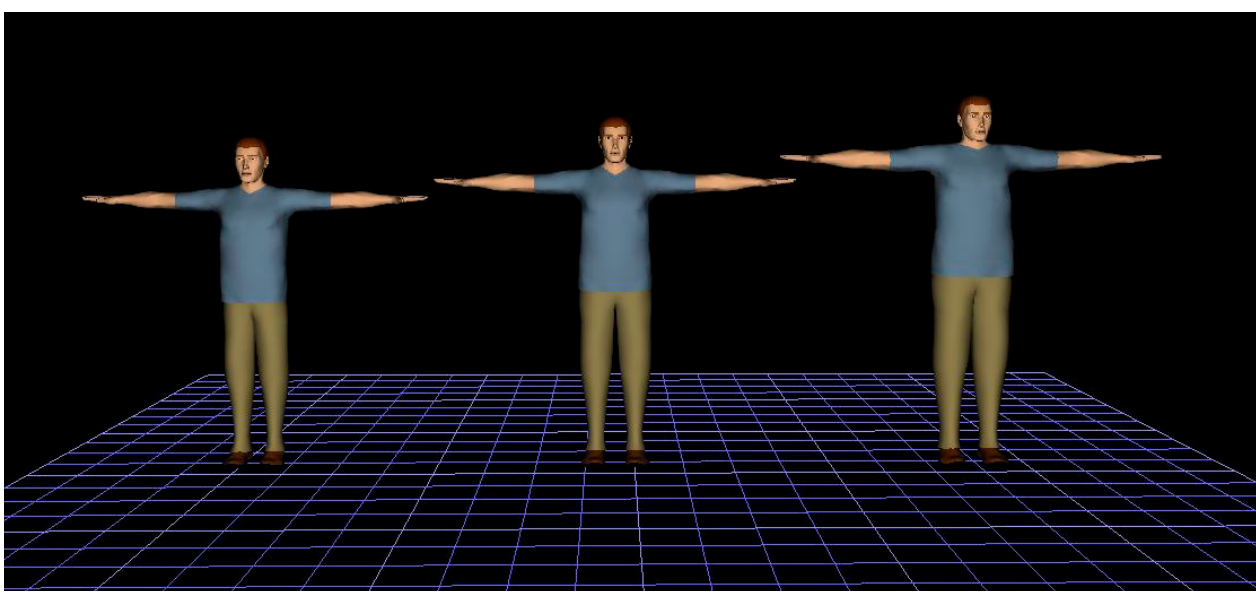

Rysunek 2. Widok manekinów reprezentujących 5, 50, 95 centyl populacji męskiej Źródło: opracowanie własne

Figure 2. Mannequins representing 5, 50, 95 centile of the male population

Za pomocą specjalistycznego oprogramowania można sprawdzić wymiary przestrzeni roboczej określonej np. w normie MIL-STD-1472G (rys. 3-5), jak również przeanalizować możliwość poboru określonego wyposażenia specjalistycznego ze skrytek (rys. 6-7). Powyższe oprogramowanie ma szerokie możliwości wykorzystania w pracach badawczych czy konstrukcyjnych. W ramach projektu realizowanego w WITPiS analizowano również takie cechy jak:

- widoczność z miejsca pracy użytkownika pojazdu;

- zasięg pracy użytkownika pojazdu (nóg i rąk);

- widoczność z miejsca kierowcy;

- widoczność w lusterkach wstecznych;

- siły w układzie szkieletowym użytkownika pojazdu w zależności od wykonywanej czynności (np. zmiana biegów, otwieranie schowka). 


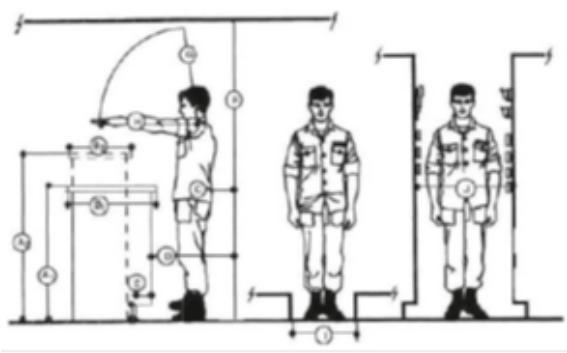

Rysunek 3. Wymiary stojącej przestrzeni roboczej [3]

Źródło: Norma MIL-STD-1472G

Figure 3. Dimensions of the standing working space [3]

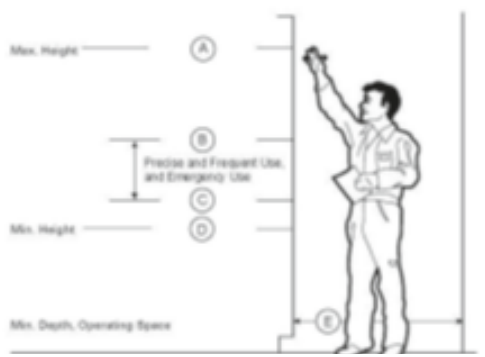

Rysunek 4. Zalecenia do montażu elementów sterujących [3]

Źródło: Norma MIL-STD-1472G

Figure 4. Recommendations for mounting control elements

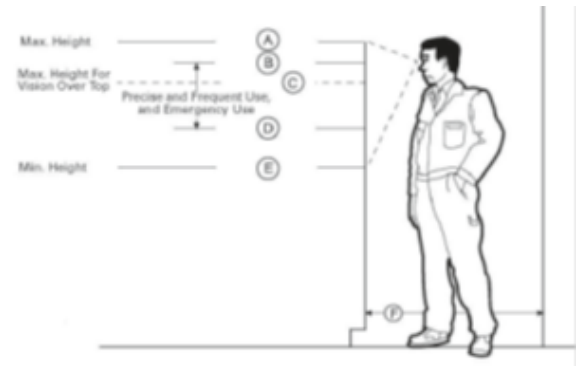

Rysunek 5. Zalecenia do montażu wyświetlaczy / zegarów / wskaźników [3] Źródło: Norma MIL-STD-1472G

Figure 5. Recommendations for mounting displays / clocks / indicators

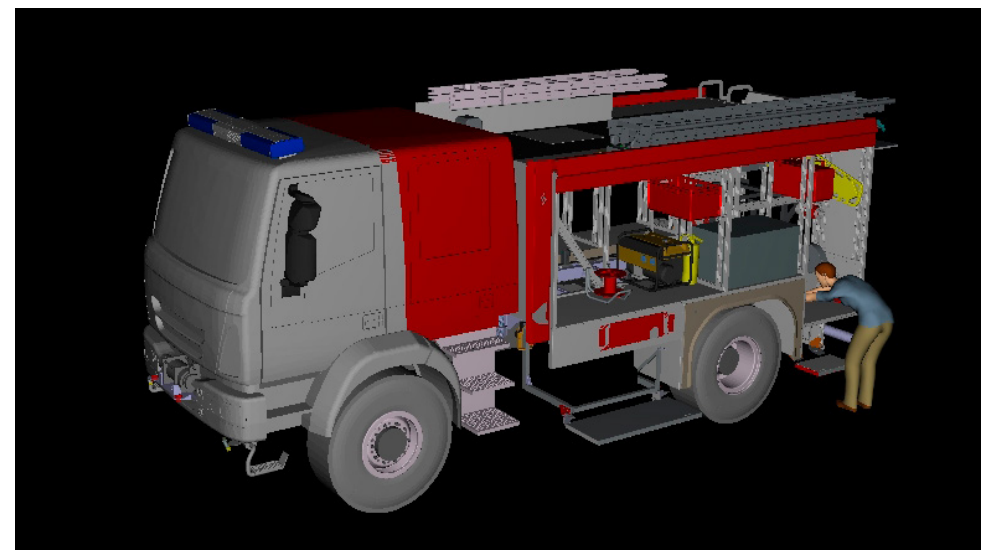

Rysunek 6. Widok podczas symulacji pobierania wyposażenia z pojazdu, wykorzystano model z oprogramowania CAD

Źródło: opracowanie własne

Figure 6. The view during the simulation of extricating the equipment from the vehicle, test was based on a model from CAD software 


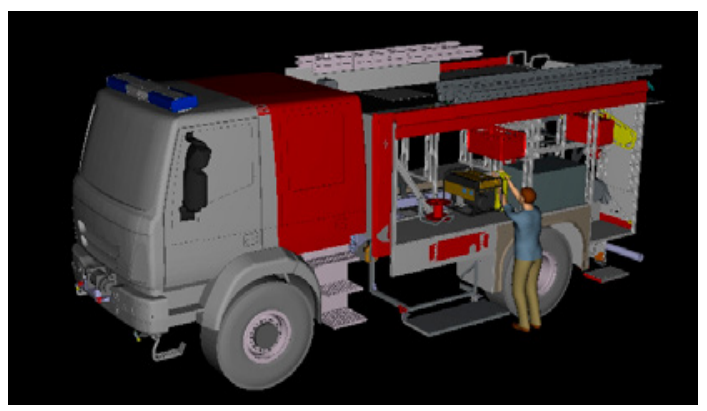

Rysunek 7. Widok podczas symulacji pobierania wyposażenia z pojazdu, wykorzystano model z oprogramowania CAD

Źródło: opracowanie własne

Figure 7. The view during the simulation of extricating the equipment from the vehicle, test was based on a model from CAD software

Tego typu sprawdzenia można wykonać na etapie projektowania, zarówno pojazdu, jak i rozmieszczenia sprzętu.

\section{Badania środowiskowe pojazdów pożarniczych}

Normy i ustawy określające wymagania dla pojazdów pożarniczych $[9,10,11$, 16] w bardzo ubogi sposób (jedno zdanie) odnoszą się do badań środowiskowych. Według opinii specjalistów z WITPiS cechy związane z:

- układem klimatyzacji wnętrza;

- skutecznością działania układu wentylacji wnętrza samochodów pożarniczych - stabilizacja temperatury (rys. 8);

- skutecznością działania układu wentylacji i klimatyzacji wnętrza samochodów pożarniczych - zapobieganie parowaniu szyb;

- funkcjonowanie układu wodno-pianowego oraz wyposażenia zabudowy w warunkach ujemnych temperatur (rys. 9);

- odpornością samochodów pożarniczych na oddziaływanie piasku i pyłu (rys. 10);

- odpornością samochodów pożarniczych na oddziaływanie zwiększonej wilgotności (rys. 11);

- odpornością samochodów pożarniczych na opady atmosferyczne

są bardzo ważne w aspekcie ergonomii i powinny być dokładnie weryfikowane przed wdrożeniem pojazdu. Powyższe cechy oddziałują znacząco na komfort pracy załogi pojazdu, co w bezpośredni sposób wpływa na efektywność ich pracy. Należy podkreślić, że dla pojazdów wojskowych (specjalnych) istnieje norma dotycząca badań środowiskowych, ściśle określająca metody badań. Porównując badania pojazdów pożarniczych do wojskowych zauważono, że jest pole do określenia metod badań środowiskowych oraz ergonomii. 


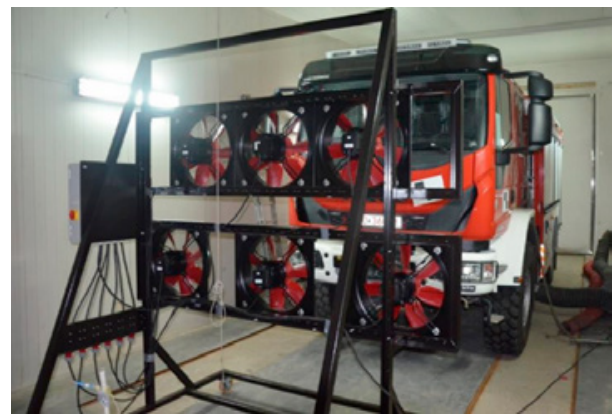

Rysunek 8. Widok pojazdu w komorze klimatycznej w trakcie badań skuteczności układu wentylacji

Źródło: opracowanie własne

Figure 8. View of the vehicle in the climatic chamber during tests of the efficiency of the ventilation system

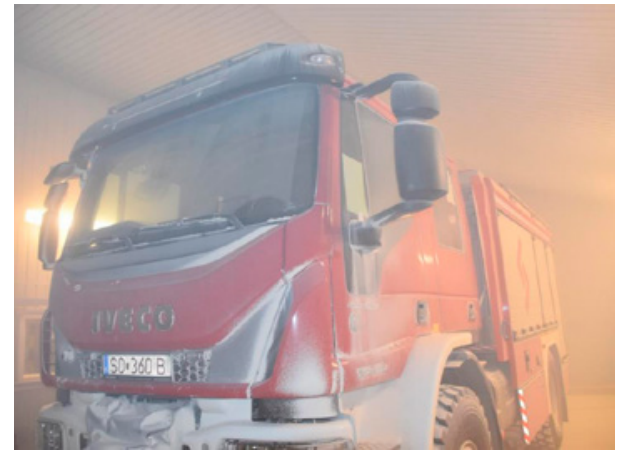

Rysunek 10. Widok pojazdu podczas badań odporności na pył

Źródło: opracowanie własne

Figure 10. View of the vehicle during dust resistance tests

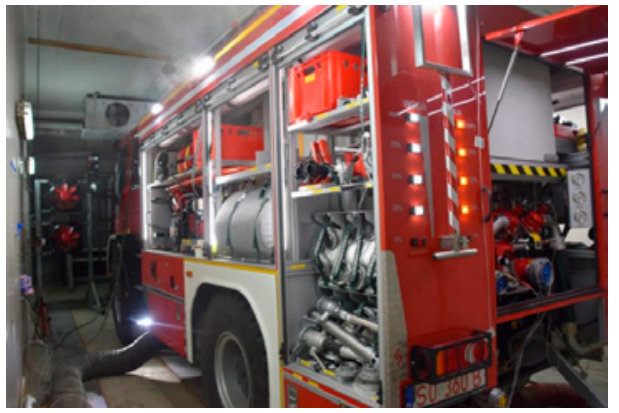

Rysunek 9. Widok pojazdu w komorze klimatycznej w trakcie sprawdzeń funkcjonowania układu wodno-pianowego oraz wyposażenia zabudowy Źródło: opracowanie własne

Figure 9. View of the vehicle in the climatic chamber during checks on the functioning of the water-foam system and special equipment

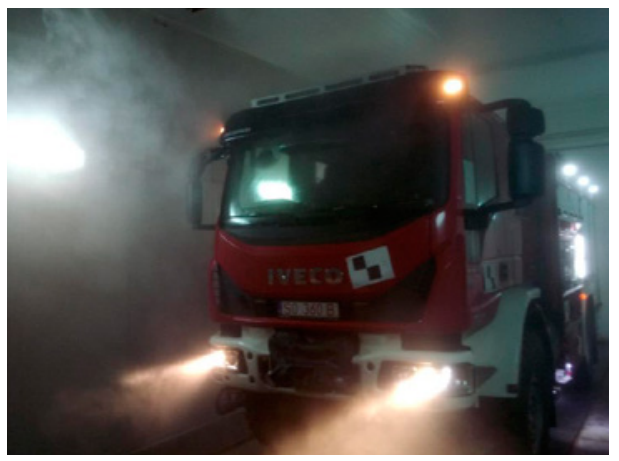

Rysunek 11. Widok pojazdu podczas badań odporności na zwiększoną wilgotność Źródło: opracowanie własne

Figure 11. View of the vehicle during tests for resistance to increased humidity

\section{Badania wibroakustyczne}

Badania wibroakustyczne są ważnym elementem badań ergonomii. Drgania oraz hałas w istotny sposób wpływają na efektywność działań ratowniczych podczas akcji. W ramach projektu prowadzonego w WITPIS badano:

- drgania na stanowiskach pracy:

- kierowcy;

- dowódcy;

- członków załogi; 
- poziom hałasu wewnętrznego samochodów pożarniczych;

- poziom hałasu na stanowiskach pracy zastępu strażackiego (rys. 12-13).

Określenie poziomu drgań, przyspieszeń jest szczególnie istotnie dla siedziska zespolonego - ławki załogi w przedziale załogowym pojazdu. Zgodnie z metodyką PN91/S04100 „Drgania. Metody badań i oceny drgań mechanicznych na stanowiskach pracy w pojazdach", należy dokonać pomiaru przyspieszeń drgań oraz ich analizy metodą FFT z filtrem 1/3 oktawy podczas jazdy ze stałą prędkością odpowiednią dla danej drogi. W metodyce badań przyjęto drogi asfaltowe o równej oraz zniszczonej nawierzchni, a także drogi brukowane i wyboiste. Zarejestrowane wyniki porównuje się z krzywymi komfortu, uciążliwości i szkodliwości. Jeżeli w którymś z pasm częstotliwości poziom przyspieszeń drgań przekracza poziom uciążliwości wówczas obliczany jest dopuszczalny czas jazdy na danym siedzisku. Ograniczenia powinny być uwzględnione $\mathrm{w}$ instrukcji eksploatacji pojazdu oraz procedurach akcji ratowniczo-gaśniczych. Niedopuszczalne są poziomy drgań powyżej granicy szkodliwości.

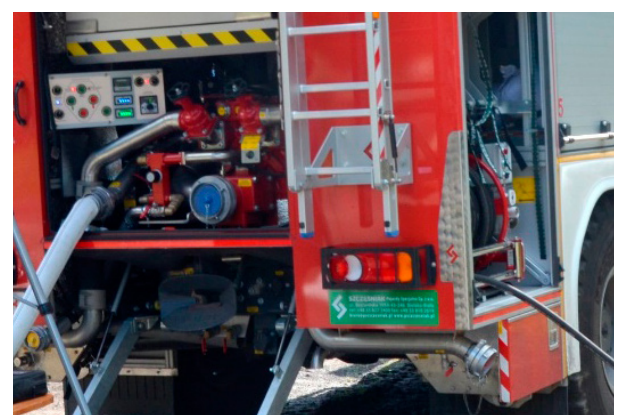

Rysunek 12. Widok rozmieszczenia urządzenia pomiarowego $\mathrm{w}$ trakcie pomiarów poziomu natężenia dźwięku na stanowisku operatora autopompy

Źródło: opracowanie własne

Figure 12. View of the arrangement of the measuring device during the measurement of the sound pressure level at the autopump operator's station

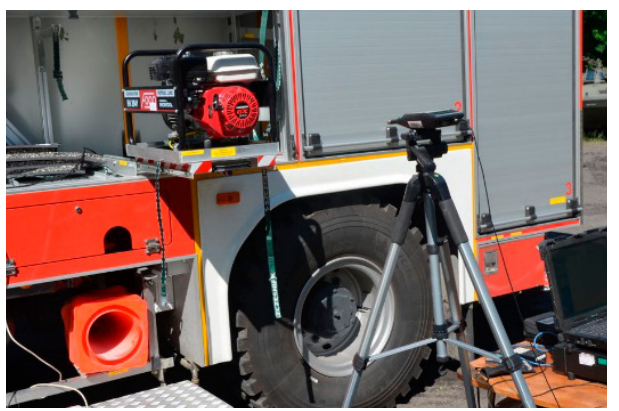

Rysunek 13. Widok rozmieszczenia urządzenia pomiarowego w trakcie pomiarów poziomu natężenia dźwięku agregatu prądotwórczego

Źródło: opracowanie własne

Figure 13. View of the arrangement of the measuring device during the measurement of the sound power level of the generator set

Hałas w pojazdach pożarniczych dotyczy zarówno miejsc całej załogi podczas jazdy, jak również stanowiska operatora autopompy podczas działań gaśniczych. Hałas wewnętrzny w kabinie pojazdu weryfikowany jest podczas badań homologacyjnych. Sygnalizacja alarmowa również powinna posiadać stosowne certyfikaty na podstawie badań wykonanych w komorze akustycznej. Jak wykazały badania poznawcze $w$ kabinach kilku pojazdów pożarniczych zanotowano przekroczenie dopuszczalnego poziomu hałasu podczas jazdy $\mathrm{z}$ włączoną sygnalizacją. $\mathrm{W}$ metodyce badań uwzględniono pomiary podczas jazdy ze stałymi prędkościami oraz 
podczas przyspieszania zgodnie z PN-90/S-04052, z włączoną sygnalizacją pracującą kolejno we wszystkich tonach.

Norma PN EN 1846-2 przewiduje pomiar hałasu na stanowisku operatora autopompy podczas jej pracy z nominalnym ciśnieniem i przy nominalnej wydajności. Metodyka normy nie przewiduje natomiast pomiarów z załączonymi innymi urządzeniami pracującymi na stałe podczas akcji ratowniczo-gaśniczych. Takim podstawowym urządzeniem silnikowym generującym wysokie poziomy hałasu jest zespół prądotwórczy. W zaproponowanej metodyce przedstawiono tok postępowania stanowiący kompilację wymagań normy PN EN 1846-2 oraz normy NO 61 A 208 na zespoły prądotwórcze wdrażane do Sił Zbrojnych RP. Pomiary wykonywane tu z załączonymi obydwoma urządzeniami (autopompa + agregat prądotwórczy) pracującymi z nominalnym obciążeniem.

\section{Podsumowanie}

Wykorzystanie wirtualnego manekina oraz technologii 3D umożliwia wyeliminowanie subiektywnej oceny badacza, obniża koszty i sumaryczny czas badań, przy założeniu, że opanowano technikę obróbki wygenerowanych powierzchni z chmur punktów.

Opisywana norma PN-EN 1846-1 (październik 2012) „Samochody pożarnicze Część 2: Wymagania ogólne Bezpieczeństwo i parametry" i Rozporządzenie Ministra Spraw Wewnętrznych i Administracji z dnia 27 kwietnia 2010 r. zmieniające rozporządzenie w sprawie wykazu wyrobów służących zapewnieniu bezpieczeństwa publicznego lub ochronie zdrowia i życia oraz mienia, a także zasad wydawania dopuszczenia tych wyrobów do użytkowania wymagają aktualizacji. Przedmiotowe odświeżenie dokumentu normatywnego powinno uwzględnić prezentowane propozycje zmian i rozszerzeń, które zostały zaproponowane $\mathrm{w}$ ramach projektu Narodowego Centrum Badań i Rozwoju - umowa nr DOB-BIO7/07/02/2015 r. pt. „Budowa pojazdów pożarniczych z zachowaniem ergonomii użytkownika”.

\section{Publikacja zrealizowana $w$ ramach projektu}

Narodowego Centrum Badań i Rozwoju - umowa nr DOB-BIO7/07/02/2015 r. pt. „Budowa pojazdów pożarniczych z zachowaniem ergonomii użytkownika”. 


\section{Bibliografia}

[1] Kończak J. , Mieteń M. , Zwierzyński M. , Problematyka badania ergonomii specjalnych pojazdów pożarniczych i wojskowych, Zeszyty Naukowe SGSP, nr 61, t. 1/2017, Warszawa.

[2] Kończak J. , Mieteń M. , Wykorzystanie skanera 3d w technice samochodowej, Rozwój, eksploatacja, przechowywanie i ochrona balistyczna środków transportu. Nowe trendy, Bel Studio, Sulejówek 2017.

[3] Norma MIL-STD-1472G.

[4] Norma Obronna NO-06-A104, pkt. 2.14.

[5] Norma PN-91 N-08018 Strefy pracy kończyn górnych.

[6] Norma PN-80 N-08001 Granice zasięgu rąk.

[7] Norma PN-81 N-08002 Granice ruchu stopy.

[8] Norma PN-83 N-08015 Ergonomia.

[9] Norma PN-EN 1846-1: 2011 Samochody pożarnicze - Podział i oznaczenie;

[10] Norma PN-EN 1846-2+A1: 2013-07 Samochody pożarnicze - Część 2: Wymagania ogólne - Bezpieczeństwo i parametry.

[11] Norma PN-EN1846-3:2013-12 Samochody pożarnicze - Część 3: Wyposażenie zamontowane na stałe - Bezpieczeństwo i parametry.

[12] Oczoś K., Cena I., Rapid Inspection - metody pomiarowo-kontrolne adekwatne do rapid-technologii, „Mechanik”, nr 3/2008.

[13] Koradecka D. (red.), Bezpieczeństwo pracy i ergonomia, tom I i II. Centralny Instytut Ochrony Pracy, Warszawa 1997;

[14] Rogowska K. (red.), Zagrożenia zdrowia kierowców pojazdów silnikowych związane ze szkodliwymi i uciążliwymi warunkami środowiska pracy, Oficyna Wydawnicza Instytutu Medycyny Pracy im. prof. J. Nofera, Łódź 2007.

[15] Tott K., Możliwości przyspieszenia wdrażania dyrektyw NATO w obszarze ergonomii techniki wojskowej, „Bezpieczeństwo Pracy”, 1/2004, Warszawa.

[16] Ustawa z dnia 24 sierpnia 1991 r. o Państwowej Straży Pożarnej (Dz.U. z 2006 r. nr 96, poz. 667 z późn. zm). 


\section{CzĘŚć III}

LOGISTYKA DZIALAŃ W JEDNOSTKACH OCHRONY PRZECIWPOŻAROWEJ 



\title{
Zarządzanie procesami logistycznymi jednostek PSP w działaniach ratowniczych
}

\author{
Management of logistics processes of state fire service \\ units in rescue operations
}

\author{
Michał Chmiel \\ Karolina Równicka \\ Emil Sulak \\ Centrum Naukowo-Badawcze Ochrony Przeciwpożarowej im. Józefa Tuliszkowskiego \\ - Państwowy Instytut Badawczy (CNBOP-PIB)
}

\section{Streszczenie}

Celem niniejszej publikacji jest ukazanie sposobu zabezpieczenia logistycznego długotrwałych akcji ratowniczych. Autorzy skupili sie na sposobie zarządzania zasobami logistycznymi, podmiotach odpowiedzialnych za organizacje zabezpieczenia logistycznego zestawiajac ze soba organizacje i główne problemy dotyczące zabezpieczenia logistycznego jakie wystapiły podczas 3 dużych zdarzeń jakimi były: pożar w Kuźni Raciborskiej w 1992 roku, powódź w 1997 roku oraz katastrofa budowlana na terenie Międzynarodowych Targów w Chorzowie. W publikacji przedstawiono postulatywne propozycje zmian $w$ organizacji zabezpieczenia logistycznego w Państwowej Straży Pożarnej, opierające się na nieustającym rozwoju technologii usprawniajacych działanie oraz zarządzanie zasobami logistycznymi w czasie rzeczywistym.

\section{Abstract}

The purpose of this publication is to show how to secure the logistic of long-term rescue operations. The authors focused on the method of logistics resource management, entities responsible for organizing logistic security, combining the organization of logistic security and main logistical security problems that occurred during three major events: fire in Kuźnia Raciborska in 1992, flood in 1997 and bulilding catastrophe site at the International Fair in Chorzów. The article presents postulated propositions of changes in the organization of logistics security in the State Fire Service, based on the continuous development of technologies to improve operations and real-time logistics management.

\section{Wstęp}

Państwowa Straż Pożarna (PSP) jest zawodową, umundurowaną i wyposażoną w specjalistyczny sprzęt formacją przeznaczoną do walki z pożarami, klęskami żywiołowymi i innymi miejscowymi zagrożeniami. 
Jednostki PSP to podmioty ratownicze powołane do wykonywania czynności ratowniczych ${ }^{1}$ :

- podstawowych - należy przez to rozumieć czynności wykonywane w poszczególnych dziedzinach ratownictwa przez wszystkich ratowników podmiotów Krajowego Systemu Ratowniczo-Gaśniczego (KSRG);

- specjalistycznych - należy przez to rozumieć czynności wykonywane z użyciem sprzętu specjalistycznego przez odpowiednio przeszkolonych ratowników podmiotów KSRG.

System logistyczny w Państwowej Straży Pożarnej ma szczególne znaczenie, nie tylko podczas prowadzonych działań ratowniczo-gaśniczych o mniejszym zasięgu zagrożenia, lecz przede wszystkim w trakcie długotrwałych akcji ratowniczych, wówczas mamy do czynienia z pełnym rozwinięciem zabezpieczenia i wsparcia logistycznego. Znaczny wpływ na jakość zabezpieczenia logistycznego, przekładającego się często na powodzenie prowadzonej akcji i zwalczania skutków powstałego zagrożenia, ma zarządzanie logistyczne $\mathrm{w}$ ujęciu procesowym, formujące bezpieczeństwo na danym terenie. Zabezpieczenie logistyczne organizowane jest w ramach Krajowego Systemu Reagowania Kryzysowego.

Termin logistyka w PSP rozumiany jest jako proces wysokowydajnego i skutecznego zarządzania potencjałem ratowniczym. Celem owego zarządzania jest optymalizacja usatysfakcjonowania potrzeb podmiotów ratowniczych, mająca na uwadze skoordynowane wykorzystanie sił i środków niezależnych, innych służb, podmiotów cywilnych, jak również zasobów i zdolności gospodarki narodowej. $\mathrm{Na}$ jednolity proces zarządzania mają wpływ:

- przedmiot zaopatrzenia (materiały, urządzenia, sprzęt);

- określenie potrzeb dotyczące dostawy sił i środków;

- funkcje: organizowanie, planowanie, realizowanie oraz kontrola.

Zabezpieczenie logistyczne jednostek PSP podczas długotrwałych akcji ratowniczych obejmuje zabezpieczenie potrzeb stałych i zmiennych takich jak (rys. 1):

Działania ratownicze rozumiane są jako każda czynność (bądź zespół działań) mająca na celu ochronę życia, zdrowia, mienia lub środowiska, a także likwidację przyczyn powstania pożaru, wystąpienia klęski żywiołowej lub innego miejscowego zagrożenia ${ }^{2}$. Procesy logistyczne w Państwowej Straży Pożarnej są ściśle związane z długotrwałymi akcjami (działaniami) ratowniczymi, często o charakterze akcji wielopodmiotowej.

1 Rozporządzenia Ministra Spraw Wewnętrznych i Administracji z 18 lutego 2011 r. w sprawie szczegółowych zasad organizacji krajowego systemu ratowniczo-gaśniczego (Dz. U. z 2011 r. Nr 46, poz. 239).

2 Rozporzadzenie Ministra Spraw Wewnętrznych i Administracji z dnia 29 grudnia 1999 r. w sprawie szczegółowych zasad organizacji krajowego systemu ratowniczo-gaśniczego, Dz. U. z 1999 r. $\mathrm{Nr} 111$, poz.1311. 

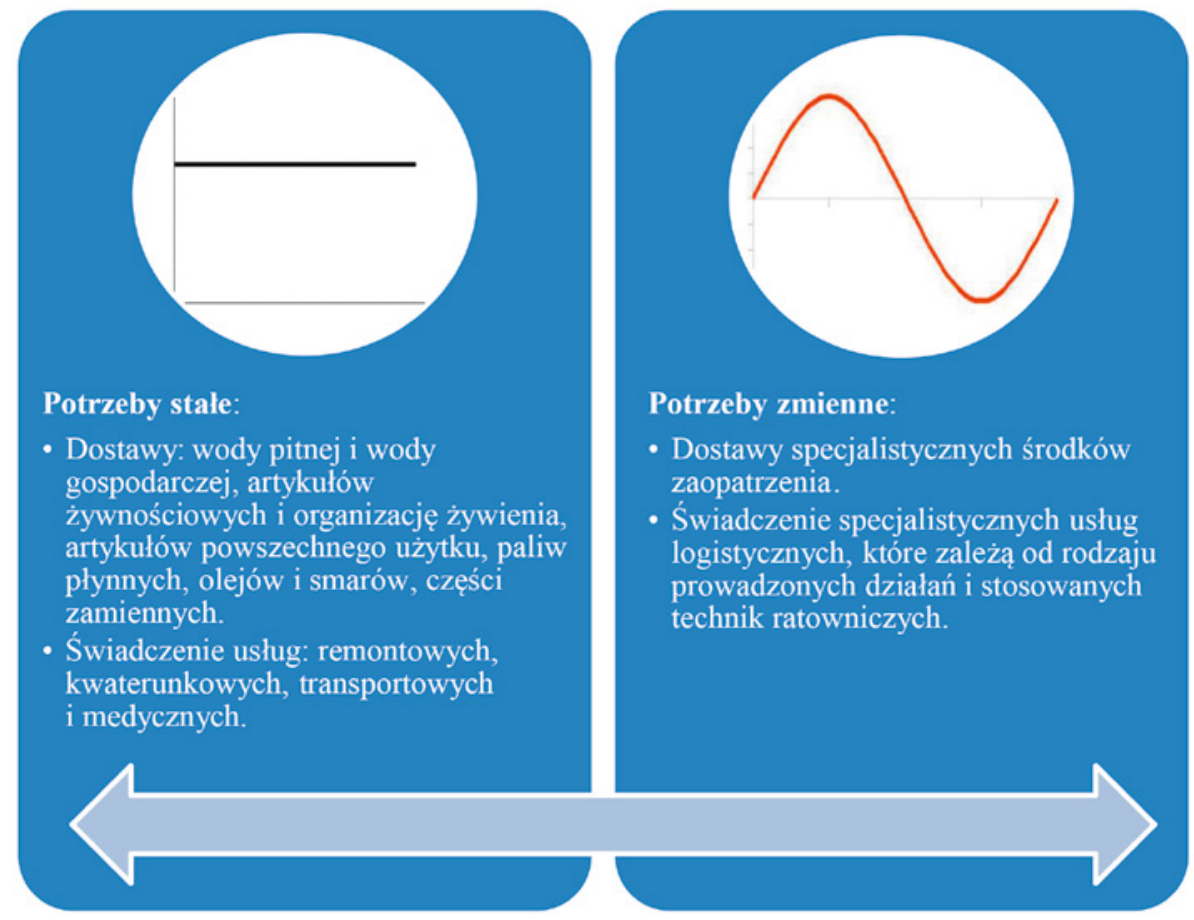

Rysunek 1. Potrzeby logistyczne jednostek PSP

Źródło: Opracowanie własne na podstawie: Nowak E., Logistyka w sytuacjach kryzysowych, Wydanie II poprawione i poszerzone, Warszawa 2009

Figure 1. Logistic needs of PSP units

Działania ratownicze rozumiane są jako każda czynność (bądź zespół działań) mająca na celu ochronę życia, zdrowia, mienia lub środowiska, a także likwidację przyczyn powstania pożaru, wystąpienia klęski żywiołowej lub innego miejscowego zagrożenia ${ }^{3}$. Procesy logistyczne w Państwowej Straży Pożarnej są ściśle związane z długotrwałymi akcjami (działaniami) ratowniczymi, często o charakterze akcji wielopodmiotowej.

Zgodnie z rozporządzeniem Ministra Spraw Wewnętrznych i Administracji z dnia 11 grudnia $1997 \mathrm{r}$. w sprawie długotrwałych akcji ratowniczych, szczegółowych norm, zasad i warunków otrzymywania wyżywienia w czasie tych akcji oraz ćwiczeń lub szkolenia przez strażaków Państwowej Straży Pożarnej lub inne osoby biorące w nich udział, a także przypadków, w których wypłaca się równoważnik pieniężny w zamian za przysługujące wyżywienie, sposobu ustalania jego wysokości oraz szczegółowych zasad wypłacania (Dz. U. z dnia 29 grudnia 1997 r.) długotrwałymi akcjami ratowniczymi są:

3 Rozporzadzenie Ministra Spraw Wewnętrznych i Administracji z dnia 29 grudnia 1999 r. w sprawie szczegółowych zasad organizacji krajowego systemu ratowniczo-gaśniczego, Dz. U. z 1999 r. $\mathrm{Nr} 111$, poz.1311. 
- każde działania ratownicze organizowane lub kierowane przez PSP trwające co najmniej 6 godzin;

- pomocnicze specjalistyczne czynności ratownicze wykonywane przez PSP w ramach udzielanej pomocy innym służbom ratowniczym, trwające co najmniej 6 godzin;

- inne działania PSP, wymagające zgrupowania strażaków przez okres co najmniej 6 godzin w czasie podwyższonej gotowości operacyjnej lub w celu współdziałania $\mathrm{z}$ innymi służbami;

- akcje ratownictwa podwodnego prowadzone przez wymagające wykonania co najmniej jednego cyklu nurkowania ${ }^{4}$.

Długotrwałe akcje ratownicze, $w$ których realizowane jest zabezpieczenie logistyczne jednostek ratowniczych PSP oraz specjalistycznych grup ratowniczych, stanowią tylko niewielki odsetek (ok. 5\%-10\%) ${ }^{5}$ wszystkich działań ratowniczych, w których uczestniczą siły i środki PSP.

W długotrwałych akcjach ratowniczych biorą udział co najmniej dwa różne podmioty, które działają pod wspólnym kierownictwem. Kierowanie to prowadzone jest jednoosobowo przez uprawnioną do sprawowania tej funkcji osobę. Osoba kierująca (dowodząca, zarządzająca) działaniami ratowniczymi, autonomicznie od rodzaju kierowania (interwencyjnego, taktycznego, strategicznego), współprzygotowuje oraz koordynuje zabezpieczenie i wsparcie logistyczne dla jednostek biorących udział w akcji. Istotnym elementem w procesie logistycznym są zasoby logistyczne, postrzegane są one jako potencjał, którym dysponuje wsparcie logistyczne, obejmuje możliwości, zaopatrzenie i usługi. Jednakże zasobami logistycznymi, które należy efektywnie wykorzystać w czasie trwania długotrwałych działań ratowniczych jest potencjał ludzki, rezerwy zaopatrzeniowe oraz zasoby usługowe o charakterze transportowym, technicznym, gospodarczo-bytowym, medycznym, sanitarnym. Zasoby ludzkie biorące udział w procesie zabezpieczenia i wsparcia logistycznego składaja się z logistycznych organów kierowania. Podmioty kierownicze odpowiedzialne są za zarządzanie danym zabezpieczeniem oraz sztaby logistyczne (zaopatrzenia, transportowe, remontowe) przygotowujące niezbędne dostawy zaopatrzenia w celu usprawnienia i przeprowadzenia z sukcesem akcji ratowniczej. Jednym z kluczowych elementów składowych zarządzania logistycznego w Państwowej Straży Pożarnej stanowią zasoby zaopatrzeniowe.

Determinantami sposobu i zakresu organizacji zabezpieczenia logistycznego jednostek PSP w długotrwałych akcjach ratowniczych są przede wszystkim: czas

4 Rozporzadzenie Ministra Spraw Wewnętrznych i Administracji z 11 grudnia 1997 r. w sprawie dlugotrwałych akcji ratowniczych, szczegółowych norm, zasad i warunków otrzymywania wyżywienia w czasie tych akcji oraz ćwiczeń lub szkolenia przez strażaków Państwowej Straży Pożarnej lub inne osoby biorace w nich udziat, a także przypadków, w których wypłaca się równoważnik pieniężny $w$ zamian za przystugujace wyżywienie, sposób ustalania jego wysokości oraz szczegółowych zasad wyptacania (Dz. U. $1997 \mathrm{nr} 160$ poz. 10980).

5 Dane na podstawie analizy Biuletynu Informacji KG PSP w latach 2010-2015 r. 
prowadzenia akcji, rodzaj występujących zagrożeń kryzysowych oraz panujące w danym czasie warunki atmosferyczne.

Trudne warunki atmosferyczne (np. ciągłe opady deszczu, silne mrozy, upały itp.) powodują potrzebę organizacji dodatkowego wyposażenia dla stanów osobowych jednostek ratowniczo-gaśniczych. Mogą to być np. ubrania przeciwdeszczowe, ciepła odzież, środki przeciwodmrożeniowe, okulary przeciwsłoneczne itp. Może okazać się również potrzebna organizacja suszarni dla odzieży, pomieszczeń ogrzewczych dla ludzi bądź chłodnych (klimatyzowanych) pomieszczeń odpoczynku itp.

Potencjał zaopatrzeniowy wykorzystywany w długotrwałych akcjach ratowniczych to zasoby własne jednostek PSP oraz środki zaopatrzenia pozyskiwane z zasobów infrastruktury terenowej.

Własny potencjał zaopatrzeniowy to etatowe środki zaopatrzenia, którymi dysponują jednostki PSP uczestniczące w długotrwałej akcji ratowniczej (rys. 2). Są to podstawowe środki zaopatrzenia (artykuły żywnościowe, woda do picia oraz do celów gospodarczych, techniczne środki materiałowe, artykuły powszechnego użytku, oleje, smary, paliwa płynne itp.) oraz specjalistyczne środki zaopatrzenia (zależą one od rodzaju prowadzonej akcji ratowniczej oraz rodzaju udzielanej pomocy).

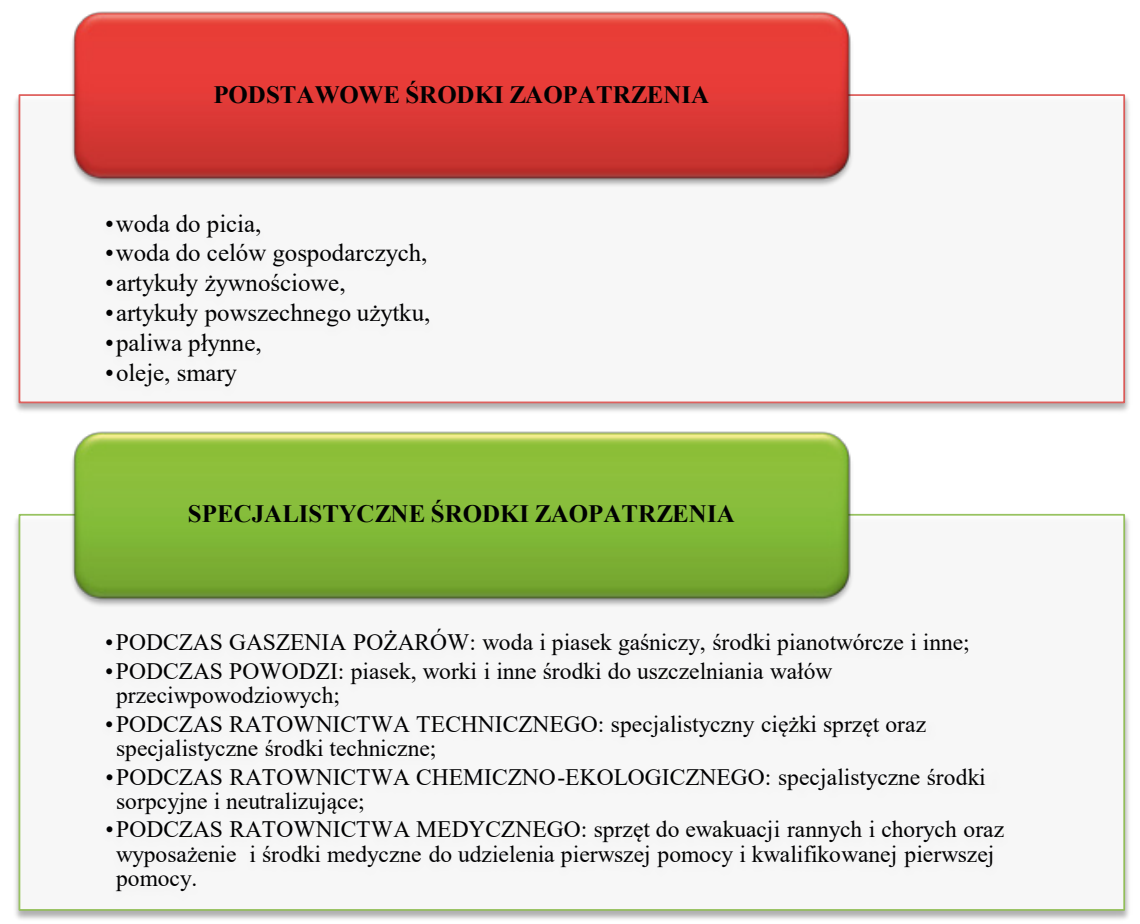

Rysunek 2. Podstawowy podział środków zaopatrzenia

Źródło: System kompleksowego zabezpieczenia logistycznego wielopodmiotowych akcji ratowniczych, Zadanie 5. Zarządzanie zasobami logistycznymi w akcjach ratowniczych, Etap 1-5.3. Opracowanie modelu wykorzystania zasobów logistycznych, s. 19-20 
Potrzeby logistyczne jednostek PSP uczestniczących w długotrwałych akcjach ratowniczych wzrastają w miarę wydłużania się czasu ich prowadzenia. Oprócz standardowych potrzeb, którymi są: pomoc medyczna dla rannych i chorych strażaków (ratowników), dostawy specjalistycznych środków zaopatrzenia w zależności od rodzaju prowadzonych działań i stosowanych technik ratowniczych (podczas pożarów są to środki gaśnicze; podczas ratownictwa chemicznego są to różnego rodzaju neutralizatory, sorbenty; podczas ratownictwa ekologicznego ponadto mogą to być środki odkażające i dezynfekcyjne); dostawy paliw płynnych, olejów i smarów, dodatkowo pojawiają się potrzeby związane z: dostawami wody pitnej (napojów chłodzących bądź ciepłych), organizacją wyżywienia (przygotowania i wydawania - dystrybucji gotowanych posiłków), remontem (naprawami) pojazdów samochodowych i sprzętu technicznego oraz ze świadczeniem usług gospodarczo-bytowych (zakwaterowanie, usługi kąpielowe, usługi handlowe itp.). Ważnym zadaniem służb logistycznych jest również zapewnienie (przygotowanie) miejsc do pracy sztabów i wyposażenie ich w niezbędne "narzędzia" sztabowe, przygotowanie punktów pomocy medycznej, zapewnienie dostaw energii elektrycznej (oświetlenie miejsc, w których prowadzona jest akcja ratownicza).

Istotnym komponentem, który ma wpływ na sprawne zarządzanie logistyczne, jest potencjał usługowy. Świadczenia realizowane w tym zakresie to głównie infrastruktura terenowa, jakiekolwiek nieruchomości i ruchomości mogące zostać wykorzystane w ramach świadczenia usług transportowych, remontowych, kwaterunkowych oraz gospodarczych na rzecz efektywnego usunięcia powstałego zagrożenia. Na płaszczyźnie zabezpieczenia logistycznego jednostek PSP w trakcie długotrwałych akcji ratowniczych, oprócz etatowego potencjału logistycznego, mogą i powinny być optymalnie zagospodarowane również zasoby terenowe.

Potencjał usługowy wykorzystywany w procesie zabezpieczenia logistycznego jednostek ratowniczych $\mathrm{w}$ akcjach długotrwałych to głównie własny potencjał usługowy jednostek PSP, a także zasoby usługowe infrastruktury terenowej wykorzystywane w procesie świadczenia usług gospodarczo-bytowych, transportowych, remontowych oraz udzielania pomocy medycznej.

W długotrwałych akcjach ratowniczych oprócz jednostek PSP uczestniczą również inne podmioty ratownicze (inspekcje, służby porządkowe, straże). Co do zasady, na miejsce prowadzonej akcji ratowniczej zwykle jako pierwsze docierają jednostki PSP. Z logistycznego punktu widzenia obliguje to jednostki PSP do przejęcia roli "gospodarza logistycznego" długotrwałej akcji ratowniczej. Jego głównym zadaniem jest koordynacja zabezpieczenia logistycznego wszystkich współdziałających w danej akcji podmiotów ratowniczych. „Gospodarz logistyczny” powinien dysponować „katalogiem możliwości logistycznych”. Katalog ten powinien zawierać zakres oraz możliwości udostępniania sił i środków logistycznych wszystkim podmiotom ratowniczym uczestniczącym w długotrwałej akcji ratowniczej.

Podmioty ratownicze kierowane do prowadzenia akcji długotrwałych powinny posiadać niezbędną autonomiczność (wystarczalność) logistyczną. W przypadku 
wystąpienia niedoborów we własnym potencjale zaopatrzeniowym lub usługowym, brakujące siły i środki logistyczne pozyskują od „gospodarza logistycznego” akcji ratowniczej.

Zabezpieczenie logistyczne długotrwałych działań ratowniczych ściśle wiąże się ze świadczeniem usług w zakresie pomocy medycznej. Mając na uwadze zagrożenia naturalne (klęski żywiołowe), gospodarcze (budowlane), destrukcyjne (akty terroru), cywilizacyjne (komunikacyjne) oraz świadomość, że każde wspomniane zjawisko wzbudza prawdopodobne zagrożenie dla ludzkiego zdrowia lub życia, potencjał medyczny powinien być nienagannie zorganizowany. Jednostki ochrony przeciwpożarowej, jako organy będące coraz częściej dysponowane do różnego rodzaju zdarzeń, powinny w swoich zespołach mieć strażaków uprawnionych do udzielenia pomocy medycznej przy zapewnieniu podstawowego i niezbędnego sprzętu.

Zabezpieczenie i wsparcie logistyczne dotyczy dystrybucji środków zaopatrzenia, jak również usług logistycznych świadczonych dla ludności poszkodowanej oraz podmiotów biorących czynny udział w długotrwałych działaniach ratowniczych. Całość zadań postawionych przed zarządzaniem logistycznym w Państwowej Straży Pożarnej charakteryzuje misja, jaką jest konsekwentne dążenie do jak najszybszego dostarczenia dostaw zaopatrzenia i usług specjalistycznych do wszystkich poszkodowanych osób i działających podmiotów ratowniczych. Celem, który przyświeca zarządzaniu logistycznemu w PSP, jest zapewnienie wszystkim optymalnych warunków do przeżycia oraz tymczasowego przebywania w warunkach zbliżonych do normalnych.

\section{Analiza wybranych akcji w kontekście zabezpieczenia logistycznego jednostek PSP}

\section{a) Pożar terenu leśnego w Kuźni Raciborskiej w 1992 roku}

Podczas katastrof naturalnych, budowlanych czy awarii technicznych szczególnie ważne jest dostarczanie podstawowych środków zaopatrzenia. Zaopatrzenie i wsparcie logistyczne zmieniało się na przestrzeni lat ze względu na uwarunkowania gospodarcze, ekonomiczne i technologiczne. Poglądy obejmujące problematykę zabezpieczenia akcji ratowniczych uległy zdecydowanej weryfikacji po pożarze obszaru leśnego na terenie Kuźni Raciborskiej w sierpniu 1992 roku. W trakcie pożaru niezbędne okazało się utworzenie na terenie akcji specjalistycznego zaplecza techniczno-zaopatrzeniowego. Przygotowana strefa zapewniała dostarczanie materiałów eksploatacyjnych na teren prowadzonych działań. Ta katastrofa ujawniła wiele nieprawidłowości w funkcjonowaniu szeroko rozumianego zabezpieczenia logistycznego długotrwałych działań ratowniczych. Struktura Państwowej Straży Pożarnej latem 1992 roku zaledwie nabierała kształtów w procesie zabezpieczenia i wsparcia logistycznego. 


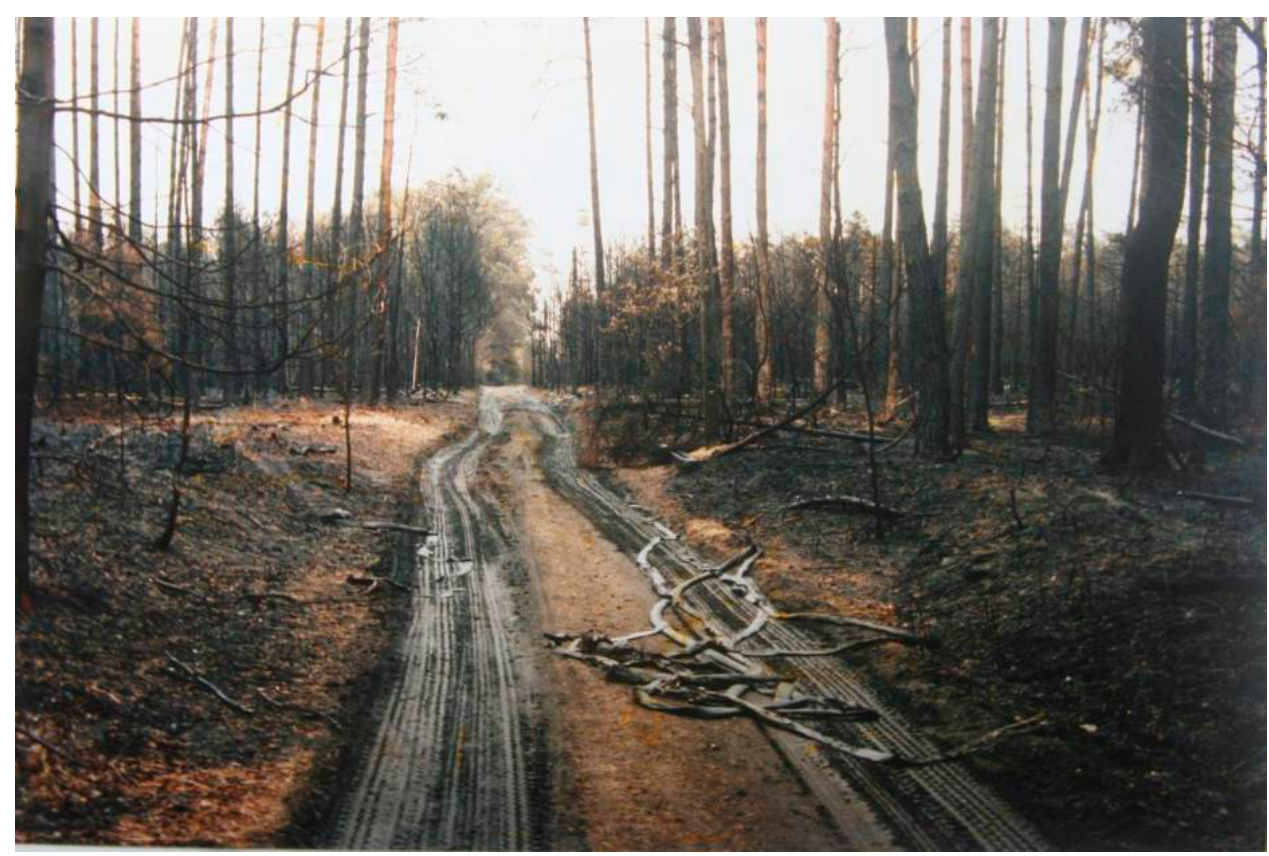

Rysunek 3. Pożar lasu w Kuźni Raciborskiej w 1992 roku

Źródło: http://raciborz.naszemiasto.pl/artykul/pozar-lasu-w-kuzni-raciborskiej-w-1992-krajobrazjak-na,1972987,artgal,t,id,tm.html (dostęp: 07.02.2018)

Figure 3. Forrest Fire in Kuźnia Raciborska in 1992

Trudności w prowadzonych działaniach ratowniczych potęgowane były ograniczonymi możliwościami dotarcia pojazdów w głąb płonących obszarów leśnych, dużym nasyceniem powietrza dwutlenkiem i tlenkiem węgla, a także zagrożeniem ze strony eksplodujących $\mathrm{w}$ niektórych miejscach z czasów wojny niewybuchów i amunicji. Ponadto jednostki straży pożarnych działały w warunkach ograniczonej widoczności i wysokiej temperatury, która u wielu osób powodowała oparzenia, rany twarzy i rąk oraz tlenie i topienie się obuwia.

Mówiąc o zabezpieczeniu logistycznym długotrwałych działań ratowniczych należy zdawać sobie sprawę z tego, że nie da się tego ująć w jednym zagadnieniu. Są to tematy bardzo obszerne, złożone, skupiające wiele różnych zagadnień. Omawiane zabezpieczenie logistyczne akcji gaśniczych dużych pożarów leśnych zależy od wielu czynników, między innymi od:

- terenu i warunków atmosferycznych w jakich prowadzone są działania;

- przewidywanego przebiegu, rozwoju, kierunku rozprzestrzeniania się pożaru;

- ilości zadysponowanych sił i środków;

- rodzaju i wieku drzewostanu, stanu zalesienia;

- dróg dojazdowych, punktów czerpania wody itp.;

- konieczności przeprowadzania ewakuacji osad leśnych oraz ochrony obiektów w strefie zagrożenia pożarem. 
Pożar lasu w Kuźni Raciborskiej w lecie 1992 roku ujawnił nieprawidłowości i braki związane $\mathrm{z}$ funkcjonowaniem zabezpieczenia logistycznego akcji ratowniczo-gaśniczej.

Niedomagania związane $\mathrm{z}$ funkcjonowaniem zaplecza techniczno-zaopatrzeniowego zaobserwowano na obszarze trzech płaszczyzn, a mianowicie:

- pierwsza i podstawowa to różnorodne awarie samochodów uczestniczących w akcji gaśniczej (dotyczyły one zarówno nadwozia, jak i podwozia), które uniemożliwiały ich dalsze wykorzystanie do likwidacji pożaru;

- drugim poważnym problemem było zaopatrzenie materiałowo-techniczne na potrzeby funkcjonowania sprzętu wykorzystywanego podczas działań;

- trzecim problemem okazała się realizacja wszelkich czynności związanych $\mathrm{z}$ wydobywaniem i usuwaniem uszkodzonych pojazdów oraz ich transportem do polowych punktów napraw bądź do warsztatów samochodowych, w których na czas prowadzenia akcji ulokowano stacjonarne punkty napraw.

Można założyć, że podobne problemy mogą wystąpić podczas innych długotrwałych działań ratowniczych takich jak: powódź, duża katastrofa budowlana czy ekologiczna.

Przedstawione zagadnienia wykorzystania zasobów terenowych do zabezpieczenia logistycznego pogrupowano w odpowiednio merytoryczne działania. Przy czym należy pamiętać, że zadania i działania zabezpieczenia logistycznego ściśle ze sobą powiązane i wzajemnie na siebie oddziałują.

b) Powódź w 1997 roku

Powódź na terenie południowej oraz zachodniej części Polski, nazywana również „powodzią tysiąclecia”, miała miejsce w lipcu 1997 roku. Stała się ona kolejnym weryfikatorem dla zaplecza logistycznego działań ratowniczych. Podczas pierwszej fazy walki z żywiołem stwierdzono, że ilość zadysponowanego sprzętu jest niewystarczająca w stosunku do potrzeb ratowniczych, szczególnie ze względu na wysoki poziom wody, jak również jej szybki nurt, co przełożyło się na większą liczbę osób wymagających ewakuacji z terenów zalewowych. Widoczna była zwłaszcza niedostateczna ilość sprzętu specjalistycznego (co przełożyło się na ograniczenie czynności ratowniczych), inżynieryjnego, pomp o wysokiej wydajności, łodzi, amfibii i dźwigów, odzieży ochronnej znajdującego się na wyposażeniu jednostek włączonych do Krajowego Systemu Ratowniczo-Gaśniczego. Dodatkowe utrudnienie w usuwaniu skutków klęski żywiołowej stanowiła łączność przewodowa oraz bezprzewodowa. Powódź okazała się potężnym sprawdzianem dla służb biorących udział w walce z żywiołem, obnażyła wówczas wiele słabości ratowniczych z obszaru zabezpieczenia logistycznego. 


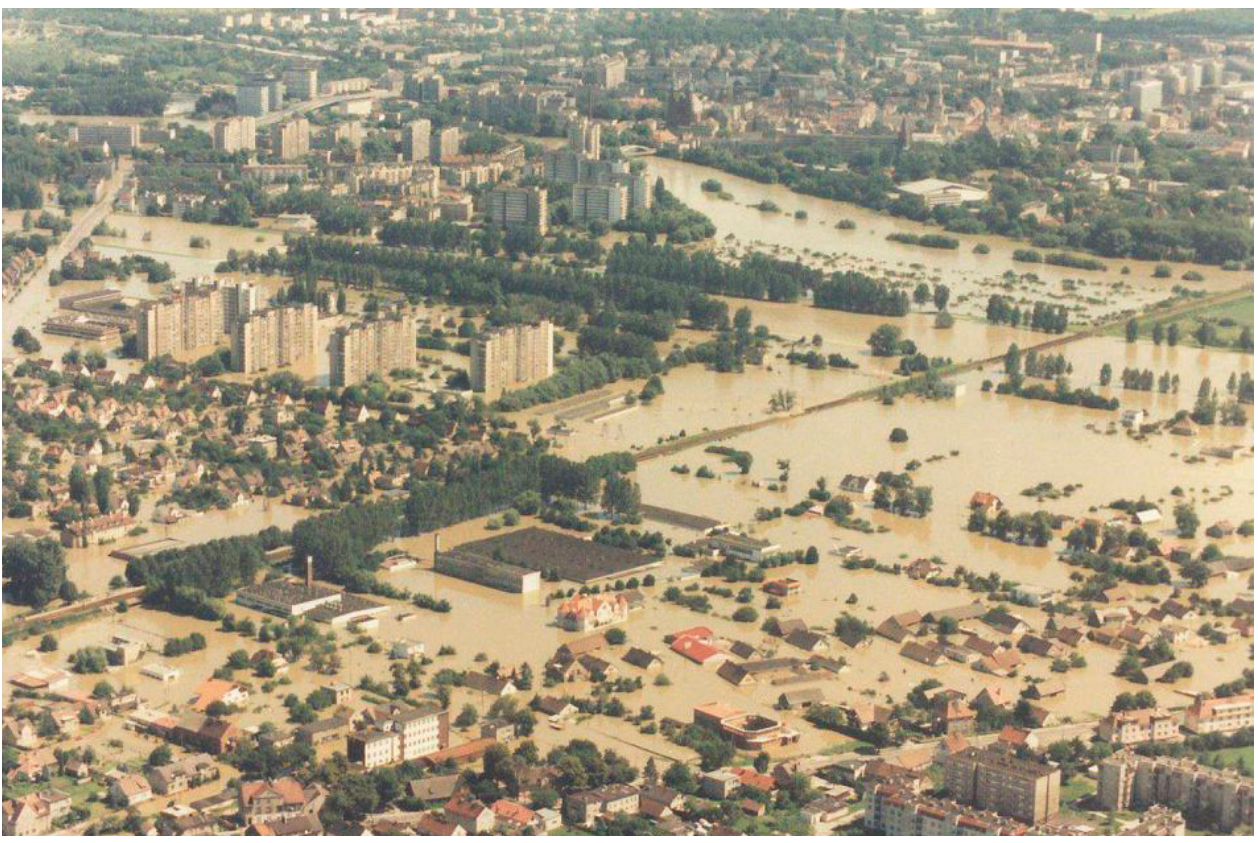

Rysunek 4. Powódź w 1997 roku, Opole

Źródło: http://opole.wyborcza.pl/opole/5,35086,22070929.html?i=1 (dostęp: 07.02.2018)

Figure 4. Flood in 1997, Opole

Akcja ratunkowa prowadzona przez jednostki PSP była oceniona pod względem technicznym i sprawnościowym na dość wysokim poziomie.

Podczas powodzi w roku 1997 procedury i sposoby wykorzystania zasobów zaopatrzeniowych i usługowych infrastruktury terenowej do zabezpieczenia logistycznego obnażyły również niedoskonałości i niedomagania takie jak:

- brak regulacji prawnych i procedur stwarzających możliwość składania przez Komendanta Głównego PSP zapotrzebowania na siły Wojska Polskiego, innych służb i podmiotów w przypadku organizacji działań ratowniczych obejmujących obszar wykraczający poza jedno województwo;

- brak współpracy i zawartych porozumień z podmiotami specjalizującymi się w budowlach hydrotechnicznych posiadającymi stosowną wiedzę i doświadczenie praktyczne w budowaniu wałów i umocnień;

- problemy z transportem ratowników i sprzętu na miejsce prowadzonych działań z powodu złej jakości dróg technicznych oraz niewłaściwie prowadzonej gospodarki wałów (wały porośnięte wysokimi trawami, krzakami, zaroślami itp.), co w znaczny sposób utrudniało realizację zadań logistycznych, a w konsekwencji i ratowniczych;

- problemy z transportem ratowników wynikające z niedoboru własnej floty autobusowej oraz niewłaściwa organizacja korzystania z okolicznych firm transportowych świadczących takie usługi; 
- służby logistyczne nie były właściwie przygotowane zarówno technicznie, jak i proceduralnie do pozyskania dużej ilości piasku do celów przeciwpowodziowych, a także uruchomienia innych rezerw niezbędnych do zachowania ciągłości działań ratowniczych;

- brak wypracowanych na szczeblu krajowym w ramach Krajowego Planu Zarządzania Kryzysowego czytelnych i skutecznych procedur dysponowania potencjałem osób osadzonych w zakładach karnych;

- brak możliwości tankowania wybranych komend przez 24 godziny na dobę;

- w wybranych przypadkach normatywy wyposażenia poziomu powiatowego, ponadpowiatowego oraz ponadwojewódzkiego nie uwzględniały skali i wielkości zagrożenia do jego skutecznej likwidacji.

Wystąpiły też utrudnienia w łączności. W działaniach ratowniczych prawie każda kompania Państwowej Straży Pożarnej dysponowała własnym zapleczem kwatermistrzowskim, co pozwoliło na zakwaterowanie załóg $\mathrm{w}$ warunkach polowych oraz wydawanie posiłków i napojów wszystkim uczestnikom akcji.

W ostatniej fazie akcji przeciwpowodziowej służbom ratowniczym brakowało wydajnego sprzętu do wypompowywania wody z zalanych obiektów i terenów. Pompy narażone były na uszkodzenia, gdyż czerpały zanieczyszczoną wodę.

Słabością był brak odpowiedniego dokumentu regulującego zbiorowe postępowanie podczas zadań powodziowych. Nie było także wystarczającej ilości materiałów paliwowych do zapewnienia prawidłowej pracy specjalistycznego sprzętu będącego w zasobach PSP.

c) Katastrofa budowlana hali MKT w Chorzowie w 2006 roku

Katastrofę budowlaną, która miała miejsce 28 stycznia 2006 roku na terenie Międzynarodowych Targów Katowickich w Chorzowie spowodowało zawalenie się dachu hali wystawowej podczas wystawy gołębi pocztowych. W momencie katastrofy na terenie obiektu znajdowało się około 700 osób, zarówno odwiedzających wystawę, jak również wystawców i organizatorów. Przyczyną katastrofy był nadmiar śniegu na dachu hali wystawowej (nieprawidłowo odśnieżany dach), błędy architektoniczne, konstrukcyjne i wykonawcze. W akcji ratowniczej udział wzięło około 130 zastępów strażaków Państwowej Straży Pożarnej, a także Żandarmeria Wojskowa, Grupy Poszukiwawczo-Ratownicze z psami, Policja, Straż Miejska, Pogotowie Ratunkowe, Ratownictwo Górnicze. Działania ratownicze były utrudnione ze względu na kilkustopniowy mróz oraz możliwość zawalenia się ocalałej części hali. Działania logistyczne skupiono na organizacji punktu przyjęcia sił, miejsca pracy sztabu logistycznego, jak najlepszym oświetleniu terenu prowadzonych działań, miejsca na potrzeby działań medycznych oraz punktu odpoczynku ratowników oraz dystrybucji ciepłych napoi. Przedmiotowa katasrofa stała się bezpośrednim przyczynkiem do nowelizacji prawa budowlanego (zwiększenie bezpieczeństwa budynków, głównie wielkopowierzchniowych). 


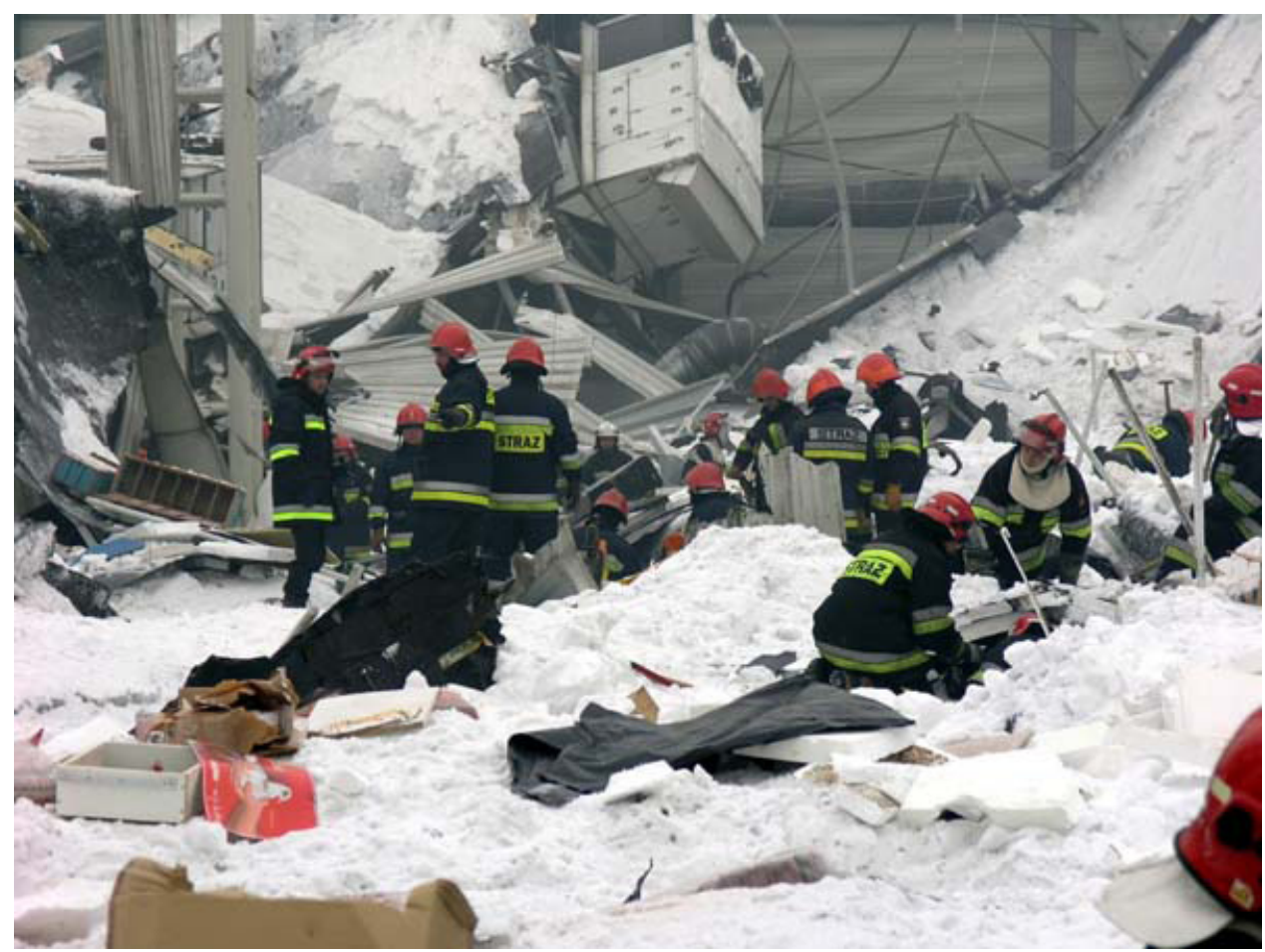

Rysunek 5. Akcja ratownicza podczas katastrofy budowlanej w Chorzowie w 2006 roku Źródło: https://remiza.com.pl/ (dostęp: 07.02.2018)

Figure 5. Rescue action during construction catastrophe in Chorzów 2006

Podczas prowadzenia akcji ratowniczej w Chorzowie procedury i sposoby wykorzystania zasobów zaopatrzeniowych i usługowych infrastruktury terenowej do zabezpieczenia logistycznego wskazały na ${ }^{6}$ :

- brak jednolitego i spójnego systemu łączności dla służb biorących udział w akcjach ratowniczych;

- niewystarczającą ilość psów ratowniczych należących do PSP, szkolonych do poszukiwania poszkodowanych;

- brak procedury jednolitego spójnego obiegu informacji pomiędzy służbami;

- brak specjalistycznej bazy magazynowej zaopatrującej służby w elementy zużywalne stanowiące części sprzętu ratowniczego; niedobór materiałów dotyczył w głównej mierze pił i tarcz do cięcia metalu;

- brak jednolitych procedur związanych $\mathrm{z}$ dysponowaniem i udziałem w akcji społecznych struktur i organizacji ratowniczych;

- niewystarczającą ilość palników plazmowych do cięcia metalu.

6 Analiza zdarzenia dot.: miejscowe zagrożenia związane z zawaleniem się dachu hali wystawowej Międzynarodowych Targach Katowickich w Chorzowie przy ulicy Bytkowskiej 1b, w dniach 28.01.2006-20.02.2006 r. opracowana przez KW PSP w Katowicach. 


\section{Analiza i ocena zabezpieczenia logistycznego}

Biorąc pod uwagę różnorodność wspomnianych wcześniej zdarzeń, poniżej $\mathrm{w}$ formie tabeli przedstawiono zabezpieczenie logistyczne oraz jego przebieg dla wyżej omawianych akcji.

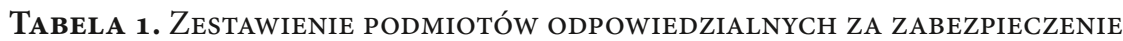
LOGISTYCZNE WYBRANYCH DŁUGOTRWAŁYCH AKCJI RATOWNICZYCH

Zestawienie podmiotów odpowiedzialnych za zabezpieczenie logistyczne na przykładzie Kuźni Raciborskiej (1992 r.), powodzi w 1997 r. oraz zawalenia się hali Międzynarodowych Targów Katowickich w Chorzowie 2006 r.

\begin{tabular}{|c|c|c|}
\hline Kuźnia Raciborska 1992 & Powódź 1997 & MTK w Chorzowie 2006 \\
\hline \multicolumn{3}{|c|}{ Koordynatorzy zabezpieczenia logistycznego } \\
\hline $\begin{array}{l}\text { Zadania zabezpieczenia logi- } \\
\text { stycznego były realizowane } \\
\text { przez zespół, w którego skład } \\
\text { wchodzili: } \\
\text { - szef tyłów (szef zabezpie- } \\
\text { czenia logistycznego akcji) } \\
\text { podlegający KDR-owi; } \\
\text { - kierownik (szef) punktu } \\
\text { przyjęć sił i środków; } \\
\text { - kierownik (szef) zabezpie- } \\
\text { czenia kwatermistrzowskie- } \\
\text { go, który realizuje zadania } \\
\text { związane z wyżywieniem, } \\
\text { zakwaterowaniem itd.; } \\
\text { - kierownik (szef) zabezpie- } \\
\text { czenia transportowo-tech- } \\
\text { nicznego odpowiadający za } \\
\text { zadania transportowe, po- } \\
\text { mocą techniczną itd.; } \\
\text { - kierownik (szef) zabezpie- } \\
\text { czenia medyczno-sanitar- } \\
\text { nego. }\end{array}$ & $\begin{array}{l}\text { Zadania zabezpieczenia logi- } \\
\text { stycznego były realizowane } \\
\text { przez sztab koordynacyjny } \\
\text { utworzony w KCKR Komen- } \\
\text { dy Głównej PSP. }\end{array}$ & $\begin{array}{l}\text { Zadania zabezpieczenia logi- } \\
\text { stycznego były realizowane } \\
\text { przez zespół zabezpieczenia } \\
\text { logistycznego. }\end{array}$ \\
\hline
\end{tabular}

Źródło: Opracowanie własne 7,8

Podczas prowadzenia długotrwałych akcji ratowniczych PSP zmagało się z wieloma problemami dotyczącymi zabezpieczenia logistycznego. W poniższej tabeli przedstawiono zestawienie głównych problemów.

7 W. Jarosz, S. Lipiński, A. Marciniak, J. Michalska, Skuteczne ratownictwo: fachowy poradnik dla służb ratowniczych, Wydawnictwo VERLAG DOSHOFER, Warszawa 2006.

8 Analiza zdarzenia dot.: miejscowe zagrożenia..., dz. cyt. 
TABela 2. Problemy zWiązane Z Zabezpieczeniem logistycznym podCZas DŁUGOTRWAŁYCH AKCJI RATOWNICZYCH

\begin{tabular}{|c|c|c|}
\hline \multicolumn{3}{|c|}{$\begin{array}{c}\text { Zestawienie podmiotów odpowiedzialnych za zabezpieczenie logistyczne } \\
\text { na przykładzie Kuźni Raciborskiej (1992 r.), powodzi w } 1997 \text { r. } \\
\text { oraz zawalenia się hali Międzynarodowych Targów Katowickich } \\
\text { w Chorzowie w } 2006 \text { r. }\end{array}$} \\
\hline Kuźnia Raciborska 1992 & Powódź 1997 & $\begin{array}{c}\text { Hala MTK } \\
\text { w Chorzowie } 2006\end{array}$ \\
\hline \multicolumn{3}{|c|}{ Główne problemy podczas długotrwałych akcji ratowniczych } \\
\hline $\begin{array}{l}\text { - awarie pojazdów, które } \\
\text { brały udział w akcji, unie- } \\
\text { możliwiające ich udział } \\
\text { w dalszych działaniach; } \\
\text { - transport pojazdów, które } \\
\text { uległy awarii do warszta- } \\
\text { tów samochodowych lub } \\
\text { polowych punktów na- } \\
\text { praw; } \\
\text { - brak odpowiedniej ilości } \\
\text { map miejsca zdarzenia, } \\
\text { które powinny być prze- } \\
\text { kazane dowódcom oddzia- } \\
\text { łów; } \\
\text { - parametry użytkowe sprzę- } \\
\text { tu łączności były niewystar- } \\
\text { czające (zbyt niska liczba } \\
\text { kanałów); } \\
\text { - użytkownicy nie stosowali } \\
\text { się do zasad prowadzenia } \\
\text { korespondencji radiowej. }\end{array}$ & $\begin{array}{l}\text { - braki w wyposażeniu jed- } \\
\text { nostek wchodzących w skład } \\
\text { KSRG w sprzęt ciężki np.: } \\
\text { dźwigi, pompy wysokiej wy- } \\
\text { dajności, amfibie a w szcze- } \\
\text { gólności sprzętu pływające- } \\
\text { go; } \\
\text { - utrudnienia w łączności } \\
\text { przewodowej i bezprze- } \\
\text { wodowej; } \\
\text { - brak ubrań ochronnych } \\
\text { niezbędnych podczas akcji } \\
\text { powodziowych; } \\
\text { - brak wspólnego kanału } \\
\text { ratowniczego do komuni- } \\
\text { kacji pomiędzy służbami; } \\
\text { - brak możliwości doprowa- } \\
\text { dzenia do pełnej sprawno- } \\
\text { ści, sprzętu uszkodzonego } \\
\text { podczas akcji; } \\
\text { - brak dokumentu regulujące- } \\
\text { go zbiorowe postępowanie } \\
\text { służb ratowniczych podczas } \\
\text { długotrwałych i wielopod- } \\
\text { miotowych akcji ratowni- } \\
\text { czych. }\end{array}$ & $\begin{array}{l}\text { - } \text { różnorodność w wyposa- } \\
\text { żeniu jednostek na miejscu } \\
\text { zdarzenia; } \\
\text { - brak jednolitego systemu } \\
\text { łączności dla służb biorą- } \\
\text { cych udział w akcjach ra- } \\
\text { towniczych; } \\
\text { - niewystarczająca ilość psów } \\
\text { należących do PSP szkolo- } \\
\text { nych do poszukiwania po- } \\
\text { szkodowanych; } \\
\text { - brak procedury jednolitego } \\
\text { obiegu informacji pomię- } \\
\text { dzy służbami. }\end{array}$ \\
\hline
\end{tabular}

Źródło: Opracowanie własne na podstawie ${ }^{9}$ oraz analizy katastrofy budowlanej w Chorzowie $2006^{10}$

W ramach prowadzonych w tym zakresie badań przeprowadzono wywiady eksperckie $\mathrm{z}$ uczestnikami omawianych akcji.

9 W. Jarosz, S. Lipiński, A. Marciniak, J. Michalska, dz. cyt.

${ }^{10}$ Analiza zdarzenia dot.: miejscowe zagrożenia..., dz. cyt. 


\section{Pożar lasu w Kuźni Raciborskiej w 1992 roku}

Z przeprowadzonych wywiadów eksperckich ${ }^{11}$ wynika, że podczas pożaru kompleksu leśnego w Kuźni Raciborskiej w 1992 roku, zabezpieczenie logistyczne (transportowe, przeładunkowe, remontowe, kwaterunkowe, gastronomiczne itp.) jakie świadczone było dla jednostek PSP przez usługodawców zewnętrznych (terenowych) było realizowane następująco:

\section{Ustugi gastronomiczne}

Usługi gastronomiczne były świadczone przez ludność lokalną (najczęściej kobiety z koła gospodyń wiejskich). To oni organizowali i przygotowywali posiłki dla ratowników, poprzedzone różnego rodzaju zbiórkami żywności od ludności objętej zagrożeniem lub z gmin sąsiednich. Należy wskazać, że teren realizacji działań gaśniczych obejmował ok. $100 \mathrm{~km}^{2} \mathrm{w}$ kształcie klepsydry. W związku $\mathrm{z}$ tym punkty żywności były organizowane w kilkunastu miejscach, głównie przy remizach, kościołach i boiskach. W skład racji żywnościowych wchodziło najczęściej pieczywo, wędliny, konserwy, grochówka, a z napoi ciepłych herbata i kawa. Nie określano jakichkolwiek norm żywieniowych. Ratownicy korzystali $\mathrm{z}$ oferowanego wyżywienia bez ograniczeń. W praktyce to dzięki uczestnictwu w akcji strażaków OSP udało się pozyskiwać produkty żywnościowe dla wszystkich ratowników. W tamtym czasie nie ustanowiono procedur określających racje żywnościowe dla ratowników, jak również kto i w jaki sposób miałby ich w takie racje zaopatrywać.

\section{Ustugi transportowe i remontowe}

Usługi remontowe i transportowe były również realizowane własnymi siłami. Dowódca akcji wyznaczył osoby odpowiedzialne za realizację napraw sprzętu i transportu. Decyzji tej dokonywał na podstawie własnej oceny podległych mu osób. Z kolei osoby wyznaczone przez dowódcę dobierały sobie zespół odpowiedzialny za naprawy bieżące sprzętu. W skład takiego zespołu wchodzili miejscowi strażacy z jednostek OSP oraz okoliczni rolnicy. Punkty napraw były zlokalizowane w działających w tym czasie kółkach rolniczych, a w przypadku ich braku - na boiskach szkolnych. Do najczęstszych awarii dochodziło w pojazdach, a główne naprawy obejmowały wymianę opon, które były przystosowane do jazdy miejskiej, a nie po terenach leśnych. Dziennie średnio wymieniano około 80 opon. W czasie trwania akcji niezbędne środki zaopatrzenia części zamienne (opony, drążki kierownicze, wirniki pomp), jak również w specjalistyczne narzędzia do napraw

11 Wywiady eksperckie przeprowadzono w ramach tworzenia referatu przez jednego z autorów celem zgłębienia zagadnienia zabezpieczenia logistycznego długotrwałych akcji ratowniczych. Wywiady zostały przeprowadzone $\mathrm{z}$ osobami biorącymi udział w przedstawionych $\mathrm{w}$ niniejszym artykule długotrwałych akcjach ratowniczych. 
(szlifierki, wiertarki, spawarki, klucze) realizowano wg potrzeb i nie wiązały się z koniecznością rozliczania się z podmiotami świadczącymi usługi zewnętrzne.

\section{Ustugi kwaterunkowe}

Podczas akcji w Kuźni Raciborskiej zagadnienie świadczenia usług kwaterunkowych praktycznie nie istniało. Każdy z ratowników w zasadzie organizował sobie wypoczynek samodzielnie. Dochodziło nawet do przypadków spania pod gołym niebem na kocu czy w kabinie samochodu. Formacja PSP nie była właściwie w ogóle przygotowana na konieczność zapewnienia warunków do odpoczynku. Co prawda przy sztabie akcji był zlokalizowany punkt odpoczynku (higieny osobistej, tóżek polowych), jednakże z uwagi na rozpiętość terenu prowadzonych akcji i do liczby ratowników nie zdał egzaminu. $Z$ utworzonego miasteczka namiotowego korzystali wyłącznie strażacy, którzy byli najbliżej tego punktu. Teren akcji obejmował rozpiętość około $100 \mathrm{~km}^{2}$. Tym samym, nawet z logistycznego punktu widzenia, powrót ratowników z oddalonego o kilkadziesiąt kilometrów punktu do sztabu akcji celem krótkiego wypoczynku mijał się z celem. Z kolei okoliczni strażacy z jednostek OSP w czasie wymiany zastępów wracali do swoich domów i tam wypoczywali. Potrzeby w tym zakresie były ogromne, jednakże możliwości bardzo małe. Wynikało to również z braku uwarunkowań formalnych i proceduralnych do organizacji miejsc wypoczynku i higieny osobistej.

\section{Usługi medyczne}

W sztabie akcji oraz w lokalnych punktach koncentracji sił i środków nie dysponowano zespołami ratowniczymi. Drobne oparzenia, otarcia czy rany były zaleczane przez samych ratowników lub wspomagającą ludność cywilną, wywodzącą się głównie z rodzin członków strażaków OSP. Niezbędne bandaże, maści i plastry były na wyposażeniu pojazdów i były doraźnie wykorzystywane. W przypadkach ciężkich oparzeń, podtrucia dymem czy innych uszkodzeń ciała wzywano pogotowie ratownicze. Sytuacja ta wymagała jednak przetransportowania poszkodowanych własnymi siłami do najbliższej utwardzonej drogi lub bazy postojowej poszczególnych jednostek. Pojazdy zespołów medycznych nie były przystosowane do jazdy po drogach leśnych. W praktyce nie było procedur określających sposób tworzenia punktów pomocy medycznej, brakowało również ratowników specjalizujących się w udzielaniu kwalifikowanej pomocy medycznej.

\section{Katastrofa budowlana hali wystawowej MTK w Chorzowie w 2006 roku}

W czasie działań ratowniczych podczas katastrofy budowlanej hali wystawowej Międzynarodowych Targów Katowickich w Chorzowie w 2006 roku w ramach zabezpieczenia logistycznego świadczone były: 
Usługi gastronomiczne

W pierwszej fazie działań (noc) wszystko zapewniało WSKR (Wojewódzkie Stanowisko Koordynacji Ratownictwa). W dużej mierze z magazynów Komendy Wojewódzkiej PSP w Katowicach zorganizowano wodę do picia i ciepłe napoje w pierwszym rzucie. Na terenie Komendy Wojewódzkiej była uruchomiona stołówka (ciepłe napoje), również na miejscu, w strefie działań była wydzielona restauracja. Ludność lokalna, przedsiębiorcy spontanicznie i nieodpłatnie przywozili ciepłe napoje.

\section{Usługi transportowe i remontowe}

Przedmiotem zadań remontowych uszkodzonych pojazdów oraz sprzętu najczęściej było usuwanie małych i średnich awarii. Wykonywano je zwykle w miejscu (rejonie) prowadzenia akcji ratowniczej siłami załóg (obsług) danego sprzętu. Zakres wykonywanych napraw zwykle ograniczał się do przywrócenia stanu zdatności danego sprzętu, czyli właściwości użytkowych. Większe (poważniejsze) awarie usuwane były przez profesjonalne zespoły serwisowe producenta danego sprzętu. Wymagało to najczęściej ewakuacji uszkodzonego sprzętu do warsztatów stacjonarnych. Głównymi mankamentami występującymi podczas napraw (remontów) była bardzo duża różnorodność marek i typów. PSP dysponuje sprzętem pochodzącym od różnych producentów. Powoduje to bardzo duże trudności w zabezpieczeniu (dostawach) części zamiennych. Ponadto sprzęt najnowszej generacji charakteryzuje się bardzo wysokim poziomem technologii, co powoduje, że jego naprawa (remont) może odbywać się tylko przez wyspecjalizowane zespoły serwisowe, często w stacjonarnych warsztatach remontowych dysponujących m.in. sprzętem diagnostycznym. Podmiany ratowników podczas akcji realizowane były przez komendy przy pomocy autokaru z Komendy Wojewódzkiej w Katowicach lub busów, które były na wyposażeniu. Należy wskazać, że teren akcji jest regionem, w którym jest możliwość zorganizowania sprzętu ratowniczego w krótkim czasie. Co można było naprawiać we własnym zakresie, było naprawiane. Wtedy w KW PSP w Katowicach był warsztat samochodowy. Zdarzały się sytuacje kiedy sprzęt musiał być odesłany do bazy z powodu awarii i po działaniach szedł do serwisu. Wszystkie drobne naprawy, regulacje były robione na miejscu. Mówimy tutaj o naprawie pił, odblokowaniu, wymianie tarcz, przeczyszczeniu świec itp. Na prośbę sztabu otwierano markety, sklepy żeby pozyskać szlifierki, tarcze do pił do betonu i stali itp.

\section{Paliwo i materiaty pędne}

Samochody jeździły tankować do wyznaczonego punktu-stacji (zgodnego z planem ratowniczym), paliwo do pił, agregatów itp. było przywożone ze stacji w beczkach. Był również zorganizowany punkt wydawania paliwa $z$ dystrybutorami, tym zajmował się pracownik techniki z KW PSP Katowice - wypisywał karty pracy, sprawdzał stany olejów, smarów itd. Na stacji benzynowej był jeden taki pracownik, na miejscu działań drugi. Pierwsze dostawy paliwa do sprzętu silnikowego 
jak również smary i oleje, były realizowane z zapasów Komendy Wojewódzkiej (na terenie komendy jest stacja paliw). Część olei (tych najbardziej potrzebnych) była ściągana z jednostek terenowych do Komendy Wojewódzkiej.

\section{Sprzęt oświetleniowy}

Wykorzystano własne (Komendy Wojewódzkiej) agregaty, najaśnice oraz sprzęt innych służb ratowniczych. Zewnętrznie takie usługi świadczyły ekipy Ratownictwa Górniczego, które przywiozły swój sprzęt oświetleniowy. Wyznaczono cztery punkty:

- punkt przechowywania zwłok - usytuowany z dala od kamer i od działań ratowniczych, musiał być dozorowany przez policję;

- punkt przechowywania rzeczy (rzeczy osobiste, dokumenty) wyjętych spod rumowiska, były katalogowane, opisywane - nadzór nad tym punktem miała policja;

- miejsce (również skatalogowane), gdzie zostały przeniesione wszystkie zwierzęta, które zostały schwytane albo były w klatkach;

- straż miała w obowiązku zorganizować miejsce gdzie psy mogły wypocząć po podróży, ogrzać się i dojść do siebie po działaniach (pies też ma wyznaczony czas przebywania na gruzach i na odpoczynek).

\section{Ustugi medyczne}

Podczas akcji w 2006 roku zorganizowano punkt medyczny (mogli z niego korzystać również strażacy), gdzie był lekarz. Jednocześnie był to punkt segregacji rannych. Nie odnotowano poważniejszych urazów wśród strażaków, zdarzały się otarcia i zadrapania, skręcenia kostki. Sztab uruchomił pomoc psychologiczną dla ludzi. Strażacy również mogli skorzystać ze wsparcia psychologicznego.

\section{Ustugi inne}

Podczas przedmiotowej katastrofy skorzystano również z usługi firmy dostarczającej sprzęt sanitarny (toalety typu toi-toi). Świadczenie specjalistycznych usług i wypożyczenie ciężkiego sprzętu oferowali przedsiębiorcy z Chorzowa i Katowic. Nie zawsze jednak skorzystanie $\mathrm{z}$ tej pomocy było możliwe $\mathrm{z}$ uwagi na teren prowadzenia działań, warunki atmosferyczne i brak ratowników przeszkolonych w tym zakresie. Dowodzenie osobami nie będącymi podległymi strażakami wiązałoby się $\mathrm{z}$ dużym ryzykiem.

\section{Powódź na Dolnym Śląsku w 1997 roku}

Podczas trwania powodzi w 1997 roku usługi logistyczne obejmowały:

\section{Usługi gastronomiczne}

Podczas działań ratowniczych nie zabrakło żywności dla ratowników biorących udział w akcji. W czasie sytuacji kryzysowej nie stosuje się norm żywieniowych 
dla ratownika, powinien być naddatek pożywienia, ponieważ osoba biorąca czynny udział w usuwaniu skutków zagrożenia powinna uzupełnić zapotrzebowanie kaloryczne według indywidualnych potrzeb, wówczas jej praca staje się najbardziej efektywna. W czasie powodzi zostały uruchomione stołówki szkolne. Obiekty te były pod nadzorem Inspekcji Sanitarnej. Należy podkreślić, że np. stołówka szkolna, aby mogła wydawać posiłki podczas akcji musi mieć wpis do rejestru zakładów podlegających urzędowej kontroli żywności prowadzonego przez Państwową Inspekcję Sanitarną, a także wpis do planu ratowniczego powiatu. Każda osoba wydająca żywność musi mieć ważne badania lekarskie dopuszczające do wykonywania określonych czynności. Jako rezerwę żywnościową stosowano produkty zapakowane: konserwy, chleb itp. Obowiązywał rozkład posiłków zgodny z normalnym cyklem biologicznym człowieka. Dodatkowo co 40-50 minut przejeżdżał samochód z ciepłym płynnym posiłkiem - zupą (jako optymalnym wyżywieniem nie powodującym nadmiernego uczucia ociężałości), korzystali z niego ratownicy, którzy czuli potrzebę. Na każdym odcinku zostały utworzone punkty żywieniowe z przechowywaniem rezerw suchego prowiantu. Te punkty również były kontrolowane przez Inspekcję Sanitarną. Zakupy wody pitnej realizowane były przez samorządy w ramach środków zabezpieczonych przez Wojewodę na prowadzenie działań. Część zapotrzebowania na wodę była realizowana z darów (przyjeżdżał samochód, który zostawiał kilka palet wody i odjeżdżał).

\section{Uslugi transportowe i remontowe}

W każdej Komendzie Powiatowej jest przynajmniej jeden samochód dostawczy. Do dyspozycji były 3-4 takie pojazdy z okolicznych powiatów i przewożono nimi potrzebny sprzęt, który nie jest konstrukcyjnie z nim związany (np. motopompy do wody zanieczyszczonej). Ratowników przewożono autobusami i mikrobusami z ośrodków szkoleniowych lub wynajmowanych z okolicznych przedsiębiorstw. Korzystano z autokarów szkół lub firm, z którymi gminy miały podpisane umowy na dowóz dzieci do placówek. Nie tworzono specjalnych procedur jeżeli na terenie powiatu dysponowano odpowiednią ilością środków transportowych. Nie zmienia to jednak faktu, że korzystanie z tego typu usług powinno być uregulowane proceduralnie w przyszłości. Optymalne byłoby korzystanie z usług zakładów komunalnych, które są w każdej gminie. Dysponują one sprzętem transportowym, sprzętem ciężkim, koparkami, ładowarkami, samochodami ciężarowymi, szambiarkami, cysternami z wodą. Realizacja tego typu usług mogłaby być realizowana na polecenie władz samorządowych. Podczas działań powodziowych najczęstszą awarią było przebicie czy przecięcie ogumienia pojazdów. Tego typu naprawy odbywały się w zakładach wulkanizacyjnych, które gwarantowały pomoc przez całą dobę. Holowanie uszkodzonych ciężkich pojazdów realizowane było przez pojazdy typu ciężkiego wyposażone w urządzenia załadowcze i rotator, które były w zasobach PSP, a lekkie pojazdy 
holowano za pośrednictwem miejscowej pomocy drogowej rekomendowanej przez policję ${ }^{12}$.

\section{Ustugi kwaterunkowe}

Wykorzystywano bazy lokalne stałe lub adaptowane własne zasoby terenowe, np. internaty szkół średnich, sale gimnastyczne i obiekty spor towe szkół podstawowych i średnich. Zaplecza socjalno-higieniczne tych obiektów nadzorowane były przez Państwową Inspekcję Sanitarną (np. mierzona była temperatura wody, która szła z instalacji wodnej; sprawdzano czy jest gdzie wysuszyć mokre środki ochrony indywidualnej i odzież). W razie jakichkolwiek problemów sztab miał wytypowane następne 2-3 obiekty (hotele), które można było użyć do tego celu. Jednakże, uruchomienie tych lokali wymagało wykonania procedur i podporządkowania się wytycznym, regulaminom i możliwościami takich obiektów, co nie zawsze było możliwe do spełnienia przez organizatorów.

\section{Ustugi medyczne}

Podczas działań powodziowych zabezpieczenie medyczne ratowników realizowane było w pierwszej fazie siłami własnych ratowników medycznych, w przypadku poważniejszych obrażeń dysponowano karetki pogotowia ratowniczego. W tamtym czasie nie zostały określone precyzyjne wytyczne realizacji takiego zabezpieczenia i opierały się na działaniach kierującego akcjami ratowniczymi, dowódcami odcinków i osób, które były najbliżej poszkodowanych ratowników. Najczęstszymi powodziami udzielania pomocy ratownikom były omdlenia z powodu przepracowania i wysokich temperatur.

Analizując powyższe tabele i wypowiedzi ekspertów, jednoznacznie można stwierdzić, że system zabezpieczenia logistycznego cały czas jest doskonalony. Każda przeprowadzona akcja ratownicza, pomimo że niesie za sobą niekorzystne skutki, daje także możliwość analizy stanu zabezpieczenia logistycznego oraz opracowania propozycji usprawnienia działań logistycznych. W ciągu 14 lat pomiędzy pożarem w Kuźni Raciborskiej a zdarzeniem w Katowicach widoczna jest poprawa zabezpieczenia logistycznego akcji ratowniczych. Wiąże się to zarówno z rozwojem technologicznym, jak i wyciąganiem wniosków oraz wdrażaniem rozwiązań opracowanych na podstawie wcześniejszych zdarzeń.

12 Podmiot rekomendowany przez policję okazał się najlepszy ponieważ działa na rzecz Skarbu Państwa i w przypadku późniejszych rozliczeń działań nie będzie zarzutów, że sobie ją wybrano bez stosownego postepowania przetargowego. W ten sposób zapobiegano nadużyciom. 


\section{Postulatywne kierunki zmian i dobrych praktyk w organizacji zabezpieczenia logistycznego}

Reasumując powyższe zagadnienia w zakresie logistycznego zabezpieczenia jednostek PSP podczas długotrwałych akcji ratowniczo-gaśniczych można stwierdzić, że opiera się ono na zasobach ${ }^{13}$ :

1) własnych - wszystkie rodzaje zabezpieczenia są realizowane przy wykorzystaniu sił i środków jednostek PSP;

2) mieszanych - niektóre określone rodzaje zabezpieczenia są realizowane w ramach współdziałania $\mathrm{z}$ innymi służbami, zakładami, przedsiębiorstwa$\mathrm{mi}$;

3) zewnętrznych - wykonywanych w ramach stosownych porozumień czy umów, w większości przez firmy zewnętrzne.

Na podstawie analizy dostępnej literatury i przeprowadzonych wywiadów można stwierdzić, że postulatywnymi kierunkami zmian w tym zakresie są:

\section{Dostarczanie wyżywienia i napojów na miejsce akcji}

Wyżywienie i napoje powinny regularnie docierać do osób uczestniczących w działaniach ratowniczych na poszczególnych odcinkach bojowych, do ratowników wypoczywających w punktach logistycznych oraz do osób pełniących służbę pomocniczą. Postulatywnym rozwiązaniem w tym zakresie jest, aby jednostki lub całe związki taktyczne przybywające na miejsce długotrwałej akcji były wyposażone we własne racje żywnościowe, które pozwalały by na ich samodzielne wyżywienie przez pierwsze 24 godziny działań. Punktem newralgicznym w zakresie wyżywienia podczas działań ratowniczych stanowi dostarczanie odpowiedniej ilości napojów ciepłych (herbaty, kawy, zup błyskawicznych) oraz napojów chłodzących. Zakłada się, że średnie zapotrzebowanie jednej osoby na płyny wynosi około 2-3 litrów na dobę.

Wyżywienie uczestników długoterminowych akcji ratowniczych może być oparte o:

- stołówki i punkty żywienia znajdujące się w bezpośredniej bliskości miejsca prowadzenia działań;

- przygotowanie własnych posiłków przy wykorzystaniu kuchni polowych i ich rozdział na poszczególne punkty żywienia;

- punkty zbiorowego żywienia; w celu usprawnienia organizacyjnego, należy opracować kartki czy talony upoważniające do wydawania żywności;

- dostawę wyżywienia i ciepłych napojów przez firmy zewnętrzne na podstawie zawartych umów cywilno-prawnych;

- możliwość skorzystania z kuchni polowej na bazie kontenera wymiennego i kontenerów socjalnych, których rozwiązanie techniczne opiera się na bazie

13 B. Kosowski, Organizacja działań i logistyka w sytuacjach kryzysowych, Międzynarodowa Konferencja Naukowo-Techniczna, Warszawa 2004. 
kontenera-chłodni; sprzęt tego typu pozwala na jednoczesne przygotowanie posiłku nawet dla kilkuset osób, z czasem przygotowanie obiadu wynosi ok. 3 godzin.

\section{Naprawy sprzętu}

Podczas długotrwałej akcji ratowniczo-gaśniczej, często prowadzonej w trudnych warunkach terenowych, w krótkim czasie wzrasta liczba awarii pojazdów i sprzętu specjalistycznego. Sprawdzonym rozwiązaniem wydaje się zastępowanie wyeliminowanych pojazdów i sprzętu poprzez dysponowanie nowych. Znajduje to zastosowanie jedynie przy akcjach trwających maksimum kilka dni. Dlatego w większości wypadków zachodzi potrzeba zorganizowania i wyposażenia polowego warsztatu naprawczego. Najkorzystniejszym rozwiązaniem byłoby, aby siły takiego warsztatu stanowili mechanicy z zapleczy technicznych zorganizowanych w jednostkach PSP, z uwagi na to, że w głównej mierze tylko oni znają problemy awaryjności sprzętu pożarniczego i metody ich szybkiego i skutecznego usunięcia. W celu zapewnienia prawidłowej pracy polowego warsztatu należy zorganizować i dostarczyć odpowiednią ilość części zamiennych, ogumienia, akumulatorów. Naprawy samochodów i sprzętu mogą być oparte o zakłady naprawcze, warsztaty, bazy sprzętowe znajdujące się w niedużej odległości od miejsca prowadzenia działań. Można również wykorzystać mobilne zakłady naprawcze $\mathrm{z}$ firm zewnętrznych na zasadzie stosownych porozumień i umów cywilno-prawnych.

Zabezpieczenie długotrwałych działań ratowniczych w zakresie zagadnień transportowo-technicznych powinno być realizowane zgodnie z poniższymi zasadami. Środki transportowe należy pogrupować w specjalnie wyznaczonym miejscu. Rozporządzać tymi środkami powinny jedynie powołane do tego celu osoby funkcyjne. Polowa baza transportowa powinna dysponować:

- samochodami dostawczymi;

- pojazdami zaopatrzeniowymi (napęd $4 \times 4$ );

- pojazdami pomocy technicznej;

- pojazdami operacyjnymi do zabezpieczania potrzeb KDR i sztabu akcji.

\section{Zaopatrzenie w paliwa i smary}

Zabezpieczenie logistyczne w zakresie materiałów pędnych, olejów i smarów jest uzależnione od ilości sprzętu, ale przede wszystkim od czasu trwania akcji ratowniczej. W zasadzie można to zadanie realizować na trzy sposoby. Najbardziej efektywną techniką jest wykorzystanie stacji benzynowych znajdujących się w pobliżu terenu akcji. Dobrze, mając na uwadze usługi logistyczne, gdy jest to jedna sieć, ponieważ w taki sposób można by była kontrolować celowość poboru paliwa. Drugi sposób polega na utworzeniu i zorganizowaniu polowego punktu tankowania pojazdów. Ostatni polega na dostarczaniu paliw do poszczególnych samochodów i sprzętu znajdujących się na odcinkach bojowych własnymi autocysternami paliwowymi lub małymi pojazdami z urządzeniami do samodzielnej dystrybucji paliwa. 
Można zatem wnioskować, że organizacja zabezpieczenia paliw i płynów eksploatacyjnych w oparciu o ogólnodostępne stacje paliwowe lub zakładowe to najlepsze rozwiązanie. Warunkiem koniecznym prawidłowego korzystania z tych stacji jest wprowadzenie od początku pełnego nadzoru i kontroli w pobieraniu i rozliczaniu paliwa. Zadanie to mogą realizować powołani przez KDR ds. logistyki strażacy znający gospodarkę paliwową obowiązującą w PSP. Praca tak powołanych funkcjonariuszy polegałaby na nadzorze nad wydawaniem materiałów pędnych, prowadzeniu wymaganych rejestrów oraz wpisywaniu pobieranych materiałów do kart drogowych i kart pracy sprzętu silnikowego. Rozliczenie realizowane by było bezgotówkowo. Wyznaczone stacje paliw powinny być czynne całodobowo. Możliwe jest także dostarczanie paliwa do pojazdów i sprzętu silnikowego przez własne pojazdy i pracowników z składów paliwa PSP.

\section{Organizacja zakwaterowania}

Zabezpieczenie logistyczne w zakresie zakwaterowania powinno umożliwić:

- odpoczynek i regenerację sił;

- wykonanie podstawowych czynności higienicznych i sanitarnych;

- wysuszenie środków ochrony indywidualnej;

- spożycie posiłków;

- opiekę medyczna i, jeśli zajdzie taka potrzeba, psychologiczną.

Zabezpieczenie logistyczne w zakresie zakwaterowania to kolejne trudne zadanie zespołu logistyki. Dobrym rozwiązaniem jest przejęcie na czas trwania akcji stałych baz lokalowych. W pierwszej kolejności należy wykorzystywać obiekty PSP, OSP, a następnie obiekty użyteczności publicznej, np.: szkoły, internaty, kolonie, ośrodki wczasowe czy pomieszczenia socjalne dużych zakładów pracy. Obiekty takie powinny znajdować się jak najbliżej miejsca prowadzenia działań. Bardzo ważne jest aby przejęcie obiektów cywilnych przez PSP było udokumentowane sporządzeniem

pisemnego porozumienia, w którym jasno określone będą obowiązki zarówno właściciela, jak i PSP.

Nie zawsze jednak stałe bazy lokalowe znajdują się w odpowiednio bliskiej odległości od miejsca prowadzenia działań lub ich udostępnienie na potrzeby uczestników akcji jest niemożliwe. W takich przypadkach należy przewidzieć potrzebę budowy obozowiska, w którym trzeba uwzględnić możliwość wykonania podstawowych zabiegów higieniczno-sanitarnych. Największe możliwości zaangażowania sił dla zorganizowania i rozwinięcia polowej bazy kwatermistrzowskiej mają szkoły PSP. $\mathrm{W}$ takim wypadku zasadnym jest dysponowanie tych jednostek organizacyjnych dla zabezpieczenia logistycznego w zakresie zakwaterowania dużych akcji ratowniczo-gaśniczych. Alternatywą jest wykorzystanie dostępnej bazy kontenerowej, tzn. kontenerów kwatermistrzowskich, sanitarno-socjalnych czy żywieniowych.

\section{Zabezpieczenie medyczne akcji}

Zabezpieczenie medyczne podczas długotrwałych działań ratowniczych to kolejne z zadań zaplecza logistycznego wpływające na bezpieczeństwo ratowników. 
Powinno być ono być oparte o personel stacji pogotowia ratunkowego, wyposażone w odpowiedni sprzęt i środki przystosowane do udzielania pomocy.

W długotrwałych akcjach ratowniczych, ze względu na ilość osób biorących udział w działaniach, pomoc medyczną bezpośrednio na odcinkach bojowych powinni zapewnić ratownicy, którzy mają odpowiednie przygotowanie w tym zakresie i dysponują odpowiednim sprzętem. Działanie ich powinno sprowadzać się do udzielenia pierwszej pomocy sanitarnej poszkodowanym w akcji strażakom, a w razie konieczności zapewnienia transportu poszkodowanego do szpitala.

Trzonem tego rodzaju zabezpieczenia powinny być szpitale i przychodnie wraz ze swoim fachowym personelem, wyposażeniem oraz środkami transportu (karetkami, ambulansami).

Długotrwałe działania ratownicze wymagają utworzenia i wyposażenia polowego punktu medycznego. Miejsce lokalizacji takiego punktu muszą znać wszystkie osoby funkcyjne zaangażowane w prowadzenie działań i powinny o nim powiadomić swoich podwładnych. Punkty medyczne powinno się zlokalizować przy punktach przyjęć sił i środków, bazach kwatermistrzowskich czy sztabie akcji. Należy zapewnić dojazd pojazdów, możliwość manewrowania nimi, jak również możliwość lądowania śmigłowców. W punkcie powinien całodobowo dyżurować przynajmniej jeden lekarz i osoby do udzielania doraźnej pomocy medycznej. Zabezpieczając od strony medycznej długotrwałe akcje ratownicze trzeba liczyć się z dużą liczbą mniej lub bardziej groźnych urazów, dlatego należy przygotować się na taką skalę interwencji zabezpieczając wcześniej odpowiednie ilości wyposażenia, np.: środków transportu, opatrunków i bandaży, odkażalników.

\section{Wymiana sił i środków}

Głównymi zadaniami logistycznymi w tym zakresie są: przyjmowanie, ewidencjonowanie i ekspediowanie na wyznaczone odcinki bojowe przybywających sił i środków. W związku z tym należy zorganizować punkt przyjmowania zadysponowanych sił i środków, który powinien spełniać następujące kryteria:

- znajdować się w miejscu łatwym do dojazdu, powinien być jasno oznaczony na mapach i planach, aby jednostki nie miały problemów z dotarciem;

- ruch na terenie placu powinien być zorganizowany i kontrolowany;

- powinien dawać możliwość uzupełnienia materiałów pędnych i eksploatacyjnych.

Jednostki przybyłe na miejsce akcji powinny być przejmowane przez osoby dobrze znające teren akcji, powinny być wyposażone w szczegółowe mapy i nawigację. Podstawę do organizacji punktu przyjęć mogą stanowić: jednostki JRG PSP, remizy OSP oraz inne stałe obiekty (szkoły, zakłady pracy itp.).

\section{Zapewnienie środków gaśniczych}

Warunkiem koniecznym powodzenia długotrwałych akcji ratowniczych jest między innymi zapewnienie w odpowiedniej ilości i odpowiednim czasie środków 
gaśniczych. Ma to szczególne znaczenie przy dużych pożarach lasów, gdzie ilość potrzebnych środków jest bardzo duża i zapewnienie ich systematycznej dostawy wymaga sprawnej organizacji logistycznej. Punkty te powinny być zorganizowane w miejscach, do których jest zapewniony swobodny dojazd i możliwość manewru samochodami gaśniczymi. W miejscach tych należy ustawić motopompy, sprzęt oraz armaturę umożliwiającą pobór wody jednocześnie przez kilka samochodów. Niezwykle istotne jest również zapewnienie bezpiecznego ruchu pojazdów w tych punktach. Zadanie to może być wykonywane przez służby PSP bądź służby porządkowe i obejmuje również pojazdy zadysponowane z innych zakładów, służb, np. MPO, PKP.

W długotrwałych akcjach gaśniczych $\mathrm{w}$ dużych ilościach wykorzystywane są również pianotwórcze środki gaśnicze i neutralizatory. Zabezpieczenie logistyczne w zakresie dostawy środków gaśniczych jest ściśle powiązane z dostawą sprzętu pożarniczego, mam tu na myśli uzupełnienie i wymianę wyposażenia specjalnego pojazdów, które zostało zużyte lub uszkodzone podczas prowadzenia działań. W tej kwestii należy mieć na uwadze:

- wymianę uszkodzonych węży pożarniczych i armatury;

- utworzenie zapasu węży do przesyłania wody na duże odległości;

- uzupełnienie wyposażenia pojazdów pożarniczych w węże gaśnicze.

Zapasy środków gaśniczych i sprzętu pożarniczego muszą być zgromadzone w jednym, przeznaczonym do tego celu miejscu. Może to być w bezpośredniej bliskości punktu przyjęcia sił i środków lub w pobliżu sztabu akcji. W tym miejscu powinny się również znaleźć środki ochrony indywidualnej. Wydawanie sprzętu powinno odbywać się na jasno określonych zasadach i przez wskazane osoby. Czynności te powinny być udokumentowane.

\section{Oświetlenie miejsca akcji}

Zabezpieczenie logistyczne w zakresie oświetlenia miejsca akcji i miejsc kwaterunkowych może być realizowane ze źródeł niezależnych, tj. agregaty prądotwórcze, kontenery inżynieryjne oraz samochody specjalne oświetleniowe. System oświetlenia terenu akcji powinien być realizowany poprzez sieć lamp, halogenów i szperaczy znajdujących się w zasobach jednostek PSP.

\section{Podsumowanie}

System zarządzania procesami logistycznymi w strukturach Państwowej Straży Pożarnej powinien być stale powiększany i modernizowany. Efektywne zabezpieczenie, sprawne i umiejętne wykorzystanie sił i środków, jakimi może dysponować Kierujący Działaniem Ratowniczym w trakcie rozległych działań ratowniczych, niejednokrotnie często tragicznych w skutkach, znacząco usprawni oraz ustabilizuje prowadzone działania na rzecz likwidacji zagrożenia. Należy jednak pamiętać, że długotrwale prowadzona akcja ratownicza obliguje do nawiązania spójnej 
współpracy z administracją samorządową lub administracją rządową bądź tė̇ z innymi służbami oraz ośrodkami zdrowia, szkołami i ludnością miejscową. Niewątpliwie na powodzenie zabezpieczenia logistycznego wpływa dobór kompetentnych ludzi do określonych zadań specjalnych, jasne przedstawienie zakresu powierzonych im obowiązków i ciężaru odpowiedzialności jaką ponoszą za podejmowane decyzje.

Obserwując istniejący system zarządzania procesami logistycznymi Państwowej Straży Pożarnej oraz opierając się na przedstawionych wiadomościach i też analizach zgromadzonej literatury przedmiotu można nakreślić wiele wniosków służących udoskonaleniu realizacji zadań w myśl zabezpieczenia logistycznego rozległych działań ratowniczych. Niezbędnym jest właściwe rozwiązanie problemu finansowania akcji. Słusznym było by stworzenie adekwatnych podstaw organizacyjno-prawnych oraz zdefiniowanie dokładnych kompetencji, zakresu uprawnień, jak również odpowiedzialności finansowej szefa logistyki (w celu bezbłędnej realizacji zadań). Koniecznym elementem staje się przeprowadzanie ćwiczeń kompanii logistycznej, co ma na celu usprawnienie koordynacji w prowadzeniu działań wielopodmiotowych oraz wyeliminowanie błędów mogących wystąpić podczas realnych działań ratowniczych. Ważnym aspektem jest także regularne przeprowadzanie szkoleń strażaków Ochotniczych Straży Pożarnych oraz odpowiednie, w zależności od potrzeb, doposażenie ich jednostek. Mogłoby to skutkować włączeniem dodatkowych jednostek Ochotniczych Straży Pożarnych do Krajowego Systemu RatowniczoGaśniczego. Kluczowe znaczenie podczas długotrwałych działań ratowniczych ma prawidłowy przepływ informacji. Niezbędne staje się opracowanie odpowiedniego systemu łączności, jak również systemu wzajemnej komunikacji pomiędzy służbami oraz podmiotami biorącymi udział w prowadzonych działaniach ratowniczych. Należy także zmodernizować łączność pomiędzy jednostkami, gdyż brak obsady tych samych kanałów w radiostacjach przewoźnych, nasobnych kooperujących jednostek i braki sprzętowe łączności znacznie utrudniają prowadzenie łączności bezprzewodowej pomiędzy podmiotami.

$\mathrm{Z}$ analizy i oceny długotrwałych akcji ratowniczych wynika, że wykorzystanie zasobów terenowych w procesie zabezpieczenia logistycznego jednostek PSP jest jednym z podstawowych warunków zapewniających skuteczność ich prowadzenia. Dotychczasowa praktyka wskazuje, że wykorzystanie tych zasobów napotyka na wiele różnych trudności. Dotyczą one przede wszystkim: identyfikacji rozmieszczenia i ewidencji zasobów miejscowych, kontraktowania dostaw środków zaopatrzenia i usług u dostawców (wykonawców) terenowych, procedur ich pozyskiwania oraz wykorzystania w czasie akcji ratowniczej, współpracy z miejscowymi zespołami zarządzania kryzysowego (ZZK) itp. Dotychczas problematyka ta rozwiązywana była w sposób doraźny. Dzieje się tak, ponieważ w zdecydowanej większości akcje ratownicze prowadzone przez jednostki PSP są akcjami krótkotrwałymi. Ogranicza to możliwości zdobywania przez osoby funkcyjne wiedzy i umiejętności z zakresu logistyki niezbędnych do organizacji i realizacji zabezpieczenia logistycznego 
jednostek PSP w akcjach długotrwałych, w tym m.in. racjonalnego wykorzystania zasobów terenowych.

Potrzeba wykorzystania zasobów terenowych w procesie zabezpieczenia logistycznego jednostek PSP w długotrwałych akcjach ratowniczych wynika m.in. z braku (niskiej) autonomiczności logistycznej PSP (np. takiej, jaką posiadają siły zbrojne), niezbędnej jej do realizacji tego zabezpieczenia własnymi siłami i środkami.

Problem wykorzystania zasobów terenowych powinien być rozwiązywany już na etapie przygotowania planów ratowniczych PSP opracowywanych na szczeblu powiatowym, wojewódzkim i krajowym (centralnym). Uwarunkowania prawne ${ }^{14}$ funkcjonowania KSRG dają komendantom PSP powiatowym (miejskim), wojewódzkim, a także KG PSP możliwość zawieranie umów-cywilnoprawnych z podmiotami współdziałającymi z jednostkami PSP w akcjach ratowniczych na realizację różnego rodzaju świadczeń (np. dostaw środków zaopatrzenia, wykonywanie różnych usług logistycznych). Umowy te, wg opinii autora [M.Ch.] mogą i powinny dotyczyć również wykorzystania zasobów terenowych.

Przedmiotem nieporuszanym w powyższym opracowaniu jest szeroko pojęte współdziałanie z podmiotami środków masowego przekazu. Należy traktować wszystkie media jako sprzymierzeńca $\mathrm{w}$ walce $\mathrm{z}$ zaistniałą sytuacją niebezpieczną i umiejętnie wykorzystać je do przekazania informacji o ewentualnych zagrożeniach, skutkach, miejscach ewakuacji i udzielania pomocy.

Zadania zabezpieczenia logistycznego takiej akcji muszą być prawidłowo zrealizowane. W tym celu proponuje się powołanie zespołu o następującym składzie:

- szef tyłów (szef zabezpieczenia logistycznego akcji) podlegający KDR-owi;

- kierownik (szef) punktu przyjęć sił i środków;

- kierownik (szef) zabezpieczenia kwatermistrzowskiego, który realizuje zadania związane $\mathrm{z}$ wyżywieniem, zakwaterowaniem itd.;

- kierownik (szef) zabezpieczenia transportowo-technicznego odpowiadającego za zadania transportowe, pomocy technicznej itd.;

- kierownik (szef) zabezpieczenia medyczno-sanitarnego.

Ważnym jest aby wszystkie wyżej wymienione osoby miały jasno określone zadania, uprawnienia oraz zakres odpowiedzialności. Obszar zadań i uprawnień osób funkcyjnych powinny być opracowane i znajdować się w teczce sztabu, teczce KDR lub stanowić załączniki do planów ratowniczych znajdujących się w WSKR -ach czy PSK.

Warunkiem sprawnego, skutecznego i bezpiecznego prowadzenia akcji gaśniczej jest zorganizowanie w pełnym zakresie zabezpieczenia logistycznego. W skład tak pojmowanego zabezpieczenia wchodzą:

- przyjmowanie i rozlokowanie zaalarmowanych, zadysponowanych sił i środków;

14 Por. Rozporządzenie Ministra Spraw Wewnętrznych i Administracji z dnia 18.02.2011 r. w sprawie szczegółowych zasad organizacji Krajowego Systemu Ratowniczo-Gaśniczego. 
- zakwaterowanie zadysponowanych sił, łącznie z siłami zadysponowanymi w celu podmiany;

- zorganizowanie, utworzenie i nadzorowanie sieci łączności, sieci powiadamiania i alarmowania;

- zabezpieczenie dostatecznej ilości oraz dostaw środków gaśniczych i innych środków chemicznych;

- zabezpieczenie medyczno-sanitarne;

- zabezpieczenie wymiany uszkodzonego, niesprawnego sprzętu, wyposażenia samochodów gaśniczych;

- zapewnienie uzupełniania materiałów pędnych i smarów;

- realizacja zapotrzebowania na sprzęt specjalistyczny, pojazdy inżynieryjne;

- zabezpieczenie części zamiennych oraz wymiany uszkodzonego sprzętu;

- zabezpieczenie transportowe.

Warunkiem prawidłowej realizacji powyższych działań jest właściwa obsada osób funkcyjnych doskonale znających się na zagadnieniach logistyki i mających ściśle określoną odpowiedzialność. Osoby te powinny znać teren działania jednostek ratowniczo-gaśniczych, a ich działanie powinno być przemyślane i zaplanowane.

Reasumując - w ocenie autorów, aby usprawnić dotychczas funkcjonujący system zabezpieczenia logistycznego długotrwałych akcji ratowniczych z udziałem jednostek PSP należy wprowadzić następujące rozwiązania:

- wydawanie pierwszego posiłku po 4 godzinach akcji, a nie jak dotąd po 6;

- rozdzielanie żywności za zgodą kierownika lub KDR;

- niewydawanie żywności w punktach czerpania wody;

- wyposażenie odwodów w suchy prowiant;

- wyżywienie wszystkich uczestników akcji;

- użycie kontenera żywnościowego;

- zakwaterowanie stałe i tymczasowe, przy organizacji baz koncentracji sił i środków dobrą praktyką jest korzystanie w pierwszej kolejności z infrastruktury szkół PSP, ośrodków szkolenia oraz obiektów użyteczności publicznej innych służb;

- stosowanie kontenerów kwatermistrzowskich;

- zaopatrzenie w paliwo i smary w pobliżu akcji;

- dostarczanie paliwa cysternami specjalistycznymi;

- stosowanie kontenerów paliwowych;

- standaryzacja i unifikacja wyposażenia kontenerowego;

- zabezpieczenie rezerwy ubrań specjalnych;

- oparcie zabezpieczenia na własnych ratownikach poprzez tworzenie roty medycznej, a także korzystanie z wolontariatu np. PCK na podstawie wypracowanych porozumień;

- zwiększenie minimalnej wydajności przewoźnych pomp z 4000 l/min do $10000 \mathrm{l} / \mathrm{min}$; 
- zwiększenie ilości sprzętu oświetleniowego;

- profesjonalizacja szkoleń i zwiększenie ich częstotliwości;

- optymalizacja łączności i informatyzacja;

- zwiększenie środków finansowych;

- dokładna analiza i ocena zdarzeń i późniejsze jej rzetelne raportowanie;

- korzystanie z nowych technologii.

Wprowadzenie wymienionych rozwiązań pozwoli na sprawniejsze prowadzenie długotrwałych akcji ratowniczych i procesów zabezpieczenia logistycznego działań oraz polepszenie warunków współpracy jednostek PSP z pozostałymi formacjami mundurowymi i władzami samorządu terytorialnego.

\section{Bibliografia}

[1] Jarosz W., Lipiński S., Marciniak A., Michalska J., Skuteczne ratownictwo: fachowy poradnik dla stużb ratowniczych, Wydawnictwo VERLAG DOSHOFER, Warszawa 2006.

[2] Kamiński A., Sytuacje pożarowe, siły i środki niezbędne w działaniach taktycznych, Wyd. SGSP, Warszawa 1998.

[3] KGPSP, Taktyka działań ratowniczych, Wyd. Centralna Szkoła PSP w Częstochowie, Częstochowa 1998.

[4] Kielin J., Akcje ratownicze podczas katastrof budowlanych, Wyd. Szkoła Aspirantów PSP w Krakowie, Kraków 1999.

[5] Kosowski B., Organizacja działań i logistyka w sytuacjach kryzysowych, Międzynarodowa Konferencja Naukowo-Techniczna, Warszawa 2004.

[6] Nowak E., Logistyka w sytuacjach kryzysowych, Wyd. AON, Warszawa 2005.

[7] Nowak E., Logistyka w sytuacjach kryzysowych, Wydanie II poprawione i poszerzone, Warszawa 2009.

[8] Szymonik A., Logistyka w bezpieczeństwie, Warszawa 2010.

\section{Inne źródła:}

[1] http://raciborz.naszemiasto.pl/artykul/pozar-lasu-w-kuzni-raciborskiej-w-1992-krajobraz-jak-na,1972987, artgal,t,id,tm.html (dostęp: 07.02.2018).

[2] https://remiza.com.pl/ (dostęp: 07.02.2018).

[3] http://opole.wyborcza.pl/opole/5,35086,22070929.html?i=1 (dostęp: 07.02.2018).

[4] Analiza zdarzenia dot.: miejscowe zagrożenia związane z zawaleniem się dachu hali wystawowej Międzynarodowych Targów Katowickich w Chorzowie przy ulicy Bytkowskiej 1 b w dniach 28.01.2006-20.02.2006 r. opracowana przez KW PSP w Katowicach. 


\section{Wykaz aktów prawnych:}

[1] Rozporządzenie Ministra Spraw Wewnętrznych i Administracji z dnia 29 grudnia 1999 r. w sprawie szczegółowych zasad organizacji krajowego systemu ratowniczo-gaśniczego (Dz. U. z 1999 r. nr 111, poz. 1311).

[2] Rozporządzenie Ministra Spraw Wewnętrznych i Administracji z 11 grudnia 1997 r. w sprawie długotrwałych akcji ratowniczych, szczegółowych norm, zasad i warunków otrzymywania wyżywienia w czasie tych akcji oraz ćwiczeń lub szkolenia przez strażaków Państwowej Straży Pożarnej lub inne osoby biorące w nich udział, a także przypadków, w których wypłaca się równoważnik pieniężny w zamian za przysługujące wyżywienie, sposób ustalania jego wysokości oraz szczegółowych zasad wypłacania (Dz. U. 1997 r. nr 160, poz. 10980). 


\title{
System kompleksowego zabezpieczenia logistycznego wielopodmiotowych akcji ratowniczych
}

\author{
A comprehensive logistic security system \\ for multi-entity rescue operations
}

\author{
Robert Piec \\ Szkoła Główna Służby Pożarniczej
}

\section{Streszczenie}

Wychodzac naprzeciw potrzebom wynikajacym $z$ zadań logistycznych $w$ długotrwatych, wielopodmiotowych akcjach ratowniczych w latach 2013-2016 zrealizowano projekt pt.: „System kompleksowego zabezpieczenia logistycznego wielopodmiotowych akcji ratowniczych". Opracowany system informatyczny wykorzystuje stworzone oprogramowanie komputerowe, które z baza wiedzy, zasadami postępowania w zakresie zabezpieczenia logistycznego oraz przyjętym sposobem dokumentowania realizowanych działań wspomaga zarzadzanie $w$ zakresie zabezpieczenia logistycznego wielopodmiotowymi działaniami ratowniczymi. W celu sprawdzenia opracowanego rozwiazania przeprowadzono demonstracje $w$ warunkach zbliżonych do rzeczywistych, na która zaproszono potencjalnych użytkowników. Przedstawione w czasie demonstracji założenia teoretyczne oraz narzędzie informatyczne zostało ocenione bardzo pozytywnie. Wnioski z wyników ankiety sa niezaprzeczalne - przydatność tego typu narzędzia do przyszłych działań ratowniczych jest bardzo duża.

\begin{abstract}
In order to meet the needs resulting from logistic tasks in long-term, multi-entity rescue actions in 2013-2016, a project was implemented: A comprehensive logistic security system for multi-entity rescue operations. The developed IT system uses created computer software which, with the knowledge base, rules of conduct in the field of logistic security and the adopted method of documenting the implemented activities, supports logistic security management of multi-agency rescue operations. In order to check the developed solution, system was tested out in conditions close to the real one on which potential users were invited. The theoretical assumptions and the IT tool presented during the demonstration were evaluated very positively. The conclusions in the survey results are undeniable - the usefulness of this type of tool for future rescue operations is very high.
\end{abstract}




\section{Wstęp}

Bezpieczeństwo w teorii potrzeb Abrahama Maslowa 1 jest podstawową potrzebą człowieka umożliwiającą trwanie i rozwój. Zapewnienie bezpieczeństwa obywateli jest jednym $z$ zadań państwa wynikającym m.in. $z$ konstytucji ${ }^{2}$. Aby zrealizować to zadanie powołane zostały odpowiednie służby. Zakres działań i ich odpowiedzialności w warunkach, które można opisać jako rutynowe jest prosty do określenia, natomiast w czasie sytuacji kryzysowej wymagającej współdziałania wielu podmiotów jest bardzo złożony. Szczególnie trudne do skoordynowania podczas tego typu akcji ratowniczych są zadania logistyczne. Słownik języka polskiego ${ }^{3}$ logistykę definiuje jako planowanie i organizację skomplikowanego przedsięwzięcia. Sytuacje kryzysowe, w których uczestniczy wiele podmiotów ratowniczych są niewątpliwie skomplikowanymi przedsięwzięciami. Logistyka w sytuacjach kryzysowych dostarcza rozwiązań teoretycznych sprzyjających kształtowaniu, sterowaniu i kontroli procesów zaopatrzeniowych i procesów usługowych realizowanych w łańcuchach logistycznych organizowanych na rzecz ludności poszkodowanej w sytuacjach kryzysowych ${ }^{4}$. Misją działań logistycznych jest ratowanie życia i zdrowia rannym i chorym oraz zapewnienie wszystkim osobom potrzebującym warunków niezbędnych do przetrwania w tych sytuacjach. Celem działań logistycznych jest organizacja dostaw podstawowych środków zaopatrzenia oraz usług logistycznych i medycznych i dotarcie z nimi do wszystkich osób poszkodowanych w możliwie krótkim czasie 5 .

Wychodząc naprzeciw potrzebom wynikającym z zadań logistycznych w długotrwałych, wielopodmiotowych akcjach ratowniczych w latach 2013-2016 zrealizowano projekt pt. „System kompleksowego zabezpieczenia logistycznego wielopodmiotowych akcji ratowniczych". Liderem była Szkoła Główna Służby Pożarniczej, która we współpracy z Akademią Sztuki Wojennej, Centrum Naukowo-Badawczym Ochrony Przeciwpożarowej PIB oraz firmą Sonovero Sp. z o.o. opracowała systemowe informatyczne rozwiązanie wspomagające organizację zabezpieczenia logistycznego długotrwałych akcji ratowniczych, w celu osiągnięcia zadowalającego stopnia spójności i sprawności podmiotów realizujących i zarządzających zabezpieczeniem logistycznym akcji ratowniczych. Opracowany system informatyczny wykorzystuje stworzone oprogramowanie komputerowe, które z bazą wiedzy, zasadami postępowania w zakresie zabezpieczenia logistycznego oraz przyjętym sposobem dokumentowania realizowanych działań wspomaga zarządzanie w zakresie zabezpieczenia logistycznego wielopodmiotowymi działaniami ratowniczymi.

1 M. Lisiecki, Zarządzanie bezpieczeństwem publicznym, Wyd. naukowe Łośgraf, Warszawa 2011, s. 208.

2 Konstytucja Rzeczypospolitej Polskiej z dnia 2 kwietnia 1997 r. Dz.U. 1997 nr 78 poz. 483.

3 http://sjp.pwn.pl/szukaj/logistyka.html (dostęp: 9.02 .2018 r.).

4 W. Nowak, E. Nowak, Podstawy logistyki w sytuacjach kryzysowych z elementami zarządzania logistycznego, Społeczna Wyższa Szkoła Przedsiębiorczości i Zarządzania, Łódź 2009, s. 8.

5 Tamże, s. 7. 


\section{Funkcjonalności systemu}

Opracowane oprogramowanie komputerowe w pełni realizuje cel główny projektu związany z wypracowaniem rozwiązań systemowych wspierających organizację zabezpieczenia logistycznego długotrwałych akcji ratowniczych. Opracowane narzędzie teleinformatyczne wspiera:

- logistykę w czasie przygotowania do akcji;

- logistykę w czasie akcji z wizualizacją wybranych zasobów na mapach cyfrowych;

- proces planowania działań w czasie akcji;

- wspomaganie zarządzania akcją ratowniczą.

Przygotowanie oprogramowania wykorzystującego architekturę klient-serwer oraz systemu zarządzania bazą danych wspomaga dostęp do aktualnych danych oraz ułatwia przepływ informacji, usprawniając w ten sposób zarząadzanie zasobami logistycznymi i szybkie reagowanie na dynamicznie zmieniające się potrzeby akcji ratowniczych.

Opracowane rozwiązanie, poprzez wykorzystanie najlepszych i sprawdzonych doświadczeń, procesów i praktyk wzorowanych na armiach NATO, umożliwia w czasie rzeczywistym wspomaganie dowodzenia w warunkach dynamicznie zmieniającego się środowiska.

Główną funkcjonalność systemu teleinformatycznego podzielono na cztery sfery tematyczne:

- umożliwienie prowadzenia ewidencji zasobów i możliwości logistycznych dostępnych podczas trwania akcji ratowniczej;

- wsparcie generowania dokumentacji logistycznej wykonywanej podczas akcji ratowniczej;

- wsparcie generowania dokumentacji dyrektywnej Kierującego Działaniami Ratowniczymi (KDR);

- wsparcie generowania niezbędnej dokumentacji pomocniczej.

Wymienione powyżej funkcjonalności mają za zadanie wspomóc szefa logistyki zarządzającego procesami zaopatrzeniowymi i procesy usługowe realizowane w łańcuchach logistycznych.

Wielopodmiotowe akcje ratownicze często są również akcjami długotrwałymi. Wymagają użycia jednostek o różnorodnej specjalizacji, które muszą jednak funkcjonować według jednolitego planu działania. Do powodzenia akcji ratowniczej niezbędna jest dobra organizacja usług logistycznych i medycznych.

Spośród usług logistycznych wzięto pod uwagę:

- usługi gospodarczo-bytowe;

- usługi transportowe;

- usługi remontowe.

Spośród usług medycznych:

- pomoc przedlekarską;

- pierwszą pomoc lekarską. 
Założono, że wszystkie wskazane wyżej usługi mogą być realizowane częściowo siłami własnymi, częściowo jako zlecenia dla usługodawców zewnętrznych.

\section{Organizacja zabezpieczenia logistycznego wielopodmiotowych akcji ratowniczych}

Niezwykle istotny jest podział ról i zadań poszczególnych funkcjonariuszy biorących udział $w$ wielopodmiotowych akcjach ratowniczych. Za przebieg działań w prowadzeniu akcji ratowniczej odpowiada Kierujący Działaniami Ratowniczymi (KDR). Elastyczność i modułowość systemu umożliwiła stworzenie ról zarówno zgodnych, jak i odbiegających od przyjętych w organizacji podmiotów Krajowego Systemu Ratowniczo-Gaśniczego (KSRG). Wzorowano się na najnowszych doświadczeniach organizacji zabezpieczenia logistycznego sił zbrojnych. Wprowadzono bardzo ważne w przypadku koordynacji działań logistycznych stanowisko zastępcy KDR ds. logistyki, który miał za zadanie przejąć obowiązki związane z procesem zarządzania logistycznego.

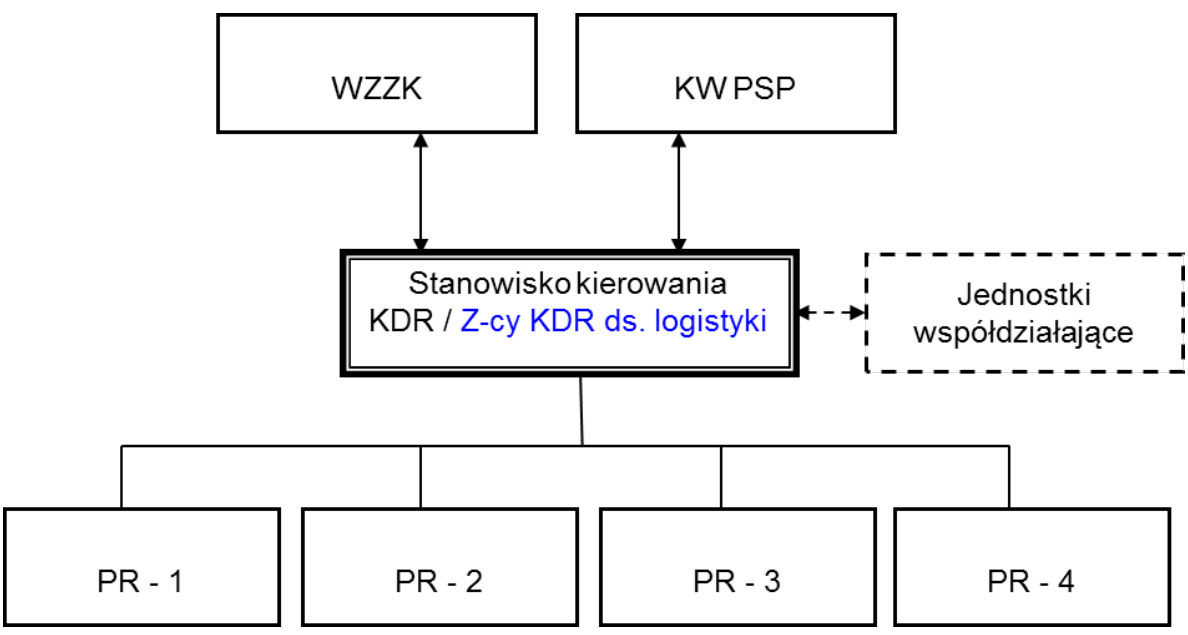

Rysunek 1. Usytuowanie stanowiska kierowania KDR/Z-cy KDR ds. logistyki podczas długotrwałej akcji ratowniczej

Źródło: Sprawozdanie z demonstracji systemu kompleksowego zabezpieczenia logistycznego wielopodmiotowej akcji ratowniczej w warunkach terenowych, zawierające analizę i ocenę prawidłowości zastosowanych rozwiąań, SGSP, Warszawa 2016

Analiza literatury umożliwiła sprecyzowanie dokumentów, które ułatwiają zastępcy KDR ds. logistyki sprawne zarządzanie zasobami logistycznymi6:

6 Sprawozdanie z demonstracji systemu kompleksowego zabezpieczenia logistycznego wielopodmiotowej akcji ratowniczej $w$ warunkach terenowych, zawierające analizę i ocenę prawidłowości zastosowanych rozwiązań, SGSP, Warszawa 2016. 
- ewidencję podmiotów ratowniczych uczestniczących w akcji ratowniczej i ich potrzeb logistycznych;

- ewidencję zasobów logistycznych i medycznych (posiadanych sił oraz środków logistycznych i medycznych) będących w dyspozycji KDR;

- plan dostaw środków zaopatrzenia w poszczególnych dniach akcji ratowniczej;

- plan świadczenia usług logistycznych w poszczególnych dniach akcji ratowniczej;

- plan świadczenia pomocy medycznej rannym i chorym oraz ewakuacji medycznej w poszczególnych dniach akcji ratowniczej;

- katalog (wykaz, zestawienie) możliwości logistycznych.

Zarządzanie wielopodmiotową akcją ratowniczą wymaga umiejętnego posługiwania się dokumentacją branżową, tworzenia zestawień i prowadzonej na bieżąco analizy zasobów. Wsparcie tego procesu narzędziem informatycznym umożliwia jego uporządkowanie. W demonstracji systemu wskazano na cztery bardzo ważne elementy:

- ewidencję zasobów i możliwości logistycznych dostępnych w akcji ratowniczej;

- opracowanie logistycznej dokumentacji planistycznej;

- opracowanie części logistycznych dokumentacji dyrektywnej (rozkazodawczej) KDR;

- opracowanie logistycznych dokumentów pomocniczych.

\section{Proces decyzyjny}

Proces decyzyjny obejmuje fazy decyzyjne i czynności. Jest wynikiem pozyskiwania, przetwarzania i wykorzystania informacji przez zespół zarządzający sytuacją kryzysową, którym, w przypadku prowadzenia działań ratowniczych zgodnie z rozporządzeniem dotyczących organizacji KSRG, będzie powołany sztab7 . Wynikiem procesu decyzyjnego jest wypracowany zamiar, plan reagowania oraz zadania dla podmiotów (jednostek) wykonawczych będących w dyspozycji sztabu ${ }^{8}$. Jest to procedura stała i powtarzalna. Zazwyczaj rozpoczyna go przydzielone zadanie lub jest inicjowany samodzielnie przez zespół w przypadku wystąpienia zagrożenia lub zagrożeń mogących spowodować sytuację niekorzystną. Kończy się postawieniem wykonawcom zadań i kontrolą ich wykonania9.

Zespół realizujący projekt, bazując na założeniach teoretycznych oraz własnym doświadczeniu, opracował koncepcję modelu procesu decyzyjnego

7 Rozporządzenie Ministra Spraw Wewnętrznych i Administracji z dnia 3 lipca 2017 r. w sprawie szczegółowej organizacji krajowego systemu ratowniczo-gaśniczego, Dz.U. 2017 poz. 1319.

8 W. Nowak, E. Nowak, Podstawy logistyki..., dz. cyt., s. 131.

9 Tamże. 
w wielopodmiotowych akcjach ratowniczych. Wskazano w nim szereg zadań jakie powinien realizować zastępca KDR-a ds. logistyki.

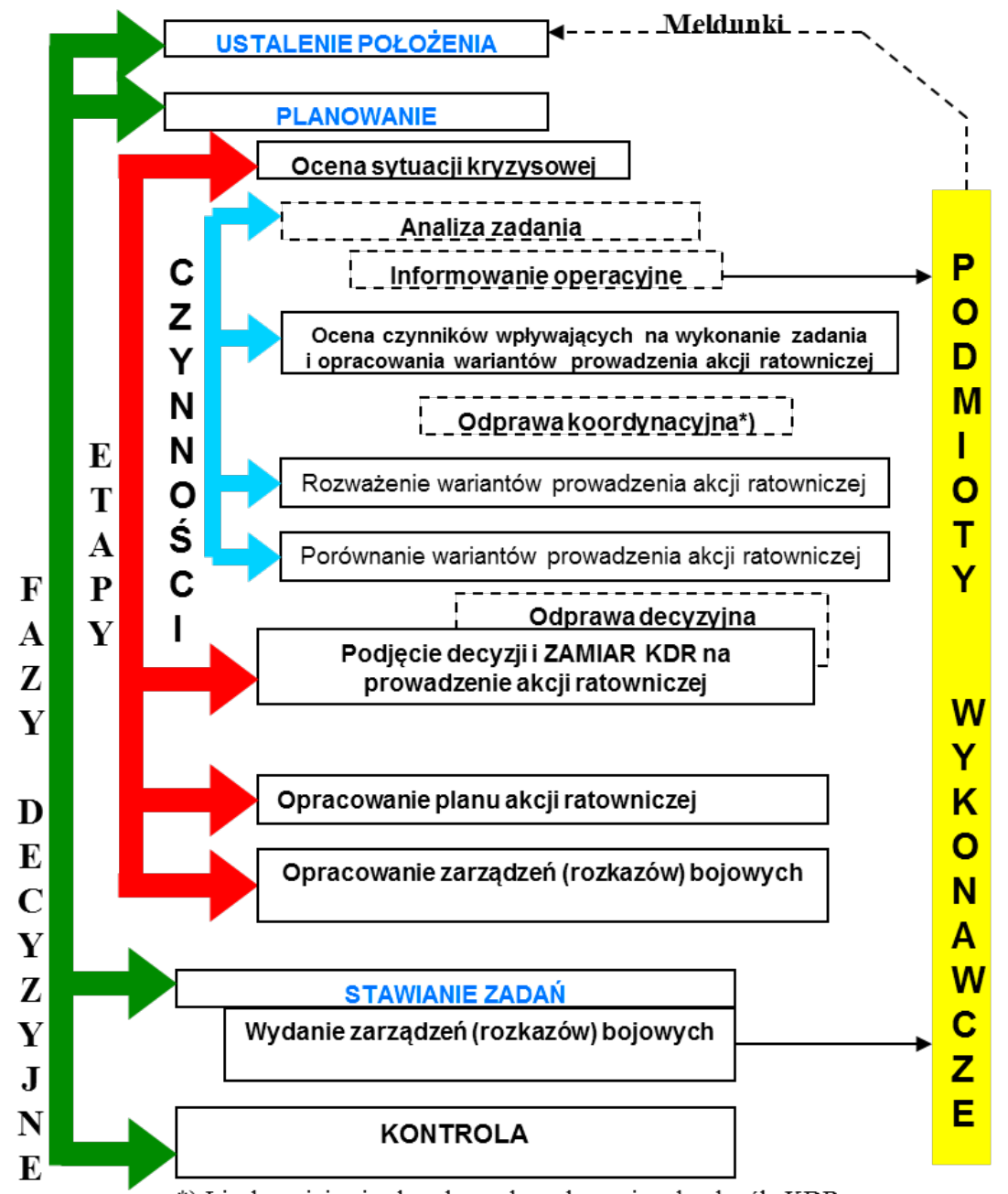

*) Liczbę miejsc i cele odpraw koordynacyjnych określa KDR

Rysynek 2. Układ cyklu decyzyjnego KDR

Źródło: Sprawozdanie $z$ demonstracji systemu kompleksowego zabezpieczenia logistycznego wielopodmiotowej akcji ratowniczej $w$ warunkach terenowych, zawierające analizę i ocenę prawidłowości zastosowanych rozwiazann, SGSP, Warszawa 2016, s. 9 
System kompleksowego zabezpieczenia logistycznego wielopodmiotowych akcji...

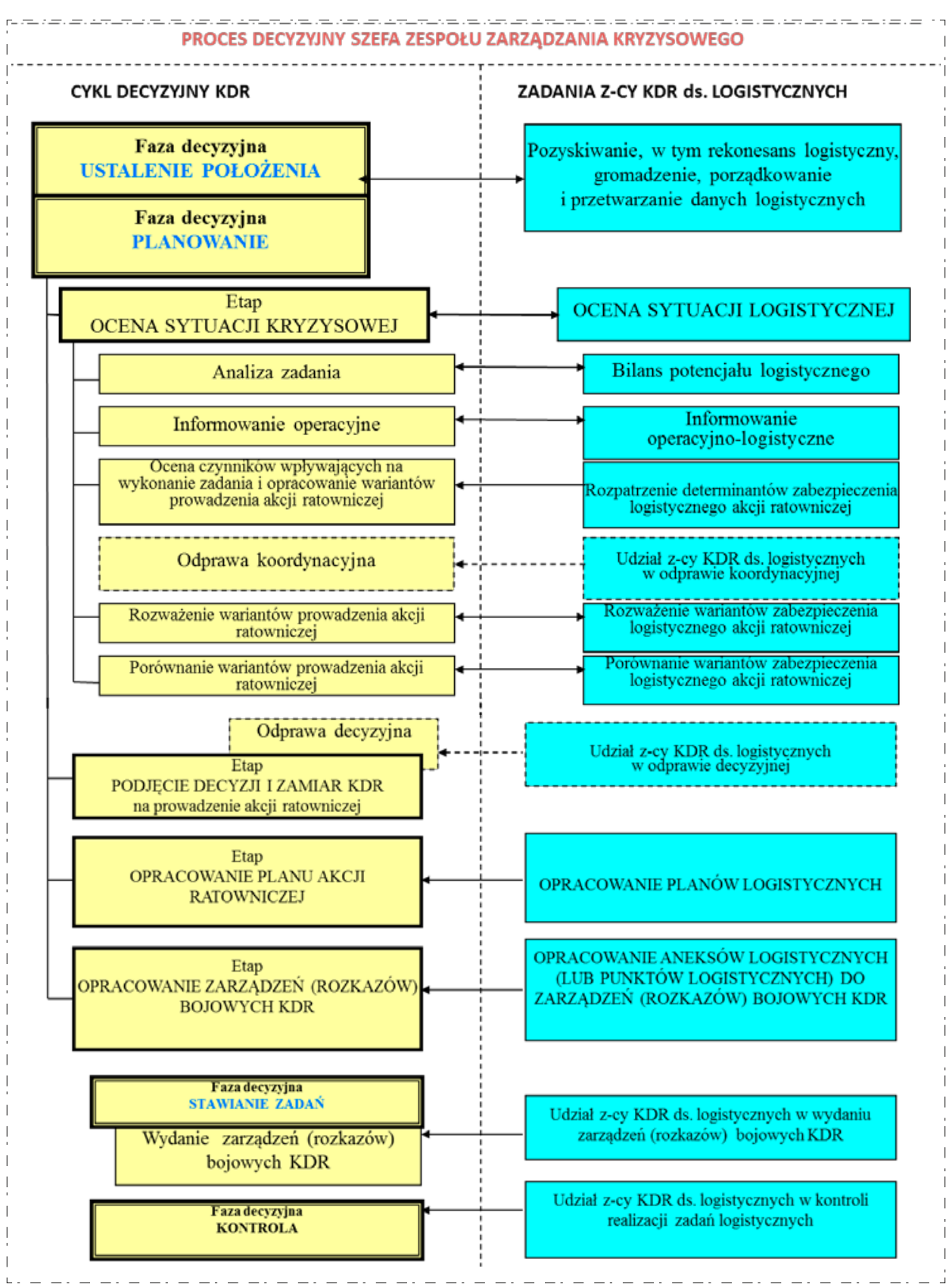

Rysunek 3. Model udziału zastępcy KDR ds. logistycznych w procesie decyzyjnym KDR

Źródło: Sprawozdanie $z$ demonstracji systemu kompleksowego zabezpieczenia logistycznego wielopodmiotowej akcji ratowniczej w warunkach terenowych, zawierające analizę i ocenę prawidłowości zastosowanych rozwiązań, SGSP, Warszawa 2016, s. 10 
W przedstawionym powyżej modelu zastępca KDR ds. logistycznych ściśle współpracuje z KDR. Zadania logistyczne są zintegrowane z procesem decyzyjnym KDR. Jakość wypracowywanych planów, zarządzeń czy rozkazów zależy przede wszystkim od sprawnej komunikacji pomiędzy KDR a jego zastępcą.

Proces decyzyjny w sytuacji kryzysowej jest nieodzownie złączony z rodzajem zagrożenia, które spowodowało konieczność działań ratowniczych. Jednym z zagrożeń, które mogą doprowadzić do powstania wielopodmiotowych akcji ratowniczych są powodzie. Są one szczególnie niebezpieczne ze względu na możliwość powstania efektów kaskadowych. Jest to sytuacja, w której dynamiczny rozwój zagrożenia, pod wpływem zdarzenia fizycznego, awarii technologicznej lub ludzkiej generuje sekwencję zdarzeń, powiązanych lub zależnych od siebie, skutkujących stratami fizycznymi, społecznymi lub wywołującymi zakłócenia gospodarcze. Początkowe oddziaływanie może wyzwalać inne zjawiska, które prowadzą do konsekwencji o znacznych wielkościach. Efekty kaskadowe są złożone, wielowymiarowe i ewoluują w miarę upływu czasu ${ }^{10}$.

Przykładem możliwości wystąpienia efektu kaskadowych może być zagrożenie powodziowe dla elektrowni Połaniec, która produkuje 5\% energii w kraju. Uporządkowane możliwe skutki takiej sytuacji przedstawiono poniżej.

\section{Zagrożenia:}

- Powódź - zalanie i uszkodzenie elektrowni oraz terenów przyległych.

\section{Efekty kaskadowe:}

- Zalanie budynków, dróg i instalacji > zakłócenia w ciągłości dostaw energii elektrycznej > ewakuacja ludności i mienia ruchomego > prawdopodobne straty ludzkie i materialne > strata miejsc pracy.

\section{Elementy narażone na ryzyko:}

- Ludzie:

- 500 pracowników;

- 3600 mieszkańców gminy;

- Budynki:

- 8674 mieszkań;

- 2875 budynków mieszkalnych;

- 10 przedszkoli;

- 12 szkół podstawowych;

- 5 gimnazjów;

- 5 szkół zawodowych;

- 9 liceów;

- 7 szkół policealnych;

- 1 szpital;

- 13 przychodni; 
- 5 hoteli;

- 2 motele;

- 3 muzea;

- 120 zabytków;

- 3 galerie;

- 3543 przedsiębiorstwa;

- 1 oczyszczalnia ścieków;

- Ekonomia:

- Lokalny PKB;

- PKB z turystyki;

- PKB z produkcji sadowniczej i ogrodniczej;

- Sieci energetyczne:

- infrastruktura sieci energetycznych;

- Transport:

- drogi;

- linie kolejowe;

- transport śródlądowy.

\section{Skutki:}

- ofiary śmiertelne i ranni ludzie;

- zniszczone budynki;

- zniszczone drogi i linie kolejowe;

- utrata miejsc pracy;

- zagrożenia epidemiologiczne;

- straty w rolnictwie.

\section{Konsekwencje dla systemów technologicznych:}

- zakłócenia w transporcie i komunikacji;

- zanieczyszczenia wodociągów;

- zniszczone sieci energetyczne;

- zniszczona linia produkcyjna w hucie.

Przestawione powyżej możliwe konsekwencje pokazują z jak dużymi przedsięwzięciami muszą się zmierzyć służby w przypadku zagrożenia powodziowego.

\section{Demonstracja systemu kompleksowego zabezpieczenia logistycznego wielopodmiotowych akcji ratowniczych}

Opracowane narzędzie przetestowano w czasie demonstracji działania systemu $\mathrm{w}$ warunkach terenowych podczas symulowanej wielopodmiotowej akcji ratowniczej. Możliwości demonstratora przedstawiono na specjalnym pokazie w obecności przyszłych użytkowników. 
Opracowano scenariusz testowy, który został następnie zaimplementowany w narzędziu. Uczestników demonstracji, przyszłych potencjalnych użytkowników, zapoznano z głównymi założeniami.

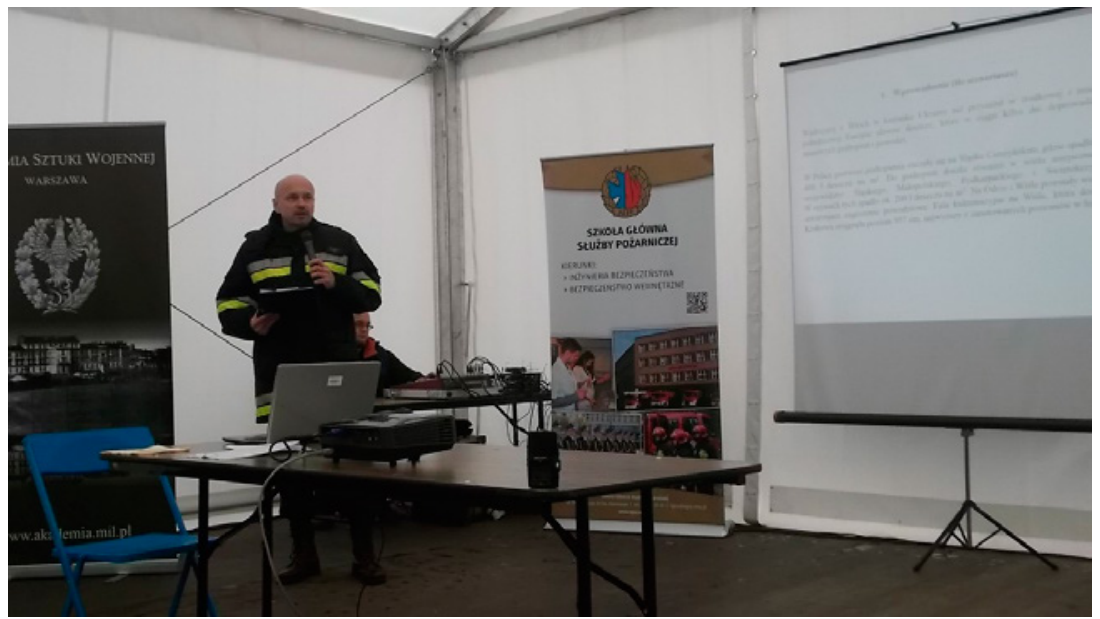

Rysunek 4. Prezentacja działania systemu w warunkach terenowych podczas symulowanej wielopodmiotowej akcji ratowniczej

Źródło: Materiały SGSP

Założenie główne obejmowało: wprowadzenie, wskazanie terenu akcji ratowniczej, charakterystykę terenu akcji ratowniczej, zadania do wykonania oraz elementy wyznaczone do prowadzenia akcji ratowniczej. Przedstawiono scenariusz testowy, który miał stanowić wprowadzenie do założeń. Scenariusz zakładał, że: „Wędrujący z Włoch w kierunku Ukrainy niż przyniósł w środkowej i środkowo-południowej Europie ulewne deszcze, które w ciągu kilku dni doprowadziły do masowych podtopień i powodzi. W Polsce pierwsze podtopienia zaczęły się na Śląsku Cieszyńskim, gdzie spadło ponad $400 \mathrm{l}$ deszczu na $\mathrm{m}^{2}$. Do podtopień doszło również w wielu miejscowościach województw: śląskiego, małopolskiego, podkarpackiego i świętokrzyskiego. W rejonach tych spadło ok. $200 \mathrm{l}$ deszczu na $\mathrm{m}^{2}$. Na Odrze i Wiśle powstały wezbrania stwarzające zagrożenie powodziowe. Fala kulminacyjna na Wiśle, która dotarła do Krakowa, osiągnęła poziom 957 cm, najwyższy z zanotowanych poziomów w historii"11.

Teren akcji ratowniczej obejmował około $30 \mathrm{~km}^{2}$, na których znajdowało się 80 budynków mieszkalnych, 5 przedsiębiorstw produkcyjno-usługowych oraz ferma drobiu. Mapę z naniesionym terenem akcji ratowniczej przedstawia rys. 2.

Zadaniami do wykonania w ramach działań ratowniczych były:

- organizacja i przeprowadzenie ewakuacji ludności poszkodowanej i jej mienia z zalanych i zagrożonych rejonów do tymczasowych miejsc zakwaterowania;

${ }^{11}$ Sprawozdanie $z$ demonstracji systemu kompleksowego..., dz. cyt., s. 6. 
- prowadzenie ochrony wałów przeciwpowodziowych na zagrożonych odcinkach;

- organizacja ochrony infrastruktury i mienia pozostawionego przez ewakuowaną ludność.
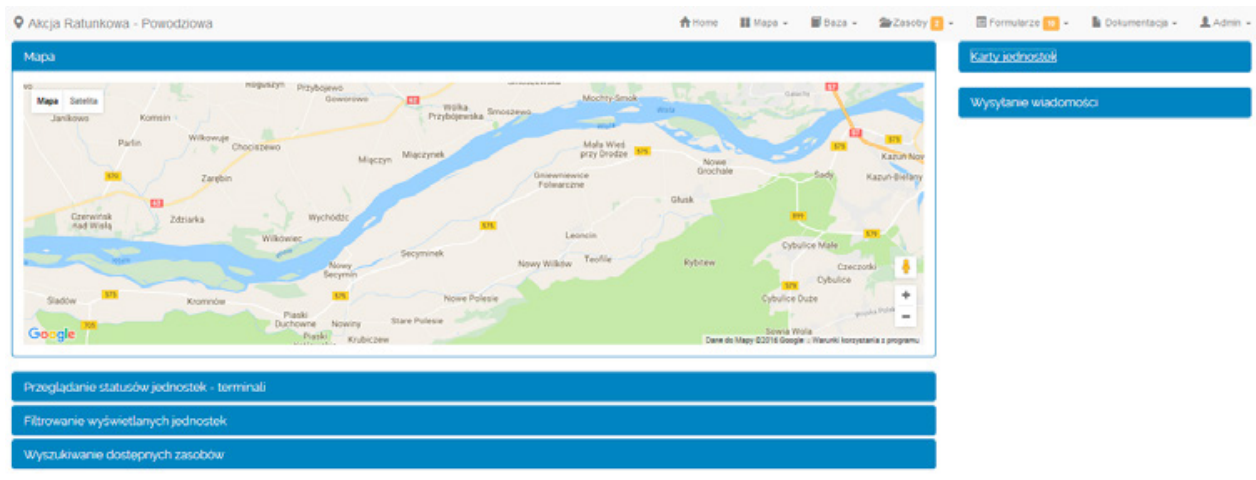

Rysunek 5. Teren akcji ratowniczej. Mapa wygenerowana z narzędzia informatycznego Źródło: Sprawozdanie $z$ demonstracji systemu kompleksowego zabezpieczenia logistycznego wielopodmiotowej akcji ratowniczej $w$ warunkach terenowych, zawierające analizę i ocenę prawidłowości zastosowanych rozwiązań, SGSP, Warszawa 2016, s. 7

W kolejnej części demonstracji przedstawiono dwa bardzo istotne elementy dotyczące sytuacji logistycznej w czasie symulowanej akcji ratowniczej:

- wykaz źródeł zaopatrzenia podmiotów ratowniczych uczestniczących w długotrwałej akcji powodziowej;

- wykaz zasobów logistycznych i medycznych w dyspozycji zastępcy KDR ds. logistyki.

W oparciu o wygłoszoną „Ocenę sytuacji logistycznej i medycznej” opracowane zostały plany:

- zaopatrzenia podmiotów ratowniczych;

- świadczenia usług logistycznych dla podmiotów ratowniczych;

- świadczenia pomocy medycznej dla podmiotów ratowniczych.

Przygotowane plany dostarczały wszelkie niezbędne dla KDR-a informacje tak, aby ten świadomie podjął decyzję dotyczącą założeń logistycznych w czasie trwania akcji.

Decyzja KDR-a o została sformalizowana w postaci „Aneksu logistycznego do zarządzenia bojowego KDR”. Aneks ten został wygenerowany z narzędzia informatycznego. Zawierał informacje ważne podczas zarządzania procesem logistycznym, takie jak: normy zaopatrzenia, informacje o równoważniku za wyżywienie, miejsce tankowania pojazdów, postępowanie z osobami zarażonymi i inne. Dynamika prowadzonych działań ratowniczych powoduje, że plany muszą zostać zmodyfikowane. W przyjętym procesie decyzyjnym zmiany takie w stosunku do aneksu 
logistycznego są realizowane w tzw. punkcie logistycznym. Zmiany wynikające $\mathrm{z}$ nieoczekiwanej sytuacji zostały przedstawione w Komunikacie nr 1 do akcji. Komunikat zakładał, że:

- Na skutek ulewnych deszczów zanieczyszczeniu uległy zbiorniki paliw w stacji paliwowej w m. Czosnów. Przechowywane w nich paliwo nie nadaje się do użycia. W związku z powyższym wyznaczono nową stację paliw w m. Kampinos.

- Na skutek ulewnych nocnych deszczów z 08.11-09.11. podmyciu uległa droga $\mathrm{nr} 579 \mathrm{z} \mathrm{m}$. Sowia Wola do m. Leszno w m. Łubiec na odcinku około $2 \mathrm{~km}$. Naprawa drogi potrwa co najmniej $2 \mathrm{dni}$. W związku z powyższym wyznaczono objazd drogą nr 579 (Sowia Wola - Kampinos).

Informacje te zostały następnie zasymulowane w narzędziu informatycznym.

\section{Kontener do wsparcia logistycznego zbudowany według wytycznych uzyskanych w projekcie}

Jednym z zakładanych efektów projektu było stworzenie kontenera logistycznego, który w czasie wielopodmiotowych akcji ratowniczych miałby stanowić mobilne centrum koordynacji działań logistycznych. Składa się on z dwóch niezależnych pomieszczeń. Jedno z pomieszczeń przeznaczone zostało na miejsce pracy sztabu, drugie - do prac zespołu ds. logistyki. W pierwszym pomieszczeniu został zamontowany serwer, telewizor, krzesła i stoły. Drugie pomieszczenie zaaranżowano dla czterech osób pracujących w zespole ds. logistyki, wyposażono je w komputery przenośne oraz terminale mobilne.

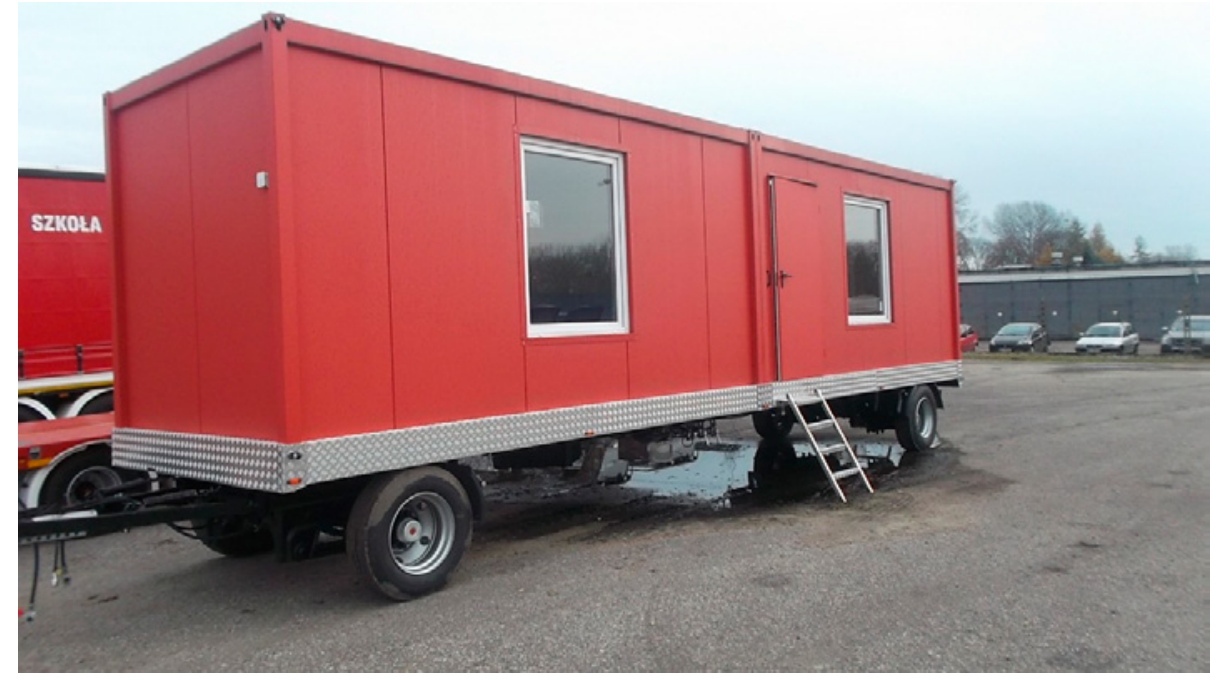

Rysunek 6. Kontener powstały w wyniku projektu Źródło: Materiały SGSP 


\section{Funkcjonalności oprogramowania}

W kolejnej części demonstracji zaprezentowano funkcjonalności narzędzia informatycznego. Szczegółowo omówiono budowę poszczególnych zakładek znajdujących się w narzędziu: mapa, baza, zasoby, formularze, dokumentacja i dane administracyjne.

W czasie omawiania zakładki „mapa” szczególną uwagę zwrócono na zdolność narzędzia do wskazywania położenia terminali, magazynów i innych miejsc kluczowych z punktu widzenia prowadzonej akcji. Została pokazana opcja śledzenia trasy danych terminali, wyznaczania im trasy do magazynów i innych oznaczonych na mapie celów.

W zakładce „baza” przedstawiono elementy, które mają ułatwić koordynację i kontrolę stanów podmiotów biorących udział w akcji i używanego przez nich sprzętu. Możliwe jest dodawanie: podmiotów, rodzajów akcji ratowniczej, etykiet, terminali, pojazdów, magazynów.

W zakładce „zasoby” umożliwiono dodawanie rezerw, można kontrolować stany zasobu, sprawdzać wyposażenie jednostek oraz generować raport ze stanami zasobów. Co istotne, wprowadzono w tym miejscu dodatkowy kanał informacyjny, za pomocą którego można wysyłać zapotrzebowanie z terminali do sztabu.

System w zakładce „formularze” umożliwia tworzenie nowych formularzy i edycję już stworzonych, daje możliwość szybkiego, automatycznego tworzenia dokumentów niezbędnych do prowadzenia akcji.

Zakładka „Dokumenty” stanowi bazę wiedzy z materiałami, które mogą wspomóc i ułatwić proces decyzyjny w czasie akcji.

Ostatnim elementem jest panel administracyjny umożliwiający między innymi kontrolę dostępu i zarządzanie hasłami.

\section{Analiza i ocena demonstracji oraz rozwiązań zastosowanych w narzędziu informatycznym}

Aby ocenić czy aplikacja komputerowa może być wykorzystana w czasie rzeczywistych akcji ratowniczych oraz $\mathrm{w}$ procesie planowania, zaproszonych gości - potencjalnych użytkowników poproszono o wypełnienie kwestionariusza. W badaniu ankietowym wzięło udział 27 osób. Wszystkie były obecne podczas całego czasu trwania demonstracji i brały udział we wszystkich jej częściach.

Respondenci zostali poproszenie o ocenę przydatności narzędzia do ich pracy zawodowej. 


\section{CZY WIDZIAŁABY PANI / WIDZIAŁBY PAN MOŻLIWOŚĆ \\ WYKORZYSTANIA SYSTEMU KOMPLEKSOWEGO \\ ZABEZPIECZENIA WIELOPODMIOTOWYCH AKCJI \\ RATOWNICZYCH W OBSZARZE SWOJEJ PRACY \\ ZAWODOWEJ?}

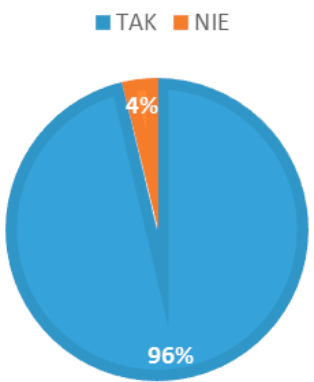

Wykres 1. Rozkład odpowiedzi na pytanie: Czy widziałaby Pani / widziałby Pan możliwość wykorzystania systemu kompleksowego zabezpieczenia wielopodmiotowych akcji ratowniczych w obszarze swojej pracy zawodowej?

Źródło: Opracowanie SGSP

Aż 96\% badanych odpowiedziało, że widziałoby możliwość wykorzystania systemu kompleksowego zabezpieczenia logistycznego wielopodmiotowych akcji ratowniczych w obszarze swojej pracy zawodowej.

Aplikacje logistyczne wykorzystywane na potrzeby ratownictwa nie są powszechnie dostępne. Istnieją jedynie programy komercyjne skierowane do przedsiębiorstw logistycznych. Ich założenia nie spełniają jednak wielu potrzeb wynikających ze specyfiki prowadzenia akcji ratowniczej.

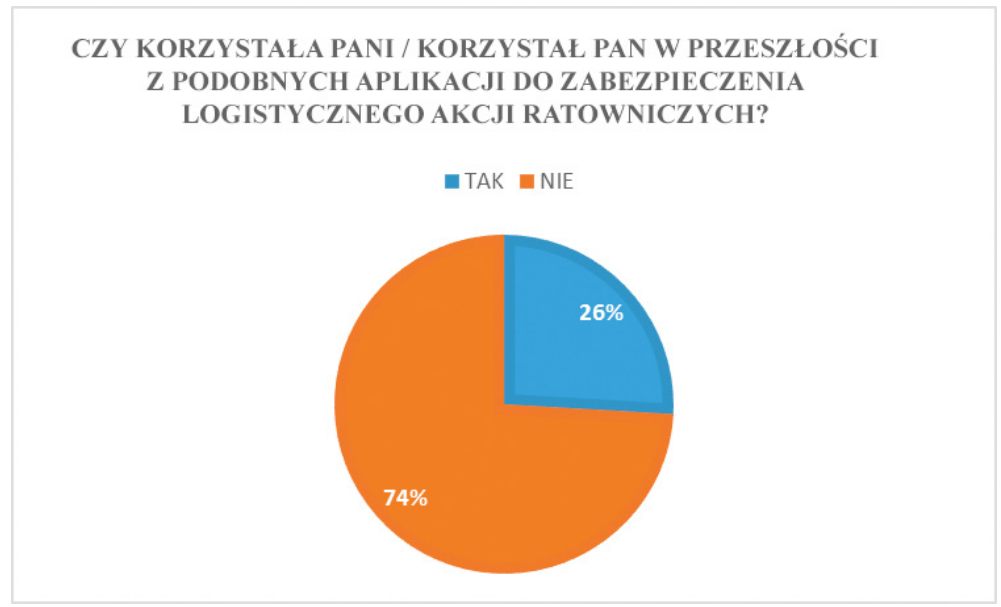

Wykres 2. Rozkład odpowiedzi na pytanie: Czy korzystała Pani / korzystał Pan w przeszłości z podobnych aplikacji do zabezpieczenia logistycznego akcji ratowniczych? Źródło: Opracowanie SGSP 
Zdecydowana większość - 74\% badanych wskazało, że wcześniej nie korzystali $\mathrm{z}$ aplikacji do zabezpieczenia logistycznego akcji ratowniczych.

Potrzeba systemu wspierającego zarządzanie logistyką w wielopodmiotowych akcjach ratowniczych oraz chęć podnoszenia własnych kwalifikacji wynika z odpowiedzi respondentów w kolejnym pytaniu.

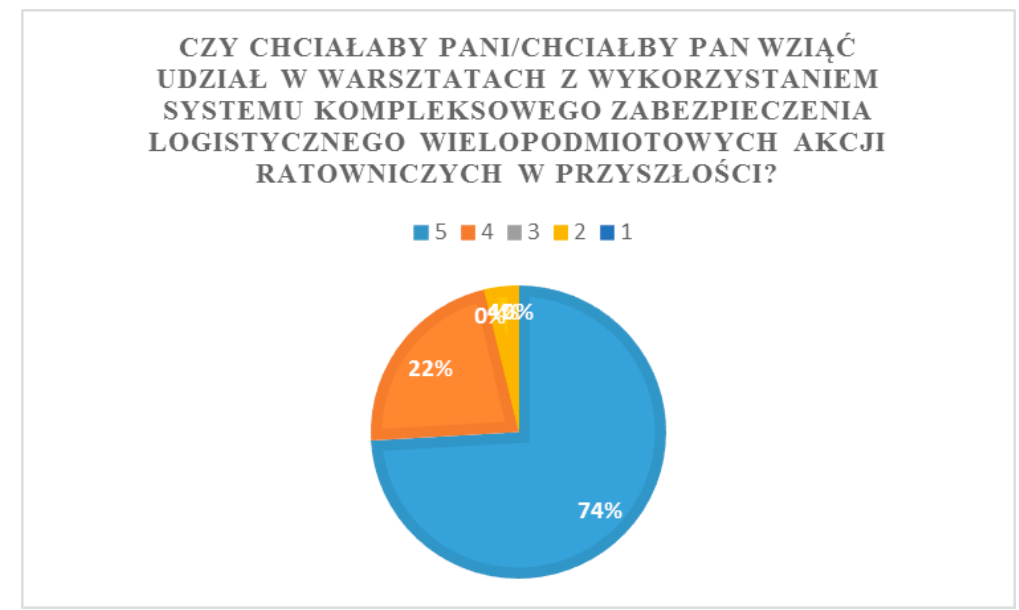

Wykres 3. Rozkład odpowiedzi na pytanie: Czy chciałaby Pani/chciałby Pan wziąć udział $\mathrm{w}$ warsztatach $\mathrm{z}$ wykorzystaniem systemu kompleksowego zabezpieczenia logistycznego wielopodmiotowych akcji ratowniczych w przyszłości?

Źródło: Opracowanie SGSP

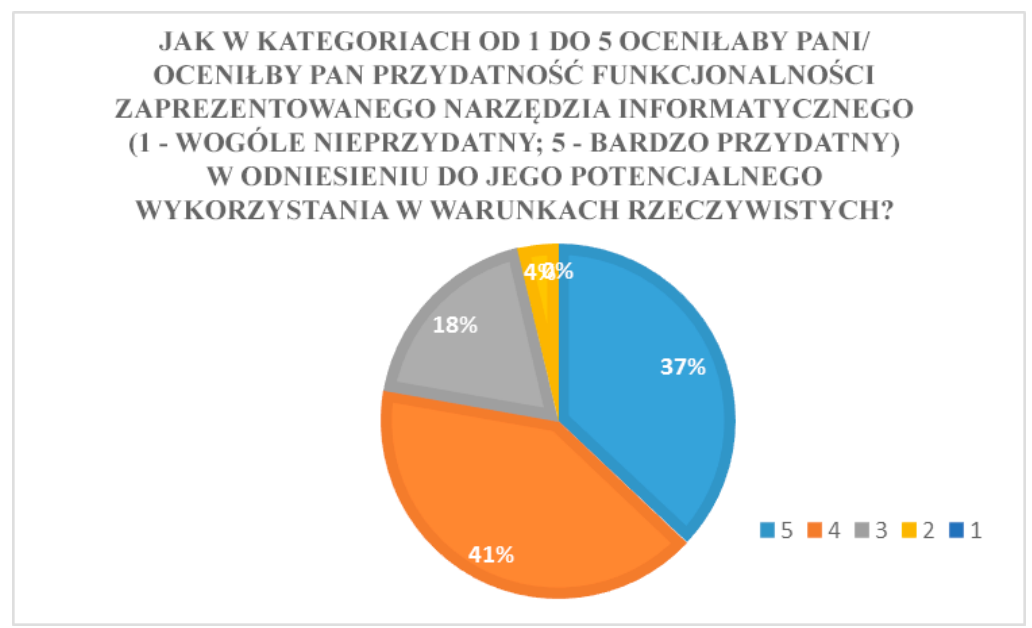

Wykres 4. Rozkład odpowiedzi na pytanie: Jak w kategoriach od 1 do 5 oceniłaby Pani oceniłby Pan przydatność funkcjonalności zaprezentowanego narzędzia informatycznego (1 - nieprzydatny; 5 - bardzo przydatny) w odniesieniu do jego potencjalnego wykorzystania w warunkach rzeczywistych?

Źródło: Opracowanie SGSP 
Deklarując w skali od 1 do 5, gdzie 1 oznacza brak skwapliwości, a 5 bardzo dużą chęć wzięcia udziału w dodatkowych warsztatach, 96\% respondentów wyraziło chęć udziału w warsztatach z oprogramowaniem do zabezpieczenia logistycznego.

Następnie poproszono o ocenę w skali od 1 do 5, gdzie 1 oznacza w ogóle nie przydatny, a 5 bardzo przydatny, przydatności funkcjonalności zaprezentowanego narzędzia.

Respondenci bardzo pozytywnie odnieśli się do przydatność funkcjonalności zaprezentowanego narzędzia informatycznego w odniesieniu do jego potencjalnego wykorzystania w warunkach rzeczywistych, $37 \%$ badanych wskazało - 5, 41\% - 4, $18 \%-3,4 \%-2$.

Kolejne pytania miały umożliwić ocenę przydatności zaprezentowanego narzędzia informatycznego w czasie działań ratowniczych. Ocenie podlegała:

- ogólna przydatność narzędzia do akcji ratowniczych;

- wsparcie logistyki i wizualizacja zasobów na mapach;

- wsparcie procesu planowania;

- wspomaganie zarządzania akcją ratowniczą;

- możliwość powiązania narzędzia z istniejącymi bazami i środkami;

- możliwość zachowania świadomości sytuacyjnej w czasie prowadzonych działań;

- możliwość planowania działań innych jednostek biorących udział w akcji ratowniczej.

Ocena poszczególnych elementów wraz z liczba odpowiadających osób została przedstawiona poniżej.

\section{CZY PANI/PANA ZDANIEM \\ ZAPREZENTOWANE NARZĘDZIE MOŻE \\ SŁUŻYĆ JAKO WSPARCIE DZIALAŃ \\ LOGISTYKI W CZASIE PRZYGOTOWANIA \\ DO AKCJI}

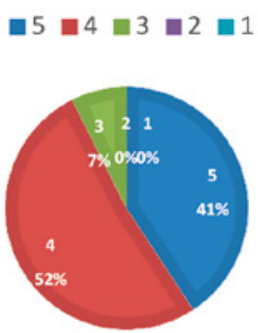

Wykres 5. Rozkład odpowiedzi na pytanie: Czy Pani/Pana zdaniem zaprezentowane narzędzie może służyć jako wsparcie działań logistyki w czasie przygotowania do akcji? Źródło: Opracowanie SGSP 


\section{CZY PANI/PANA ZDANIEM \\ ZAPREZENTOWANE NARZĘDZIE MOŻE \\ SLUŻYĆ, JAKO WSPARCIE LOGISTYKI \\ W CZASIE AKCJI WRAZ Z WIZUALIZACJĄ \\ ZASOBÓW NA MAPACH CYFROWYCH?}

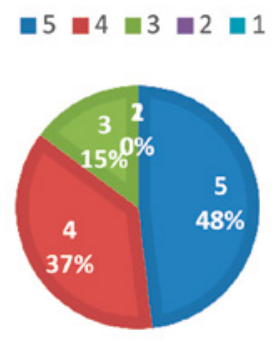

Wykres 6. Rozkład odpowiedzi na pytanie: Czy Pani/Pana zdaniem zaprezentowane narzędzie może służyć jako wsparcie logistyki w czasie akcji wraz z wizualizacją zasobów na mapach cyfrowych?

Źródło: Opracowanie SGSP

\section{CZY PANI/PANA ZDANIEM \\ ZAPREZENTOWANE NARZĘDZIE MOŻE \\ SLUŻYĆ JAKO WSPARCIE PROCESU \\ PLANOWANIA DZIALAŃ W CZASIE AKCJI?}

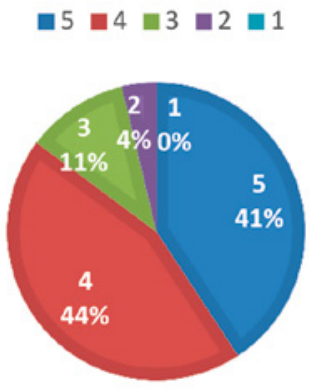

Wykres 7. Rozkład odpowiedzi na pytanie: Czy Pani/Pana zdaniem zaprezentowane narzędzie może służyć jako wsparcie procesu planowania działań w czasie akcji? Źródło: Opracowanie SGSP 


\section{CZY PANI/PANA ZDANIEM \\ ZAPREZENTOWANE NARZĘDZIE MOŻE \\ SŁUŻYĆ WSPOMAGANIU ZARZĄDZANIA \\ AKCJĄ RATOWNICZĄ?}

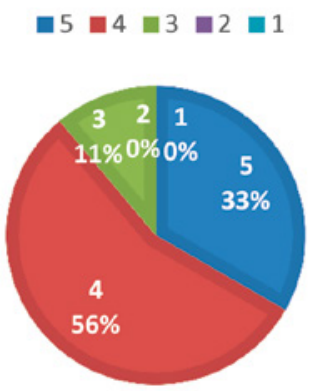

Wykres 8. Rozkład odpowiedzi na pytanie: Czy Pani/Pana zdaniem zaprezentowane narzędzie może służyć wspomaganiu zarządzania akcją ratowniczą?

Źródło: Opracowanie SGSP.

\section{CZY PANI/PANA ZDANIEM \\ ZAPREZENTOWANE NARZĘDZIE \\ DAJE MOŻLIWOŚĆ POWIĄZANIA GO \\ Z ISTNIEJĄCYMI BAZAMI SIŁ I ŚRODKÓW?}

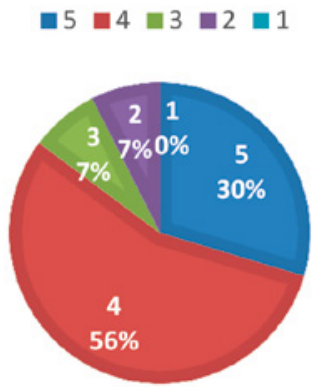

Wykres 9. Rozkład odpowiedzi na pytanie: Czy Pani/Pana zdaniem zaprezentowane narzędzie daje możliwość powiązania go z istniejącymi bazami sił i środków? Źródło: Opracowanie SGSP. 


\section{CZY PANI/PANA ZDANIEM \\ ZAPREZENTOWANE NARZEDZIE STWARZA \\ MOŻLIWOŚĆ ZAPEWNIENIA \\ (ZACHOWANIA) ŚWIADOMOŚCI \\ SYTUACYJNEJ PODCZAS PROWADZENIA \\ AKCJI RATOWNICZEJ?}

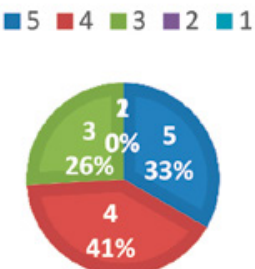

Wykres 10. Rozkład odpowiedzi na pytanie: Czy Pani/Pana zdaniem zaprezentowane narzędzie stwarza możliwość zapewnienia (zachowania) świadomości sytuacyjnej podczas prowadzenia akcji ratowniczej?

Źródło: Opracowanie SGSP.

\section{CZY PANI/PANA ZDANIEM \\ ZAPREZENTOWANE NARZĘDZIE MOŻE \\ WSPIERAĆ PROCES PLANOWANIA \\ DZIALAŃ RÓŻNYCH JEDNOSTEK PODCZAS \\ AKCJI RATOWNICZEJ?}

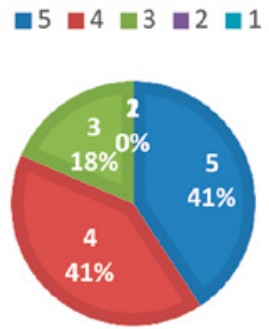

Wykres 11. Rozkład odpowiedzi na pytanie: Czy Pani/Pana zdaniem zaprezentowane narzędzie może wspierać proces planowania działań różnych jednostek podczas akcji ratowniczej?

Źródło: Opracowanie SGSP.

Analiza wykresów 5, 6, 7, 8, 9, 10, 11 pozwala bardzo pozytywnie ocenić przydatność zaprezentowanego narzędzia informatycznego w czasie działań ratowniczych. 
Po zaprezentowaniu systemu wywiązała się dyskusja. Stwierdzono wielokrotnie o przydatności narzędzia informatycznego w czasie długich akcji ratowniczych. Bardzo istotnym punktem dyskusji były wskazówki, jak przedstawione narzędzie powinno być rozwijane w przyszłości. Powtarzającym się postulatem była sugestia dotycząca wprowadzenia kompatybilności z funkcjonującymi w PSP bazami danych. Do najważniejszych komentarzy można zaliczyć:

- „Przedstawiony program dotyczący zabezpieczenia logistycznego podczas długotrwałych akcji, byłby bardzo pomocny, gdy udałoby się go zintegrować $\mathrm{z}$ działającym programem w PSP (SWD);

- przydatna będzie wspólna wymiana danych i informacji, które znajdują się w tych programach";

- „Po doświadczeniach związanych z akcją powodziową w 2010 powstało wiele rozwiązań logistycznych. Pododdziały COO i WOO posiadają już wyznaczone tymczasowe bazy logistyczne (wyznaczone miejsca noclegowe, miejsca tankowania paliw itp.) «System» można uzupełnić o posiadane już informacje oraz przewidzieć możliwość współpracy «systemu» z SWD”;

- „Uważam, że program mógłby być kompatybilny z systemem SWD, poza tym interfejs dobrze by się spełniał, gdyby podpowiadał pytania z zagadnieniami logistycznymi, na które obsługujący udzielałby odpowiedzi (np. Ile masz wody, ile potrzebujesz miejsc noclegowych itd.), w ten sposób system wymusiłby, aby nie przeoczyć jakiejś ważnej danej. Podobnie jak SWD byłby aktualizowane co jakiś określony czas".

\section{Podsumowanie}

Przedstawione w czasie demonstracji założenia teoretyczne oraz narzędzie informatyczne zostało ocenione bardzo pozytywnie. Wnioski w wyników ankiety są niezaprzeczalne - przydatność tego typu narzędzia do przyszłych działań ratowniczych jest bardzo duża. Przeprowadzona w Centrum Badań Terenowych i Szkolenia Poligonowego Szkoły Głównej Służby Pożarniczej w Nowym Dworze Mazowieckim demonstracja, mająca na celu przedstawienie przybyłym gościom efektów projektu "System kompleksowego zabezpieczenia logistycznego wielopodmiotowych akcji ratowniczych”, potwierdziła słuszność przyjętych założeń. Znaczna część osób uczestniczących w demonstracji wskazywała na celowość połączenia przedstawionego narzędzia informatycznego z systemem SWD-ST. Innym ciekawym rozwiązaniem zaproponowanym przez gości byłby interfejs, który wspierałby decydenta zadając pytania związane z zagadnieniami logistycznymi, takie jak: ile masz wody, ile potrzebujesz miejsc noclegowych itd. W ten sposób można byłoby zmniejszyć ryzyko pominięcia ważnego zasobu. 


\section{Bibliografia}

[1] Lisiecki M., Zarządzanie bezpieczeństwem publicznym, Wyd. Naukowe Łośgraf, Warszawa 2011.

[2] Nowak W., Nowak E., Podstawy logistyki w sytuacjach kryzysowych z elementami zarządzania logistycznego, Społeczna Wyższa Szkoła Przedsiębiorczości i Zarządzania, Łódź 2009.

\section{Inne źródła:}

[3] Sprawozdanie z demonstracji systemu kompleksowego zabezpieczenia logistycznego wielopodmiotowej akcji ratowniczej $\mathrm{w}$ warunkach terenowych, zawierające analizę i ocenę prawidłowości zastosowanych rozwiązań, SGSP, Warszawa 2016.

[4] sjp.pwn.pl/szukaj/logistyka.html (dostęp: 9.02.2018 r.).

[5] www.snowball-project.eu (dostęp: 9.02.2018 r.).

\section{Wykaz aktów prawnych:}

[6] Konstytucja Rzeczypospolitej Polskiej z dnia 2 kwietnia 1997 r. (Dz.U. 1997 r. nr 78, poz. 483).

[7] Rozporządzenie Ministra Spraw Wewnętrznych i Administracji z dnia 3 lipca 2017 r. w sprawie szczegółowej organizacji krajowego systemu ratowniczo-gaśniczego (Dz.U. 2017 poz. 1319). 



\section{Część IV}

INNOWACYJNE SYSTEMY GAŚNICZE W DZIALANIACH RATOWNICZO-GAŚNICZYCH 



\title{
Mobilny turbinowy system ratowiczo-gaśniczy. Podstawowe założenia systemu gaśniczego bazującego na wykorzystaniu turbiny samolotowej SO3
}

\author{
Mobile turbine fire-extinguishing system. Basic assumptions \\ of the extinguishing system based on the use of the SO3 turbine
}

\author{
Tomasz Węsierski \\ Małgorzata Majder-Łopatka \\ Wiktor Wąsik \\ Bernard Król \\ Szkoła Główna Służby Pożarniczej
}

\section{Streszczenie}

Cel: Celem publikacji jest określenie optymalnego zakresu zastosowań oraz ograniczeń mobilnego turbinowego systemu ratowniczo-gaśniczego (MTSRG) w trakcie działań ratowniczych.

Metoda badawcza: Wykonano szereg wielkoskalowych badań poligonowych, a $w$ tym pożary testowe grupy A (stosy drewna) oraz B (tace z olejem napędowym), badanie zasiegu rzutu, badania kroplistości, badanie liczby spieniania, efektywność zasilania systemu przez agregaty pompowe i inne samochody pożarnicze.

Wyniki i dyskusja: Określono zasięg maksymalny rzutu środków gaśniczych (wody oraz środków pianotwórczych), optymalny zasięg roboczy, a także wpływ warunków atmosferycznych na parametry rzutu. Określono liczbę spienienia podawanej piany, a także możliwość jej wykorzystania $w$ działaniach obronnych przed przemieszczajacym się pożarem wierzchołkowym drzewostanu. Wykazano ograniczenia wykorzystania samej technologii turbinowej do gaszenia pożarów grupy A związaną $z$ brakiem penetracji stosu. Gaszenie pożarów grupy $B$ środkiem typu AFFF wypadło pozytywnie, przy czym wykazano bardzo duży wpływ warunków atmosferycznych oraz ustawienia pojazdu na obszar skutecznego działania technologii. Wykazano skuteczność zasilania technologii na odległość z wykorzystaniem agregatów pompowych.

\section{Abstract}

Purpose: The purpose of the publication is to determine the optimal range of applications and limitations of the mobile turbine rescue and fire extinguishing system (MTSRG) during rescue operations.

Research method: A series of large-scale field tests were carried out, including Group A Fires (wood piles) test Group B Fires (diesel fuel trays), stream throw range, dropness testing, number of foaming test, effectiveness of system water delivery via pump sets and other firefighting cars. It has been shown that the use of the turbine technology itself to extinguish Group A Fires associated with the insufficient penetration of the stack. Extinguishing Group B 
Fires with an AFFF foasming agent was positive, showing a great influence of atmospheric conditions and setting the vehicle on the effective area of the technology. The effectiveness of water supply technologies at a distance with the use of pump aggregates has been demonstrated.

\section{Wprowadzenie}

Turbinowe systemy gaśnicze wykorzystujące silniki odrzutowe działają na zasadzie rozpraszania prądów gaśniczych za pomocą energii kinetycznej gazów spalinowych. Jako efekt końcowy tego działania powstaje prąd rozproszony o dużym rozpyleniu i zasięgu rzutu charakteryzujący się dużą powierzchnią odbioru ciepła oraz sorpcji na granicy faz powierzchnia kropli/powietrze. Stwarza to możliwość wykorzystania przedmiotowej technologii między innymi do:

- likwidacji zjawisk pożarowych na zasadzie odbioru ciepła ze strefy spalania oraz efektu inhibicyjnego po wprowadzeniu do wody soli gaśniczych lub proszków;

- likwidacji przestrzennej chmur substancji niebezpiecznych poprzez rozpraszanie ich objętościowym strumieniem gazów spalinowych oraz poprzez sorpcję na powierzchni kropel;

- działań chłodzących w dystansie polegających na bronieniu obiektów zagrożonych pożarem oraz oddziaływaniem strumienia cieplnego;

- dekontaminacji powierzchniowej między innymi sprzętu ruchomego.

Energia kinetyczna powstałych w trakcie spalania gazów jest odpowiedzialna za ekstremalnie duży jak dla prądów mgłowych zasięg działania technologii. Umożliwia to wykorzystanie technologii w działaniach w głębokim dystansie bez narażania ratowników na bezpośrednie działanie czynnika stwarzającego zagrożenie [1-5].

\section{Bojowe wykorzystanie turbinowych systemów gaśniczych}

Pierwsze próby wykorzystania turbin samolotowych do celów gaśniczych miały miejsce w początku lat sześćdziesiątych na terenie ZSRR. Rozwiązań takich uży to bojowo w trakcie gaszenia pożarów pól naftowych i gazowych. Turbinę samolotową pochodzącą od myśliwca MIG-15 zamontowano na podwoziu czołgowym oraz platformie samochodów ciężarowych [5]. Próby wykorzystania bojowego rozwiązań turbinowych okazały się na tyle obiecujące, że w krajach byłego bloku wschodniego podjęto kolejne badania tego typu rozwiązań konstrukcyjnych. Zbudowany w 1991 roku na terenie Węgier pojazd na podwoziu radzieckiego czołgu T34, wyposażony w dwie turbiny myśliwca MIG-21 został natychmiast wykorzystany bojowo do gaszenia szybów naftowych w Kuwejcie podpalonych w 1991 przez armię iracką. W ciągu 43 dni węgierskiej załodze pojazdu udało się skutecznie 
ugasić 9 pożarów szybów naftowych [5]. Pojazd zużywał tak ogromnie ilości wody (roboczo $30 \mathrm{~m}^{3} / \mathrm{min}$ ), iż do jego zasilania konieczne było przekopanie specjalnego kanału zasilającego z Zatoki Perskiej. Niemniej dzięki ogromniej sile ciągu oraz dużej ilości podawanej w jednostce czasu wody było możliwe zaburzenie i odcięcie dopływu materiału palnego wydobywającego się z szybu do strefy spalania.

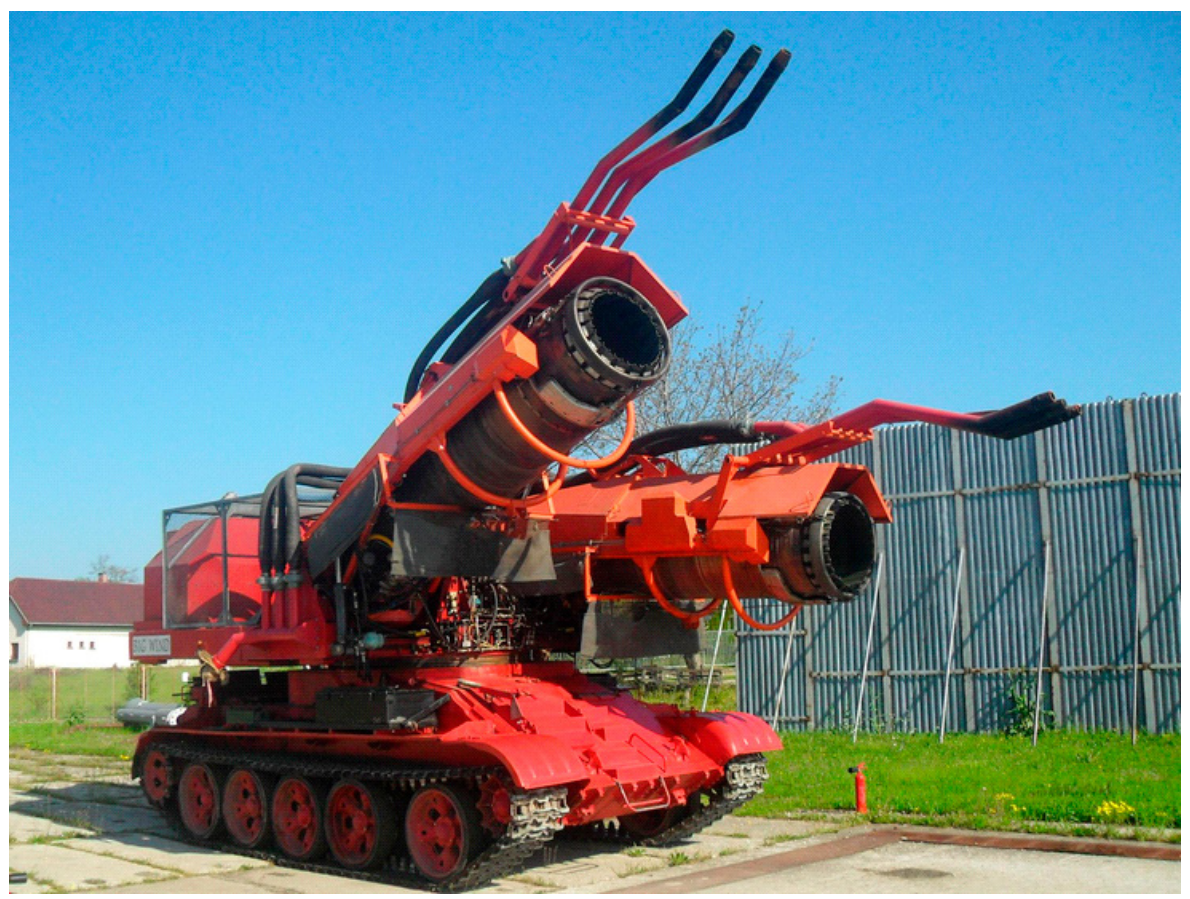

Rysunek 1. Pojazd turbinowy węgierskiej produkcji zabudowany na podwoziu czołgowym T34, wyposażony w dwie turbiny myśliwca MIG-21 [6]

Figure 1. Turbine vehicle of Hungarian production built on a T34 tank chassis, equipped with two turbines from MIG-21 fighter [6]

Innymi pojazdami wykorzystanymi bojowo w działaniach ratowniczych były rozwiązania techniczne wyprodukowane w Republice Federalnej Niemiec. Od maja 2005 roku zakładowa straż pożarna ZZSP BASF posiada na wyposażeniu pojazd typu Turbolöscher II o wydajności wodnej $8 \mathrm{~m}^{3} / \mathrm{min}$, w którym silniki odrzutowe zainstalowano na obrotowym wieńcu, umożliwiając pracę systemu w zakresie $180^{\circ}$. Pojazd posiada dwie turbiny o sile ciągu $11 \mathrm{kN}$ każda. Maksymalny zasięg podawania prądów wody przez turbinę wynosi 120-150 metrów przy kroplistości prądu wynoszącej $375 \mathrm{~mm}$ [4]. Pojazdy Turbolöscher II wykorzystano bojowo podczas pożaru gazociągu $\mathrm{z}$ etylenem oraz zbiornika $\mathrm{z}$ akrylonitrylem w Köln (17 marca 2008 r.) a także podczas pożaru hali magazynowej w Ludwigshafen ( 22 czerwca 2013 r.). Zdjęcie pojazdu podczas gaszenia pożaru w Köln oraz podczas ćwiczeń przedstawiono na rys. 2. Analiza wspomnianych zdarzeń umożliwiła wyciągnięcie następujących wniosków praktycznego wykorzystania technologii: 
- Zaletą podawanego strumienia gaśniczego wody jest stosunkowo duży zasięg, który wg danych producenta wynosi nawet $150 \mathrm{~m}$. Na podstawie zdjęć należy jednak jako zasięg praktyczny przyjąć połowę tej odległości, maksymalnie $100 \mathrm{~m}$.

- Rozproszenie strumienia wody pozwala w maksymalny sposób wykorzystać potencjał chłodzący wody. Jest to niemożliwe do osiągnięcia przy użyciu tradycyjnych działek wodno-pianowych, jedynych urządzeń podających wodę na porównywalną odległość.

- Strumień rozproszonej cieczy jest szczególnie podatny na działanie wiatru. Istnieje konieczność precyzyjnego ustawienia pojazdu, zgodnie z kierunkiem wiatru. Powoduje to znaczące ograniczenia manewrowości pojazdu na miejscu zdarzenia.

- Strumień wody powinien mieć wydajność co najmniej 2-3 tys. 1/min. Tylko wówczas technologia wykaże swą przewagę nad tradycyjnymi systemami podawania wody. Stąd też istotne jest zapewnienie sprawnego systemu zasilania $\mathrm{w}$ wodę. Nie powinno to stanowić szczególnego problemu na terenach zakładów wyposażonych w duże zbiorniki przeciwpożarowe i wewnętrzną sieć hydrantową w przypadku możliwości sprawienia zasilania na niewielkie odległości.

- Strumień wody może spowodować turbulencje unoszącego się dymu pożarowego i zadymienie obszaru objętego działaniami gaśniczymi w przypadku klasy stabilności atmosfery utrudniającej jego unoszenie i wywiewanie

- Technologia posiada ograniczony czas ciągłego działania bojowego ze względu na konieczność zasilania silnika turbinowego paliwem. Duże zużycie paliwa lotniczego (kerozyna) powoduje konieczność dotankowywania (dodatkowy osprzęt).

- Bardzo wysoki poziom hałasu technologii utrudnia jej użytkowanie w bezpośredniej bliskości pojazdu.

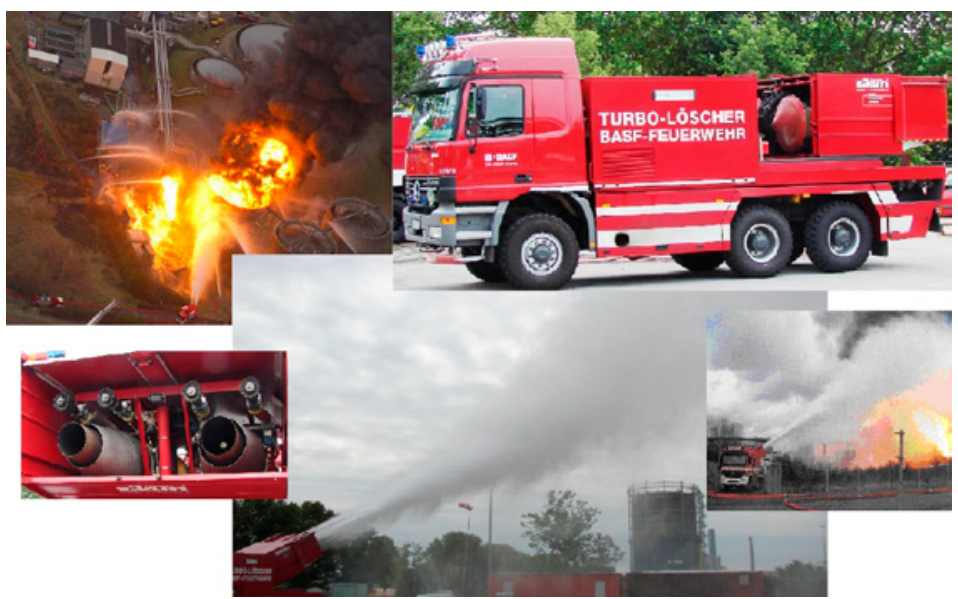

Rysunek 2. Kompilacja zdjęciowa pojazdu Turbolöscher II biorącego udział w gaszeniu pożaru zbiornika akrylonitrylu w Köln (17 marca 2008 r.) oraz podczas pokazów. Autor - kompilacja własna

Figure 2. Photo compilation of the Turbolöscher II vehicle taking part in the firefighting event of the acrylonitrile tank fire in Köln (17 March 2008) and during the demonstrations 


\section{Pierwszy turbinowy system gaśniczy bazujący na silnikach SO3}

Pierwsze próby wykorzystania silnika SO3 pochodzącego od samolotu TS-11 Iskra w formie mobilnego systemu gaśniczego podjęto w latach $80 \mathrm{XX}$ wieku w ramach współpracy Instytutu Lotnictwa i CNBOP. Zabudowano prototyp wielofunkcyjnego agregatu gaśniczego AG-84, wyposażonego w silnik turbinowo-odrzutowy SO3. Według założeń konstrukcyjnych twórców rozwiązania agregat miał spełniać trzy funkcje:

- wytwarzanie niepalnych gazów spalinowych o niskiej zawartości tlenu, obniżających szybkość procesu palenia i w konsekwencji prowadzących do likwidacji ogniska pożaru;

- likwidacja skutków awarii chemicznych poprzez proces ejekcyjnego odsysania oraz przepuszczenie par substancji chemicznych przez komory dopalacza silnika, gdzie następowało ich całkowite spalanie;

- ejekcyjne odsysanie dymów i pyłów pożarowych z miejsc awarii.

Agregat gaśniczy AG-84 został zabudowany na podwoziu samochodu terenowego Star 266. Zabudowa wykonana została na platformie obrotowej, zwiększającej operacyjne pole działania agregatu. Umożliwiło to obrót zabudowy $\pm 90^{\circ} \mathrm{w}$ stosunku do podłużnej osi pojazdu.

Schemat pojazdu i jego zabudowy przedstawiono na rysunku 3.

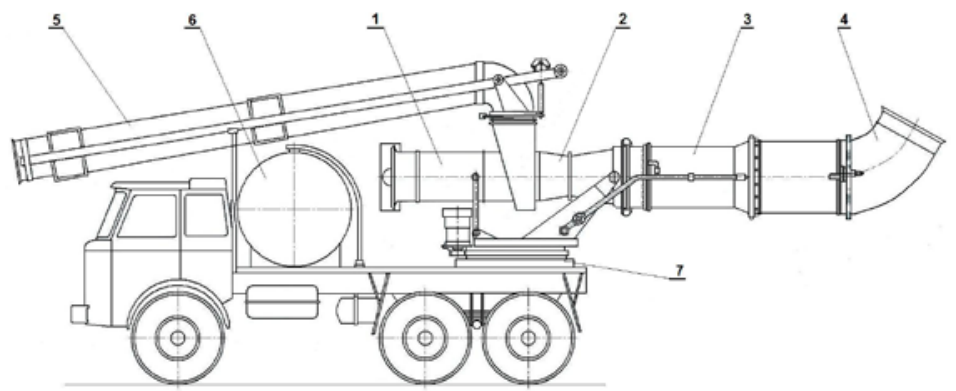

Rysunek 3. Schemat wielofunkcyjnego agregatu gaśniczego AG-84 bazującego na silniku SO3 pochodzącym z samolotu TS-11 ISKRA zabudowanego na podwoziu Star 266: 1 - silnik odrzutowy, 2 - dyfuzor z ejektorem, 3 - dopalacz, 4 - dysza wylotowa, 5 - rurociąg ssawny, 6 - zbiornik paliwa do silnika odrzutowego i dopalacza, 7 - platforma obrotowa [4]

Figure 3. Scheme of multifunctional AG-84 extinguishing unit based on SO3 engine coming from TS11 ISKRA aircraft mounted on Star 266 chassis 1 - jet engine, 2 - ejector diffuser, 3 - afterburner, 4 - discharge nozzle, 5 - suction pipe, 6 - fuel tank for jet engine and afterburner, 7 - rotating platform [4]

\subsection{Praca agregatu w funkcji gaśniczej}

Podczas procesu gaszenia silnik turbinowy pracował z włączonym dopalaczem; jednocześnie doprowadzana była woda do chłodzenia ścianek komory dopalacza oraz strumienia wylotowego gazów. Zawarty w gazach wylotowych silnika 
turbinowego tlen ulegał dalszemu procesowi dopalenia w komorze dopalacza, w efekcie czego gazy wylotowe komory dopalacza zawierały nie więcej niż $10 \% \mathrm{O}_{2}$. Woda na wyjściu z komory dopalacza powodowała obniżenie temperatury gazów wylotowych do około $350^{\circ} \mathrm{C}$. Mieszanina gazów wylotowych wraz z parą wodną była kierowana dyszą wylotową z prędkością w zakresie $70-80 \mathrm{~km} / \mathrm{h}$ na ognisko pożaru lub w przestrzeń zamkniętą objętą pożarem. Planowano wykorzystanie technologii głównie do gaszenia tuneli kablowych, w górnictwie oraz ewentualnie w elektrowni atomowej, która miała powstać w Żarnowcu. Agregat natomiast w ogóle nie nadawał się do gaszenia otwartych pożarów. Jak wykazała wykonana symulacja, wskutek mieszania się strumienia gazów wylotowych dyszy z otaczającą atmosferą następował szybki wzrostu zawartości tlenu. Skutkiem tego wykorzystanie technologii byłoby możliwe zaledwie w odległości 2-3 m.

\subsection{Praca agregatu $w$ funkcji neutralizacji gazów toksycznych}

Podczas wariantu neutralizacji gazów, podobnie jak w pierwszym wariancie, silnik turbinowy pracował z włączonym dopalaczem. Rurociąg ssawny zasysał pary substancji niebezpiecznych, po czym następowało mieszanie ich w dyfuzorze ejektora z gazami spalinowymi silnika. Następnie wprowadzał tę mieszaninę do komory dopalacza. W zależności od rodzaju substancji pary zasysanych substancji ulegały w komorze degradacji termicznej, utlenianiu lub też ulegały reakcji z parą wodną. Po procesie neutralizacji w komorze dopalacza powstałe produkty były wyrzucane przez dyszę wylotową do góry, gdzie następowało ich rozproszenie na większej wysokości.

\subsection{Praca agregatu $w$ funkcji odsysającej}

W przedstawionym wariancie silnik turbinowy pracował bez włączonego dopalacza. Gazy spalinowe silnika przechodzące z dużą prędkością przez dyfuzor i ejektor wytwarzały podciśnienie statyczne, które powodowało ejekcyjne odsysanie gazu rurociągiem ssawnym ejektora. W ten sposób planowano odsyssać pyły, dymy lub chemiczne substancje gazowe powstałe na skutek procesów pożarowych lub też niekontrolowanych uwolnień. Gazy spalinowe silnika zmieszane wraz z gazami ejekcyjnymi przechodziły przez niepracującą komorę dopalacza. Następnie poprzez dyszę wylotową były wyrzucane do otoczenia. W zależności od odsysanego czynnika do niepracującej komory dopalacza można było podawać wodę w celu zwiększenia efektywności procesu neutralizacji.

\subsection{Podstawowe parametry techniczne oraz użytkowe agregatu AG-84}

Podstawowe parametry techniczne agregatu gaśniczego AG-84 przedstawiono w tabeli 1. Jak można zauważyć, agregat zużywał duże ilości paliwa w procesie dopalania w porównaniu ze zużyciem paliwa samej turbiny. Dodatkowo wykorzystanie praktycznie jedynie gazów spalinowych w procesach gaśniczych w znaczny sposób ograniczało potencjał użycia bojowego technologii. Po zbudowaniu prototypu przeprowadzono badania wstępne agregatu gaśniczego, w zakresie sprawdzenia działania. Duże trudności wystąpiły z zapewnieniem stateczności pojazdu podczas 
Mobilny turbinowy system ratowniczo-gaśniczy. Podstawowe założenia systemu... 145

pracy, co wynikało między innymi z braku podstaw stabilizujących pojazd i wysoko zamieszczonego środka ciężkości. Z uwagi na dużą masę agregatu z osprzętem nastąpiło również przekroczenie dopuszczalnych mas i nacisków pojazdu bazowego, co wymusiłoby zastosowanie innego typu podwozia. Z tego też względu nie było możliwe zamontowanie bezpośrednio na pojeździe zbiornika wody niezbędnej do schładzania ścianek dopalacza oraz gazów spalinowych.

Tabela 1. Podstawowe parametry techniczne agregatu gaśniczego AG-84 [4] Table 1. Elementary technical parameters of extinguishing unit AG-84 [4]

\begin{tabular}{|l|c|}
\hline \multicolumn{1}{|c|}{ Parametr } & Wartość \\
\hline Pojemność zbiornika paliwa agregatu & $3 \mathrm{~m}^{3}$ \\
\hline Szczątkowa siła ciągu & $4,5 \mathrm{kN}$ \\
\hline Typ silnika odrzutowego agregatu & $\mathrm{SO} 3$ „Kaszub” \\
\hline Wydatek powietrza turbiny & $14,2-15,2 \mathrm{~kg} / \mathrm{s}$ \\
\hline Temperatura gazów wylotowych za turbiną & $738-753^{\circ} \mathrm{C}$ \\
\hline Zużycie paliwa turbiny & $500-662 \mathrm{~kg} / \mathrm{h}$ \\
\hline Wydatek powietrza zasysanego przez ejektor & $10 \mathrm{~kg} / \mathrm{s}$ \\
\hline Prędkość gazów na wylocie ejektora & $50 \mathrm{~m} / \mathrm{s}$ \\
\hline Zakres sterowania rurociągiem ejektora w płaszczyźnie pionowej & $+/-15^{\circ}$ \\
\hline Średnica rurociągu ejektora & $0,5 \mathrm{~m}$ \\
\hline Zużycie paliwa dopalacza agregatu & $1300-1920 \mathrm{~kg} / \mathrm{h}$ \\
\hline Wydatek wodny przeznaczony na chłodzenie komory dopalacza & $0,7 \mathrm{~kg} / \mathrm{s}(42 \mathrm{dm} 3 / \mathrm{min})$ \\
\hline $\begin{array}{l}\text { Wydatek wodny chłodzenia strumienia gazów wylotowych } \\
\text { dopalacza }\end{array}$ & $4,5 \mathrm{~kg} / \mathrm{h}$ \\
\hline Zakres sterowania dyszą agregatu & $360^{\circ}$ \\
\hline Średnica dyszy & $0,8 \mathrm{~m}$ \\
\hline Temperatura gazów wylotowych w wersji gaśniczej agregatu & $350^{\circ} \mathrm{C}$ \\
\hline Prędkość wylotowa gazów w wersji gaśniczej agregatu & $80 \mathrm{~m} / \mathrm{s}$ \\
\hline Stężenie procentowe tlenu na wylocie dyszy w wersji gaśniczej & $\mathrm{C}<10 \%$ \\
\hline Prędkość wylotowa gazów w wersji neutralizacyjnej & $135 \mathrm{~m} / \mathrm{s}$ \\
\hline
\end{tabular}

\section{Mobilny turbinowy system ratowniczo-gaśniczy (MTSRG)}

Mobilny turbinowy system ratowniczo-gaśniczy jest efektem realizacji projektu DOB-BIO6/06/113/2014 współfinansowanego przez NCBR. Tworzenie technologii realizowane jest w konsorcjum w składzie:

- Szkoła Główna Służby Pożarniczej (SGSP) - lider projektu;

- Centrum Naukowo-Badawcze Ochrony Przeciwpożarowej - Państwowy Instytut Badawczy (CNBOP-PIB) - konsorcjant naukowy; 
- Wojskowy Instytut Chemii i Radiometrii (WIChiR) - konsorcjant naukowy,

- JAS Technologie - konsorcjant przemysłowy.

Zgodnie z życzeniem gestora efektem projektu ma być pojazd klasy uterenowionej o wydajności wodnej co najmniej $6 \mathrm{~m}^{3} / \mathrm{min}$, którego zasięg prądów gaśniczych wytwarzanych poprzez rozproszenie strumienia wody w strumieniu gazów spalinowych turbiny ma wynosić co najmniej $90 \mathrm{~m}$.

Celem głównym projektu było opracowanie i wykonanie demonstratora technologii turbinowego systemu gaśniczego, którego zadaniem będzie:

- wspieranie akcji gaszenia pożarów dużych instalacji technologicznych, magazynowych oraz działań w czasie pożarów lasów na dużej przestrzeni;

- zabezpieczanie infrastruktury krytycznej państwa polskiego;

- dekontaminacja masowa (rozumiana przez dekontaminację przestrzeni, obiektów, a nie osób);

- ograniczenie propagacji substancji niebezpiecznych i przestrzenna likwidacja skażeń.

\subsection{Od założeń wstępnych do wersji końcowej demonstratora technologii MTSRG}

Wstępne założenia funkcjonalne demonstratora zostały opracowane przy współudziale użytkownika końcowego, którym jest Komenda Wojewódzka PSP w Gorzowie Wielkopolskim. Ustalenia dotyczące ogólnych parametrów technicznych i funkcjonalnych pojazdu stanowiącego podstawę „Mobilnego turbinowego systemu ratowniczo-gaśniczego" podjęto na spotkaniu roboczym Kierowników Zespołów Badawczych, które odbyło się na terenie SGSP 27 stycznia 2016 roku, oraz na spotkaniu z przedstawicielami gestora, które odbyło się 25 lutego 2017 roku w Gorzowie Wielkopolskim.

Po wielu konsultacjach konstrukcyjno-inżynieryjnych oraz po zapoznaniu się z potrzebami użytkownika końcowego ustalono, co następujące:

- do demonstratora zostanie zastosowane podwozie spełniające wymagania pożarnicze klasy średniej kategorii uterenowionej z kabiną w układzie $1+2$;

- planowane jest sterowanie oprzyrządowaniem z kabiny oraz sterowanie zewnętrzne oparte na instalacjach przewodowych;

- na pojeździe zostanie zamontowana autopompa o wielkości A 60/8 z kolektorem tłocznym i ssącym;

- na pojeździe zostaną zamontowane turbina/turbiny w oparciu o silnik odrzutowy SO3 oraz dwie dysze o wydajności co najmniej $3 \mathrm{~m}^{3} / \mathrm{min}$ umiejscowione odgórnie i o ciśnieniu zasilania 6-8 bar; układ turbiny i dysz zasilających zamontowany zostanie na konstrukcji obrotowej, zasilany z systemu hydraulicznego do silnika pojazdu poprzez przystawkę odbioru mocy; układ platformy roboczej umożliwi podawanie strumieni gaśniczych pod różnymi kątami nachylenia względem podłoża; 
- zasilanie w wodę realizowane będzie przez zassanie wody z zewnętrznego zbiornika oraz pobór wody z sieci wodociągowej; system umożliwi bezpośrednie zasilanie głowic poprzez pojazdy ratowniczo-gaśnicze oraz układy pompowe $z$ pominięciem pompy zamontowanej na pojeździe demonstratora;

- głównym źródłem zasilania demonstratora będą pojazdy ratowniczo-gaśnicze i zestawy pompowe jednostek ochrony przeciwpożarowej;

- planowane jest umiejscowienie w konstrukcji pojazdu skrytek z mocowaniem na sprzęt pożarniczy;

- na pojeździe zostanie zamontowany zbiornik na paliwo lotnicze o pojemności $1 \mathrm{~m}^{3}$;

- nie planuje się montażu na pojeździe zbiornika na wodę, środków gaśniczych oraz dekontaminacyjnych;

- w pojeździe zostaną zamontowane podpory stabilizujące;

- podawanie środków neutralizacyjnych oraz środków gaśniczych w dużej ilości będzie możliwe dzięki zastosowaniu rozkładanych zbiorników zewnętrznych i dozowników umożliwiających podanie właściwego stężenia z koncentratu;

- system uruchamiania silnika turbinowego powinien być realizowany poprzez przystawkę mocy silnika spalinowego samochodu;

- podawanie prądów proszku musi następować przez równoległy wyrzut proszku do strumienia gazów spalinowych i równoległy do wyrzutu wody. Usytuowanie głowicy wyrzutowej proszku powinno znajdować się pomiędzy głowicami wyrzutowymi wody.

17 maja 2016 r. na lądowisku przed hangarem Fundacji Biało-Czerwone Skrzydła w Świdniku przeprowadzono testy uruchomienia pojedynczej wyremontowanej turbiny $\mathrm{SO} 3$. W teście wstępnym uruchomienia brał również udział zastęp JRG Świdnik dysponujący samochodem GBA. Jego zadaniem było podanie prądu zwartego wody w odpowiednim momencie i pod odpowiednim katem równolegle do strumienia gazów spalinowych turbiny. Testy uruchomienia przebiegły pomyślnie. Na podstawie obserwacji rozproszenia oraz zasięgu podawanego prądu gaśniczego (o intensywności $500 \mathrm{dm}^{3} / \mathrm{min}$ ) oszacowano, że ilość gazów wylotowych turbiny powinna w zupełności wystarczyć do osiągnięcia przez demonstrator systemu zakładanych parametrów, mimo iż nie osiągnięto maksymalnych obrotów silnika.

Na spotkaniu roboczym 19 października 2016 r. ustalono, co następujące:

- ze względu na bardzo wysoki koszt oraz niemożliwość prostego i szybkiego pozyskania elementu rozruchowego silnika SO3 o wydatku prądowym rzędu 700 A zdecydowano się na układ akumulatorów, który będzie spełniać warunki prawidłowego uruchomienia silnika; planowany wcześniej profesjonalny rozrusznik turbin samolotowych jest trudno dostępny, gdyż przy żądanym przez nas wydatku prądowym traktowany jest jako technologia wojskowa i wymaga koncesji na zakup; powyższe utrudnia, a wręcz uniemożliwia proces budowy demonstratora w planowanym terminie; 
- ustalano formę i zakres mocowania osprzętu wokół silnika turbinowego SO3, stwierdzając, że zamiast mocowania dwóch głowic o wydajności wodnej minimum $3000 \mathrm{dm}^{3} / \mathrm{min}$ każda (ciśnienie zasilania 8 bar) należy zamocować na platformie roboczej bezpośrednio wzdłuż turbiny jedno działko o wydajności min. $6000 \mathrm{dm}^{3} / \mathrm{min}$; rozwiązanie powinno spełniać pozostałe warunki opisane $\mathrm{w}$ trakcie procesu badawczego takie jak:

- przewody zasilania działka powinny umożliwiać obrót platformy w całym jej zakresie;

- działko konstrukcyjnie powinno odpowiadać prądownicom typu Turbo Jet stanowiącym zakończenie działek gaśniczych;

- działko powinno wprowadzać strumień wody lub wodnych roztworów bezpośrednio do gazów wytwarzanych przez turbinę;

- wytwarzany przez działko strumień powinien mieć formę zwartą lub lekko rozproszoną;

- działko powinno być odporne na korozyjne działanie wody i wodnych roztworów stosowanych w systemie;

- powinno się wyposażyć działko w zawór odcinający, którego praca będzie sterowana z miejsca obsługi demonstratora;

- działko powinno być wytrzymałe na ciśnienie wody wynoszące min. 16 bar;

- działko powinny przemieszczać się wraz z turbiną podczas zmiany kąta pionowego i poziomego platformy roboczej;

- przy sterowaniu pracą platformy wzajemne ustawienie turbiny i działka nie powinno się zmieniać;

- działko powinno mieć zapewnioną możliwość wprowadzenia strumienia wody do gazu roboczego w różnych odległościach od wylotu z turbiny. Powinno zostać to zrealizowane przez zmiany kąta pochylenia pionowego głowicy działka;

- zmiana kąta podawania wody z głowicy działka powinna być realizowana ze stanowiska obsługi demonstratora;

- preferowane jest, aby sterowanie działkiem było realizowane z wykorzystaniem napędu elektrycznego.

Proponowane zmiany z założenia nie umniejszały parametrów pracy budowanego demonstratora, a pozwoliłyby na lepsze i łatwiejsze umocowanie na konstrukcji silnika SO3 działka. Spowodowałoby to bardziej zbliżony do centralnego wyrzut środka oraz dużo łatwiejszą operatywność systemu.

W dniach 20-21.10.2016 w siedzibie jednostek PSP w Nowej Soli, Zielonej Górze i Gorzowie Wielkopolskim w trakcie spotkań roboczych dokonano oceny stanu możliwości budowy pojazdu w celu przygotowania zabudowy do podawania proszku gaśniczego, stwierdzając:

- system zasilania proszkiem gaśniczym ma umożliwiać wprowadzenie strumienia proszku do gazów wytwarzanych przez turbinę; 
- system zasilania proszkiem będzie działać niezależnie od układu wodnego i będzie posiadać możliwość równoległego podawania proszku i wody lub wodnych roztworów;

- system proszkowy demonstratora będzie opierać się na zewnętrznym zasilaniu wykorzystywanym przez tradycyjne samochody proszkowe lub samochody gaśnicze posiadające moduły proszkowe stosowane w jednostkach ochrony przeciwpożarowej między innymi znajdujące się na terenie woj. lubuskiego;

- przewód zasilający - proszkowy będący pierwotnie przewodem szybkiego natarcia powinien mieć średnicę $32 \mathrm{~mm} / 1$ i 1/4 cala i być zakończony nasadą STORZ 52/DN 52. Zawór odcinający kulowy ma być zamocowany na podwoziu demonstratora w bezpośrednim sąsiedztwie nasady STORZ 52 i otwierany ręcznie. Zakończenie wylotu na demonstratorze powinna stanowić prosta rura o średnicy DN 32;

- zbadano również zasilanie działka proszkowego na samochodzie GCPr 3000. Średnica przewodu doprowadzającego proszek wynosi $70 \mathrm{~mm}$ i pozwala na osiągnięcie wydajności około $30 \mathrm{~kg} / \mathrm{s}$; na podstawie danych literaturowych przeanalizowano potrzebę zamontowania przewodu proszkowego mogącego podać ww. ilość proszku w jednostce czasu; przeprowadzona analiza potrzeb wykazała, iż takie rozwiązanie nie jest konieczne; ostateczna decyzja zostanie podjęta na etapie walidacji systemu, przy czym na czas ćwiczeń poligonowych zamontowano pyszczki o średnicy 1 cala.

Po konsultacjach merytorycznych i ustaleniu z gestorem punkt dotyczący sterowania oprzyrządowaniem uległ zmianie i zamiast sterowania przewodowego zastosowano sterowanie zdalne z zastrzeżeniem działania systemu na odległość wynoszącą co najmniej 100 metrów. Przyczyną zmiany okazały się przewidywane trudności techniczne związane z przeciąganiem kabla (ze względu na długość i ciężar) przez obsługę demonstratora, powstanie dodatkowej przeszkody, na którą trzeba uważać podczas działań oraz zajmowanie znacznej ilości miejsca w skrytce. Wyżej wymieniona zmiana spowodowała również możliwość zdalnego sterowania systemem poza obszarem występowania najwyższego poziomu hałasu.

W dniu 16.03.2017 r. w trakcie spotkania roboczego po dokonaniu oceny stanu realizacji zabudowy pojazdu stwierdzono, że występują możliwości uzupełniania wyżej wymienionej zabudowy w następujące elementy w kolejnym etapie realizacji projektu:

- montaż wyciągarki elektrycznej o maks. uciągu 8 ton z przodu pojazdu;

- montaż osłon lamp w kabinie - światła drogowe, kierunkowskazy;

- wykonania oświetlenia ostrzegawczego na podporach hydraulicznych stabilizacyjnych w kolorze żółtego światła;

- zakup podkładów z uchwytami pod podpory hydrauliczne zabezpieczających przed „miękkim” podłożem;

- montaż dodatkowych lamp koloru niebieskiego pod zabudową silnika turbinowego z tyłu pojazdu - nad zderzakiem; 
- montaż uchwytów na sprzęt w skrytkach wykonanej zabudowy do mocowania przełączników, węży itp;

- montaż amperomierza do odczytu przed rozruchem silnika SO3 na tablicy rozdzielczej;

- umocowanie drabinki do wejścia na podest turbiny;

- wykonanie montażu obramowania dachu i przebudowanie go na podest roboczy zabudowy z wykonaniem uchwytów na węże ssawne;

- montaż zbiornika na środek pianotwórczy o pojemności $1 \mathrm{~m}^{3} \mathrm{wraz}$ z dozownikiem ręcznym i przebudową układu wodno-pianowego.

\subsection{Badania poligonowe demonstratora technologii MTSRG}

W dniach 24-28 kwietnia 2017 r. nastąpiła weryfikacja systemu wykonana $\mathrm{w}$ ramach testów poligonowych przeprowadzonych na poligonie w Wędrzynie 24-28 kwietnia 2017 r. w symulowanych warunkach rzeczywistych. Badania zasięgu rzutu strumienia gaśniczego wykazały, iż strumień jest bardzo podatny na warunki pogodowe. Przy wietrze przeciwnym do kierunku rzutu strumienia i wynoszącym zaledwie 3-5 m/s zaobserwowano bardzo znaczący spadek zasięgu rzutu. W takich warunkach nie uzyskiwano odległości większej niż 60 metrów. Przy małej prędkości wiatru lub też pogodzie bezwietrznej osiągano zakładany poziom zasięgu (wg założeń projektowych 90 metrów). Jego maksymalna wartość wynosiła 95-105 metrów, przy czym preferowana skuteczna odległość robocza to około 50-60 metrów.

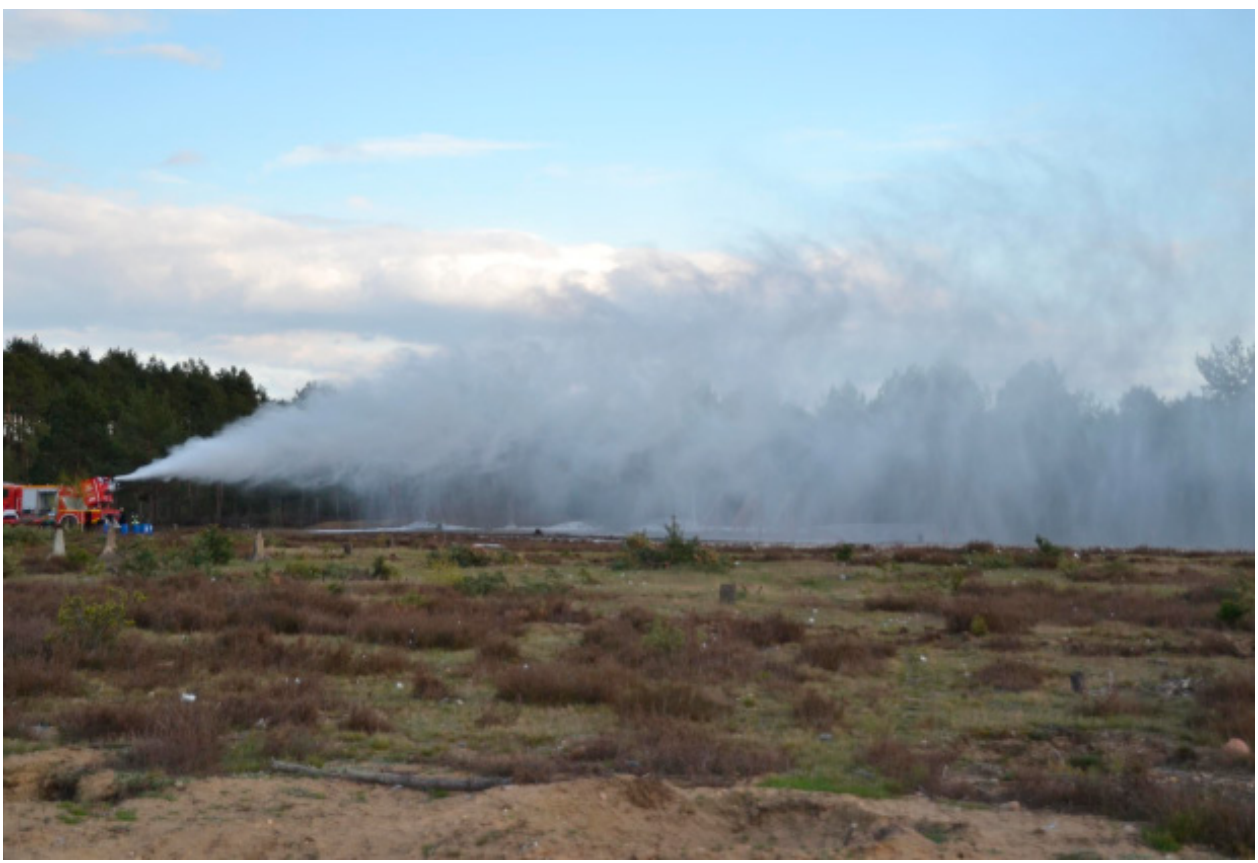

Rysunek 4. Prąd wody działka rozpraszany przez gazy wylotowe turbiny SO3. Fot. Bernard Król Figure 4. Water stream from dispersed by exhaust turbine SO3 gases. Phot. Bernard Król 
Wartość jego była najwyższa dla położenia turbiny wynoszącego $0^{\circ}$. Przy podniesieniu turbiny pod kątem $15^{\circ}$ oraz $30^{\circ}$ obserwowano nieco mniejszy zasięg rzutu. Zasięg rzutu piany był bardzo zbliżony. Ze środka gaśniczego typu S o nazwie Protektol SAT-10 przy jego standardowym stężeniu roboczym wynoszącym $3 \%$ otrzymywano pianę ciężką o liczbie spienienia $L S=5$. Jest to $t z w$. piana mokra posiadająca dobre właściwości gaśnicze i chłodzące. Przykładowe zdjęcia obrazujące podawanie prądów gaśniczych wody i piany przedstawiono odpowiednio na rys. $4-5$.

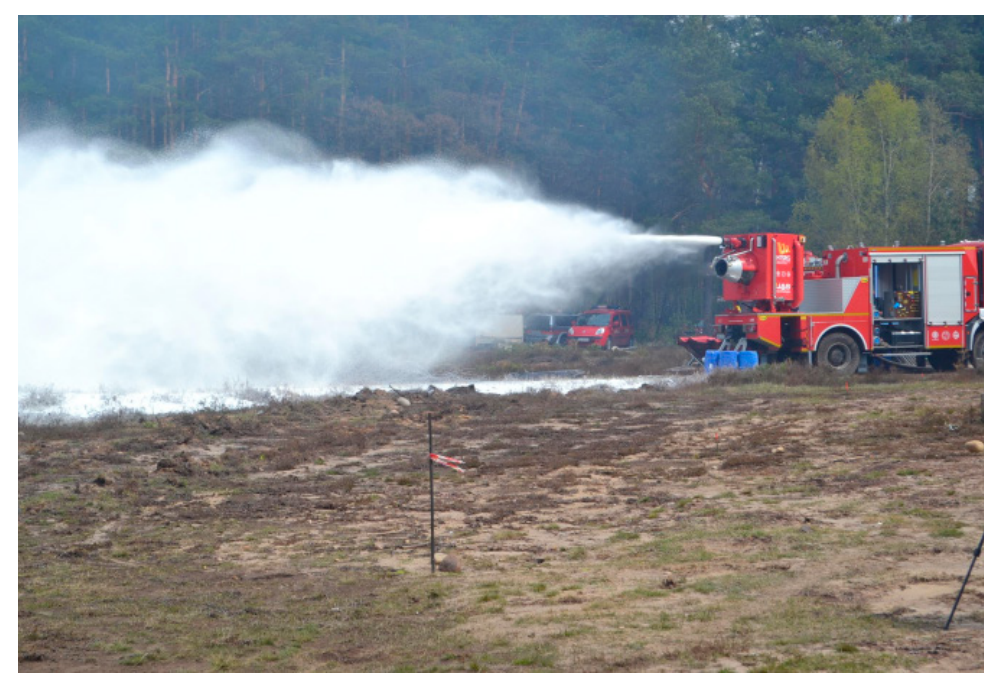

Rysunek 5. Podawanie prądu piany przez turbinę. Osiągnięto liczbę spienienia LS=5 ze środka pianotwórczego Protektol SAT-10 przy stężeniu roboczym c=3\%. Zdjęcie własne autorów

Figure 5. Supply offoam by a turbine. The number of foaming $L S=5$ from the Protektol SAT-10 foaming agent was reached with the working concentration $c=3 \%$

Powodzeniem zakończyło się zasilanie demonstratora z samochodu GCBA ze zbiornikiem o pojemności $5 \mathrm{~m}^{3}$ posiadającym pompę o wydajności $6000 \mathrm{dm}^{3} /$ min (rys. 6). Wartość taką osiągała pompa Zieglera FPM 10-6000 przy wartości ciśnienia $\mathrm{p}=10$ bar. Zasilanie demonstratora poprzez agregat pompowy Mo 80/8 Halle (ujęcie wody prosto z jeziora), analogiczny agregat podtrzymujący ciśnienie i zbiornik pośredni o pojemności $50 \mathrm{~m}^{3}$ również dało zadawalające rezultaty. Sumaryczna odległość zasilania demonstratora systemu przez agregat pompowy wynosiła 700 metrów przy całkowitym wzniesieniu terenu wynoszącym około 12,5 metra. Agregat podtrzymujący ciśnienie znajdował się w odległości 300 metrów od agregatu zasilającego. Zasilanie demonstratora przez cztery smoki ssawne pływające (rys. 7) nie wykazało ograniczenia przepływu i zmniejszenia ilości podawanej wody w zakresie badanym (do $6000 \mathrm{dm}^{3} / \mathrm{min}$ ). Wynik ten jest bardzo ważny w aspekcie możliwości samodzielnego wykonania zasilania demonstratora w warunkach płytkiego i zamulonego zbiornika wodnego. 


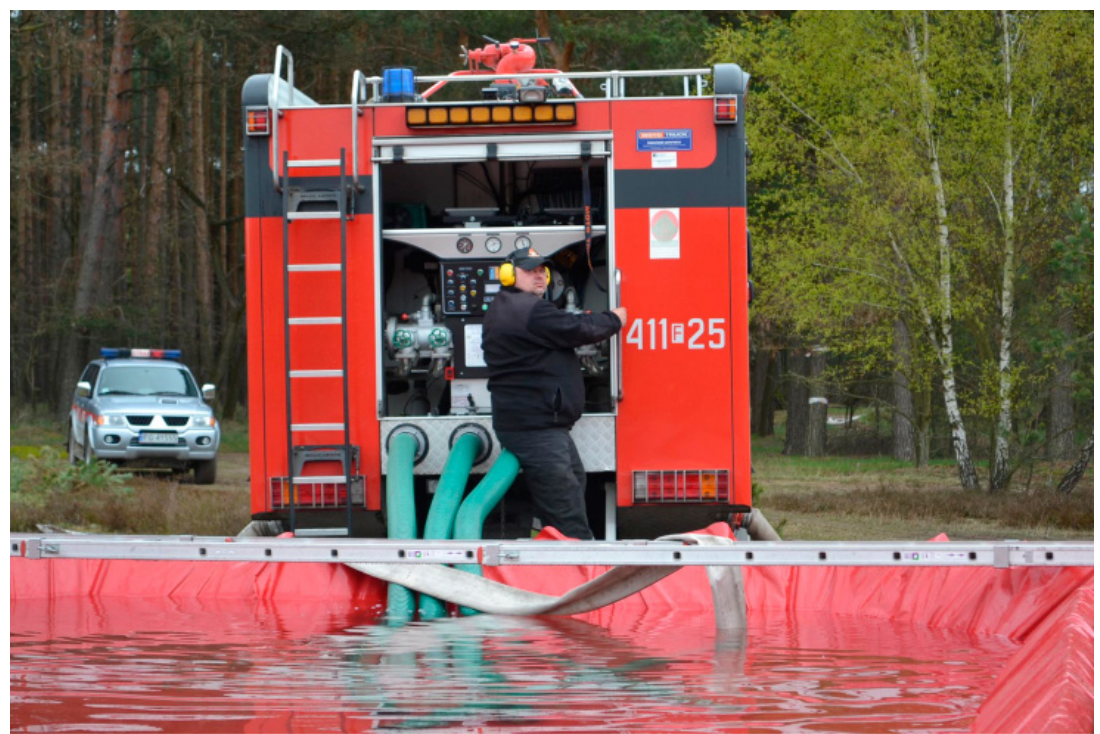

Rysunek 6. Zasilanie pośrednie poprzez GCBA ze zbiornikiem o pojemności $5 \mathrm{~m}^{3}$ posiadającym pompę o wydajności $6000 \mathrm{dm}^{3} / \mathrm{min}$ (pompa Zieglera FPM 10-6000). Zdjęcie własne autorów Figure 6. Indirect water supply through GCBA with a $5 \mathrm{~m}^{3}$ capacity tank having a pump with a yield of $6000 \mathrm{dm}^{3} / \mathrm{min}$ (Ziegler FPN 10-6000 pump)

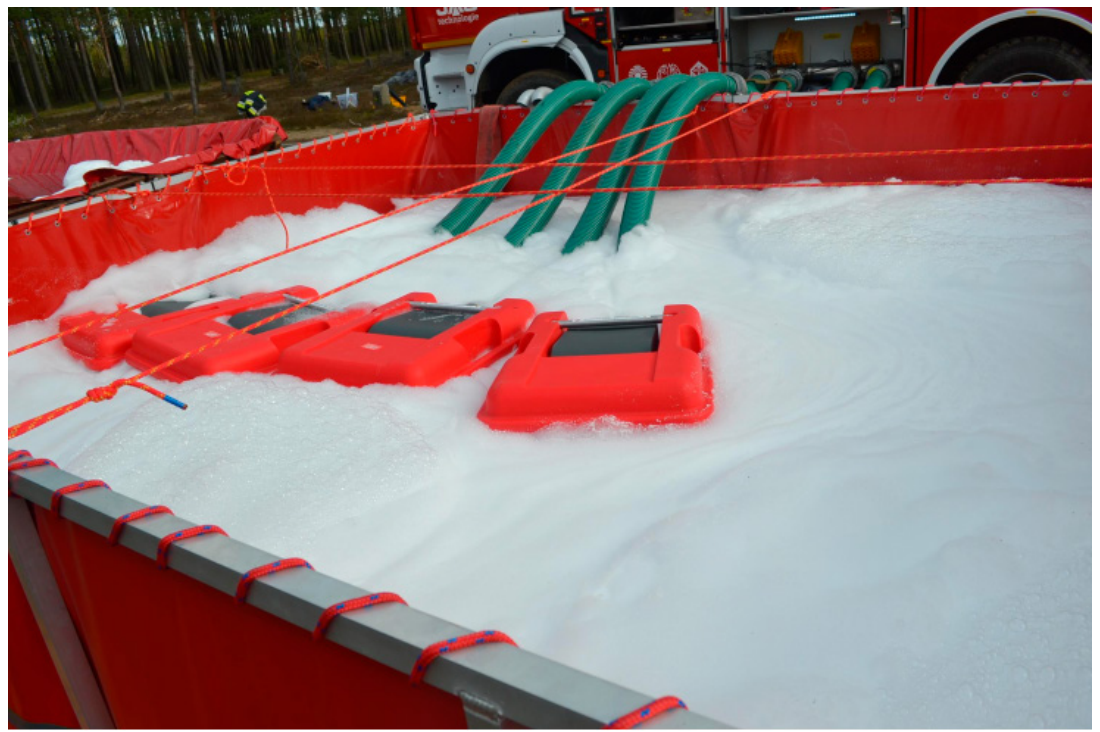

Rysunek 7. Zasilanie demonstratora realizowane poprzez 4 smoki ssawne pływające. Zdjęcie własne autorów

Figure 7. Demonstrator water supply by 4 swimming suction

Współpraca samochodu proszkowego GCPR3000 z demonstratorem wypadła bardzo pomyślnie. Efektywny zasięg chmury proszku wyniósł przy kącie położenia 
turbiny wynoszącym $15^{\circ}$ ponad 100 metrów. Część chmury proszku uniosła się na dystans ponad 250 metrów. Zasilanie demonstratora odbyło się poprzez dwie nasady szybkiego natarcia. Szacowana szybkość podawania proszku przez calowe rury wynosiła sumarycznie około 10-12 kg proszku gaśniczego ABC w ciągu sekundy.

Sterowanie działka względem turbiny odbywa się za pomocą pilotów. Daje się osiągnąć w pełni zakładane projektowo kąty oraz odległości podawania prądu gaśniczego w strumień gazów wylotowych turbiny. Turbinę z powodzeniem da się podnieść do kąta wynoszącego $30^{\circ}$, a więc do wartości teoretycznie odpowiadającej największemu rzutowi strumienia. O ile jednak takie założenie jest słuszne dla działek i prądownic przy prądzie zwartym, to w przypadku turbinowego systemu ratowniczego okazuje się, iż największy zasięg otrzymuje się dla położenia poziomego względem gruntu. Takie położenie również gwarantuje najmniejszą tendencję do zaburzania ruchu kropel cieczy przez prądy powietrzne. Jak wspomniano wcześniej, nawet niewielka prędkość wiatru przeciwnego do kierunku wyrzutu gazów wylotowych turbiny powoduje drastyczne zmniejszenie zasięgu demonstratora. Jego wpływ pokazano na rys. 8 przedstawiającym test gaszenia pożarów grupy B 3-procentowym roztworem środka pianotwórczego typu AFFF o nazwie Towalex AFFF 3\%. Ugaszenie nastąpiło do 55 metra mimo znacznie dalszego zasięgu rzutu prądu gaśniczego piany. Na dalszym dystansie piana została zniesiona przez wiatr.

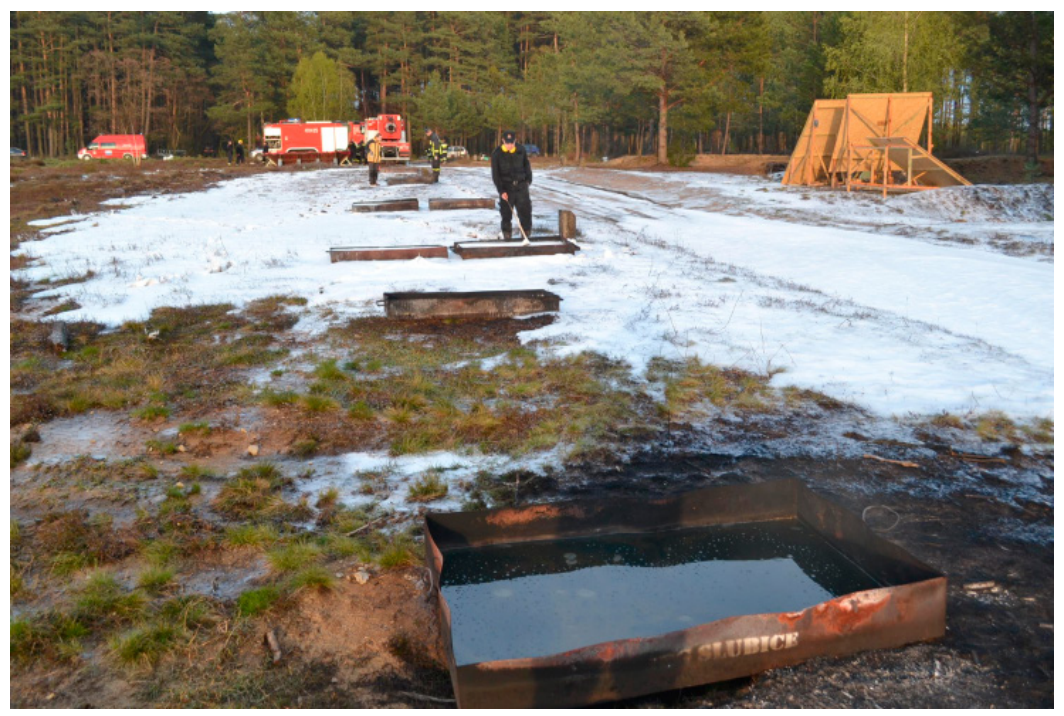

Rysunek 8. Efekt wpływu wiatru na gaszenie tac. Tace do 55 metra zostały ugaszone. Powyżej tej odległości wiatr powodował odchylenie prądu gaśniczego i ominięcie tac. Test gaśniczy pożarów grupy $\mathrm{B}$ z wykorzystaniem 3-procentowego roztworu środka pianotwórczego typu AFFF o nazwie Towalex AFFF 3\%. Zdjęcie własne autorów

Figure 8. The effect of the wind on the extinguishing of trays with diesel oil. Trays up to 55 meters have been extinguished. Above this distance, the wind caused a deviation of the extinguishing stream and omitted the trays. Fire extinguishing test of Group B Fires using a 3\% AFFF foam agent solution (Towalex AFFF 3\%) 
Testy gaśnicze grupy A przeprowadzono dla stosu drewna o wymiarze $3,6 \times 3,6$ metra składającego się z 26 warstw. Stosy rozpalono mieszaniną oleju napędowego i benzyny i pozwolono im płonąć swobodnie przez około 6 minut. Drewno użyte w badaniach stanowiły łaty budowlane o wymiarze $4 \times 6 \mathrm{~cm}$ i wilgotności około 15\%. Łącznie każdy ze stosów zawierał 7,5 $\mathrm{m}^{3}$ drewna. Badania wykazały ograniczoną możliwość penetracji systemu przez gęsto ułożone łaty. Wyraźny efekt gaśniczy był obserwowany do głębokości stosu wynoszącej około 2 metrów. Skuteczności gaśniczej nie polepszyło zastosowanie piany. Przykładowe zdjęcia testów pożarów grupy A przedstawiono na rys. 9-10. Przyczyną takiego stanu rzeczy był brak możliwości głębszej penetracji dla systemu znajdującego się $\mathrm{w}$ pozycji stacjonarnej. Krople powstające w wyniku rozbicia wody przez strumień gazów wylotowych turbiny były także zbyt małe, aby takową penetrację zapewnić. Aby skuteczność systemu była odpowiednia, krople musiałyby być większe. Jednakże zastosowanie wysokowydajnego działka zamontowanego na demonstratorze systemu, którego praktycznie zmierzony zasięg maksymalny wynosił około 70 metrów, pozwoliłoby na podanie prądu o odpowiednio większych kroplach i zdecydowanie większych możliwościach zwilżających bez udziału samej turbiny.

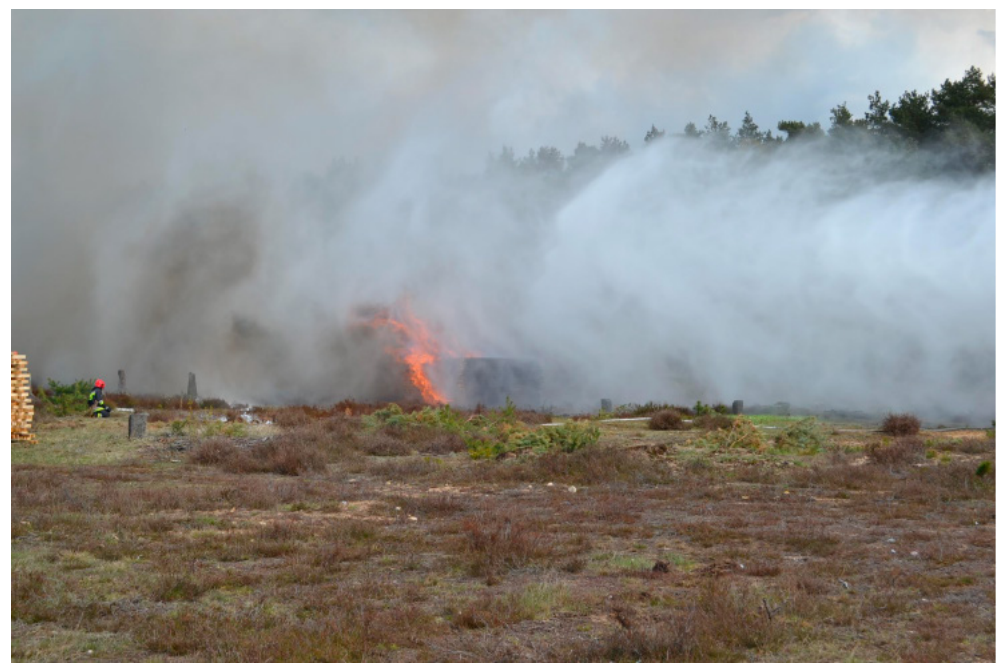

Rysunek 9. Gaszenie turbiną pożaru grupy A. Stos drewna o wymiarach 3,6×3,6 m składający się z 26 warstw. Ilość palącego się drewna 7,5 $\mathrm{m}^{3}$. Zdjęcie własne autorów Figure 9. Extinguishing a Group A Fire with turbine. A stack of 3.6x3.6 wood consisting of 26 layers. The amount of burning wood is $7.5 \mathrm{~m}^{3}$

W przypadku przedmiotowego testu (odległość od stosu około 35 metrów) byłoby to możliwe przy odpowiednio wysokim kącie podniesienia działka. Możliwość szerokiej regulacji ustawienia kąta działko-turbina i łatwa możliwość obrotu działka i turbiny powoduje także możliwość podania w nieznacznym stopniu rozproszonego prądu bez wyłączania turbiny, a przy redukcji jej obrotów do ok. $7000 \mathrm{obr} / \mathrm{min}$. Wynik tego 
testu wyraźnie wskazuje na ograniczenia systemu do gaszenia pożarów torfowisk oraz dużej ilości palącego się i przewróconego drewna. Wynika to z ograniczeń zdolności penetracji poprzez małe krople. W takim przypadku należy zastosować prąd z działka o dużej wydajności i posiadający odpowiedni potencjał zwilżania.

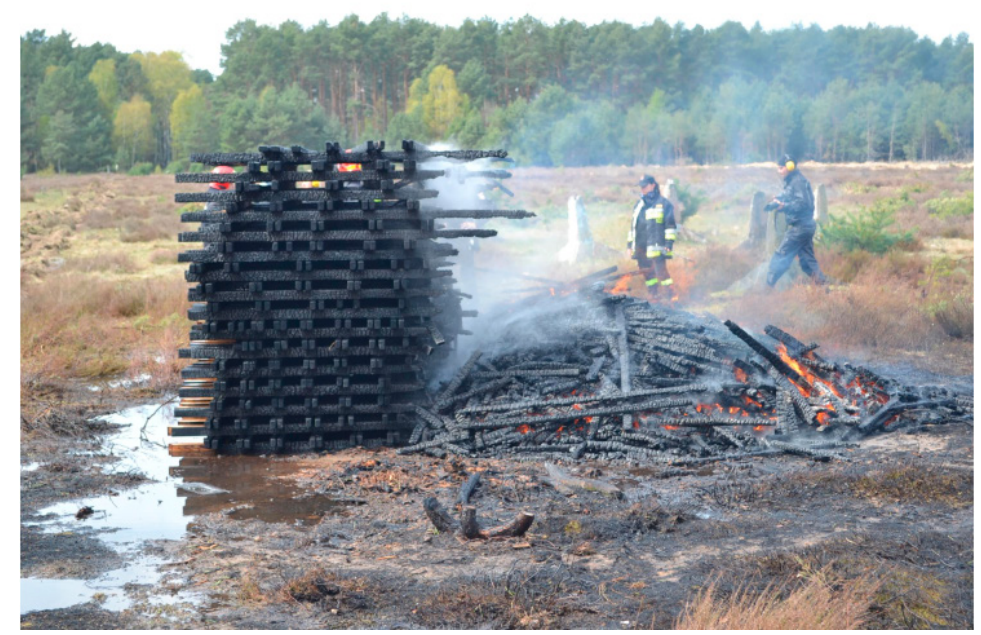

Rysunek 10. Efekt gaszenia turbiną pożaru grupy A. Połowa stosu została obroniona. Druga połowa uległa spaleniu. Zdjęcie własne autorów

Figure 10. The effect of extinguishing the Group A Fire with a turbine. Half of the stack was defended. The other half was burned

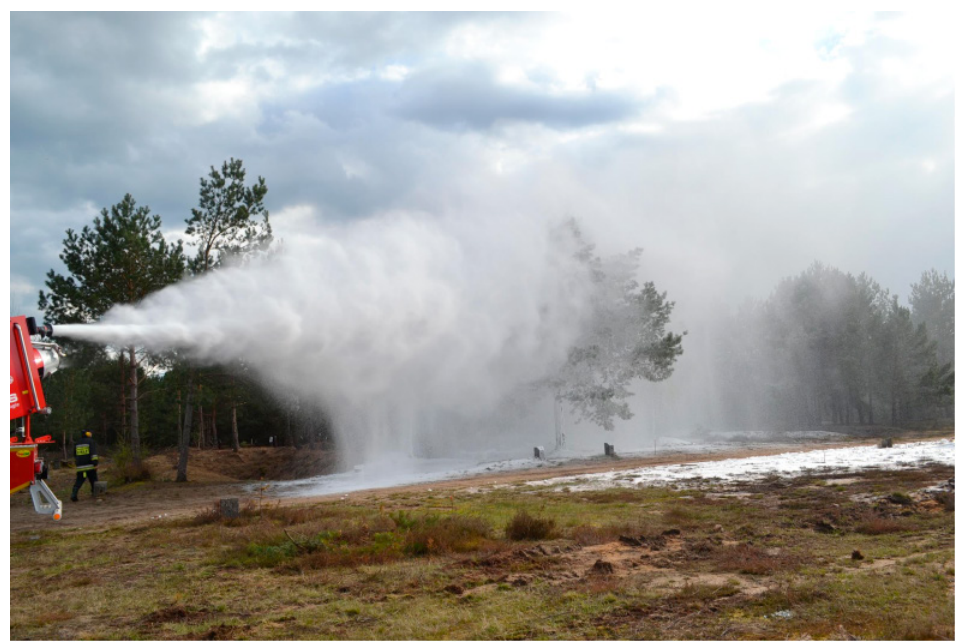

Rysunek 11. Podawanie prądu gaśniczego turbiny na wierzchołki drzew. 3-proc. roztwór środka pianotwórczego typu S Protektol SAT-10. Zdjęcie własne autorów

Figure 11. Extinguishing stream generated by turbine on tops of trees. 3\% S-type foaming agent Protektol SAT-10 
System turbinowy nadaje się jednak do walki z przenoszącym się pożarem wierzchołkowym. Umożliwia podanie prądu na stosunkowo dużą wysokość (rys. 11-12). Dodatkowo odległości pomiędzy drzewami są znacząco większe, co powoduje, iż efekt zwilżania już nie jest tak istotny.

Testy pożarów grupy B przeprowadzono na 11 tacach o wymiarze $1 \mathrm{x} 1,5$ metra znajdujących się w następującej odległości od demonstratora: 20 metrów - 1 taca, 30 metrów - 1 taca, 40 metrów - dwie tace, 50 metrów - 2 tace, 55 metrów - 1 taca, 60 metrów - 1 taca, 70 metrów - 1 taca, 80 metrów - 1 taca, 90 metrów - 1 taca. Jako środek gaśniczy zastosowano 3-procentowy roztwór środka pianotwórczego typu AFFF o nazwie Towalex AFFF 3\%. Rozstawienie wanien przedstawiono na rys. 13. Rzut strumienia piany natomiast przedstawiono wcześniej na rys. 8.

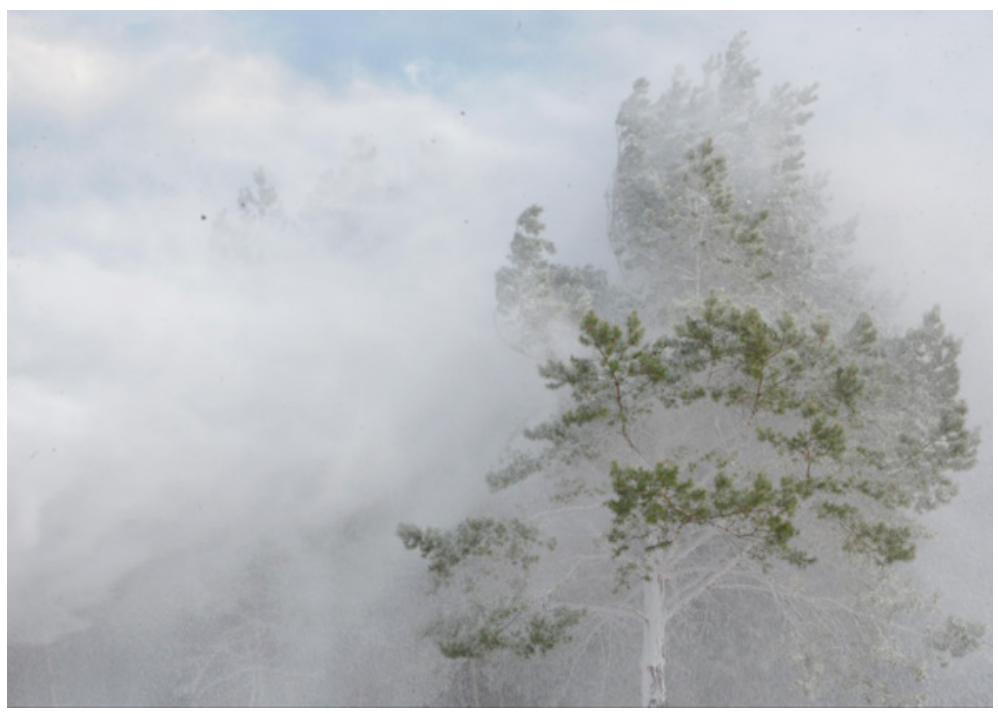

Rysunek 12. Podawanie prądu gaśniczego turbiny na wierzchołki drzew. Bardzo dobre pokrycie zwilżaniem, o ile wytworzona piana nie jest zbyt mokra. 3-proc. roztwór środka typu S Protektol SAT-10. Zdjęcie własne autorów

Figure 12. Extinguishing stream generated by turbine on the tops of trees. Very good wetting coverage if the foam produced is not too wet. 3\% solution of S-type foaming agent Protektol SAT-10

Tace zawierały olej napędowy rozpalany niewielką ilością benzyny. W celu równego wypełnienia tac paliwo wlewano na warstwę wody grubości $5 \mathrm{~cm}$. Następnie wlewano $4 \mathrm{~cm}$ oleju napędowego. Po rozpaleniu tac pożarowi pozwolono się rozwijać przez okres co najmniej 3 minut. Wszystkie tace do odległości 55 metra uległy ugaszeniu poprzez demonstrator. Reszty tac nie ugaszono. Jednakże przyczyną nie był brak zasięgu prądu gaśniczego, lecz znoszenie tego prądu przez wiatr. Ślady piany podanej przez demonstrator znaleziono jeszcze na 105 metrze, licząc od krańcowego miejsca położenia turbiny demonstratora. Taki rezultat daje dobre rokowania na przyszłość, o ile zostanie poprawiony system obrotu turbiny w poziomie. Praca turbiny w pionie nie nastręczała natomiast trudności. 


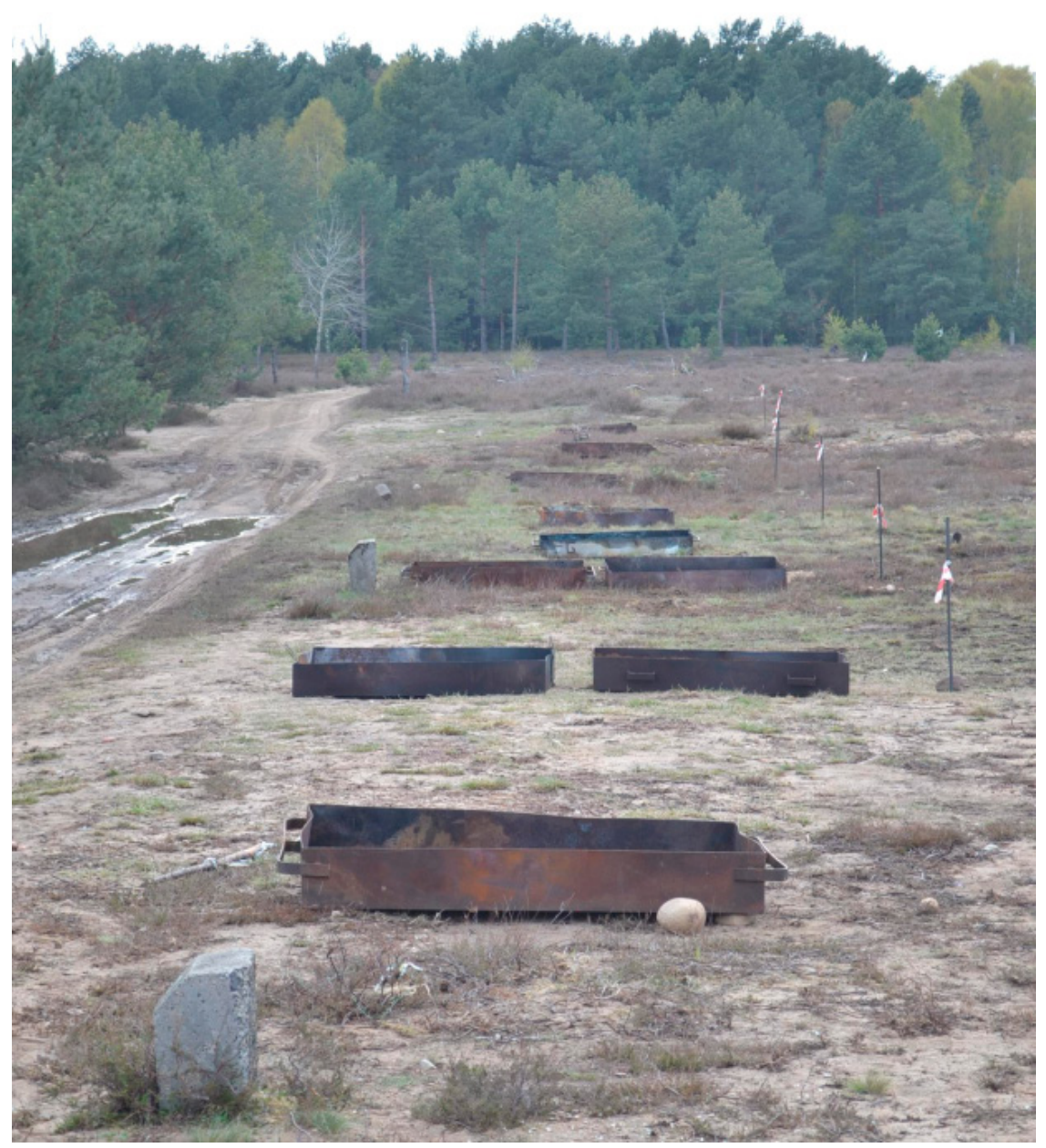

Rysunek 13. Rozstawienie wanien $1 \times 1,5$ do testu dla pożarów grupy B widziane od strony demonstratora systemu. Zdjęcie własne autorów

Figure 13. The spatial arragement of $1 \times 1,5$ bath tubs for the Group B Fires test (seen from the system demonstrator direction)

Praca demonstratora jest stabilna. Maksymalne parametry pracy połączone z bezpieczeństwem użytkowania systemu uzyskuje się przy obrotach rzędu 15000 $\mathrm{obr} / \mathrm{min}$. Zaobserwowane spalanie pozwala na pracę demonstratora wynoszącą co najmniej 1,5 godziny przy pełnym zbiorniku paliwa lotniczego. Zatem demonstrator przy zbiorniku o pojemności $1 \mathrm{~m}^{3}$ osiąga zakładany czas pracy turbiny bez tankowania wynoszący co najmniej jedną godzinę. Kąt podawania strumienia turbiny wynoszący $30^{\circ}$ umożliwia wykorzystanie demonstratora w działaniach chłodzących oraz likwidacji przestrzennej chmur chemicznych. Potwierdzają to zdjęcia podczas pracy urządzenia (rys. 14). 


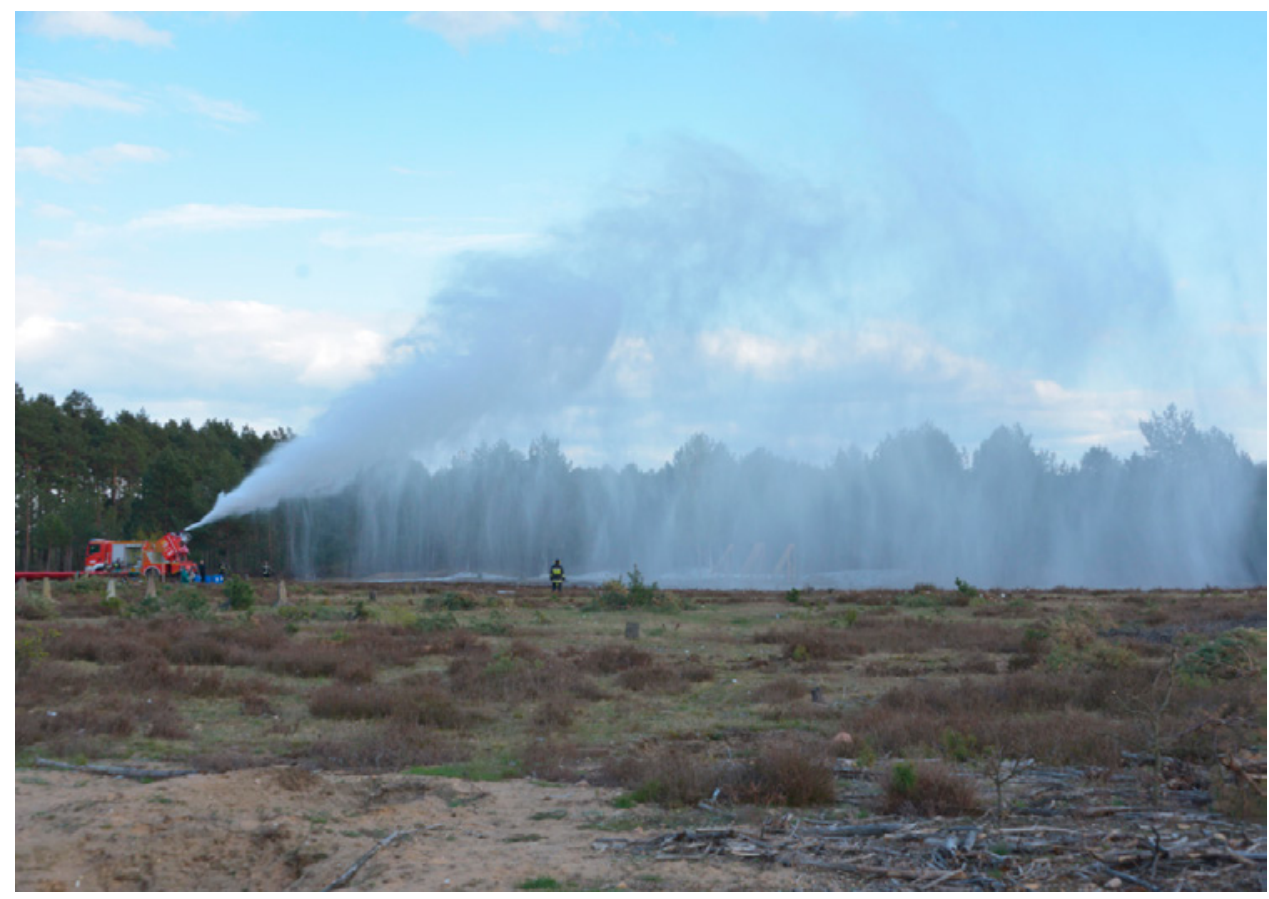

Rysunek 14. Praca demonstratora przy wysokim kącie podawania umożliwia likwidację chmur chemicznych oraz działania chłodzące w obronie. Zdjęcie własne autorów

Figure 14. The work of the system demonstrator at a high monitor angle enables liquidation of chemical clouds and cooling actions in defense

Zastosowanie podpór stabilizujących rozkładanych hydraulicznie zapewnia pełną stabilność pracy demonstratora. Jest to istotne choćby w ujęciu problemów testowania agregatu gaśniczego AG-84, który to mimo wykorzystania mniejszej szczątkowej siły ciągu 4,5 kN miał problemy ze stabilnością podczas pracy układu. W przypadku MTSRG nie zaobserwowano, aby podczas pracy demonstrator odsuwał się lub też był niestabilny przy nieosiowej względem pojazdu pracy turbiny. Jazda demonstratora $\mathrm{w}$ terenie odbywała się płynnie i nie miał problemów z pokonywaniem wzniesień. Wynika to ze stosunkowo małej masy pojazdu wynoszącej 11 ton. Przy zwiększeniu masy demonstratora o środek pianotwórczy, paliwo i armaturę masa ta będzie i tak stosunkowo niewielka. Niemniej konieczne będzie przeprowadzenie prób wymaganych przez przepisy prawa oraz normy PN-EN 1864-1, PN-EN 1864-2 oraz PN-EN 1864-3. Badania te będą obejmować:

- znakowanie podwozia i nadwozia;

- wymiary geometryczne;

- pomiar czasu wyjazdu i uruchomienia silnika;

- badanie zwrotności pojazdu;

- próbę drogową podczas długotrwałej jazdy;

- próbę drogową w warunkach leśnych; 
- stateczność dynamiczną podczas hamowania;

- badanie minimalnej osiąganej prędkości demonstratora;

- badanie czasu rozpędzania pojazdu ze startu zatrzymanego na 100-metrowym odcinku drogi;

- badanie czasu rozpędzania samochodu do prędkości równej $65 \mathrm{~km} / \mathrm{h}$ ze startu zatrzymanego.

Badania wstępne przedpoligonowe demonstratora potwierdziły, iż pojazd będzie spełniał wymagania normowe między innymi w kwestii masy, kąta natarcia, kąta zejścia, kąta rampowego, prześwitu, prześwitu pod osią, obrysowej średnicy zawracania, zdolności pokonywania wzniesień.

Badania poziomu hałasu, dające średni wynik w granicach 120 decybeli na stanowisku obsługi demonstratora, wskazują konieczność stosowania środków ochrony słuchu. Nie jest też możliwe porozumiewanie się ratowników bez specjalnego systemu umożliwiającego pracę w warunkach wysokiego poziomu hałasu. Takie rozwiązania są konieczne w celu bezpiecznego prowadzenia działań ratowniczych i zapewnienia odpowiedniego poziomu komunikacji. Ze względu na bardzo dużą ilość możliwych opcji sterowania systemu nie jest też możliwe zastosowanie w pełni porozumiewania się gestowego. Stąd też warto zapoznać się z systemami łączności używanymi przez załogi śmigłowcowe również narażone na bardzo wysoki poziom hałasu.

Tak jak wskazano we wcześniejszych opracowaniach, podawanie środków neutralizacyjnych oraz środków gaśniczych (w postaci roztworów soli gaśniczych np. $\mathrm{NaHCO}_{3}$ ) w znacznych ilościach umożliwi się dzięki zastosowaniu rozkładanych zbiorników zewnętrznych i dozowników ułatwiających podanie właściwego stężenia z koncentratu. Wspomniano, iż w tym przypadku bezkonkurencyjne mogą okazać się samonośne zbiorniki bez stelaża o odpowiedniej odporności chemicznej. Jest to wynikiem ich bardzo szybkiego czasu przygotowania oraz zajmowania stosunkowo niewielkiej przestrzeni w stanie złożonym, co ma istotne znaczenie w przypadku przewożenia tego typu zbiorników w skrytkach demonstratora. Okazuje się jednak, iż posiadane przez gestora zbiorniki rozkładane o pojemności $50 \mathrm{~m}^{3}$ oraz $13 \mathrm{~m}^{3}$ doskonale nadają się do przygotowywania roztworów. Przykładowe zdjęcie zbiornika o pojemności $50 \mathrm{~m}^{3}$ przedstawiono na rys. 15. Rozkładanie zestawu na miejscu trwa od 20 do 30 minut. Bardzo dużą zaletą jest niska wysokość zbiorników i ich bardzo duża pojemność. Zbiornik o pojemności $50 \mathrm{~m}^{3}$ ma wysokość zaledwie niecałego metra, co bardzo upraszcza operowanie wężami ssawnymi. Analogiczny zbiornik ciśnieniowy miałby wysokość przekraczającą 2 metry i bardzo utrudnione dojście z boku (kształt gruszkowaty). Dodatkowo uszkodzenia zbiorników rozkładanych z matą można bardzo łatwo naprawić. W warunkach zbiorników ciśnieniowych napełnianych powietrzem byłoby to zdecydowanie bardziej skomplikowane i bardziej zawodne. Inna kwestią pozostaje fakt, iż zamówiony przez nas zbiornik pneumatyczny musiałby mieć co najmniej dwa wejścia 110, co czyniłoby tę ofertę bardzo niestandardową i drogą. 

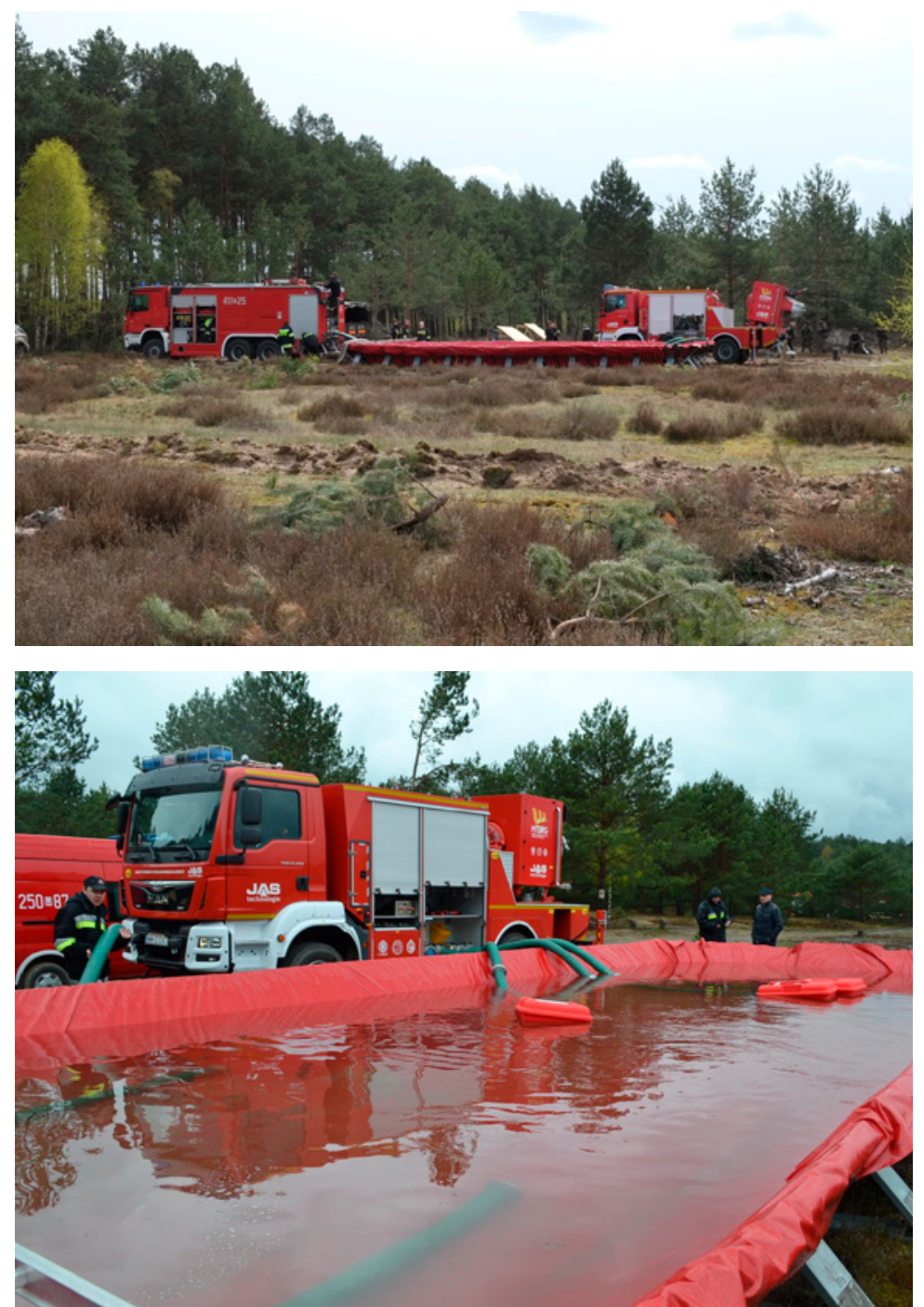

Rysunek 15. Zbiornik rozkładany o pojemności $50 \mathrm{~m}^{3}$ będący na wyposażeniu KW PSP w Gorzowie Wielkopolskim. Czas rozkładania 20-30 minut. Zdjęcie własne autorów Figure 15. Folding tank (capacity of $50 \mathrm{~m}^{3}$ ), owned by the State Fire Service Gorzów Wielkopolski. Preparatring time 20-30 minutes

Podsumowując najważniejsze kwestie wynikające $\mathrm{z}$ badań poligonowych demonstratora, można wywnioskować, że:

- demonstrator spełnia założenia projektowe w kwestii maksymalnego zasięgu rzutu środków gaśniczych podawanych w strumień gazów wylotowych turbiny wynoszącego $90 \mathrm{~m}$;

- demonstrator posiada zdalny system sterowania turbinami umożliwiający jego sterowanie w dystansie (co najmniej 100 metrów); 
- demonstrator posiada stabilną konstrukcję nie przesuwającą się w czasie jego pracy;

- demonstrator współpracuje z zestawami pompowymi gestora;

- demonstrator współpracuje z samochodem proszkowym, dając bardzo duży zasięg działania. Zastosowanie dwóch linii szybkiego natarcia, licząc jedynie wydajność sumaryczną 10-12 kg/s (600-720 kg/min), daje nam możliwość osiągnięcia masowego stężenia proszku w granicach $10 \%$ przy jednoczesnym podawaniu prądu gaśniczego wody lub roztworu środka pianotwórczego;

- najbardziej optymalny system zewnętrznego zasilania demonstratora oprócz zestawów pompowych obejmuje rozkładany zbiornik ze stelażem o pojemności $50 \mathrm{~m}^{3}$;

- praca demonstratora wymaga stosowania ochrony słuchu i uzupełnienia systemu w urządzenia umożliwiające komunikację ratowników przy wysokim poziomie hałasu;

- praca demonstratora jest skuteczna pod warunkiem ustawienia go z wiatrem;

- demonstrator nadaje się do gaszenia pożarów grupy B;

- demonstrator w wersji pracy turbiny SO3 wykazuje ograniczone zastosowanie do pożarów grupy A (gdy wymagane jest duże zwilżenie i penetracja ośrodka). Dobre zwilżenie w takim przypadku zapewni zastosowanie tradycyjnego działka przy wyłączonej turbinie lub przy ustawieniu jej w sposób nie zakłócający podawania prądu z samego działka (ustawienie działka i turbiny w innej osi, niskie obroty turbiny $7000 \mathrm{obr} / \mathrm{min}$ );

- demonstrator nadaje się do walki z pożarami wierzchołkowymi;

- demonstrator może mieć duże znaczenie w działaniach obronnych (chłodzenie) oraz przy likwidacji przestrzennych chmur substancji organicznych;

- demonstrator dobrze sprawuje się w warunkach dróg nieutwardzonych dzięki uterenowionemu napędowi podwozia $2 \times 2$;

- zbiornik paliwa lotniczego zapewnia możliwość ciągłej pracy turbiny przez okres znacznie przewyższający planowaną jedną godzinę;

- demonstrator ma możliwość samodzielnego zasilenia się poprzez nasobną pompę o wydajności $6000 \mathrm{dm}^{3} / \mathrm{min}$;

- działko demonstratora zapewnia wymaganą projektem wydajność wynoszącą co najmniej $6000 \mathrm{dm} 3 / \mathrm{min}$. przy czym ta wydajność może być znacząco większa (maksymalna wydajność pompy przy wysokości podnoszenia $3 \mathrm{~m}$ i dwóch wężach ssawnych DN110 wynosi 6900 dm³ zgodnie $\mathrm{z}$ rys 16$)$;

- istnieje możliwość zwiększenia wydajności wodnej demonstratora poprzez zastępcze wykorzystanie rur doprowadzających proszek gaśniczy (dwie linie zasilające na złącze Storz 52 i średnicy wewnętrznej 1 cal). 


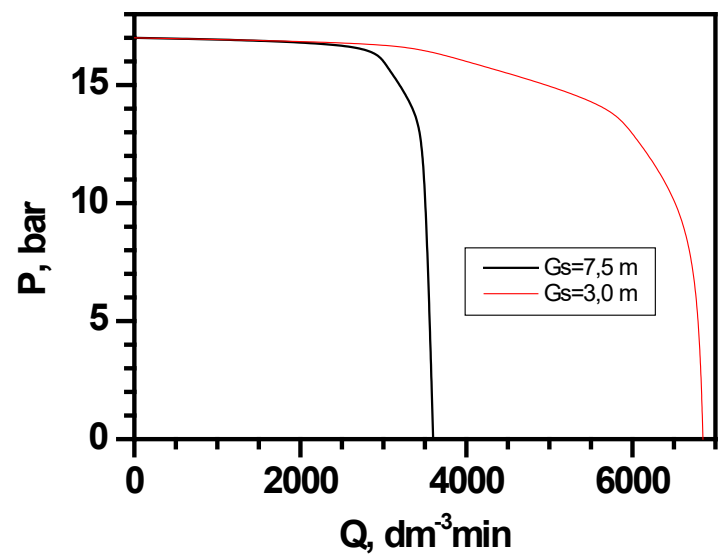

Rysunek 16. Parametry pompy A60/8 zamontowanej na demonstratorze systemu Źródło: opracowanie własne autorów

Figure 16. Pomp A60/8 parameters installed on system demonstrator

\subsection{Ograniczenia MTSRG przy dekontaminacji masowej}

W trakcie analizy systemu wyciągnięto wnioski, iż nie da się go wykorzystać podczas masowej dekontaminacji ludzi, lecz jedynie do dekontaminacji sprzętu lub też przestrzennej likwidacji skażenia w powietrzu. W takiej choćby roli wykorzystywano technologię WUS 3 (Wojskowe Urządzenie Specjalne) bazujące również na silniku SO3. Podanie natomiast chmury wody na ubranych ludzi mogłoby spowodować głębsze wniknięcie substancji w ubranie, a także zwiększony jej kontakt ze skórą w postaci roztworu. Byłoby to bardzo niekorzystne przy skażeniach substancjami o charakterze wybitnie toksycznym oraz charakteryzujących się dobrą rozpuszczalnością w wodzie. Dodatni efekt dekontaminacyjny mógłby zostać osiągnięty, gdy strumień podawany z turbiny opadałby poza dekontaminowanych ludzi. $\mathrm{W}$ przypadku substancji polarnych osiągnięto by efekt pochłaniania i rozpraszania $\mathrm{w}$ atmosferze poprzez wywiewanie substancji niebezpiecznej strumieniem powstającym z turbiny. Dla substancji niepolarnych byłby to jedynie efekt wywiewania. Proces dekontaminacji masowej ludzi byłby jednak ciężki do zrealizowania choćby ze względu na duży hałas, panikę, trudności w uporządkowaniu ruchu poszkodowanych podczas zdarzenia masowego.

\subsection{Sposoby zasilania w wodę MTSRG oraz jego współpraca z pompami pożarniczymi}

Układ wodny pojazdu musi być na tyle wszechstronny, aby możliwe było zapewnienie odpowiedniej wydajności systemu przy różnych wariantach zasilania. Podstawę zasilania $\mathrm{w}$ wodę powinny stanowić standardowe pojazdy ratowniczogaśnicze jednostek ochrony przeciwpożarowej, sieci wodociągowe oraz zbiorniki wody zarówno naturalne, jak i sztuczne. W systemie turbinowym przewiduje się następujące sposoby zasilania w wodę: 
- bezpośrednie zasilanie realizowane przez samochody ratowniczo-gaśnicze czerpiące wodę ze zbiorników lub sieci wodociągowej;

- bezpośrednie zasilanie realizowane przez motopompy pożarnicze czerpiące wodę ze zbiorników lub sieci wodociągowej;

- bezpośrednie zasilanie realizowane przez pompę systemu czerpiącą wodę ze zbiorników lub sieci wodociągowej;

- zasilanie pośrednie realizowane przez pompę systemu współpracującą z pompami pożarniczymi czerpiącymi wodę ze zbiorników lub sieci wodociągowej.

Zasilanie bezpośrednie $\mathrm{z}$ autopomp i motopomp powinno być stosowane w przypadku gdy ciśnienie w rurociągu zasilającym przy wydajności nominalnej systemu będzie przekraczało wartość około 5 bar. W takim przypadku pompa systemu nie będzie wykorzystywana, a woda zostanie skierowana bezpośrednio do głowic. W zasilaniu tego typu może być wykorzystywana motopompa pożarnicza co najmniej typoszeregu M60/8 lub samochód ratowniczo-gaśniczy z autopompą co najmniej A60/8. W opisywanym wariancie istnieje również możliwość bezpośredniego zasilenia głowic z dwóch i większej liczby motopomp lub autopomp połączonych równolegle do systemu. W takim przypadku będzie istniała możliwość zastosowania autopomp i motopomp typoszeregach mniejszych niż A60/8 lub M60/8, np. dwóch motopomp M32/8. Można tu również zastosować układ mieszany, wykorzystujący połączone szeregowo motopompy i autopompy. Schemat bezpośredniego zasilania systemu z wykorzystaniem autopompy i motopompy przedstawiają odpowiednio rys. 17 i 18 .

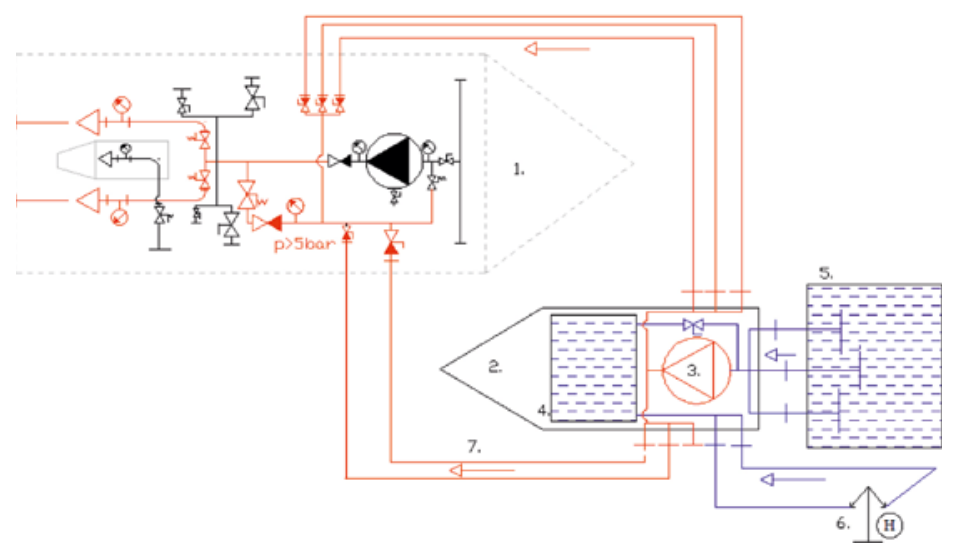

Rysunek 17. Zasilanie bezpośrednie systemu z wykorzystaniem samochodu ratowniczo-gaśniczego

Opis rysunku: 1 - turbinowy pojazd gaśniczy, 2 - samochód ratowniczo-gaśniczy, 3 - autopompa np. A60/8, 4 - zbiornik wody samochodu ratowniczo-gaśniczego, 5 - zewnętrzny zbiornik wody, 6 - hydrant zewnętrzny, 7 - pożarnicze węże tłoczne

Źródło: opracowanie własne autorów

Figure 17. Direct water supply of the system using the rescue and firefighting vehicle. Description: 1 - turbine fire-fighting vehicle, 2 - rescue and fire-fighting vehicle, 3 -autopompa, eg A 60/8, 4-water tank of rescue and fire-fighting vehicle, 5 - external water reservoir, 6 - external hydrant, 7 - discharge hoses. 


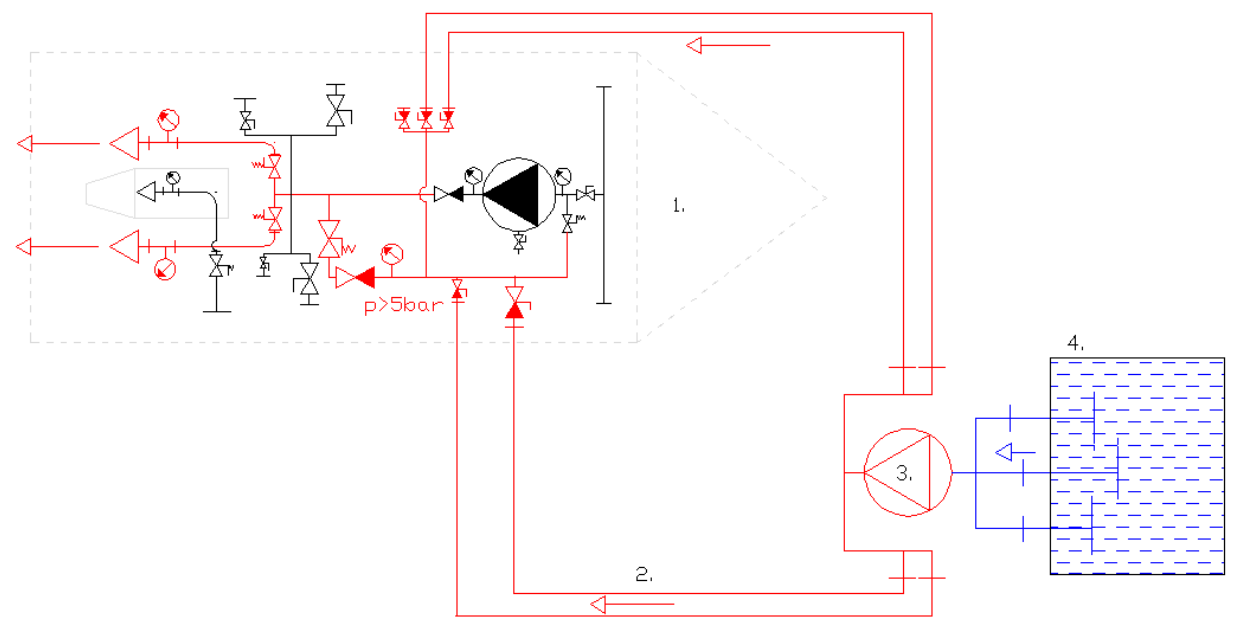

Rysunek 18. Zasilanie bezpośrednie systemu z wykorzystaniem motopompy pożarniczej. Opis rysunku: 1 - turbinowy pojazd gaśniczy, 2 - węże tłoczne, 3 - motopompa np. M60/8, 4 - zewnętrzny zbiornik wody

Źródło: opracowanie własne autorów

Figure 18. Direct water supply of the system with the use of a fire engine pump. Description: 1 - turbine fire-fighting vehicle, 2 - discharge hoses, 3 - motor pump, eg M60/8, 4 - external water tank

Zarówno przy wykorzystaniu motopomp, jak i autopomp niezbędne jest zapewnienie im odpowiedniego zasilania w wodę. Zbiorniki wody samochodów ratowniczo-gaśniczego, z powodu dużej wydajności wykonywanego systemu, mogą stanowić jedynie doraźny zapas wody. W praktyce nawet przy wykorzystaniu kilku pojazdów, przy wydajności nominalnej systemu wynoszącej $6000 \mathrm{dm} 3 / \mathrm{min}$, maksymalny czas pracy nie przekroczy 10 minut. $Z$ tego względu we wszystkich sposobach zasilania wodnego kwestię priorytetową powinno stanowić zorganizowanie odpowiedniej ilości wody dostarczanej do pomp pożarniczych. Można to zrealizować zwłaszcza przez wykorzystanie naturalnych lub sztucznych zbiorników wodnych oraz sieci wodociągowych.

Jeżeli podczas działań system turbinowy nie będzie posiadał wsparcia w postaci samochodów ratowniczo-gaśniczych lub motopomp, woda będzie dostarczana do głowic z wykorzystaniem pompy zasilającej pojazdu. Woda do pompy może zostać dostarczona przez sieć wodociągową lub zassana ze zbiorników naturalnych lub sztucznych. Zastosowana pompa zasilająca w turbinowym systemie gaśniczym sprawi, że będzie on bardziej funkcjonalny i samowystarczalny. Praca układu ze ssaniem wymaga zastosowania w systemie urządzenia zasysającego. Urządzenie takie mogą stanowić na przykład pompy wyporowa lub strumienica. Schemat bezpośredniego zasilania przez własną pompę systemu czerpiącą wodę ze zbiornika przedstawia rys. 19. 


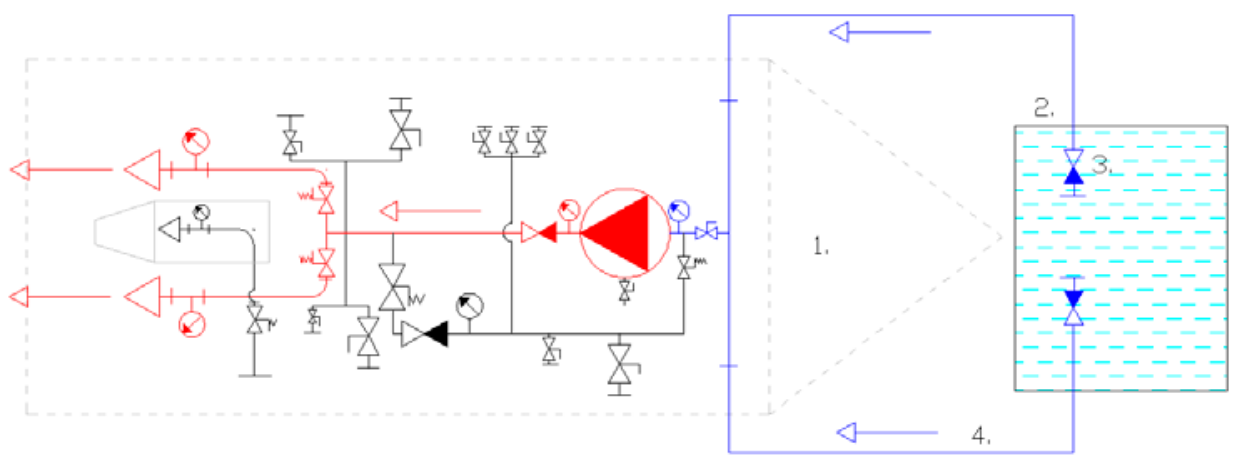

Rysunek 19. Schemat zasilania bezpośredniego z wykorzystaniem pompy systemu. Opis rysunku: 1 - turbinowy pojazd gaśniczy, 2 - zbiornik wody, 3 - smok ssawny, 4 - węże ssawne wielkości 110

Źródło: opracowanie własne autorów

Figure 19. Diagram of direct water supply using the system pump installed on MTSRG. Description: 1 - turbine fire fighting vehicle, 2 -water tank, 3 -suction, 4 -suction hoses, size 110

Zasilanie pośrednie realizowane przez pompę systemu współpracującą z pompami pożarniczymi czerpiącymi wodę ze zbiorników lub sieci wodociągowej przedstawiają rys. 20 i 21.

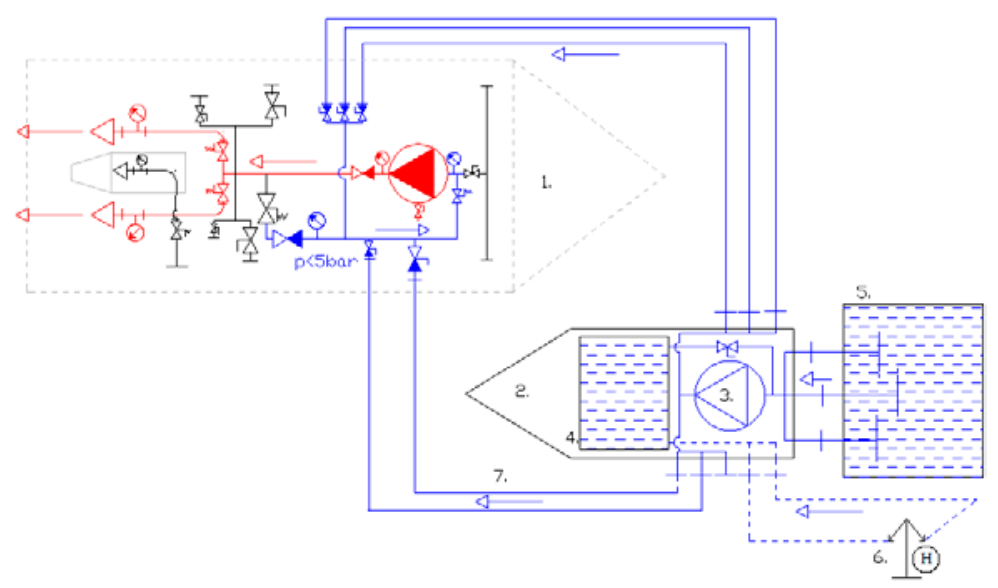

Rysunek 20. Zasilanie pośrednie realizowane przez pompę systemu współpracującą $\mathrm{z}$ autopompą

Opis rysunku: 1 - turbinowy pojazd gaśniczy, 2 - samochód ratowniczo-gaśniczy, 3 - autopompa, 4 - zbiornik wody samochodu ratowniczo-gaśniczego, 5 - zewnętrzny zbiornik wody, 6 - hydrant zewnętrzny, 7 - pożarnicze węże tłoczne Źródło: opracowanie własne autorów

Figure 20. Indirect water suppy by the system pump cooperating with the autopump. Description: 1 - turbine fire fighting vehicle, 2 - rescue and firefighting vehicle, 3 -autopump, 4 - water tank of rescue and firefighting vehicle, 5 - external water tank, 6- external hydrant, 7 - fire discharge hoses 


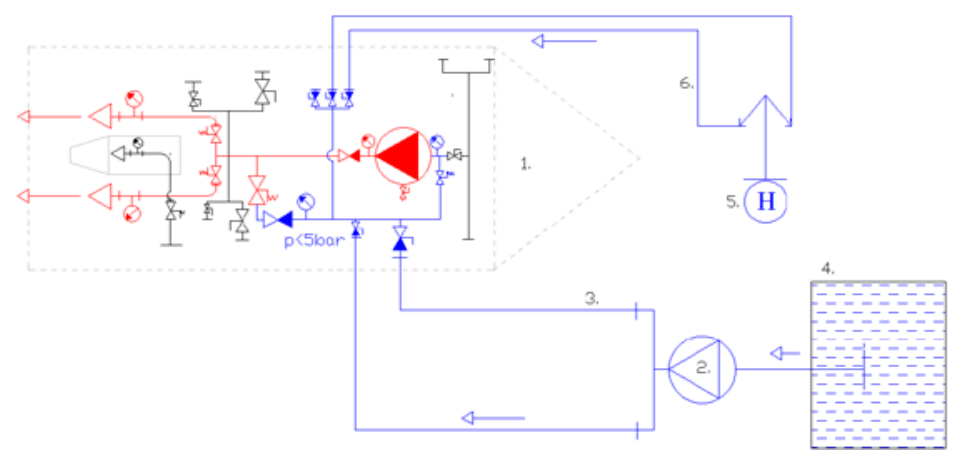

Rysunek 21. Zasilanie pośrednie realizowane przez pompę systemu współpracującą $\mathrm{z}$ autopompą i siecią wodociągową

Opis rysunku: 1 - turbinowy pojazd gaśniczy, 2 - motopompa np. P60/2, 3 i 6 - pożarnicze węże tłoczne, 4 - zbiornik wody samochodu ratowniczo-gaśniczego, 5 - hydrant zewnętrzny Źródło: opracowanie własne autorów

Figure 21. Indirect water supply by the system pump cooperating with the pump and water supply network

Description: 1 - turbine fire fighting vehicle, 2 - motor pump, eg P60/2, 3 and 6 - fire hoses, 4 - water tank of rescue and firefighting vehicle, 5 - external hydrant

W zasilaniu pośrednim możliwe jest wykorzystanie bedących na wyposażeniu jednostek ochrony przeciwpożarowej motopomp do wody zanieczyszczonej. Zazwyczaj posiadają one duże wydajności, jednak niskie wyskości podnoszenia. Sprawia to, że nie są one w stanie bezpośrednio zasilać głowic wodnych. Mogą jednak w połączeniu ze zbiornikiem wody stanowić odpowiednie zasilanie pompy systemu turbinowego.

\section{Wnioski}

Mobilny turbinowy system ratowniczo-gaśniczy jest rozwiązaniem powstałym na bazie doświadczeń eksploatacji podobnych systemów w innych krajach oraz bazującym na potrzebach użytkownika końcowego, którym jest Państwowa Straż Pożarna. System, by spełniać pokładane w nim nadzieje, musi wykazać się mobilnością, skutecznością oraz kompatybilnością z innymi technologiami wykorzystywanymi przez jednostki ratownicze. MTSRG został również stworzony z myślą o w miarę ekonomicznym, jak na warunki silnika turbinowego, wykorzystaniu technologii przy zachowaniu uniwersalności rozwiązania. Próby poligonowe wykazały ograniczenia systemu co do gaszenia pożarów grupy A, jednakże w kontekście wykorzystania samego systemu gaszenia turbiną. Posiadanie wysokowydajnego sterowalnego działka zapewnia systemowi uniwersalność, gdyż wyżej wymieniony brak skuteczności turbiny uzupełniany jest właśnie obecnością wspomnianego działka. Jest ono w pełni sterowalne zarówno w kontekście kątów podawania, jak i rozproszenia prądu. Podanie zatem prądu kroplistego lub zwartego zapewnia odpowiednie zwilżenie materiału. Słaba skuteczność samego systemu turbinowego 
przy gaszeniu pożarów grupy A nie wyklucza stosowania technologii przy zabezpieczaniu i obronie przed przemieszczaniem się pożaru wierzchołkowego lasu. System wykazuje dobre pokrycie wierzchołków drzew, o ile wytworzona piana nie jest zbyt ciężka oraz podana ze zbyt bliskiej odległości. Tu dość istotne znaczenie ma jakość stosowanego środka pianotwórczego.

Technologia wykazała skuteczność do gaszenia pożarów grupy B. Jednakże i tutaj należy pamiętać o odpowiednim ustawieniu zgodnie z kierunkiem wiatru. Bardzo mała wartość średnich średnic powierzchniowych kropli wynosząca zaledwie $100 \mathrm{~mm}$ powoduje znoszenie kropli przez wiatr. Ustawienie MTSRG pod wiatr powoduje natomiast spadek zasięgu działania do 50-60 metrów. Ustawienie zgodnie $z$ wiatrem lub w warunkach bezwietrznych powoduje, iż technologia posiada zasięg co najmniej 100 metrów, przy czym odległość robocza to 50-60 metrów. Wartość jego była najwyższa dla położenia turbiny wynoszącej $0^{\circ}$. Przy podniesieniu turbiny pod kątem $15^{\circ}$ oraz $30^{\circ}$ obserwowano nieco mniejszy zasięg rzutu, przy czym osiągano lepsze parametry do likwidacji unoszących się w powietrzu chmur przestrzennych toksycznych środków przemysłowych. Kroplistość rzędu 100 mm zapewniłaby dobrą likwidację przestrzenną chmur, przy czym jak wykazano dla symulacji pojazdu Turbolösher II, efektywność zapewnia przede wszystkim znacząca objętość wyrzucanych gazów spalinowych turbiny rozcieńczających chmurę [7]. Sorpcja powierzchniowa na granicy faz stanowi mniejszy udział, przy czym efektywność ta wzrasta wraz z polarnością i rozpuszczalnością danych par w wodzie [7-12]. Zasięg rzutu piany był bardzo zbliżony do rzutu wody. Ze środka gaśniczego typu S o nazwie Protektol SAT-10 przy jego standardowym stężeniu roboczym wynoszącym 3\% otrzymywano pianę ciężką o liczbie spienienia $\mathrm{LS}=5$. Jest to tzw. piana mokra posiadająca dobre właściwości gaśnicze i chłodzące. Technologia emitowała dość znaczną ilość hałasu. Wartość na poziomie $120 \mathrm{~dB}$ powoduje znaczne problemy logistyczne i konieczność wykorzystania łączności helikopterowej oraz pracy w środkach ochrony słuchu. Pewnym problemem jest również tankowanie urządzenia. Co prawda zapas paliwa starcza na około 1,5 h pracy, jednakże nie ma możliwości tankowania demonstratora w czasie pracy. Sam zakup i przechowywanie paliwa również są bardzo problematyczne. System posiada również możliwość wprowadzenia proszków gaśniczych do układu z intensywnością podawania rzędu $12 \mathrm{~kg} / \mathrm{s}$. Proszek podawany razem z wodą podnosi wyraźnie potencjał wykorzystania technologii. Wykorzystanie doprowadzenia proszku jako elementu dodatkowo doprowadzającego wodę powoduje, iż rzeczywista wydajność demonstratora przy zewnętrznym zasilaniu może wzrosnąć aż do $7500 \mathrm{dm}^{3} / \mathrm{min}$. Badania jednak wyraźnie pokazały, iż potencjał turbiny pozwala na rozproszenie znacznie większej ilości wody. Wymaga to jednak szczegółowych badań.

Podsumowując, demonstrator MTSRG może być efektywnie wykorzystany w działaniach przede wszystkim obronnych zarówno w terenach leśnych, jak i przemysłowych ze względu na alternatywną możliwość wykorzystania działka przy zapewnieniu odpowiedniego zaopatrzenia wodnego. 


\section{Bibliografia}

[1] Jann T., Materialschlacht in Ludwigshafen, "Schweizerische Feuerwehr-Zeitung”, $1 / 2015$.

[2] Neuhoff S., Feyrer J., Gravierender Störfall in einem Chemiebetrieb in Köln, „Brandschutz - Deutsche Feuerwehr-Zeitung", 8/2008.

[3] Störfall in einem Chemiebetrieb in Köln-Worringer, „Brandschutz - Deutsche Feuerwehr-Zeitung", 5/2008.

[4] Węsierski T., Kielin J., Gontarz A., Samochody z turbinowym systemem gaśniczym, „Bezpieczeństwo i Technika Pożarnicza”, 4 (20)/2010, 139-150.

[5] http://www.caranddriver.com/features/stilling-the-fires-of-war (dostęp: 06.01.2018).

[6] https://imgur.com/gallery/xGw08 (dostęp: 31.01.2018).

[7] Węsierski T., Majder-Łopatka M., Wąsik W., Likwidacja skażeń przestrzennych amoniaku za pomoca turbinowych pojazdów gaśniczych, „Przemysł Chemiczny”, 5 (96)/2017, 1080-1084.

[8] Węsierski T., Badanie efektywności kurtyn wodnych przy niekontrolowanym uwolnieniu par acetonu, „Przemysł Chemiczny”, 7(96)/2017, 1539-1542.

[9] Majder-Łopatka M., Węsierski T., Wąsik W., Wpływ typu dyszy rozpylającej na skuteczność absorpcji obłoku amoniaku powstałego w wyniku awarii przemysłowej, „Bezpieczeństwo i Technika Pożarnicza”, 2(42)/2016, 127-134.

[10] Węsierski T., Majder-Łopatka M., Walczak A., Wykorzystanie turbinowego systemu ratowniczo-gaśniczego do ograniczenia skutków wycieku amoniaku z zbiorników ciśnieniowych i bezciśnieniowych, „Logistyka”, 5/2015, 1121-1127.

[11] Węsierski T., Efektywność kurtyn wodnych przy zwalczaniu par liniowych nasyconych alkoholi małoczasteczkowych podczas ich niekontrolowanego uwolnienia, „Przemysł Chemiczny", 5(94)/2015, 728-730.

[12] Węsierski T., Majder-Łopatka M., Matuszkiewicz R., Porowski R., Badanie efektywności kurtyn wodnych przy zwalczaniu par amoniaku podczas jego niekontrolowanego uwolnienia, „Przemysł Chemiczny”, 7(91)/2012, 1424-1426. 


\title{
Organizacja zaopatrzenia wodnego mobilnego turbinowego systemu ratowniczo-gaśniczego
}

\author{
Organization of water supply for mobile turbine rescue \\ and fire extinguishing system
}

\author{
Aleksander Adamski \\ Wiktor Wąsik \\ Tomasz Węsierski \\ Małgorzata Majder-Łopatka \\ Szkoła Główna Służby Pożarniczej
}

\section{Streszczenie}

Cel: Celem publikacji jest określenie optymalnego wyposażenia oraz taktyki niezbędnej do realizacji zaopatrzenia wodnego turbinowego systemu ratowniczo-gaśniczego (MTSRG) w trakcie działań ratowniczych.

Metoda badawcza: Dokonano analizy wyposażenia sprzętowego dostępnego na terenie województwa lubuskiego mającego użytkować MTSRG. Przeanalizowano znane taktyki organizacji zaopatrzenia oraz zasad wykorzystania sprzętu. Wykonano obliczenia szacowania wymaganej wydajności wodnej uwzględniającej niezbędna wielkość zaopatrzenia wodnego dla MTSRG. W obliczeniach uwzględniano między innymi średnice linii zasilajacych, ich długość, powierzchnię pożaru.

\begin{abstract}
Purpose: The purpose of the publication is to determine the optimal equipment and tactics necessary to implement the water supply of the turbine rescue and extinguishing system (MTSRG) during rescue operations.

Research metod: An analysis of the equipment available in the Lubuskie Voivodship to be used by MTSRG was made. The known tactics of the supply organization and the rules of using the equipment were analyzed. Calculations were made to estimate the required water capacity taking into account the necessary water supply capacity for MTSRG. In the calculations, the diameters, lenght of the feeding lines, and the fire surface were taken into account.
\end{abstract}

Organizacja zaopatrzenia wodnego na terenie dużych akcji zawsze stanowi poważne wyzwanie logistyczne. Dzieje się tak szczególnie gdy niezbędne jest doprowadzenie znacznej ilości wody na znaczne dystanse. Mobilny turbinowy system ratowniczogaśniczy (MTSRG) posiadający nasobną turbinę samolotową SO3 wymaga zasilania o wydajności $6 \mathrm{~m}^{3} / \mathrm{min}$. Dodatkowe wykorzystanie doprowadzeń proszkowych umożliwia podanie nawet $7,5 \mathrm{~m}^{3} / \mathrm{min}$. O ile system jest się w stanie sam zasilić, stojąc 
przy pobliskim ujęciu wody, o tyle zwłaszcza w warunkach pożarów lasów konieczna jest organizacja zaopatrzenia wodnego na odpowiednio wysokim poziomie. Stąd też niezwykle ważny staje się aspekt organizacji zaopatrzenia.

\section{Wybór optymalnej armatury pożarniczej współdziałającej z MTSRG na wypadek pożarów lasów}

Duże zdarzenia, zarówno na terenie zakładów przemysłowych, jak i na terenach leśnych, wymagają organizacji sprawnie działającego i wysoko wydajnego zaopatrzenia wodnego [1-5]. Specyfika pożarów obszarów leśnych wyklucza możliwość dysponowania sił i środków mniejszych niż sekcja gaśnicza, zwłaszcza że powstający demonstrator systemu przeznaczony jest z definicji do zdarzeń o znacznym rozmiarze. W celu maksymalnego zabezpieczenia działań gaśniczych konieczne jest alarmowanie zastępów, które będą tworzyły plutony zadaniowe i docelowo wejdą w skład kompanii realizującej zadania na wyznaczonym obszarze. Plutony wchodzące w skład kompanii gaśniczej do gaszenia pożarów leśnych powinny się charakteryzować maksymalną samodzielnością i samowystarczalnością w działaniach na rozpoznanym obszarze zagrożonym. Plutony stworzone do współdziałania z mobilnym turbinowym systemem ratowniczo-gaśniczym powinny być przeszkolone i uczulone na specyfikę zadaniową demonstratora, choćby w kwestii organizacji zaopatrzenia wodnego, co wynika $z$ dużych potrzeb niezbędnych do pełnego i skutecznego wykorzystania technologii. Oczywiście warunkami idealnymi do pełnego wykorzystania potencjału sił ratowniczych byłaby sytuacja, kiedy to pierwsze zastępy są w stanie opóźnić rozwój pożaru, a w sprzyjających warunkach doprowadzić do jego lokalizacji i likwidacji. Główną zasadą prowadzenia akcji gaśniczej jest ustalenie jej priorytetów i ich realizacja na podstawie możliwości taktyczno-technicznych sformowanego pododdziału. Każdy Kierujący Działaniami Ratowniczymi (KDR) powinien umieć dokonać kalkulacji i porównania w zakresie oceny rozwoju sytuacji pożarowej do oceny możliwości własnych sił i środków (SiS). Z założenia jednak wykorzystanie demonstratora dotyczy zdarzeń dużych, więc mało prawdopodobna jest lokalizacja i likwidacja pożaru przez pierwsze zastępy poza przypadkiem, gdyby to sekcja wyposażona w demonstrator została skierowana jako pierwsza na miejsce zdarzenia w swoim terenie operacyjnym i mogła w dogodny sposób skorzystać ze zbiorników wodnych.

KDR powinien mieć przygotowany wstępny plan działań ratowniczo-gaśniczych na podstawie osobistego rekonesansu obszaru chronionego (rozpoznanie przed akcją), wniosków z analiz operacyjnych, ćwiczeń na chronionych obszarach leśnych oraz ciągłego rozpoznania rozwoju sytuacji pożarowej w trakcie pożaru danego obszaru. Do opracowania wariantów taktycznych potrzebne są następujące informacje o:

- topografii kompleksu leśnego; 
- powierzchni, wieku i rodzaju drzewostanu;

- usytuowaniu elementów infrastruktury leśnej: dróg, zbiorników i cieków wodnych, dostrzegalni i innych obiektów;

- usytuowaniu obszarów zabudowy mieszkalnej, produkcyjno-magazynowej oraz szlaków komunikacyjnych będących w bezpośrednim sąsiedztwie obszarów leśnych;

- siłach ratowniczych na terenie nadleśnictw (ilość pracowników przeszkolonych do działań związanych z likwidacją zagrożeń oraz rodzaj i ilość sprzętu ratowniczego i gaśniczego będącego w dyspozycji bazy);

- harmonogramie wejścia do działań powiatowych (wojewódzkich) sił ratowniczych PSP i OSP;

- parametrach taktyczno-technicznych pododdziałów na miejscu akcji i dysponowanych w trakcie działań;

- parametrach rozwoju pożaru: powierzchni objętej pożarem, szybkości rozprzestrzeniania się pożaru na jego froncie i skrzydłach (tab. 1 i 2);

- możliwościach organizacji terenu akcji gaśniczej.

Ze względu na zaopatrzenie wodne należy podzielić teren akcji na cztery strefy (rys. 1):

- strefę stanowisk gaśniczych;

- strefę magazynowania i dystrybucji środków gaśniczych;

- strefę transportu wody (środków gaśniczych);

- strefę punktów czerpania wody.

Dwie podstawowe czynności związane z gaszeniem pożaru to sprawienie stanowisk gaśniczych dostosowanych do sytuacji pożarowej oraz maksymalnie szybkie sprawienie zaopatrzenia wodnego w celu zapewnienia ciągłości podawania środków gaśniczych do pożaru z wydajnością rokującą szybką jego lokalizację i likwidację w zakładanym wariantem taktycznym czasie operacyjnym. Jest to szczególnie istotne w przypadku współdziałania z planowanym demonstratorem technologii ze względu na potrzebę organizacji zaopatrzenia wodnego na poziomie co najmniej $6000 \mathrm{dm}^{3} / \mathrm{min}$.

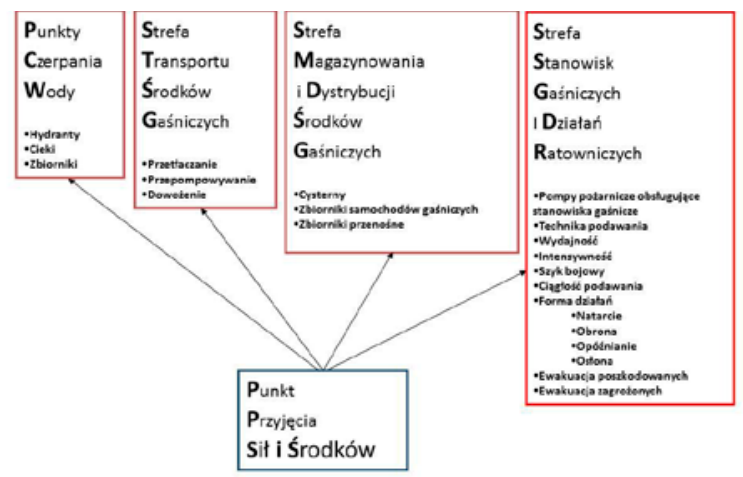

ORGANIZACIA TERENU AKCII GAŚNICZEJ

Rysunek 1. Organizacja terenu akcji gaśniczej [1]

Figure 1. Organization of firefighting action area [1] 
Zaopatrzenie demonstratora w odpowiednią ilość wody można osiągnąć na kilka sposobów:

- pobór i przetłaczanie wody z pobliskich zbiorników oraz cieków wodnych (główny filar budowy zasilania wodnego);

- uzupełniający dowóz wody w cysternach oraz zbiornikach samochodów pożarniczych;

- pobór wody z hydrantów (uzupełniająco).

Realizując wariant główny zaopatrzenia wodnego poprzez pobór i przetłaczanie wody z pobliskich zbiorników oraz cieków wodnych, warto skorzystać z wydajnych systemowych rozwiązań taktycznych stosowanych na świecie. Najtańszym sposobem, uwzględniając efekt minimum kosztów maksimum korzyści, podniesienia potencjału ratowniczego sekcji lub plutonu gaśniczego, jest dodatkowe wyposażenie tych pododdziałów w Moduł Wsparcia Działań Gaśniczych (MWDG) w oparciu o przyczepę. Przykład takiej przyczepy z samochodem przedstawiono na rys. 2.

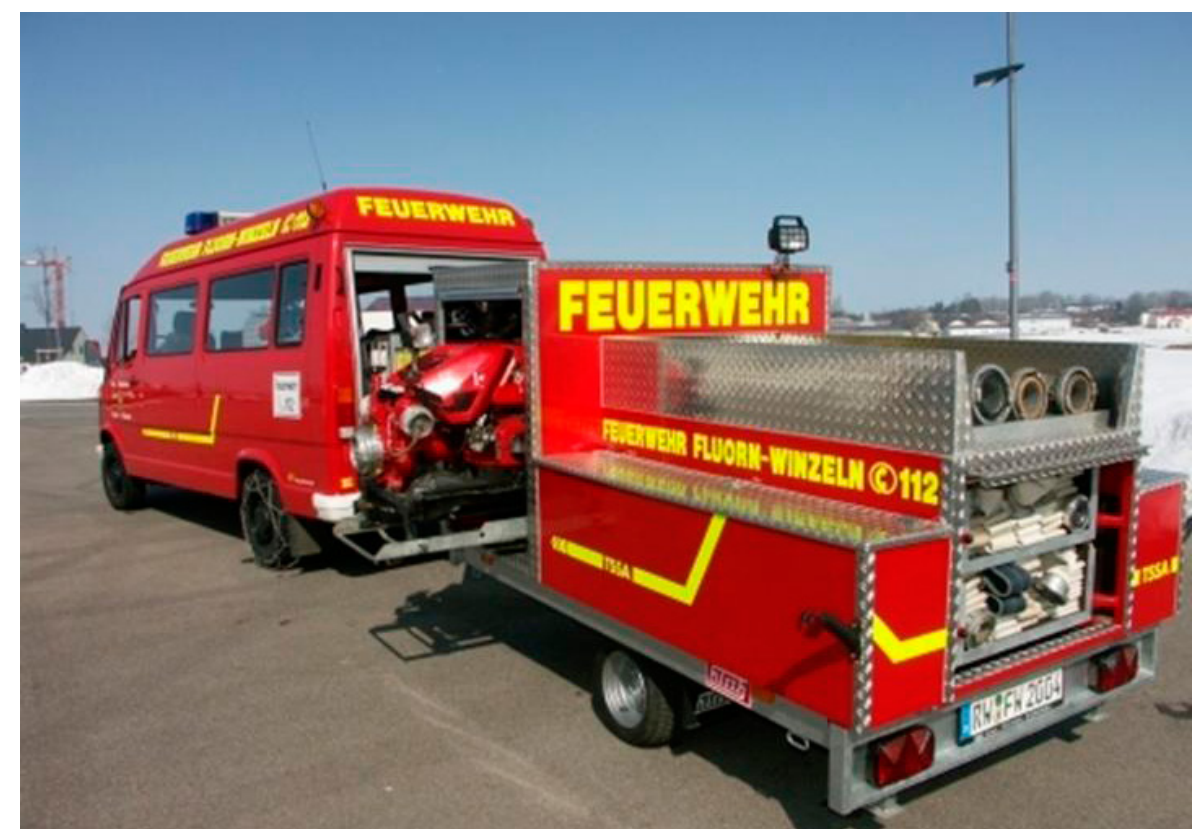

Rysunek 2. Moduł wsparcia działań gaśniczych (MWDG)

Figure 2. Support module for fire fighting activities (MWDG)

Taki moduł wsparcia działań gaśniczych powinien być wyposażony w:

- 30 odcinków węży tłocznych W75 - systemowo ułożonych i przygotowanych do rozwinięcia (sprawienia), połączonych ze sobą - powinno umożliwić podczas jednokrotnego przejazdu modułu sprawienie równoległej, podwójnej linii zasilającej na dystansie $300 \mathrm{~m}$;

- motopompa M16/8 - parametry te pozwalają tłoczyć wodę przez podwójną równoległą linię zasilającą na dystansie $500 \mathrm{~m}$; 
- motopompy pływające MP4/2;

- zbiornik (zbiorniki) o łącznej pojemności $5\left[\mathrm{~m}^{3}\right]$ do magazynowania wody do celów gaśniczych, pojemność ta gwarantuje współpracę, podczas stosowania systemu dowożenia, z dwoma typowymi zastępami typoszeregu GBA 2/20 lub jednym typoszeregu GCBA 5/24;

- komplet armatury wodno-pianowej.

Tak wyposażony moduł jest przygotowany do budowy części albo całości systemu przepompowywania czy dowożenia. Na uwagę zasługuje fakt, że w obecnej chwili KDR, który zdecyduje się na zbudowanie magistrali wężowej o długości 600 [m] musi zadysponować dodatkowo od 3 do 4 zastępów gaśniczych typoszeregu GBA 2/20. To konkretne wyposażenie MWDG jest w stanie podnieść parametry taktyczne sekcji gaśniczej o 100\%. Zapas węży tłocznych W75 z 400 [m] zwiększy się do 1000 [m] (w tym 600 [m] systemowego sprawiania linii zasilających), pomp pożarniczych o ciśnieniu nominalnym tłoczenia $0,8[\mathrm{MPa}]$ o 1 szt., zbiornik $5\left[\mathrm{~m}^{3}\right]$, będący w dyspozycji sekcji od początku akcji gaśniczej, pozwoli na magazynowanie wody do gaszenia, jego zastosowanie wpłynie na skrócenie czasów cykli dowożenia oraz pozwoli magazynować wodę z każdego powstałego układu pompowo-wężowego.

Wydajność wodna konieczna dla uzyskania przez demonstrator odpowiednich parametrów wiąże się z zastosowaniem pomp oraz modułów pompowych o odpowiedniej wydajności wynoszącej co najmniej 6000 [dm³/min]. Pompy o mniejszej wydajności mogą być stosowane jako element wspomagający i wymagają uzupełniania poprzez dodatkowe elementy. Na terenie województwa lubuskiego, w którym docelowo ma stacjonować demonstrator mobilnego turbinowego systemu ratowniczo-gaśniczego, znajduje się kilkanaście pomp, które można wydajnie wykorzystać jako pompy zasilające demonstrator technologii. W tabeli 1 zestawiono pompy o wydajności pow. 5000 [ $\left.\mathrm{dm}^{3} / \mathrm{min}\right]$ w jednostkach PSP województwa. W czasie dostarczania wody $z$ dystansu należy przewidzieć dodatkowo motopompy wpięte szeregowo podnoszące ciśnienie w linii zasilającej. Ciśnienie pracy demonstratora przy wydajności sumarycznej nie mniejszej niż $6\left[\mathrm{~m}^{3} / \mathrm{min}\right]$ powinno optymalnie wynosić około 6 bar.

TABela 1. Pompy O WYdajNości POW. 5000 DM33/MIN W JEDNOSTKACH PSP WOJEWÓDZTWA LUBUSKIEGO, KTÓRYMI MOŻNA ZASILIĆ DEMONSTRATOR MTSRG

TABle 1. Pumps With output Capacity higher than 5000 DM 3 /Min. In The PSP Units of The Lubuskie VoIVOdship, Which MAY BE USED to THE MTSRG REINFORCMENT.

\begin{tabular}{|c|c|c|}
\hline Komenda & JRG & $\begin{array}{l}\text { Wydajność przy ciśnieniu } \\
\text { nominalnym }\left(\mathrm{dm}^{3} / \mathrm{min}\right)\end{array}$ \\
\hline $\begin{array}{l}\text { KM PSP } \\
\text { Gorzów Wielkopolski }\end{array}$ & $\begin{array}{l}\text { JRG nr } 1 \\
\text { Gorzów Wielkopolski }\end{array}$ & 13333 \\
\hline $\begin{array}{l}\text { KM PSP } \\
\text { Gorzów Wielkopolski }\end{array}$ & $\begin{array}{l}\text { JRG nr } 2 \\
\text { Gorzów Wielkopolski }\end{array}$ & 8000 \\
\hline
\end{tabular}




\begin{tabular}{|l|l|c|}
\hline \multicolumn{1}{|c|}{ Komenda } & \multicolumn{1}{|c|}{ JRG } & \multicolumn{1}{c|}{$\begin{array}{c}\text { Wydajność przy ciśnieniu } \\
\text { nominalnym (dm } \mathbf{3} \text { (min) }\end{array}$} \\
\hline $\begin{array}{l}\text { KM PSP } \\
\text { Gorzów Wielkopolski }\end{array}$ & $\begin{array}{l}\text { JRG nr 2 } \\
\text { Gorzów Wielkopolski }\end{array}$ & 11500 \\
\hline KM PSP Zielona Góra & JRG nr 2 Zielona Góra & 77000 \\
\hline $\begin{array}{l}\text { KP PSP } \\
\text { Krosno Odrzańskie }\end{array}$ & JRG Gubin & 5400 \\
\hline KP PSP Międzyrzecz & JRG Międzyrzecz & 8000 \\
\hline KP PSP Międzyrzecz & JRG Międzyrzecz & 7634 \\
\hline KP PSP Nowa Sól & JRG Nowa Sól & 7750 \\
\hline KP PSP Słubice & JRG Słubice & 9200 \\
\hline KP PSP Słubice & JRG Słubice & 7750 \\
\hline KP PSP Sulęcin & JRG Sulęcin & 9200 \\
\hline KP PSP Sulęcin & JRG Sulęcin & 8000 \\
\hline KP PSP Świebodzin & JRG Świebodzin & 8000 \\
\hline KP PSP Wschowa & JRG Wschowa & 12023 \\
\hline KP PSP Żagań & JRG Szprotawa & 12023 \\
\hline KP PSP Żagań & JRG Żagań & \\
\hline
\end{tabular}

Wartym rozważenia rozwiązaniem wydaje się być zbadanie kompatybilności co najmniej 3 typów pomp o różnych wydajnościach (np. 5400, 8000 oraz $12023\left[\mathrm{dm}^{3} / \mathrm{min}\right]$ ) sformowanych w pluton pompowy podczas prowadzenia testów poligonowych. By wykorzystać potencjał bojowy podstawowego plutonu gaśniczego i sprostać założeniom taktycznym dążącym do optymalnego wykorzystania potencjału bojowego kompanii WBO (Wojewódzkiego Batalionu Obwodowego), należy warianty taktyczne oprzeć na rozwiązaniach taktycznych wykorzystujących użycie przede wszystkim systemowych rozwiązań, gdzie zastosowane będą sprzętowe moduły wężowe. Do takich rozwiązań należą samochody wężowe SW, zestawy kontenerowe $\mathrm{z}$ wężami i przyczepy wężowe PW. Po analizie kilkudziesięciu wariantów taktycznych realizowanych podczas rzeczywistych, dużych pożarów należy stwierdzić, że najlepszym rozwiązaniem systemowym do zasilania zastępów gaśniczych współdziałających w ramach kompanii gaśniczej jest samochód wężowy SW. Najlepiej kiedy posiada on na swoim wyposażeniu 5000 [m] węża tłocznego W110 ułożonego w harmonijkę w dwóch łożach. Takie ułożenie pozwala na budowę jednocześnie podwójnej linii zasilającej z węży tłocznych W 110, a co za tym idzie o podwójnej wydajności. Zastosowanie węży co najmniej W 110 jest konieczne ze względu na około trzykrotnie większą wydajność niż mają linie W75 (tabela 2). Zastosowanie większych przekrojów wiąże się z dużymi problemami logistycznymi ze względu na niewielkie ilości tego typu armatury na terenie kraju 
TABELA 2. WYdAJNOŚĆ WODNA POJEDYNCZEJ LINII ZASILAJĄCEJ O RÓŻNEJ ŚREDNICY W ZALEŻNOŚCI OD DYSTANSU TŁOCZENIA PRZY CIŚNIENIU POMPY TŁOCZĄCEJ 8 BAR.

TABLE 2. WATER EFFICIENCY OF A SINGLE FEED LINE OF VARIOUS DIAMETERS DEPENDING ON THE DISCHARGE DISTANCE AT THE PRESSURE OF THE PUMP 8 BAR.

\begin{tabular}{|c|c|c|c|c|}
\hline Dystans & W 75 & W 110 & W 125 & W 150 \\
\hline$[\mathbf{m}]$ & {$\left[\mathbf{d m}^{\mathbf{3}} / \mathbf{m i n}\right]$} & {$\left[\mathbf{d m}^{\mathbf{3}} / \mathbf{m i n}\right]$} & {$\left[\mathbf{d m}^{\mathbf{3}} / \mathbf{m i n}\right]$} & {$\left[\mathbf{d m}^{\mathbf{3}} / \mathbf{m i n}\right]$} \\
\hline 300 & 1150 & 3450 & 4750 & 8600 \\
\hline 500 & 890 & 2690 & 3680 & 6700 \\
\hline 700 & 750 & 2270 & 3110 & 5670 \\
\hline 1000 & 630 & 1900 & 2600 & 4740 \\
\hline 1500 & 510 & 1550 & 2120 & 3870 \\
\hline 3000 & 360 & 1100 & 1500 & 2730 \\
\hline
\end{tabular}

Efektów jakie uzyskuje się po sprawieniu pojedynczej czy podwójnej magistrali wężowej z samochodu wężowego, nie da się porównać pod względem stabilności, wydajności i ciągłości dostarczania wody do celów gaśniczych z żadnym systemem dowożenia. Stosując system dowożenia wody do celów gaśniczych, teoretycznie można uzyskać wydajność zbliżoną do wydajności z układu pompowo-wężowego, ale wiąże się to $z$ udziałem $w$ akcji gaśniczej 3-4 razy więcej samochodów gaśniczych typoszeregu GBA 2/20 i GCBA 5/32. Wydajność systemu dowożenia realizowanego przez pozostałe plutony w ramach kompanii WBO (około 7-8 zastępów) będzie kilka razy mniejsza niż rzeczywista wydajność autopomp podstawowego plutonu gaśniczego (5200 [ $\left.\left.\mathrm{dm}^{3} / \mathrm{min}\right]\right)$.

W sytuacji, gdy uzupełnianie środka gaśniczego poprzez dowożenie okaże się koniecznością (w przypadku uzupełniania systemu turbinowego o wydajności $6000\left[\mathrm{dm}^{3} / \mathrm{min}\right]$ dowożenie może być tylko i wyłącznie metodą uzupełniającą, a nie podstawową), ocena składu kompanii gaśniczej powinna opierać się na następujących zasadach:

- określenie wydajności wymaganej do pożaru i wytypowanie samochodów gaśniczych, których wydajność autopomp zasilających stanowiska gaśnicze będzie większa o $25 \%$ od wartości wydajności wymaganej;

- określenie maksymalnych możliwości odbioru i gromadzenia wody na potrzeby utrzymania ciągłości podawania środków gaśniczych do stanowisk gaśniczych (tworzenie buforów wodnych, najpraktyczniejszym rozwiązaniem są zbiorniki składane);

- określenie wydajności pomp pożarniczych (autopomp, motopomp i motopomp pływających), które zostały zadysponowane do punktów czerpania wody;

- określenia wydajności źródeł i ich odległości od pożaru (na te parametry systemu KDR ma najmniejszy wpływ);

- wytypowanie samochodów o największych możliwościach taktycznych na potrzeby dowożenia w danych warunkach terenowych. 
Organizując uzupełniające zasilanie wodne, nie można zapomnieć o możliwości wykorzystania cystern. Na terenie województwa lubuskiego znajduje się 9 cystern o pojemności powyżej $15\left[\mathrm{~m}^{3}\right]$ (tabela 3). Działania takie mogą być jedynie uzupełniające ze względu na fakt, iż pojedyncza cysterna nawet o największej pojemności $\left(25 \mathrm{~m}^{3}\right)$ starcza na zaledwie 4 minuty działania systemu turbinowego. Dodatkowym utrudnieniem będzie dojazd cysterny na miejsce zdarzenia. W warunkach leśnych przy dużych naciskach na oś jest to bardzo trudne zadanie, a w wielu wypadkach wręcz prawie niemożliwe do realizacji. W ramach testów poligonowych wskazane jest jednak przetestowanie cysterny o pojemności $25\left[\mathrm{~m}^{3}\right]$ (bezpośredni dojazd do miejsca zdarzenia i zasilanie $\mathrm{z}$ bliska) oraz $\mathrm{w}$ wersji organizacji $\mathrm{z}$ niej dodatkowego punku zaopatrzenia wodnego $\mathrm{z}$ odległości co najmniej $1,5 \mathrm{~km}$ od demonstratora (zasilanie $\mathrm{z}$ dystansu).

TABela 3. Cysterny NA TERENIE WOJEWÓDZTWA LUbUSKiego O POJEMNOŚCI CO NAJMNIEJ 15 [M33] - STAN NA SIERPIEŃ 2015

TABle 3. WATER TANKS IN THE LUBUSKie VoIVOdEShip With A CAPACITY of AT Least 15 [M3] - State at August 2015.

\begin{tabular}{|c|c|c|c|}
\hline Cysterna & Komenda & JRG & $\begin{array}{c}\text { Pojemność } \\
\text { zbiornika }\left[\mathrm{dm}^{3}\right]\end{array}$ \\
\hline Scen 25000 SCANIA & $\begin{array}{l}\text { KM PSP Gorzów } \\
\text { Wielkopolski }\end{array}$ & $\begin{array}{l}\text { JRG nr } 1 \text { Gorzów } \\
\text { Wielkopolski }\end{array}$ & 25000 \\
\hline Scen 25000 IVECO & $\begin{array}{l}\text { KM PSP } \\
\text { Zielona Góra }\end{array}$ & $\begin{array}{l}\text { JRG nr } 2 \text { Zielona } \\
\text { Góra }\end{array}$ & 25000 \\
\hline Scen 18000 DAF & $\begin{array}{l}\text { KP PSP Krosno } \\
\text { Odrzańskie }\end{array}$ & $\begin{array}{l}\text { JRG Krosno } \\
\text { Odrzańskie }\end{array}$ & 18000 \\
\hline $\begin{array}{l}\text { Scen } 18000 \\
\text { RENAULT }\end{array}$ & KP PSP Słubice & JRG Słubice & 18000 \\
\hline Scen 18000 JELCZ & $\begin{array}{l}\text { KP PSP } \\
\text { Strzelce Krajeńskie }\end{array}$ & $\begin{array}{l}\text { JRG PSP Strzelce } \\
\text { Krajeńskie }\end{array}$ & 18000 \\
\hline Scen 18000 JELCZ & KP PSP Sulęcin & JRG Sulęcin & 18000 \\
\hline $\begin{array}{l}\text { Scen } 18000 \\
\text { JELCZ } 417\end{array}$ & KP PSP Wschowa & JRG Wschowa & 18000 \\
\hline Scen 19000 JELCZ & KP PSP Żagań & JRG Szprotawa & 19000 \\
\hline Scen 18000 VOLVO & KP PSP Żary & JRG Żary & 18000 \\
\hline
\end{tabular}

W ramach formowanych kompanii wchodzących w skład Lubuskiej Brygady Odwodowej wyróżnia się następujące typy plutonów ratowniczo-gaśniczych, które mogą zostać wykorzystane do akcji gaszenia pożarów leśnych:

Pluton typu „A” - składający się z 3 zastępów GBA lub GCBA o obsadzie min. 5 osób. Ustala się min. pojemność zbiornika wody na $2 \mathrm{~m}^{3}$ wody.

Pluton typu „B” składa się z 3 zastępów GCBA o wydajności autopomp min. $3200\left[\mathrm{dm}^{3} / \mathrm{min}\right](\mathrm{A} 32 / 8)$ i obsadzie min. 3 osób. Ponadto ustala się min. pojemność 
zbiornika wody na $5\left[\mathrm{~m}^{3}\right]$ wody. Zaleca się, aby samochody w miarę możliwości, posiadały napęd terenowy.

Pluton typu „C” (wsparcia) - składający się z sekcji wodnej oraz sekcji z zapasem środka pianotwórczego. W skład sekcji wodnej wchodzą SW min. 3000/110 oraz dwie motopompy pożarnicze o wydajności min. $4000\left[\mathrm{dm}^{3} / \mathrm{min}\right](\mathrm{M} 40 / 8) \mathrm{wraz}$ z samochodem do ich transportu, oraz GCBM/GCBA o min. pojemności zbiorników na wodę i środek pianotwórczy liczącej łącznie $11\left[\mathrm{~m}^{3}\right]$ i wyposażony w autopompę/motopompę o wydajności min. 1200 [ dm³/min]. W skład sekcji z zapasem środka pianotwórczego wchodzą samochody ze środkiem pianotwórczym w ilości minimum $15\left[\mathrm{~m}^{3}\right]$.

Pluton typu „D” (ciężki pluton gaśniczy) w składzie 3 zastępów GCBA o minimalnej wydajności autopomp stosownej do parametrów DWP (w tym przypadku A50/8), które będą zasilać oraz minimalnej obsadzie 3 osób. Do każdego samochodu powinno być dobrane DWP (przewoźne lub przenośne) o wydajności min. 3800 [ $\left.\mathrm{dm}^{3} / \mathrm{min}\right]$.

Podstawowy pododdział kompanii (pluton typu A), czyli pluton w składzie GBA2/20, GBA2/20 i GCBA5/30, dysponuje autopompami o łącznej wydajności nominalnej 7000 [dm³/min], a z punktu widzenia praktyki wydajność rzeczywista jest zbliżona do 75\% wartości nominalnej, czyli około 5200 [dm $3 / \mathrm{min}]$. Do wspierania działań demonstratora systemu w warunkach rzeczywistych niezbędne byłoby zatem wykorzystanie co najmniej plutonu typu B.

W wyniku analizy operacyjnej potrzeb, jakie wynikają z lokalizacji i likwidacji pożarów leśnych w obrębie województwa lubuskiego podjęto decyzję o sformowaniu plutonu pompowego. W skład danego plutonu wchodzą cztery motopompy o wydajności nie mniejszej niż 8000 [dm³/min] (M80/8) oraz 4 zastępy typoszeregu GBA. Zastępy te posiadają minimum pięcioosobową obsadę ratowników. Współdziałanie plutonu pompowego $\mathrm{z}$ demonstratorem należałoby przetestować $\mathrm{w}$ warunkach badań poligonowych.

Jak wspomniano wcześniej, podawanie wody z dużych odległości wiąże się oprócz zastosowania agregatu pompowego o odpowiedniej wydajności z koniecznością szeregowego włączania motopomp w linię zasilającą w celu uzyskania odpowiedniej wartości ciśnienia oraz z położeniem znacznej długości linii zasilających. Należy zatem przetestować w warunkach poligonowych współdziałanie mobilnego turbinowego systemu ratowniczo-gaśniczego z typowym plutonem wsparcia kompanii gaśniczej COO wyposażonym w: SW 3000 (W110), dwie pompy M80/8, GCBM 18/16 (najnowsze cysterny posiadają zbiornik $25000 \mathrm{dm}^{3}$ ) i dwa samochody typoszeregu GBA 2/20, przy czym łączne parametry plutonu wsparcia będą następujące:

- łączna wydajność autopomp - $4000\left[\mathrm{dm}^{3} / \mathrm{min}\right]$;

- łączna wydajność motopomp - 17600 [dm³/min];

- łączny zapas węży tłocznych:

- $\mathrm{W} 110$ - $3000[\mathrm{~m}]$;

- $\mathrm{W} 75-500[\mathrm{~m}]$; 
- łączny zapas wody - $22000\left[\mathrm{dm}^{3}\right]$;

- łączny zapas środków pianotwórczych - $400\left[\mathrm{dm}^{3}\right]$;

- ratownicy - 10;

- systemowe rozwiązania do budowy układów pompowo-wężowych;

- samochód wężowy (połączone, przygotowane do ułożenia węże w dwóch niezależnych modułach sprzętowych po 1500 [m] węża tłocznego W 110 w każdym);

- cysterna jako bufor wodny powinna posiadać po dwie nasady 110 i 75 do napełniania zbiornika (współpraca z zasilającymi liniami z węży tłocznych W110 oraz przepompowywanie przy pomocy W110 i W75);

- motopompy M80/8 do przetłaczania i przepompowywania;

- systemowe rozwiązania do budowy układów dowożenia:

- cysterna jako bufor wodny z nasadami 110 i 75 do napełniania zbiornika (przepompowywanie przy pomocy W110 i W75);

- motopompy w punkcie czerpania M80/8 do przepompowywania wody do zbiorników samochodowych;

- GBA 2/20 jako samochody dowożące.

\section{Organizacja działań gaśniczych oraz armatura współdziałająca z demonstratorem podczas pożarów obiektów przemysłowych}

Na potrzeby lokalizacji i likwidacji pożarów o charakterze przemysłowym systemami, które mogą spełnić oczekiwania KDR we współdziałaniu z mobilnym turbinowym systemem ratowniczo-gaśniczym, są systemy polegające na wykorzystaniu pomp pożarniczych i węży tłocznych. W przeciwieństwie do terenów leśnych problem organizacji zaopatrzenia wodnego jest o tyle prostszy, iż na terenie obiektów przemysłowych muszą znajdować się przeciwpożarowe zbiorniki wodne połączone $\mathrm{z}$ siecią miejską oraz wewnętrzna sieć hydrantowa o stosownej wydajności zasilana $\mathrm{z}$ własnej pompowni. To w znacznym stopniu ułatwia organizację zaopatrzenia zwłaszcza w początkowych etapach akcji. Jako system wiodący podczas akcji gaśniczych w zakładach przemysłowych powinien być stosowany system przetłaczania, a system przepompowywania jako system uzupełniający.

$\mathrm{Z}$ analizy operacyjnej obszarów przemysłowych można wnioskować, że zbiorniki wody przeciwpożarowej nie powinny znajdować się w odległości większej niż 3000 [m] od miejsca zdarzenia. Jest to odległość maksymalna. W wypadku wyczerpania się zapasów wody zgromadzonych w lokalnych zbiornikach przeciwpożarowych (w promieniu $3000[\mathrm{~m}]$ od miejsca pożaru) należy rozpoznać inne najbliższe ujęcia wody, które mogą spełnić zapotrzebowanie danej akcji gaśniczej. Jednym z podstawowych problemów z poborem wody ze źródeł oddalonych od pożaru o ponad $3000[\mathrm{~m}]$ będzie transport wody na tych dystansach i zastosowanie do jego realizacji wielu pododdziałów gaśniczych. 
Przy założeniu gaszenia obiektów i obszarów o charakterze przemysłowym trzeba zakładać powierzchnię pożaru związaną z powierzchnią ciągu technologicznego lub obiektu magazynowego. Wielkości trzeba indywidualnie uwzględniać na potrzeby działań gaśniczych. $Z$ analizy kilkudziesięciu wariantów taktycznych realizowanych w trakcie rzeczywistych dużych i bardzo dużych pożarów wynika, że budowa układów zaopatrzenia wodnego zapewniających ciągłość podawania środków gaśniczych jest niemożliwa bez zastosowania wysokowydajnych układów pompowo-wężowych. Armatura pompowo-wężowa zastosowana w przypadku zdarzeń na terenie zakładów przemysłowych będzie analogiczna jak w przypadku pożarów lasów. Jednakże przy sprawnie funkcjonującej sieci hydrantowej na terenie zakładu oraz dostatecznych zapasach wody przeciwpożarowej zbiorników będzie można również z powodzeniem zastosować mniej wydajne tradycyjne elementy armatury pożarniczej podczas działań zasilających system turbinowy, gdy działania będą prowadzone w niewielkiej odległości od rezerwuaru.

Problem zabezpieczenia odpowiedniego zapasu wody gaśniczej i budowy sprawnego sytemu utrzymującego ciągłość jej dostarczania do miejsca akcji jest podstawową kwestią dla każdego KDR. Można je określić dzięki analizie danych operacyjnych, wartości opracowanych za pomocą modeli matematycznych, wniosków z przebiegu innych pożarów rzeczywistych, wniosków z ćwiczeń doświadczalnych i zgrywających na obiektach, a także wartości wynikających $\mathrm{z}$ aktów prawnych i opracowań dotyczących bezpieczeństwa danego obszaru.

Warunkiem koniecznym powodzenia akcji gaśniczej jest, by warianty taktyczne dotyczące zaopatrzenia wodnego były przygotowywane zawsze przed akcją. KDR, który je opracowuje, powinien założyć najmniej korzystny wariant rozwoju pożaru i stopnia zagrożenia dla sąsiednich obiektów/obszarów. Za wartości wyjściowe do naliczania sił i środków należy przyjąć dane określające zapotrzebowanie na wodę do celów gaśniczych wynikające $\mathrm{z}$ form prowadzonych działań w natarciu, opóźnianiu rozwoju, obronie, osłonie czy też kombinacji tych form występujących $\mathrm{w}$ tym samym czasie operacyjnym. KDR powinien być przygotowany na wybranie wariantu taktycznego dla konkretnego obiektu/obszaru objętego pożarem oraz dla konkretnych obiektów/obszarów zagrożonych pożarem.

Rzeczą nadrzędną do zbudowania systemu zaopatrzenia o założonych parametrach wynikających z danej sytuacji pożarowej i rozwijającego się zagrożenia jest określenie wydajności wymaganej $\mathbf{Q}_{\mathbf{w}}\left[\mathrm{dm}^{3} / \mathrm{min}\right]$ do lokalizacji i likwidacji pożaru i zagrożeń jemu towarzyszących. W celu lokalizacji i likwidacji pożaru należy przeprowadzić następujące formy działań gaśniczych: $\mathbf{Q}_{\text {wnatarcia }}\left[\mathrm{dm}^{3} /\right.$ $\mathrm{min}]$ natarcie gaśnicze, $\mathbf{Q}_{\text {wopóźniania }}\left[\mathrm{dm}^{3} / \mathrm{min}\right]$ opóźnianie rozprzestrzeniania się pożaru, $\mathbf{Q}_{\text {wobrony }}\left[\mathrm{dm}^{3} / \mathrm{min}\right]$ obronę i $\mathbf{Q}_{\text {wosłony }}\left[\mathrm{dm}^{3} / \mathrm{min}\right]$ osłonę.

$$
\mathbf{Q}_{\mathbf{w}}\left[\mathrm{dm}^{3} / \mathrm{min}\right]=\mathbf{Q}_{\mathbf{w n a t a r c i a}}+\mathbf{Q}_{\mathbf{w o p o ́ z ́ n i a n i a ~}}+\mathbf{Q}_{\text {wobrony }}+\mathbf{Q}_{\text {wosłony }}
$$


Kolejnym parametrem, jaki powinien uwzględnić KDR, jest powierzchnia pożaru $\mathbf{F}_{\text {póz }}\left[\mathrm{m}^{2}\right]$ lub powierzchnia obrony $\mathbf{F}_{\text {obr }}\left[\mathrm{m}^{2}\right]$ oraz powierzchnia gaszenia $\mathbf{F}_{\text {gasz }}\left[\mathrm{m}^{2}\right]$. Powierzchnia gaszenia jest parametrem stanowiska gaśniczego, a ono jest związane bezpośrednio z zastosowanym typem urządzeń do podawania strug gaśniczych, obronnych i osłonowych, ciśnieniem $\mathbf{P}[\mathrm{MPa}]$ dostarczonym do tego urządzenia oraz z zasięgami rzutu poziomego $\mathbf{L}_{\mathbf{p o z}}[\mathrm{m}]$ i pionowego $\mathbf{L}_{\text {pio }}$ strugi gaśniczej. Dla pożarów o charakterze przemysłowym należy stosować, do kalkulacji operacyjnych naliczania sił i środków ratowniczych niezbędnych do lokalizacji i likwidacji pożaru, wartości intensywności podawania powierzchniowego środków gaśniczych $\mathbf{I}_{\text {pow }}$ w zakresie od $3\left[\mathrm{dm}^{3} /\left(\mathrm{m}^{2 *} \mathrm{~min}\right)\right]$ do $12\left[\mathrm{dm}^{3} /\left(\mathrm{m}^{2 *} \mathrm{~min}\right)\right]$, a przypadkach szczególnych nawet $20\left[\mathrm{dm}^{3} /\left(\mathrm{m}^{2 *} \mathrm{~min}\right)\right]$. Podczas określania wartości intensywności należy uwzględnić rodzaj środka gaśniczego. Do urządzeń gaśniczych może być dostarczana woda lub wodny roztwór środków pianotwórczych.

W celu określenia wydajności systemów zaopatrzenia KDR musi znać wartość $\mathbf{Q}_{\mathbf{W}}$, aby zaprojektować układ zasilający spełniający wymagania i zapewniający ilość dodatkową (awaryjną) w zakresie $25-50 \% \mathbf{Q}_{\mathbf{w}}$. Do gaśniczych działań przemysłowych podstawowym urządzeniem do podawania strug gaśniczych są działka wodno-pianowe DWP o wydajności wodnej w zakresie od $2500 \mathrm{do} 12000\left[\mathrm{dm}^{3} / \mathrm{min}\right]$ w zakładach przemysłowych i rafineriach, w szczególnych przypadkach znalazły zastosowanie DWP o wydajności wodnej 24000 [dm³/min].

\section{Przykładowa kalkulacja}

Zakładana powierzchnia pożaru:

$$
\mathrm{F}_{\mathrm{poz}}=100 * 50=5000\left[\mathrm{~m}^{2}\right]
$$

Zakładana intensywność powierzchniowa natarcia:

$$
\mathrm{I}_{\text {pownat }}=6\left[\mathrm{dm}^{3} /\left(\mathrm{m}^{2 *} \mathrm{~min}\right)\right]
$$

Szacowana wydajność wymagana do lokalizacji i likwidacji pożaru:

$$
\begin{aligned}
\mathrm{Q}_{\mathrm{w} \text { natarcia }} & =\mathrm{F}_{\mathrm{poz}}{ }^{\star} \mathrm{I}_{\mathrm{pow}}=5000\left[\mathrm{~m}^{2}\right]^{\star} 6\left[\mathrm{dm}^{3} /\left(\mathrm{m}^{2 \star} \mathrm{min}\right)\right]= \\
& =30000\left[\mathrm{dm}^{3} / \mathrm{min}\right]=30\left[\mathrm{~m}^{3} / \mathrm{min}\right]
\end{aligned}
$$

Zakładana powierzchnia obrony (obwód pierwotnej powierzchni pożaru $\times$ głębokość działania stanowisk obronnych $20[\mathrm{~m}])$ :

$$
\mathrm{F}_{\text {obr }}=(100+50+100+50) \star 20=6000\left[\mathrm{~m}^{2}\right]
$$

Zakładana intensywność powierzchniowa obrony:

$$
I_{\text {powobr }}=3\left[\mathrm{dm}^{3} /\left(\mathrm{m}^{2 \star} \min \right)\right]
$$

Szacowana wydajność wymagana do obrony:

$$
\mathrm{Q}_{\text {wobrony }}=6000 * 3=18000\left[\mathrm{dm}^{3} / \mathrm{min}\right]=18\left[\mathrm{~m}^{3} / \mathrm{min}\right]
$$


Z powyższej kalkulacji wynika, że łączne zapotrzebowanie na wodę do działań gaśniczych i obronnych wynosi:

$$
\mathrm{Q}_{\mathrm{W}}=48000\left[\mathrm{dm}^{3} / \mathrm{min}\right]=48\left[\mathrm{~m}^{3} / \mathrm{min}\right]
$$

Uwzględniając dodatkowy 25-proc. (awaryjny) zapas wody, zapotrzebowanie na wodę do działań gaśniczych i obronnych wynosi:

$$
\mathrm{Q}_{\mathrm{w}+25 \%}=48\left[\mathrm{~m}^{3} / \mathrm{min}\right]+\mathrm{Q}_{\mathrm{w}} 25 \%=60\left[\mathrm{~m}^{3} / \mathrm{min}\right]
$$

Uwzględniając dodatkowy 50-proc. (awaryjny) zapas wody, zapotrzebowanie na wodę do działań gaśniczych i obronnych wynosi:

$$
\mathrm{Q}_{\mathrm{w}+50 \%}=48\left[\mathrm{~m}^{3} / \mathrm{min}\right]+\mathrm{Q}_{\mathrm{w}} 50 \%=72\left[\mathrm{~m}^{3} / \mathrm{min}\right]
$$

Ważnym parametrem do określenia zapotrzebowania na środki gaśnicze jest czas podawania środków gaśniczych. Natarcie i obrona mogą trwać od kilkudziesięciu minut do nawet kilkunastu godzin. $Z$ uwzględnienia powyższych kalkulacji i określenia czasu trwania podawania środków gaśniczych np.: 180 [min] wynika, że zapas wody do wszystkich działań gaśniczych, zakładając 25-proc. zapas awaryjny, nie może być mniejszy niż $10800\left[\mathrm{~m}^{3}\right]$.

Potencjał bojowy pododdziału lub oddziału wyznaczonego do realizacji zadań ratowniczych jest związany ściśle z rodzajami pojazdów i sprzętu gaśniczego i rodzajami pojazdów i sprzętu wsparcia działań gaśniczych. Pododdział, jaki powinien zostać zadysponowany do pożaru zbiornika czy instalacji technologicznej w zakładzie przemysłowym, nie może być mniejszy niż kompania gaśnicza, charakteryzująca się maksymalną samodzielnością i samowystarczalnością. Jej skład powinien pozwalać na realizację wariantów taktycznych podczas pożarów dużych i bardzo dużych. Ze względu na skuteczność i wielowariantowe wykorzystanie powinna składać się z czterech plutonów. Za realizację zadań wynikających $\mathrm{z}$ budowy układu zaopatrzenia wodnego odpowiedzialne są pododdziały wsparcia działań gaśniczych, których podstawowym elementem jest sekcja pompowo-wężowa w składzie: samochód wężowy (SW) z wężami tłocznymi W110 o zasięgu wężowym od 3000 do 5000 [m] oraz dwie motopompy o wydajności wodnej nie mniejszej niż $4000\left[\mathrm{dm}^{3} / \mathrm{min}\right]$ i ciśnieniu nominalnym nie mniejszym niż 0,8 $[\mathrm{MPa}]=8$ [bar] np.: M40/8, M60/8, M80/8. W celu usprawnienia procesu podejmowania decyzji przez KDR w zakresie budowy układu zaopatrzenia wodnego należy wykorzystać dane operacyjne zawarte $\mathrm{w}$ tab. 3. Tabela zawiera dane dla węży tłocznych stosowanych w Polsce W75 i W110 oraz węży W125 i W150 stosowanych w innych krajach na świecie. Badania realizowane w skali rzeczywistej, dla określenia optymalnych parametrów przesyłania wody do celów gaśniczych z wykorzystaniem węży, armatury i pomp pożarniczych stosowanych powszechnie w Polsce wykazały, że przy ciśnieniu tłoczenia wody rzędu 0,8 [MPa] dla węży tłocznych W75 optymalną odległością tłoczenia wody będzie dystans wężowy około 300 [m], gdzie wydajność wodna układu zasilającego będzie wynosiła około 
1150 [dm³/min], a dla węży tłocznych W110 optymalną odległością tłoczenia wody będzie dystans wężowy około 500 [m], gdzie wydajność wodna układu zasilającego będzie wynosiła około $2690\left[\mathrm{dm}^{3} / \mathrm{min}\right]$.

\section{Analiza możliwości techniczno-taktycznych kompanii gaśniczej}

1. Analiza możliwości techniczno-taktycznych kompanii gaśniczej w wariancie podstawowym do realizacji zaopatrzenia wodnego pomiędzy stanowiskiem czerpania wody a miejscem magazynowania i dystrybuowania wody do gaszenia przy zastosowaniu układu pompowo-wężowego $\mathrm{z}$ wykorzystaniem wszystkich zastępów gaśniczych.

1.1. na dystansie $3000[\mathrm{~m}] \mathrm{z}$ wykorzystaniem:

1.1.1. 3000 m węża tłocznego W 110 - pojedyncza linia zasilająca $1 \times 3000[\mathrm{~m}]$;

1.1.2. pomp pożarniczych rozstawionych co $500 \mathrm{~m}$ : A50/8, A50/8, A50/8, M40/8, M40/8, A32/8.

Przewidywana wydajność układu zaopatrzenia, w terenie płaskim, wynosić będzie około $2600\left[\mathrm{dm}^{3} / \mathrm{min}\right]$.

1.2. na dystansie $1500[\mathrm{~m}] \mathrm{z}$ wykorzystaniem:

1.2.1. $3000 \mathrm{~m}$ węża tłocznego W 110 - linia zasilająca składająca się $\mathrm{z}$ dwóch równolegle ułożonych węży $2 \times 1500[\mathrm{~m}]$;

1.2.2. pomp pożarniczych rozstawionych co 500 [m]: M40/8, M40/8, A32/8, A32/8, A32/8, A32/8, A32/8, A20/8.

Przewidywana wydajność układu zaopatrzenia, w terenie płaskim, wynosić będzie około $5200\left[\mathrm{dm}^{3} / \mathrm{min}\right]$.

1.3. na dystansie $1000[\mathrm{~m}]$

1.3.1. $3000 \mathrm{~m}$ węża tłocznego W 110 - linia zasilająca składająca się $\mathrm{z}$ trzech równolegle ułożonych węży $3 \times 1000$ [m];

1.3.2. pomp pożarniczych rozstawionych co 500 [m]: M40/8, M40/8, A32/8, A32/8, A32/8, A32/8, A32/8, A20/8, A20/8.

Przewidywana wydajność układu zaopatrzenia, w terenie płaskim, wynosić będzie około $7800\left[\mathrm{dm}^{3} / \mathrm{min}^{2}\right.$.

1.4. na dystansie $500[\mathrm{~m}]$

1.4.1. $3000 \mathrm{~m}$ węża tłocznego W 110 - linia zasilająca składająca się z sześciu równolegle ułożonych węży 6 x 500 [m];

1.4.2. pomp pożarniczych tłoczących na dystansie 500 [m]: M40/8, M40/8, A32/8, A32/8, A32/8, A32/8. 
Przewidywana wydajność układu zaopatrzenia, w terenie płaskim, wynosić będzie około $15600\left[\mathrm{dm}^{3} / \mathrm{min}\right]$.

2. Analiza możliwości techniczno-taktycznych kompanii gaśniczej w wariancie przemysłowym do realizacji zaopatrzenia wodnego pomiędzy stanowiskiem czerpania wody a miejscem magazynowania i dystrybuowania wody do gaszenia przy zastosowaniu układu pompowo-wężowego $\mathrm{z}$ wykorzystaniem wszystkich zastępów gaśniczych .

2.1. na dystansie $3000[\mathrm{~m}] \mathrm{z}$ wykorzystaniem:

2.1.1. 3000 m węża tłocznego W 110 - pojedyncza linia zasilająca $1 \times 3000[\mathrm{~m}]$;

2.1.2. pomp pożarniczych rozstawionych co $500 \mathrm{~m}$ : A50/8, A50/8, A50/8, M40/8, M40/8, A32/8.

Przewidywana wydajność układu zaopatrzenia, w terenie płaskim, wynosić będzie około 2600 [ $\left.\mathrm{dm}^{3} / \mathrm{min}\right]$.

2.2. na dystansie $1500[\mathrm{~m}] \mathrm{z}$ wykorzystaniem:

2.2.1. $3000 \mathrm{~m}$ węża tłocznego W 110 - linia zasilająca składająca się $\mathrm{z}$ dwóch równolegle ułożonych węży $2 \times 1500$ [m];

2.2.2. pomp pożarniczych rozstawionych co 500 [m]: M40/8, M40/8, A50/8, A50/8, A50/8.

Przewidywana wydajność układu zaopatrzenia, w terenie płaskim, wynosić będzie około $5200\left[\mathrm{dm}^{3} / \mathrm{min}^{\mathrm{m}}\right.$.

2.3. na dystansie $1000[\mathrm{~m}] \mathrm{z}$ wykorzystaniem:

2.3.1. $3000 \mathrm{~m}$ węża tłocznego W 110 - linia zasilająca składająca się $z$ trzech równolegle ułożonych węży $3 \times 1000[\mathrm{~m}]$;

2.3.2. pomp pożarniczych rozstawionych co 500 [m]: M40/8, M40/8, A50/8, A50/8, A32/8, A32/8, A32/8.

Przewidywana wydajność układu zaopatrzenia, $w$ terenie płaskim, wynosić będzie około $7800\left[\mathrm{dm}^{3} / \mathrm{min}\right]$.

2.4. na dystansie $500[\mathrm{~m}] \mathrm{z}$ wykorzystaniem:

2.4.1. $3000 \mathrm{~m}$ węża tłocznego W 110 - linia zasilająca składająca się z sześciu równolegle ułożonych węży $6 \times 500[\mathrm{~m}]$;

2.4.2. pomp pożarniczych tłoczących na dystansie $500[\mathrm{~m}]: \mathrm{M} 40 / 8$, M40/8, A50/8, A50/8.

Przewidywana wydajność układu zaopatrzenia, $w$ terenie płaskim, wynosić będzie około $15600\left[\mathrm{dm}^{3} / \mathrm{min}\right]$.

3. Analiza możliwości techniczno-taktycznych kompanii gaśniczej w wariancie przemysłowym, $z$ dwoma plutonami wsparcia, do realizacji zaopatrzenia wodnego pomiędzy stanowiskiem czerpania wody a miejscem magazynowania 
i dystrybuowania wody do gaszenia przy zastosowaniu układu pompowo-wężowego z wykorzystaniem wszystkich zastępów gaśniczych .

3.1. na dystansie 3000 [m] z wykorzystaniem:

3.1.1. 10000 m węża łłocznego W 110 - linia zasilająca składająca się $\mathrm{z}$ trzech równolegle ułożonych węży $3 \times 3000[\mathrm{~m}]$;

3.1.2. pomp pożarniczych rozstawionych co $500 \mathrm{~m}: \mathrm{M} 80 / 8, \mathrm{M} 80 / 8$, M80/8, M80/8, A50/8, A32/8, A50/8, A32/8.

Przewidywana wydajność układu zaopatrzenia, w terenie płaskim, wynosić będzie około 7800 [ $\left.\mathrm{dm}^{3} / \mathrm{min}\right]$.

3.2. na dystansie 1500 [m] z wykorzystaniem:

3.2.1. 10000 m węża tłocznego W 110 - linia zasilająca składająca się z sześciu równolegle ułożonych węży $6 \times 1500[\mathrm{~m}]$;

3.2.2. pomp pożarniczych rozstawionych co 500 [m]: M80/8, M80/8, M80/8, M80/8, A50/8, A32/8, A50/8, A32/8.

Przewidywana wydajność układu zaopatrzenia, w terenie płaskim, wynosić będzie około 15600 [ $\left.\mathrm{dm}^{3} / \mathrm{min}\right]$.

3.3. na dystansie $1000[\mathrm{~m}] \mathrm{z}$ wykorzystaniem:

3.3.1. 10000 m węża tłocznego W 110 - linia zasilająca składająca się $\mathrm{z}$ dziewięciu równolegle ułożonych węży $9 \times 1000[\mathrm{~m}]$;

3.3.2. pomp pożarniczych rozstawionych co 500 [m]: M80/8, M80/8, M80/8, M80/8, A50/8, A32/8, A50/8, A32/8.

Przewidywana wydajność układu zaopatrzenia, w terenie płaskim, wynosić będzie około 23400 [ $\left.\mathrm{dm}^{3} / \mathrm{min}\right]$.

3.4. na dystansie 500 [m]

3.4.1. 10000 m węża tłocznego W 110 - linia zasilająca składająca się $\mathrm{z}$ osiemnastu równolegle ułożonych węży $18 \times 500[\mathrm{~m}]$;

3.4.2. pomp pożarniczych tłoczących na dystansie $500[\mathrm{~m}]: \mathrm{M} 80 / 8$, M80/8, M80/8, M80/8, A50/8, A32/8, A50/8, A32/8.

Przewidywana wydajność układu zaopatrzenia, $w$ terenie płaskim, wynosić będzie około 46800 [ $\left.\mathrm{dm}^{3} / \mathrm{min}\right]$.

W Europie do budowy wysokowydajnych systemów zaopatrzenia w wodę do celów gaśniczych stosowane są obecnie zestawy pompowe o wydajności nie mniejszej niż 10000 $\left[\mathrm{dm}^{3} / \mathrm{min}\right]$ i ciśnieniu tłoczenia wody nie mniejszym niż 1,2 [MPa]. Do współpracy z powyższymi pompami przygotowane są moduły wężowe wyposażone w węże tłoczne o średnicy 150 lub 300 [mm]. W jednym module wężowym może być od 5000 [m] do $10000[\mathrm{~m}]$ węży ułożonych w systemie szybkiego sprawiania. Rozpatrując moduł wężowy o długości 5000 [m] i założeniu, że pojazd z modułem będzie poruszał się z prędkością $250[\mathrm{~m} / \mathrm{min}]$ czas sprawienia linii zasilającej na dystansie 5000 [m] wynosić będzie około 20 [min]. Dla porównania w Polsce samochód wężowy, ze względów konstrukcyjnych, nie będzie poruszał się szybciej niż 80 [m/min], czyli czas sprawienia SW 5000 będzie 
trwał około 62 [min]. Przy zastosowaniu węży tłocznych o średnicy 150 [mm] straty ciśnienia w zasilających liniach wężowych będą mniejsze niż dla węży stosowanych w Polsce. Parametry do porównania przedstawia tabela nr 2. Jeżeli zastosuje się węże zasilające o średnicach 150 [mm], odległości między pompami mogą być większe nawet pięciokrotnie przy zachowaniu podobnych parametrów wydajności wodnej dostarczanej do kolejnych punktów transportowania wody do celów gaśniczych.

\section{Przykłady techniki pożarniczej wchodzącej w skład WBO dostępnej na terenie województwa lubuskiego, jakie mogą być wykorzystane do współpracy z MTSRG}

Na rysunkach 3-11 przedstawiono wybrane przykłady techniki pożarniczej wchodzącej w skład Lubuskiej Wojewódzkiej Brygady Obwodowej (WBO), które mogą być wykorzystane do współpracy z MTSRG podczas działań rzeczywistych oraz testów poligonowych.

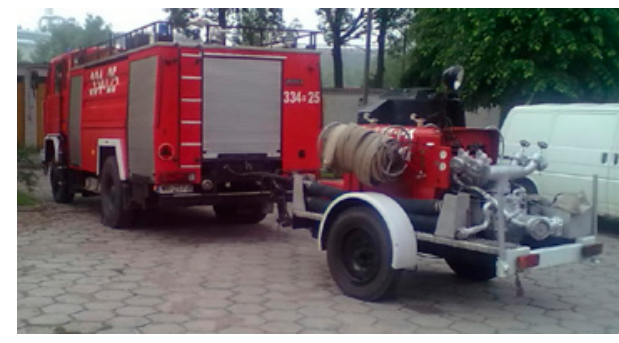

Rysunek 3. Samochód GCBA 5/32 wraz z motopompą M48/8

Figure 3. Heavy firefighting vehicle GCBA 5/32 with motor pomp M48/8

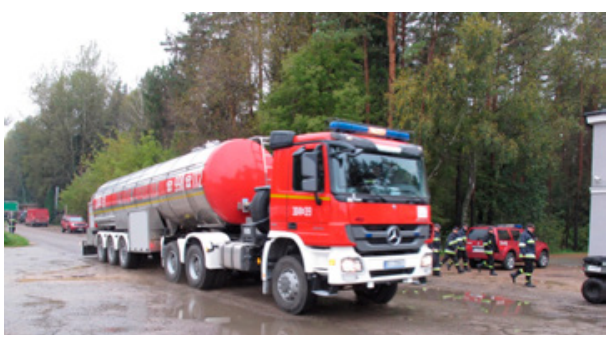

Rysunek 5. Cysterna GCBM 25/16 podczas działań gaśniczych - dowożenie wody do pożaru Figure5. Heavy water tank GCBM 25/16 in time of rescue operation

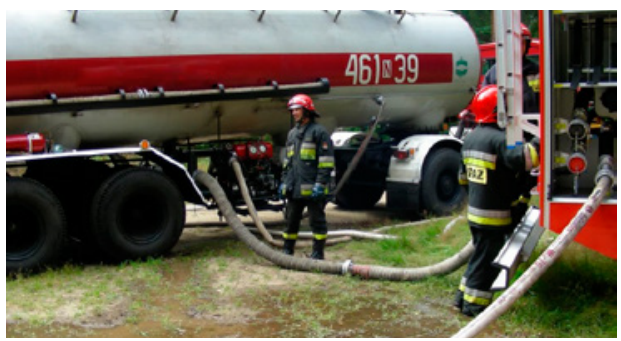

Rysunek 4. Cysterna GCBM 18/8 podczas działań gaśniczych - magazynowanie i dystrybucja wody do celów gaśniczych podczas sytemu dowożenia

Figure 4. Heavy water tank GCBM 18/8 in time of rescue operation - storage and distribution of water for extinguishing purposes during the trucking system

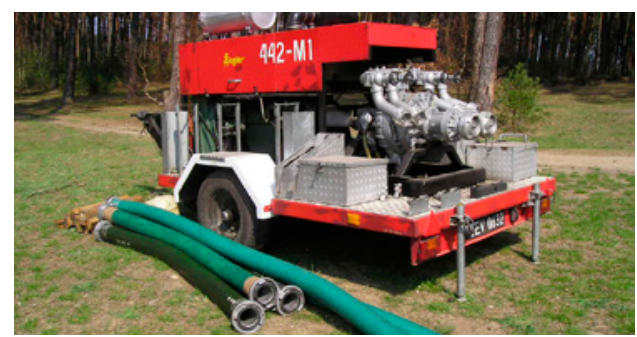

Rysunek 6. Motopompa M48/8 wraz z wężami ssawnymi o długości 2,4 [m] i 4,0 [m]

Figure 6. Motor pump M48/8 with 2,4 and 4 [m] suck hoses 


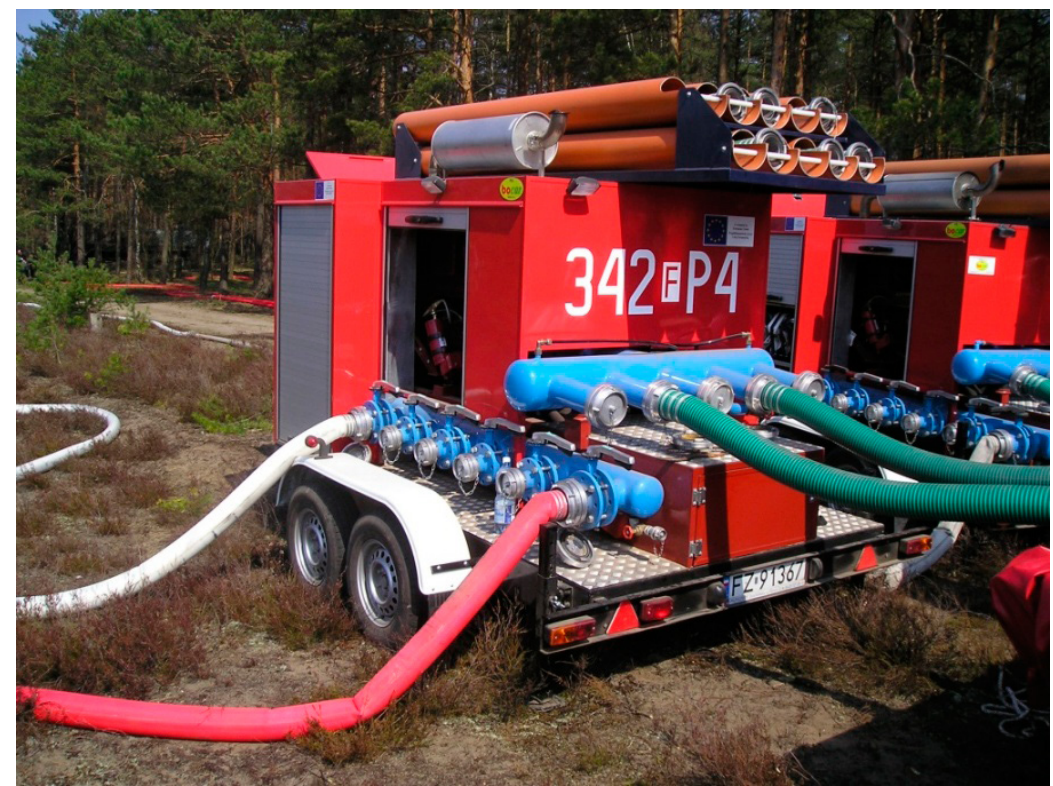

Rysunek 7. Motopompa M80/8

Figure 7. Motor pump M80/8

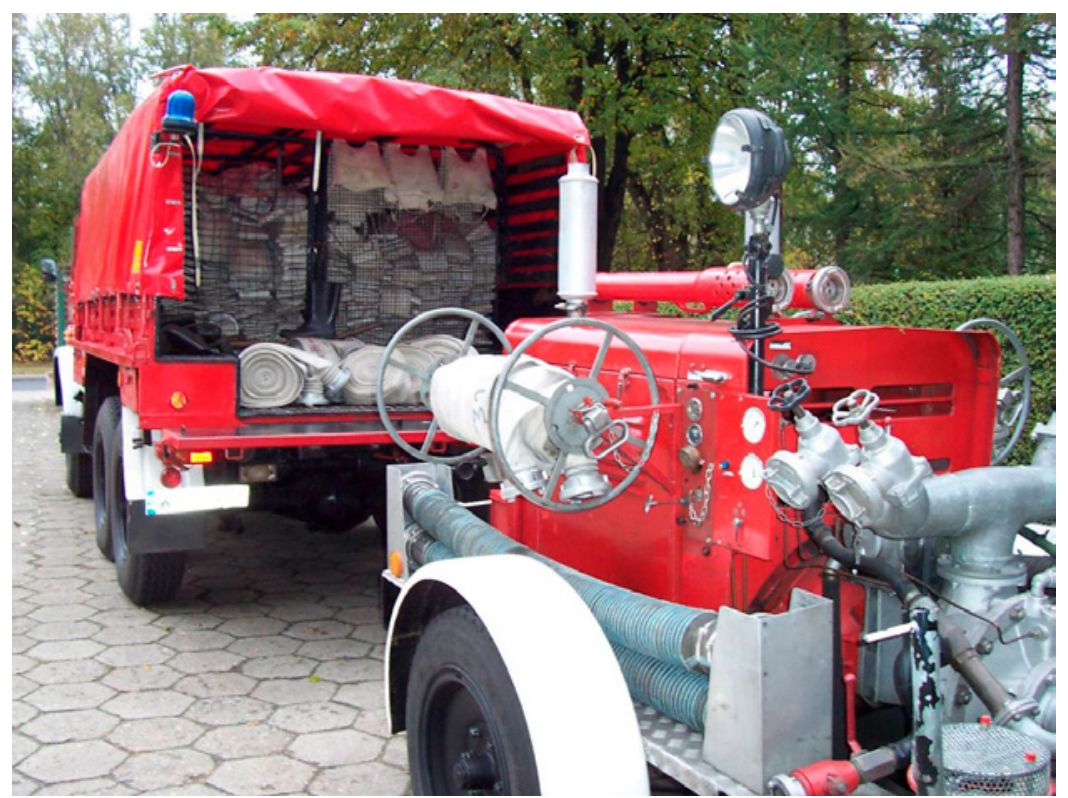

Rysunek 8. Zastęp SW 5000 wraz z motopompą M48/8 - powszechne rozwiązanie techniczno-organizacyjne w latach 80 i $90 \mathrm{XX}$ wieku - konstrukcja o optymalnych parametrach taktyczno-technicznych

Figure 8. Unit of the SW 5000 with the M48/8 water pump - a common technical and organizational solution in the 80's and 90's of the last century - a structure with optimal tactical and technical parameters 


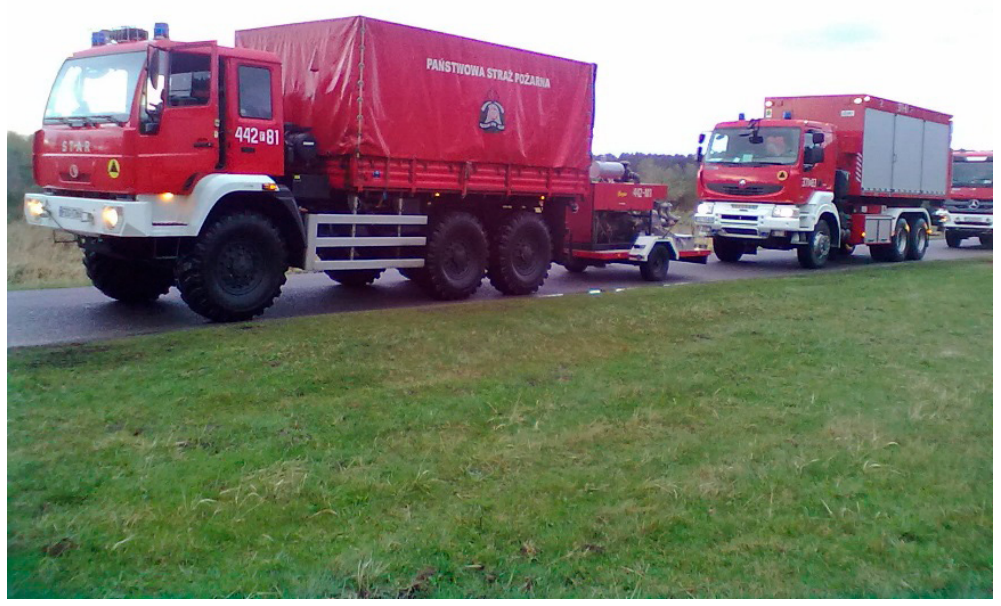

Rysunek 9. Sekcja pompowo-wężowa kompanii gaśniczej WBO składająca się zastępu kwatermistrzowskiego SCKw przewożącego zbiornik do magazynowania wody do celów gaśniczych o pojemności $50 \mathrm{~m}^{3}$ wraz z motopompą M80/8 oraz nośnik kontenerowy z modułem wężowym do przewożenia 150 szt. węży tłocznych W 110 (zasięg taktyczny sekcji 3000 [m]) Figure 9. Pumping and hose section of the WBO firefighting company consisting of a quartermaster unit SCKw carrying a water storage tank for $50 \mathrm{~m}^{3}$ with motor pump M80/8 and a container carrier with a hose module for carrying 150 feeding hoses W 110 (tactical range of section 3000 [m])

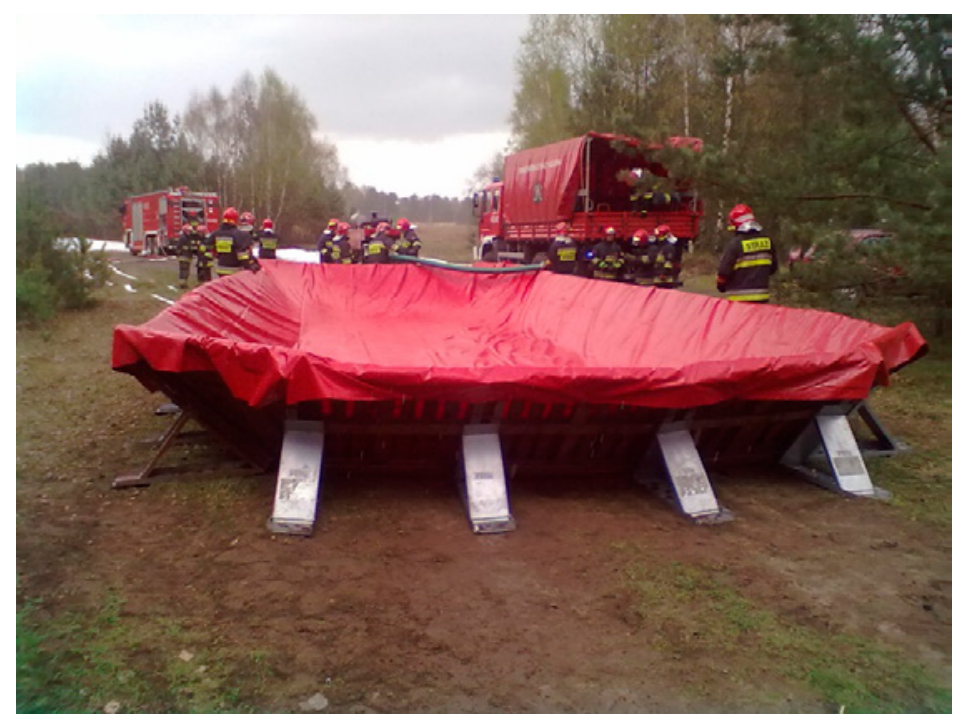

Rysunek 10. Zbiornik składany do magazynowania wody do celów gaśniczych o pojemności $50\left[\mathrm{~m}^{3}\right]$

Figure 10. Folding tank for storage of water for extinguishing purposes with a capacity $50\left[\mathrm{~m}^{3}\right]$ 


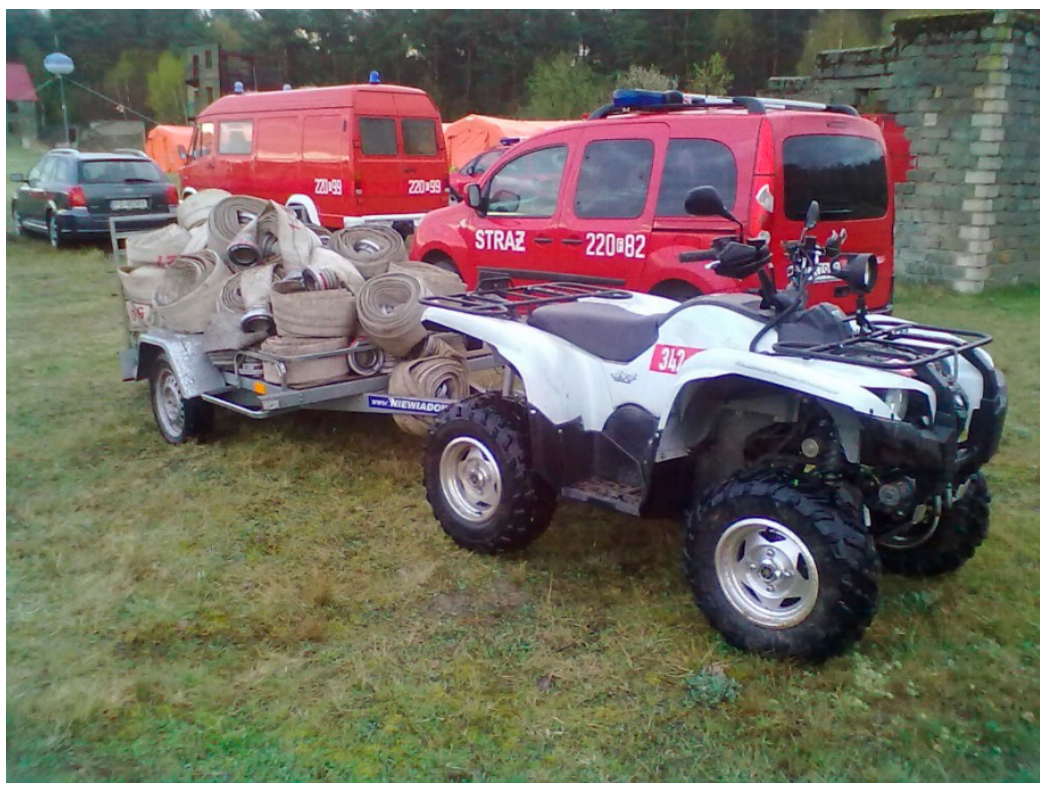

Rysunek 11. Quad z przyczepą do dozorowania zasilających linii wężowych Figure 11. Quad with a trailer for monitoring of feeding hose lines

\section{Wnioski}

Zważywszy na fakt, iż w czasie dużych zdarzeń działanie na terenie obszarów leśnych oraz przemysłowych, a także sama konieczność zasilenia mobilnego turbinowego systemu ratowniczo-gaśniczego (MTSRG) wymaga znacznych ilości wody, niezbędne jest zastosowanie sprawnych rozwiązań umożliwiających ciągłe i wydajne dostarczanie wody. Należy zatem stosować się do niniejszych zasad:

- Czas sprawienia linii zasilających przy użyciu samochodów wężowych, zestawów kontenerowych z wężami czy przyczepek wężowych zależny jest od prędkości przejazdu zestawu podczas sprawiania, sposobu ułożenia i przygotowania węży do transportu. Prędkość ta wynosić powinna około $10[\mathrm{~km} / \mathrm{h}]=$ $=166[\mathrm{~m} / \mathrm{min}]$.

- Czas sprawienia linii zasilającej na dystansie 500 [m] nie powinien przekroczyć trzech minut, a na dystansie 1000 [m] - sześciu minut. W kalkulacji należy uwzględnić czas sprawienia pomp pożarniczych przy źródle wody oraz sprawiania pomp zasilających stanowiska gaśnicze, w zależności od wariantów taktycznych.

- Przy dystansach, między pożarem i źródłem wody, w granicach 1000 m należy uwzględnić zastosowanie pomp pośrednich do przetłaczania. Zwiększy to wydajność istniejących linii zasilających. 
- Podczas sprawiania linii zasilających istotnym elementem całego układu zasilania są rozdzielacze, zbieracze i zawory liniowe dostosowane do stosowanych średnic węży tłoczących wodę. Do współpracy z wężami W 110 najlepiej nadają się rozdzielacze wyposażone w następujące nasady: 110-75/75/75/75-110 m.

- Uszkodzone odcinki tłoczące wodę powinny być w pierwszej kolejności naprawiane bandażami do węży, a w ostateczności wymieniane. Wymianę uszkodzonych odcinków ułatwiają specjalne zaciski do węży. Zapobiegają one wylewaniu się wody z magistrali zasilających, co skraca czas ponownego włączenia magistrali do dalszej pracy.

- Sprawna budowa układów gaśniczych jest możliwa po wcześniejszym rozpoznaniu (przed pożarem) źródeł wody sieci hydrantowej, zbiorników i cieków, które można wykorzystać do celów zaopatrzenia; należy precyzyjnie określić ich wydajności i/lub pojemności oraz odległości od ewentualnych miejsc wystąpienia zagrożenia do źródeł wody.

- W celu maksymalnego wykorzystania środków technicznych użytych do budowy układów gaśniczych w pierwszej kolejności należy stosować przetłaczanie, a potem przepompowywanie.

- Dowożenie wody do gaszenia pożaru przy zapotrzebowaniu większym niż 3000 l/min jest błędem i można je stosować jedynie jako element uzupełniający przy dostatecznej ilości sił i środków.

- Budując rozległe sieci magistrali zasilających, tarasujące drogi dojazdowe do obiektów, należy stosować mostki przejazdowe lub/i systemy pomostów nad magistralami. Najlepszym rozwiązaniem jest zaplanowanie bezkolizyjnego ułożenia magistrali zasilających.

- Zwiększenie średnic węży stosowanych do zasilania redukuje liczbę węży tarasujących drogi dojazdowe, dzięki czemu zwiększają się możliwości przegrupowania sił i środków.

- Należy dążyć do tego, by kompanie gaśnicze o charakterze przemysłowym były wyposażone $w$ rozwiązania systemowe ułatwiające sprawianie magistrali zasilających z minimalnym udziałem ratowników.

- Za rozwiązanie systemowe należy uznać możliwość przewożenia w jednym module sprzętowym węży W 110 o łącznej długości 5000 [m]. Jeden przejazd musi umożliwiać ułożenie co najmniej dwóch równoległych linii zasilających. W przypadku stosowania węży W 110 idealnym rozwiązaniem byłoby ułożenie czterech równoległych magistrali podczas jednego przejazdu (węże ułożone w czterech łożach).

- Moduły sprzętowe do pożarów przemysłowych powinny być wyposażone w węże tłoczne o średnicy minimum 150 [mm]. 


\section{Bibliografia}

[1] Adamski A., Król B., Techniczne aspekty zaopatrzenia wodnego, materiały konferencyjne „Tendencje rozwojowe w technikach ratowniczych i wyposażeniu technicznym”, Kraków 2009.

[2] Adamski A., Król B., Zaopatrzenie wodne XXL, „Przegląd Pożarniczy”, 9/2009.

[3] Adamski A., Wysoczyński P., Systemy pompowo-wężowe zaopatrzenia wodnego podczas akcji gaśniczych $w$ bazach paliw płynnych, materiały konferencyjne „Bezpieczeństwo pożarowe w bazach paliw płynnych", Bydgoszcz 2011.

[4] Adamski A., Wysoczyński P., Taktyka kompanii KSRG podczas pożarów w magazynowych bazach paliw płynnych, materiały konferencyjne „Bezpieczeństwo pożarowe w bazach paliw płynnych", Reda 2012.

[5] Eckaman W.F., The Fire Department Water Supply Handbook, Fire Engineering Book and Videos, 1994. 


\title{
Wykorzystanie środków dekontaminacyjnych w mobilnym turbinowym systemie ratowniczo-gaśniczym
}

\author{
Usage of decontaminants in the mobile turbine \\ powered extinguishing system
}

\author{
Jacek Pirszel \\ Wojskowy Instytut Chemii i Radiometrii
}

\section{Streszczenie}

Cel: Celem przedstawionych badań było sprawdzenie stabilności wybranych składników odkażalników w warunkach symulujacych strumień gazów wylotowych z silnika turboodrzutowego w mobilnym turbinowym systemie ratowniczo-gaśniczym.

Wprowadzenie: Użycie turbinowego sytemu ratowniczo-gaśniczego do likwidacji skażeń substancjami wysokotoksycznymi, takimi jak bojowe środki trujące, wymaga użycia odkażalników zawierających $w$ składzie reaktywne substancje, między innymi związki nadtlenowe i podchloryny. Te składniki odkażalników moga reagować nie tylko z substancjami, które stanowia skażenie, ale także $z$ innymi reaktywnymi związkami, np. obecnymi $w$ strumieniu gazów wylotowych z silnika turboodrzutowego.

Metodologia: W celu sprawdzenia stabilności odkażalników wprowadzano roztwory odkażalników do strumienia gazów spalinowych symulujących strumień gazów wylotowych z silnika i badano zmianę stężenia aktywnych składników odkażalników po kontakcie z gazami spalinowymi stosujac metody miareczkowe.

Wyniki: Stwierdzono, że dichloroizocyjanuronian sodu, podchloryn wapnia, nadsiarczan sodu nie ulegaja w tych warunkach rozkładowi w stopniu mogacym wpływać na aktywność odkażalników. Nie stwierdzono także rozkładu środków powierzchniowo czynnych stosowanych $w$ odkażalnikach. Jedynie w przypadku nadftalanu magnezu stwierdzono rozkład w stopniu mogacym mieć wpływ na działanie odkażalnika.

Wnioski: Wyniki badań wskazuja, że większość badanych odkażalników może być stosowana $w$ turbinowym systemie ratowniczo-gaśniczym bez znaczacej zmiany aktywności.

\section{Abstract}

Objective: The objective was stability measurement of decontaminants in exhaust gases from jet turbine engine used in mobile turbine powered extinguishing system (combustion gases stream was used instead of exhaust gases from jet turbine).

Introduction: Decontaminants used for decontamination of chemical warfare contains highly reactive compounds, eg. hypochlorites or peroxy compounds. These substances can to react with some reactive compounds present in exhaust gases from jet turbine, therefore stability of decontaminants in such conditions must be examined. 
Methodology: Solutions of decontaminants were injected into stream of combustion gases simulating exhaust gases from jet turbine engine and changes of concentration of decontaminants components were measured. Titration methods were used for determination of concentration of peroxy compounds, hypochlorites and surfactants.

Results: Changes of concentration of sodium salt of dichloroisocyanuric acid, sodium persulfate, calcium hypochlorite, and surfactants was small, only stability of magnesium perftalate was lower.

Conclusions: Most of tested decontaminants can be used in mobile turbine powered extinguishing system without risk of significant drop of activity.

\section{Wstęp}

Jedną z zalet turbinowego sytemu ratowniczo-gaśniczego jest możliwość wykorzystania go do odkażania dużych powierzchni w krótkim czasie. Ma to istotne znaczenie w przypadku skażeń m.in. zakładów przemysłowych lub obiektów infrastruktury o krytycznym znaczeniu dla komunikacji i transportu, takich jak lotniska, węzły drogowe i kolejowe, porty. Dla obiektów tego typu naturalne jest ich zagrożenie skażeniem $\mathrm{z}$ uwagi na transport i przeładunek niebezpiecznych materiałów lub ich produkcję i przetwarzanie. Należy także uwzględnić zagrożenie wynikające z celowych działań, zwłaszcza że obserwowany jest wzrost zagrożenia terroryzmem. „Typowe” skażenia chemiczne powodowane są często wyciekami z uszkodzonych rurociągów, cystern itp., ich zlokalizowanie jest łatwe, a działania zwykle prowadzone są na stosunkowo niewielkim obszarze i związane są w dużym stopniu z likwidacją nieszczelności, przepompowywaniem substancji, likwidacją rozlewów. W przypadku działań terrorystycznych, celem może być skażenie jak największego obszaru. Należy przy tym założyć możliwość użycia substancji wysokotoksycznych o właściwościach zbliżonych do bojowych środków trujących, lub nawet mogą to być bojowe środki trujące. Substancje takie mogą powodować zagrożenie dla życia lub zdrowia już w ilościach mikrogramowych, a skażenie powierzchni na poziomie miligramów/m² może wymagać przeprowadzenia zabiegów likwidacji skażeń na obszarach tysięcy metrów kwadratowych. Możliwość użycia do tego celu tak wydajnych narzędzi jak turbinowy system ratowniczo-gaśniczy może pozwolić na efektywne odkażanie dużych powierzchni (obiektów) i szybkie przywrócenie ich do użytkowania. Ma znaczenie nie tylko ekonomiczne, ale także i psychologiczne. Duża część preparatów stosowanych do likwidacji skażeń związkami wysokotoksycznymi może być użyta także do likwidacji skażeń biologicznych. Dotyczy to zwłaszcza odkażalników opartych na związkach nadtlenowych i zawierających aktywny chlor.

Istotnym warunkiem takiego użycia turbinowego sytemu ratowniczo-gaśniczego jest zbadanie kompatybilności odkażalników z warunkami panującymi w strumieniu gazów wylotowych. Odkażalniki służące do likwidacji skażeń chemicznych, zwłaszcza substancjami wysokotoksycznymi cechują się reaktywnością i istnieje potencjalna możliwość utraty ich aktywności na skutek rozkładu termicznego lub 
Wykorzystanie środków dekontaminacyjnych w mobilnym turbinowym systemie... 193

reakcji ze składnikami gazów wylotowych. Wiele odkażalników opartych jest na substancjach utleniających. Przy niepełnym spalaniu paliwa mogą bowiem powstawać związki o właściwościach redukujących reagujące $z$ aktywnymi składnikami preparatów do dekontaminacji i zmniejszające przez to efektywność dekontaminacji. Aby zbadać możliwość użycia preparatów do dekontaminacji w turbinowym systemie ratowniczo-gaśniczym, przeprowadzono badania wpływu mieszanin gazowych symulujących gazy wylotowe z silnika turboodrzutowego na ich właściwości.

W tab. 1 zamieszczono przykłady najczęściej stosowanych aktywnych składników odkażalników do likwidacji skażeń chemicznych i biologicznych (dezynfekcji).

TABELA 1. WŁaśCIWOŚCI WYBRANYCH SUBSTANCJI AKTYWNYCH UŻYWANYCH W ŚRODKACH DO LIKWIDACJI SKAŻEŃ

\begin{tabular}{|c|c|c|c|c|}
\hline Nazwa & Wzór & $\begin{array}{c}\text { Masa } \\
\text { molowa }\end{array}$ & $\begin{array}{c}\text { Mierzony } \\
\text { wskaźnik } \\
\text { aktywności }\end{array}$ & $\begin{array}{l}\text { Rozpusz- } \\
\text { czalność } \\
\text { w wodzie }\end{array}$ \\
\hline $\begin{array}{l}\text { Dichloroizocyja- } \\
\text { nuran sodu } \\
\text { (sól sodowa kwasu } \\
\text { dichloroizocyja- } \\
\text { nurowego) }\end{array}$ & $\mathrm{C}_{3} \mathrm{Cl}_{2} \mathrm{~N}_{3} \mathrm{O}_{3} \mathrm{Na}$ & 256 & $\begin{array}{c}56,8 \% \text { chloru } \\
\text { aktyw. }\end{array}$ & $\begin{array}{l}250 \mathrm{~g} / \mathrm{l} \\
\left(25^{\circ} \mathrm{C}\right)\end{array}$ \\
\hline $\begin{array}{l}\text { Mononadftalan } \\
\text { magnezu }\end{array}$ & $\mathrm{C}_{16} \mathrm{H}_{10} \mathrm{O}_{10} \mathrm{Mg}$ & 495 & $\begin{array}{l}5,45 \% \text { tlenu } \\
\text { aktywnego }\end{array}$ & $\begin{array}{l}220 \mathrm{~g} / \mathrm{l} \\
\left(20^{\circ} \mathrm{C}\right)\end{array}$ \\
\hline Kwas nadoctowy & $\mathrm{CH}_{3} \mathrm{COOOH}$ & 76 & $\begin{array}{l}\text { 6,7\% tlenu } \\
\text { aktywnego }\end{array}$ & $\begin{array}{l}\text { nieograni- } \\
\text { czona } \\
\text { mieszalność }\end{array}$ \\
\hline Nadsiarczan sodu & $\mathrm{Na}_{2} \mathrm{~S}_{2} \mathrm{O}_{8}$ & 238 & $\begin{array}{l}\text { 6,9\% tlenu } \\
\text { aktywnego }\end{array}$ & $\begin{array}{l}556 \mathrm{~g} / \mathrm{l} \\
\left(20^{\circ} \mathrm{C}\right)\end{array}$ \\
\hline Nadwęglan sodu & $\mathrm{Na}_{2} \mathrm{CO}_{3} 1,5 \mathrm{H}_{2} \mathrm{O}_{2} \cdot \mathrm{H}_{2} \mathrm{O}$ & & $\begin{array}{l}\text { 12-15\% tlenu } \\
\text { aktywnego }\end{array}$ & $\begin{array}{l}180 \mathrm{~g} / \mathrm{l} \\
\left(40^{\circ} \mathrm{C}\right)\end{array}$ \\
\hline $\begin{array}{l}\text { Podchloryn } \\
\text { wapnia }\end{array}$ & $\mathrm{Ca}(\mathrm{OCl})_{2}$ & 143 & $\begin{array}{l}66 \% \text { aktyw- } \\
\text { nego chloru }\end{array}$ & $\begin{array}{l}\text { ok. } 200 \mathrm{~g} / \mathrm{l} \\
\quad\left(20^{\circ} \mathrm{C}\right)\end{array}$ \\
\hline
\end{tabular}

Źródło: opracowanie własne

Istotnym składnikiem odkażalników są także środki powierzchniowo czynne. Ułatwiają one zwilżanie skażonych powierzchni i przyspieszają proces odkażania; ma to szczególne znaczenie w przypadku substancji trudno rozpuszczalnych w wodzie. Ze względu na reaktywność odkażalników środki powierzchniowo czynne wchodzące w ich skład muszą wykazywać się odpowiednią stabilnością chemiczną. Warunki te spełniają siarczany alkilosodowe (C12-C18) użyte m. in w odkażalniku UOP. W związku z tym wykonano także analizy stężenia związków powierzchniowo czynnych w tym odkażalniku po jego narażeniu na działanie gazów spalinowych. 


\section{Sprzęt, materiały i metody}

Na rys. 1 przedstawiono uproszczony schemat zestawu do badania zachowania środków dekontaminacyjnych w strumieniu gazów spalinowych. Rys. 1 nie oddaje proporcji elementów, pominięto także niektóre elementy, takie jak zawory, zasilanie itp. W komorze spalania umieszczony był palnik (P) zasilany mieszanką propan-butan (P-B). Przepływy mieszanki propan-butan i powietrza były kontrolowane przy użyciu rotametrów (R). Palnik ten był też używany jako pilot przy spalaniu mieszaniny węglowodorów (10\% toluenu, 50\% oktanu, $40 \%$ dekanu) imitującej paliwo lotnicze, podawanej do płomienia przez pompę ze zbiornika F. Do regulowania wilgotności stosowano rozpylanie wody (podawanej ze zbiornika $\mathrm{W}$ ), a podwyższanie temperatury gazów uzyskiwano przy pomocy grzałki G. Warunki panujące w strumieniu gazów były kontrolowane przy użyciu czujników temperatury (T) i wilgotności (RH). W końcowym odcinku toru gazów spalinowych wprowadzano do strumienia gazu roztwory odkażalników podawanych przez pompę ze zbiornika ODK1, a w zbiorniku ODK2 zbierano odkażalnik po ekspozycji na gazy spalinowe. Ze zbiornika ODK2 pobierano próbki odkażalnika do analiz chemicznych.

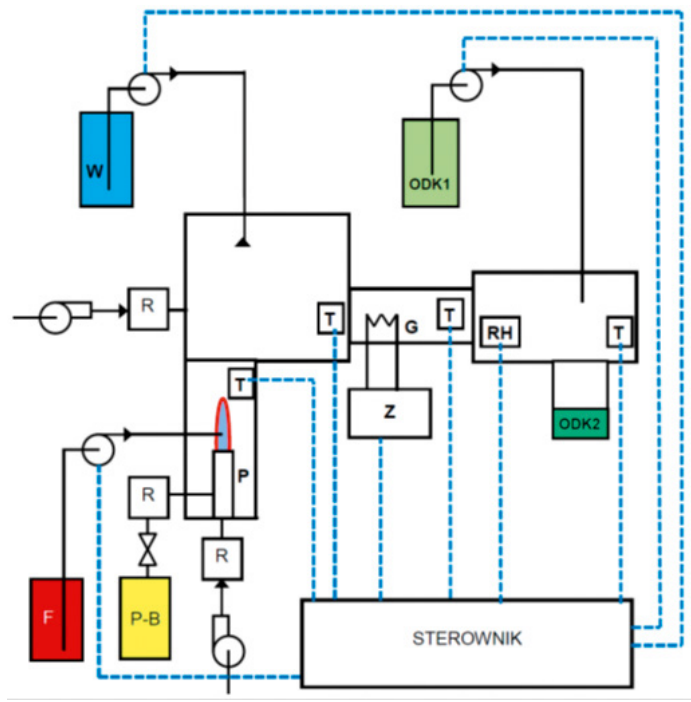

Rysunek 1. Schemat układu do badania zachowania środków dekontaminacyjnych w strumieniu gazów spalinowych

Źródło: opracowanie własne

Figure 1. Diagram of the installation for testing of decontaminants in combustion gas stream

$\square$ - butla z gazem propan-butan, $\square$ - zbiornik wody, $\square \square$ - zbiornik odkażalnika,

- zbiornik odkażalnika poddanego działaniu gazów, $\square$ - zbiornik ciekłych substancji wprowadzanych do płomienia. P- palnik, G - grzałka, R - rotametr, RH - czujnik wilgotności powietrza, $\mathrm{T}$ - czujnik temperatury, $\mathrm{Z}$ - zasilacz. 
Spalanie zarówno mieszaniny propan-butan, jak i ciekłej mieszaniny węglowodorów prowadzono w warunkach:

- stechiometrycznych;

- 50\% nadmiaru powietrza.

Wilgotność względna gazów spalinowych mieściła się w granicach $60-80 \%$ a temperatura $90 \pm 5^{\circ} \mathrm{C}$.

Do badań wybrano dichloroizocyjanuran sodu, mononadftalan magnezu, nadsiarczan sodu, podchloryn wapnia oraz uniwersalny odkażalnik proszkowy oparty na dichloroizocyjanuranie sodu.

2.1. Oznaczanie zawartości substancji powierzchniowo czynnych metodą bezpośredniego miareczkowania dwufazowego

\subsubsection{Odczynniki i roztwory:}

a) chloroform;

b) hyamine 1622 - roztwór o stężeniu $\mathrm{C}_{27} \mathrm{H}_{42} \mathrm{ClNO}_{2}=0,004 \mathrm{~mol} /$ zgodnie z PN-ISO 2271, p. 4.6;

c) wskaźnik mieszany - kwaśny roztwór przygotowany zgodnie z PN-ISO 2271, p. 4.8.2;

d) nadtlenek wodoru, roztwór $30 \%(\mathrm{~m} / \mathrm{m})$.

2.1.2. Aparatura i przyrządy:

a) kolby stożkowe $\mathrm{z}$ korkiem na szlif o pojemności $500 \mathrm{~cm}^{3}$;

b) biureta pojemności $50 \mathrm{~cm}^{3}$;

c) waga analityczna;

d) kuchenka elektryczna $\mathrm{z}$ regulacją mocy.

2.1.3. Wykonanie oznaczenia.

Do kolby stożkowej odważano z dokładnością do $1 \mathrm{mg}$ ok. 0,8 g prób$\mathrm{ki}$, rozpuszczano w $100 \mathrm{~cm}^{3}$ wody, dodawano $0,5 \mathrm{~cm}^{3}$ roztworu nadtlenku wodoru i gotowano przez 5 minut, dodawano $15 \mathrm{~cm}^{3}$ chloroformu i $10 \mathrm{~cm}^{3}$ wskaźnika mieszanego. Miareczkowano roztworem hyaminy, po dodaniu każdej porcji odczynnika zamykano kolbę korkiem i energicznie wstrząsano. Za punkt końcowy miareczkowania przyjmowano moment, kiedy dolna warstwa chloroformowa poprzez kolor różowy i lekko fioletowy zmieniała się na jasnoszaroniebieski.

\subsubsection{Obliczanie wyników}

Zawartość substancji powierzchniowo czynnych, w procentach $(\mathrm{m} / \mathrm{m})$, obliczano zgodnie z wzorem:

$$
X \cdot \frac{V}{m} \cdot 100
$$


w którym:

$X=$ mnożnik analityczny $=\frac{0,004 \cdot(\text { średnia } m \cdot c z \cdot z w \cdot \text { powierzchniowo czynnych })}{1000}$

- 0,004 - stężenie roztworu hyaminy $1622 \mathrm{~mol} / \mathrm{dm}^{3}$;

- V-objętość roztworu hyaminy 1622 zużytego do miareczkowania próbki $\left[\mathrm{cm}^{3}\right]$;

- $m$ - masa próbki [g].

Za wynik oznaczenia przyjmowano średnią arytmetyczną min. dwóch równoległych oznaczeń różniących się nie więcej niż 10\% wartości średniej.

\subsection{Oznaczenie tlenu aktywnego metodą jodometryczną}

\subsubsection{Odczynniki i roztwory.}

a) tiosiarczan sodu, roztwór $0,1000 \mathrm{~mol} / \mathrm{dm}^{3}$;

b) jodek potasu, roztwór wodny $10 \%(\mathrm{~m} / \mathrm{m})$;

c) kwas siarkowy, roztwór $\left(\mathrm{H}_{2} \mathrm{SO}_{4}\right.$ o d = 1,84 : woda $\left.1: 1, \mathrm{v} / \mathrm{v}\right)$;

d) skrobia rozpuszczalna, roztwór wodny $1 \%(\mathrm{~m} / \mathrm{m})$.

\subsubsection{Aparatura i przyrządy}

a) waga analityczna;

b) biureta o pojemności $25 \mathrm{~cm}^{3} \mathrm{z}$ działką elementarną $0,1 \mathrm{~cm}^{3}$;

c) kolby stożkowe $\mathrm{z}$ korkiem na szlif o pojemności $250 \mathrm{~cm}^{3}$;

d) pipety o pojemności 5 i $10 \mathrm{~cm}^{3}$;

e) miarowy pojemności $100 \mathrm{~cm}^{3}$.

\subsubsection{Wykonanie oznaczenia}

Ok. 0,5 g odkażalnika odważonego z dokładnością do $1 \mathrm{mg}$ umieszczano w kolbie stożkowej, dodawano $10 \mathrm{~cm}^{3}$ roztworu jodku potasu, ok. $100 \mathrm{~cm}^{3}$ wody, $5 \mathrm{~cm}^{3} \mathrm{kwasu}$ siarkowego (jeżeli używany był roztwór odkażalnika, odmierzano objętość zawierającą 0,2-0,5 g substancji aktywnej i odpowiednio zmniejszano objętość dodanej do kolby wody). Kolbę zamykano korkiem, mieszano zawartość do rozpuszczenia odkażalnika i odstawiano w ciemne miejsce na 15 minut. Następnie miareczkowano roztworem tiosiarczanu sodu do uzyskania jasnożółtego zabarwienia, po czym dodawano $0,5 \mathrm{~cm}^{3}$ roztworu skrobi i dalej miareczkowano do odbarwienia utrzymującego się co najmniej 20 sekund.

\subsubsection{Obliczenie wyników}

Zawartość tlenu aktywnego w \% (m/m) obliczano wg wzoru:

$$
8 \times 10^{-4} \cdot \frac{V}{m} \cdot 100
$$


w którym:

- $V$ - objętość tiosiarczanu sodowego zużyta na miareczkowanie $\left[\mathrm{cm}^{3}\right]$;

- $8 \times 10^{-4}$ - ilość tlenu [g] odpowiadająca $1 \mathrm{~cm}^{3}$ roztworu tiosiarczanu sodu o c $\left(\mathrm{Na}_{2} \mathrm{~S}_{2} \mathrm{O}_{3}\right)=0,1000 \mathrm{~mol} / \mathrm{dm}^{3}$;

- $m$ - naważka odkażalnika [g].

\subsection{Oznaczenie chloru czynnego metodą jodometryczną}

\subsubsection{Aparatura i przyrządy:}

a) waga analityczna;

b) biureta o pojemności $25 \mathrm{~cm}^{3} \mathrm{z}$ działką elementarną $0,1 \mathrm{~cm}^{3}$;

c) kolby stożkowe z korkiem na szlif o pojemności $250 \mathrm{~cm}^{3}$;

d) pipety o pojemności 5 i $25 \mathrm{~cm}^{3}$;

e) cylinder miarowy pojemności $100 \mathrm{~cm}^{3}$.

\subsubsection{Odczynniki i roztwory}

a) tiosiarczan sodu, roztwór $0,1000 \mathrm{~mol} / \mathrm{dm}^{3}$;

b) jodek potasu, roztwór wodny $10 \%(\mathrm{~m} / \mathrm{m})$;

c) kwas siarkowy, roztwór $\left(\mathrm{H}_{2} \mathrm{SO}_{4}\right.$ o $d=1,84$ : woda $\left.1: 1, \mathrm{v} / \mathrm{v}\right)$;

d) skrobia rozpuszczalna, roztwór wodny $1 \%(\mathrm{~m} / \mathrm{m})$.

\subsubsection{Wykonanie oznaczenia}

Ok. 0,15 g odkażalnika odważonego z dokładnością do $1 \mathrm{mg}$ umieszczano w kolbie stożkowej, dodawano ok. $100 \mathrm{~cm}^{3}$ wody, $20 \mathrm{~cm}^{3}$ roztworu jodku potasu, $5 \mathrm{~cm}^{3}$ kwasu siarkowego (jeżeli używany był roztwór odkażalnika, odmierzano objętość zawierającą 0,05-0,1g substancji aktywnej i odpowiednio zmniejszano objętość dodanej do kolby wody). Kolbę zamykano korkiem, mieszano zawartość do rozpuszczenia odkażalnika i odstawiano w ciemne miejsce na 20 minut. Następnie miareczkowano roztworem tiosiarczanu sodu do uzyskania jasnożółtego zabarwienia, po czym dodawano $0,5 \mathrm{~cm}^{3}$ roztworu skrobi i dalej miareczkowano do odbarwienia utrzymującego się co najmniej 20 sekund.

\subsubsection{Obliczenie wyników}

Zawartość chloru czynnego w \% (m/m) obliczano wg wzoru:

$$
3,546 \cdot 10^{-3} \cdot \frac{V_{1}}{m_{1}} \cdot 100
$$

w którym:

- $V_{1}$ - objętość tiosiarczanu sodowego zużyta na miareczkowanie $\left[\mathrm{cm}^{3}\right]$;

- 3,546 $10^{-3}$ - ilość chloru [g] odpowiadająca $1 \mathrm{~cm}^{3}$ roztworu tiosiarczanu sodu o c $\left(\mathrm{Na}_{2} \mathrm{~S}_{2} \mathrm{O}_{3}\right)=0,1000 \mathrm{~mol} / \mathrm{dm}^{3}$;

- $m_{1}$ - naważka odkażalnika [g]. 


\section{Wyniki}

W tabelach 2-6 przedstawiono wyniki oznaczeń chloru aktywnego w roztworach dichloroizocyjanuranianu sodu i podchlorynu wapnia oraz tlenu aktywnego $\mathrm{w}$ roztworach nadsiarczanu sodu i mononadftalanu magnezu. $Z$ wyjątkiem roztworu mononadftalanu magnezu (tab. 5) nie stwierdzono zmian mogących w istotny sposób wpływać na skuteczność odkażalników opartych na tych związkach.

Nie stwierdzono istotnego statystycznie wpływu stężenia $\mathrm{CO}_{2}$ na poziom chloru aktywnego w roztworach nadsiarczanu sodu i mononadftalanu magnezu oraz tlenu aktywnego w roztworach nadsiarczanu sodu i mononadftalanu magnezu.

TABELA 2. WYNIKI BADAŃ CHLORU AKTYWNEGO W ROZTWORZE DICHLOROIZOCYJANURANIANU SODU PO NARAŻENIU $2 \%$ ROZTWORU NA DZIAŁANIE GAZÓW SPALINOWYCH $\left(90^{\circ} \mathrm{C}\right)$

\begin{tabular}{|l|l|c|c|}
\hline & $\begin{array}{c}\text { warunki spalania } \\
\text { paliwa }\end{array}$ & aktywny chlor (\%) & zmiana (\%) \\
\hline próba kontrolna & \multicolumn{1}{|c|}{1,13} & \\
\hline \multirow{2}{*}{ propan-butan } & stechiometrycznie & 1,04 & $-8,0$ \\
\cline { 2 - 4 } & nadmiar powietrza & 1,10 & $-2,7$ \\
\hline \multirow{2}{*}{ ciekłe paliwo } & stechiometrycznie & 1,02 & $-9,7$ \\
\cline { 2 - 4 } & nadmiar powietrza & 1,05 & $-7,1$ \\
\hline
\end{tabular}

Źródło: opracowanie własne

TABELA 3. WYNIKI BADAŃ CHLORU AKTYWNEGO W ROZTWORZE PODCHLORYNU WAPNIA PO NARAŻENIU $2 \%$ ROZTWORU NA DZIAŁANIE GAZÓW SPALINOWYCH $\left(90^{\circ} \mathrm{C}\right)$

\begin{tabular}{|l|l|c|c|}
\hline & $\begin{array}{c}\text { warunki spalania } \\
\text { paliwa }\end{array}$ & aktywny chlor (\%) & zmiana (\%) \\
\hline próba kontrolna & \multicolumn{1}{|c|}{1,37} & \\
\hline \multirow{2}{*}{ propan-butan } & stechiometrycznie & 1,35 & $-1,5$ \\
\cline { 2 - 4 } & nadmiar powietrza & 1,35 & $-1,5$ \\
\hline \multirow{2}{*}{ ciekłe paliwo } & stechiometrycznie & 1,29 & $-5,8$ \\
\cline { 2 - 4 } & nadmiar powietrza & 1,33 & $-2,9$ \\
\hline
\end{tabular}

Źródło: opracowanie własne

TABELA 4. WYNIKI BADAŃ TLENU AKTYWNEGO W ROZTWORZE NADSIARCZANU SODU PO NARAŻENIU 5\% ROZTWORU NA DZIAŁANIE GAZÓW SPALINOWYCH $\left(90^{\circ} \mathrm{C}\right)$

\begin{tabular}{|l|l|c|c|}
\hline & $\begin{array}{c}\text { warunki spalania } \\
\text { paliwa }\end{array}$ & aktywny tlen (\%) & zmiana (\%) \\
\hline próba kontrolna & \multicolumn{1}{|c|}{0,34} & \\
\hline \multirow{2}{*}{ propan-butan } & stechiometrycznie & 0,34 & 0,0 \\
\cline { 2 - 4 } & nadmiar powietrza & 0,33 & $-2,9$ \\
\hline
\end{tabular}


Wykorzystanie środków dekontaminacyjnych w mobilnym turbinowym systemie... 199

\begin{tabular}{|l|l|c|c|}
\hline & $\begin{array}{c}\text { warunki spalania } \\
\text { paliwa }\end{array}$ & aktywny tlen (\%) & zmiana (\%) \\
\hline \multirow{2}{*}{ ciekłe paliwo } & stechiometrycznie & 0,30 & $-11,8$ \\
\cline { 2 - 4 } & nadmiar powietrza & 0,32 & $-5,9$ \\
\hline
\end{tabular}

Źródło: opracowanie własne

TABEla 5. WYNiKi BADAŃ TLENU AKTYWNEgo W ROZTWORZE MONONADFTALANU MAgNEZU PO NARAŻENIU 5\% ROZTWORU NA DZIAŁANIE GAZÓW SPALINOWYCH ( $90^{\circ} \mathrm{C}$ )

\begin{tabular}{|l|l|c|c|}
\hline & $\begin{array}{c}\text { warunki spalania } \\
\text { paliwa }\end{array}$ & aktywny tlen (\%) & zmiana (\%) \\
\hline próba kontrolna & \multicolumn{1}{|c|}{0,28} & \\
\hline \multirow{2}{*}{ propan-butan } & stechiometrycznie & 0,22 & -21 \\
\cline { 2 - 4 } & nadmiar powietrza & 0,23 & -18 \\
\hline \multirow{2}{*}{ ciekłe paliwo } & stechiometrycznie & 0,18 & -36 \\
\cline { 2 - 4 } & nadmiar powietrza & 0,20 & -29 \\
\hline
\end{tabular}

Źródło: opracowanie własne

TABELA 6. WyNiki BADAŃ CHLORU AKTYWNEgo W 2\% ROZTWORZE UNIWERSALNEgo ODKaŻalNiKa ProsZKoWEgo (UOP) PO NARAŻENIU NA DZIAŁANIE GAZÓW SPALINOWYCH $\left(90^{\circ} \mathrm{C}\right)$

\begin{tabular}{|l|l|c|c|}
\hline & $\begin{array}{c}\text { warunki spalania } \\
\text { paliwa }\end{array}$ & aktywny chlor (\%) & zmiana (\%) \\
\hline próba kontrolna & \multicolumn{1}{|c|}{0,68} & \\
\hline \multirow{2}{*}{ propan-butan } & stechiometrycznie & 0,63 & $-7,4$ \\
\cline { 2 - 4 } & nadmiar powietrza & 0,64 & $-5,9$ \\
\hline \multirow{2}{*}{ ciekłe paliwo } & stechiometrycznie & 0,62 & $-8,8$ \\
\cline { 2 - 4 } & nadmiar powietrza & 0,63 & $-7,4$ \\
\hline
\end{tabular}

Źródło: opracowanie własne

W Tabeli 7 przedstawiono wyniki analiz stężenia środków powierzchniowo czynnych w 2\% roztworze Uniwersalnego Odkażalnika Proszkowego (UOP) po narażeniu na działanie gazów spalinowych. Zmiany stężenia środków powierzchniowo czynnych mieszczą się w dopuszczalnym przedziale, ponadto tego rzędu różnice mogą być wynikiem błędów analitycznych.

Stwierdzono także, że aktywne składniki odkażalników mogą reagować $\mathrm{z}$ aldehydami i związkami nienasyconymi mogącymi powstawać przy niepełnym spalaniu węglowodorów. Jednakże ze względu na brak danych odnośnie do obecności i ewentualnych stężeń tych związków w gazach wylotowych z silnika, który będzie użyty w turbinowym systemie ratowniczo-gaśniczym nie prowadzono szczegółowych badań. 
Uzyskane wyniki wskazują, że zastosowanie turbinowego sytemu ratowniczogaśniczego do dekontaminacji wymaga doboru warunków pracy silnika turbinowego ograniczającego tworzenie reaktywnych, mających właściwości redukujące produktów niepełnego spalania paliw.

TABELA 7. WYNIKI BADAŃ ŚRODKÓW POWIERZCHNIOWO CZYNNYCH W 2\% ROZTWOrZe Uniwersalnego OdKażalnika Proszkowego (UOP) Po NARAżeniU NA DZIAŁANIE GAZÓW SPALINOWYCH $\left(90^{\circ} \mathrm{C}\right)$

\begin{tabular}{|l|l|c|c|}
\hline & $\begin{array}{c}\text { warunki spalania } \\
\text { paliwa }\end{array}$ & $\begin{array}{c}\text { środki } \\
\text { powierzchniowo } \\
\text { czynne (\%) }\end{array}$ & zmiana (\%) \\
\hline próba kontrolna & stechiometrycznie & 0,32 & 0 \\
\hline \multirow{2}{*}{ propan-butan } & nadmiar powietrza & 0,33 & 3 \\
\hline \multirow{2}{*}{ ciekłe paliwo } & stechiometrycznie & 0,31 & -3 \\
\cline { 2 - 4 } & nadmiar powietrza & 0,31 & -3 \\
\hline
\end{tabular}

Źródło: opracowanie własne

W tabeli 8 przedstawiono wyniki badań skuteczności likwidacji skażeń bojowymi środkami trującymi przy użyciu 2\% roztworu Uniwersalnego Odkażalnika Proszkowego (UOP) po poddaniu go działaniu gazów spalinowych. Analizy skażeń resztkowych bojowymi środkami trującymi wykonano techniką GC-MS i enzymatyczną zgodnie z procedurami przyjętymi w WIChiR. Uzyskane wyniki skażeń resztkowych mieszczą się w dopuszczalnym przedziale, co wskazuje na zachowanie przez odkażalnik wystarczającej aktywności.

TABELA 8. WYNIKI BADAŃ SKUTECZNOŚCI LIKWIDACJI SKAŻEŃ BOJOWYMI ŚRODKAMI TRUJĄCYMI PRZY UŻYCIU 2-Proc. ROZTWORU UniWERSAlNEgo OdKaŻalnika ProszKowego (UOP) PO NARAŻENIU NA DZIAŁANIE GAZÓW SPALINOWYCH $\left(90^{\circ} \mathrm{C}\right)$.

SKAŻENIE POCZĄTKOWE POWIERZCHNI: IPERYT SIARKOWY - 7 G/M $\mathrm{M}^{2}, \mathrm{VX}-5 \mathrm{G} / \mathrm{M}^{2}$

\begin{tabular}{|c|c|c|c|}
\hline & $\begin{array}{c}\text { warunki spalania } \\
\text { paliwa }\end{array}$ & bojowy środek trujący & skażenie resztkowe \\
\hline \multirow{2}{*}{$\begin{array}{l}\text { próba } \\
\text { kontrolna }\end{array}$} & & iperyt siarkowy & $2,5 \cdot 10^{-2} \mathrm{~g} / \mathrm{m}^{2}$ \\
\hline & & VX & $2,1 \cdot 10^{-3} \mathrm{~g} / \mathrm{m}^{2}$ \\
\hline \multirow{4}{*}{ ciekłe paliwo } & \multirow{2}{*}{ stechiometrycznie } & iperyt siarkowy & $4,6 \cdot 10^{-2} \mathrm{~g} / \mathrm{m}^{2}$ \\
\hline & & VX & $3,3 \cdot 10^{-3} \mathrm{~g} / \mathrm{m}^{2}$ \\
\hline & \multirow{2}{*}{$\begin{array}{l}\text { nadmiar } \\
\text { powietrza }\end{array}$} & iperyt siarkowy & $2,1 \cdot 10^{-2} \mathrm{~g} / \mathrm{m}^{2}$ \\
\hline & & $\mathrm{VX}$ & $3,0 \cdot 10^{-3} \mathrm{~g} / \mathrm{m}^{2}$ \\
\hline
\end{tabular}

Źródło: opracowanie własne 


\section{Wnioski}

Stwierdzono, że w modelowych warunkach, imitujących wpływ spalin na odkażalniki w większości przypadków nie następują zmiany składu odkażalników mogące w istotny sposób pogarszać ich właściwości użytkowe. Dotyczy to zarówno aktywnych składników odkażalników takich jak dichloroizocyjanuranian sodu, podchloryn wapnia, nadsiarczan sodu, jak i składników pomocniczych takich jak środki powierzchniowo czynne. Jedynie w przypadku mononadftalanu magnezu stwierdzono stopień rozkładu mogący mieć wpływ na skuteczność odkażalnika.

Przedstawione opracowanie zostało przygotowane na podstawie sprawozdania Wojskowego Instytutu Chemii i Radiometrii wykonanego w ramach projektu „Mobilny turbinowy system ratowniczo-gaśniczy" DOB-BIO6/06/113/2014. 



\section{Część V}

\section{INNOWACYJNE TECHNOLOGIE W DZIALANIACH}

RATOWNICZO-GAŚNICZYCH 



\title{
Projekt OZAB - innowacyjne podejście do ochrony przeciwpożarowej
}

\section{OZAB project - an innovative approach to fire protection}

\author{
Beata Wojtasiak \\ Konrad Zaciera
}

Centrum Naukowo-Badawcze Ochrony Przeciwpożarowej - Państwowy Instytut Badawczy

\section{Streszczenie}

Cel: Przedstawienie innowacyjnego podejścia do ochrony przeciwpożarowej na podstawie zastosowanych rozwiązań technologicznych $w$ ramach realizowanego przez Konsorcjum Naukowe projektu pt. „Opracowanie innowacyjnego systemu zarządzania bezpieczeństwa obiektów zabytkowych w zurbanizowanych centrach miast". Artykuł przedstawia także ideę certyfikacji obiektów zabytkowych $w$ zakresie bezpieczeństwa pożarowego tych obiektów, w tym muzeów i gromadzonych $w$ nich zbiorów.

Wstęp: Rozwój technologiczny jest tak szybki i efektywny, że jest nam trudno nadązyć za nim, a z pewnościa bardzo trudno nadążý $z$ adekwatnymi zmianami przepisów prawa i norm technicznych, w tym tych dla stosowanych wyrobów. Rynek nieustannie wskazuje na nowe potrzeby, które powinny być zaspokajane, a co za tym idzie koniecznym jest stosowanie rozwiazań innowacyjnych również w obszarach bezpieczeństwa osób i mienia. W następstwie w obszarach ratownictwa i ochrony przeciwpożarowej spotykamy się z nowymi technologiami, które w przyszłości moga być wykorzystywane np. przez jednostki straży pożarnej. W niniejszym artykule autorzy omówili nową technologię, zastosowana w ramach realizowanego projektu oraz przedstawili koncepcję systemu certyfikowania obiektów zabytkowych, który koncentrowałby się na poziomie bezpieczeństwa przeciwpożarowego takich obiektów i ich zbiorów.

\footnotetext{
Abstract

Purpose: Presentation of an innovative approach to fire protection based on the applied technological solutions within the project implemented by the Scientific Consortium „Development of an innovative safety management system for historic buildings in urbanized city centers". The article also presents the idea of certification of historic buildings in the field of fire safety of these facilities, including museums and collections collected in them.

Introduction: Technological development is so fast and effective that it is difficult for us to keep up with it and it is certainly very difficult to keep up with adequate changes in law regulations and standards, including those for used products. The market is constantly points to the new needs that should be met and therefore it is necessary to use innovative solutions in the areas of security of people and property. As a result, in the areas of rescue and fire protection, we meet new technologies which in the future could be used, for example, by fire brigades units. In article mentioned below, the authors described the new technology which is used in the realized project and presented the concept of a certification process for historic buildings that focuses on the level of fire safety of such facilities and their collections.
} 


\section{Wstęp}

Wychodząc naprzeciw potrzebom rynku ochrony przeciwpożarowej, Centrum Naukowo-Badawcze Ochrony Przeciwpożarowej im. Józefa Tuliszkowskiego - Państwowy Instytut Badawczy wraz z członkami konsorcjum:

- Szkołą Główną Służby Pożarniczej (lider projektu);

- Szkołą Aspirantów Państwowej Straży Pożarnej w Krakowie;

- Dynamic Safety Corporation;

realizuje projekt pt. Opracowanie innowacyjnego systemu zarzadzania bezpieczeństwem obiektów zabytkowych $w$ zurbanizowanych centrach miast (akronim OZAB).

Projekt OZAB to innowacyjny, teleinformatyczny system wspomagania zarządzania bezpieczeństwem $\mathrm{w}$ kontekście podniesienia poziomu bezpieczeństwa kompleksów obiektów zabytkowych. Demonstrator będzie uwzględniał scenariusze zagrożeń dla kompleksów zabytkowych wraz z możliwością reagowania ratowniczego, kompleksowej technologii ratowniczej i systemu szkoleniowego.

Wypracowane w trakcie projektu OZAB rekomendacje (np. certyfikacja obiektów pod względem bezpieczeństwa ppoż.) dotyczące zarządzania bezpieczeństwem obiektów zabytkowych zlokalizowanych w centrach miast doprowadzą do zwiększenia zarówno bezpieczeństwa samych obiektów, jak i eksponatów o szczególnej wartości.

Wdrożenie wyników projektu wpłynie w istotny sposób na bezpieczeństwo obywateli poprzez wprowadzenie systemu zarządzania obiektami zabytkowymi. Dzięki wprowadzeniu innowacyjnego systemu nastąi poprawa procesu ewakuacji dóbr i eksponatów znajdujących się w chronionych obiektach. Znacząco spadnie ryzyko ich uszkodzenia lub zniszczenia podczas sytuacji nadzwyczajnych.

\section{Opis techniczny systemu OZAB i elementów składowych}

Podczas realizacji projektu OZAB zdefiniowano wstępnie założenia dla poniższych elementów systemu:

1. Koncepcja interfejsu graficznego aplikacji.

2. Koncepcja interfejsu użytkownika aplikacji mobilnej.

3. Koncepcja interfejsu użytkownika aplikacji desktopowej.

4. Koncepcja zastawu sensorów, wraz z zestawem terminali.

W wyniku czego stwierdzono, iż głównymi komponentami użytkowanymi bezpośrednio przez jednostki ratownicze będą terminale wraz $\mathrm{z}$ aplikacjami, jak również zestawy sensorów. Konsorcjum określiło przybliżone parametry techniczne technologii sensorów, która ma być wykorzystana do opracowania systemu sensorów aktywnych i/lub pasywnych wspomagających proces ewakuacji i logistyki ewakuowanych dóbr. Dokonano komparacji dostępnych technik bezprzewodowych 
dla wykorzystywanych rozwiązań technologicznych (tabela 1), oraz opracowano zbiór poszczególnych technologii w kontekście ich wykorzystania $\mathrm{w}$ ramach prowadzonych działań. Tabela 2 wskazuje, jaką funkcję dana technologia spełnia w konkretnym obszarze zastosowań1.

TABela 1. Porównanie technik Bezprzewodowych

TABLE 1. COMPARISON OF WIRELESS TECHNIQUES

\begin{tabular}{|c|c|c|c|c|}
\hline Technika & IEEE 802.11 & Beacon BLE & NFC & RFID \\
\hline Zasięg & $\begin{array}{l}\text { typowo }<100 \mathrm{~m} \\
\text { wewnątrz budyn- } \\
\text { ków, w zależności } \\
\text { od mocy nadawa- } \\
\text { nia i zastosowanych } \\
\text { anten }\end{array}$ & $\begin{array}{l}<30 \mathrm{~m} \text {, zależy } \\
\text { od ustawionej } \\
\text { mocy nadaw- } \\
\text { czej Tx }\end{array}$ & $<20 \mathrm{~cm}$ & $<10 \mathrm{~m}$ \\
\hline $\begin{array}{l}\text { Dokładność } \\
\text { lokalizacji }\end{array}$ & $\begin{array}{l}\text { max. } 1 \mathrm{~m} \text { (widocz- } \\
\text { ność co najmniej } \\
4 \mathrm{AP})\end{array}$ & $\begin{array}{l}\text { max. } 1 \mathrm{~m} \\
\text { (widoczność co } \\
\text { najmniej kilku } \\
\text { beaconów) }\end{array}$ & $\begin{array}{l}20 \mathrm{~cm} \\
\text { od znacznika }\end{array}$ & $\begin{array}{l}10 \text { m od } \\
\text { znacznika } \\
\text { (można } \\
\text { zwiększyć } \\
\text { przez } \\
\text { zmniejszenie } \\
\text { zasięgu) }\end{array}$ \\
\hline $\begin{array}{l}\text { Min. gęstość } \\
\text { czujników dla } \\
\text { nawigacji (tak, } \\
\text { aby być w zasięgu } \\
\text { przynajmniej } \\
\text { jednego czujnika) }\end{array}$ & $\begin{array}{l}\text { około } 100 \mathrm{~m} \text { dla } \\
\text { standardowych } \\
\text { anten dookólnych } \\
\text { z zyskiem } 0 \mathrm{dBi}\end{array}$ & $\begin{array}{l}\text { od } 2 \text { do } 20 \mathrm{~m} \\
\text { w zależności } \\
\text { od konfiguracji } \\
\text { mocy } \\
\text { nadawczej }\end{array}$ & nie dotyczy & co $20 \mathrm{~m}$ \\
\hline Zasilanie & aktywne & bateria do 2 lat & pasywne & pasywne \\
\hline $\begin{array}{l}\text { Zapewnie- } \\
\text { nie łączności } \\
\text { (zestawienie } \\
\text { połączeń } \\
\text { sieciowych) }\end{array}$ & tak & nie & nie & nie \\
\hline Koszt & od 30 PLN wzwyż & $\begin{array}{l}\text { koszt około } \$ 30 \\
\text { za sztukę }\end{array}$ & $\begin{array}{l}\text { od } 1 \text { PLN do kil- } \\
\text { kunastu złotych } \\
\text { za znacznik }\end{array}$ & $\begin{array}{l}\text { poniżej } \\
1 \text { PLN za } \\
\text { znacznik }\end{array}$ \\
\hline Zaleta & $\begin{array}{l}\text { możliwość dyna- } \\
\text { micznego zestawie- } \\
\text { nia topologii sieci } \\
\text { transportowej }\end{array}$ & $\begin{array}{l}\text { wykrycie obec- } \\
\text { ności obiektu }\end{array}$ & $\begin{array}{l}\text { identyfikacja } \\
\text { obiektu }\end{array}$ & $\begin{array}{l}\text { wykrycie } \\
\text { obecności } \\
\text { obiektu }\end{array}$ \\
\hline
\end{tabular}

1 Sprawozdanie z zadania badawczego Etap I, Zadanie nr 7: realizacja projektu rozwojowego nr umowy DOB-BIO7/08/01/2015 pt. „Opracowanie innowacyjnego systemu zarządzania bezpieczeństwem obiektów zabytkowych w zurbanizowanych centrach miast”. 


\begin{tabular}{|c|c|c|c|c|}
\hline & $\begin{array}{l}\text { wykrycie obecności } \\
\text { w danym obszarze } \\
\text { możliwość } \\
\text { lokalizacji }\end{array}$ & $\begin{array}{l}\text { wykrycie } \\
\text { przemieszcza- } \\
\text { nia obiektu } \\
\text { możliwość } \\
\text { lokalizacji } \\
\text { dodatkowe } \\
\text { sensory } \\
\text { (akcelerometr, } \\
\text { czujnik } \\
\text { temperatury) }\end{array}$ & & \\
\hline Wada & $\begin{array}{l}\text { konieczność za- } \\
\text { pewnienia zasilania } \\
\text { (PoE + zasilanie ba- } \\
\text { teryjne powerbank) }\end{array}$ & $\begin{array}{l}\text { zasilanie } \\
\text { bateryjne, } \\
\text { konieczność } \\
\text { okresowej } \\
\text { wymiany } \\
\text { możliwość } \\
\text { odczytu } \\
\text { identyfikatora } \\
\text { z większej } \\
\text { odległości }\end{array}$ & $\begin{array}{l}\text { brak możliwości } \\
\text { śledzenia prze- } \\
\text { mieszczania się } \\
\text { obiektu } \\
\text { konieczność } \\
\text { bliskiej identyfi- } \\
\text { kacji obiektu }\end{array}$ & $\begin{array}{l}\text { możliwość } \\
\text { odczytu } \\
\text { identyfikatora } \\
\text { z większej } \\
\text { odległości }\end{array}$ \\
\hline
\end{tabular}

Źródło: Sprawozdanie z zadania badawczego Etap I, Zadanie nr 7, DSC Sp. z o.o., realizacja projektu rozwojowego. Nr umowy DOB-BIO7/08/01/2015 pt. „Opracowanie innowacyjnego systemu zarządzania bezpieczeństwem obiektów zabytkowych w zurbanizowanych centrach miast”

TABELA 2. ZESTAWIENIE FUNKCJONALNOŚCI TECHNOLOGII W RÓŻNYCH OBSZARACH ZASTOSOWAŃ

TABle 2. A SUMMARY OF THE TECHNOLOGY'S FUNCTIONALITY IN VARIOUS AREAS OF APPLICATION

\begin{tabular}{|l|l|l|l|l|}
\hline $\begin{array}{c}\text { Obszar zasto- } \\
\text { sowań }\end{array}$ & \multicolumn{1}{|c|}{ Beacon } & \multicolumn{1}{c|}{$\begin{array}{c}\text { NFC } \\
\text { [obligatoryjne } \\
\text { dla wszystkich } \\
\text { scenariuszy] }\end{array}$} & $\begin{array}{c}\text { Wi-Fi [obli- } \\
\text { gatoryjne dla } \\
\text { wszystkich } \\
\text { scenariuszy] }\end{array}$ \\
\hline $\begin{array}{l}\text { Ewidencja/Iden- } \\
\text { tyfikacja dóbr } \\
\text { kultury }\end{array}$ & $\begin{array}{l}\text { Identyfikacja } \\
\text { obiektu } \\
\text { (z dużej } \\
\text { odległości), } \\
\text { śledzenie } \\
\text { zmian } \\
\text { położenia, } \\
\text { lokalizacja } \\
\text { obiektu } \\
\text { [opcjonalnie] }\end{array}$ & $\begin{array}{l}\text { Identyfikacja } \\
\text { obiektu (ze śred- } \\
\text { niej odległości) } \\
\text { [opcjonalnie] }\end{array}$ & $\begin{array}{l}\text { Identyfikacja } \\
\text { obiektu (z bli- } \\
\text { skiej odległości) } \\
\text { [obligatoryjnie] }\end{array}$ & $\begin{array}{l}\text { Sieć transporto- } \\
\text { wa do przesyła- } \\
\text { nia identyfikato- } \\
\text { rów obiektów } \\
\text { [obligatoryjnie] }\end{array}$ \\
\hline
\end{tabular}




\begin{tabular}{|c|c|c|c|c|}
\hline $\begin{array}{c}\text { Obszar zasto- } \\
\text { sowań }\end{array}$ & Beacon & RFID & $\begin{array}{c}\text { NFC } \\
\text { [obligatoryjne } \\
\text { dla wszystkich } \\
\text { scenariuszy] }\end{array}$ & $\begin{array}{l}\text { Wi-Fi [obli- } \\
\text { gatoryjne dla } \\
\text { wszystkich } \\
\text { scenariuszy] }\end{array}$ \\
\hline $\begin{array}{l}\text { Monitorowanie } \\
\text { położenia obiek- } \\
\text { tu muzealnego }\end{array}$ & $\begin{array}{l}\text { Identyfikacja } \\
\text { obiektu (z dużej } \\
\text { odległości), } \\
\text { śledzenie zmian } \\
\text { położenia, loka- } \\
\text { lizacja obiektu } \\
\text { [obligatoryjnie } \\
\text { lub zamiennie } \\
\text { z RFID] }\end{array}$ & $\begin{array}{l}\text { Identyfikacja } \\
\text { obiektu (ze śred- } \\
\text { niej odległości), } \\
\text { zgrubne określe- } \\
\text { nie położenia } \\
\text { [obligatoryjnie } \\
\text { lub zamiennie } \\
\text { z Beacon] }\end{array}$ & Brak & $\begin{array}{l}\text { Sieć transporto- } \\
\text { wa do przesyła- } \\
\text { nia identyfikato- } \\
\text { rów obiektów } \\
\text { [obligatoryjnie] }\end{array}$ \\
\hline $\begin{array}{l}\text { Monitorowanie } \\
\text { poprawności } \\
\text { akcji ratowniczej } \\
\text { i ewakuacji dóbr } \\
\text { kultury }\end{array}$ & $\begin{array}{l}\text { Identyfikacja } \\
\text { obiektu (z dużej } \\
\text { odległości) } \\
\text { [obligatoryjnie } \\
\text { lub zamiennie } \\
\text { z RFID] }\end{array}$ & $\begin{array}{l}\text { Identyfikacja } \\
\text { obiektu (ze śred- } \\
\text { niej odległości) } \\
\text { [obligatoryjnie } \\
\text { lub zamiennie } \\
\text { z Beacon] }\end{array}$ & $\begin{array}{l}\text { Identyfikacja } \\
\text { obiektu (z bli- } \\
\text { skiej odległości) } \\
\text { [obligatoryjnie] }\end{array}$ & $\begin{array}{l}\text { Sieć transporto- } \\
\text { wa do przesyła- } \\
\text { nia identyfikato- } \\
\text { rów obiektów } \\
\text { [obligatoryjnie] }\end{array}$ \\
\hline $\begin{array}{l}\text { Monitorowa- } \\
\text { nie lokalizacji } \\
\text { członków zespo- } \\
\text { łów ratowniczo } \\
\text {-ewakuacyjnych }\end{array}$ & $\begin{array}{l}\text { Śledzenie zmian } \\
\text { położenia i loka- } \\
\text { lizacja terminala } \\
\text { członka roty } \\
\text { [obligatoryjnie } \\
\text { lub zamiennie } \\
\text { z Wi-Fi] }\end{array}$ & Brak & Brak & $\begin{array}{l}\text { Sieć transpor- } \\
\text { towa, } \\
\text { śledzenie zmian } \\
\text { położenia i loka- } \\
\text { lizacja terminala } \\
\text { członka roty } \\
\text { [obligatoryjnie] }\end{array}$ \\
\hline $\begin{array}{l}\text { Nawigacja } \\
\text { podczas akcji } \\
\text { ratunkowej }\end{array}$ & $\begin{array}{l}\text { Śledzenie zmian } \\
\text { położenia i loka- } \\
\text { lizacja terminala } \\
\text { członka roty } \\
\text { [obligatoryjnie } \\
\text { lub zamiennie } \\
\text { z Wi-Fi] }\end{array}$ & Brak & Brak & $\begin{array}{l}\text { Sieć transpor- } \\
\text { towa, śledzenie } \\
\text { zmian położenia } \\
\text { i lokalizacja ter- } \\
\text { minala członka } \\
\text { roty } \\
\text { [obligatoryjnie] }\end{array}$ \\
\hline $\begin{array}{l}\text { Ewakuacja dóbr } \\
\text { kultury przez } \\
\text { miejsce pośred- } \\
\text { nie }\end{array}$ & $\begin{array}{l}\text { Identyfikacja } \\
\text { obiektu (z dużej } \\
\text { odległości), } \\
\text { śledzenie zmian } \\
\text { położenia, loka- } \\
\text { lizacja obiektu } \\
\text { [obligatoryjnie } \\
\text { lub zamiennie } \\
\text { z RFID] }\end{array}$ & $\begin{array}{l}\text { Identyfikacja } \\
\text { obiektu (ze śred- } \\
\text { niej odległości), } \\
\text { zgrubne określe- } \\
\text { nie położenia } \\
\text { [obligatoryjnie } \\
\text { lub zamiennie } \\
\text { z Beacon] }\end{array}$ & $\begin{array}{l}\text { Identyfikacja } \\
\text { obiektu (z bli- } \\
\text { skiej odległości) } \\
\text { [obligatoryjnie] }\end{array}$ & $\begin{array}{l}\text { Sieć transporto- } \\
\text { wa do przesyła- } \\
\text { nia identyfikato- } \\
\text { rów obiektów } \\
\text { [obligatoryjnie] }\end{array}$ \\
\hline
\end{tabular}

Źródło: Sprawozdanie z zadania badawczego Etap I, Zadanie nr 7, DSC Sp. z o.o., realizacja projektu rozwojowego Nr umowy DOB-BIO7/08/01/2015 pt. „Opracowanie innowacyjnego systemu zarządzania bezpieczeństwem obiektów zabytkowych w zurbanizowanych centrach miast” 
W skład systemu będą wchodziły następujące komponenty:

- smartfon - urządzenie wykorzystywane przez ratowników (rotę), którzy za zadanie mają ewakuację zagrożonych dóbr;

- tablet - urządzenie przeznaczone dla KDR i ułatwiające mu prowadzenie działań ratowniczych;

- laptop - urządzenie wspomagające prace muzealnika i nie wykorzystywane w warunkach prowadzenia działań ewakuacyjnych;

- serwer - komputer stacjonarny z aplikacją serwerową;

- sensor lokalizacyjny - urządzenie mające za zadanie wskazywać aktualne położenie ekip ratowniczych w obiekcie;

- sensor pozycjonujący - urządzenie znajdujące się w ewakuowanym obiekcie, wskazuje pozycje ewakuowanego obiektu;

- sensor zewnętrzny - urządzenie wskazujące pozycje ewakuowanego obiektu poza budynkiem;

- kontener - urządzenie przeznaczone do tymczasowego przechowywania ewakuowanych dóbr muzealnych.

\section{Zamierzone zastosowanie systemu}

Zgodnie z założeniami projektu przewiduje się, iż głównym zastosowaniem systemu będzie ochrona dóbr muzealnych/zabytków, która będzie realizowana poprzez usprawnienie procesu ewakuacyjnego w przypadku wystąpienia zdarzenia niekorzystnego, np. pożaru. Elementy systemu mają również za zadanie usprawnić procesy logistyczne związane z magazynowaniem dóbr po opuszczeniu ewakuowanego obiektu. Ważnym podkreślenia jest fakt, iż pewne elementy systemu, tj. tablet oraz smartfon będą wykorzystywane przez kierującego działaniami ratowniczymi oraz przez samych ratowników, i w tym przypadku elementy będą zarówno wspomagały ochronę zdrowia ratowników, jak również ułatwiały nawigację w pomieszczeniach.

\section{Certyfikacja obiektów zabytkowych jako innowacyjne podejście do ochrony ppoż.}

Prezentowane zagadnienie obejmuje problematykę dotyczącą zabezpieczenia przeciwpożarowego (prewencyjnego) obiektów muzealnych i zabytkowych w zakresie warunków techniczno-budowlanych i zabezpieczeń przeciwpożarowych występujących w tych obiektach, a także ocenę ich rzeczywistego poziomu przygotowania do działań ratowniczo-gaśniczych w kontekście opiniowania i certyfikowania rozwiązań organizacyjnych i technicznych występujących w tych obiektach. Określenie wymagań, zarówno w zakresie prewencyjnym, jak i operacyjnym to wstęp do stworzenia wytycznych w opiniowaniu i certyfikacji rozwiązań organizacyjnych 
i technicznych obiektów zabytkowych. Przy czym wytyczne te powinny dotyczyć zarówno obiektów zabytkowych i muzealnych, jak i innych obiektów (również nowych), przeznaczonych do gromadzenia zbiorów muzealnych o dużej wartości materialnej i kulturowej. Na potrzeby programu certyfikacji w ramach jednego z zadań badawczych VI.4.2.3 został opracowany wzorzec karty kontrolnej zagadnień technicznych i organizacyjnych występujących w rozpatrywanych obiektach. Szczegółowa analiza tych obszarów powinna stanowić podstawę do wydania oceny końcowej (pozytywnej lub negatywnej) dla takiego obiektu w odniesieniu do występujących w nim warunków ochrony przeciwpożarowej. Otrzymanie w tym procesie oceny pozytywnej pozwalałoby na uzyskanie certyfikatu dla obiektu zabytkowego lub muzeum, potwierdzającego akceptowalny poziom bezpieczeństwa w zakresie warunków ochrony przeciwpożarowej. Na potrzeby opracowania został przeprowadzony audyt (ocena) bezpieczeństwa pożarowego z zastosowaniem opracowanej karty kontrolnej w pilotażowym obiekcie muzealnym wytypowanym na potrzeby przeprowadzenia badania. Ponadto w artykule przedstawiono także metodykę wyznaczania obiektów zabytkowych do udziału w przedmiotowym systemie opiniowania i certyfikacji. Prace nad programem poprzedzono konsultacjami, uzgodnieniami w przedmiotowym zakresie z wykorzystaniem dokumentów i informacji uzyskanych od przedstawicieli Państwowej Straży Pożarnej, NIMOZ oraz wykonawców projektu „OZAB” z CNBOP-PIB.

\section{Wyniki prowadzonych prac}

Na etapie prowadzonych prac i badań sformułowano szereg wniosków i rekomendacji:

1. Program certyfikacji powinien zawierać rejestr (katalog) obiektów zabytkowych i muzealnych oraz innych obiektów, w których gromadzone są zbiory, objętych procesem opiniowania i certyfikacji występujących w nich rozwiązań organizacyjnych i technicznych wynikających z wymagań ochrony przeciwpożarowej jednocześnie zainteresowanych udziałem w systemie certyfikacji. Program certyfikacji powinien objąć przede wszystkim obiekty zabytkowe i muzea, na których spoczywa obowiązek wyposażenia w system sygnalizacji pożarowej oraz obiekty znajdujące się w Państwowym Rejestrze Muzeów MKiDN. Niezależnie od powyższego warto, aby ww. listę pozostawić jako otwartą, dając możliwość dobrowolnego certyfikowania - w uzasadnionych przypadkach - również innych obiektów, wskazanych przez właściwego konserwatora zabytków; ostateczny katalog (rejestr) obiektów zabytkowych i muzealnych, objętych niniejszym projektem, powinien być wyznaczony przez właściwy państwowy instytut kultury (np. Narodowy Instytut Muzealnictwa i Ochrony Zbiorów) lub inny podmiot kompetentny w zakresie ochrony przeciwpożarowej, działający w uzgodnieniu lub w ramach współpracy z podmiotem (podmiotami) wyspecjalizowanym i właściwym w zakresie ochrony dóbr kultury. Takim podmiotem może być np. CNBOP-PIB. 
2. Wyznaczenie obszaru zagadnień ochrony przeciw pożarowej odnoszących się do zabezpieczenia przeciwpożarowego obiektów muzealnych i zabytkowych, dotyczących głównie aspektów:

a) technicznych - odnoszących się do warunków ochrony przeciwpożarowej konkretnego obiektu w zakresie występujących warunków techniczno-budowlanych, warunków ewakuacji ludzi, wyposażenie obiektu w wymagane techniczne środki zabezpieczeń przeciwpożarowych (urządzenia przeciwpożarowe), wymagane przez przepisy ochrony przeciwpożarowej, oraz przygotowania obiektu do prowadzenia działań ratowniczo-gaśniczych itp.;

b) organizacyjnych - odnoszących się w szczególności do zagadnień ewakuacji zbiorów oraz przygotowania personelu do realizacji zadań z zakresu ochrony przeciwpożarowej i właściwego postępowania w razie pożaru lub innego miejscowego zagrożenia, które powinny być określone np. w instrukcji bezpieczeństwa pożarowego. Zaleca się, aby dokumenty (instrukcje) dotyczące ewakuacji zbiorów w obiektach objętych programem certyfikacji były każdorazowo uzgadniane (opiniowane) przez właściwe państwowe instytucje kultury (np. NIMOZ).

3. Wskazanie podmiotu (państwowy instytut kultury, np. NIMOZ, CNBOP-PIB), właściwego do wydawania stosownych opinii i certyfikatów świadczących o odpowiednim przygotowaniu obiektu zabytkowego (bądź obiektu, w którym znajdują się cenne zbiory) do działań ratowniczo-gaśniczych, ewakuacji zbiorów oraz oceny występujących warunków techniczno-budowlanych i zabezpieczeń przeciwpożarowych występujących w tych obiektach. Proponuje się rozważenie przyjęcia obowiązku wydawania ww. opinii i certyfikatów przez właściwy państwowy insty tut kultury w uzgodnieniu z komendantem powiatowym (miejskim) Państwowej Straży Pożarnej właściwym dla miejsca lokalizacji obiektu.

4. Wypracowanie propozycji odpowiednich ram formalno-prawnych, pozwalających na funkcjonowanie zasad opiniowania i certyfikowania przedmiotowego programu oraz podmiotów biorących udział w tym procesie. Podobnie będzie w przypadku wypracowania „korzyści” dla właścicieli, zarządców i użytkowników obiektów objętych programem opiniowania i certyfikowania, wynikających $z$ ich udziału w tym procesie. (np. uzyskanie tzw. upustów ubezpieczeniowych, wpisanie na listę „obiektów bezpiecznych i przyjaznych dla zwiedzających" itp.).

5. Opracowanie wzorca karty kontrolnej zagadnień, uwzględniającej aspekty techniczne i organizacyjne, które powinny być uwzględniane podczas procesu certyfikacji i opiniowania; uzyskany wynik pozytywny dla konkretnego obiektu powinien być podstawą do wydania certyfikatu na czas określony.

W przypadku uzyskania wyniku negatywnego, wynikającego w szczególności z:

a) występowania elementów stanowiących podstawę do uznania użytkowanego budynku istniejącego za zagrażający życiu ludzi, gdy występujące 
w nim warunki techniczne nie zapewniają możliwości ewakuacji ludzi; podstawę do stwierdzenia, że użytkowany budynek istniejący uznaje się zagrażający życiu ludzi - określają przepisy przeciwpożarowe;

b) niepełnego wyposażenia obiektu w urządzenia przeciwpożarowe i/lub występowania niesprawnych urządzeń przeciwpożarowych oraz niedoprowadzenia drogi pożarowej, których zastosowanie w rozpatrywanym obiekcie jest wymagane; stanowić to powinno wystarczającą podstawą do odmowy wydania certyfikatu.

W przypadkach niewyposażenia obiektu w wymagane urządzenia przeciwpożarowe oraz niezapewnienia drogi pożarowej, wymaganych przez przepisy - powinno się uwzględnić ewentualne przypadki zastosowania rozwiązań zamiennych, uzgodnionych $\mathrm{z}$ właściwym komendantem wojewódzkim PSP, zgodnie z odrębnymi przepisami.

\section{Konkluzje}

1. Podstawą do wydania przez uprawniony podmiot certyfikatu dla obiektu zabytkowego powinna być wyłącznie pozytywna ocena końcowa, sporządzana na podstawie karty kontrolnej, która w szczególności powinna uwzględniać: a) niewystępowanie warunków technicznych, które nie zapewniają możliwości ewakuacji ludzi, stanowiących podstawę do uznania rozpatrywanego obiektu (budynku) istniejącego za zagrażający życiu ludzi;

b) pełne wyposażenie rozpatrywanego obiektu w sprawne urządzenia przeciwpożarowe oraz zapewnienie drogi pożarowej, zgodnie z wymaganiami przepisów przeciwpożarowych i ochrony przeciwpożarowej.

2. Dopuszcza się również występowanie rozwiązań zamiennych, pozwalających na spełnienie wymagań ochrony przeciwpożarowej w sposób inny niż określony w przepisach, jeżeli proponowane rozwiązania zamienne ograniczają możliwość powstania pożaru, a w razie jego wystąpienia zapewniają zachowanie nośności konstrukcji przez określony czas, zapewniają ograniczenie rozprzestrzenianie się ognia i dymu wewnątrz obiektu budowlanego oraz zapewniają ograniczenie rozprzestrzeniania się pożaru na sąsiednie obiekty budowlane lub tereny przyległe; tryb stosowania rozwiązań zamiennych szczegółowo regulują odrębne przepisy. Obiekt musi być przygotowany do działań ratowniczo-gaśniczych oraz do przygotowania zbiorów do ewakuacji.

3. Certyfikat dla obiektu zabytkowego powinien być wydawany na czas określony, nie dłuższy jednak niż dwa lata, i podlegać nadzorowi w okresie jego ważności, a w razie wystąpienia w okresie ważności certyfikatu istotnych zmian w warunkach ochrony przeciwpożarowej - być wydawany ponownie lub cofany. Natomiast ewidencję obiektów objętych opiniowaniem i certyfikacją 
powinien prowadzić uprawniony podmiot, przy czym wykaz tych obiektów powinien być ogólnodostępny.

\section{Podsumowanie}

Jak wynika z powyższego, innowacyjne podejście do ochrony ppoż. aktualnie w Polsce nie dotyczy jedynie wykorzystywania nowych technologii, lecz również wiąże się z koniecznością tworzenia nowych procedur operacyjnych oraz nowych usług, które będą w istotny sposób wpływały na działania podejmowane przez jednostki straży pożarnej zarówno w perspektywie prewencji, jak i działań operacyjnych. Projekt OZAB jest doskonałym przykładem połączenia innowacyjnych technologii z podejściem prewencyjnym. W projekcie następuje połączenie dwóch światów, które z pierwszego punktu widzenia nic ze sobą wspólnego nie mają, ale po głębszym przyjrzeniu się ukazują nam zależności, które trzeba razem połączyć. 


\section{ZAŁACCZNIK}

Karta kontrolna zagadnień - aspekty techniczne i organizacyjne ochrony przeciwpożarowej w obiektach zabytkowych wydanie 1, CNBOP-PIB 2016, uwzględniająca występujące aspekty techniczne i organizacyjne w obiektach zabytkowych - założenia do wytycznych opiniowania i certyfikacji obiektów muzealnych (wzorzec)

\section{OCHRONA PRZECIWPOŻAROWA}

\section{CHARAKTERYSTYKA POŻAROWA}

1. Dane ogólne

1) rok budowy $\square$ /lub data przekazania do użytkowania $\square$ :

2) wysokość budynku [m]: powierzchnia całkowita [m²]:

3) kubatura budynku $\left[\mathrm{m}^{3}\right]$ : budynek wolnostojącyi: TAK $\square$ NIE

4) liczba kondygnacji nadziemnychii:

5) liczba kondygnacji podziemnych: budynek zabytkowy:

6) palne elementy konstrukcji: ściany $\square$, stropy $\square$, dach

7) liczba klatek schodowych w budynku:

8) klatka schodowa / klatki schodowe:

Obudowana zamykana drzwiami

Otwarta

Wyposażona/e w urządzenia zabezpieczające przed zadymieniem

9) liczba wejść do budynku:

10) kategoria zagrożenia ludzi (ZL) $\square /$ magazyn<smiles>C1=CCCCC1</smiles>

i Budynek wolnostojący jest to budynek posiadający własne fundamenty, ściany i dach, który jest oddalony o minimum 8 metrów od innych zabudowań.

ii Przez kondygnację należy rozumieć liczbę pięter lub poziomy wyodrębnione i ponumerowane jako oddzielne. Antresola posiadająca minimum jedno wydzielone ścianami pomieszczenie winna być traktowana jako kondygnacja. 
11) gęstość obciążenia ogniowego $\left[\mathrm{MJ} / \mathrm{m}^{2}\right]$

(dotyczy budynku magazynowego lub strefy magazynowej):

12) strefy pożarowe $\square /$ pomieszczenia $\square$ zagrożone wybuchem: TAK $\square$ NIE

13) liczba stref pożarowych występująca w budynku:

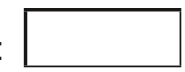

14) powierzchnia największej strefy pożarowej $\left[\mathrm{m}^{2}\right]$ :

15) instalacja gazowa: TAK $\square$ NIE

16) odległość od sąsiednich budynków [m]:

Należy wskazać w przypadku wydania postanowienia KW PSP; w przypadku braku - należy wstawić znak, „-"

17) data uzyskania zgody komendanta wojewódzkiego PSP na zastosowanie rozwiązań zamiennych

18) dyżur (nadzór)iii w budynku: NIE

TAK $\square$, w godz. od

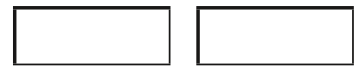

\section{Urządzenia przeciwpożarowe w budynkuiv:}

\begin{tabular}{|c|c|c|c|c|}
\hline $\begin{array}{c}\text { RODZAJ } \\
\text { URZĄDZENIA }\end{array}$ & Wymagane & Zainstalowane & Sprawne & $\begin{array}{c}\text { Data ostatniego } \\
\text { przeglądu }\end{array}$ \\
\hline $\begin{array}{c}\text { Hydranty } \\
\text { wewnętrzne 25 / 52 }\end{array}$ & & & \\
$\begin{array}{l}\text { \$19 ust. 1 i r rozporzą- } \\
\text { dzenia Ministra Spraw }\end{array}$ & & & \\
$\begin{array}{l}\text { Wewnętrznych i Admini- } \\
\text { stracji z dnia 7 czerwca } \\
\text { 2010 r. w sprawie ochrony } \\
\text { przeciwpożarowej bu- } \\
\text { dynków, innych obiektów } \\
\text { budowlanych i terenów } \\
\text { (Dz. U. Nr 109, poz. } 719 \text { ). }\end{array}$ & NIE $\square$ & $\square$ & $\square$ & \\
\hline
\end{tabular}

iii Dyżur (nadzór) w budynku - należy przyjąć jako ciągłą obecność osób lub osoby w obiekcie w wyznaczonych godzinach, które/która w razie wymagającej tego sytuacji mogą/może przedsięwziąć odpowiednie kroki (np. zawiadomić odpowiednie służby).

iv Urządzenia przeciwpożarowe są to urządzenia wszelkiego typu (uruchamiane ręcznie lub automatycznie, stałe lub półstałe) mające za zadanie zapobieganie, wykrywanie, zwalczanie lub ograniczenie skutków pożaru. 


\begin{tabular}{|c|c|c|c|c|}
\hline $\begin{array}{c}\text { RODZAJ } \\
\text { URZĄDZENIA }\end{array}$ & Wymagane & Zainstalowane & Sprawne & $\begin{array}{c}\text { Data ostatniego } \\
\text { przeglądu }\end{array}$ \\
\hline $\begin{array}{c}\text { System sygnalizacji } \\
\text { pożarowej i lokalizacja } \\
\text { centrali CSPvii }\end{array}$ & \multirow{2}{*}{$\begin{array}{l}\text { TAK } \square \\
\text { NIE } \square\end{array}$} & \multirow[t]{2}{*}{$\square$} & \multirow[t]{2}{*}{$\square$} & \\
\hline \multirow{4}{*}{$\begin{array}{l}\$ 28 \text { ust. } 1 \text { rozporządze- } \\
\text { nia Ministra Spraw We- } \\
\text { wnętrznych i Administra- } \\
\text { cji z dnia } 7 \text { czerwca } 2010 \\
\text { r. w sprawie ochrony prze- } \\
\text { ciwpożarowej budynków, } \\
\text { innych obiektów budow- } \\
\text { lanych i terenów (Dz. U. } \\
\text { Nr 109, poz. } 719 \text { ). }\end{array}$} & & & & \\
\hline & $-\cdots$ & \multicolumn{3}{|c|}{ Ochrona całkowita: $\square$ Ochrona częściowa: $\square$} \\
\hline & ------ & \multicolumn{3}{|c|}{$\begin{array}{l}\text { W przypadku ochrony częściowej podać strefy chro- } \\
\text { nione (np. magazyny, pracownie, ekspozycje etc.): }\end{array}$} \\
\hline & -1 & \multicolumn{3}{|c|}{ Lokalizacja centrali: } \\
\hline $\begin{array}{c}\text { Monitoring } \\
\text { pożarowy do PSPviii }\end{array}$ & $\begin{array}{l}\text { TAK } \square \\
\text { NIE } \square\end{array}$ & $\square$ & $\square$ & \\
\hline $\begin{array}{l}\text { Dźwiękowy System } \\
\text { Ostrzegawczyix } \\
\text { §29 rozporządzenia Mini- } \\
\text { stra Spraw Wewnętrznych } \\
\text { i Administracji z dnia } \\
7 \text { czerwca } 2010 \text { r. w spra- } \\
\text { wie ochrony przeciwpoża- } \\
\text { rowej budynków, innych } \\
\text { obiektów budowlanych } \\
\text { i terenów (Dz. U. Nr 109, } \\
\text { poz. 719). }\end{array}$ & $\begin{array}{l}\text { TAK } \square \\
\text { NIE } \square\end{array}$ & $\square$ & $\square$ & \\
\hline
\end{tabular}

vii Monitoring pożarowy do PSP należy rozumieć jako fizyczną możliwość przekazania zgodnie z przyjętymi wytycznymi sygnałów alarmowych oraz uszkodzeniowych z systemu sygnalizacji pożaru do najbliższej jednostki ratowniczo-gaśniczej straży pożarnej bezpośrednio.

viii Dźwiękowy System Ostrzegawczy jest w większości przypadków zestawem urządzeń umożliwiających nadania sygnałów i komunikatów ostrzegawczych dla osób przebywających w budynku w przypadku wykrycia pożaru, zarówno w sposób automatyczny, jak i na żądanie operatora systemu.

ix Awaryjne oświetlenie ewakuacyjne należy rozumieć jako urządzenia wykorzystujące źródło zasilania własne lub inne niż oświetlenia podstawowego i umożliwiające oświetlenie drogi ewakuacyjnej w przypadku awarii oświetlenia podstawowego.

$\mathrm{x}$ Urządzenia do usuwania dymu i miejsce uruchomienia ręcznego należy rozumieć jako urządzenia uruchamiane ręcznie lub automatycznie i umożliwiające usuwanie zadymienia z pomieszczeń w zaprojektowany sposób (np. oddymianie grawitacyjne - sterowane klapy, sterowane okna etc.). 


\begin{tabular}{|c|c|c|c|c|}
\hline $\begin{array}{c}\text { RODZAJ } \\
\text { URZĄDZENIA }\end{array}$ & Wymagane & Zainstalowane & Sprawne & $\begin{array}{c}\text { Data ostatniego } \\
\text { przeglądu }\end{array}$ \\
\hline $\begin{array}{l}\begin{array}{c}\text { Awaryjne oświetlenie } \\
\text { ewakuacyjne }\end{array} \\
\text { \$ } 181 \text { rozporządzenia } \\
\text { Ministra Infrastruktury } \\
\text { z dnia } 12 \text { kwietnia } 2002 \text { r. } \\
\text { w sprawie warunków tech- } \\
\text { nicznych, jakim powin- } \\
\text { ny odpowiadać budynki } \\
\text { i ich usytuowanie (Dz. U. } \\
\text { z } 2015 \text { r., poz. } 1422) \text {. }\end{array}$ & $\begin{array}{l}\text { TAK } \square \\
\text { NIE } \square\end{array}$ & $\square$ & $\square$ & \\
\hline $\begin{array}{l}\text { Urządzenia do usuwa- } \\
\text { nia dymuxi } \\
\$ 245 \text { rozporządzenia } \\
\text { Ministra Infrastruktury } \\
\text { z dnia } 12 \text { kwietnia } 2002 \mathrm{r} \text {. } \\
\text { w sprawie warunków tech- } \\
\text { nicznych, jakim powin- } \\
\text { ny odpowiadać budynki } \\
\text { i ich usytuowanie (Dz. U. } \\
\text { z } 2015 \text { r., poz. } 1422) \text {. }\end{array}$ & $\begin{array}{l}\text { TAK } \square \\
\text { NIE } \square\end{array}$ & $\square$ & $\square$ & \\
\hline 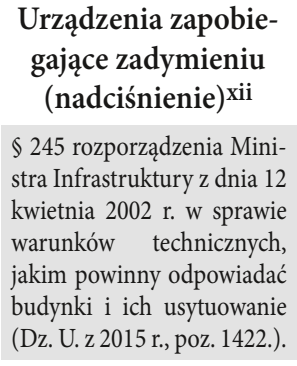 & $\begin{array}{l}\text { TAK } \square \\
\text { NIE } \square\end{array}$ & $\square$ & $\square$ & \\
\hline $\begin{array}{l}\text { Pompownia } \\
\text { przeciwpożarowa } \\
\S 26 \text { rozporządzenia Mini- } \\
\text { stra Spraw Wewnętrznych } \\
\text { i Administracji z dnia } \\
7 \text { czerwca } 2010 \text { r. w sprawie } \\
\text { ochrony przeciwpożarowej } \\
\text { budynków, innych obiek- } \\
\text { tów budowlanych i terenów } \\
\text { (Dz. U. Nr 109, poz. } 719 \text { ). }\end{array}$ & $\begin{array}{l}\text { TAK } \square \\
\text { NIE } \square\end{array}$ & $\square$ & $\square$ & \\
\hline
\end{tabular}

xi Urządzenia zapobiegające zadymieniu (nadciśnienie) należy rozumiećjako urządzeniakontrolującesterujące różnicąciśnień w sposób umożliwiający przedostawanie się dymu do strefykontrolowanejzinnych obszarów.

xii Stałe/półstałe urządzenia gaśnicze wodne należy rozumieć jako automatyczne urządzenia wykorzystujące środki gaśnicze, który współdziała z systemem sygnalizacji pożaru. Przez stałe urządzenia tego typu należy rozumieć urządzenia na stałe związane z konstrukcją budynku i posiadające zapas środka gaśniczego. 


\begin{tabular}{|c|c|c|c|c|}
\hline $\begin{array}{c}\text { RODZAJ } \\
\text { URZĄDZENIA }\end{array}$ & Wymagane & Zainstalowane & Sprawne & $\begin{array}{c}\text { Data ostatniego } \\
\text { przeglądu }\end{array}$ \\
\hline $\begin{array}{l}\text { Sieć wodociągowa } \\
\text { przeciwpożarowa } \\
\S 9 \text { rozporządzenia Mini- } \\
\text { stra Spraw Wewnętrznych } \\
\text { i Administracji z dnia } 7 \\
\text { czerwca } 2010 \mathrm{r} \text {. w sprawie } \\
\text { ochrony przeciwpożarowej } \\
\text { budynków, innych obiek- } \\
\text { tów budowlanych i tere- } \\
\text { nów (Dz. U. Nr 109, poz. } \\
\text { 719) oraz } \$ 5 \text { rozporządze- } \\
\text { nia Ministra Spraw We- } \\
\text { wnętrznych i Administra- } \\
\text { cji z dnia } 24 \text { lipca } 2009 \mathrm{r} \text { r. } \\
\text { w sprawie przeciwpożaro- } \\
\text { wego zaopatrzenia w wodę } \\
\text { oraz dróg pożarowych (Dz. } \\
\text { U. Nr 124, poz. 1030). }\end{array}$ & $\begin{array}{l}\text { TAK } \square \\
\text { NIE } \square\end{array}$ & $\square$ & $\square$ & $\begin{array}{c}\square \mathrm{dm}^{3} / \mathrm{s} / \square \mathrm{dm} 3 / \mathrm{s} \\
\text { Podać rzeczywista wydajność } \\
\text { sieci wodociagowej wstosunku } \\
\text { do wydajności wymaganej przzez } \\
\text { przepisy rozporzadzenia Ministra } \\
\text { Spraw Wewnetrznych } \\
\text { iAdministraciz zdnia } \\
24 \text { lipca 2009r. } \\
\text { wsprawie przeciwpozarowego } \\
\text { zaopatrzenia w wode oraz dróg } \\
\text { pozzarowych (Dz. U.Nr 124, } \\
\text { poz. 1030). }\end{array}$ \\
\hline $\begin{array}{l}\begin{array}{l}\text { Zbiornik wody o poj. } \\
\qquad\left(\mathrm{m}^{3}\right)\end{array} \\
\S 24 \text { rozporządzenia Mini- } \\
\text { stra Spraw Wewnętrznych } \\
\text { i Administracji z dnia } 7 \\
\text { czerwca } 2010 \mathrm{r} \text {. w sprawie } \\
\text { ochrony przeciwpożarowej } \\
\text { budynków, innych obiek- } \\
\text { tów budowlanych i tere- } \\
\text { nów (Dz. U. Nr 109, poz. } \\
\text { 719) oraz } \$ 5 \text { rozporządze- } \\
\text { nia Ministra Spraw We- } \\
\text { wnętrznych i Administra- } \\
\text { cji z dnia } 24 \text { lipca } 2009 \text { r. } \\
\text { w sprawie przeciwpożaro- } \\
\text { wego zaopatrzenia w wodę } \\
\text { oraz dróg pożarowych (Dz. } \\
\text { U. Nr 124, poz. 1030). }\end{array}$ & $\begin{array}{l}\text { TAK } \square \\
\text { NIE } \square\end{array}$ & $\square$ & $\square$ & $\begin{array}{l}\text { Lależy podać } \\
\text { pojemność } \\
\text { zbiornika } \mathrm{w}^{3} \mathrm{~m}^{3}\end{array}$ \\
\hline $\begin{array}{c}\text { Stałe / półstałe } \\
\text { urządzenia gaśnicze } \\
\text { wodne } \\
\text { xiii }\end{array}$ & $\begin{array}{l}\text { TAK } \square \\
\text { NIE } \square\end{array}$ & $\square$ & $\square$ & \\
\hline
\end{tabular}

xiii Przeciwpożarowy wyłącznik prądu nie jest tożsamy z głównym wyłącznikiem prądu. Umożliwia on odcięcie zasilania do głównych obwodów budynku za wyjątkiem systemów i urządzeń, których praca jest niezbędna podczas pożaru. 


\begin{tabular}{|c|c|c|c|c|}
\hline $\begin{array}{c}\text { RODZAJ } \\
\text { URZĄDZENIA }\end{array}$ & Wymagane & Zainstalowane & Sprawne & $\begin{array}{c}\text { Data ostatniego } \\
\text { przeglądu }\end{array}$ \\
\hline & \multicolumn{4}{|c|}{ Instalacja tryskaczowa $\square$} \\
\hline & \multicolumn{4}{|c|}{ Instalacja zraszaczowa $\square$} \\
\hline & \multicolumn{4}{|c|}{ Instalacja mgły niskociśnieniowej $\square$} \\
\hline & \multicolumn{4}{|c|}{ Instalacja mgły wysokociśnieniowej $\square$} \\
\hline & \multicolumn{4}{|c|}{ Dodatek środka pianotwórczego: $\square$} \\
\hline & \multicolumn{2}{|r|}{ Rodzaj: } & & \\
\hline & \multicolumn{2}{|r|}{ Inna: } & & \\
\hline \multirow[t]{2}{*}{$\begin{array}{l}\text { Stałe urządzenia } \\
\text { gaśnicze gazowe }\end{array}$} & $\begin{array}{l}\text { TAK } \square \\
\text { NIE } \square\end{array}$ & $\square$ & $\square$ & \\
\hline & \multicolumn{4}{|c|}{ Rodzaj środka gaśniczego (gazu): } \\
\hline $\begin{array}{c}\text { Przeciwpożarowy } \\
\text { wyłącznik prądu } \\
\text { i miejsce jego lokalizacji }\end{array}$ & \multirow[b]{2}{*}{$\begin{array}{l}\text { TAK } \square \\
\text { NIE } \square\end{array}$} & \multirow[b]{2}{*}{$\square$} & \multirow[b]{2}{*}{$\square$} & \\
\hline $\begin{array}{l}\$ 183 \text { ust. } 2,3 \text { i } 4 \text { rozpo- } \\
\text { rządzenia Ministra Infra- } \\
\text { struktury z dnia } 12 \text { kwietnia } \\
2002 \text { r. w sprawie warunków } \\
\text { technicznych, jakim powin- } \\
\text { ny odpowiadać budynki } \\
\text { i ich usytuowanie (Dz. U. } \\
\text { z } 2015 \text { r., poz. 1422). }\end{array}$ & & & & \\
\hline $\begin{array}{l}\text { Dźwig dla ekip } \\
\text { ratowniczych }\end{array}$ & \multirow[b]{2}{*}{$\begin{array}{l}\text { TAK } \square \\
\text { NIE } \square\end{array}$} & \multirow[b]{2}{*}{$\square$} & \multirow[b]{2}{*}{$\square$} & \\
\hline $\begin{array}{l}\$ 253 \text { rozporządzenia Mini- } \\
\text { stra Infrastruktury z dnia } 12 \\
\text { kwietnia } 2002 \text { r. w sprawie } \\
\text { warunków technicznych, } \\
\text { jakim powinny odpowiadać } \\
\text { budynki i ich usytuowanie } \\
\text { (Dz. U.Z } 2015 \text { r., poz. } 1422 .) \text {. }\end{array}$ & & & & \\
\hline Główny kurek gazu & & \multirow[b]{2}{*}{$\square$} & \multirow[b]{2}{*}{$\square$} & \\
\hline $\begin{array}{l}\$ 159 \text { rozporządzenia Mini- } \\
\text { stra Infrastruktury z dnia } 12 \\
\text { kwietnia } 2002 \text { r. w sprawie } \\
\text { warunków technicznych, } \\
\text { jakim powinny odpowiadać } \\
\text { budynki i ich usytuowanie } \\
\text { (z } 2015 \text { r., poz. } 1422 \text { ). }\end{array}$ & $\begin{array}{l}\text { TAK } \square \\
\text { NIE } \square\end{array}$ & & & Lokalizacja: \\
\hline
\end{tabular}

xiv Lokalizację należy wskazać skrótowo i przyjmując nazwę pomieszczenia, ciągu komunikacyjnego lub innego punktu charakterystycznego w budynku 


\begin{tabular}{|c|c|c|c|c|}
\hline $\begin{array}{c}\text { RODZAJ } \\
\text { URZĄDZENIA }\end{array}$ & Wymagane & Zainstalowane & Sprawne & $\begin{array}{c}\text { Data ostatniego } \\
\text { przeglądu }\end{array}$ \\
\hline $\begin{array}{l}\text { Rozwiązania zamienne } \\
\text { W przypadku braku wypo- } \\
\text { sażenia budynku w wyma- } \\
\text { gane urządzenia przeciw- } \\
\text { pożarowego (vide przypis } \\
5 \text { do objaśnień wskazanych } \\
\text { terminów) należy uwzględ- } \\
\text { nić ewentualne przypadki } \\
\text { zastosowania rozwiązań } \\
\text { zamiennych, uzgodnionych } \\
\text { z właściwym komendantem } \\
\text { wojewódzkim PSP, zgodnie } \\
\text { z odrębnymi przepisami }\end{array}$ & $\begin{array}{l}\text { TAK } \square \\
\text { NIE } \square\end{array}$ & $\square$ & $\square$ & $\begin{array}{c}\begin{array}{c}\text { Postanowienie KW } \\
\text { PSP } \\
\text { (znak i data) }\end{array} \\
\begin{array}{c}\text { Podać zastosowanie } \\
\text { rozwiązania } \\
\text { zamienne, } \\
\text { zgodnie z ww. }\end{array} \\
\text { postanowieniem: } \\
\text { 1. .... } \\
\text { 2. .... } \\
\text { 3. .... }\end{array}$ \\
\hline
\end{tabular}

\section{Ewakuacja}

\begin{tabular}{|l|l|l|}
\hline 1 & $\begin{array}{l}\text { Występowanie warunków technicznych, } \\
\text { stanowiących podstawę do uznania istnie- } \\
\text { jącego budynku za zagrażający życiu ludzi }\end{array}$ & $\begin{array}{l}\text { Podstawą uznania budynku istniejącego za za- } \\
\text { grażający życiu ludzi może być występowanie } \\
\text { warunków technicznych, o których mowa w } \$ 16 \\
\text { ust. 2 rozporządzenia MSWiA z dna 7.06.2010 r } \\
\text { w sprawie ochrony przeciwpożarowej budynków, } \\
\text { innych obiektów budowlanych i terenów (Dz.U. } \\
\text { Nr 109, poz. 719) }\end{array}$ \\
\cline { 2 - 4 } & $\begin{array}{l}\text { W przypadku występowania warunków } \\
\text { technicznych, stanowiących podstawę do } \\
\text { uznania budynku istniejącego za zagraża- } \\
\text { jący życiu ludzi - należy je wymienić (obok } \\
\text { w kolumnie) }\end{array}$ & TAK \\
\hline 2 & $\begin{array}{l}\text { Zapewniona ochrona pionowych dróg ewa- } \\
\text { kuacyjnych przed zadymieniem }\end{array}$ & \\
\hline 3 & $\begin{array}{l}\text { Zapewniona ochrona poziomych dróg ewa- } \\
\text { kuacyjnych przed zadymieniem }\end{array}$ & TAK $\square$ / NIE $\square$ \\
\hline 4 & $\begin{array}{l}\text { Awaryjne oświetlenie ewakuacyjne pozio- } \\
\text { mych dróg ewakuacyjnych }\end{array}$ & TAK $\square$ / NIE $\square$ \\
\hline 5 & $\begin{array}{l}\text { Awaryjne oświetlenie pionowych dróg ewa- } \\
\text { kuacyjnych }\end{array}$ \\
\hline
\end{tabular}




\begin{tabular}{|c|c|c|}
\hline 6 & $\begin{array}{l}\text { Awaryjne oświetlenie ewakuacyjne pomiesz- } \\
\text { czeń, w których przebywa ponad } 50 \text { osób }\end{array}$ & TAK $\square$ / NIE $\square$ \\
\hline 7 & $\begin{array}{l}\text { Awaryjne oświetlenie ewakuacyjne we } \\
\text { wszystkich pomieszczeniach budynku }\end{array}$ & TAK $\square$ / NIE $\square$ \\
\hline 8 & $\begin{array}{l}\text { Możliwość nadawania komunikatów przez } \\
\text { radiowęzeł }\end{array}$ & TAK $\square$ / NIE $\square$ \\
\hline 9 & $\begin{array}{l}\text { Czy wyznaczono miejsce koncentracji ewa- } \\
\text { kuowanych? }\end{array}$ & TAK $\square /$ NIE $\square$ \\
\hline 10 & $\begin{array}{l}\text { Czy jest opracowana instrukcja bezpieczeń- } \\
\text { stwa pożarowego? }\end{array}$ & TAK $\square$ / NIE $\square$ \\
\hline 11 & Lokalizacja miejsc koncentracji ewakuowanych & \\
\hline 12 & Czy jest opracowany plan ewakuacji zbiorów? & TAK $\square /$ NIE $\square$ \\
\hline 13 & $\begin{array}{l}\text { Czy wyznaczono miejsce koncentracji } \\
\text { oznakowanych zbiorów? }\end{array}$ & TAK $\square /$ NIE $\square$ \\
\hline 14 & $\begin{array}{l}\text { Czy wyznaczono osoby odpowiedzialne } \\
\text { w obiekcie? }\end{array}$ & TAK $\square$ / NIE $\square$ \\
\hline 15 & $\begin{array}{l}\text { Czy personel (pracownicy) został zapozna- } \\
\text { ny z instrukcją postępowania na wypadek } \\
\text { pożaru lub innego miejscowego zagrożenia? }\end{array}$ & TAK $\square /$ NIE $\square$ \\
\hline 16 & $\begin{array}{l}\text { Czy personel (pracownicy) został zapozna- } \\
\text { ny z planem ewakuacji zbiorów? }\end{array}$ & TAK $\square /$ NIE $\square$ \\
\hline
\end{tabular}

\section{Przygotowanie obiektu (budynku) do prowadzenia działań ratowniczo-gaśniczych}

a) drogi pożarowexvi.

Czy jest wymagana droga pożarowa?

Wykaz obiektów, do których doprowadzenie drogi pożarowej jest wymagane reguluje $\$ 12$ ust. 1 rozporządzenia Ministra Spraw Wewnętrznych i Administracji z dnia 24 lipca 2009 r. w sprawie przeciwpożarowego zaopatrzenia w wodę oraz dróg pożarowych (Dz. U. Nr 124, poz. 1030).

TAK $\square /$ NIE $\square$

Czy jest zapewniona droga pożarowa do obiektu?

Wymagania dla dróg pożarowych regulują $\$ \$ 12 \div 14$ rozporządzenia Ministra Spraw Wewnętrznych i Administracji z dnia 24 lipca 2009 r. w sprawie przeciwpożarowego zaopatrzenia w wodę oraz dróg pożarowych (Dz. U. Nr 124, poz. 1030).

xvi Drogi pożarowe należy rozumieć jako drogę o nawierzchni utwardzonej, której konstrukcja umożliwia dojazd jednostek ochrony pożarowej, z uwzględnieniem zmian pór roku. 


\begin{tabular}{|l|c|}
\hline $\begin{array}{l}\text { Czy droga jest zastawiana parkującymi samo- } \\
\text { chodami? }\end{array}$ & TAK $\square$ / NIE $\square$ \\
\hline $\begin{array}{l}\text { Czy w związku z niespełnieniem wymagań dla } \\
\text { drogi pożarowej uzyskano zgodę właściwego } \\
\text { komendanta wojewódzkiego PSP na zastoso- } \\
\text { wanie rozwiązań zamiennych w trybie przewi- } \\
\text { dzianym w przepisach przeciwpożarowych? }\end{array}$ & \\
$\begin{array}{l}\text { @13 ust. } 4 \text { rozporządzenia Ministra Spraw Wewnętrz- } \\
\text { nych i Administracji z dnia 24 lipca 2009 r. w sprawie } \\
\text { przeciwpożarowego zaopatrzenia w wodę oraz dróg } \\
\text { pożarowych (Dz. U. Nr 124, poz. 1030). }\end{array}$ & \\
\hline $\begin{array}{l}\text { W jakiej odległości od budynku przebiega } \\
\text { droga [m]? / NIE }\end{array}$ \\
\hline $\begin{array}{l}\text { Opis utrudnień związanych z ruchem i usta- } \\
\text { wieniem pojazdów gaśniczych i specjalnych } \\
\text { straży pożarnej }\end{array}$ \\
\hline $\begin{array}{l}\text { Czy istnieje możliwość przejazdu bez koniecz- } \\
\text { ności zawracania? }\end{array}$ \\
\hline Liczba dojazdów i wjazdów \\
\hline
\end{tabular}

b) Zaopatrzenie w wodę do zewnętrznego gaszenia:

\begin{tabular}{|c|c|c|c|c|c|c|}
\hline & Występuje & $\begin{array}{c}\text { Liczba } \\
\text { hydrantów } \\
\text { w odległo- } \\
\text { ści do } 75 \mathrm{~m}\end{array}$ & $\begin{array}{c}\text { W odle- } \\
\text { głości }\end{array}$ & $\begin{array}{c}\text { Możliwość } \\
\text { czerpania } \\
\text { wody }\end{array}$ & $\begin{array}{c}\text { Wydaj- } \\
\text { ność / } \\
\text { Pojemność }\end{array}$ & $\begin{array}{c}\text { Lokalizacja } \\
\text { (nazwa } \\
\text { ulicy, } \\
\text { nr domu, } \\
\text { narożnik } \\
\text { /strona } \\
\text { budynku) }\end{array}$ \\
\hline $\begin{array}{l}\text { Hydranty } \\
\text { nadziemne }\end{array}$ & $\square$ & & & & & \\
\hline $\begin{array}{l}\text { Hydranty } \\
\text { podziemne }\end{array}$ & $\square$ & & & & & \\
\hline $\begin{array}{l}\text { Zbiornik } \\
\text { naturalny }\end{array}$ & $\square$ & & & & & \\
\hline $\begin{array}{l}\text { Zbiornik } \\
\text { sztuczny }\end{array}$ & $\square$ & & & & & \\
\hline $\begin{array}{l}\text { Ciek } \\
\text { wodny }\end{array}$ & $\square$ & & & & & \\
\hline
\end{tabular}




\section{Ocena stanu technicznego urządzeń przeciwpożarowych}

1. Czy system SSP jest sprawny?

TAK (w całości)

NIE (w całości)

NIE (w części)

Wymienić niesprawności:

W przypadku funkcjonowania ochrony częściowej SSP budynku wskazać zabezpieczone:
ekspozycje stałe
(wszystkie $\square$ ) / (wybrane $\square$ )
ekspozycje czasowe
(wszystkie $\square$ ) / (wybrane
magazyny
(wszystkie $\square$ ) / (wybrane
wybrane ciągi komunikacyjne
(wszystkie $\square$ ) / (wybrane
pozostałe pomieszczenia
(strych, piwnica, etc.)
(wszystkie $\square$ ) / (wybrane

2. Czy system DSO jest sprawny?

TAK (w całości)

NIE (w całości)

NIE (w części)

Wymienić niesprawności:

W przypadku funkcjonowania ochrony częściowej DSO budynku wskazać obszar działania:

ekspozycje stałe

ekspozycje czasowe

magazyny

wybrane ciągi komunikacyjne

pozostałe pomieszczenia

(strych, piwnica, etc.) (wszystkie $\square$ ) / (wybrane $\square$ )

(wszystkie $\square$ ) / (wybrane $\square$ )

(wszystkie $\square$ ) / (wybrane $\square$ )

(wszystkie $\square$ ) / (wybrane $\square$ )

(wszystkie $\square$ ) / (wybrane $\square$ )

3. Czy awaryjne oświetlenie ewakuacyjne jest sprawne?

TAK (w całości)

NIE (w całości)

NIE (w części)

Wymienić niesprawności:

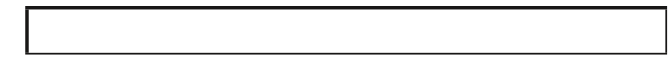

4. Czy instalacja stałych/półstałych urządzeń gaśniczych wodnych jest sprawna?

TAK (w całości)

NIE (w całości) 
NIE (w części)

Wymienić niesprawności:

W przypadku funkcjonowania ochrony stałymi/półstałymi urządzeniami gaśniczymi wodnymi wskazać zabezpieczone:

ekspozycje stałe

ekspozycje czasowe

(wszystkie $\square$ ) / (wybrane $\square$ )

magazyny

(wszystkie $\square$ ) / (wybrane $\square$ )

wybrane ciągi komunikacyjne

(wszystkie $\square$ ) / (wybrane $\square$ )

(wszystkie $\square$ ) / (wybrane $\square$ )

pozostałe pomieszczenia

(strych, piwnica, etc.)

(wszystkie $\square$ ) / (wybrane $\square$ )

5. Czy instalacja stałych urządzeń gaśniczych gazowych jest sprawna?

TAK (w całości)

NIE (w całości)

NIE (w części)

Wymienić niesprawności:

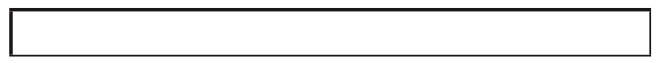

W przypadku funkcjonowania ochrony stałymi urządzeniami gaśniczymi gazowymi wskazać zabezpieczone:
ekspozycje stałe
(wszystkie $\square$ ) / (wybrane
ekspozycje czasowe
(wszystkie $\square$ ) / (wybrane
magazyny
(wszystkie $\square$ ) / (wybrane
wybrane ciągi komunikacyjne
(wszystkie $\square$ ) / (wybrane
pozostałe pomieszczenia
(strych, piwnica, etc.)
(wszystkie $\square$ ) / (wybrane $\square$ )

\section{OCENA KOŃCOWA}

\begin{tabular}{|l|l|}
\hline $\begin{array}{l}\text { Stanowisko właściwego państwowego insty- } \\
\text { tutu kultury w uzgodnieniu z komendantem } \\
\text { powiatowym (miejskim) PSP właściwym dla } \\
\text { miejsca lokalizacji obiektu }\end{array}$ & pozytywne /negatywne ${ }^{*}{ }^{* *}$ ) \\
\hline UWAGI: & \\
& \\
\hline
\end{tabular}




\section{Bibliografia}

[1] Wojtaszewski P., Zaciera K., Wojtasiak B., Certyfikacja obiektów muzealnych i zabytkowych, „Przegląd Pożarniczy” 10 (2017), s. 25-26.

[2] Zboina J., Wojtaszewski P., Wytyczne i certyfikacja rozwiązań organizacyjnych i technicznych obiektów zabytkowych, [w:] Wybrane zagadnienia bezpieczeństwa pożarowego obiektów zabytkowych. Wyniki badań i rekomendacje, J. Zboina (red), wydawnictwo CNBOP-PIB, Józefów 2017, s.131.

\section{Sprawozdania naukowe}

[1] Wojtaszewski P., Opracowanie założeń do wytycznych do opiniowania i certyfikacji rozwiązań organizacyjnych i technicznych obiektów zabytkowych, Zał. 1. Karta kontrolna zagadnień - aspekty techniczne i organizacyjne ochrony przeciwpożarowej w obiektach zabytkowych wydanie 1, CNBOP-PIB 2016, uwzględniająca występujące aspekty techniczne i organizacyjne w obiektach zabytkowych - do projektu zasad certyfikacji muzeów (wzorzec), opracowanie w ramach realizacji projektu „Opracowanie innowacyjnego systemu zarządzania bezpieczeństwa obiektów zabytkowych w zurbanizowanych centrach miast", projekt finansowany przez NCBR, nr umowy projektu: DOB-BIO7/08/01/2015.

[2] Wojtaszewski P., Opracowanie projektu zasad certyfikacji muzeów, opracowanie w ramach realizacji projektu „Opracowanie innowacyjnego systemu zarządzania bezpieczeństwa obiektów zabytkowych w zurbanizowanych centrach miast”, projekt finansowany przez NCBR, nr umowy projektu: DOB-BIO7/08/01/2015.

[3] Wojtaszewski P., Określenie potrzeb systemu opiniowania i potencjalnej certyfikacji rozwiązań organizacyjnych i technicznych obiektów zabytkowych, opracowanie w ramach realizacji projektu „Opracowanie innowacyjnego systemu zarządzania bezpieczeństwa obiektów zabytkowych w zurbanizowanych centrach miast”, projekt finansowany przez NCBR, nr umowy projektu: DOB-BIO7/08/01/2015.

[4] Kielin J., Zaciera K., Wojtasiak B., Bąk D., „Analiza koncepcji systemu sensorów prototypu Systemu OZAB pod kątem oceny zastosowania elementów fizycznych (urządzeń, sensorów). Zorganizowanie warsztatów dedykowanych przedstawieniu założeń Systemu na potrzeby sformułowania wymagań techniczno-użytkowych dla elementów fizycznych systemu typu Systemu OZAB” opracowanie w ramach realizacji projektu „Opracowanie innowacyjnego systemu zarządzania bezpieczeństwa obiektów zabytkowych w zurbanizowanych centrach miast”, projekt finansowany przez NCBR, nr umowy projektu: DOB-BIO7/08/01/2015.

[5] Kielin J., Zaciera K., Wojtasiak B., Bąk D., „Opracowanie wymagań klimatycznych oraz kompatybilności elektromagnetycznej dla elektronicznych/fizycznych elementów dla systemów typu System OZAB” opracowanie w ramach realizacji projektu „Opracowanie innowacyjnego systemu zarządzania bezpieczeństwa obiektów zabytkowych w zurbanizowanych centrach miast”, projekt finansowany przez NCBR, nr umowy projektu: DOB-BIO7/08/01/2015. 


\section{Akty prawne}

[1] Ustawa z dnia 21 listopada 1996 r. o muzeach (Dz.U. z 2017 poz. 972 ze zm.).

[2] Ustawa z dnia 24 sierpnia 1991 r. o ochronie przeciwpożarowej (Dz.U. z 2017 poz. 736 ze zm.).

[3] Ustawa z dnia 23 lipca 2003 r. o ochronie zabytków i opiece nad zabytkami (Dz.U. z 2017 poz. 2187 ze zm.).

[4] Rozporządzenie Ministra Spraw Wewnętrznych i Administracji z dnia 7 czerwca 2010 r. w sprawie ochrony przeciwpożarowej budynków, innych obiektów budowlanych i terenów (Dz.U. Nr 109, poz. 719).

[5] Rozporządzenie Ministra Kultury z dnia 25 sierpnia 2004 r. w sprawie organizacji i sposobu ochrony zabytków na wypadek konfliktu zbrojnego i sytuacji kryzysowych (Dz.U. Nr 212, poz. 2153).

[6] Rozporządzenie Ministra Kultury i Dziedzictwa Narodowego z dnia 2 września 2014 r. w sprawie zabezpieczania zbiorów muzeum przed pożarem, kradzieżą i innym niebezpieczeństwem grożącym ich zniszczeniem lub utratą (Dz.U. z 2014 poz. 1240). 



\title{
Bezzałogowe systemy rozpoznania uszkodzonych konstrukcji budowlanych
}

\author{
Unmanned systems for the identification \\ of damaged building structures
}

\author{
Norbert Tuśnio \\ Paweł Wolny \\ Paweł Ogrodnik \\ Szkoła Główna Służby Pożarniczej
}

\section{Streszczenie}

W opracowaniu przedstawiono koncepcje jednoczesnego zastosowania dwóch systemów: bezzałogowych statków powietrznych (BSP) w połaczeniu z mobilnymi robotami ladowymi, w działaniach ratowniczych prowadzonych podczas katastrof budowlanych. Technologia ta zostanie opracowana $w$ ramach osiagnięcia IX poziomu gotowości technologicznej w projekcie nr DOB-BIO6/03/48/2014, pt. „Innowacyjne rozwiazania metod stabilizowania konstrukcji budowlanych i technologicznych $w$ warunkach działań ratowniczych podczas likwidacji skutków katastrofy budowlanej”. Zgodnie z sugestiami Gestora powstały system złożony z mobilnego robota lądowego oraz tachimetru elektronicznego, który spełnit dotychczasowe oczekiwania, należy rozbudować o „komponent pozwalajacy na dokonywanie rozpoznania uszkodzonych konstrukcji budowlanych z wykorzystaniem bezzałogowych platform latających, które stałyby się naturalnym uzupełnieniem możliwości oferowanych przez przygotowana platformę kołową". W opracowaniu zaprezentowano możliwości oraz warianty użycia BSP $w$ działaniach ratowniczych, $w$ tym stosowane $w$ ramach KSRG oraz przez stużby innych państw.

Celem opracowania jest zaprezentowanie koncepcji połączonego zastosowania różnych systemów $w$ działaniach ratownictwa technicznego oraz korzyści płynących $z$ takiego rozwiązania. W ocenie autorów rozszerzenie możliwości pozyskiwania danych z poziomu lądu o dane zbierane przez sensory umieszczone na platformie latajacej zdecydowanie wpłynie na czas i jakość podejmowanych decyzji, zarówno na poziomie interwencyjnym, jak i taktycznym. W przypadku zdarzeń o dużych rozmiarach, takich jak wielkie awarie przemysłowe oraz katastrofy naturalne (trzęsienia ziemi), pozwoli to na dobór odpowiedniej strategii działań ratowniczych prowadzonych na szeroka skalę.

Podstawa do analiz był przeglad literaturowy oraz wyniki badań terenowych prowadzonych $w$ ramach wcześniejszych etapów projektu na poligonie Wydziału Szkolenia Specjalistycznych Grup Ratowniczych w Nowym Sączu oraz w Przeciwpożarowej Bazie Leśnej SGSP w Zamczysku Nowym.

Wyniki z badań dostarczyly informacji zarówno o zaletach rozwiązania, jak i jego niedoskonałościach. Przedstawione wnioski dotycza kierunku przyszłych badań oraz potencjalnych korzyści płynących $z$ wdrożenia obu rozwiązań technicznych $w$ ramach zintegrowanego systemu. 


\section{Abstract}

The concept of the simultaneous use of two systems: unmanned aerial vehicles (UAV) in combination with mobile land robots, in rescue operations carried out during construction disasters were presented in this paper. This technology will be developed as part of the achievement of the IX level of technological readiness in the project No. DOB-BIO6/03/48/2014 titled "Innovative solutions of methods for stabilizing construction and technological structures in the conditions of rescue operations during the elimination of the consequences of a construction disaster". According to Gestor's suggestions, the results of system consisting of a mobile land robot and a total station that met the expectations, should be expanded with $a$ "component that allows to recognize damaged construction structures using unmanned aerial platforms, which would become a natural complement to the possibilities offered by the prepared wheeled platform". The paper presents the possibilities and variants of the use of UAV in rescue operations, including those applied within the polish national rescue and fire-fighting system (KSRG) and by the services of other countries.

The aim of the study is to present the concept of the combined use of various systems in technical rescue operations and the benefits of such a solution. According to the authors, extending the possibility of acquiring data from the land level by data collected by sensors placed on a flying platform will definitely affect the time and quality of decisions made, both at the intervention and tactical levels. In the case of large-scale events, such as major industrial failures and natural disasters (earthquakes), this will allow the selection of an appropriate strategy for large-scale rescue operations.

The basis for the analysis was a literature review and the results of field research conducted as part of earlier stages of the project at the training ground of the Training Department of Specialist Rescue Groups in Nowy Sacz and in the Fire Forest Base of the Main School of Fire Service in Zamczysko Nowe.

The results of the research provided information both about the advantages of the solution and its imperfections. The conclusions presented concern the direction offuture research and the potential benefits of implementing both technical solutions within an integrated system.

\section{Wprowadzenie}

Stosowanie technologii bezzałogowych statków powietrznych (BSP) podczas akcji prowadzonych po katastrofach budowlanych o wielkich rozmiarach wpisuje się w nowoczesną strategię działań ratowniczych. Na masową skalę użyto BSP po trzęsieniu ziemi w Nepalu w 2015 r., gdzie pracowało co najmniej 15 zespołów „dronowych” (rys. 1).

Wykorzystując technologię BSP w Nepalu, wysyłano je do odległych, objętych katastrofą obszarów, w celu oceny sytuacji. Na podstawie pozyskanych danych, opracowywano optymalne plany prowadzenia operacji poszukiwawczo-ratowniczych. Dzięki temu rozwiązaniu informacje o faktycznej skali zniszczeń oraz potrzebach w zakresie sił i środków niezbędnych do skutecznego niesienia pomocy poszkodowanym docierały w znacznie krótszym czasie do centrum dowodzenia. Przykładem podanym w [1] jest skrócenie czasu zebrania informacji ze zniszczonej 
wioski do niecałych pięciu minut. Osiągnięcie tego samego celu bez użycia BSP zajęłoby ponad trzy godziny.

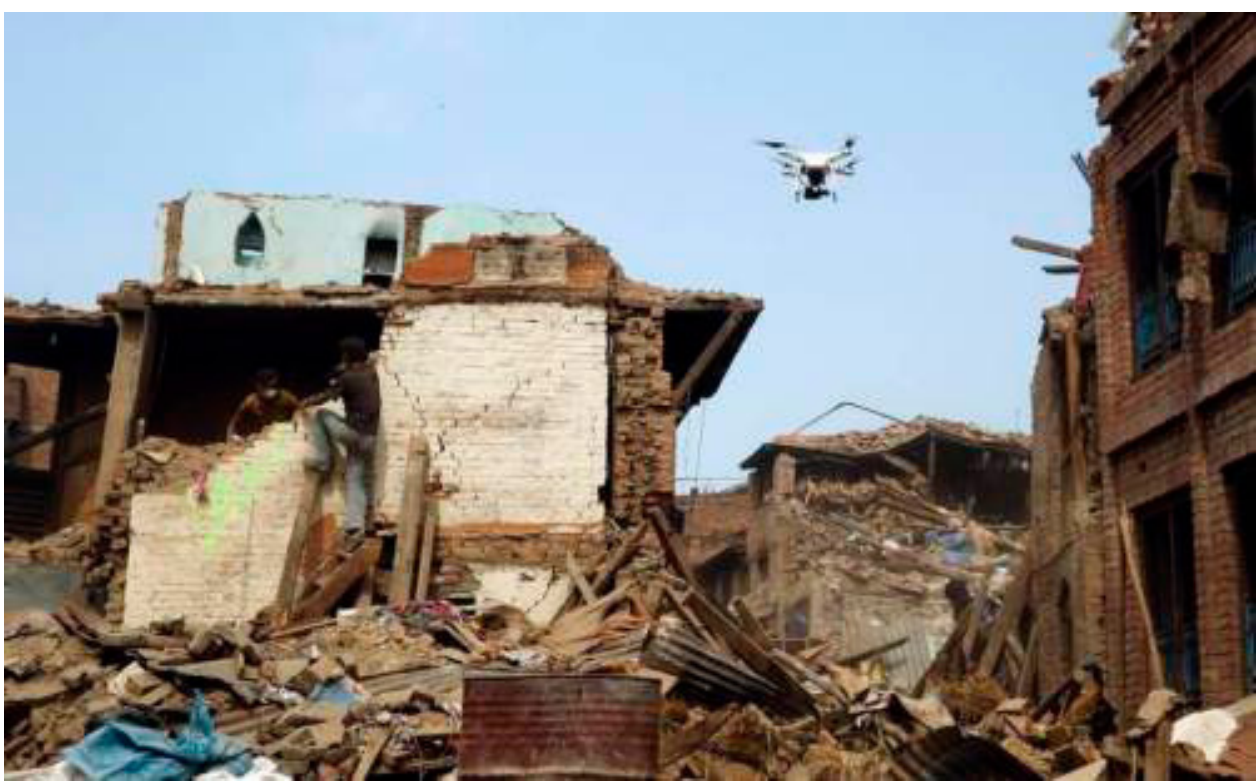

Rysunek 1. Nepal po trzęsieniu ziemi o sile 8,0 w skali Richtera Źródło: https://irevolutions.org/category/dronesuavs/

Figure 1. Nepal after 8,0 Richter-scale earthquake, source: https://irevolutions.org/category/dronesuavs/

W Polsce nie występują trzęsienia ziemi na taką skalę, ale zastosowanie dużej liczby BSP znacznie ułatwiłoby prace ratownikom KSRG po wydarzeniach z sierpnia 2017 r., kiedy w wyniku wichur i trąb powietrznych zniszczonych zostało 15,2 tys. ha lasów. Tego typu zdarzenia dodatkowo prowadzą do zerwania dachów na budynkach mieszkalnych i gospodarczych oraz odcięcia dopływu prądu. Z raportów Departamentu Inspekcji i Kontroli Budowlanej Głównego Urzędu Nadzoru Budowlanego wynika, że w latach 2010-2017 odnotowano ponad 4000 katastrof budowlanych. Pomimo tego, że tylko około $4 \%$ zdarzeń to katastrofy spowodowane przez wybuch gazu, powodują one największe straty ludzkie i materialne, a przyczyną większości z nich były wybuchy gazu płynnego w butlach. Działalność człowieka wbrew powszechnemu przekonaniu nie stanowi głównego źródła katastrof budowlanych. Przykładowo w roku 2016 na 362 przeanalizowane przypadki za przyczyny katastrof budowlanych uznano [2]:

- silne wiatry (189);

- pożar (61);

- wybuch gazu (19);

- intensywne opady atmosferyczne (18);

- uszkodzenie obiektów budowlanych przez pojazdy (4);

- inne wybuchy (3); 
- obciążenia śniegiem (2);

- przewrócenie drzewa (2);

- kradzież elementów konstrukcyjnych (2);

- wyładowania atmosferyczne (1).

Jak najszybszy przepływ informacji ma kluczowe znaczenie dla efektywności prowadzonej akcji, dlatego zdaniem autorów zastosowanie technologii BSP $\mathrm{w}$ takich przypadkach jest konieczne. Jednak wdrożenie latających systemów bezzałogowych podczas katastrof wymaga znacznie wcześniejszego przygotowania praktycznych mechanizmów koordynacji pomiędzy pracującymi zespołami, nadzorem lotniczym (Urząd Lotnictwa Cywilnego, Polska Agencja Żeglugi Powietrznej i inne) a dowodzącymi akcją. Rzetelne opracowanie takich procedur pozwoli uniknąć problemów, z jakimi zetknęli się operatorzy BSP w Nepalu (wielokrotne przeszukiwanie tego samego obszaru i pominięcie innych, zagrożenie kolizją ze śmigłowcami ratowniczymi, chaos komunikacyjny i kompetencyjny). Znaczącym zwiększeniem potencjału operacyjnego przy użyciu BSP byłoby stworzenie spójnych zasad i przepisów o współpracy z wolontariuszami posiadającymi odpowiednie kwalifikacje i sprzęt. Tego typu rozwiązanie wdrożono już w roku 2014 w Australii [3].

Do likwidacji skutków katastrof budowlanych można wykorzystywać nie tylko jeden system bezzałogowy. W Japonii od lat $90 \mathrm{XX}$ w. stosowane są bezzałogowe maszyny budowlane, a obecnie prowadzony jest projekt połączenia zalet tego systemu i BSP.

W Polsce również prowadzone są badania nad połączeniem tych dwóch systemów bezzałogowych $\mathrm{w}$ ramach realizacji projektu z obszaru bezpieczeństwa i obronności.

\section{Pozakrajowe rozwiązania w zakresie technologii bezzałogowych stosowane w ratownictwie budowlanym}

Latającym systemem bezzałogowym przeznaczonym do prac wewnątrz budynków lub inspekcji instalacji technologicznych o ograniczonym lub utrudnionym dostępie jest „Elios” szwajcarskiej firmy Flyability (rys. 2).

Unikalną cechą tego systemu jest osłona $\mathrm{z}$ włókna węglowego. Jest ona odporna na kolizje przy prędkości do $15 \mathrm{~km} / \mathrm{h}$, ma budowę modułową (co umożliwia szybką wymianę uszkodzonych elementów) oraz stabilizatory kamery. Konstrukcja samego BSP umożliwia szybką wymianę akumulatorów. W celu ułatwienia nawigacji oraz rejestracji obrazu z zaciemnionych miejsc zastosowano oświetlenie LED-owe.

System Elios jest odporny na trudne warunki pracy (kurz, wilgoć, temperatury w zakresie od 0 do $50^{\circ} \mathrm{C}$ ), a jego odporność na błędy manewrowania jest tak duża, że nawet niedoświadczony operator może skutecznie realizować powierzone zadania. Producent deklaruje, że niezbędne minimum umiejętności nabywa się po kilkugodzinnym treningu. Dodatkową zaletą tego rozwiązania jest fakt, że zostało 
ono zaprojektowane do lotów w pomieszczeniach, a w związku z tym procedury użycia są mocno uproszczone (brak wymogu otrzymania zgody na odbycie lotu).

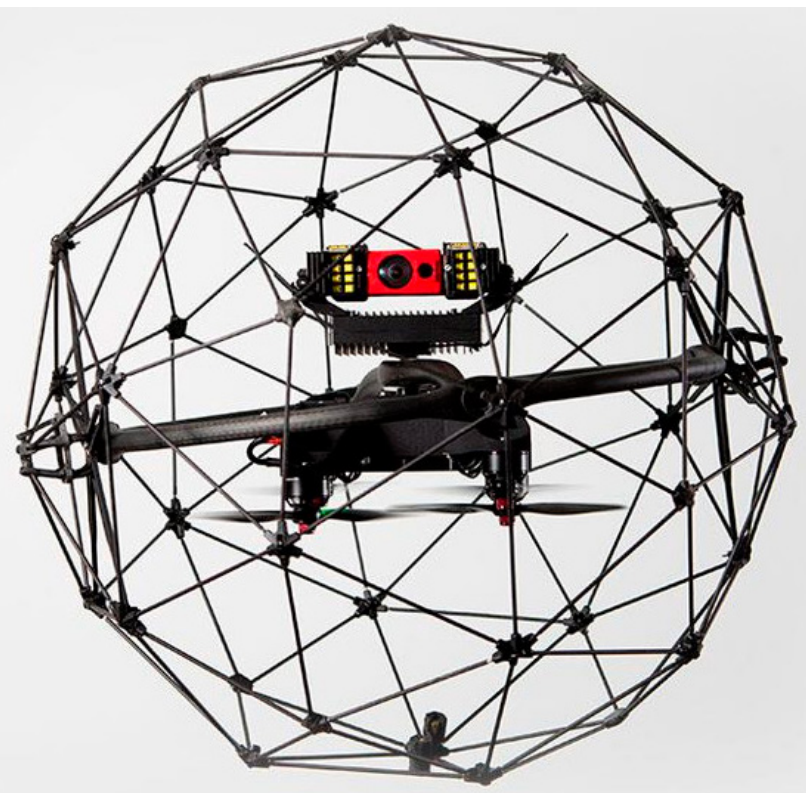

Rysunek 2. Bezzałogowy statek powietrzny Elios

Źródło: https://www.flyability.com/

Figure 2. Elios UAV, source: https://www.flyability.com/

Sterowanie i przepływ danych opiera się na komunikacji na paśmie $2,4 \mathrm{GHz}$, co gwarantuje zasięg BSP w przestrzeniach zamkniętych do $150 \mathrm{~m}$ od operatora w tunelach o nieznacznych łukach czy wewnątrz kominów. Nie ma również zakłóceń sygnału w standardowych, wielokondygnacyjnych budynkach [4].

Na pomysł stosowania bezzałogowych maszyn budowlanych używanych łącznie z BSP w likwidacji skutków katastrof budowlanych wpadła grupa japońskich naukowców z Uniwersytetu Tohoku (Field Robotics Laboratory). Do tego celu zastosowano zdalnie sterowaną minikoparkę, na której zainstalowano lądowisko dla wielozadaniowego BSP (ryc. 3). Aby uniknąć problemów z łącznością i zasilaniem, które są słabym elementem systemów bezzałogowych, użyto rozwiązania sterowania przewodowego (model na uwięzi). System ten jest przydatny do prowadzenia prac związanych z usuwaniem pozostałości konstrukcji z punktu widzenia bezpieczeństwa osób znajdujących się w strefie potencjalnie zagrożonej. W początkowej fazie realizacja zadań przez operatorów bezzałogowego sprzętu specjalnego jest utrudniona z powodu ograniczenia informacji wizualnych, co jest spowodowane brakiem ruchomych kamer. Aby rozwiązać ten problem, dodano możliwość obserwacji z punktu widzenia osoby trzeciej. W tym celu opracowany został helipad, który oprócz funkcji lądowiska zapewnia zasilanie i przesył sygnału sterującego poprzez 
przewód wielożyłowy. Aby uniknąć sytuacji, w której przewód jest nieodpowiedniej długości, zastosowano system kontroli jego prawidłowego napięcia [5].

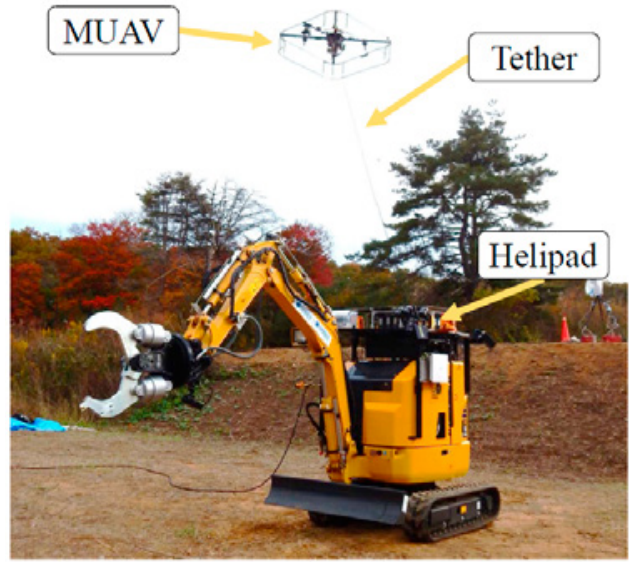

Rysunek 3. Komponenty systemu bezzałogowego: maszyna budowlana $\mathrm{z}$ helipadem dla BSP na uwięzi

Źródło:www.fsr.ethz.ch/papers/FSR_2017_paper_24.pdf

Figure 3. The components of unmanned system: construction machine with helipad for tethered UAV, source: www.fsr.ethz.ch/papers/FSR_2017_paper_24.pdf

Japonia znajduje się w obszarze wysokiej aktywności sejsmicznej. Konsekwencją tego jest narażenie nie tylko na trzęsienia ziemi o różnej skali, ale także erupcje wulkanów oraz fale tsunami. Zniszczenia infrastruktury przy tego typu katastrofach naturalnych wymagają dobrego przygotowania od strony technicznej i organizacyjnej. Użycie ciężkiego sprzętu budowlanego do usuwania skutków tych zdarzeń wiąże się z zagrożeniem dla operatorów, np. na skutek wtórnych wstrząsów. Dlatego, aby zapewnić bezpieczeństwo operatorom, w Japonii opracowano i wdrożono bezzałogowe maszyny budowlane. Działający system zdalnie sterowanych maszyn budowlanych (Tele-earthwork) powstał już w latach $90 \mathrm{XX}$ w. Został on przetestowany w praktyce do usuwania pyłów wulkanicznych i budowy zapór przeciwpowodziowych po erupcjach wulkanu Unzen i po trzęsieniu ziemi w 2011 r. [5].

Niedoskonałości dotychczas stosowanego rozwiązania, dostrzeżone przez naukowców z Uniwersytetu Tohoku, są następujące:

- zdalnie sterowane maszyny budowlane wymagają długotrwałego przygotowania przed operacją;

- liczba zdalnie sterowanych maszyn budowlanych jest niewielka;

- transport maszyn do miejsca katastrofy zajmuje dużo czasu, a w początkowej fazie likwidacji skutków katastrofy niezbędna jest jak największa liczba ciężkiego sprzętu (w związku z tym pożądany jest system teleoperacji do szybkiego montażu na klasycznych maszynach budowlanych);

- obraz widziany przez operatora pochodzi jedynie z kamer zamontowanych na korpusie urządzenia, co w znacznym stopniu ogranicza jego pole widzenia 
(do precyzyjnego prowadzenia działań wielokrotnie potrzebny jest widok „z lotu ptaka” lub łyżki koparki).

Aby wyeliminować wymienione problemy, w Field Robotics Laboratory opracowano bezzałogowy system złożony z koparki i BSP (rys. 4).

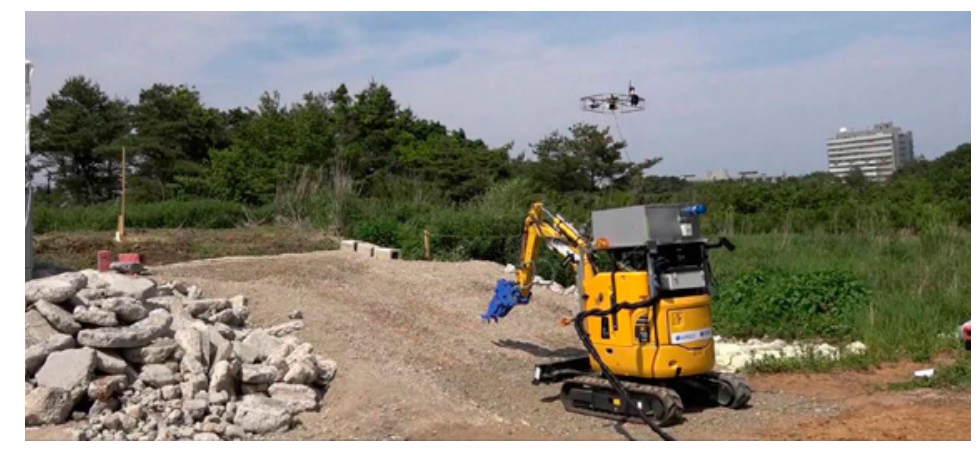

Rysunek 4. Testy systemu opracowanego w Field Robotics Laboratory Tohoku University Źródło: http://frl.niche.tohoku.ac.jp/en/research/

Figure 4. Field tests of the system developed at Field Robotics Laboratory, Tohoku University, source: http://frl.niche.tohoku.ac.jp/en/research/

Testy polowe systemu przeprowadzone w 2016 r. wykazały skuteczność przedstawionego rozwiązania. Jego ogromną zaletą jest czas działania BSP - urządzenie znajdowało się w powietrzu nieprzerwanie ponad godzinę, zużywając poniżej $40 \%$ pojemności baterii. W tych testach, ze względów bezpieczeństwa, ograniczono długość uwięzi do $12 \mathrm{~m}$.

\section{Elementy systemu stabilizowania konstrukcji budowlanych w warunkach działań ratowniczych}

W Polsce przyjęto inną koncepcję wykorzystania dwóch systemów bezzałogowych w ratownictwie technicznym. Nie jest on przeznaczony do bezpiecznego usuwania skutków katastrof budowlanych, a jedynie służy podniesieniu poziomu bezpieczeństwa ratowników podczas akcji poszukiwawczo-ratowniczych. W skład systemu zbudowanego $\mathrm{w}$ ramach realizacji projektu „Innowacyjne rozwiązania metod stabilizowania konstrukcji budowlanych i technologicznych w warunkach działań ratowniczych podczas likwidacji skutków katastrofy budowlanej" wchodzi:

- mobilny robot PIAP Scout;

- tachimetr elektroniczny Leica MS60;

- stanowisko oficera bezpieczeństwa.

Testy terenowe kompletnej platformy sprzętowej były realizowane w trakcie warsztatów na poligonie SA PSP w Krakowie (wydział w Nowym Sączu) oraz w Przeciwpożarowej Bazie Leśnej Szkoły Głównej Służby Pożarniczej w Zamczysku Nowym. Ponadto oddzielne badania efektywności i sprawności poszczególnych 
systemów platformy sprzętowej i stanowisk badawczych były prowadzone podczas prób realizowanych zgodnie $\mathrm{z}$ harmonogramem prac III etapu projektu. Prezentacje sprzętowe były rejestrowane przy użyciu systemów zapisu wideo: naziemnych i umieszczonych na bezzałogowych statkach powietrznych.

W testach w Nowym Sączu uczestniczyli przedstawiciele konsorcjum z ramienia Szkoły Głównej Służby Pożarniczej w Warszawie, Szkoły Aspirantów Państwowej Straży Pożarnej w Krakowie, Centrum Naukowo-Badawczego Ochrony Przeciwpożarowej w Józefowie, firmy CMGI Sp. z o.o. oraz Leica Geosystems, a także reprezentanci specjalistycznych grup poszukiwawczo-ratowniczych.

Zakres testów obejmował sprawdzenie integralności systemu, przesyłu danych i obrazu, realnego zasięgu pracy w zależności od jej warunków (tłumienie sygnałów przez elementy konstrukcji). Scenariusz zakładał obserwację zbudowanej podpory drewnianej na stanowisku badawczym, której elementy poddane były działaniu siły niszczącej. Była ona prowadzona za pomocą tachimetru elektronicznego oraz kamer robota lądowego, który może być wyposażony w miernik wielogazowy.

W testach poligonowych prowadzonych na obiektach SGSP w Zamczysku Nowym, oprócz wykonawców projektu, uczestniczyli przedstawiciele jednostek ratowniczo-gaśniczych: $\mathrm{nr} 15 \mathrm{z}$ Warszawy (specjalizacja: grupa poszukiwawczo-ratownicza) oraz szkolna JRG SGSP. Scenariusze działań dotyczyły podjęcia czynności z użyciem chwytaka robota. Podnoszono nim atrapę butli z gazem propan-butan, bez kontaktu wzrokowego operatora $\mathrm{z}$ robotem (sterowanie prowadzono tylko w oparciu o podgląd dostępny z kamer). Następną próbę wykonano $\mathrm{z}$ butlą znajdującą się $\mathrm{w}$ pomieszczeniu $\mathrm{z}$ ograniczonym dostępem światła, sprawdzając możliwości adaptacji obrazu przesyłanego $\mathrm{z}$ kamery przeznaczonej do stosowania w takich warunkach. Na trasie, jaką musiał pokonać robot, znajdowała się przeszkoda w postaci stopnia przed wjazdem do pomieszczenia. Kolejnym zadaniem było wydobycie gaśnicy z uszkodzonego pojazdu poprzez uchylone drzwi. Operator był w stanie przesunąć chwytakiem gaśnicę do dogodnej pozycji, a następnie ją podnieść. Dodatkowo wykonano zadanie polegające na podnoszeniu gaśnicy z podwyższenia oraz układaniu jej na podłożu. Następnie testowano zdolność robota do przemieszczania się po trudnym terenie. Dzielność terenowa została zweryfikowana w trakcie wjazdu na stopień autobusu przeznaczonego do ćwiczeń na poligonie.

Po przeprowadzeniu badań platformy lądowej wyciągnięto następujące wnioski:

1. Sterowanie w trudnym terenie wymaga doświadczonego operatora. Wpływ na to ma konstrukcja robota oraz sposób umiejscowienia i mocowania aparatury pomiarowej (co powoduje niestabilność robota i możliwość jego upadku, szczególnie podczas pokonywania schodów).

2. W zastosowanym systemie przesyłu obrazu, po wjeździe do budynku, stwierdzono znaczne pogorszenie jakości transmisji, do utraty sygnału włącznie.

3. W czasie testów robota zanikł obraz z czwartej, największej kamery (uszkodzenie niemechaniczne wymagające serwisu producenta). 
4. Brak alternatywnego sposobu ładowania akumulatorów - dostępna tylko ładowarka sieciowa.

5. Wystąpiły poważne zakłócenia łączności bezprzewodowej operatora z platformą w przypadku użytkowania w obszarze ograniczonym przegrodami żelbetowymi. Sugerowanym rozwiązaniem tego problemu jest zastosowanie łączności przewodowej, ale wadą tego sposobu sterowania jest znaczne ograniczenie zasięgu oraz mobilności platformy.

6. Integracja danych płynących z platformy mobilnej (obraz z kamer, odczyt z miernika wielogazowego) oraz tachimetru elektronicznego (stały przesył wyników pomiarów przemieszczeń w niestabilnej konstrukcji) przyniosła oczekiwane efekty w przypadku monitorowania budynków naziemnych. Informacja o przekroczeniu zadanych granicznych ugięć przekazywana jest ratownikom za pomocą sygnalizatora dźwiękowo-świetlnego. Funkcja ta nie zdała egzaminu podczas prac w wykopie.

7. Podczas pomiaru stężenia gazu mobilny robot PIAP Scout (rys. 5) nie może być jednocześnie wykorzystany jako moduł rozpoznawczy oraz do transportu butli z gazem. Zastosowany detektor uniemożliwia wykonanie takich czynności jednocześnie (zajętość chwytaka). Celowe jest zastosowanie innego rozwiązania, np. montaż stałych detektorów lub użycie cięższego modelu robota [6].

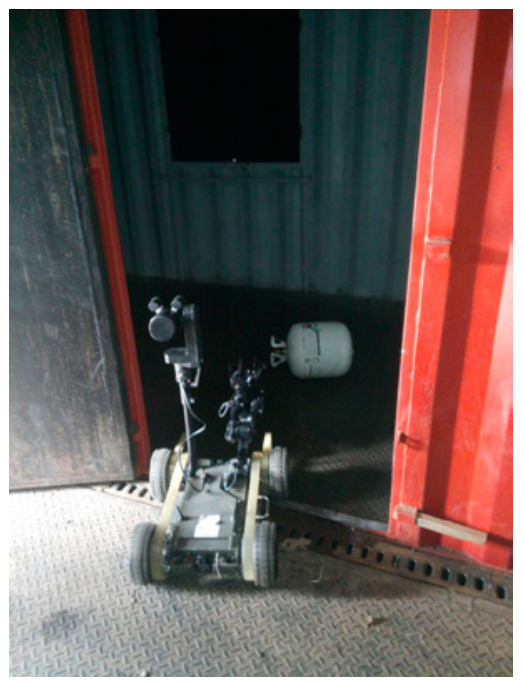

Rysunek 5. Mobilny robot „PIAP Scout” - podnoszenie atrapy butli z gazem propan-butan Źródło: T. Drzymała, Sprawozdanie z zadania badawczego III.17.1.1.1 „Testowanie i demonstracja platformy sprzętowej”. Warszawa 2017

Figure 5. Mobile robot „PIAP Scout” - lifting of propane-butane tank mockup, source: T. Drzymała, Sprawozdanie z zadania badawczego III.17.1.1.1 „Testowanie i demonstracja platformy sprzętowej”. Warszawa 2017

W ramach prac zrealizowanych w projekcie „Innowacyjne rozwiązania metod stabilizowania konstrukcji budowlanych i technologicznych w warunkach działań 
ratowniczych podczas likwidacji skutków katastrofy budowlanej" potwierdzono, że testowana platforma (mobilny robot PIAP Scout) może być wykorzystana jako moduł rozpoznawczy, pomocny do bezpośredniego wsparcia ratowników na obszarach objętych katastrofą budowlaną, m.in. w zakresie: rozpoznania obszaru katastrofy pod kątem bezpieczeństwa, przemieszczania się po trudnym terenie i pokonywania przeszkód (mobilność) oraz wykonywania czynności technologicznych w miejscach akcji (monitorowanie warunków środowiskowych oraz transmisja obrazu podczas rozpoznania, np. przepustów).

Obsługa platformy oraz tachimetru jest realizowana drogą radiową przez operatorów odpowiednio na stanowiskach instrumentu i oficera bezpieczeństwa. Pomimo że przeprowadzone testy wykazały ogólną przydatność sensorów znajdujących się standardowo na wyposażeniu mobilnego robota, to jednak zauważono podczas prób pewne problemy z łącznością radiową. Były one związane z zakłóceniami spowodowanymi przez antenę od interkomu. Rozwiązaniem mogłoby być tutaj zastosowanie radiotelefonu lub odpornej na zakłócenia światłowodowej łączności przewodowej.

W celu spełnienia oczekiwań Gestora projektu, w ramach prac prowadzonych wraz ze studentami-wolontariuszami (członkami Koła Naukowego Nowoczesnych Technologii) prowadzone są działania przygotowawcze. Polegają one na skonstruowaniu, podczas warsztatów, małego BSP mającego służyć jako uzupełnienie systemu gromadzenia i transferu danych z mobilnej platformy lądowej i tachimetru elektronicznego, a tym samym do wspomagania decyzji Kierownika Działań Ratowniczych.

Wielowirnikowiec „Hornet” (rys. 6) jest dedykowany do wykonywania lotów wewnątrz budynków. W tym celu został wyposażony w specjalne osłony wirników, które chronią maszynę w przypadku kontaktu z przeszkodą, np. ścianą. Jego niewielkie rozmiary sprawiają, że można nim dotrzeć w miejsca trudnodostępne.

Ten prototyp BSP jest wyposażony w akumulator o pojemności $2200 \mathrm{mAh}$, co umożliwia około $20 \mathrm{~min}$. nieprzerwanego lotu w jednym z trzech trybów. Posiada dwie wersje: treningową bez kamery oraz operacyjną wyposażoną w kamerę, nadajnik i monitor do podglądu.

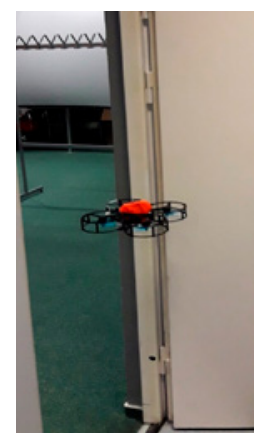

Rysunek 6. Wielowirnikowiec „Hornet” podczas testów w pomieszczeniach Źródło: fot. K. Orzepowski

Figure 6. „Hornet” multi-copter during room testing, source photo: K. Orzepowski 


\section{Podsumowanie i wnioski}

Kierownictwo Komendy Głównej Państwowej Straży Pożarnej dostrzegło zalety bezzałogowych systemów powietrznych stosowanych m.in. do rozpoznania sytuacji oraz przeprowadzania inspekcji uszkodzonych konstrukcji budowlanych. Na początku 2017 r. ogłoszony został przetarg na dostawę kilku typów bezzałogowców. W zależności od ich przeznaczenia miały się różnić budową, funkcjonalnością i wyposażeniem (np. w kamerę termowizyjną) [7].

Efektem podjętych przez KG PSP działań jest wdrożenie do służby następujących bezzałogowych systemów powietrznych w warszawskiej Jednostce RatowniczoGaśniczej nr 15 (specjalizacja: grupa poszukiwawczo-ratownicza):

- podstawowy model DJI Inspire do poszukiwań ludzi w terenie otwartym oraz obserwacji rozwoju pożaru lasów;

- prezentowany wcześniej Elios, do poszukiwań poszkodowanych i oceny stanu konstrukcji wewnątrz obiektu;

- BSP dalekiego zasięgu o wydłużonym czasie działania (akumulatory wystarczają na 40-50 min lotu) przekazujący obraz z kamer do samochodu sztabu.

Aby spełnić oczekiwania i zaspokoić potrzeby treningowe operatorów służb, z inicjatywą przygotowania i przeprowadzenia szkoleń wystąpiło Centrum Naukowo-Badawcze Ochrony Przeciwpożarowej - Państwowy Instytut Badawczy. Komplementarność kursów przygotowanych przez CNBOP w Józefowie zapewniają długotrwałe analizy niezbędnych w służbie kwalifikacji i umiejętności.

Jest to pierwsze w Polsce szkolenie BSP w całości przeznaczone dla służb bezpieczeństwa powszechnego i publicznego takich jak straż pożarna, Straż Graniczna oraz Policja. Zgodnie z podejściem dowódców poszczególnych formacji mundurowych biorących udział w programie operowanie BSP jest traktowane jako narzędzie do osiągania celów, a nie jako cel sam w sobie. Głównym założeniem szkolenia jest unifikacja jego programu dla wszystkich podmiotów podobnie jak wdrożenie do służby takich samych BSP, wyposażonych w takie same systemy i osprzęt niezbędny do ich działania i efektywnego wykorzystania. Różnice będą występowały tylko w przypadku procedur operacyjnych. Grupą docelową szkolenia są dowódcy lub kierownicy zespołów zadaniowych BSP - analitycy GIS.

Wielką słabością wdrożenia systemów bezzałogowych (głównie dotyczy to BSP) jest brak przepisów wykonawczych dla operatorów działających w stanach wyższej konieczności, czyli funkcjonariuszy służb mundurowych podczas akcji ratowniczych. Obecne prawo nie uwzględnia takich przypadków. Nie istnieje również systemowe podejście do stosowania tej technologii na poziomie taktycznym czy strategicznym. Pojedyncze egzemplarze BSP, które zostały zakupione w ramach PSP, nie są ze sobą w pełni kompatybilne. Nie wypracowano wewnętrznych procedur ich użycia, określenia liczby operatorów na zmianie służbowej i sposobu ich szkolenia do specyficznych zadań. Rozwiązaniem ostatniego problemu mogłaby być decyzja Komendanta Głównego PSP o obowiązku odbycia przez wszystkich 
strażaków-operatorów BSP szkolenia w Centrum Systemów Bezzałogowych „Centrum Dronów” w Józefowie.

Moduł „dronowy” nie został także włączony do struktury Centralnego Odwodu Operacyjnego, choć w Centrum Informacji Kryzysowej (zespół w Centrum Badań Kosmicznych PAN) rozważane jest jego stworzenie z udziałem podchorążych SGSP (posiadających certyfikat UAVO).

Przyjęty kierunek rozwoju jest więc właściwy, ale pełne wykorzystanie efektów pracy zespołów badawczych będzie możliwe tylko i wyłącznie wtedy, kiedy zostanie wykonany ogrom pracy administracyjnej i planistycznej w celu przygotowania odpowiednich spójnych procedur, przepisów i wytycznych, a także przećwiczenia scenariuszy potencjalnych zdarzeń.

\section{Bibliografia}

[1] Ferris-Rotman A., How Drones Are Helping Nepal Recover From The Earthquake. www.huffingtonpost.com/2015/05/07/nepal-earthquake-drones_n_7232764.html (dostęp: 27.01.2018).

[2] Rejestr katastrof budowlanych GUNB, www.gunb.gov.pl/sites/default/files/attachment/kat_2016.pdf (dostęp: 28.01.2018).

[3] Engagement and Operation of RPA or UAVs in Support of Emergency Operations. Document number SO-Q-OM-4.28, Queensland 2014.

[4] Elios Inspect\&Explore Indoor and Confined Spaces. Broszura firmy Flyability. Lozanna 2018.

[5] Kiribayashi S., Yakushigawa K., Nagatani K., Design and Development of Tether-Powered Multirotor Micro Unmanned Aerial Vehicle System for Remote-Controlled Construction Machine, [w:] Field and Service Robotics, Sendai 2018.

[6] Drzymała T., Sprawozdanie z zadania badawczego III.17.1.1.1 „Testowanie i demonstracja platformy sprzętowej”, Warszawa 2017.

[7] KG PSP, Dostawa bezzałogowych platform latających do rozpoznania sytuacji wraz z oprzyrządowaniem, oprogramowaniem oraz przeszkoleniem użytkowników. Informacje przetargowe ze strony www.straz.gov.pl/aktualnosci/zamowienia_zrealizowane/402 


\section{Część VI}

MONITORING STANU TECHNICZNEGO SPRZĘTU W STRAŻY POŻARNEJ 



\title{
System Internetu Rzeczy do monitorowania wyposażenia sprzętu straży pożarnej
}

\section{Internet of things system for monitoring fire brigade equipment}

\author{
Łukasz Apiecionek \\ Uniwersytet Kazimierza Wielkiego w Bydgoszczy
}

\section{Streszczenie}

Cel: Celem niniejszego publikacji jest przedstawienie możliwości wykorzystania Internetu Rzeczy do monitorowania wyposażenia sprzętu straży pożarnej.

Wprowadzenie: Systemy komputerowe sq obecnie dostępne na każdym kroku. W dziedzinie komputeryzacji przeżywamy ere Internetu Rzeczy (ang. Internet of Things, IoT). Idea ta polega na podłaczaniu wszystkich możliwych urzadzeń do sieci Internet $w$ celu uzyskania nowych ustug, co polepszy nasz standard życia. Idea zmierza do tego, aby każdy uzyskat dostęp do dowolnej usługi, w każdym miejscu, w którym się znajdzie, przez każde możliwe medium transmisyjne i uzyskał dowolnie potrzebna mu usługę. W najprostszym z możliwych ogólnych obrazów Internetu Rzeczy jest budowa takiego systemu, $w$ którym lodówka podłaczona do sieci Internet będzie rozpoznawała poziom produktów, które się w niej znajdują, a w przypadku ich wyczerpywania sama dokona zamówienia w sklepie, zapłaci za pomoca zapisanych numerów karty kredytowej i zamówi dostawe kurierem. Po odbiorze paczki i wstawieniu nowych produktów do lodówki, rozpozna ona znów ich liczbę oraz rodzaj, a następnie przewidzi, kiedy będa się one kończyły. W chwili obecnej Internet Rzeczy można określić jako rozwiqzanie w budowie. Stale pojawiaja się nowe architektury, ale i technologia pozwala na budowanie nowych usług. Jedna z obecnie dostępnych i bardzo często wykorzystywanych usług jest monitorowanie różnego rodzaju wielkości fizycznych, linii produkcyjnych, procesów im towarzyszacych. Dostarczane rozwiązania pozwalaja podejmować lepsze decyzje. Maciej Kranz w swojej książce podaje, $\dot{z}$ e połaczenie technologii i podejmowania decyzji pozwala na osiagnięcie lepszego wyniku finansowego przedsiębiorstw $i$ właśnie dlatego rozwiązania te powinny być rozważane do wdrożenia. Jednak wdrażanie rozwiązań generuje problemy: jak dokonać analizy, jakie rozwiazanie wybrać, komu zaufać przy jego modelowaniu, wykonaniu $i$ wdrażaniu. Ze względu na proces wdrażania, idealnym rozwiazaniem byłaby uniwersalna architektura rozwiązania, która uwzględniałaby wszystkie aspekty pracy: szybkość działania, bezpieczeństwo transmisji i przetwarzania danych. Taka uniwersalna architektura może zostać zastosowana również w systemach monitorowania sprzętu Straży Pożarnej. Wspomniany system powstał podczas realizacji projektu „Opracowanie metodologii stałego nadzoru eksploatacji wybranych obszarów wyposażenia straży pożarnej w zakresie niezawodności i skuteczności działania". W niniejszym artykule wprowadzono $w$ zagadnienia Internetu Rzeczy oraz pokazano na prawdziwym przykładzie, jak zastosować go do monitorowania wyposażenia sprzętu Straży Pożarnej. 
Metodologia: W publikacji wykorzystano metodę analizy, aby rozważyć możliwość zastosowania idei Internetu Rzeczy do wytworzenia systemu monitorowania wyposażenia sprzętu straży pożarnej.

Wnioski: Wykonana analiza wykazała, że zastosowanie idei Internetu Rzeczy sprawdza się również w przypadku budowy systemów rozproszonych dla Straży Pożarnej.

\section{Abstract}

Objective: The main aim of this article is to answer the question whether it is possible to use an idea of Internet of Things to build a system for monitoring the fire brigade equipment.

Introduction: IT systems are nowadays widely used. One of the newest trend is Internet of Things. This idea was developed for connecting machine to machine devices which let to transfer data faster and made better decision according to the data. This idea was developed also for providing new services and features. The next aim of Io $T$ is to provide services in any places, any time, over any possible interfaces. Right now the IoT idea is on development phase. There are lot of new architectures, and technology let to provide new features day after day. One of the main used features is monitoring systems parameters. Such solutions let to made better and faster decisions. Maciej Kranz claims that the technology and decision making connections provide better finance results for business. But IoT implementation generate lot of problems too. The problems are connected with the decision what kind of IoT system architecture should be used. The best solutions could be a general architecture which could provide the best transmission speed, security, and data processing. Such general architecture could also be used according to monitoring fire brigade equipment as it was used in the project called the Development of the methodology of continuous supervision of operation of selected areas of fire-fighting equipment in terms of reliability and effectiveness of operation project. In this paper the idea of IoT for monitoring fire brigade equipment is presented.

Methodology: In this publication an observational method was used to consider if the Internet of Things idea could be used for monitoring fire brigade equipment.

Conclusions: The analysis demonstrated that there is a possibility to build a huge system for fire brigade using the Internet of Things idea.

\section{Wprowadzenie}

Internet Rzeczy pozwala na fizyczne połączenie obiektów, które dzięki temu mogą współdzielić informacje i dzięki temu istnieje możliwość podejmowania lepszych decyzji. IoT zmienia tradycyjne obiekty w obiekty zwane smart. Dzieje się to poprzez dodanie możliwości przetwarzania danych, wzajemnej komunikacji, dodania sensorów, protokołów transmisji i aplikacji. Rysunek 1 przedstawia ogólna koncepcję IoT.

Zakłada się, że z upływem czasu coraz więcej urządzeń zostanie włączonych do sieci Internet i stworzą inteligentne środowisko. Synchronizując rozwiązania, możliwe będzie np. wcześniejsze otworzenie bramy garażowej w momencie, gdy auto zbliża się już do posesji. Wykorzystując inteligentne systemy transportu, możliwe będzie lepsze sterowanie ruchem. Umożliwi to rozładowanie korków, przepuszczenie 
przez światła pojazdów uprzywilejowanych. Wymaga to jednak rozwiązania wielu problemów. Często problemem jest fakt:

- konieczności posiadania zasilania dla elementów rozwiązania IoT;

- konieczności transmisji danych na odległość - na jakim terenie pracuje rozwiązanie;

- konieczności opracowania protokołów transmisji danych - jak wysyłać dane, jak efektywnie je przekazywać;

- budowy centrum zbierania i przetwarzania danych - gdzie zbierać duże ilości danych, jak je magazynować, jak je udostępniać;

- algorytmów analizy zebranych danych - jak analizować dane, jak wyciągać właściwe wnioski;

- konieczności połączenia różnorodnych sprzętów, wcześniej niekompatybilnych - jak połączyć różne elementy, jakie przetworniki opracować, jakie gatewaye;

- adresacji urządzeń - jak adresować i identyfikować urządzenia.

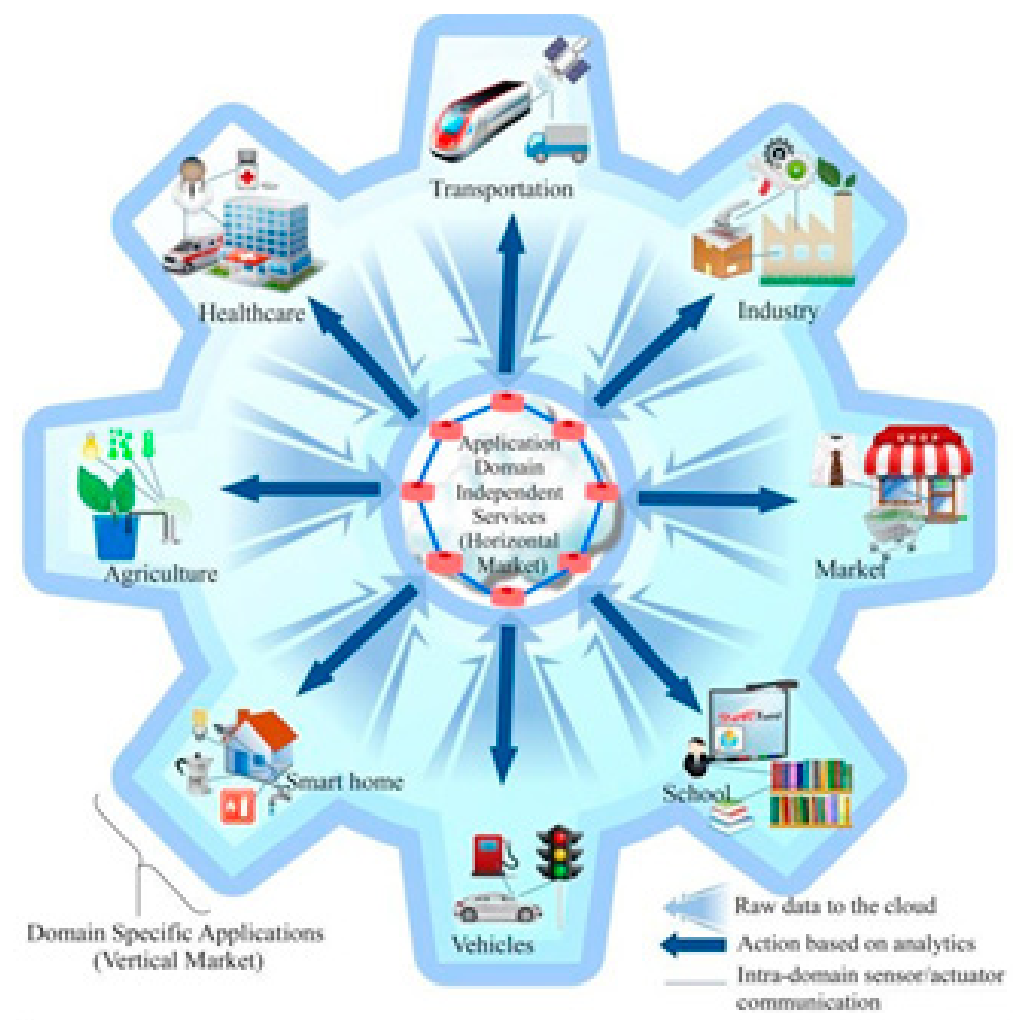

Rysunek 1. Ogólna koncepcja IoT

Źródło: Al-Fuqaha A.I., Aledhari M., Ayyash M., Guizani M. \& Mohammadi M. (2015), Internet of Things: A Survey on Enabling Technologies, Protocols, and Applications. IEEE Communications Surveys and Tutorials, 17, 2347-2376 
Jedną z ciekawych idei dla Smart City jest Intelligent Transport System. Taki system w połączeniu z inteligentnymi, a w przyszłości autonomicznymi autami, może pozwolić nie tylko na generowanie zielonego światła dla pojazdów uprzywilejowanych, ale i może rozładowywać korki w sposób inteligentny, sterując długością zielonego światła dla różnych kierunków ruchu. Idąc dalej, inteligentne rozwiązania mogą otworzyć bramę wjazdową na posesję w momencie gdy pojazd zbliża się do niej.

Ze względu na wymienione problemy rozwiązań., trudno jest znaleźć jedno uniwersalne rozwiązanie architektury. W literaturze można znaleźć różne podejścia. Rysunek 2 prezentuje różne podejścia do definicji architektury rozwiązania.

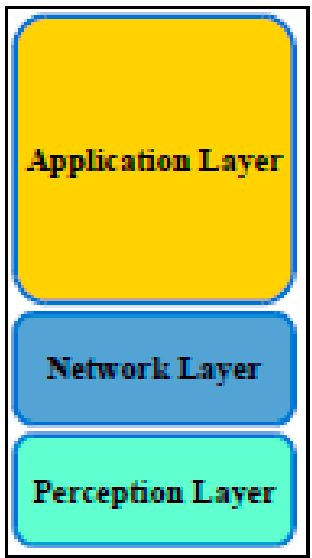

a) three-layer

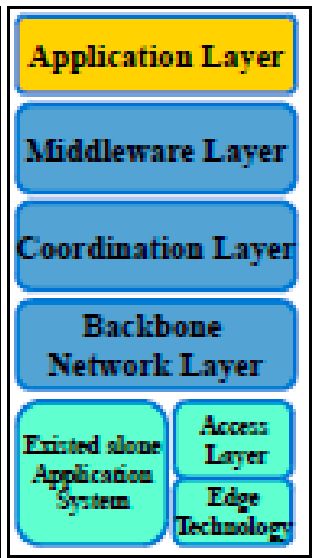

b) middle-ware based

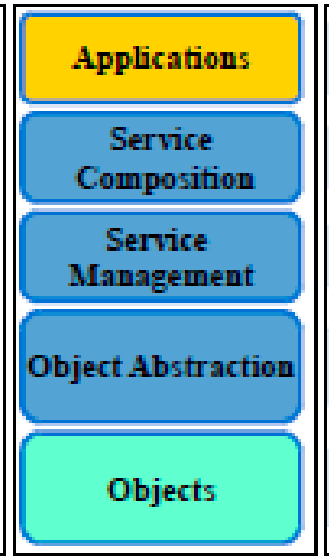

c) $\$ O A$ based

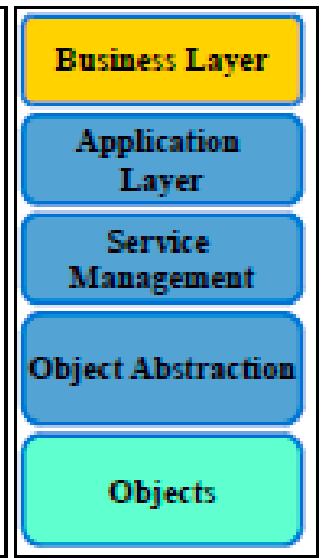

d) five-layer

Rysunek 2. Architektura IoT

Źródło: Al-Fuqaha A.I., Aledhari M., Ayyash M., Guizani M. \& Mohammadi M. (2015). Internet of Things: A Survey on Enabling Technologies, Protocols and Applications. IEEE Communications Surveys and Tutorials, 17, 2347-2376

Figure 2. IoT architecture

Najczęściej stosowanym rozwiązaniem jest rozwiązanie pięciowarstwowe (ang. Five layer). Warstwa Objects reprezentuje fizyczne sensory, które zbierają dane. Ich rodzaj jest zależny od konkretnego zastosowania. W celu generalizacji rozwiązań, $\mathrm{w}$ warstwie tej powinny zaistnieć mechanizmy typu plug and play, ale działające nie tylko na warstwie fizycznego podłączenia sensora. Podłączenie sensora powinno wygenerować odpowiednią informację do warstw wyższych, aby umożliwić podejmowanie decyzji na bazie uzyskanych danych. Warstwa Object Abstraction odpowiada za bezpieczną komunikację pomiędzy obiektami a warstwą wyższą. Ważnym aspektem tutaj jest fakt, że komunikacja może odbywać się za pomocą różnorakich mediów: RFID, 3G, GSM, UMTS, WiFi, Bluetooth Low Energy, infrared, ZigBee, Lora etc. Service Management layer odpowiada za adresację rozwiązań. Pozwala ona na operowanie obiektami fizycznymi przez warstwę aplikacji za pomocą nazw i adresów. Warstwa aplikacji dostarcza rozwiązania dla końcowego użytkownika 
zgodnie z jego potrzebami. Natomiast Business layer odpowiada za zarządzanie całościowym rozwiązaniem IoT.

Rozwiązania IoT są również przedstawiane poprzez ich elementy. Na rysunku 3 przedstawiono elementy rozwiązania, a są to:

- Identification - kluczowe zagadnienie związane z identyfikacją właściwego sensora poprzez jego nazwę, element ten zawiera w sobie również adresację rozwiązań w sieci, np. IPv6, IPv4, 6LoWPAN;

- Sensing - oznacza zbieranie danych z sensorów i przesyłanie ich do miejsca przetwarzania i podejmowania decyzji;

- Communication - obejmuje zagadnienia transmisji danych pod względem zastosowanych technologii, które obecnie umożliwiają transmisję na różne odległości, z różną prędkością, ale również ich koszt zastosowania jest bardzo zróżnicowany, jest obecnie technologią, z którą wiąże się największe nadzieje jest LTE;

- Computation - przetwarzanie danych wiąże się z użyciem różnych technologii sensorów i ich systemów operacyjnych;

- Services - usługi, które IoT dostarcza, są kluczowym elementem, gdyż to właśnie dla nich powstaje całe rozwiązanie, wymienia się tutaj głównie usługi z zakresu Intelligent transportation systems (ITS) or Transportation Cyber-Physical Systems (T-CPS), Industrial automation, Smart healthcare, Smart grids, smart city;

- Semantics - odpowiada za mozliwośc eksploracji wiedzy w sposób inteligenty aby dostarczać wymagane usługi.

Obecnie można znaleźć wiele projektów, które rozwijają swoje rozwiązania dla IoT oraz próby ich standaryzacji. Wiele rozwiązań jest typu open source, co ułatwia ich rozwój i zwiększa skalę zastosowań.

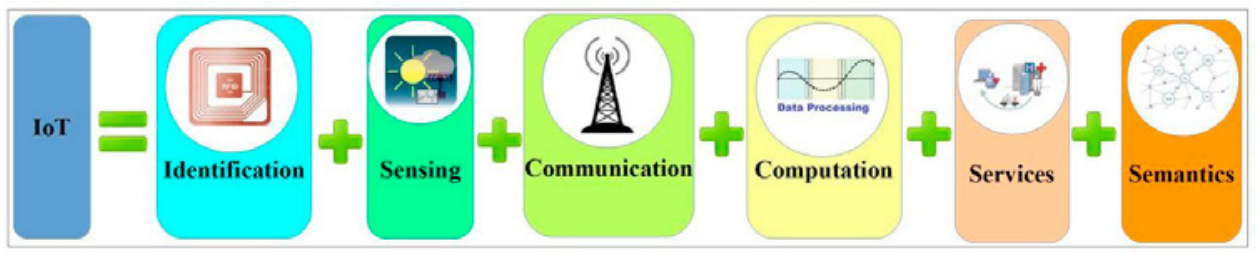

Rysunek 3. Elementy IoT

Źródło: Al-Fuqaha A.I., Aledhari M., Ayyash M., Guizani M., \& Mohammadi M. (2015), Internet of Things: A Survey on Enabling Technologies, Protocols, and Applications, IEEE Communications Surveys and Tutorials, 17, 2347-2376

Figure 3. IoT elements 


\section{Wspólna architektura loT}

Szukając uniwersalnej architektury, trzeba dokonać przeglądu istniejących. Analizując obecne propozycje, można je podzielić ze względu na miejsce przetwarzania danych: albo w samym sensorze, albo w punkcie centralnym. Ze względu na to kryterium można wyznaczyć architektury typu:

- Sensors;

- Fog;

- Cloud Computing.

Rozwiązanie te zostały zobrazowane na rysunku 4. Na najniższym szczeblu znajdują się sensory, urządzenia IoT zbierające dane. Tych urządzeń jest i będzie najwięcej, gdyż to one podłączają rozwiązania do sieci. Ze względu na ich liczbę to one generują największe potrzeby na pule adresowe oraz ruch w sieci transmitujące zbierane dane. Warstwę wyższą stanowi rozwiązanie typu Fog. Rozwiązanie to zbiera, agreguje i przetwarza wstępnie zebrane dane. Takie podejście pozwala zmniejszyć ruch w sieci. Przewiduje się, że miliony sensorów IoT wygeneruje, bardzo dużo niepotrzebnego ruchu. Dlatego warstwa Fog pozwala na uniknięcie tego zjawiska. Rozwiązania występujące w tej warstwie są rozwiązaniami bardziej skomplikowanymi niż w warstwie sensorów. Dysponują większą mocą obliczeniową i najczęściej wymagają innych warunków pracy. Najwyższa warstwa to warstwa Cloud. W rozwiązaniu typu Cloud wszystkie dane przetwarzane są w chmurze. Takie rozwiązanie wymaga odpowiedniej struktury, budowy centrum przetwarzania danych, odpowiedniego zarządzania nim, ale również przesyłania wszystkich danych do centrum, gdzie następuje ich przetwarzanie.

Wszystkie warstwy mogą występować samodzielnie lub w połączeniu z pozostałymi świadcząc usługi dla innych. W warstwie Sensors działają zarówno sensory, które mierzą wartości fizyczne, ale i efektory, których zadaniem jest sterowanie, zmiana, nastawy wartości fizycznych. Warstwa ta wymaga opracowania odpowiednich przetworników, które mogą być aktywne, pasywne, mechaniczne, optyczne, magnetyczne, terminie, elektryczne, biologiczne, chemiczne etc. Warstwa Fog może działać jako pomost pomiędzy warstwą sensorów i Cloud, agregując zbierane dane i ograniczając ilość ruchu w sieci. Pozwala ona na przesunięcie usług przetwarzania danych bliżej elementów końcowych - sensorów. 


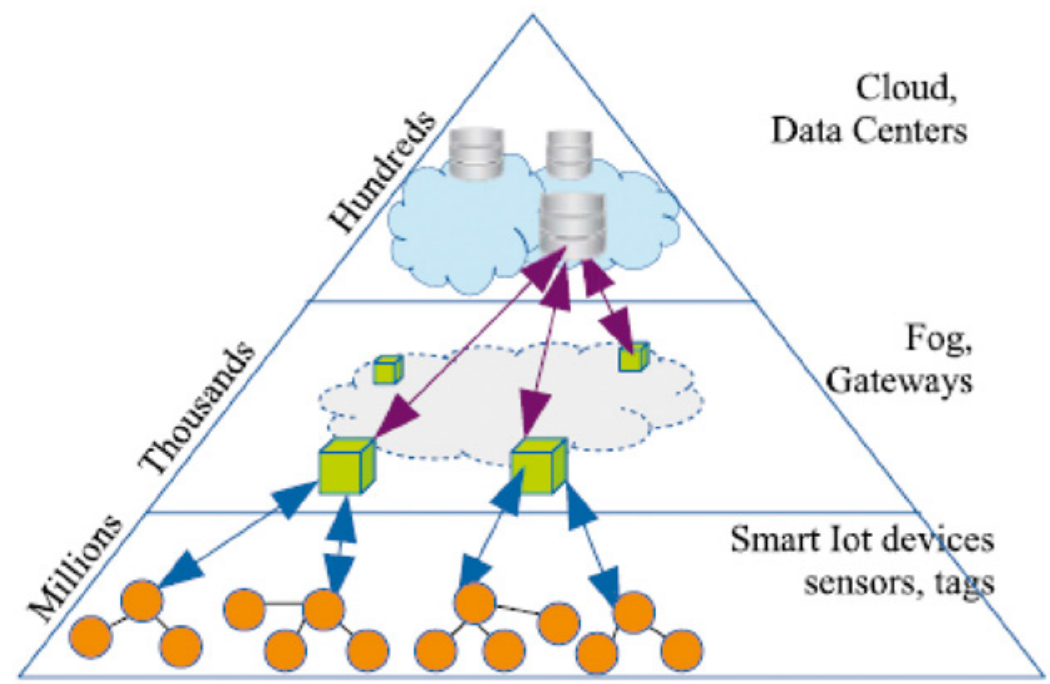

Rysunek 4. Warstwy IoT

Źródło: Al-Fuqaha A.I., Aledhari M., Ayyash M., Guizani M. \& Mohammadi M. (2015), Internet of Things: A Survey on Enabling Technologies, Protocols, and Applications, IEEE Communications Surveys and Tutorials, 17, 2347-2376

Figure 4. IoT layers

Warstwa Fog umożliwia również szybsze reakcje na dane otrzymane z sensorów. Rozwiązania Fog można uruchamiać hierarchicznie, tworząc multiwarstwowe rozwiązania, np. tak jak pokazano na rysunku 5.

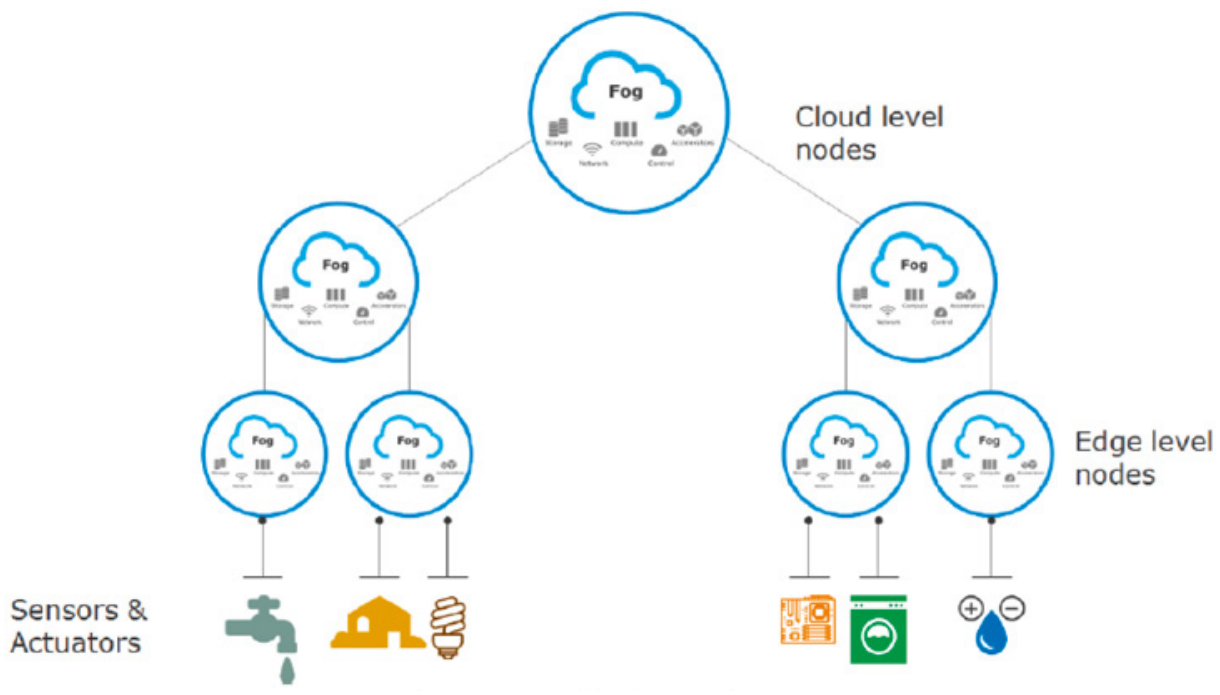

Rysunek 5. Rozwiązanie wielowarstwowe IoT

Źródło: OpenFog Reference Architecture for Fog Computing, online www.OpenFogConsortium.org, 2017.12.27

Figure 5. Multi Layer IoT 
Dla warstwy Fog opracowano wiele gotowych rozwiązań typu opensource, które można łatwo zaimplementować dla swoich potrzeb. Jednym z nich jest zastosowanie rozwiązania typu LinuX Container. Szeroko stosowanym jest rozwiązanie Docker.

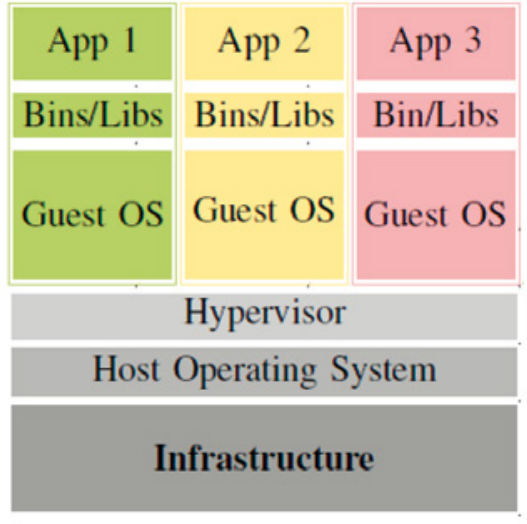

(a) Virtual machines

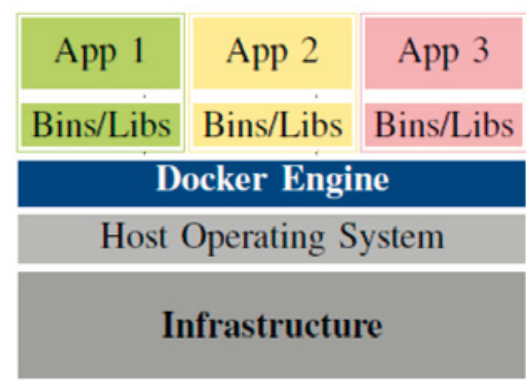

(b) Container virtualization

Rysunek 6. Rozwiązanie typu kontener

Źródło: Marcel Großmann, Andreas Eiermann, Automated Establishment of a Secured Network for Providing a Distributed Container Cluster, 2016 28th International Teletraffic Congress

Figure 6. Container solutions

Rysunek 7 przedstawia wszystkie warstwy IoT, obrazując miejsca przetwarzania surowych danych oraz umiejscowienia inteligencji rozwiązania.

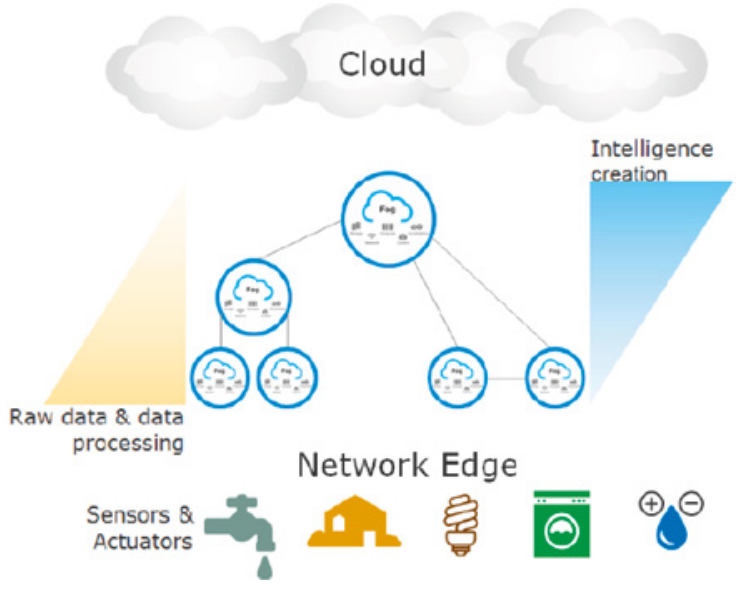

Rysunek 7. Umiejscowienie inteligencji IoT

Źródło: OpenFog Reference Architecture for Fog Computing, online www.OpenFogConsortium.org, 2017.12.27

Figure 7. IoT intelligence place

Ważną warstwą wyróżnianą obecnie w architekturach jest Middleware layer. Zadaniem tej warstwy jest zapewnienie dostępu do rozwiązania IoT dla użytkownika: 
zarówno administratora systemu, jak i użytkownika końcowego. Dlatego warstwę tę oznacza się często warstwą management. W zależności od rozwiązania warstwa ta umożliwia dostęp do usług świadczonych przez rozwiązanie IoT poprzez urządzenia mobilne typu laptop, tablet, smartfone i stacjonarne punkty dostępu. Ważnym aspektem tej warstwy jest konieczność zapewnienia bezpiecznego dostępu jak i odpowiednich algorytmów: najczęściej lekkich, bez niepotrzebnego narzutu danych. W tym celu można zastosować opracowane już protokoły Message Queue Telemetry Transport (MQTT) i Message Queue Telemetry Transport for Sensor Networks (MQTT-SN), które zostały opracowane i zoptymalizowane do komunikacji typu machine-to-machine.

\section{Bezpieczeństwo rozwiązań}

Zbieranie danych z sensorów w obecnych czasach wymaga zapewnienia ich bezpieczeństwa pod kątem nieuprawnionego przejęcia. Rozwiązania IoT dostarczają wiele różnych możliwości monitorowania parametrów fizycznych i podejmowania szybszych i lepszych decyzji. Zbieranie danych wrażliwych np. o stanie zdrowia pacjentów przy monitoringu zdalnym jest zbieraniem danych wrażliwych, co jest regulowane prawnie. W celu zapewnienia ich poufności trzeba je szyfrować. Natomiast szyfrowanie danych wymaga odpowiednio dobranych algorytmów, badania i monitorowania ich podatności. Z kolei algorytmy te wymagają odpowiedniej mocy obliczeniowej od sensorów zbierających dane. Kolejnym z ważnych aspektów jest dostępność danych. Wybierając rozwiązanie IoT dla optymalizacji np. procesu produkcji w firmie, należy zapewnić dostępność do danych, na bazie których podejmowane są decyzje. Brak dostępu do danych lub blokada urządzeń przez atak typu Denial of Service. Tego typu atak może zablokować dostęp do sensora. System bez tego dostępu może np. zablokować linię produkcyjną, co może wygenerować straty finansowe. Dlatego zagadnienia bezpieczeństwa dla rozwiązań IoT są bardzo ważne, szczególnie w momencie, gdy rozwiązanie działa w sieci publicznej. Z racji faktu pracy w sieci, rozwiązania IoT zmagają się z tymi samymi problemami jak każde inne rozwiązanie sieciowe działające w sieci publicznej. Utrzymanie systemu dotyczy zagadnień automatycznej instalacji, aktualizacji, podłączenia nowych elementów do systemu, włączenia ich w system bezpieczeństwa, automatycznemu i autonomicznemu wykrywaniu awarii. Często ze względu na charakter systemu żaden z elementów nie może zostać pominięty. Przykładowo system IoT sterujący światłami drogowymi po ataku może wyłączyć całkowicie zielone światła. Taka sytuacja może doprowadzić do gigantycznych korków, a dalej niepokojów społecznych. Ponadto ważnym aspektem jest prawidłowa adresacja i identyfikacja elementów, tak aby uzyskać pewność, że dany element jest tym, który powinien podawać te informacje, i nikt się nie podszył pod niego. 


\section{System Monitoring}

System Monitoring powstały w ramach projektu „Opracowanie metodologii stałego nadzoru eksploatacji wybranych obszarów wyposażenia straży pożarnej w zakresie niezawodności i skuteczności działania” może być rozpatrywany jako system IoT służący do monitorowania sprzętu straży pożarnej. Ogólną ideę systemu przedstawia rysunek 8 .

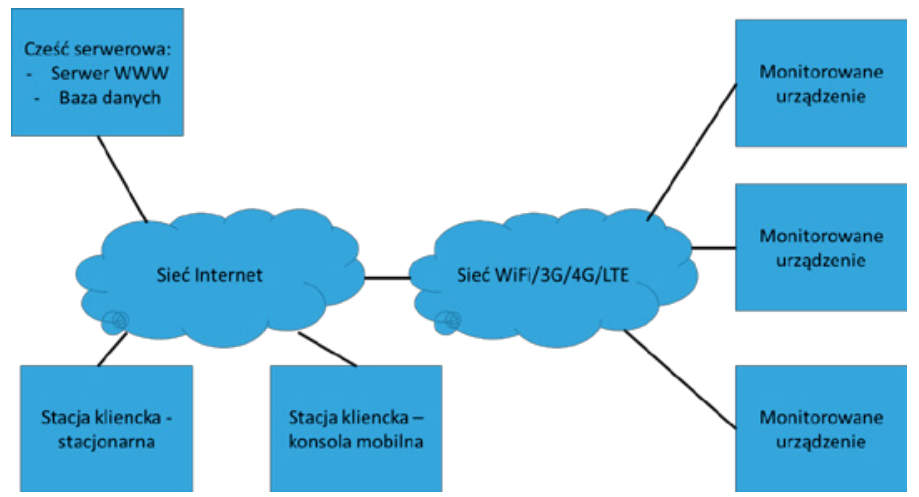

Rysunek 8. System Monitoring

Źródło: opracowanie własne

Figure 8. Monitoring system

W warstwie sensorów podłączono urządzenia: pompy, elektryczne nożyce i autopompę. W ramach monitorowania tychże urządzeń mierzone są ich parametry pracy. Mierzone parametry pracy dla danych typów urządzeń zebrano w tabeli 1.

Kolejną warstwę stanowią urządzenia JAD - odpowiedzialne za zbieranie danych z czujników i przesyłanie ich dalej oraz wskazywanie pozycji GPS urządzeń, dzięki czemu można dokonać ich lokalizacji. Urządzenia te można zakwalifikować do warstwy Fog. System posiada centralne rozwiązanie typu Cloud, w którym przechowywane są dane zebrane z warstwy Fog. Do transmisji danych zaprojektowano architekturę zaprezentowaną na rysunku 9. Do zbierania danych z czujników wykorzystywane są połączenia przewodowe. W warstwie Fog do połączenia wybrano sieć Wi-Fi, która tworzy sieć mesh. Transmisja do warstwy Cloud odbywa się poprzez sieć 3G/4G.

TABEla 1. ZestaWienie PARAmetróW URZĄDZEŃ MONitoroWANYCH W SYSTEMie

TABLE 1. EQUiPMENT PARAMETERS

\begin{tabular}{|c|c|}
\hline Urządzenie & Przepływ paliwa \\
\hline Niagara 1 & Przepływ paliwa \\
& Poziom paliwa \\
& Ciśnienie tłoczenia \\
& Poziom przepływu wody \\
& Temperatura oleju \\
& Temperatura spalin \\
\hline
\end{tabular}




\begin{tabular}{|c|c|}
\hline \multirow[t]{2}{*}{ Urządzenie } & Przepływ paliwa \\
\hline & $\begin{array}{c}\text { Temperatura wody - ssanie } \\
\text { Temperatura wody - tłoczenie } \\
\text { Położenie przepustnicy } \\
\text { Obroty silnika/wału }\end{array}$ \\
\hline Honda SST50 & $\begin{array}{c}\text { Przepływ paliwa } \\
\text { Poziom paliwa } \\
\text { Ciśnienie tłoczenia } \\
\text { Ciśnienie ssania } \\
\text { Poziom przepływu wody } \\
\text { Temperatura oleju } \\
\text { Temperatura spalin } \\
\text { Temperatura wody - ssanie } \\
\text { Temperatura wody - tłoczenie } \\
\text { Położenie przepustnicy } \\
\text { Obroty silnika/wału }\end{array}$ \\
\hline Tohatsu VC72AS & $\begin{array}{c}\text { Przepływ paliwa } \\
\text { Poziom paliwa } \\
\text { Ciśnienie tłoczenia } \\
\text { Ciśnienie ssania } \\
\text { Poziom przepływu wody } \\
\text { Temperatura oleju } \\
\text { Temperatura spalin } \\
\text { Temperatura wody - ssanie } \\
\text { Temperatura wody - tłoczenie } \\
\text { Położenie przepustnicy } \\
\text { Obroty silnika/wału }\end{array}$ \\
\hline Autopomp A16/8 & $\begin{array}{c}\text { Ciśnienie tłoczenia } \\
\text { Ciśnienie ssania } \\
\text { Poziom przepływu wody } \\
\text { Temperatura wody - ssanie } \\
\text { Temperatura wody - tłoczenie } \\
\text { Obroty silnika/wału } \\
\text { Nacisk na wysokim poziomie }\end{array}$ \\
\hline Autopomp A24/8 & $\begin{array}{c}\text { Ciśnienie tłoczenia } \\
\text { Ciśnienie ssania } \\
\text { Poziom przepływu wody } \\
\text { Temperatura wody - ssanie } \\
\text { Temperatura wody - tłoczenie } \\
\text { Obroty silnika/wału } \\
\text { Nacisk na wysokim poziomie }\end{array}$ \\
\hline Hydraulic scisors & $\begin{array}{l}\text { Temperatura oleju } \\
\text { Temperatura silnika }\end{array}$ \\
\hline
\end{tabular}




\begin{tabular}{|c|c|}
\hline Urządzenie & Przepływ paliwa \\
\hline & Ciśnienie oleju \\
& Napięcie zasilania \\
& Zużycie energii \\
\hline
\end{tabular}

Oczywiście, budując sieć mesh w momencie, gdy wszystkie urządzenia stanowią połączenie hop-by-hop, uzyskuje się spadek transmisji, jednakże wystarczający dla działania niniejszej sieci.

Warstwę Middleware zbudowano, wykorzystując połączenie Wi-Fi typu klient dla tabletów mobilnych, używanych przez strażaków podczas akcji oraz poprzez sieć Internet $\mathrm{z}$ dowolnego jej miejsca. W tym celu opracowano dwie wersje aplikacji - kliencką mobilną dla tabletów oraz stacjonarną dla centrum zarządzania pracującego blisko warstwy Cloud (zostały pokazane na rysunku 10). W warstwie Cloud na bazie zebranych danych odbywa się analiza i wnioskowanie, który sprzęt może w najbliższej przyszłości ulec awarii.

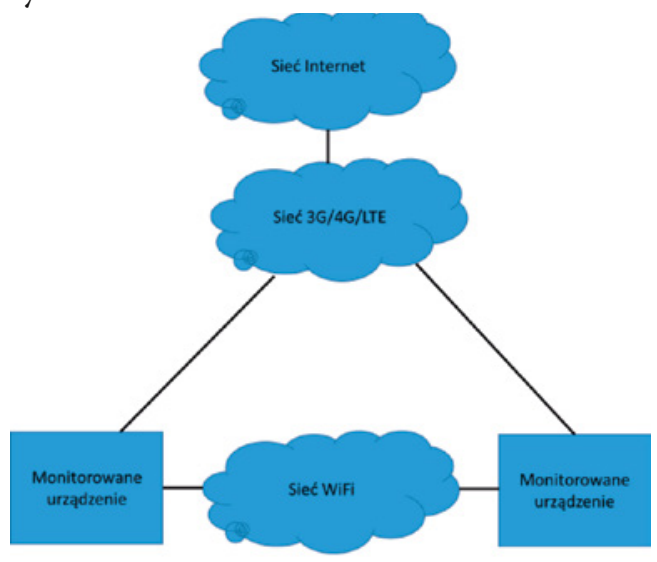

Rysunek 9. Architektura komunikacji systemu Monitoring

Źródło: opracowanie własne

Figure 9. Communication system for Monitoring
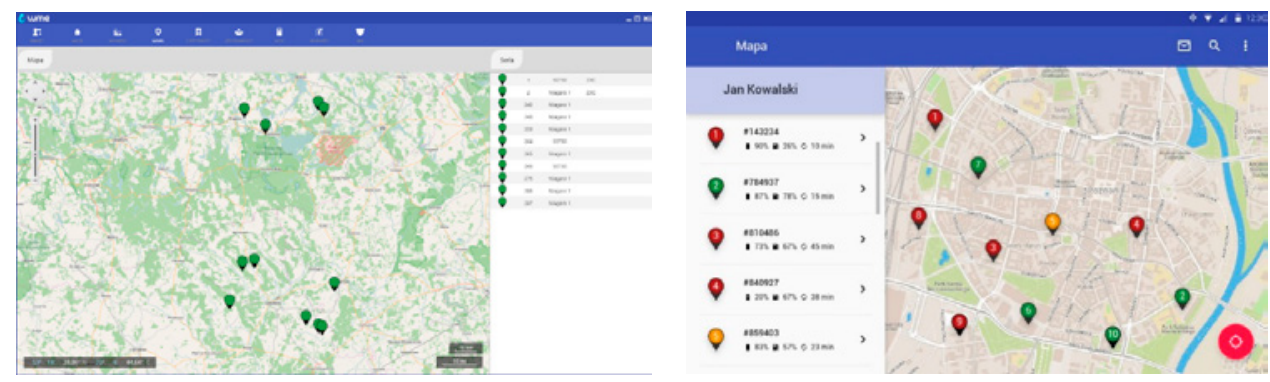

Rysunek 10. Przykładowe widoki aplikacji klienckiej

Źródło: opracowanie własne

Figure 10. User application screen shots 
Problemy bezpieczeństwa, jakie występują w systemie, to problem szyfrowania danych, kontrolowanego dostępu, ataku typu DoS na system. System jest w fazie testów i problemy te są obecnie rozwiązywane.

System rozwiązuje problem monitorowania używanego sprzętu. Przykładowo proces wypompowywania wody z zalanej piwnicy trwa godzinami. Dotychczas strażak pilnował procesu działania pompy. Dzięki zastosowanemu systemowi pompę można zostawić pod opieką systemu, który wygeneruje alarm w przypadku wykrycia problemów w działaniu.

Na architekturę systemu wpływ miał czynnik zasilania - we wszystkich urządzeniach występuje zewnętrzne zasilanie (np. prądnica), jednakże poziom napięcia jest niestabilny. W tym celu opracowano odpowiedni układ zasilania akumulatorowego doładowywany ze źródła zasilania, co wyeliminowało problemy.

Drugim elementem mającym kluczowy wpływ na architekturę systemu był system łączności pomiędzy warstwą Fog a Cloud. Ze względu na fakt, że istniejący system łączności był analogowy, trzeba było zbudować łączność cyfrową. Nie bez znaczenia były tutaj koszty systemu - system projektowano tak, aby był jak najtańszy w użytkowaniu. Obliczono liczbę danych wysyłanych przez system. Urządzenia posiadają maksymalnie 15 miar z próbkowaniem sekundowym, generują $7 \mathrm{MB}$ danych na godzinę pracy. Na tej podstawie zdecydowano o wykorzystaniu sieci 3G/4G/LTE z kartą prepaid pozwalającą na transfer $300 \mathrm{MB}$ danych miesięcznie w standardzie 4G/LTE, a następnie pozwalającą na transfer z prędkością $32 \mathrm{kbps}$. Prędkość ta pozwala na transfer $14 \mathrm{MB}$ danych w ciągu godziny pracy, co na bazie analizy liczby generowanych danych jest prędkością wystarczającą.

Podsumowaniem analizy rozwiązania IoT dla Straży Pożarnej jest tabela 2, która zawiera zestawienie elementów, protokołów i standardów zaimplementowanych w systemie.

TABela 2. Elementy systemu Monitoring jako rozwiązania IoT

TABle 2. IoT elements of Monitoring system

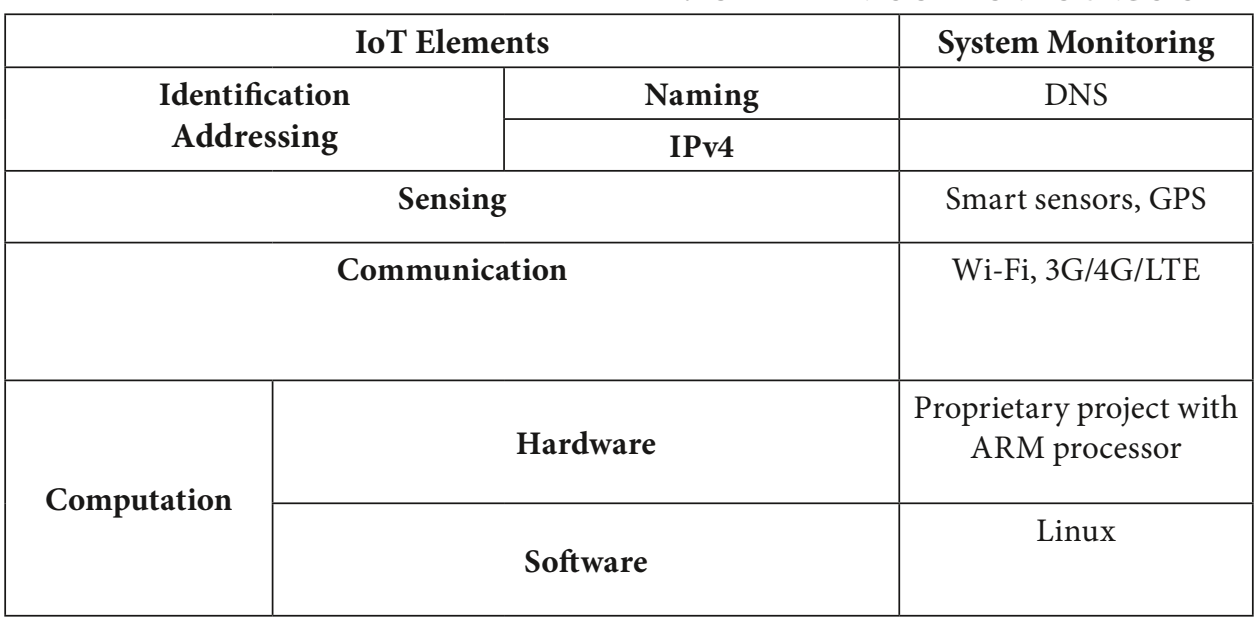




\begin{tabular}{|c|c|}
\hline IoT Elements & System Monitoring \\
\hline Service & $\begin{array}{c}\text { Data analysis, failure } \\
\text { prediction, equipment } \\
\text { position monitoring }\end{array}$ \\
\hline Semantic & - \\
\hline & \\
\hline
\end{tabular}

\section{Wnioski}

Rozwiązania IoT są rozwiązaniami nie tylko przyszłości, ale też teraźniejszości. Obecnie opracowuje się dla nich wiele nowych technologii, możliwości, optymalizuje się techniki wirtualizacji. Wykorzystując gotowe technologie i rozwiązania open source można szybko osiągnąć nowe możliwości, zrealizować nowe usługi dla użytkowników. Właśnie te usługi są kluczowe w rozwiązaniach IoT. Rozwiązania te mają właśnie dostarczać nowych usług, które ułatwią życie, przyspieszą procesy, zwiększą wydajność produkcji, jednocześnie zmniejszając jej koszty. Stosując architektury IoT można w szybki sposób tworzyć nowe rozwiązania systemowe, dostarczając nowe usługi dla odbiorów, tak jak ma to miejsce w przypadku systemu monitorowania wyposażenia Straży Pożarnej.

Ten artykuł powstał przy finansowaniu z Narodowego Centrum Nauki grantu Miniatura 1 numer 2017/01/X/ST6/00613.

\section{WYKAZ SKRÓTÓW}

3G - 3rd Generation

3GPP - 3rd Generation Partnership Project

$4 \mathrm{G}$ - 4th Generation

$5 \mathrm{G}-5$ th Generation

$\mathrm{kb} / \mathrm{s}$ lub kbps lub kbit/s - kilobit per second

LTE - Long Term Evolution

$\mathrm{MB}$ - Megabyte

$\mathrm{MB} / \mathrm{s}$ - Megabyte per second

Mbit/s - Megabit per second

mesh - Mesh Topology Network

Wi-Fi - Wireless Fidelity

WPA - Wi-Fi Protected Access

WPA2 - Wi-Fi Protected Access II 


\section{Bibliografia}

[1] Al-Fuqaha A.I., Aledhari M., Ayyash M., Guizani M. \& Mohammadi M. Internet of Things: A Survey on Enabling Technologies, Protocols, and Applications, „IEEE Communications Surveys and Tutorials”, 17/2015, 2347-2376. Wniosek nr 13087 „Monitoring”.

[2] Sprawozdanie z realizacji zadania badawczego 25172505 projektu „Monitoring” - Opracowanie planu testów demonstratora. Przeprowadzenie testów i wyciągnięcie wniosków z praktycznego zastosowania systemu łączności: możliwości transmisji danych, dostęp zdalny do urządzeń, niezawodność połączeń, prędkość transmisji.

[3] Sprawozdanie z realizacji zadania badawczego 25172504 projektu „Monitoring” - Wykonanie demonstratora - podsystem transmisyjny.

[4] Apiecionek Ł., Motylewski R., Stosik P., Bezpieczeństwo transmisji danych w systemach monitorowania wyposażenia Straży Pożarnej. Problemy monitoringu eksploatacji sprzętu i wyposażenia Straży Pożarnej, CNBOP-PIB, DOI 10.17381/2015.2, Józefów 2015, 41-48.

[5] Makowski W., Motylewski R., Stosik P., Jeliński M., Apiecionek Ł., Jakość i wydajność transmisji danych $w$ sieci Wi-Fi MESH WDS systemu monitorowania urządzeń eksploatowanych $w$ straży pożarnej. Wspomaganie procesów zarządzania działaniami w straży pożarnej, J. Roguski (red.), 39-47, Józefów 2016.

[6] OpenFog Reference Architecture for Fog Computing, online www.OpenFogConsortium.org (dostęp: 2017.12.27).

[7] Großmann M., Eiermann A., Automated Establishment of a Secured Network for Providing a Distributed Container Cluster, 2016 28th International Teletraffic Congress.

[8] Stanford-Clark A.S., and Truong H.L., MQTT for sensor networks (MQTT-S) protocol specification, 2008, http://mqtt.org/MQTT-S_spec_v1.1.pdf (dostęp: 2018.02.07). 



\title{
Możliwości zastosowania sieci 4G do monitorowania urządzeń eksploatowanych w straży pożarnej
}

\author{
Possibilities of using 4G network for monitoring brigade devices
}

\author{
Łukasz Apiecionek \\ Robert Palka \\ Piotr Brążkiewicz \\ Mateusz Biedziak
}

\section{Streszczenie}

Cel: Celem niniejszego artykułu jest głównie znalezienie odpowiedzi na pytanie, czy możliwe jest zastosowanie sieci $4 G$ do monitorowania urządzeń eksploatowanych $w$ straży pożarnej, jakie to daje możliwości zasięgu oraz prędkości transmisji.

Wprowadzenie: Systemy monitoringu wymagają łączności. W przypadku gdy obszar monitorowania jest bardzo rozległy, można wykorzystać sieci kratowe - mesh, budując w ten sposób własna sieć. Istnieje jednak inne rozwiązanie. Mianowicie można spróbować wykorzystać istniejącą architekturę sieci komórkowej 3G/4G/LTE, a w przyszłości nawet 5G. Na wykorzystanie tego typu łączności pozwala obecny stopień pokrycia sieci na terytorium Rzeczpospolitej Polskiej. Taką łączność zastosowano w rozwiązaniu projektu „Opracowanie metodologii stałego nadzoru eksploatacji wybranych obszarów wyposażenia straży pożarnej w zakresie niezawodności i skuteczności działania”. Wykorzystana sieć 3G/4G/LTE pozwala na połaczenie węzłów sieci do serwera, umożliwiając użytkownikom mobilnym dostęp do zasobów niezależnie od miejsca ich pracy, ponieważ budowany $w$ ramach projektu system obejmowat tylko sześć węzłów, konieczna była analiza wykorzystania sieci w przyszłości na szeroka skalę, uwzględniając poza zasięgami i prędkościami transmisji również koszty utrzymania systemu.

Metodologia: W artykule wykorzystano metodę obserwacyjną, aby rozważyć zagadnienia wydajności transmisji danych $w$ sieciach 3G/4G/LTE, wykorzystując wiele urządzeń $w$ sieci.

Wnioski: Wykonana analiza wykazała, że zastosowanie sieci 3G/4G/LTE do monitorowania eksploatacji urządzeń straży pożarnej spełnia oczekiwania odnośnie do prędkości działania $i$ możliwych zasięgów pracy. Zastosowanie $w$ przyszłości sieci $5 G$ powinno jeszcze przyspieszyć działanie systemu.

\section{Abstract}

Objective: The main aim of this article is to answer the question whether it is possible to use a $4 G$ network to monitor the devices used by the Fire Brigades and what are the transmission range and speed limits.

Introduction: Every monitoring system requires communication. If the monitored area is too big for one device, it is possible to use mesh networks to build a new network. There is also a different solution for this problem. It is possible to use the $3 G / 4 G / L T E$, or even $5 G$ in the future, network architecture. The current state of network coverage in the Republic of Poland allows to use this type of connectivity, which has been used in the solution of the Development of the methodology 
of continuous supervision of operation of selected areas of fire-fighting equipment in terms of reliability and effectiveness of operation project. The used 3G/4G/LTE network allows to connect the nodes to the server, allowing the mobile users to access the resources regardless of the place of their operation. Because the system built within the project included only six nodes, an analysis of the use of the network on a larger scale was needed, including not only the range and speed aspects but also the costs of the system maintenance.

Methodology: In this paper an observational method was used to consider the issues of transmission quality and performance in the 3G/4G/LTE networks using many the devices connected through this network.

Conclusions: The analysis demonstrated that using the 3G/4G/LTE network to monitor the state of Fire Brigades' devices meets the fundamental needs of the transmission speed and the possible operating ranges. Using the $5 G$ networks in the future will only increase the speed of system operation.

\section{Wprowadzenie}

W celu umożliwienia dozoru nad urządzeniami eksploatacyjnymi straży pożarnej systemy monitoringu wymagają zastosowania sieci rozległych. Takie sieci pozwalają na połączenie mobilnych urządzeń ze stanowiskami stacjonarnymi wykorzystywanymi do monitorowania pracy sprzętu. Obecnie na terytorium Rzeczpospolitej Polskiej można uzyskać łączność na poziomie sieci 3G, 4G, LTE. Technologią opracowywaną dla przyszłości jest technologia sieci 5G.

\section{Sieci $3 G / 4 G / L T E / 5 G$}

Sieć $3 G$ to telefonia komórkowa trzeciej generacji. W stosunku do sieci ją poprzedzającej poszerzono jej pojemność, co umożliwiło wprowadzenie dodatkowych usług opartych na transmisji wideo oraz transmisji pakietowej poprzez komutację pakietów. Do najpopularniejszej w Europie technologii 3G należy standard Universal Mobile Telecommunications System (UMTS). Początkowo UMTS zapewniał prędkość pobierania danych do $384 \mathrm{~kb} / \mathrm{s}$ w przypadku wersji R99. Standard ciągle rozwijano, co zaowocowało wdrożeniem rodziny High Speed Packet Access (HSPA). Następnie opracowano rodzinę transmisji określoną jako HSPA+, znaną również jako Evolved High-Speed Packet Access. Umożliwia ona pobieranie danych z szybkością do $84 \mathrm{Mb} / \mathrm{s}$ i wysyłanie do $22 \mathrm{Mb} / \mathrm{s}$. Sieci, które wykorzystują HSPA lub HSPA+, określa się jako 3G+ lub 3.5G, a czasem nawet jako 4G. Na rynku polskim wykorzystywane są również dwie inne technologie transmisji, zwane High Speed Downlink Packet Access (HSDPA) i High Speed Uplink Packet Access (HSUPA). Najnowsza technologia transmisji danych to Long Term Evolution (LTE). Maksymalne docelowe prędkości to w tym przypadku 326,4 Mb/s - pobieranie i aż $86,4 \mathrm{Mb} / \mathrm{s}$ - wysyłanie. Sieci wykorzystujące tę technologię bywają nazywane sieciami 3.9G lub $4 \mathrm{G}$. 
Prace nad technologią LTE rozpoczęły się już w 2004 roku przez 3GPP. W pracach mogły uczestniczyć wszystkie zainteresowane podmioty i organizacje, niezależnie czy były członkami grupy 3GPP. Każdy uczestnik mógł zgłaszać swoje propozycje dotyczące zmian dla sieci Universal Terrestrial Radio Access Network (UTRAN). Podczas pierwszych prac zdefiniowano podstawowe wymagania dla projektowanej sieci, a mianowicie postawiono za cel:

- redukcję kosztów transmisji;

- zwiększenie możliwości świadczenia usług - więcej usług za niższy koszt;

- płynniejsze możliwości użycia istniejących i nowych częstotliwości;

- prostszą architekturę;

- otwartość interfejsów;

- utrzymanie sensownego poziomu konsumpcji mocy przez terminale.

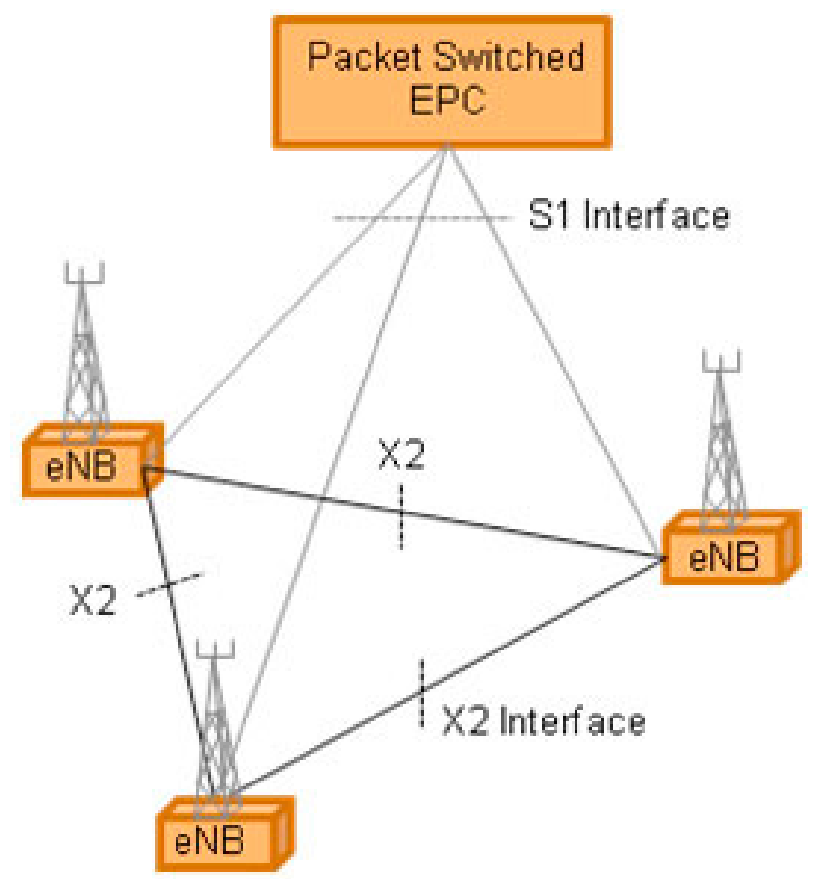

Rysunek 1. Interfejsy X2 i S1 w sieci LTE

Źródło: http://www.3gpp.org/technologies/keywords-acronyms/98-lte, dostęp online 2014.11.21

Figure 1. Interfaces X2 and S1 in LTE network

Sieć LTE ma prostą architekturę ze stacją bazową eNB, tworzącą płaską architekturę. W sieci nie jest wykorzystywany żaden inteligentny centralny kontroler, a stacje bazowe eNB łączone są poprzez interfejsy X2, a ponad siecią główną poprzez interfejsy S1. Powodem, dla którego zdecydowano o przesunięciu inteligencji sieci do stacji bazowych, było przyspieszenie połączeń.

W celu uzyskania wysokiej efektywności wykorzystania częstotliwości, zarówno jeśli chodzi o domenę czasu jak i częstotliwości, została wybrana technologia 
wielu nośnych przy jednoczesnym zachowaniu wielodostępu. Dla transmisji do użytkownika, tzw. downlink, została wybrana technologia OFDMA (ang. Orthogonal Frequency Division Multiple Access), natomiast od użytkownika, tzw. uplink, SC-FDMA (ang. Single Carrier - Frequency Division Multiple Access) znana również jako DFT (ang. Discrete Fourier Transform) poszerzona o OFDMA.

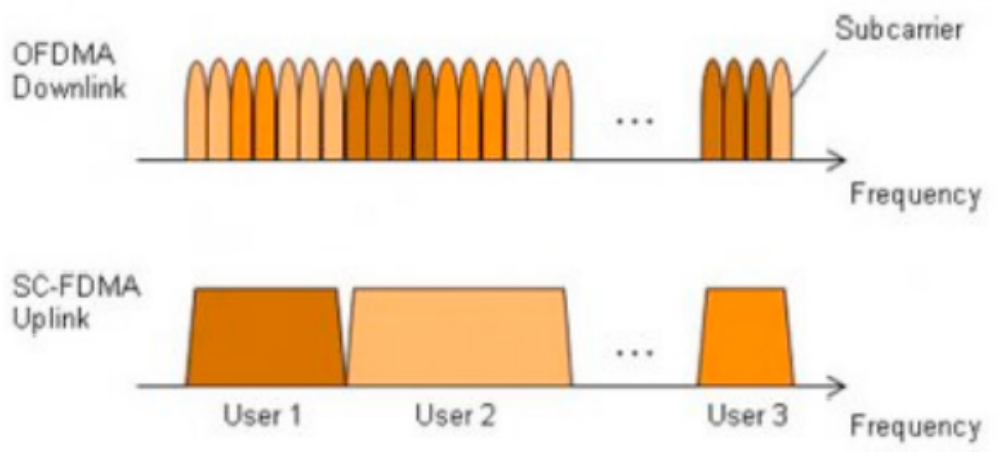

Rysunek 2. OFDMA i SC-FDMA

Źródło: http://www.3gpp.org/technologies/keywords-acronyms/98-lte, dostęp online 2014.11.21

Figure 2. OFDMA and SC-FDMA

Opracowany standard transmisji danych umożliwia osiągnięcie bardzo dużych przepływności. Porównanie uzyskiwanych przepływności uzyskiwanych przez różne technologie transmisji danych w sieciach komórkowych zebrano w tabeli 1.

TABela 1. ZestaWienie PRĘDKoŚCi TRANSMisji TECHNOLOGII PRZESYŁU DANYCH

TABle 1. SPECification of TRANSMission SPEED DATA TRANSFER TECHNOLOGY

\begin{tabular}{|c|c|}
\hline Standard transmisji & Prędkość transmisji \\
\hline GPRS & $115 \mathrm{kbit} / \mathrm{s}$ \\
\hline EDGE & $250 \mathrm{kbit} / \mathrm{s}$ \\
\hline UMTS & $384 \mathrm{kbit} / \mathrm{s}$ \\
\hline CDMA & $9,3 \mathrm{Mbit} / \mathrm{s}$ \\
\hline HSDPA & $21,6 \mathrm{Mbit} / \mathrm{s}$ \\
\hline HSPA+ & $42 \mathrm{Mbit} / \mathrm{s}$ \\
\hline LTE & $150 \mathrm{Mbit} / \mathrm{s}$ \\
\hline
\end{tabular}

Jak widać, największe przepływności uzyskuje obecnie technologia LTE. Dlatego wybór tej technologii dla zastosowania w projekcie wydawał się oczywisty.

Kolejną opracowywaną technologią jest sieć 5G. Głównym problemem wdrożenia tej sieci jest aspekt biznesowy. Mianowicie dostawcy telefonii dużo zainwestowali w sieci GSM/3G/LTE i w pierwszej kolejności ich działania skupiają się 
na odzyskaniu tych środków. Dopiero później może nastąpić wyczekiwany skok technologii, który wymaga również dużych inwestycji w infrastrukturę teleinformatyczną.

W aspektach technicznych sieć 5G definiują następujące parametry:

- opóźnienie pomiędzy elementami sieci wynoszące zaledwie 1 milisekundę;

- 1000 razy większe pasmo na jednostkę obszaru obsługiwanej sieci;

- do 100 razy większa liczba podłączonych urządzeń;

- dostępność sieci zachowana na poziomie 99,999\%;

- 100-proc. pokrycie terenu sieci;

- redukcja zużycia energii o 90\%;

- możliwość pracy małych elementów sieci na baterii do 10 lat.

Dopiero sieć spełniająca wymienione parametry może zostać nazwana siecią 5G. Dodatkowym parametrem technicznym jest nowy interfejs radiowy. Interfejs ten umożliwia pracę $z$ więcej niż jednym nadajnikiem oraz odbiornikiem i nazywany jest MIMO (z ang. multiple-input, multiple-output). Ważną cechą sieci $5 \mathrm{G}$ jest fakt możliwości koegzystencji sieci z siecią starej generacji oraz możliwość użycia sieci Ethernet jako swoistego łącza zapasowego. Jest to niezmiernie ważny aspekt we wszelkiego rodzaju sieciach wrażliwych, np. infrastruktury krytycznej, gdzie dostępność sieci jest niezmiernie istotna. Wśród prac naukowych dotyczących sieci 5G można znaleźć propozycje jej dalszego rozwoju poprzez użycie mechanizmów zwielokrotniania ścieżki transmisji takich jak np. Multi-Path Transmission Control Protocol. Technologia ta pozwala na użycie wszystkich dostępnych środków transmisji do uzyskania stałego i szybkiego połączenia pomiędzy punktami sieci. Propozycja użycia tej technologii wydaje się oczywista ze względu na fakt posiadania interfejsu MIMO, który właśnie umożliwi takie zwielokrotnienie. Użycie technologii zwielokrotnienia ścieżek może również pozwolić na jeszcze większe oszczędności energii poprzez eliminację niepotrzebnych retransmisji w sieci. W tym celu można zastosować różnego rodzaju techniki wykrywania i prognozowania wystąpienia błędów w transmisji na niestabilnym połączeniu. Przykładem takiej techniki jest zastosowanie logiki rozmytej, a dokładnie Skierowanych Liczb Rozmytych.

\section{System wykorzystujący sieci $3 G / 4 G / L T E$}

Powstały w ramach projektu „Opracowanie metodologii stałego nadzoru eksploatacji wybranych obszarów wyposażenia straży pożarnej w zakresie niezawodności i skuteczności działania” system jest rozwiązaniem służącym do monitorowania sprzętu straży pożarnej. Ogólną ideę systemu przedstawia rysunek 3. 


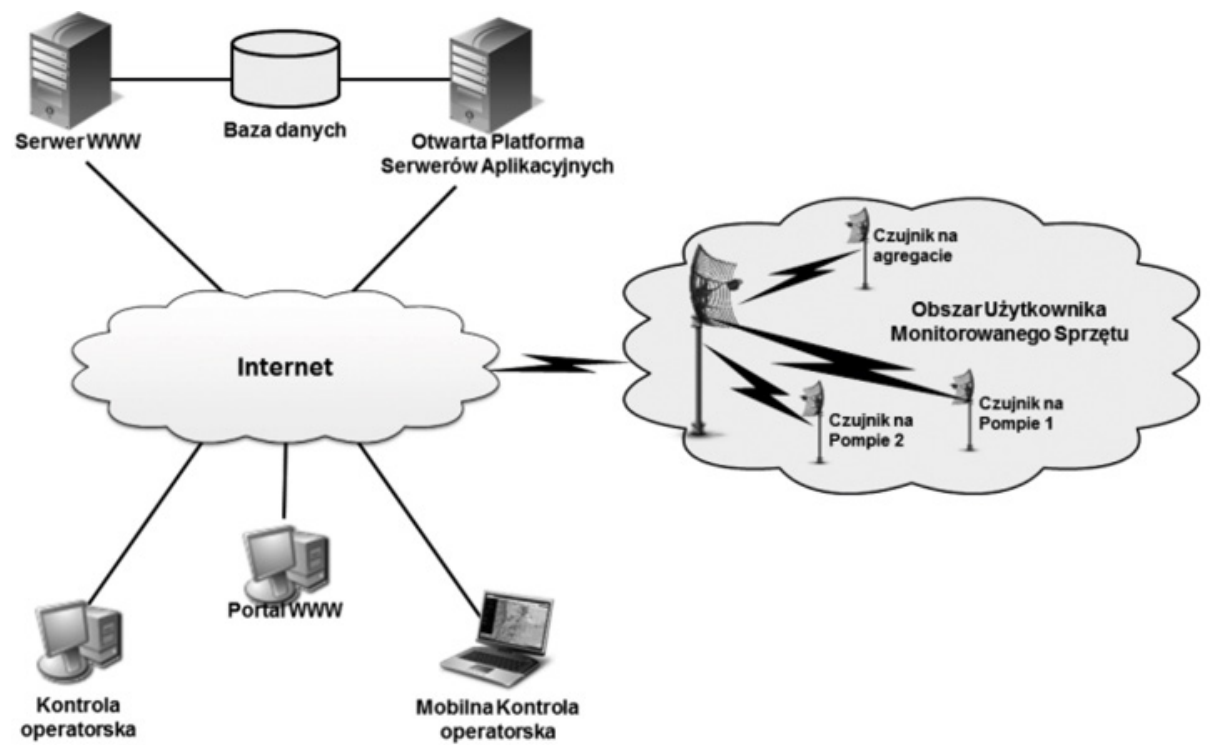

Rysunek 3. Idea systemu monitorowania sprzętu straży pożarnej Źródło: opracowanie własne

Figure 3. An idea of fire brigade monitoring system

W warstwie urządzeń podłączono następujące wyposażenie: pompy, elektryczne nożyce i autopompę. W ramach monitorowania tychże urządzeń mierzone są ich parametry pracy (są one zebrane wraz z wykazem sprzętu w tabeli 2).

Tabela 2. Parametry urządzeń monitorowane W Systemie

TABLE 2. DeVICES PARAMETERS MONITORING IN THE SYSTEM

\begin{tabular}{|c|c|c|c|c|c|c|c|c|c|c|c|c|c|c|c|c|}
\hline 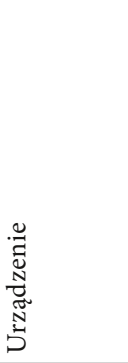 & 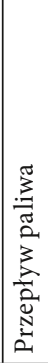 & 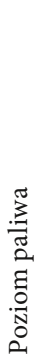 & 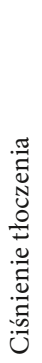 & 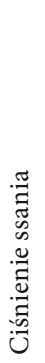 & 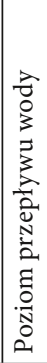 & 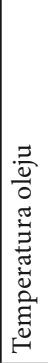 & 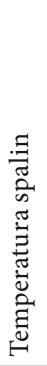 & 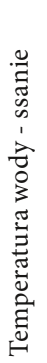 & 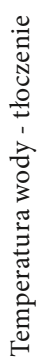 & 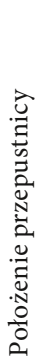 & 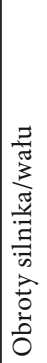 & 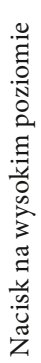 & 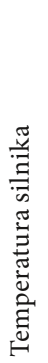 & 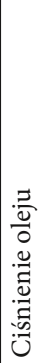 & 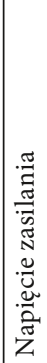 & 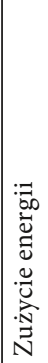 \\
\hline Niagara 1 & & & & & & & & & & & 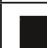 & & & & & \\
\hline $\begin{array}{l}\text { Honda } \\
\text { SST50 }\end{array}$ & & & & & & & & & & & & & & & & \\
\hline $\begin{array}{l}\text { Tohatsu } \\
\text { VC72AS }\end{array}$ & & & & & & & & & & & & & & & & \\
\hline $\begin{array}{l}\text { Autopomp } \\
\text { A16/8 }\end{array}$ & & & & & & & & & & & & & & & & \\
\hline
\end{tabular}




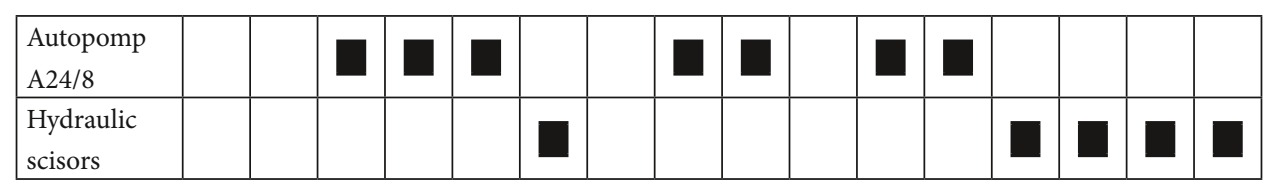

Kolejny element systemu stanowią urządzenia JAD, odpowiedzialne za zbieranie danych z czujników i przesyłanie ich dalej oraz wskazywanie pozycji GPS urządzeń, dzięki czemu można dokonać ich lokalizacji.

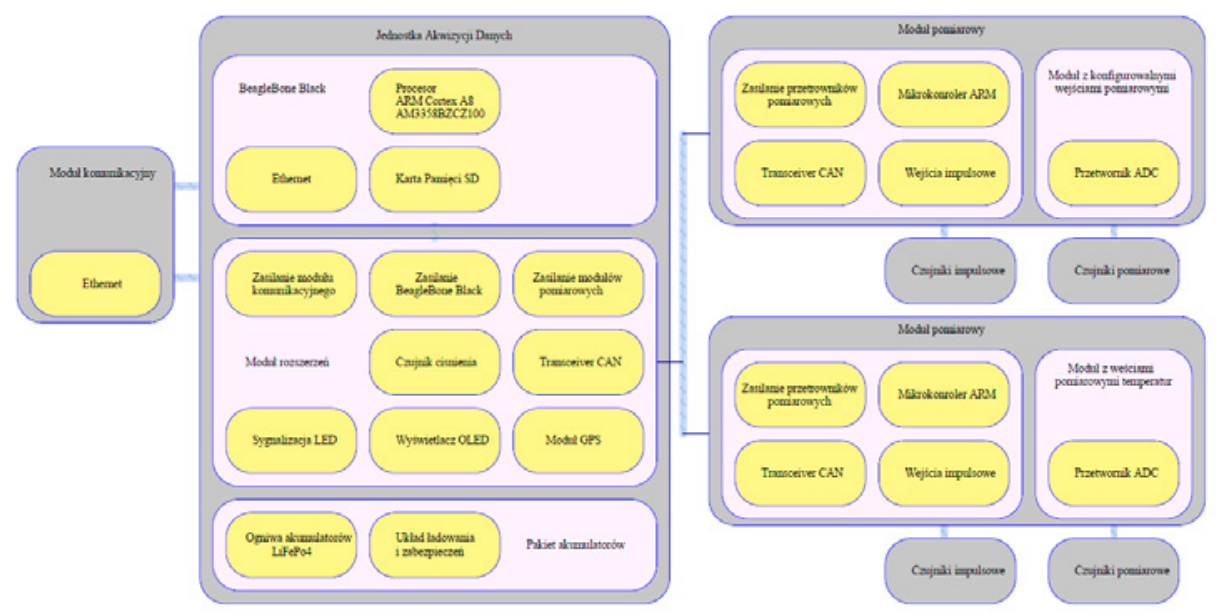

Rysunek 4. Architektura urządzeń JAD

Źródło: opracowanie własne

Figure 4. An architecture of JAD component

System posiada centralne rozwiązanie, w którym przechowywane są dane zebrane z urządzeń. Do zbierania danych z czujników wykorzystywane są połączenia przewodowe, następnie informacje przesyłane są poprzez sieć mesh Wi-Fi, a dalej poprzez sieć 3G/4G/LTE. Do transmisji tych danych zaprojektowano architekturę zaprezentowaną na rysunku 5. Transmisja ta jest możliwa poprzez Moduł Komunikacji. Składa się on z dwóch głównych elementów, zabudowanych w ragedyzowanej obudowie; są to: modem 3G/LTE i router. Elementy te zostały zabudowane w obudowie odpornej na zachlapania. Zastosowana została także technologia pozwalająca na pracę urządzenia podczas wstrząsów, np. generowanych przez motopompy. Moduł Komunikacji posiada wyprowadzone cztery anteny: dwie Wi-Fi oraz dwie sieci komórkowej, które umożliwiają uzyskanie lepszych osiągów tej sieci oraz poprawiają zasięg modemu. Modem jest urządzeniem sieciowym modelującym sygnał w celu zakodowania informacji cyfrowych, tak aby mogły być przesyłane w wybranym medium transmisyjnym. Demoduluje on także zakodowany sygnał, w celu dekodowania odbieranych danych. Modem Modułu Komunikacji umożliwia bezprzewodowy dostęp do sieci Internet. Zadaniem tego urządzenia jest nawiązanie połączenia GSM, może on pracować w trybie sieci 3G lub LTE, w zależności 
od zasięgu dostępnej sieci. Preferowaną siecią jest LTE, zapewniająca lepszą jakość oraz wyższą prędkość transmisji danych od sieci 3G. W przypadku słabego zasięgu lub jego braku, uniemożliwiającego prawidłowe funkcjonowanie podsystemu transmisyjnego, modem będzie pracował w dostępnej sieci 3G.

Router to urządzenie komunikacyjne, służące do sprzęgania sieci cyfrowych. Jego zadaniem jest połączenie sieci w jednolitą całość. Umożliwia on współdzielenie łącza sieciowego przez kilku użytkowników. Urządzenie to jest zgodne ze standardem IEEE $802.11 \mathrm{n}$, co oznacza, że pozwala tworzyć bezprzewodowe sieci o prędkości transmisji $300 \mathrm{Mb} / \mathrm{s}$, ograniczając straty sygnału powstałe na skutek dużych odległości lub przeszkód (stalowych lub betonowych ścian budynków). Ponadto, w porównaniu do produktów starszego standardu 11g, routery 11n umożliwiają transmisję sygnału bezprzewodowego na znacznie dalsze odległości. Standard ten pozwala na efektywne wykorzystanie nie tylko sieci $3 \mathrm{G}$, ale także $4 \mathrm{G} / \mathrm{LTE}$. Za bezpieczeństwo transmisji bezprzewodowej w sieci LAN rozgłaszanej przez router odpowiada szyfrowanie WPA i WPA2. Router Modułu Komunikacji wspiera technologię WDS.

Oczywiście, budując sieć mesh w momencie, gdy wszystkie urządzenia stanowią połączenie hop-by-hop uzyskuje się spadek transmisji, jednakże wystarczający dla działania niniejszej sieci. Spadek prędkości transmisji w zależności od liczby połączeń hop-by-hop zaprezentowano w tabeli 3.

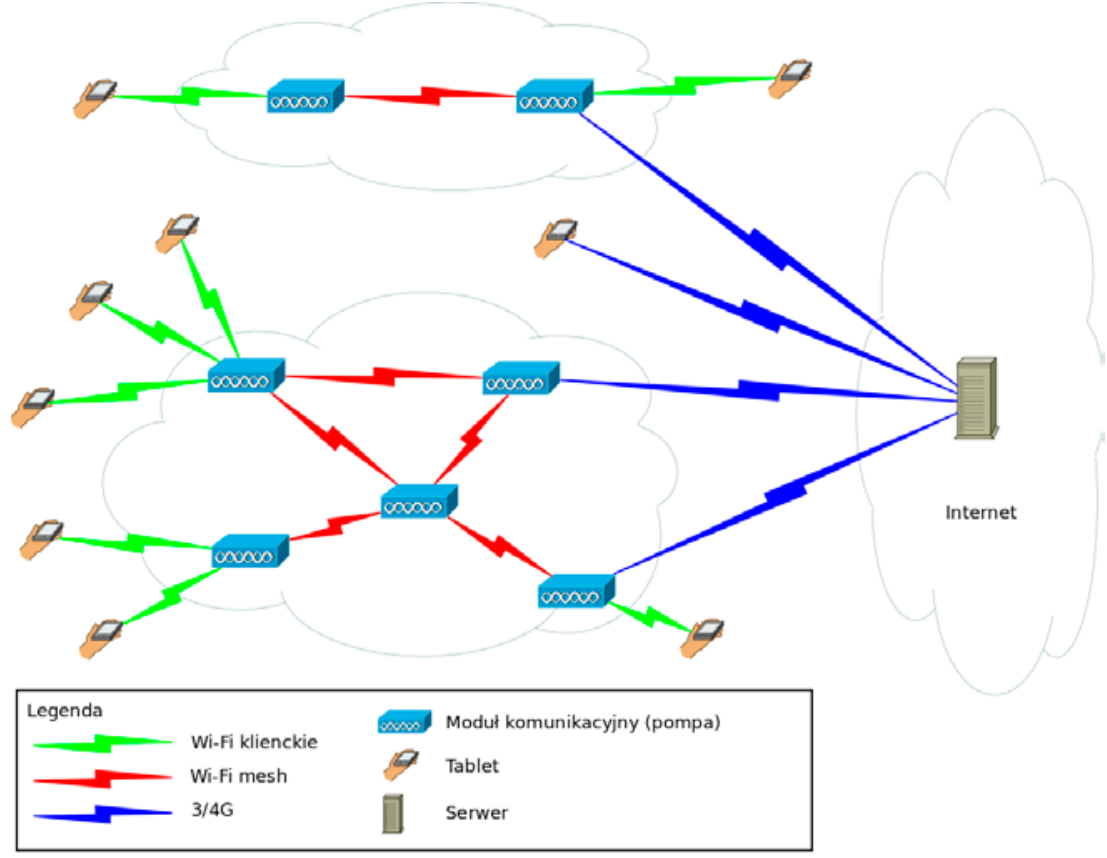

Rysunek 5. Architektura komunikacji

Źródło: opracowanie własne

Figure 5. Communication architecture 
Możliwości zastosowania sieci 4G do monitorowania urzadzeń eksploatowanych... 267

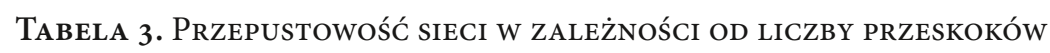

TABle 3. Throughput By hop COUNT

\begin{tabular}{|c|c|}
\hline Licznik skoków & $\begin{array}{c}\text { Wydajność } \\
{[\text { Mbit/s] }}\end{array}$ \\
\hline 1 & 272,81 \\
\hline 2 & 141,54 \\
\hline 3 & 69,35 \\
\hline 4 & 35,48 \\
\hline 5 & 18,45 \\
\hline 6 & 8,62 \\
\hline
\end{tabular}

System rozwiązuje problem monitorowania używanego sprzętu. Przykładowo proces wypompowywania wody z zalanej piwnicy trwa godzinami. Dotychczas strażak pilnował procesu działania pompy. Dzięki zastosowanemu rozwiązaniu pompę można zostawić pod opieką systemu, który wygeneruje alarm w przypadku wykrycia problemów w działaniu.

$\mathrm{Na}$ architekturę systemu wpływ miał czynnik zasilania - we wszystkich urządzeniach występuje zewnętrzne zasilanie (np. prądnica), jednakże poziom napięcia jest niestabilny. W tym celu opracowano odpowiedni układ zasilania akumulatorowego doładowywany ze źródła zasilania, co wyeliminowało problemy.

Drugim elementem mającym kluczowy wpływ na architekturę systemu był system łączności pomiędzy elementami zbierającymi dane a elementem obrazującym wynik pracy dla operatora. Ze względu na fakt, że istniejący system łączności był analogowy, trzeba było zbudować łączność cyfrową. Nie bez znaczenia były tutaj koszty systemu, który projektowano tak, aby był jak najtańszy w użytkowaniu, w tym celu obliczono liczbę danych wysyłanych przez system. Urządzenie, które posiada 15 miar z próbkowaniem sekundowym generuje $7 \mathrm{MB}$ danych na jedną godzinę pracy, na tej podstawie zdecydowano o wykorzystaniu sieci $3 \mathrm{G} / 4 \mathrm{G}$ z kartą prepaid pozwalającą na transfer 300 MB danych miesięcznie w standardzie LTE $4 \mathrm{G}$, a następnie pozwalającą na transfer z prędkością $32 \mathrm{kbps}$. Prędkość ta pozwala na transfer $14 \mathrm{MB}$ danych w ciągu godziny pracy, co jest wystarczającą prędkością. Koszt utrzymania takiej karty w latach 2017-2018 w Polsce, gdzie zbudowano system, wynosił 5 złotych rocznie. 


\section{Podsumowanie i wnioski}

Wykonanie projektu wymagało zaprojektowania odpowiednich urządzeń teletransmisyjnych, w tym celu firma TELDAT opracowała Moduł Komunikacji, który stanowił podstawowe urządzenie sieciowe, zapewniające łączność pomiędzy wszystkimi elementami systemu. Pozwala on na łączność z lokalną siecią Wi-Fi WDS, a także z siecią Internet poprzez zastosowany interfejs 3G/4G/LTE. Testy rozwiązania przeprowadzono w różnych lokalizacjach: Józefów, Bydgoszcz, Poznań, Warszawa, poligon SGSP pod Warszawą.

Podczas testów zauważono spadek prędkości transmisji w zależności od lokalizacji, jednakże nawet łączność $3 G$ jest wystarczająca dla uzyskania wymaganej przepływności. Przyszłościowa sieć 5G będzie łatwa w implementacji w systemie dzięki jego modułowej architekturze i pozwoli na zwiększenie szybkości i niezawodności działania.

\section{WYKAZ SKRÓTÓW}

3G - 3rd Generation

3GPP - 3rd Generation Partnership Project

$4 \mathrm{G}-4$ th Generation

$5 \mathrm{G}-5$ th Generation

DFT - Discrete Fourier Transform

eNB - Evolved Node B

GPS - Global Positioning System

GSM - Global System for Mobile Communications

HSDPA - High Speed Downlink Packet Access

HSPA - High Speed Packet Access

HSPA - Evolved High-Speed Packet Access

HSUPA - High Speed Uplink Packet Access

HWMP+ - Hybrid Wireless Mesh Protocol+

IEEE - Institute of Electrical and Electronics Engineers

$\mathrm{kb} / \mathrm{s}$ lub kbps lub kbit/s - kilobit per second

LAN - Local Area Network

LTE - Long Term Evolution

MB - Megabyte

$\mathrm{MB} / \mathrm{s}$ - Megabyte per second

Mbit/s - Megabit per second

mesh - Mesh Topology Network

MIMO - Multiple Input, Multiple Output

OFDMA - Orthogonal Frequency Division Multiple Access

SC-FDMA - Single Carrier - Frequency Division Multiple Access

SGSP - Szkoła Główna Służby Pożarniczej

UMTS - Universal Mobile Telecommunications System

UTRAN - Universal Terrestrial Radio Access Network

WDS - Wireless Distribution System 
Wi-Fi - Wireless Fidelity

WPA - Wi-Fi Protected Access

WPA2 - Wi-Fi Protected Access II

\section{Bibliografia}

[1] http://www.3gpp.org/technologies/keywords-acronyms/98-lte (dostęp: 2014.11.21).

[2] Wniosek nr 13087 „Monitoring”.

[3] Sprawozdanie z realizacji zadania badawczego 25172505 projektu „Monitoring” - Opracowanie planu testów demonstratora. Przeprowadzenie testów i wyciągnięcie wniosków z praktycznego zastosowania systemu łączności: możliwości transmisji danych, dostęp zdalny do urządzeń, niezawodność połączeń, prędkość transmisji.

[4] Sprawozdanie z realizacji zadania badawczego 25172504 projektu „Monitoring” - Wykonanie demonstratora - podsystem transmisyjny.

[5] Gębczyński T., Apiecionek Ł., Technologia LTE dla łączności z pojazdem komunikacji miejskiej, Studia i Materiały Informatyki Stosowanej, tom 6, 15/2014, s. 24-28.

[6] Apiecionek Ł., Motylewski R., Stosik P., Bezpieczeństwo transmisji danych w systemach monitorowania wyposażenia Straży Pożarnej. Problemy monitoringu eksploatacji sprzętu i wyposażenia Straży Pożarnej, CNBOP-PIB, DOI 10.17381/2015.2, Józefów 2015, 41-48.

[7] Makowski W., Motylewski R., Stosik P., Jeliński M., Apiecionek Ł., Jakość i wydajność transmisji danych $w$ sieci Wi-Fi MESH WDS systemu monitorowania urządzeń eksploatowanych $w$ straży pożarnej. Wspomaganie procesów zarządzania działaniami w straży pożarnej, J. Roguski (red.), Józefów, 2016, 39-47. 



\title{
Opracowanie funkcjonalnej koncepcji systemu monitorowania sprzętu $\mathrm{z}$ uwzględnieniem rodzaju danych i poziomu raportowania
}

\section{Design of a functional concept of the equipment monitoring system taking into account the type of data and reporting level}

\author{
Włodzimierz Kupicz \\ Paweł Ogrodnik \\ Dariusz Baranowski \\ Szkoła Główna Służby Pożarniczej w Warszawie
}

\section{Streszczenie}

$W$ publikacji przedstawiono wyniki prac nad realizacja projektu rozwojowego nr DOBR-BIO4/051/13087/2013 „Opracowanie metodologii stałego nadzoru eksploatacji wybranych obszarów wyposażenia straży pożarnej w zakresie niezawodności i skuteczności działania”. Zadania Szkoły Głównej Służby Pożarniczej obejmowały opracowanie funkcjonalnych założeń koncepcyjnych oraz przeprowadzenie badań w rzeczywistych warunkach eksploatacji. Wyniki badań wskazują na duża przydatność opracowanego systemu do nadzorowania eksploatacji wybranego sprzętu straży pożarnej.

\section{Abstract}

The publication presents the results of work on the implementation of the development project No. DOBR-BIO4 / 051/13087/2013 „Description of methodology for constant supervision of the exploitation of selected areas of firefighting equipment in scope of reliability and effectiveness". Tasks of the Main School of Fire Service included the elaboration of functional conceptual assumptions and examination in real operating of exploitation conditions. The results of the research indicate the high usefulness of the developed system to supervise the operation of selected fire-fighting equipment.

\section{Wstęp}

W publikacji przedstawiono wyniki prac nad realizacją projektu rozwojowego nr DOBR-BIO4/051/13087/2013 „Opracowanie metodologii stałego nadzoru eksploatacji wybranych obszarów wyposażenia straży pożarnej w zakresie niezawodności i skuteczności działania”. Zadania Szkoły Głównej Służby Pożarniczej obejmowały opracowanie funkcjonalnych założeń koncepcyjnych oraz przeprowadzenie badań w rzeczywistych warunkach eksploatacji. Wyniki badań wskazują na dużą przydatność opracowanego systemu do nadzorowania eksploatacji wybranego sprzętu straży pożarnej. 


\section{Koncepcja funkcjonalna systemu}

W ramach prac badawczych związanych z realizacją projektu „Opracowanie metodologii stałego nadzoru eksploatacji wybranych obszarów wyposażenia straży pożarnej w zakresie niezawodności i skuteczności działania” opisano strukturę systemu monitorowania, którą zamierza się wykorzystać podczas dalszych prac związanych z projektowaniem docelowego systemu monitorowania eksploatacji sprzętu pożarniczego. Przyjęta koncepcja struktury dla sprzętu, który ma zostać objęty monitorowaniem, przedstawia się następująco.

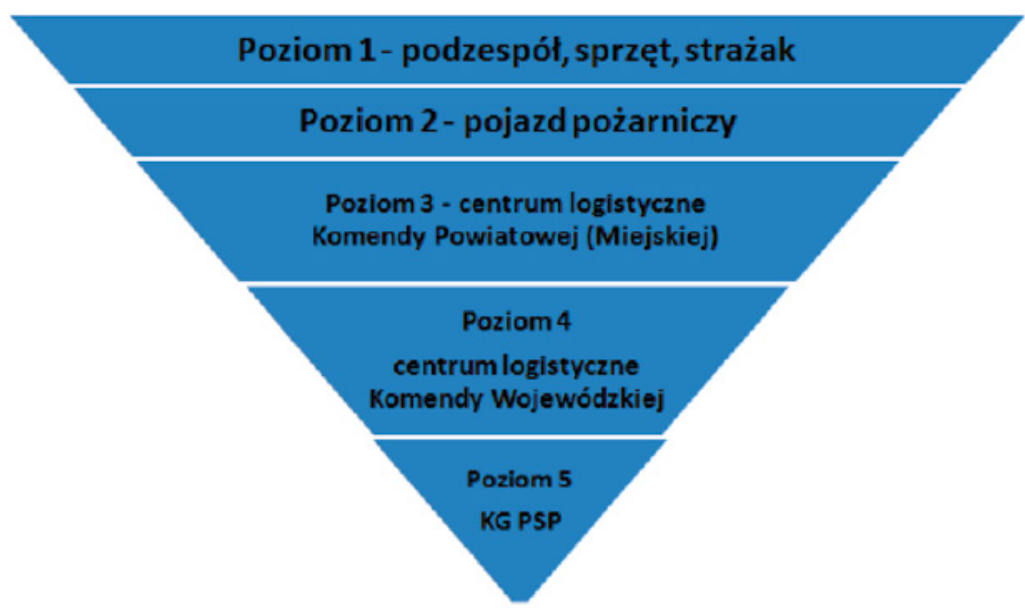

Rysunek 1. Koncepcja struktury dla sprzętu, który ma zostać objęty monitorowaniem Źródło: zadania badawcze nr 11081503 pt. „Opracowanie scenariusza działań ratowniczo-gaśniczych” Figure 1. Structure concept for the equipment to be monitored

\subsection{Poziom 1: monitorowany podzespół/sprzęt/strażak}

\subsubsection{Motopompa}

Sterownik pompy:

1. informacje bazowe: producent, model, typ, rok produkcji, nr seryjny;

2. licznik motogodzin;

3. przetwarzanie sygnałów, algorytmy diagnozowania, poziomy krytyczne sygnałów i parametrów diagnostycznych;

4. komunikacja z poziomem wyższym (2): logowanie do poziomu wyższego (2), po załączeniu zgłaszane informacje podstawowe, na żądanie - odpytanie systemu; meldunek stanowi zdatny-niezdatny, jeśli system generuje szczególowy raport - opis.

Podzespół silnika - sygnały/czujniki:

- temperatura spalin;

- zużycie paliwa;

- prędkość obrotowa wału; 
- temperatura oleju;

- temperatura otoczenia;

- ciśnienie otoczenia;

- hałas (amplituda, widmo częstotliwości);

- czujnik położenia przepustnicy.

Parametry diagnostyczne silnika:

- charakterystyki temperatury spalin w funkcji prędkości obrotowej i mocy pobieranej przez pompę;

- charakterystyki zużycia paliwa w funkcji prędkości obrotowej i mocy pobieranej przez pompę;

- charakterystyka mocy silnika szacowana na podstawie parametrów pompy: ciśnienia i intensywności przepływu.

Podzespół pompy - sygnały/czujniki:

- temperatura wody na wejściu;

- temperatura wody na wyjściu;

- podciśnienie na wejściu;

- ciśnienie na wyjściu;

- intensywność przepływu.

Parametry diagnostyczne pompy:

- nadwyżka antykawitacyjna obliczana na podstawie podciśnienia, intensywności przepływu i temperatur wody;

- charakterystyki ciśnienia w funkcji intensywności przepływu dla danej prędkości obrotowej wirnika;

- temperatura wody podczas pracy przy zamkniętych zaworach.

\subsubsection{Agregat urządzeń hydraulicznych}

Sterownik agregatu:

1. informacje bazowe: producent, model, typ, rok produkcji, nr seryjny;

2. licznik motogodzin;

3. przetwarzanie sygnałów, algorytmy diagnozowania, poziomy krytyczne sygnałów i parametrów diagnostycznych;

4. komunikacja z poziomem wyższym (2): logowanie do poziomu wyższego (2), po załączeniu zgłaszane informacje podstawowe, na żądanie - odpytanie systemu, meldunek stanowi zdatny-niezdatny, jeśli niezdatny, system generuje szczegółowy raport - opis algorytmów.

Podzespół silnika - sygnały/czujniki:

- temperatura spalin;

- zużycie paliwa;

- prędkość obrotowa wału;

- temperatura oleju;

- temperatura otoczenia (zasysanego powietrza);

- ciśnienie otoczenia; 
- hałas (amplituda, widmo częstotliwości);

- czujnik położenia przepustnicy.

Parametry diagnostyczne silnika:

- charakterystyki temperatury spalin w funkcji mocy pobieranej przez pompe hydrauliczną;

- charakterystyki zużycia paliwa w funkcji mocy pobieranej przez pompę hydrauliczną;

- charakterystyka mocy silnika szacowana na podstawie parametrów pompy hydraulicznej: ciśnienia nominalnego i prędkości obrotowej.

Podzespół pompy hydraulicznej wysokiego ciśnienia - sygnały/czujniki;

- temperatura oleju hydraulicznego;

- ciśnienie oleju hydraulicznego;

- intensywność przepływu.

Parametry diagnostyczne:

- charakterystyki ciśnienia w funkcji intensywności przepływu (siła działania urządzeń hydraulicznych);

- temperatura oleju podczas pracy z urządzeniami hydraulicznymi.

\subsubsection{Agregat prądotwórczy}

Sterownik agregatu:

1. informacje bazowe: producent, model, typ, rok produkcji, nr seryjny;

2. licznik motogodzin;

3. przetwarzanie sygnałów, algorytmy diagnozowania, poziomy krytyczne sygnałów i parametrów diagnostycznych;

4. komunikacja z poziomem wyższym (2): logowanie do poziomu wyższego (2), po załączeniu zgłaszane informacje podstawowe, na żądanie - odpytanie systemu;

5. meldunek stanowi zdatny - niezdatny, jeśli niezdatny system generuje szczegółowy raport - opis algorytmów.

Podzespół silnika - sygnały/czujniki:

- temperatura spalin;

- zużycie paliwa;

- prędkość obrotowa wału;

- temperatura oleju;

- temperatura otoczenia (zasysanego powietrza);

- ciśnienie otoczenia;

- hałas (amplituda, widmo częstotliwości);

- czujnik położenia przepustnicy.

Parametry diagnostyczne silnika:

- charakterystyki temperatury spalin w funkcji mocy pobieranej przez generator prądu;

- charakterystyki zużycia paliwa w funkcji mocy pobieranej przez generator prądu; 
- charakterystyka mocy silnika szacowana na podstawie parametrów generatora prądu: napięcia i natężenia prądu elektrycznego.

\subsection{Poziom 2: Samochód pożarniczy}

Samochód pożarniczy stanowić ma drugi poziom systemu logistycznego. System nadzorować ma zalogowany w nim sprzęt oraz swoje kluczowe podzespoły:

- silnik;

- skrzynia biegów;

- zespół napędowy;

- przystawka odbioru mocy;

- autopompa;

- zabudowa pożarnicza.

Rozwiązania systemu mają wspomagać dowódcę zastępu przy podejmowaniu decyzji. System ma posiadać funkcję zobrazowania informacji diagnostycznych na wewnętrznym monitorze takich jak:

- zbliżający się termin obsługi technicznej;

- ostrzeżenie o niezdatnych podzespołach;

- ostrzeżenie o nie w pełni sprawnym monitorowanym sprzęcie.

Ponadto posiadać ma następujące moduły:

- pozycjonowania i nadzorowania swojej prędkości jazdy;

- zużycia paliwa;

- łączności dalekiego zasięgu, za pomocą którego na bieżąco raportuje o stanie technicznym dwustanowo sprawny/niesprawny do:

- dyżurnego stanowiska kierowania na poziomie jednostki lub powiatu;

- samochód specjalny dowodzenia i łączności, a także o stanie technicznym dwustanowo zdatny/niezdatny.

- łączności bliskiego zasięgu np. Wi-Fi który po powrocie do jednostki przekazuje szczegółowe informacje do systemu logistycznego JRG, który w przyszłości ma być sprzęgnięty z systemem SWD-ST. SWD-ST umożliwia wpisywanie ręczne informacji np. o wycofaniu z podziału, wykonanych naprawach, obsługach i przeglądach, zmianie uszkodzonego sprzętu itp. W przypadku podłączenia do istniejącego SWD-ST informacje przekazywane byłyby automatycznie.

Dowódca zastępu ma być wyposażony w tablet typu RUGGED, do którego napływać mają sygnały o krytycznym znaczeniu dla powodzenia akcji, m.in.:

- czerwone pole i informacja: w motopompie wzrasta temperatura lub po zapchaniu się smoka ssawnego zaczyna pracować w zakresie kawitacji;

- żółte pole i informacja: w motopompie kończy się zapas paliwa.

Informacje krytyczne powodują konieczność natychmiastowej reakcji, np. rozkaz kontroli sprzętu i ewentualny kontakt z dyżurnym stanowiska kierowania z prośbą o podmianę sprzętu jeszcze przed wystąpieniem faktycznego problemu. Dane mniej krytyczne służące np. do prognozowania stanu czy też bieżące wartości parametrów 
są dostępne na wywołanie. Pełne przekazywanie historii poszczególnych parametrów i ewentualne diagnozowanie odbywa się po powrocie do bazy.

\subsection{Poziom 3: Centrum logistyczne komendy powiatowej (miejskiej)}

Zakłada się, aby w przyszłości system monitorowania współpracował z istniejącym systemem SWD-ST.

Funkcje systemu monitorowania:

1. nadzoruje zalogowane w nim pojazdy pożarnicze;

2. gromadzi w bazie danych informacje o:
a) interwałach obsługowych;
b) dopuszczalnych resursach pracy poszczególnego sprzętu;
c) ilości i rodzaju napraw;
d) wycofaniu z podziału;
e) ilości niesprawnego sprzętu.

3. posiada moduł logistyczny umożliwiający planowanie zakupów, materiałów eksploatacyjnych, paliw i środków gaśniczych, usług naprawczych, przeglądów i obsług;

4. monitoruje koszty;

5. okresowo raportuje do centrum wyższego szczebla informacje:

- ilość wycofań;

- rodzaj i typ wycofywanych;

- koszty miesięczne, roczne;

- przebieg pojazdów;

- ilość przepracowanych motogodzin sprzętu;

- zgłoszenia dotyczące potrzeb w podległych jednostkach.

Dowództwo jednostki oraz sekcja kwatermistrzowska będzie posiadać pełną informację o stanie technicznym poszczególnego sprzętu. Jeżeli jeden z parametrów zmieni swoje wartości i na podstawie prognozowania stanu zaistnieje ryzyko uszkodzenia, będzie możliwość odpowiednio wcześniej zarządzić jego wycofanie z podziału. Podobnie, jeżeli kończy się resurs do wymiany olejów i innych płynów eksploatacyjnych, możliwa jest wymiana w odpowiednim czasie (informacja będzie widoczna odpowiednio wcześniej w interfejsie diagnostycznym).

\subsection{Poziom 4: Centrum logistyczne komendy wojewódzkiej}

Funkcje:

1. analizuje dane o kosztach, strukturze sprzętu, ilości interwencji i na takiej podstawie decyduje o ewentualnym zwiększeniu ilości pojazdów i etatów;

2. posiada dostęp do szczegółowych danych dotyczących wykorzystywanego sprzętu, co pozwala na sprawne koordynowanie akcji o dużym zasięgu i skali np. powodziowej;

3. prowadzi analizy dotyczące niezawodności na dużej ilości prób;

4. raportuje do centrum wyższego poziomu. 


\subsection{Poziom 5: Komenda główna}

Funkcje:

1. otrzymuje przetworzone dane nt. kosztów, niezawodności, stanu technicznego i potrzeb;

2. z poziomu krajowego planuje i koordynuje zakupy i wybór sprzętu przy współpracy z CNBOP;

3. posiada dostęp do szczegółowych informacji z każdego poziomu systemu logistycznego.

System ma docelowo być wsparciem istniejącego systemu SWD-ST, dane odnośnie do poszczególnego sprzętu mają trafiać do SWD-ST automatycznie - bez potrzeby ich ręcznego wprowadzania, tak jak to ma miejsce obecnie.

Poszczególne szczeble dowodzenia mają posiadać szczegółowe informacje o niezawodności sprzętu oraz kosztach niezbędnych do jego prawidłowego utrzymania.

Pozwoli to na racjonalne i poparte rzetelnymi odczytami planowanie i zapobieganie awarii podczas prowadzonych działań ratowniczo-gaśniczych.

\section{Demonstracja systemu w warunkach operacyjno-ratowniczych}

\subsection{Montaż na pojazdach i sprzęcie w JRG SGSP systemu monitorowania, testy systemu w warunkach operacyjnych oraz demonstracja podczas ćwiczeń}

Jednym z pojazdów stanowiących wyposażenie Jednostki Ratowniczo-Gaśniczej Szkoły Głównej Służby Pożarniczej jest średni samochód ratowniczo-gaśniczy o nr operacyjnym 250W22. Został on skarosowany przez firmę Piotr Wawrzaszek Inżynieria Samochodów Specjalnych z siedzibą w Bielsku-Białej przy ul. Leszczyńskiej 22. Pojazd ten został zbudowany na seryjnym podwoziu Renault-Midlum $220.14 \mathrm{z}$ napędem $4 \times 4$. Ogólny wygląd średniego samochodu ratowniczo-gaśniczego 250W22 pokazano na rys. 2 .
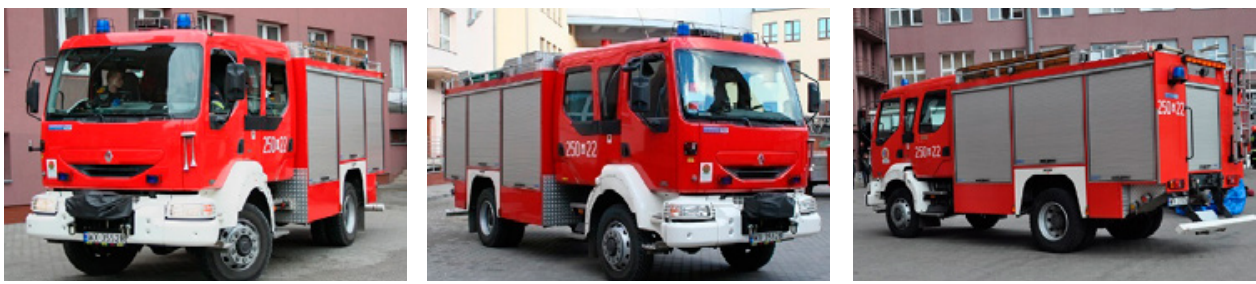

Rysunek 2. Średni samochód ratowniczo-gaśniczy na podwoziu Renault Midlum 220.14 Źródło: opracowanie własne

Figure 2. Fire Engine on Renault Midlum 220.14 chassis 


\section{Dane techniczne autopompy}

Średni samochód ratowniczo-gaśniczy 250W22 wyposażony jest w autopompę RUBERG R 30/2,5. Pompa ta jest wielostopniową odśrodkową pompą pożarniczą.

W opisanym samochodzie ratowniczo-gaśniczym na podwoziu Renault Midlum 220.14, posiadającym numer operacyjny 250W22, stanowiącym wyposażenie Jednostki Ratowniczo-Gaśniczej SGSP zamontowano następujące elementy systemu:

1. czujnik ciśnienia ssania Wika A-10 - 1/16 bar;

2. czujnik temperatury wody Introl CE $2 \times 2$;

3. uchwyt mocowania modułów;

4. JAD - jednostka akwizycji danych;

5. moduł baterii;

6. modul pomiarowy;

7. czujnik obrotów wału ZM7;

8. przepływomierz wody FLS X3 F3.00;

9. mocowanie modułu łączności wraz z modułem Teldat;

10. czujnik ciśnienia tłoczenia Wika A10 - 1/16 bar;

11. antena GPS;

12. króciec ssania ZM11.
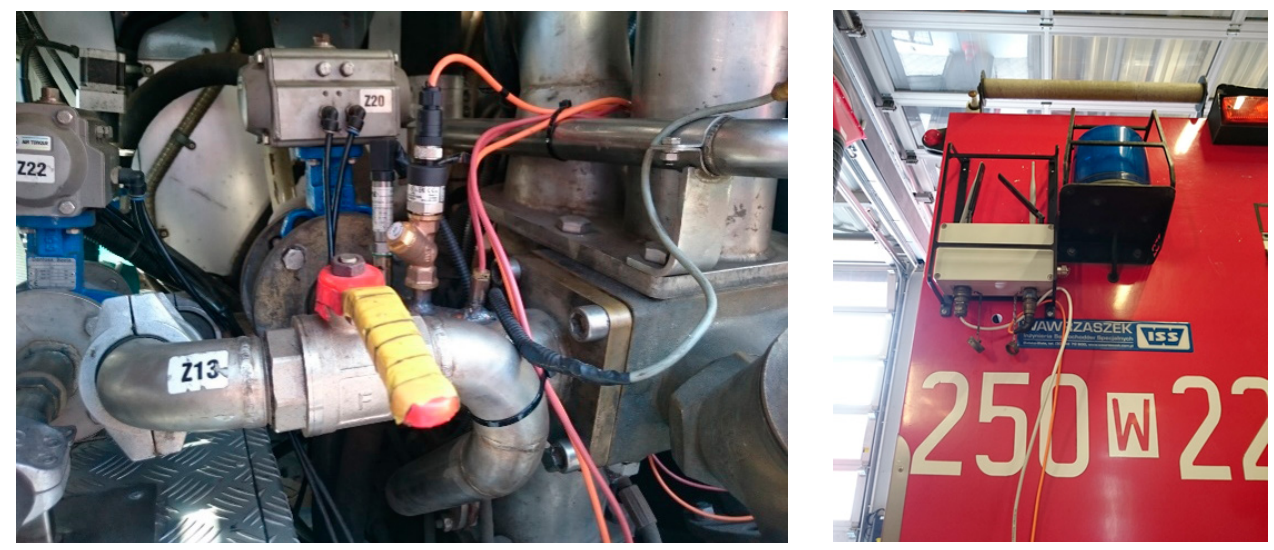

Rysunek 3. Ogólny wygląd wybranych zamontowanych elementów systemu Źródło: opracowanie własne

Figure 3. View of selected installed system components

\subsection{Montaż systemu monitorowania na pozostałym sprzęcie ratowniczo-gaśniczym}

Pompa pływajaca Niagara1 KZWM Ogniochron - motopompy pływające posiadają szerokie zastosowanie w służbach ratowniczych. Napęd spalinowy pozwala na zastosowanie pomp w każdym miejscu, bez potrzeby dostępu do sieci elektrycznej. Motopompy mogą służyć do napełniania zbiorników pojazdów pożarniczych bez potrzeby budowania stanowiska wodnego, jak również do awaryjnego nawadniania lub osuszania terenów rolniczych. 
Motopompa szlamowa Honda SST50 - pompa do zanieczyszczonej wody. Pompy te mogą być stosowane do: odwadniania wykopów, usuwania wody z zalanych piwnic i studzienek kanalizacyjnych. W budowie tego typu pomp zastosowano wirnik i korpus o zwiększonej gęstości, co zapobiega szybkiemu zużywaniu się tych części. Jej największą zaletą jest niewielka masa oraz małe wymiary przy jednoczesnym zachowaniu dużego ziarna zanieczyszczeń stałych.

Motopompa Tohatsu VC72AS - przenośna motopompa pożarnicza M 8/8 TOHATSU VC72AS z rozruchem ręcznym i elektrycznym. Benzyna i olej są mieszane automatycznie w proporcji dopasowanej do prędkości obrotowej silnika. System ten eliminuje potrzebę wstępnego mieszania paliwa. Kiedy $3 / 4$ oleju w zbiorniku zostanie zużyte, włączy się lampka na monitorze oraz brzęczyk. Zarówno na otworze wlotowym, jak i wylotowym zamontowano tłumiki, co znacznie obniża poziom hałasu silnika. Zamontowano również specjalny, chłodzony wodą tłumik dźwięków, redukujący hałas silnika. Po użytkowaniu pompy, paliwo pozostające w komorze pływakowej gaźnika psuje się bardzo szybko, powodując trudności z uruchomieniem silnika i możliwość jego uszkodzenia. Model VC72AS jest wyposażony w zawór spustowy komory pływakowej zapewniający łatwe usuwanie niezużytego paliwa z gaźnika. Paliwo powinno być spuszczane z komory pływakowej po każdym użytkowaniu pompy, aby zapewnić stałą możliwość szybkiego uruchomienia silnika w nagłych wypadkach. Aby zabezpieczyć silnik przed stratami wody chłodzącej oraz chronić pompę, kiedy nie ma tłoczenia wody, w modelach tych przewidziano ochronę przed przegrzaniem. Urządzenie automatycznie zatrzymuje silnik, kiedy temperatura pracy osiąga $80^{\circ} \mathrm{C}$. Wyjście tłoczne może być dowolnie ustawiane w zakresie $180^{\circ}$, pozwalając na zmianę kierunku węży tłocznych bez potrzeby przemieszczania pompy.

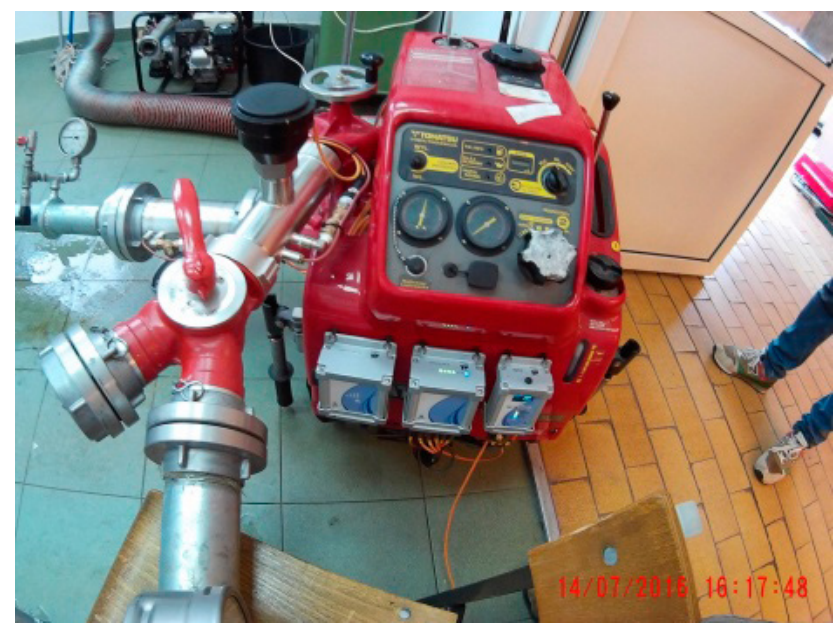

Rysunek 4. Elementy systemu zamocowane na motopompie Tohatsu VC72AS Źródło: opracowanie własne

Figure 4. Elements of the system on the fire pump Tohatsu VC72AS 


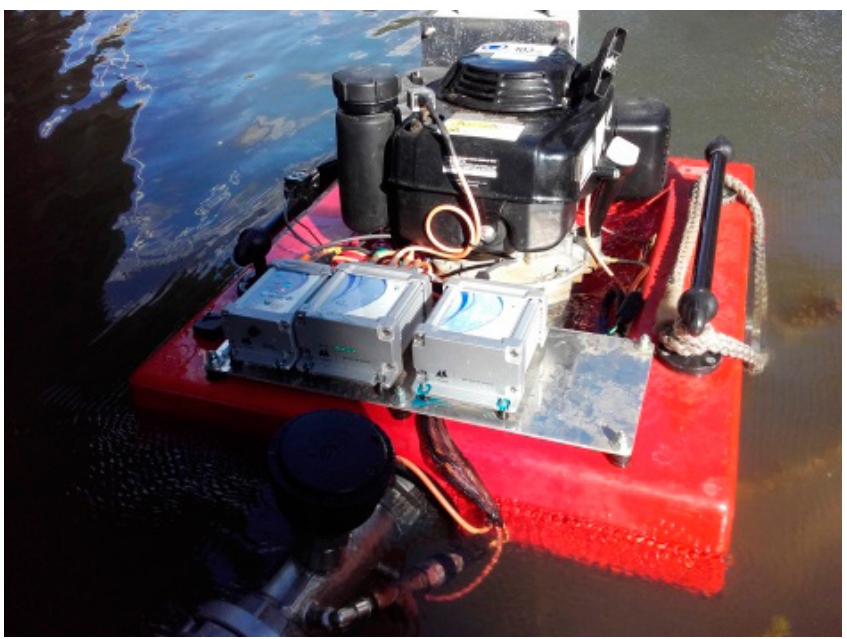

Rysunek 5. Elementy systemu zamocowane na motopompie Niagara 1 KZWM Ogniochron Źródło: opracowanie własne

Figure 5. Elements of the system on the fire pump Niagara 1 KZWM Ogniochron

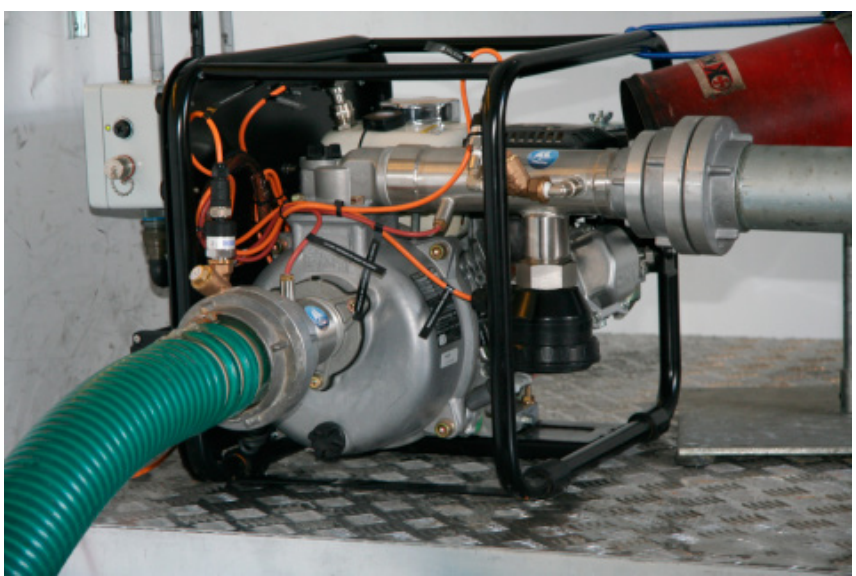

Rysunek 6. Elementy systemu zamocowane na motopompie Honda SST50 Źródło: opracowanie własne

Figure 6. Elements of the system on the fire pump Honda SST50

\subsection{Sprawdzenie funkcjonowania systemu monitorowania podczas symulowanych akcji ratowniczych}

W ramach badań przeprowadzono symulowane działania podczas wypadku drogowego, pożaru, działań przeciwpowodziowych.

1. Działania podczas wypadku drogowego

Badania przeprowadzono w dniu 13.09.2016 r. na terenie bazy leśnej Zamczysko. Po otrzymaniu zgłoszenia dyspozytor upewnił się co do statusu autopompy (pojazd pożarniczy GBA 2,5/16) oraz narzędzi hydraulicznych Weber. Stwierdzono status 
„sprawny”. Pozycjonowanie jednostek sprzętowych wskazywało na ich obecność na terenie bazy leśnej Zamczysko SGSP. Dyspozytor zadysponował załogę pojazdu GBA 2,5/16 do wypadku drogowego o godz. 13.04.

Stwierdzono, że na skutek braku zasięgu sieci GSM na komputerze dyspozytora nie wyświetlało się aktualne położenie pojazdu na mapie w aplikacji LUME. Jednocześnie stwierdzono, że na tablecie dowódcy komunikującym się z pojazdem za pomocą sieci Wi-Fi aktualizacja przebiega poprawnie. Przez cały czas akcji ratowniczej brak było łączności GSM i bieżące parametry wyświetlano wyłącznie na tablecie dowódcy. Stwierdzono następnie, że po przemieszczeniu pojazdu w inny rejon bazy leśnej i nawiązaniu łączności GSM dane spłynęły do serwera systemu o godz. 17.31.

Po przybyciu na miejsce załoga zauważyła pożar rozbitego samochodu osobowego. Przystąpiono do gaszenia przy pomocy linii szybkiego natarcia.
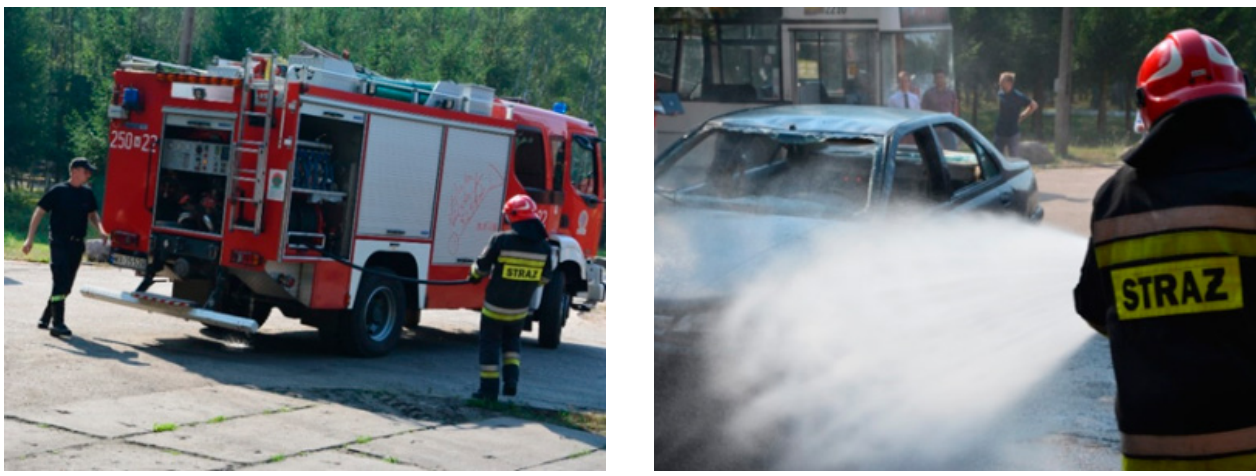

Rysunek 7 i 8. Gaszenie pojazdu podczas testowania systemu Źródło: opracowanie własne

Figure 7, 9. Extinguishing a fires vehicle during testing the system

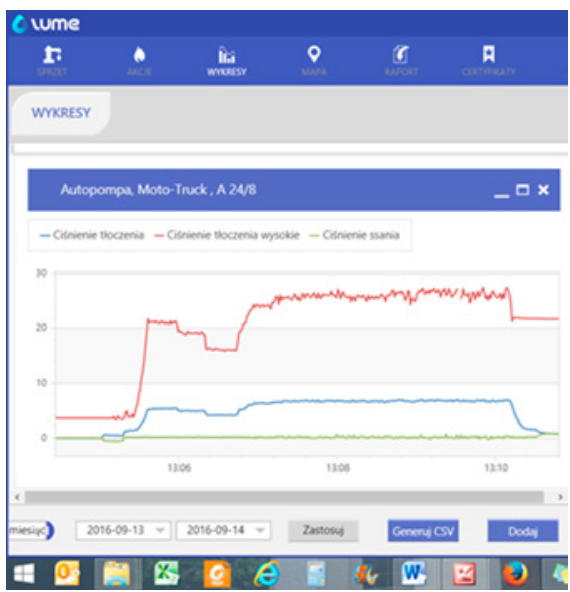

Rysunek 9. Parametry autopompy odczytane podczas gaszenia pojazdu Źródło: opracowanie własne

Figure 9. Fire pump parameters during fires vehicle extinguishing 
Następnie po ugaszeniu pożaru przystąpiono do uwalniania poszkodowanych $z$ rozbitego pojazdu. Za pomocą rozpieracza ramieniowego otworzono zakleszczone drzwi pojazdu i usunięto z zawiasów.

Potem za pomocą nożyc przecięto słupki przednie i środkowe i usunięto dach pojazdu. Konieczne było jeszcze uwolnienie nóg kierowcy przygniecionych przez zdeformowaną deskę rozdzielczą. W tym celu użyto rozpieracza kolumnowego.

Na tym działania ratownicze przy zdarzeniu miejscowym zakończono, pojazd powrócił do JRG (wiata bazy leśnej Zamczysko). Po odzyskaniu łączności z siecią GSM wszystkie dane szczegółowe spłynęły na serwer systemu monitorowania. Oceniono status narzędzi hydraulicznych i pojazdu pożarniczego i stwierdzono, że są sprawne i gotowe do wyjazdu do następnego zgłoszenia.
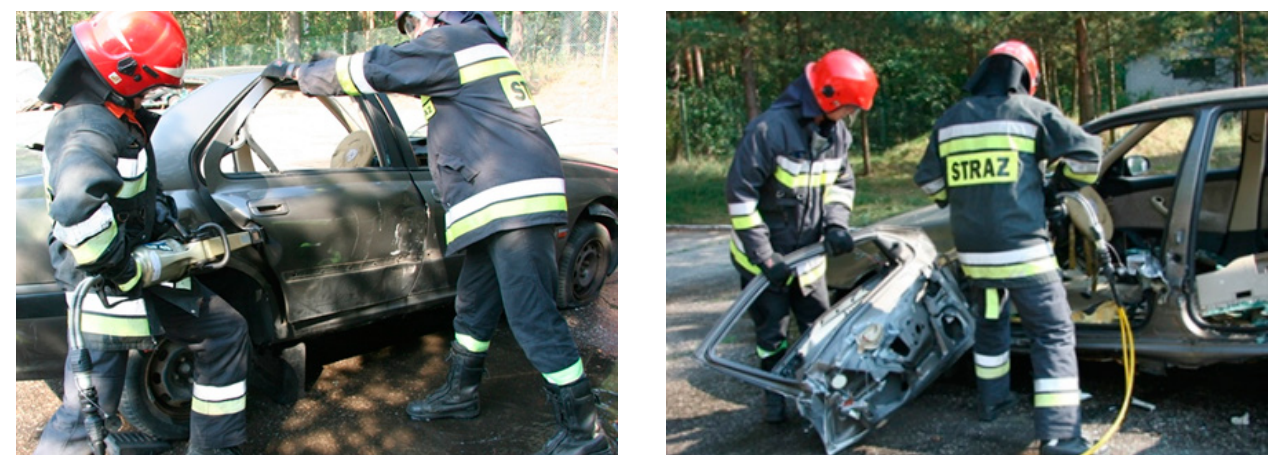

Rysunek 10 i 11. Uwalnianie poszkodowanych przy użyciu narzędzi hydraulicznych podczas testowania systemu

Źródło: opracowanie własne

Figure 10, 11. Evacuation of the victims using hydraulic tools during system testing

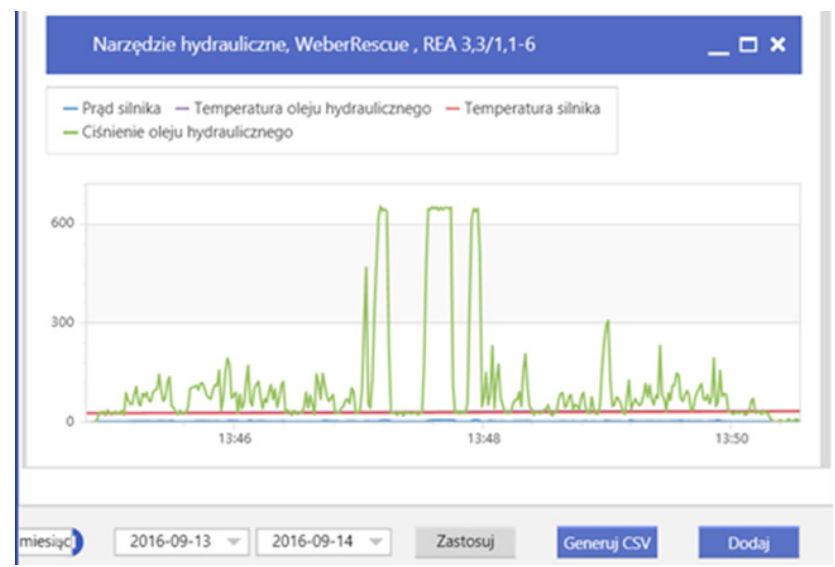

Rysunek 12. Parametry agregatu hydraulicznego odczytane podczas pracy narzędziami hydraulicznymi

Źródło: opracowanie własne

Figure 12. Parameters of the hydraulic aggregate during working hydraulic tools 
Przeprowadzone ćwiczenia oraz analiza zarejestrowanych wyników umożliwiają stwierdzenie, że:

- zaprojektowany system pozwala na pełne nadzorowanie zarówno stanu technicznego urządzeń, jak i przebiegu prowadzonej akcji ratowniczej;

- dzięki zdublowanemu systemowi zapisu danych, pomimo długiego braku zasięgu GSM, dane spłynęły do serwera po odzyskaniu połączenia;

- podczas działań ratowniczych duże rozmiary tabletu dowódcy utrudniają działania, stąd powinien być on umieszczony w stacji dokującej w pojeździe. Należy rozważyć zmianę panelu głównego oprogramowania w celu jego uproszczenia.

\section{Działania podczas akcji gaśniczej}

Symulowaną akcję gaśniczą przeprowadzono na terenie bazy leśnej Zamczysko w dniu 13.09.2016 r. Ze względu na brak zasięgu GSM modułu komunikacji pojazdu GBA 2,5/16 nie było możliwe wykonanie sprawdzenia statusu stanu technicznego autopompy przed zadysponowaniem pojazdu. Stwierdzono, że pozostały sprzęt biorący udział w działaniach gaśniczych jest sprawny. Rozpoczęto podawanie prądów gaśniczych liniami normalnego ciśnienia. Jednocześnie ustawiono w pobliżu zbiornika wodnego motopompę pożarniczą TOHATSU i podawano prąd gaśniczy przez ok. 1,5 godziny. Na zbiorniku wodnym umieszczono motopompę pływającą Niagara i okresowo przy jej pomocy tankowano zbiornik wodny samochodu gaśniczego. Następnie ćwiczono podawanie prądów gaśniczych za pomocą działka wodno-pianowego pojazdu.
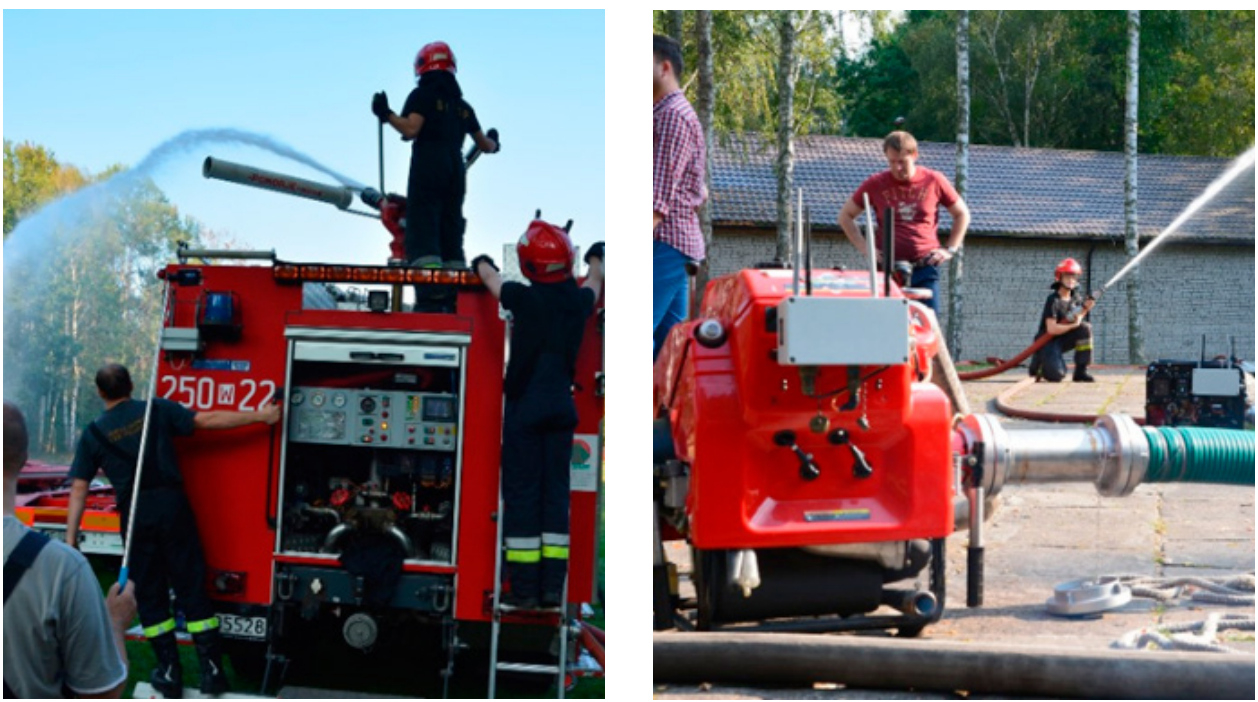

Rysunek 13 i 14. Symulowana akcja gaśnicza podczas testowania systemu Źródło: opracowanie własne

Figure 13, 14. Simulated extinguishing action during system testing 


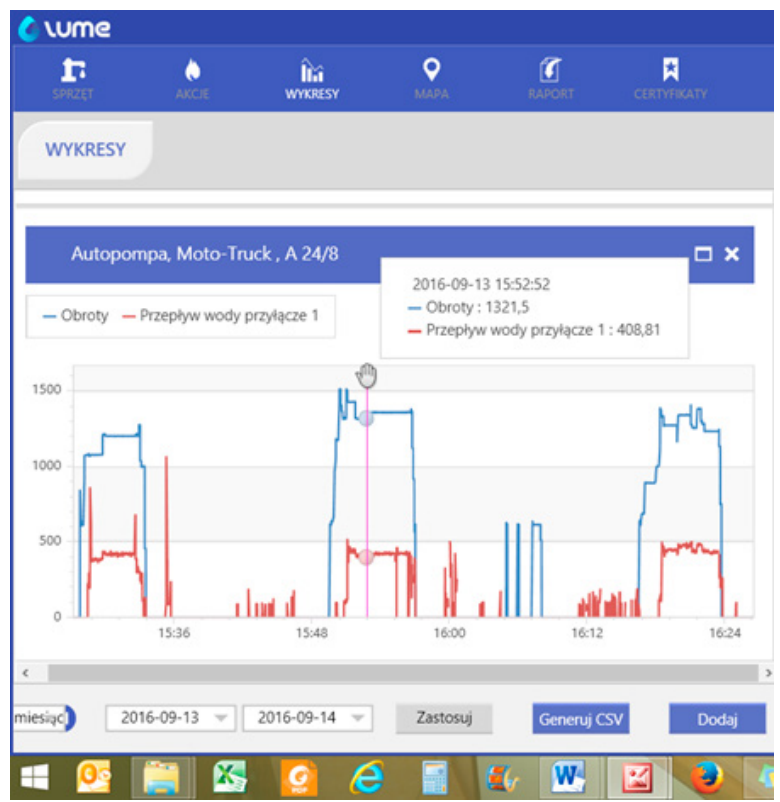

Rysunek 15. Parametry autopompy podczas symulowanej akcji gaśniczej Źródło: opracowanie własne

Figure 15. Fire pump parameters during simulated fire extinguishing
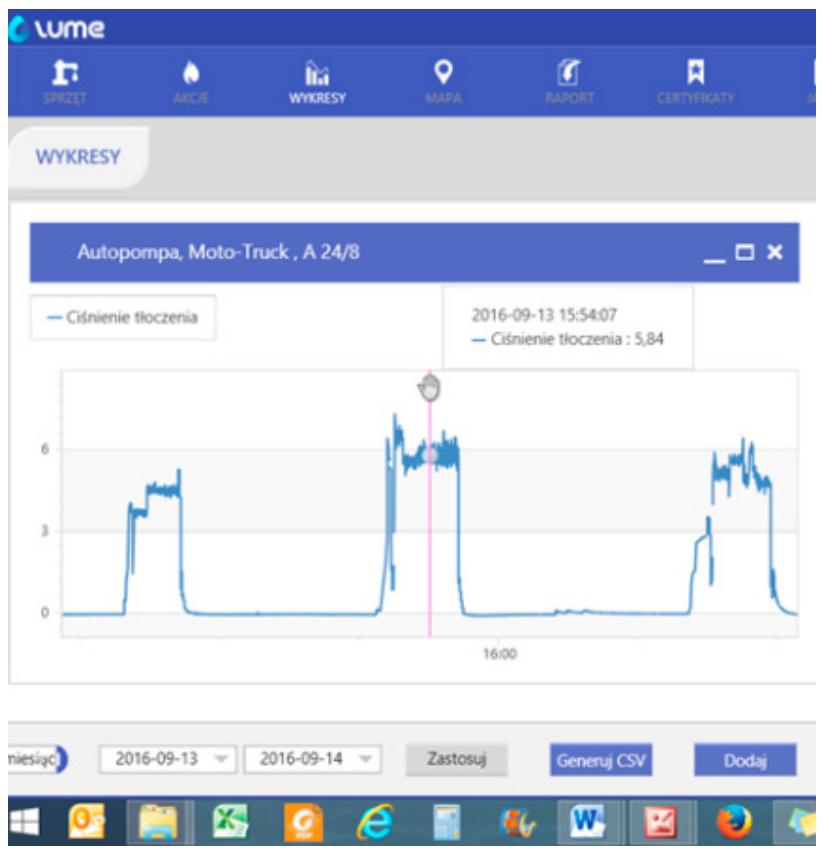

Rysunek 16. Parametry autopompy podczas symulowanej akcji gaśniczej Źródło: opracowanie własne

Figure 16. Fire pump parameters during simulated fire extinguishing 


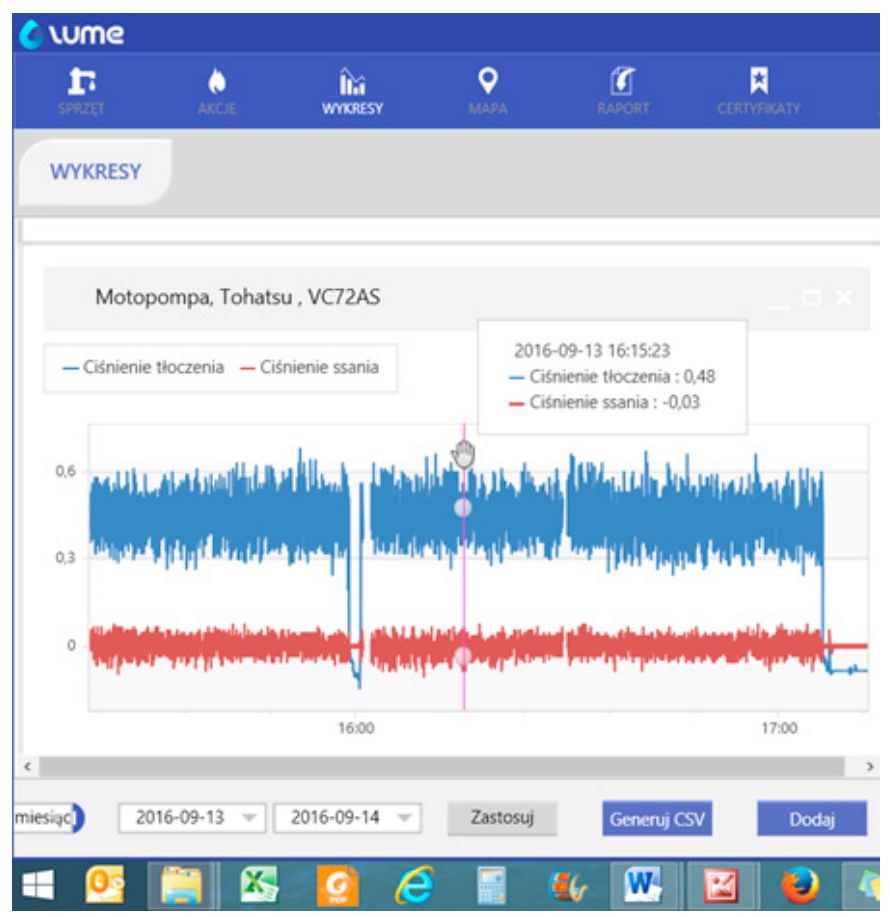

Rysunek 17. Parametry autopompy podczas symulowanej akcji gaśniczej Źródło: opracowanie własne

Figure 17. Fire pump parameters during simulated fire extinguishing

Podczas całej akcji gaśniczej stwierdzono okresowe problemy z zasięgiem sieci GSM. Podgląd parametrów obserwowano na tablecie dowódcy. Konieczne było jednak załączanie poszczególnych jednostek sprzętu w odpowiedniej kolejności, przewidzianej w konfiguracji sieci Wi-Fi. W momencie wyłączenia któregokolwiek z monitorowanego sprzętu występowały problemy z przekazywaniem danych na tablet dowódcy. Pod koniec akcji gaśniczej moduł komunikacji pojazdu odzyskał łączność GSM i dane spłynęły do serwera systemu.

Na podstawie przeprowadzonych badań należy stwierdzić, że:

- opracowany system monitorowania stanu technicznego urządzeń pozwala na pełną kontrolę podczas akcji gaśniczych;

- sposób zapisu danych oraz ich przedstawiania zapewnia pełną odtwarzalność parametrów urządzeń podczas akcji gaśniczych;

- niezbędna jest zmiana w konfiguracji systemu łączności przy użyciu sieci Wi-Fi, tak aby możliwe było automatyczne przełączanie pomiędzy urządzeniami;

- konieczne jest zastosowanie urządzeń zapewniających większy (min. kilkusetmetrowy) zasięg sieci Wi-Fi;

- dwukanałowe przekazywanie danych pozwala na stabilną pracę systemu nawet w warunkach słabego zasięgu sieci GSM. 


\section{Działania podczas podtopień}

Badania przeprowadzono w pomieszczeniu zamkniętym laboratorium Zakładu Sprzętu Pomiarowego w SGSP. Pompę umieszczono na zbiorniku wodnym laboratorium, podłączono wyciąg spalin i węże tłoczne. Podczas sprawdzeń stwierdzono nieprawidłowości pozycjonowania motopompy pływającej. Badania prowadzono przez ok. 3,5 godziny wymuszając zmienne parametry pracy poprzez dławienie zaworem klapowym na rurociągu pomiarowym oraz poprzez zmianę prędkości obrotowej silnika motopompy.

Po zakończeniu działań wyłączono motopompę i sprawdzono status stanu technicznego. W zakładce Lume zarejestrowane zostały komunikaty o stanach ostrzegawczych, dotyczących niskiego poziomu baterii, niskiego stanu paliwa oraz przekroczonego ciśnienia tłoczenia.

Twórca oprogramowania - firma Mlabs dokonała korekty ustawień poziomu alarmowego sygnału ciśnienia, tak aby alarm poziomu ciśnienia tłoczenia wzbudzał się przy wyższych wartościach.

Na podstawie przeprowadzonych badań należy stwierdzić, że:

- rejestrowane parametry systemu monitorowania stanu technicznego pozwalają na jego pełne nadzorowanie podtopień w pomieszczeniach zamkniętych;

- podczas badań stwierdzono nieprawidłowości w pozycjonowaniu motopompy pływającej, co wymaga wprowadzenia stosownych korekt w oprogramowaniu lub zastosowania lepszego odbiornika/anteny sygnału GPS.

\section{Działania podczas powodzi}

Badania przeprowadzono w dniu 30.08.2016 r. Przed rozpoczęciem działań sprawdzono w systemie przy pomocy aplikacji LUME. Stwierdzono obecność ostrzeżenia technicznego, które wg systemu dotyczyło przypadków zbyt niskiego poziomu naładowania baterii i niskiego poziomu paliwa. Wszystkie ostrzeżenia były typu „historycznego" i wyświetlane były w systemie w zakładce „LOGI”, bieżący status motopompy był „Sprawny”. Bieżąca pozycja pompy to plac manewrowy SGSP. Pompa pływająca Niagara została przewieziona na kanałek Kępa Potocka pod wiadukt trasy S8.

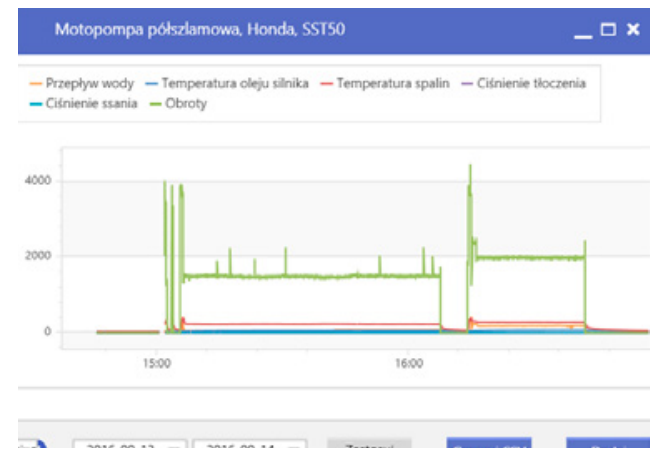

Rysunek 18. Parametry motopompy pływającej podczas symulowanej akcji powodziowej Źródło: opracowanie własne

Figure 18. Parameters of the floating fire pump during the simulated flood action 

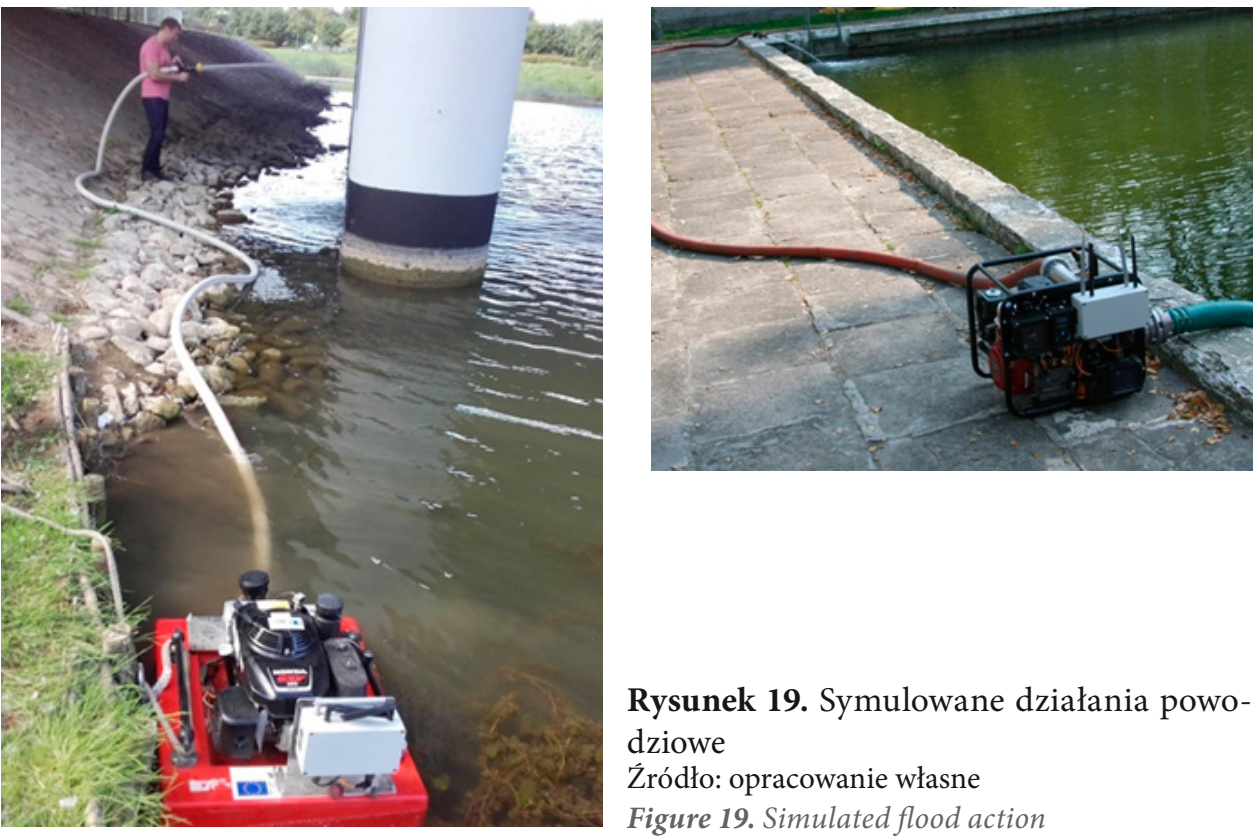

Rysunek 19. Symulowane działania powodziowe

Źródło: opracowanie własne

Figure 19. Simulated flood action

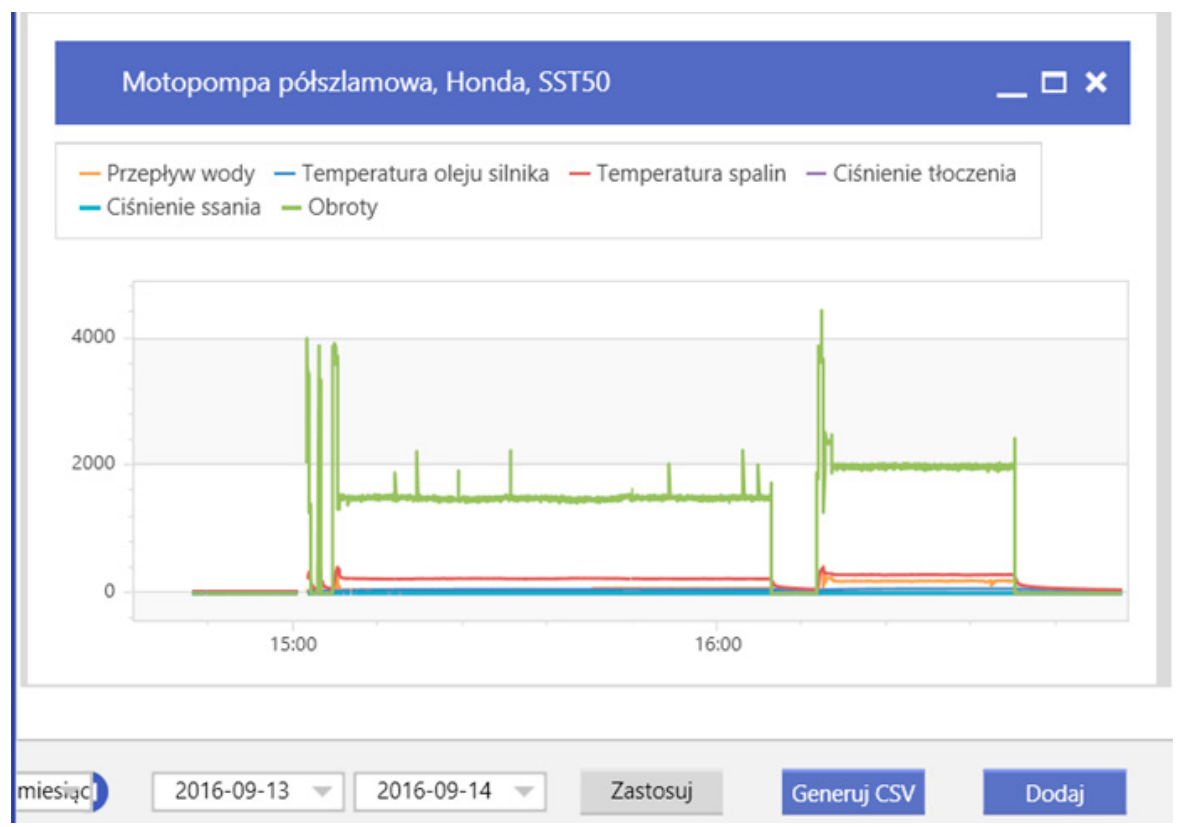

Rysunek 20. Parametry motopompy półszlamowej podczas symulowanej akcji powodziowej Źródło: opracowanie własne

Figure 20. Parameters of the floating fire pump during the simulated flood action

Podczas działań zaobserwowano, że pompa podczas swobodnego pływania zanurza się znacznie - poniżej linii wodnej znajdują się zamontowane moduły 
pomiarowe i JAD, co wskazuje na zbyt dużą masę dodatkowych urządzeń systemu monitorowania. Przeprowadzono próby długotrwałej pracy przy różnych ustawieniach prądownicy

Obserwowano rejestrację parametrów pompy na tablecie dowódcy i na komputerze $\mathrm{z}$ aplikacją desktop. Stwierdzono poprawną aktualizację poprzez wyłączenie i ponowne włączenie pompy i obserwowano reakcję oprogramowania.

Badania prowadzono przez ok. 1,5 godziny do wyczerpania paliwa w zbiorniku pompy. Stwierdzono wyświetlenie komunikatu o niskim stanie paliwa, zarówno na tablecie dowódcy, jak i komputerze dyspozytora JRG.

W dniu 13.09.2016 r. przeprowadzono symulowane działania powodziowe z użyciem pompy szlamowej HONDA, na zbiorniku wodnym w miejscowości Zamczysko.

Przed uruchomieniem pompy stwierdzono w aplikacji LUME dyspozytora JRG, określono jej położenie na mapie oraz określono status techniczny jako „Ostrzeżenie” podświetlony na kolor pomarańczowy. W zakładce „LOGI” stwierdzono występowanie szeregu alarmów dotyczących niskiego poziomu paliwa oraz niskiego stanu naładowania baterii. Aktualne ostrzeżenia po uruchomieniu motopompy nie występowały. Uruchomiono motopompę nad brzegiem zbiornika wodnego. Pompa szlamowa pracowała $\mathrm{z}$ ustalonym obciążeniem i otwartą prądownicą przez ok. 2 godziny.

Stwierdzono poprawne wskazania systemu monitorowania, zarówno na tablecie dowódcy, jak i w aplikacji na komputerze dyspozytora JRG. Dane zostały przesłane do serwera i są dostępne w postaci parametrów historycznych.

Na podstawie przeprowadzonych badań należy stwierdzić, że:

- rejestrowane w systemie dane są wystarczające do monitorowania parametrów motopompy pływającej i motopompy szlamowej podczas symulowanych akcji powodziowych;

- konieczne jest w docelowej wersji systemu zastosowanie modułu komunikacji Wi-Fi o zasięgu min. kilkaset metrów tak, aby możliwa była bezpośrednia komunikacja pomiędzy urządzeniami a tabletem dowódcy w odległościach charakterystycznych dla akcji powodziowej. Jest to tym bardziej istotne, że na terenach objętych powodzią zazwyczaj występują problemy z komunikacją GSM.

\subsection{Sprawdzenie funkcjonowania systemu monitorowania podczas rzeczywistych działań w JRG SGSP}

W październiku samochód ratowniczo-gaśniczy GBA 2,5/16 pełnił służbę w Jednostce Ratowniczo-Gaśniczej w SGSP. W tym czasie wielokrotnie dysponowany był do akcji ratowniczych. Po zalogowaniu do systemu LUME i wybraniu sprzętu „AUTOPOMPA” widoczny jest status urządzenia jako „Sprawny”. Ponadto system wskazuje, że sumaryczny czas pracy autopompy wynosi 23 motogodziny. Termin 
następnej obsługi technicznej określono na 26.11.2016 r. W zakładce LOGI w październiku zanotowano jedno ostrzeżenie o zbyt wysokiej temperaturze wody w kolektorze ssawnym.

W zakładce MAPA po wybraniu autopompy i okresu służby 1.10.2016 do 17.10.2016 ukazuje się historia położenia pojazdu na mapie.

Po uruchomieniu zakładki Wykresy i wybraniu żądanego okresu wyświetla się wykres z zarejestrowanymi parametrami. Na podstawie wykresu odczytać można, że pojazd uruchamiano 21 razy podczas żądanego czasu pracy. Autopompa pojazdu pracowała w tym okresie tylko 4-krotnie - pozostałe zarejestrowane zdarzenia nie wymagały podawania prądów gaśniczych.

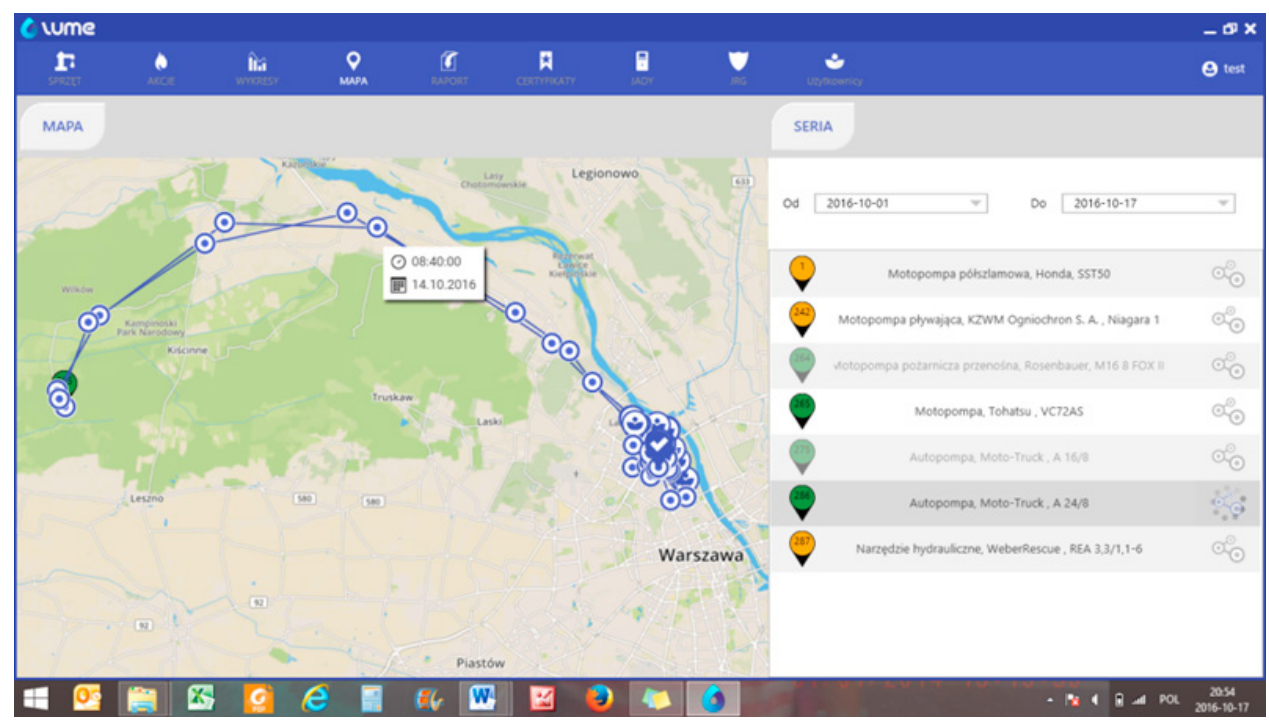

Rysunek 21. Historia przemieszczeń pojazdu GBA podczas działań w rzeczywistych warunkach operacyjnych

Źródło: opracowanie własne

Figure 21. History of Fire Engine displacements during under real operating

W zakładce Akcje podjęto próbę zapisania ćwiczebnego wyjazdu w dniu 14.10.2016 do bazy leśnej Zamczysko. Dodano poprawnie tę akcję, jednak nie było możliwości dodania monitorowanego sprzętu - autopompy. Problemy te występują prawdopodobnie na skutek błędu w oprogramowaniu. Z tego powodu uzyskane wydruki z zakładki Raport nie zawierały wszystkich niezbędnych danych. Podobnie z innymi rzeczywistymi akcjami w JRG prowadzonymi w październiku. Przebieg zdarzeń w obecnej wersji oprogramowania (edycja z dnia 26.09.2016 r.) śledzić można jedynie na podstawie wykresów parametrów. Przykładowo na podstawie historii położenia pojazdu ustalono, że w dniu 14.10.2016 r. o godz. 9.10 przebywał w bazie leśnej Zamczysko. Po uruchomieniu zakładki Wykresy i wybraniu daty 14.10.2016, ustalono, że w czasie od godz. 9.50 do godz. 12.16 podawano prądy gaśnicze za pomocą linii normalnego ciśnienia. 


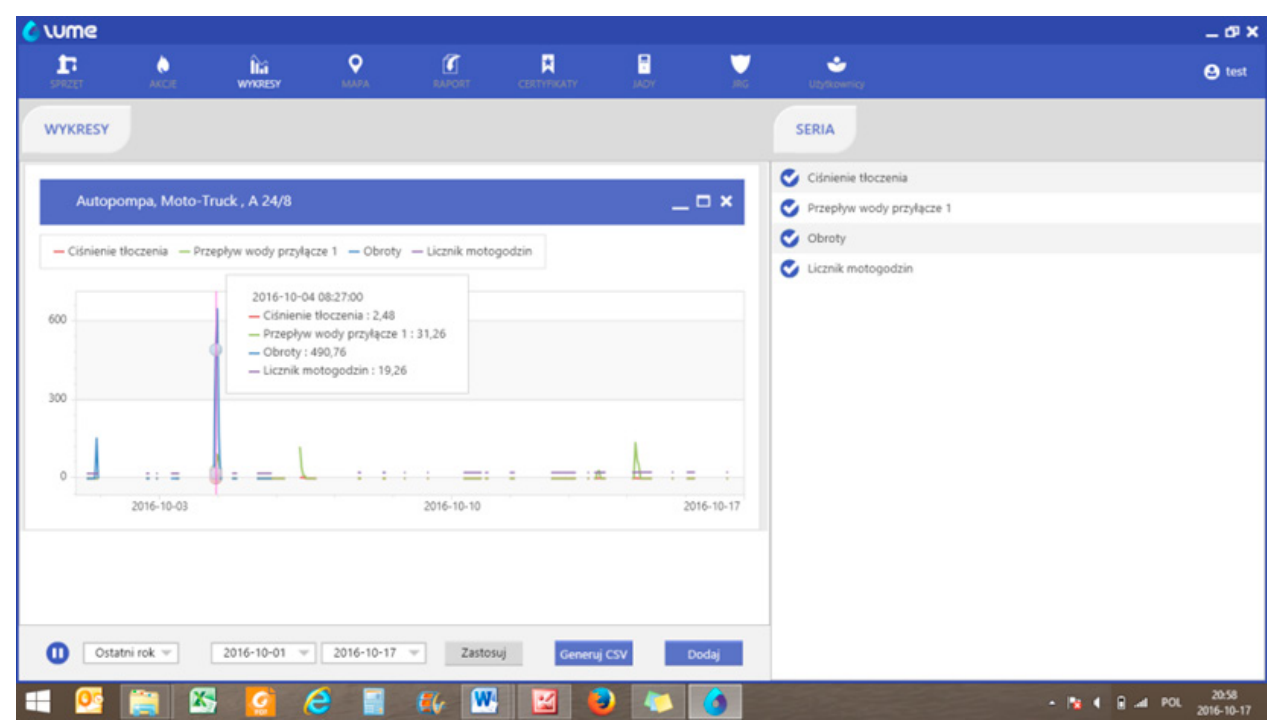

Rysunek 22. Parametry pracy autopompy pojazdu GBA podczas działań w rzeczywistych warunkach operacyjnych

Źródło: opracowanie własne

Figure 22. Parameters of the fire pump on the Fire Vehicle during under real operating

\section{Wnioski}

Przeprowadzone badania końcowe opracowanego systemu monitorowania stanu technicznego wybranych urządzeń potwierdziły, że:

- możliwe jest prowadzenie monitorowania stanu technicznego urządzeń podczas rzeczywistej służby w Jednostce Ratowniczo-Gaśniczej;

- wszystkie kluczowe parametry diagnostyczne zapisywane są w systemie w sposób poprawny, umożliwiający ich odczyt po upływie czasu;

- na podstawie danych zapisanych w systemie możliwe jest określenie położenia sprzętu w dowolnym wybranym przedziale czasowym;

- korzystając z menu Wykresy możliwe jest monitorowanie szczegółowych parametrów nadzorowanego sprzętu w dowolnie wybranym okresie czasu.

Potwierdzono zatem podstawowe złożenia projektowe proponowanego systemu.

Niestety prace nad dalszym udoskonaleniem systemu nie są kontynuowane ze względu na brak finasowania. 


\section{Zakończenie}

Publikacja Innowacyjne technologie w straży pożarnej to efekt projektów badawczych z obszaru bezpieczeństwa i obronności realizowanych z funduszy Narodowego Centrum Badań i rozwoju (NCBiR). Zaprezentowane opracowania w większości wypadków dotyczą zagadnień badawczych, w których realizacji aktywnie uczestniczyło CNBOP-PIB. Zastosowane rozwiązania systemowe zarówno z obszaru zarządzania, jak i obszaru logistyki i eksploatacji, zdaniem autorów spełniają oczekiwania gestora będącego przedstawicielem środowiska zawodowego.

W części I „Przykłady rozwiązań konstrukcyjnych opracowanych w czasie realizacji projektów naukowo-badawczych" zastały przedstawione najciekawsze przykłady rozwiązań konstrukcyjnych pojazdów przeznaczonych do prowadzenia działań ratowniczo-gaśniczych oraz wspomagających zarządzanie działaniami.

Część II „Innowacyjne rozwiązania konstrukcyjne w pojazdach pożarniczych” poświęcona została omówieniu niestandardowych rozwiązań konstrukcyjnych związanych z ewaluacją technologii działań ratowniczo-gaśniczych oraz badania ergonomii i bezpieczeństwa pojazdów pożarniczych.

Część III „Logistyka działań w jednostkach ochrony przeciwpożarowej” została poświęcona wypracowaniu rozwiązań systemowych wspierających organizację zabezpieczenia logistycznego długotrwałych akcji ratowniczych, pozwalających na osiągnięcie zadowalającego stopnia spójności i sprawności podmiotów realizujących i zarządzających zabezpieczeniem logistycznym tych akcji ratowniczych.

Część IV „Innowacyjne systemy gaśnicze w działaniach ratowniczo-gaśniczych” zawiera informacje związane $\mathrm{z}$ wykorzystaniem nowych konstrukcji sprzętu w szeroko pojętych działaniach ratowniczo-gaśniczych.

Część V „Innowacyjne technologie w działaniach ratowniczo-gaśniczych” poświęcono systemowi wspomagania zarządzania bezpieczeństwem w celu podniesienia poziomu bezpieczeństwa kompleksów obiektów zabytkowych. Jednocześnie zaprezentowano system złożony z mobilnego robota lądowego oraz tachimetru elektronicznego rozbudowanego o „komponent pozwalający na dokonywanie rozpoznania uszkodzonych konstrukcji budowlanych z wykorzystaniem bezzałogowych platform latających".

Część VI „Monitoring eksploatacji sprzętu w straży pożarnej”, w którym przedstawiono ciągłą ewaluację systemów informatycznych pozwalających na obiektywną ocenę eksploatacji sprzętu pożarniczego. Zarządzanie działaniami służb ratowniczych wymusza potrzebę systemowego podejścia do realizacji postawionych zadań, skutecznego wdrażania innowacyjnych technik i technologii w obszarze techniczno-logistycznym.

Możemy doskonalić systemy decyzyjne, tak aby w odniesieniu do prowadzonych działań ratowniczo-gaśniczych uzyskać najbardziej efektywny sposób zarządzania. Doskonalimy również narzędzia - sprzęt i wyposażenie do prowadzenia działań 
ratowniczych, aby uzyskać możliwie najbardziej skuteczne gaszenie pożarów oraz efektywne działania ratownicze. Podjęte działania w obu płaszczyznach wykorzystują elementy innowacyjności zarówno w aspekcie organizacyjno-zarządczym, jak i techniczno-logistycznym. Przedstawiona monografia Innowacyjne technologie w straży pożarnej powinna przybliżyć czytelnikowi tę tematykę, zarówno w obszarze zarządzania działaniami straży pożarnej, jak i technicznych środków wsparcia w zarządzaniu eksploatacją sprzętu oraz możliwych kierunków rozwoju sprzętu pożarniczego. Realizując zadania z zakresu zarządzania logistycznego oraz procesami eksploatacyjnymi, należy jednak pamiętać, że nawet najbardziej innowacyjny sprzęt i nowoczesny sposób zarządzania nie zwalnia nas z odpowiedzialności za bezpieczeństwo ratowników i osób ratowanych we wszystkich aspektach systemu ochrony i bezpieczeństwa ludności. 


\section{NOTKI BIOGRAFICZNE}

Aleksander Adamski, st. bryg. mgr inż. - dowódca JRG SGSP. Specjalista w zakresie organizacji zaopatrzenia wodnego. Wcześniej starszy wykładowca w Katedrze Działań Ratowniczych.

Lukasz Apiecionek, dr nauk technicznych - stopień naukowy uzyskał w Instytucie Podstawowych Problemów Techniki Polskiej Akademii Nauk. Adiunkt na Uniwersytecie Kazimierza Wielkiego w Bydgoszczy w Zakładzie Informatyki Instytutu Techniki. Uczestniczył w realizacji wielu projektów B+R, które zostały w szerokim zakresie wdrożone u użytkowników.

Dariusz Baranowski, kpt. mgr inż. - asystent w Zakładzie Badania Przyczyn Pożarów Szkoły Głównej Służby Pożarniczej. Ekspert Państwowej Komisji Badania Wypadków Lotniczych oraz Wojskowego Instytutu Techniki Pancernej i Samochodowej.

Mateusz Biedziak, inżynier - tytuł zawodowy uzyskał na Uniwersytecie Kazimierza Wielkiego w Bydgoszczy w Zakładzie Informatyki Instytutu Techniki.

Piotr Brążkiewicz, mgr inż. - tytuł zawodowy uzyskał na Akademii Techniczno-Rolniczej w Bydgoszczy na Wydziale Telekomunikacji i Elektroniki. Współautor wielu nowatorskich rozwiązań w zakresie IT, wykonawca prac badawczo-rozwojowych.

Michał Chmiel, mgr inż. - absolwent studiów na Wydziale Inżynierii Bezpieczeństwa Pożarowego Szkoły Głównej Służby Pożarniczej w Warszawie. Od 2007 r. pracownik Jednostki Certyfikującej CNBOP-PIB. Aktualnie na stanowisku zastępcy kierownika. Doktorant na Wydziale Zarządzania i Dowodzenia Akademii Sztuki Wojennej. Temat rozprawy doktorskiej związany z zabezpieczeniem logistycznym strażaków jednostek ochrony przeciwpożarowej podczas długotrwałych akcji ratowniczych. Autor i współautor kilkudziesięciu publikacji z zakresu systemu dopuszczeń, wymagań dla sprzętu i wyposażenia strażaków, bezpieczeństwa pożarowego.

Marcin Grubek, mgr inż. - absolwent Wydziału Mechanicznego Energetyki i Lotnictwa na Politechnice Warszawskiej, specjalista inżynieryjno-techniczny w Wojskowym Instytucie Techniki Pancernej i samochodowej.

Jarosław Kończak, dr inż. - absolwent Wydziału Mechanicznego Wojskowej Akademii Technicznej, adiunkt w Wojskowym Instytucie Techniki Pancernej i Samochodowej, doświadczony logistyk, eksploatator, ergonomista, konstruktor-wizjoner, menadżer projektu.

Bernard Król, mł. bryg. dr inż. - absolwent SGSP, dr nauk chemicznych, adiunkt w SGSP, specjalizuje się w badaniach nad zastosowaniem środków gaśniczych 
do gaszenia pożarów ciał stałych i tłuszczów, autor kilkudziesięciu publikacji z zakresu zastosowania środków gaśniczych i sprzętu gaśniczego.

Włodzimierz Kupicz, dr inż. - adiunkt w Zakładzie Sprzętu Ratowniczo-Gaśniczego w Szkole Głównej Służby Pożarniczej oraz Szef Pionu Badań w Wojskowym Instytucie Techniki Pancernej i Samochodowej.

Małgorzata Majder-Łopatka, mł. bryg. dr inż. - absolwentka Wydziału Inżynierii Bezpieczeństwa Pożarowego SGSP (2002) i Wydziału Inżynierii, Chemii i Fizyki Technicznej WAT (2003). Tytuł doktora w dyscyplinie ochrona i kształtowanie środowiska otrzymała w 2013 r. Obecnie adiunkt w Zakładzie Ratownictwa Chemicznego i Ekologicznego w Szkole Głównej Służby Pożarniczej. Obszary zainteresowań naukowych: inżynieria i ochrona środowiska, inżynieria bezpieczeństwa pożarowego.

Marcin Mieteń, mgr inż. - absolwent Wydziału Transportu na Politechnice Warszawskiej, asystent w Wojskowym Instytucie Techniki Pancernej i Samochodowej.

Paweł Ogrodnik, mł. bryg. dr inż. - absolwent Wydziału Inżynierii Budowlanej i Sanitarnej Politechniki Lubelskiej (kierunek: budownictwo). W 2001 roku rozpoczął pracę w Zakładzie Mechaniki Stosowanej Szkoły Głównej Służby Pożarniczej. W 2006 roku obronił rozprawę doktorską na temat „Wpływ temperatur występujących w czasie pożaru na przyczepność pomiędzy stalą a betonem". Prowadzi badania eksploatacyjne, wytrzymałości i mechanizmów uszkodzeń materiałów konstrukcyjnych i funkcjonalnych oraz komponentów sprzętu pożarniczego i ochron osobistych w warunkach narażeń termicznych i mechanicznych.

Robert Palka, mgr inż. - tytuł zawodowy uzyskał na Akademii Techniczno-Rolniczej w Bydgoszczy na Wydziale Telekomunikacji i Elektroniki. Dyrektor Techniczny $\mathrm{w}$ firmie TELDAT, kierujący pionami technicznymi, w tym w zakresie realizacji prac badawczo-rozwojowych, projektowych, wytwórczo-produkcyjnych i wdrożeniowych.

Robert Piec, bryg. dr inż. - absolwent inżynierskich i magisterskich studiów na Wydziale Inżynierii Bezpieczeństwa Pożarowego Szkoły Głównej Służby Pożarniczej. Doktor nauk technicznych w dyscyplinie inżynieria środowiska nadany uchwałą Rady Naukowej Centralnego Instytutu Ochrony Pracy - Państwowego Instytutu Badawczego. Ukończył również studia podyplomowe: „Zarządzenie w stanach zagrożeń” w Szkole Głównej Służby Pożarniczej, studia podyplomowe: „Bazy danych” w Wyższej Szkole Informatyki Stosowanej i Zarządzania oraz studia podyplomowe z seminariami doktoranckimi: „Analiza ryzyka” w Akademii Finansów. Jest autorem lub współautorem wielu artykułów, monografii oraz referatów prezentowanych na konferencjach krajowych i zagranicznych. Obecnie pełni obowiązki Kierownika Katedry Bezpieczeństwa Inżynierii Wydziału Inżynierii Bezpieczeństwa Cywilnego Szkoły Głównej Służby Pożarniczej. 
Jacek Pirszel, dr - w roku 1990 ukończył studia na Wydziale Chemii Uniwersytetu Marii Curie-Skłodowskiej w Lublinie. Jest doktorem nauk biologicznych i adiunktem w Wojskowym Instytucie Chemii i Radiometrii. Specjalność - technologie likwidacji skażeń, toksykologia oraz analityka chemiczna, ze szczególnym uwzględnieniem analizy chromatograficznej bojowych środków trujących i toksyn naturalnego pochodzenia.

Jacek Roguski, dr inż. - adiunkt w Biurze Projektów i Obsługi Badań CNBOP-PIB. Zajmuje się naukowo aspektami związanymi z zagadnieniami ochron osobistych oraz problemami eksploatacji urządzeń technicznych. Jest autorem i współautorem szeregu artykułów i monografii oraz wystąpień na konferencjach krajowych i zagranicznych.

Karolina Równicka, mgr inż. - absolwentka studiów na Wydziale Inżynierii Bezpieczeństwa Pożarowego Szkoły Głównej Służby Pożarniczej w Warszawie i Wydziału Bezpieczeństwa Narodowego w Akademii Obrony Narodowej w Warszawie. Doktorantka na Wydziale Zarządzania i Dowodzenia Akademii Sztuki Wojennej. Od 2017 r. pracownik Zakładu Ocen Technicznych CNBOP-PIB na stanowisku specjalisty.

Emil Sulak, mgr inż. - absolwent studiów na Wydziale Inżynierii Bezpieczeństwa Cywilnego oraz Inżynierii Bezpieczeństwa Pożarowego Szkoły Głównej Służby Pożarniczej w Warszawie. Od 2017 r. pracownik jednostki certyfikującej CNBOP-PIB na stanowisku młodszego specjalisty.

Norbert Tuśnio, mł. bryg. dr inż. - absolwent Szkoły Głównej Służby Pożarniczej. W 1998 roku rozpoczął pracę w Zakładzie Badania Przyczyn Pożarów Szkoły Głównej Służby Pożarniczej. W 2010 roku obronił rozprawę doktorską na temat „Numeryczna analiza wytrzymałości konstrukcji stalowych w warunkach pożaru”. Obecnie kierownik Zakładu Systemów W spomagania Decyzji oraz projektu „Innowacyjne rozwiązania metod stabilizowania konstrukcji budowlanych i technologicznych w warunkach działań ratowniczych podczas likwidacji skutków katastrofy budowlanej”.

Wiktor Wąsik, kpt. mgr inż. - asystent w Zakładzie Sprzętu Ratowniczo-Gaśniczego. Od 2011 r. pracownik Szkoły Głównej Służby Pożarniczej. Absolwent studiów pierwszego i drugiego stopnia na Wydziale Inżynierii Bezpieczeństwa Pożarowego Szkoły Głównej Służby Pożarniczej. Obszar zainteresowań zawodowych: sprzęt ratowniczo-gaśniczy i pojazdy pożarnicze, pompy pożarnicze, stałe urządzenia gaśnicze, certyfikacja wyrobów w ochronie przeciwpożarowej.

Beata Wojtasiak, mgr - absolwentka Akademii Pedagogiki Specjalnej w Warszawie na Wydziale Nauk Pedagogicznych, studia podyplomowe: „Menadżer Innowacji”, Szkoła Główna Handlowa w Warszawie. Młodszy specjalista inżynieryjno-techniczny w Zakładzie Ocen Technicznych CNBOP-PIB. 
Tomasz Węsierski, kpt. dr - absolwent Wydziału Chemii UAM w Poznaniu. Tytuł doktora w dziedzinie nauk chemicznych uzyskał w 2007 roku. Obecnie adiunkt w Zakładzie Fizyki i Chemii w Szkole Głównej Służby Pożarniczej. Obszary zainteresowań naukowych: ratownictwo chemiczne, inżynieria i ochrona środowiska, inżynieria bezpieczeństwa pożarowego.

Grzegorz Wiśniewski, mgr inż. - absolwent Wydziału Nauk Technicznych na Uniwersytecie Warmińsko-Mazurskim w Olsztynie, specjalista inżynieryjno-techniczny w Wojskowym Instytucie Techniki Pancernej i Samochodowej.

Paweł Wolny, mgr inż. - absolwent Szkoły Głównej Służby Pożarniczej. W roku 2008 ukończył uzupełniające studia magisterskie na kierunku „Organizacja i finansowanie ratownictwa” w Akademii Finansów w Warszawie, a w roku 2010 studia podyplomowe z zakresu Bezpieczeństwa i Higieny Pracy. Obecnie realizuje w SGSP rozprawę doktorską nt. „Analiza efektywności gaśniczej systemów hybrydowych wykorzystujących mgłę wodną z czynnikiem roboczym w postaci gazów obojętnych".

Konrad Zaciera, mgr inż. - absolwent Wydziałów Inżynierii Bezpieczeństwa Cywilnego oraz Inżynierii Bezpieczeństwa Pożarowego Szkoły Głównej Służby Pożarniczej. Specjalista ds. certyfikacji urządzeń sygnalizacji alarmu pożarowego i automatyki pożarniczej, audytor jednostki certyfikującej w zakresie tych urządzeń. Współautor standardów CNBOP-PIB. Członek KT 53 Polskiego Komitetu Normalizacyjnego. Kierownik Zakładu Ocen Technicznych CNBOP-PIB. 
Publikacja zawiera wyniki badań będące efektem realizacji projektów z zakresu bezpieczenstwa i obronnosci finansowanych przez Narodowe Centrum Badań i Rozwoju, Których rezultatem jest szereg rozwiązań o interesujących i zhaczaccych propozycjach podnoszenia jakości i efektywności realizacji zadan przez straż pożarna. Wielowatkowośc oraz uczestnictwo wielu autorów jest zhaczącym walorem publikacji, Która pozwala zaprezentować różnorodne spojrzenie na zagadnienia z obszaru badan prowadzonych nad poprawa jakosci i sposobów wsparcia dziatań straży pożarnej, przez autorów wywodzacych się z róznych srodowisk naukowych i instytucji. Tak przekrojowa grupa autorów i zakres rozważanych w publikacji zagadnień, podnosi celowość wydania niniejszego opracowania.

Publikacja w wiekszości obejmuje nowator skie rozwiązania poprawiajace i wspierajace techniczno-technologiczne aspekty realizacji zadan statutowych straży pożarnej. Krytyczne podejście do niektórych problemów pozwolito na twórcza interpretacje faktów, jak równiez sugestie rozwiązan w postaci innowacyjnych a także perspektywicznych kierunków zmian oraz propozycji w analizowanych obszarach.

ISBN 978-83-948534-1-9 DOI $10.17381 / 2018.3$

Wydawnictwo CNBOP-PIB www.cnbop.pl

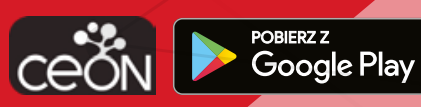

